ИСТОРИЧЕСКИЕ ИССЛЕДОВАНИЯ В КОНТЕКСТЕ НАУКИ О ДАННЫХ

ИНФОРМАЦИОННЫЕ РЕСУРСЫ

\author{
АНАЛИТИЧЕСКИЕ МЕТОДЫ \\ И ЦИФРОВЫЕ ТЕХНОЛОГИИ
}

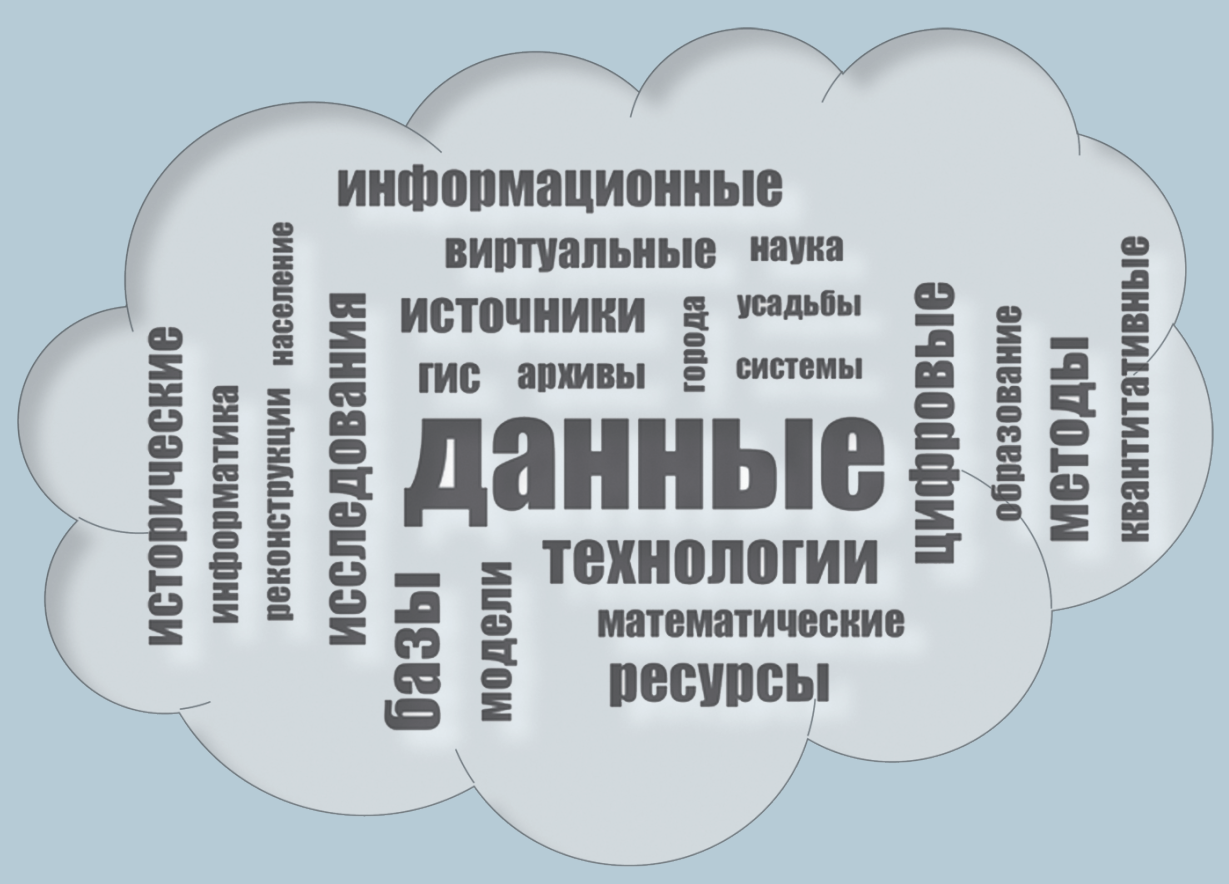


ИСТОРИЧЕСКИЙ ФАКУЛЬТЕТ МГУ ИМЕНИ М. В. АОМОНОСОВА АССОЦИАЦИЯ "ИСТОРИЯ И КОМПЬЮТЕР"

\section{ИСТОРИЧЕСКИЕ ИССАЕАОВАНИЯ В КОНТЕКСТЕ НАУКИ О ААННЫХ:}

Информационные ресурсы, аналитические методы и цифровые технологии

Материалы международной конференции

Москва, 4-6 декабря 2020 г.

$\frac{\text { Масква }-2020}{\text { Мост }}$


УДК 930.2

ББК 63ф1я431

И90

Конференция поддержана Российским фондом фундаментальных исследований, грант 20-09-22024\20

Ответственный редактор: И. М. Гарскова

Редколлегия:

чл.-корр РАН, д.и.н. Л. И. Бородкин, д.и.н. В. Н. Владимиров, к.и.н. И. М. Гарскова

Рецензенты:

чл.-корр. РАН Н. М. Арсентьев, д.т.н. Г. З. Залаев

Редакционный совет:

д.и.н. С.А Баканов (Челябинск), д. и.н. Ш. Д. Батырбаева (Бишкек), д. и.н. С. И. Корниенко (Пермь), д. и.н. Л. Н. Мазур (Екатеринбург), д. и.н. Ю. Ю. Юмашева (Москва)

Исторические исследования в контексте науки о данных: И90 информационные ресурсы, аналитические методы и цифровые технологии. Материалы международной конференции. Москва, 4-6 декабря 2020 г. - Москва : МАКС Пресс, 2020. - 484 с. ISBN 978-5-317-06529-4

https://doi.org/10.29003/m1781.978-5-317-06529-4

Сборник содержит тексты докладов Международной конференции. В рамках указанной международной конференции была проведена XVII конференция Межрегиональной Ассоциации «История и компьютер».

Ключевые слова: история, историческая информатика, наука о данных, методы исследования, информационные ресурсы, цифровые технологии.

УДК 930.2

ББК 63ф1я431

(C) Ассоциация «История и компьютер», 2020

(C) Исторический факультет МГУ имени М. В. Ломоносова, 2020

(C) Оформление. ООО «МАКС Пресс», 2020 


\section{Предисловие}

Предлагаемое Вашему вниманию издание содержит статьи участников международной конференции «Исторические исследования в контексте науки о данных: информационные ресурсы, аналитические методы и цифровые технологии», состоявшейся в онлайнформате 4-6 декабря 2020 г. при поддержке РФФИ. Организаторами конференции были исторический факультет МГУ имени М.В. Ломоносова и Межрегиональная ассоциация «История и компьютер» (АИК). Одна из старейших в Российской Федерации ассоциаций гуманитарного профиля (учреждена в 1992 г.), АИК объединяет более 100 специалистов из России и стран ближнего зарубежья, применяющих цифровые технологии и математические методы в исторических исследованиях, изучении и сохранении историко-культурного наследия. В рамках указанной международной конференции была проведена XVII конференция АИК.

В работе международной конференции приняли участие более 200 специалистов из научно-образовательных центров России и ряда стран дальнего и ближнего зарубежья. Основная цель конференции обсуждение перспектив и проблем дальнейшего развития исторических исследований в условиях цифровизации и возрастания значения процессов обработки и анализа данных исторических источников на базе накопленного опыта. В этом процессе актуализируется значение нового раздела информационных наук, который получил название «наука о данных» (Data Science), растет востребованность апробации формирующихся в данной области практик, используемых историками, вводящими в научный оборот большие массивы исторической информации. Для этого требуется владение современным уровнем аналитического инструментария (как специализированного, так и универсального), разработка и освоение новых методик и технологий исследований, соответствующих быстро растущему объему цифровых историко-ориентированных ресурсов. 
Эти вопросы были в центре программы конференции, включающей как теоретико-методологические аспекты «цифрового поворота», так и обсуждение результатов конкретно-исторических исследований, ведущихся на базе оцифрованных источников в приоритетных областях отечественной и зарубежной истории (в экономической, социальной, политической истории, исторической демографии и т.д.). Новые грани актуальности приобретают вопросы репрезентации и анализа исторических источников, представленных в цифровых форматах и возникающих, например, в задачах построения трехмерных виртуальных реконструкций объектов историко-культурного наследия, использования геоинформационных технологий для изучения пространственных аспектов исторических исследований, компьютеризованного анализа текстовых источников, математического моделирования исторических процессов и т.п. При этом в качестве основного критерия эффективности новых методов и технологий рассматривается приращение нового знания в рассматриваемых областях исторической науки. Важное место в работе конференции заняли и вопросы источниковедения цифровых исторических источников, методик создания электронных публикаций, процессов цифровизации архивов и музеев, а также актуальные вопросы онлайнобразования в современных условиях, осложненных пандемией.

Программа конференции включала 124 доклада и сообщения, представленных на 9 секциях, трех пленарных заседаниях и двух круглых столах. Структура данного сборника соответствует программе конференции и включает следующие разделы:

- Квантитативная история и компьютерное моделирование исторических процессов.

- Компьютеризованный анализ текстовых источников.

- Базы данных и информационные ресурсы.

- Методы и технологии сетевого анализа в исторических исследованиях.

- Историческая геоинформатика: традиции и трансформации.

- 3D-реконструкции объектов историко-культурного наследия. Виртуальная и дополненная реальность (VR/AR).

- Информационные технологии в архивах и музеях: проблемы методологии и методики в контексте исторической науки. 
- Цифровые ресурсы и технологии в профессиональном историческом образовании.

- Информатика: страницы истории

Ключевым понятием в работе конференции были «данные». Тематика работы с данными нашла отражение в пленарных докладах известных ученых из России, Голландии, Норвегии, а также была представлена в работе обоих круглых столов: «Цифровые данные исторической статистики: как провести их верификацию и корректировку?» и «Историческая информатика в ракурсе Data Science». В секции, посвященной использованию цифровых ресурсов и технологий в профессиональном историческом образовании, состоялась актуальная дискуссия «Приведет ли пандемия к трансформации университетского исторического образования?»

Материалы конференции отражены в двух изданиях. Данный сборник включает полные тексты секционных докладов, второй публикацией является 48-й выпуск Информационного бюллетеня АИК с тезисами сообщений ${ }^{1}$. Публикации дают представление о достаточно высоком научном уровне конференции, в работе которой приняли участие ведущие специалисты из научно-образовательных центров РФ, а также из ряда стран ближнего и дальнего зарубежья, что позволило осуществить эффективный обмен опытом в данной актуальной сфере исторических исследований.

Л.И. Бородкин, В.Н. Владимиров, И.М. Гарскова

\footnotetext{
${ }^{1}$ Информационный бюллетень Ассоциации «История и компьютер». № 48, специальный выпуск, декабрь 2020 г. Тезисы Международной конференции «Исторические исследования в контексте науки о данных: информационные ресурсы, аналитические методы и цифровые технологии». Москва, 4-6 декабря 2020 г. - М.: МАКС Пресс, 2020.
} 


\section{КВАНТИТАТИВНАЯ ИСТОРИЯ И КОМПЬЮТЕРНОЕ МОДЕЛИРОВАНИЕ ИСТОРИЧЕСКИХ ПРОЦЕССОВ}

https://doi.org/10.29003/m1782.978-5-317-06529-4/6-13

Аблаев Э.Ю.

Московский государственный университет имени М.В. Ломоносова

\section{Отраслевая специфика краткосрочного кредитования в 1928-1935 гг.: количественный анализ по архивным материалам Государственного банка СССР}

Аннотация. Работа посвящена трансформации механизма отраслевого кредитования в СССР в ходе кредитной реформы 1930-х гг. События реформы и их влияние проанализированы на комплексе архивных и опубликованных источников. В начале реформы из-за отсутствия чётко установленных объектов кредита наблюдается значительный рост краткосрочневых ссуд, повлекший за собой дополнительную эмиссию. Данный эффект обозначил необходимость регламентации кредитования. Устанавливая правила в соответствии с текущей ситуацией, Госбанк регулировал доступ отраслей к заёмным ресурсам.

Ключевые слова: кредитная реформа 1930-1932 гг., краткосрочное кредитование, Государственный банк СССР, советская финансовая система, советская отраслевая специфика.

Ablaev E.Yu. Lomonosov Moscow State University

Industrial structure of short-term lending in 1928-1935:

a quantitative analysis of archival materials of the State Bank of the USSR

Abstract. The study deals with the transformation of the industrial lending practices in the USSR during the credit reform of the 1930s. The reform and its impact are analyzed using a set of archival and published sources. At the beginning of the reform, due to the imprecisely defined assets to be credited, there was a significant increase in short-term loans, which entailed additional money issue. This drawback caused new lending regulations. By continuous adapting the rules to the current situation, the State Bank was regulating the access of industries to borrowed resources.

Keywords: Soviet credit reform of 1930-1932, short-term lending, State Bank of the USSR, Soviet financial system, Soviet industrial structure.

Во второй половине 1920-х - первой половине 1930-х гг. экономическое и политическое устройство СССР претерпели коренные 
изменения, заложившие основы дальнейшего исторического развития. Именно в этот период была создана зрелая советская кредитноденежная система, в которой все финансовые инструменты полностью контролировались государством. Одним из ключевых сюжетов в реорганизации кредитной системы являлось проведение кредитной реформы, которую традиционно датируют 1930-1932 гг.

Вопросы, связанные с кредитной реформой, уже освещались в зарубежных и отечественных работах, как советского, так и постсоветского периода. В целом их можно разделить на две большие группы. К первой относятся исследования, во многом ограничивающиеся изложением хода преобразований и их результатов $[1,2,3]$. Вторая группа представляет собой совокупность исследований, целью которых является характеристика взаимодействия финансов и экономики в социалистической системе, включая такие общие сюжеты, как значимость денег и возможность их подчинения планированию [4], принципы управления сферами наличного и безналичного денежного обращения [5], причины упадка советской денежной системы [6].

Наблюдается заметное смещение внимания авторов в сторону изучения вопросов общего характера - значение и эффективность советской финансовой системы, в то время как ещё не до конца изучены более частные моменты, одним из которых является механизм взаимодействия Государственного банка (далее - Госбанк) и отраслей советской экономики. Однако перед тем, как быть готовым к ответу на вопрос, как советские предприятия получали и распоряжались заёмными средствами, и способствовало ли это экономическому росту, необходимо понять, что представляла собой и как регулировалась система краткосрочного кредитования отдельных отраслей экономики, на что делается акцент в работе. Таким образом, целью данного исследования является выявление и анализ отраслевой специфики кредитования, проводимого Госбанком в 1928-1935 гг.

Ключевым источником количественной информации о деятельности Госбанка СССР является его ежегодная отчетность, которая мало подвергалась систематическому изучению [7]. Эта отчетность является основным источником данного исследования. Опубликованные на сегодняшний день балансы Госбанка 1930-х гг. не содержат отраслевой детализации кредитов [8, с. 115-125], поэтому пришлось обратиться к отчётности банка, хранящейся в фонде Госбанка в Российской государственном архиве экономики (РГАЭ). Это ежегодные оборотные ведомости за 1928-1935 гг., один из разделов которых посвящён кредитно-расчётному обслуживанию предприятий и 
организаций [9]. Данные ведомости помимо информации об оборотах содержат интересующие нас балансовые записи.

Преобразования Госбанка начала 1930-х гг. не могли не отразиться в его отчётной документации, что обнаруживается при сопоставлении отчётов до, во время и после проведения кредитной реформы. Важной задачей становится изучение происходивших изменений и решение проблемы сопоставимости данных. В рассматриваемом периоде 1928-1935 гг. можно наблюдать три различных вида номенклатуры, в которых структура данных о кредитно-расчётных операциях претерпевает трансформацию от фиксации вида и формы операции к ведомственно-отраслевому, а затем к ведомственному принципу в чистом виде. Так как список представленной в ней клиентуры оставался в целом стабильным, то стало возможным определение таких отраслевых групп народного хозяйства, которые бы охватывали наибольшее количество статей. Совокупность из 717 балансовых записей банковской клиентуры была сгруппирована в соответствии с принципами деления отраслевых ведомств-наркоматов, сформированных к началу 1935 г. В результате были выделены следующие группы отраслей экономики: тяжёлая, лёгкая, лесная и пищевая промышленности, торговля, сельское хозяйство и заготовки, транспорт и связь, промысловая кооперации. Полученные данные представлены в Таблице 1. Данная группировка позволила нам подготовить собранные первичные данные к последующему анализу.

Таблииа 1

Баланс краткосрочных кредитов в Госбанке по отраслям (в млн руб.)*

\begin{tabular}{|l|c|c|c|c|c|c|c|c|}
\hline \multicolumn{1}{|c|}{ Отрасли } & $1928 *$ & 1929 & 1930 & 1931 & 1932 & 1933 & 1934 & 1935 \\
\hline Торговля & 447,5 & 645,1 & 2230,7 & 2573,6 & 2280,4 & 2576,4 & 4300,2 & 6071,7 \\
\hline Тяжёлая промышленность & 710,4 & 849,0 & 989,6 & 1158,6 & 740,9 & 850,8 & 1205,9 & 1818,5 \\
\hline Лесная промышленность & 225,8 & 297,9 & 769,7 & 849,3 & 908,1 & 455,1 & 651,6 & 576,3 \\
\hline Лёгкая промышленность & 665,8 & 749,1 & 587,4 & 678,2 & 572,4 & 673,3 & 844,9 & 1025,5 \\
\hline Пищевая промышленность & 400,5 & 625,6 & 1271,9 & 1502,1 & 2177,5 & 1646,3 & 2050,7 & 2358,0 \\
\hline $\begin{array}{l}\text { Сельское хозяйство, } \\
\text { заготовки }\end{array}$ & 149,7 & 417,2 & 1593,2 & 1641,9 & 2065,9 & 2664,5 & 3067,5 & 3115,2 \\
\hline Транспорт и связь & 107,5 & 44,7 & 70,6 & 119,0 & 440,7 & 436,3 & 507,0 & 567,0 \\
\hline Промысловая кооперация & 71,1 & 95,7 & 249,6 & 255,1 & 398,5 & 349,3 & 317,0 & 307,2 \\
\hline Прочее & 507,1 & 273,9 & 302,7 & 489,7 & 507,8 & 171,1 & 228,7 & 868,3 \\
\hline Всего & 3285,4 & 3998,3 & 8065,4 & 9267,3 & 10092,2 & 9823,0 & 13173,5 & 16707,7 \\
\hline
\end{tabular}

* Датой баланса является начало операционного года: 1 октября для 1928-1930 гг. и 1 января для 1931-1935 гг.

Источник: составлено автором по данным [9]. 
Проведение кредитной реформы в начале 1930 г. привело к почти двукратному увеличению баланса за счёт краткосрочных кредитов, доля которых среди других активов в 1931 г. составляла 80-85\%. Значительное увеличение выданных кредитов объясняется тем, что в самом начале реализации реформы определение объекта кредита не предполагало чёткой спецификации. Согласно положению 1930 г. по кредитованию промышленности банковский кредит должен был предоставляться для восполнения недостающих оборотных средств [10, с. 15]. Авторы реформы предполагали, что деньги и кредит будут автоматически следовать за производством товаров и услуг без активного участия Госбанка, что означало создание такой системы, при которой своевременность оплаты покупателя поставщику гарантируется банком. Однако на практике это позволило предприятиям требовать неограниченные кредиты, а поставщики были заинтересованы в реализации продукции по завышенным ценам или в поставке невостребованных товаров [4, с. 282].

На первом этапе реализации реформы в 1930 году среди прочих кредитов по Таблице 1 особо сильно заметен рост кредитования торговли (с 645,1 до 2230,7 млн рублей), что объясняется большим использованием коммерческого кредита накануне реформы именно в торговых операциях. Если кредитование промышленности консолидировалось в Госбанке уже со второй половины 1920-х гг., то в других сферах коммерческий кредит занимал доминирующее положение вплоть до своей формальной ликвидации, поэтому прирост в 1929/30 г. банковского кредита объясняется во многом за счёт роста кредитования торговли и сельского хозяйства: из 4 млрд руб. общего прироста кредитов на эти отрасли пришлось около 2,8 млрд руб.

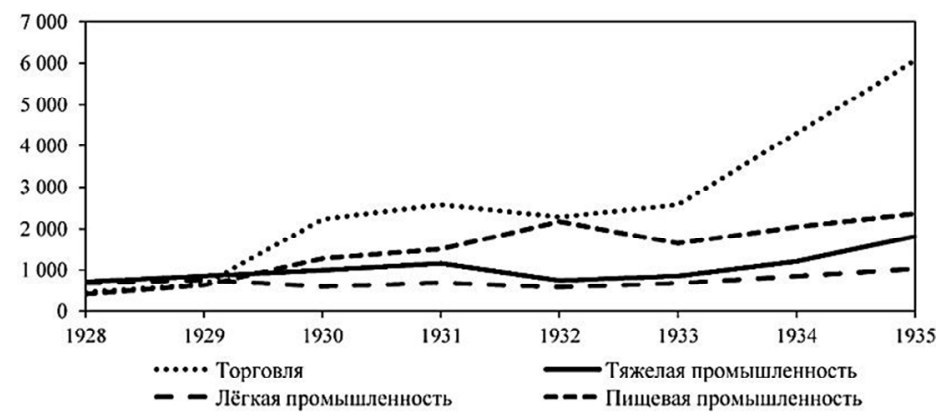

Рис. 1. Сопоставление кредитования основных отраслевых групп по балансовым данным, млн руб.

Источник: составлено по Таблице 1. 
Анализ общей структуры пассивных операций Госбанка показал, что из трех основных ресурсов банка (бюджетных средств, текущих и расчётных счетов предприятий и организаций, а также денежной эмиссии) основным источником средств в 1920-30-е гг. оставалась эмиссия [8, с. 115-125], в связи с чем увеличение кредитов определило необходимость дополнительной эмиссии. Этот эффект в сочетании с возникшей напряжённостью между покупателями и поставщиками привел к отказу от «автоматического» кредитования по плану, переходу к строгой регламентации и контролю над выдаваемыми краткосрочными ссудами [11, с. 16].

Постановление СТО от 23 июля 1931 года «Об оборотных средствах государственных объединений, трестов и других хозяйственных организаций» устанавливало объектом краткосрочного кредитования только потребности, связанные с ценностями в пути (получение кратковременной ссуды до того момента, пока покупатель не оплатит поставку), накопление сезонных запасов сырья, материалов, топлива, готовых изделий и другие временные производственные нужды. Собственные оборотные средства, размер которых определялся устанавливаемыми нормативами, должны были обеспечивать потребность в минимально необходимых запасах сырья, топлива, полуфабрикатов, готовых изделий и незавершённого производства [12, с. 206]. Отдельно оговаривались такие положения, которые, часто нарушались в практике первого года реформы, что кредит Госбанка должен являться целевым, срочным, возвратным и быть обеспеченным товарно-материальными ценностями.

Производство в большинстве отраслей тяжёлой промышленности не имело ярко выраженного сезонного характера, поэтому эти отрасли были относительно слабо затронуты банковским кредитованием. Несезонные отрасли хозяйства могли получать кредиты преимущественно на товары в пути, а свои производственные затраты и вложения в товарные запасы осуществляли в основном за счёт собственных средств. Поэтому предприятия в большей степени должны были использовать собственные оборотные средства. Это подтверждается количественными данными, представленными на рис. 1, демонстрирующими относительно небольшое количество выданных предприятиям тяжёлой промышленности краткосрочных кредитов, сумма которых за рассматриваемый период в среднем составляла 1,3 млрд руб., а доля относительно общего объема краткосрочных кредитов в пореформенный период не превышала $13 \%$.

В легкой промышленности, хотя во многом присутствовал сезонный характер, но мы видим устойчивый рост только после 
1932 г., когда стали открываться новые предприятия, выросла производительность. В 1929-1930 гг. можно наблюдать в этой сфере спад кредитов с 749,1 до 587,4 млн руб., который вероятнее всего объясняется производственными затруднениями, имевшимися в лёгкой промышленности в данный период.

Примером сильной сезонной зависимости, отразившейся на доступе к краткосрочному кредитованию, служат предприятия пищевой промышленности, а также сфера сельскохозяйственного производства и заготовок. Новые условия кредитования, принятые в 1931 г., изначально способствовали росту банковских ссуд. В результате развития старых и открытия новых предприятий производство в сфере пищевой промышленности расширялось, для чего требовалось увеличение оборотных средств. Новые правила кредитования способствовали увеличению объёма кредитования пищевой промышленности с 1502,1 до 2358 млн руб. в 1931-1935 гг., а её доля от всех краткосрочных кредитов Госбанка составляла $15-20 \%$.

Торговля, а особенно потребительская кооперация, в больших объёмах пользовалась коммерческим кредитованием, используя отсрочки платежей, авансирование, расписки, векселя, предполагавшие прямые договорённости между поставщиком и торговой организацией. В Госбанке до 1930 г. было сосредоточено кредитование государственной торговли и небольшой части потребкооперации, поэтому в результате преобразований уже в конце 1930 г., как уже отмечалось выше, можно наблюдать значительный рост банковских ссуд, предоставляемых торговле. Далее на протяжении 3 лет общий объём кредитования торговли, составляя 2,2-2,5 млрд руб., был относительно стабильным. Ключевое значение имело Постановление СНК от 16 августа 1933 года «О порядке кредитования торговых организаций», которое позволило торгующим организациям, помимо кредитования на сезонные потребности и товары в пути, получать также кредиты по товарообороту [13, с. 1]. Новый порядок кредитования предусматривал оплату товаров за счёт банковских ссуд, выдаваемых на срок плановой реализации, который определялся по средней оборачиваемости продукции. Кредит по товарообороту не имел лимита, он предоставлялся в форме подтоварных ссуд для пополнения недостатка нормы оборотных средств, а также в форме ссуд для приобретения товара сверх установленных нормативов.

На рисунке 1 наглядно представлен рост кредитования торговли, вызванный данным постановлением. В результате введения нового порядка кредитования сумма кредитов, выданных торговым органи- 
зациям, увеличилась с 2,6 млрд руб. в начале 1933 г. до 6,1 млрд руб. на 1 января 1935 г.

После введения новой системы кредитования происходит снижение роли государственной промышленности в структуре активной части банковского баланса. По данным таблицы 1 можно увидеть, что к началу 1935 г. кредитование торговли занимало $35 \%$ от суммы всего краткосрочного кредита. Однако внутри государственной промышленности, ввиду изменения условий кредитования, доля кредита тяжёлой промышленности, хотя и превосходила долю легкой, но уступала предприятиям пищевой промышленности. Предполагается, что новая система краткосрочного кредита должна была способствовать развитию потребительского сектора экономики, что встраивается в общую картину развития экономики СССР к середине 1930-х гг.

Советские исследователи изначально ограничивали реформу рамками 1930-1931 гг., позднее в науке установился период реформы как 1930-1932 гг. Однако, хотя основное ядро преобразований в виде централизации кредитно-расчётных отношений в Госбанке было проведено в самом начале, важные изменения в банковской системе происходили на протяжении десятилетия, вплоть до начала войны. Они были продиктованы изменениями в экономике СССР, развитие и расширение которой требовало постоянной «подгонки» кредитно-расчётной системы под конкретные задачи.

Таким образом, Госбанком были установлены определённые правила, регулирующие объекты и цели кредитования, кредитные лимиты, предприятиям были предоставлены собственные оборотные средства. Все это должно было ограничивать объемы отраслевого кредитования, а, следовательно, кредитной эмиссии. Этот механизм контроля эмиссии находился «в руках» Госбанка, от которого зависел доступ отраслей к заемным ресурсам. В то же время для дальнейшей работы важно понимать, что номинальные изменения в объемах банковского кредитования могло отражать не изменение реальной потребности предприятий в заёмных средствах, а быть следствием изменений в правилах кредитования, поэтому при анализе отраслевого кредитования в СССР необходимо уделять особое внимание институциональной стороне банковского регулирования.

\section{Библиография}

1. Атлас М.С. Кредитная реформа в СССР. - М.: Госфиниздат, 1952. - 228 с.

2. История Банка России, 1860-2010: в 2 т. / Отв. ред. Петров Ю.А., Татаринов С.В. - Т. 2: Государственный банк СССР. Центральный банк Российской Федерации (Банк России). - М.: РОССПЭН, 2010. - 679 с. 
3. Уразова С.А. Особенности и значение кредитной реформы 1930-1932 годов // Деньги и кредит. - 2011. - № 4. - С. 58-63.

4. Грегори П. Политическая экономия сталинизма [пер. с англ. И. Кузнецова, А. Маркевича]. - М.: РОССПЭН, 2006. -398 с.

5. Nakamura Y. Did the Soviet Command Economy Command Money? A Quantitative Analysis // Europe-Asia Studies. Vol. 63. - 2011. - № 7. - P. 1133-1156.

6. Кочеврин Ю.Б. Финансовые реформы 1930-х гг. и их последствия для развития денежной системы СССР // Экономическая история: Ежегодник. - М.: ИРИ РАН, 2012. C. 381-428.

7. Nakamura Y. Soviet Banking, 1922-1987: An Analysis of Gosbank Balance Sheets // Comparative Economic Studies. Vol. 55. - 2013. - P. 167-197.

8. По страницам архивных фондов Центрального банка Российской Федерации. Выпуск 9. Балансы Государственного банка СССР (1922-1990 гг.) / Сост. Ю.И. Кашин, В.В. Миков. Науч. ред. Ю.И. Кашин. - Москва, 2010. - 164 с.

9. Сводные оборотные ведомости Госбанка СССР за 1928-1935 гг. // Российский государственный архив экономики (РГАЭ). Фонд 2324. Опись 20. Д. 963. Л. 35; Д. 965. Л. 12; Д. 966. Л. 29-31; Д. 968. Л. 29-31; Д. 973. Л. 30.

10. Сборник положений и инструкций по кредитной реформе. - Москва, 1930. $88 \mathrm{c}$.

11. По страницам архивных фондов Центрального банка Российской Федерации. Выпуск 16. Из неопубликованного (ведомственные материалы) / Сост. Ю.И. Кашин, Т.В. Козлова. Науч. ред. Ю.И. Кашин. - Москва, 2014. - 183 с.

12. Денежное обращение и кредит СССР. - М.: Госфиниздат, 1947. -420 с.

13. Инструкция о кредитовании торговых организаций по товарообороту на основе постановления Совнаркома СССР от 16 августа 1933 г. - Астрахань, 1933. - 23 с.

https://doi.org/10.29003/m1783.978-5-317-06529-4/13-21

Акашева А.A.

Национальный исследовательский Нижегородский государственный университет им. Н.И. Лобачевского

Земельная аренда как фактор модернизации пореформенного города. На примере Нижнего Новгорода 1860-1910-х гг.

Аннотация. Поставлена проблема изучения цен, площадей, количества арендаторов, длительности аренды земли для производства строительных материалов - красного кирпича и распилованного леса в Нижнем Новгороде на длительном промежутке времени. Исходные временные ряды в текущих ценах были дефлированы. Проведен первичный анализ динамики. Выявлены три этапа развития процессов земельной аренды. Сделан вывод о невысоких темпах городской модернизации. Исследование сопровождается онлайновыми электронными таблицами, где размещены исходные данные, приведены расчеты и графики.

Ключевые слова: историческая урбанистика, модернизация, временные ряды, цены, земля, аренда, Нижний Новгород. 
Akasheva A.A.

Lobachevsky National Research StateUniversity of Nizhny Novgorod

\title{
Land rent as a factor in the modernization of the post-reform city. On the example of Nizhny Novgorod 1860-1910s
}

\begin{abstract}
The problem of studying prices, areas, the number of tenants, and the duration of land lease for the production of building materials - red bricks and sawn wood in Nizhny Novgorod over a long period of time is posed. The original time series in current prices were deflated. A primary analysis of the dynamics was carried out. Three stages of development of land lease processes are identified. The conclusion is made about low rates of urban modernization. The study is accompanied by online spreadsheets containing the source data, calculations and graphs.

Keywords: historical urbanism, modernization, time series, prices, land, rent, Nizhny Novgorod.
\end{abstract}

\section{Постановка проблемы и цель исследования}

Во второй половине XIX в. происходит активная модернизация городской экономики Российской империи. Власти старались изыскать новые источники доходов для своих касс, а также пересмотреть подходы к управлению землями. Как итог, накануне революционных преобразований 1917 г. большие города существенно расширили возможности использования своих земель в предместьях, которые в дореформенный период использовались преимущественно по своему главному назначению - для выпаса скота, сенокошения и хлебопашества. К началу ХX в. эти выгонные территории стали активно застраиваться жилыми кварталами, обрастать крупными промышленными предприятиями и складами, объектами инженерной инфраструктуры, транспортными коммуникациями, использоваться под дачные поселки. При этом, однако, необходимо отметить низкую эффективность управления «земельными» богатствами города в силу разных причин.

В настоящее время исследователями городской жизни России сделано уже немало для понимания общих тенденций развития муниципального земельного фонда страны [1]. Среди многочисленных результатов исследований отметим некоторые. Так, разработана функционально-типологическая классификация выгонных (пригородных) земель городов Томской губернии [2]. Показано развитие околоселитебных территорий Москвы [3]. С использованием ГИСтехнологий дана экспертная оценка антропогенного воздействия на экологию предместий Барнаула [4].

Вместе с тем, в основе приведенных выше примеров развития конкретных городов лежали доходы, получаемые от земельной 
аренды. Проблема городской аренды как таковой с ее характеристиками цены и стоимости, длительности, размерами участков, сменой владельцев не становилась предметом специального изучения историков. Это верно как для историографии по Нижнему Новгороду, так и по другим городам России. Причина заключается в трудоемкости сбора «микроданных» ${ }^{1}$ из опубликованных и архивных источников и последующей их обработки. Мы попытались преодолеть эту проблему, собрав сведения по каждому участку, и на примере восстановленных ежегодных показателей об аренде земель для производства строительных материалов - красного кирпича и распилованного леса в Нижнем Новгороде проанализировали земельно-арендную статистику. В рамках настоящего доклада мы представим результаты первого этапа исследования - дефлированные ряды и первичные показатели их динамики.

\section{Источники}

Источниками исследования послужили архивные дела о сдаче в аренду конкретных земельных участков, бухгалтерские книги, учитывавшие взносы арендаторов, и хранящиеся в фонде Нижегородской городской управы (Ф.30, Центральный архив Нижегородской области), а также опубликованные протоколы заседаний Нижегородской городской думы, из которых мы выбирали вопросы, посвященные соответствующим оброчным статьям².

\section{Хронологические рамки}

Хронологический срез, на который удалось восстановить арендную статистику, включает пятьдесят пять лет с 1859 по 1914 г. для кирпичных заводов и сорок лет с 1870 по 1910 г. для лесных

\footnotetext{
${ }^{1}$ Имеются ввиду первичные, неагрегированные значения по каждому, пусть даже маленькому участку земли. В этом случае трактовка наших «микроданных» отличается, например, от трактовки, которую дали создатели pecypca «Integrated Public Use Microdata Series» (IPUMS, https://ipums.org) историко-демографическим показателям, представлявшим собой обобщенные, агрегированные значения из переписей.

${ }^{2}$ Оброчными статьями применительно к городу назывались сдаваемые в аренду (оброк) с торгов на определенный срок его движимые и недвижимые имущества с целью извлечения дохода, т.е. под оброчными статьями в данном случае подразумевается сдача участков под кирпичную выделку и обработку древесины.
} 
складов ${ }^{3}$. «ирпичный» ряд представляет 51 уровень, т.е. ряд практически ежегодный; «лесной» - 35 уровней. Часть пропусков связана с тем, что мы работали с т.н. естественной выборкой значений, дошедших до нас, другая часть - с невозможностью работать пока в библиотеках и архивах, пропуски последнего рода вполне устранимы в будущем. Нижняя хронологическая граница по «кирпичной» статистике - 1859 г. - связана с самыми ранними имеющими у нас данными, начиная с которых можно восстановить ежегодный ряд значений. По «лесной» статистике нижняя граница исследования остановилась на 1870 г., т.к. именно с этого момента лесные склады по решению нижегородской думы были перенесены с пристаней города в специально отведенное место на выгоне, где и занимались прежде всего промышленной обработкой привезенного леса для продажи, а не столько его хранением. Верхняя граница исследования в обоих случаях совпадает с обработанными на сегодняшний день материалами источников.

\section{Дефляторы}

Известно, что в отечественной экономической истории отсутствуют ряды дефляторов для многих видов товаров [5], это справедливо и к ценам на аренду земли в городах. Мы постарались «погасить» влияние инфляции следующим образом. Текущие цены, взятые из источников, были пересчитаны в постоянные цены: за 1859-1899 гг. в соответствии с курсом кредитного рубля к золотому рублю [6], и за 1900-1914 гг. в соответствии с индексом цен С.П. Боброва на оптовые товары [6]. Мы остановились на индексах оптовых, а не розничных цен, т.к., безусловно, по природе своей кирпич и распилованный лес являлись оптовой продукцией, цена на который формировалась исходя из тысячи и ста штук соответственно. Цены на этот «результат» аренды, естественно, сильно влияли на цены при сдаче земли на очередной срок, следовательно, так мы сможем в какой-то степени скорректировать и арендные земельные цены. Среди оптовых индексов был выбран коэффициент С.П. Боброва, т.к. он приводится одновременно для кредитного и золотого рубля, т.о., у нас есть возможность рассчитать курс рубля до конца изучаемого нами периода, продлив его с 1899 г. Кроме того, индекс, ориентированный на грузоперевозки страны, более чувствителен к одному из товаров - лесу, который являлся полностью привозным.

\footnotetext{
3 Лесные склады или дворы - производственно-складские помещения, где хранился лес и производилась его распиловка на специальных машинах, оборудованных двигателями, на доски и брус для строительных нужд.
} 


\section{Электронные данные}

Bce данные доступны в формате электронных таблиц MS Excel (.xlsx) по https://yadi.sk/d/qvo6jCQdScGb-g. В качестве объекта учета был выбран земельный участок, арендованный под кирпичное производство / лесообработку. Получившиеся ряды включают пять показателей:

1) цена аренды за квадратную сажень (среднее);

2) длительность аренды (среднее);

3) площадь арендованного участка (среднее);

4) общая площадь арендованных земель под кирпичную и лесную аренду в конкретном году (суммарное);

5) количество арендаторов (суммарное).

Кроме того, для «кирпичной» аренды приводятся отрывочные сведения, начиная с 1894 г., о рыночной и заготовительной цене кирпича. Для лесных материалов таких данных нет, т.к. в источниках, которые попали в поле нашего зрения, эта информация никак не фиксировалась.

Все ценовые показатели представлены в постоянных ценах, но по нажатию на ячейку открывается формула, из которой можно узнать исходные данные в текущих ценах, взятые непосредственно из источников. Если же выбрать любую ячейку из столбца со средними или общими площадями участков, то в строке формул будут показаны размеры всех участков, арендованных в данном году.

Отметим, что созданные таблицы не претендуют на полноценный цифровой ресурс в области исторической статистики и приведены в открытом доступе в качестве технического сопровождения исследования, как это было сделано, например, Томасом Пикетти при написании им «Капитала в XXI веке» (Tomas Piketty) [7].

\section{Содержательные результаты исследования ${ }^{4}$}

\section{Цена аренды}

Предваряя анализ, скажем, что для всех изучаемых показателей (цена, площади, длительность, арендаторы) исходя из визуального анализа графиков были выделены три этапа развития процесса и рассчитаны средние величины. Ознакомиться с ними можно в приложен-

\footnotetext{
4 В случаях с ценой и площадью аренды под кирпичные заводы в расчетах и визуализации пришлось отказаться от последнего значения ряда за 1914 г., т.к. он создавал сильные выборы в значениях, мешавших интерпретации данных.
} 
ных к докладу электронных таблицах на вкладке «индексы_графики». Ниже приводятся средние значения для всего ряда в целом.

Средний абсолютный прирост по обеим видам аренды был невысоким, 3 копейки на каждый изучаемый уровень ряда. По нашим примерным оценкам, дешевле $(0,01$ руб.) стоила только аренда земли для занятий сельским хозяйством - хлебопашеством, сенокошением, животноводством, огородничеством.

Визуальный анализ графиков средних цен показал следующие закономерности: виден плавный рост цен для кирпичной выделки с 1859 до 1894 г., после указанного года и до конца периода фиксируется сильный подъем с постоянными выраженными колебания; поведение «лесной» аренды схоже, но период колебаний начался раньше, с 1883 г., он был менее выраженным, а с 1900 г. стабилизировался. В целом, выделяются две реперных точки - 1880-1890 гг. и 1900 г., которые разграничивали три этапа развития процессов аренды.

В обоих случаях проявилась положительная динамика роста цен, но значительнее она оказалась для земли, арендуемой лесными заводчиками, здесь средний темп роста составил 107\% в то время, как для кирпичной аренды $103 \%$, соответственно, средний годовой темп прироста остановился на 7\% и на 3\%. Отметим, что при этом среди абсолютных значений в текущих ценах наибольшие ежегодные вариации наблюдались у кирпичезаводчиков - арендные цены соседних участков могли отличаться друг от друга в три раза.

В итоге, оба ряда свидетельствуют об изменении ценовой политики нижегородской городской управы - до 1880-1890-х гг. она не вмешивалась в торги на землю, предоставляя арендаторам свободно соревноваться в выкупе оброчных статей и цены росли медленно; после указанного десятилетия управа с одобрения думы «назначает» цены. Роль торгов сводится на нет, арендаторы уходят на соседние с городом уездные земли, где крестьяне сдают им участки в три раза дешевле.

\section{Площзадь участков}

Средний абсолютный прирост площадей свидетельствует об уменьшении участков, сданных под лесные склады и увеличении участков под кирпичными заводами, показатели составили 15 кв. саж. и 73 кв. сажени соответственно. Это объяснимо спецификой производственной деятельности каждого из видов аренды - кирпичное производство базировалось на разработке местной глины и требовало больших участков земли, а распиловка леса, привозимого в город, не нуждалась в этом. Если сравнить средние темпы прироста, то 
площадь лесных складов сократилась на 2\% за изучаемый период, а кирпичных заводов возросла всего на $1 \%$, хотя масштаб каменного строительства в городе возрастал. Сокращение «лесных» арендных площадей и непринципиальное увеличение «кирпичных» можно объяснить тем, что власти создали муниципальные общегородские лесные склады и кирпичные заводы, с которых стройматериалы централизованно продавались жителям и использовались для городских нужд. Несмотря на это, потребность в кирпиче не могла полностью удовлетвориться за счет муниципальных предприятий и частные оброчные статьи все равно оставались значимы в земельной аренде Нижнего Новгорода.

\section{Длительность арендьь}

Как и в случаях с предыдущими параметрами, длительность земельной аренды под лесные склады была менее вариативной, чем под разработку глины на кирпич. Но в обоих случаях за вторую половину XIX в. длительность волнообразно снижалась с 12 лет до одного года, отражая переход от дореформенной долгосрочной аренды к краткосрочной, позволявшей чаще повышать цену управе и учитывавшей экономическую конъюнктуру. Выявленная тенденция очень хорошо описывается значением среднего темпа прироста: для «кирпичной» аренды он снизился на 5\% по сравнению с начальным уровнем ряда, для «лесной» на 2\%. Длительность явилась параметром, наиболее тесно связывавшем два вида аренды, если построить линейные тренды, то буквально сливаются в конце изучаемого периода в одну прямую.

\section{Количество арендаторов}

Сокращается и круг арендаторов-предпринимателей, которые участвовали в торгах. Снижение было заметнее среди лесных заводчиков (средний темп роста 0,96$)$, чем среди «кирпичников» $(0,99)$. Как было объяснено выше, они уходили на соседние с городом уездные земли, где аренда была втрое дешевле. В 1874 г. наблюдалось пиковое значение кирпичезаводчиков, когда одновременно на городском выгоне действовало 12 заводов, для лесных заводчиков пик пришелся на 1889 г., когда лесообработкой занимались 16 арендаторов. Наиболее подходящей моделью для выделения тренда явились полиномиальные модели.

Число арендаторов было обратно пропорционально длительности аренды и площади. Думается, что это связано с периодами введения в действие новых планов застройки города, когда разворачи- 
валось строительство новых жилых кварталов. Впрочем, эта идея должна быть подтверждена на базе привлечения дополнительных материалов. Динамика этих показателей была циклична, судя по визуальному анализу.

\section{Выводы}

Фактор - движущая сила какого-либо процесса. Земельная аренда как фактор модернизации русского города должен был откликаться на расширение каменной застройки и в целом на увеличением темпов строительства, проявившись в (1) увеличении цены арендуемого участка, (2) увеличении средней площади одного участка, (3) в росте количества арендаторов, (4) в интенсификации производства, (5) увеличении объемов производимых стройматериалов. Использованные источники позволили нам проследить изменения на длительном отрезке времени только для первых трех параметров. Их анализ выявил рост цен, неоднозначную динамику площадей, сокращение числа арендаторов и длительности аренды. Значи ли это, что аренда предместий показала отсутствие модернизации экономической и градостроительной сферы Нижнего Новгорода? Безусловно, нет город модернизировался, но скорость изменений оказалась не столь высокой, как представлялось изначально. Кроме того, выявилась специфика процесса - власти вмешивались в ценообразование на рынке аренды, а также город постепенно переходил к созданию муниципальных заводов.

\section{Библиография}

1. Дегтярев Д.С. Пригородные зоны городов Томской губернии во второй половине XIX - ХХ в. - Барнаул: Азбука, 2012. - 176 с.

2. Кошман, Л.В. Город и городская жизнь в России в ХІХ столетии. - М: Росспэн, 2008. -448 с.

3. Владимиров В.Н., Крупочкин Е.П., Сарафанов Д.Е. Опыт разработки предметно-ориентированной исторической ГИС (на примере инфраструктуры Барнаула конца XVIII - начала XX вв.) // Историческая информатика. - 2020. - № 1. - С. 66-80. - DOI: 10.7256/2585-7797.2020.1.32091. - URL: https://nbpublish.com/library_read_article. php ?id=32091 (дата обращения: 23.08.2020).

4. Акашева А.А. Земли русских городов во второй половине XIX - начале $\mathrm{XX}$ вв. Историография вопроса // Актуальные проблемы исторической науки. - 2011. № 8. - C. 145-151. - URL: https://www.academia.edu/22039943/Земли_русских_городов _во_второй_половине_XIX_начале_XX_вв_Историография_вопроса (дата обращения: $\overline{2} 3 . \overline{08} .2020)$.

5. Валетов Т.Я. Структура экспорта Российской империи по ежегодникам внешней торговли 1802-1915 гг. // Электронный научно-образовательный журнал «История». - 2017. - Т. 8. - № 7(61). - Абзац 68. - 10.18254/S0001954-8-1. - DOI: 10.18254/S0001954-8-1. - URL: http://www.hist.msu.ru/Dynamics/data/Valetov_ENOJ 2017.pdf (дата обращения: 23.08.2020). 
6. Динамика экономического и социального развития России в XIX - начале XX в.: тематический электронный ресурс. - URL: http://www.hist.msu.ru/Dynamics/ (дата обращения: 18.08.2020).

7. Le capital au 21e siècle / Thomas Piketty; Paris School of Economics. - URL: http://piketty.pse.ens.fr/fr/capital21c (дата обращения: 23.08.2020).

https://doi.org/10.29003/m1784.978-5-317-06529-4/21-25

Баканов С.A.

Челябинский государственный университет

\section{Электронная база данных «Государственный бюджет СССР в 1950-1980-е гг.»: особенности создания и анализа ${ }^{1}$}

Аннотация. Электронная база данных «Государственный бюджет СССР в 1950-1980-е гг.» конструировалась и наполнялась на основе официальных сведений о бюджетной системе СССР, опубликованных Министерством финансов СССР в специальных статистических сборниках. База представляет собой две электронные таблицы Excel созданные отдельно по государственным доходам и расходам. Наличие ежегодных данных позволяет осуществлять необходимые статистические расчеты на длительных исторических интервалах.

Ключевые слова: история финансов, государственный бюджет СССР, электронная база данных, советская экономика в 1950-1980-е гг.

Bakanov S.A. Chelyabinsk State University

\section{Electronic database "State budget of the USSR in the 1950s-1980s": features of creation and analysis}

Abstract. Electronic database "State budget of the USSR in the 1950s1980s" was designed and filled on the basis of official information about the budgetary system of the USSR, published by the Ministry of Finance of the USSR in special statistical compilations. The database consists of two Excel spreadsheets created separately for government revenues and expenditures. The availability of annual data allows you to carry out the necessary statistical calculations over long historical intervals.

Keywords: History of Finance, USSR State Budget, Electronic Database, Soviet Economy in 1950-1980-s

История советских финансов второй половины XX века остается относительно слабо изученной темой. Основной интерес исследова-

\footnotetext{
${ }^{1}$ Статья подготовлена при финансовой поддержке РФФИ. Проект № 20-0900175 «Городские бюджеты, межбюджетные отношения и бюджетное неравенство в СССР в 1950-1980-е гг.».
} 
телей вызывают более ранние периоды: 1920-е гг., когда происходило складывание бюджетной системы СССР; 1930-е гг., когда эта система переформатировалась под нужды ускоренной индустриализации; 1940-е гг., когда она была испытана на прочность трудностями военного и послевоенного времени. Из всего сорокалетнего периода «позднего СССР» определенное внимание привлекал лишь бюджетный кризис конца 1980-х гг. Между тем, 1950-1980-е гг. были для финансовой истории СССР не менее интересным и значимым временем, когда осуществлялся переход от сталинской мобилизационной экономики к более децентрализованному варианту командно-административной системы. И на этом пути Советский Союз пережил несколько крупных хозяйственных реформ и несколько смен курса экономической политики, зачастую противоречивших друг другу. Однако сквозных исследований, охватывающих эти четыре десятилетия так до сих пор и не появилось ни в рамках исторической, ни в рамках экономической науки. Поэтому одной из основных целей реализуемого автором проекта было построение непрерывных и сопоставимых рядов данных о состоянии государственного бюджета СССР для их последующего анализа. Наиболее удобным способом формализации такой информации было выбрано создание базы данных на основе электронных таблиц Excel. База «Государственный бюджет СССР в 1950-1980-е гг.» конструировалась в виде двух самостоятельных таблиц, отдельных для доходной и расходной частей бюджета. Собранные данные охватывают период с 1950 по 1989 гг. Таблица по доходам включает в себя 26 объемных показателей, выраженных абсолютными значениями в млн. руб. и 18 расчетных показателей, выраженных относительными величинами в процентах. Таблица по расходам включает 42 объемных показателей, выраженных абсолютными значениями в млн. руб. и 18 расчетных показателей, выраженных относительными величинами в процентах. Общее количество записей в базе приближается к 4000. При конструировании базы учитывалась необходимость решения проблем непрерывности и сопоставимости данных.

История советских финансов 1950-1980-х гг. достаточно хорошо обеспечена опубликованными статистическими источниками. В первую очередь речь идет о статистических сборниках «Государственный бюджет СССР и бюджеты союзных республик», издаваемых Министерством финансов СССР на протяжении всего рассматриваемого периода [1-8]. Данные сборники обычно агрегировали материалы официальной статистики за истекшую пятилетку, иногда с сопровождением сравнительных данных за другие предшествующие годы. 
Единственным периодом, по которому самостоятельный статистический сборник не издавался была вторая половина 1950-х гг., когда правительство осуществило эксперимент с переходом от пятилетнего к семилетнему планированию. Отчасти этот пробел закрывается данными о государственном бюджете, приведенными в сборниках серии «Народное хозяйство СССР» за отдельные годы [9-10]. Степень полноты информации о бюджетной системе СССР в этой серии существенно ниже чем в специализированных сборниках, указанных выше, но, все же достаточна для конструирования некоторых финансовых показателей. Таким образом, имеющиеся источники позволили построить непрерывные ряды данных по целому ряду показателей, характеризующих состояние государственного бюджета СССР и входящих в него союзных республик.

Важнейшими показателями доходной части бюджета являются общий размер доходов государственного бюджета СССР и размеры доходов его структурных частей, таких как бюджет союза, находящийся в распоряжении союзных властей, бюджеты союзных республик, которыми распоряжались республиканские власти и суммарные доходы местных бюджетов. Вычисление соотношения пропорций в распределении доходов между различными уровнями бюджетов в отдельные исторические периоды способно продемонстрировать изменения вектора государственной бюджетной политики. Самостоятельную ценность представляют показатели, характеризующие структуру государственных доходов и их распределение между уровнями бюджетной системы. Среди них: объем собираемого налога с оборота, отчисления с прибыли предприятий, размер подоходного налога с колхозов, кооперативов и общественных организаций, налоги с населения, местные налоги и сборы, государственные займы, средства фонда социального страхования, таможенный доход, лесной доход, доходы от внешнеэкономической деятельности и др.

Основными показателями, характеризующими государственные расходы, стали: общий размер расходов государственного бюджета СССР и его структурных частей - бюджета союза, республиканских и местных бюджетов. А также показатели, раскрывающие структуру государственных расходов, такие как: расходы на народное хозяйство, в том числе на содержание и развитие системы ЖКХ; расходы на социально-культурные мероприятия, в том числе расходы на образование, здравоохранение, культуру; расходы на социальное обеспечение, расходы на оборону, расходы на государственное управление, расходы на науку и др. Отдельно в таблице по расходам базы 
данных приводятся сведения об объемах расходования средств через бюджеты каждой из союзных республик.

Определенную сложность при создании электронной базы данных вызвала проблема сопоставимости данных, которая проявилась в нескольких ракурсах. Во-первых, - это изменение бюджетного законодательства, произошедшее на рубеже 1950-1960-х гг., которое несколько изменило структуру государственного бюджета, поэтому некоторые статьи доходной и расходной частей бюджета в сборниках были перемещены из одной укрупненной категории в другую и при создании базы приходилось это учитывать. Во-вторых, - это изменения в бюджетной системе, произошедшие в 1990-1991 гг. которые привели к появлению множества новых статей доходов и направлений расходов, что вынудило ограничить верхнюю хронологическую границу базы 1989 г. В-третьих, - это денежная реформа 1961 г., изменившая номинальную стоимость национальной валюты. Поэтому при построении непрерывных данных приходилась пересчитывать данные за 1950-е гг. в постоянных ценах 1961 г. И, наконец, вчетвертых, - это то, что составители статистических сборников, лежащих в основе базы данных, были ограничены в возможностях опубликования ряда показателей, считавшихся секретными или имевшими гриф для служебного пользования. Причем в отдельные периоды в эту категорию могли попадать разные источники доходов или направления расходов. Поэтому в базе некоторые статьи присутствуют только в локальные хронологические периоды и сквозных данных по ним нет.

К материалам, собранным в электронной базе данных применялись методы статистического анализа динамических рядов, которые позволили выявить периоды наиболее интенсивных изменений государственных доходов и расходов. Так, среднегодовой темп прироста доходов государственного бюджета в 1950-1980-е гг. находился на уровне около $6,5 \%$, с колебаниями от 2 до $11 \%$ в отдельные годы. Основными источниками дохода были: налог с оборота и отчисления от прибыли предприятий. Роль налогов с населения в формировании советского государственного бюджета была довольно скромной. Они приносили бюджету только от 7 до 9\% всех доходов. Пропорционально доходам росли и государственные расходы. Среди них важнейшую роль играли расходы на народное хозяйство, составлявшие около половины всех государственных расходов, а также расходы на социально-культурные мероприятия. Большую часть исследуемого периода баланс между доходами и расходами бюджета был положительным, однако, во второй половине 1980-х гг. из-за 
неблагоприятной внешнеэкономической конъюнктуры, сокращения поступлений от налога с оборота алкогольной продукции, роста непредвиденных расходов на ликвидацию последствий катастроф в Чернобыле и Спитаке, сохранения высоких военных расходов, а также из-за попыток правительства пересмотреть размер отчислений от прибыли предприятий, этот баланс был нарушен. Что в свою очередь привело страну к острому бюджетному кризису и последовавшему за ним коллапсу.

\section{Список источников}

1. Государственный бюджет СССР за четвертую и пятую пятилетки (1946-1950 и 1951-1955 гг.) Статистический сборник. Ленинград, 1956.

2. Государственный бюджет СССР и бюджеты союзных республик. Статистический сборник. М., 1966.

3. Государственный бюджет СССР и бюджеты союзных республик 19661970 гг. Статистический сборник. М., 1972.

4. Государственный бюджет СССР и бюджеты союзных республик 19711975 гг. Статистический сборник. М., 1976.

5. Государственный бюджет СССР и бюджеты союзных республик 19761980 гг. Статистический сборник. М., 1982.

6. Государственный бюджет СССР. 1981 - 1985 гг.: Статистический сборник. M., 1987.

8. Государственный бюджет СССР. 1988: Краткий статистический сборник. М., 1988. 1990.

9. Государственный бюджет СССР. 1990: Краткий статистический сборник. М.,

10. Народное хозяйство СССР в 1958 году. Статистический ежегодник. М., 1959.

11. Народное хозяйство СССР в 1959 году. Статистический ежегодник. М., 1960.

https://doi.org/10.29003/m1785.978-5-317-06529-4/25-32

Воронкова Д.С.

Московский государственный университет имени М.В. Ломоносова

\section{Сравнительный анализ тематики публикаций журнала «Вестник финансов, промышленности и торговли» за 1913 и 1917 гг.}

Аннотация. Отражение экономической ситуации в 1913 и 1917 гг. на страницах официального печатного органа Министерства финансов «Вестника финансов, промышленности и торговли» может быть интересно и историкам, и экономистам. Журнал является ценным источником по широкому кругу проблем отечественной экономической истории. В статье проводится сравнительный тематический анализ материалов журнала с использо- 
ванием количественных методов. Для этого автор опирается, в том числе, на ежеквартальные «Систематические перечни статей» и библиографическую базу данных, созданную в НГУ в 2005 г. Лучше всего представить изменения в приоритетах редакционной политики журнала позволяет обращение к поквартальной динамике тематики аналитических статей и сообщений.

Ключевые слова: количественные методы, 1913 год, 1917 год, «Вестник финансов», рубрики, тематические категории, динамика.

Voronkova D.S. Lomonosov Moscow State University

\title{
Comparative analysis of the topics of publications of the journal «Bulletin of Finance, Industry and Trade» for 1913 and 1917
}

\begin{abstract}
The reflection of the economic situation in 1913 and 1917 in the official press organ of the Ministry of Finance - «Bulletin of Finance, industry and trade» may be interesting to both historians and economists. The journal is a valuable source on a wide range of issues in Russian economic history. The article provides a comparative thematic analysis of the journal materials using quantitative methods. For this purpose, the author relies, among other things, on the quarterly "Systematic lists of articles" and the bibliographic database created at NSU in 2005. The best way to present changes in the priorities of the editorial policy of the journal is to refer to the quarterly dynamics of the topics of analytical articles and reports.
\end{abstract}

Keywords: quantitative methods, 1913, 1917, «Vestnik of Finance», thematic categories, dynamics.

Данная работа посвящена количественному анализу содержания официального печатного органа Министерства финансов Российской империи - журнала «Вестник финансов, промышленности и торговли», на страницах которого находила отражение экономическая ситуация в стране. Для анализа выбраны 1913 и 1917 годы, каждый посвоему, переломные в отечественной истории. Первый - прежде всего, как последний мирный год перед Первой мировой войной, а второй как год, в котором (на фоне продолжавшейся войны) произошли коренные общественно-политические изменения, оказавшие влияние на последующее развитие не только России, но и мира. Контраст между названными годами во многом очевиден сам по себе, но особенно разителен в экономической сфере. В связи с этим интересно привлечь в качестве источника историческую прессу и наметить некоторые тенденции отражения проблем экономики на её страницах.

Еженедельный журнал «Вестник финансов, промышленности и торговли» начал издаваться по инициативе министра финансов Н.Х. Бунге (1823-1895, министр с 06.05.1881 по 31.12.1886) взамен 
«Указателя правительственных распоряжений по Министерству финансов», который выходил в Петербурге в 1865-1884 гг. (последний редактор «Указателя...» А.К. Веселовский стал первым редактором «Вестника...»). Причём преемственность по отношению к «Указателю...» чётко декларировалась на протяжении всего периода существования «Вестника...». Например, в номерах за 1913 г. можно встретить слова «XXX год издания», а 1917 г. аналогично считался тридцать четвёртым (он же стал годом прекращения издания «Вестника...»). Из-за этого по сей день существует путаница: в различных библиографических указателях по-разному написан год начала издания «Вестника...»- 1883 или 1885. Редакционная политика журнала не ограничивалась возложенной на него Министерством финансов обязанностью публикации справочных материалов; журнал предлагал читателям и серьёзные аналитические статьи известных экономистов и статистиков.

В статье представлены некоторые результаты сравнительного тематического анализа номеров журнала за 1913 и 1917 гг. соответственно. Необходимо отметить, что в 1913 г. вышло 52 номера, а в 1917 г. - только 43, после чего журнал прекратил существование. Корректность сравнения различных по объёму текстовых массивов обеспечивается единством принципа анализа - и для 1913, и для 1917 г. были отобраны те материалы (аналитические статьи и сообщения), частота встречаемости категорий которых суммарно за год не меньше $4 \%$.

Для построения системы семантических категорий анализа в данной работе использовались «Систематические перечни статей», которые публиковались в журнале в конце каждого квартала. «Систематические перечни статей» классифицируют публикации по двухуровневой системе тематических рубрик. Нами используется также база данных «Вестник финансов, промышленности и торговли» 1917 г.», разработанная А.К. Кирилловым и В.С. Терентьевым в 2005 г. [1] Для этой базы данных разработана система разделов, подразделов и ключевых слов, в основном повторяющих систему рубрик «Систематических перечней». Рубрикация этой базы данных использовалась нами в работе с выпусками №№ 27-43 1917 года, для которых, в связи с закрытием журнала, нет «Систематических перечней». Эта же рубрикация с некоторыми изменениями используется для анализа номеров «Вестника...» за 1913 г. В ходе работы нами проанализирован каждый из 52 номеров «Вестника...» за 1913 г., для каждой статьи выделены ключевые слова и определена тематическая 
категория (некоторые статьи принадлежат одновременно нескольким категориям).

Отметим, что в структуре журнала отводится заметное место публикациям в разделе «Статистика» статистических таблиц: «Балансы главнейших эмиссионных банков», «Вексельные курсы», а также сведений по операции страхования доходов и капиталов в государственных сберегательных кассах и предварительных кассовых сведений о государственных доходах и расходах за определенные периоды. Эти публикации являются не аналитическими или обзорными, а чисто информационными. Значительное место занимает также раздел «Статистика», где регулярно приводится много таблиц в рубрике «Сельское хозяйство, промышленность и торговля», например, таблиц «Обороты чисто-рафинадных заводов за период ...», «Обороты песочных и песочно-рафинадных заводов за период ...», а также менее регулярных сведений о состоянии свекловичных плантаций и результатах сахароварения. Поэтому было решено включить в анализ только аналитические материалы (статьи и сообщения); по ним и формировались тематические категории.

Сравним специфику тематики материалов «Вестника...» по каждому году в целом, представленную в табл. 1 и 2.

\section{Распределение тематических категорий по частоте встречаемости в 1913 году}

\begin{tabular}{|l|c|c|}
\hline \multicolumn{1}{|c|}{ Категория } & Частота & \% \\
\hline Торговля & 40 & 12,6 \\
\hline Государственное регулирование & 30 & 9,5 \\
\hline Мировая экономика & 28 & 8,8 \\
\hline Социальные проблемы & 27 & 8,5 \\
\hline Сельское хозяйство & 26 & 8,2 \\
\hline Кредит & 26 & 8,2 \\
\hline Госбюджет & 25 & 7,9 \\
\hline Акционерное дело & 25 & 7,9 \\
\hline Промышленность & 23 & 7,3 \\
\hline Транспорт & 18 & 5,7 \\
\hline Налоги & 17 & 5,4 \\
\hline
\end{tabular}

Приоритетными в 1913 г. оказались одиннадцать категорий: «торговля», «государственное регулирование», «мировая экономика», «социальные проблемы», «сельское хозяйство», «кредит», «го- 
сударственный бюджет», «акционерное дело», «промышленность», «налоги и сборы», «транспорт». Три первые категории составляют более трети всех публикаций, первые пять - более половины.

Распределение тематических категорий Таблица 2 по частоте встречаемости в 1917 году

\begin{tabular}{|l|c|c|}
\hline \multicolumn{1}{|c|}{ Категория } & Частота & \% \\
\hline Кредит & 116 & 16,4 \\
\hline Финансы & 103 & 14,5 \\
\hline Промышленность & 81 & 11,4 \\
\hline Торговля & 79 & 11,1 \\
\hline Госбюджет & 76 & 10,7 \\
\hline Налоги и сборы & 54 & 7,6 \\
\hline Социальные проблемы & 40 & 5,6 \\
\hline Мировая экономика & 30 & 4,2 \\
\hline Транспорт & 27 & 3,9 \\
\hline
\end{tabular}

В 1917 году на страницах журнала главными были 9 категорий: «кредит», «финансы», «промышленность», «торговля», «государственный бюджет», «налоги и сборы», «социальные проблемы», «мировая экономика» и «транспорт». Первые три категории составляют почти половину, а первые пять - почти две трети всех учтённых публикаций за год.

Прежде всего, отметим, что все основные категории журнала для 1917 года, за исключением категории «финансы», вошли и в список 1913 года, к ним добавились «государственное регулирование», «сельское хозяйство» и «акционерное дело». Однако внимание к ним было неодинаковым. Из наиболее часто встречающихся категорий для 1913 и 1917 гг. совпадают только две: торговля и кредит.

Наиболее пристальное внимание в «Вестнике...» за 1913 г. уделялось торговле (в структуре этой категории внешняя торговля значительно, по числу статей - почти в пять раз, превалировала над внутренней); внимание к вопросам государственного регулирования, к мировой экономике, социальным проблемам, сельскому хозяйству, сфере кредитования, государственному бюджету, акционерному делу и промышленности-находилось примерно на одинаковом, среднем уровне. Меньшую частоту встречаемости имели категории «налоги» и «транспорт». 
Иная картина в 1917 году. На первый план на протяжении 1917 года выходят категории «финансы» и «кредит», по частоте встречаемости они заметно опережают остальные категории. «Промышленность», «торговля» и «госбюджет» достаточно близки по частоте встречаемости и находятся на втором плане, а «социальные проблемы», «мировая экономика» и «транспорт» заметно отстают. Если рассмотреть не среднегодовую, а поквартальную динамику встречаемости категорий, то становится очевидным рост внимания к социальным и связанным с ними проблемам в течение года, когда «продовольственный вопрос», а именно проблема снабжения населения вызывает также существенное увеличение доли категории «торговля». Перебои в торговле хлебом в Петрограде уже с начала 1917 г. вызывают появление в журнале статей, связанных с оценкой хлебных запасов, организацией хлебных закупок, опытом зарубежных стран по обеспечению населения продовольствием во время войны. Во втором квартале 1917 г. мы видим много публикаций, которые связаны не только с ухудшением снабжения, продовольственным и транспортным кризисом, но и общими оценками влияния войны на внутренний рынок. Уже с июля 1917 г. ощутимо ухудшается социально-экономическое положение, продолжается падение производства, растёт безработица, развивается гиперинфляция. Возможно, поэтому на страницах журнала интерес к финансовым темам вновь возрастает, хотя публикуется и много материалов по проблемам финансирования промышленности и снабжения населения не только хлебом, но и другими товарами, например, сахаром или тканями. Отметим, что социальные проблемы в статьях журнала за 1913 год, в отличие от 1917 года, в основном были связаны с вопросами страхования, охраны труда, минимума заработной платы, мирового рабочего законодательства, а также с забастовочным движением в апреле и мае.

Транспортный и топливный кризис 1917 года, как ни странно, не привел к более заметному проявлению в «Вестнике...» категории «транспорт»; отметим также, что анализ экономического развития отдельных стран и влияния войны на мировую экономику, присутствовавший в журнале весь год, тем не менее, не вывел соответствующую тематическую категорию на первые позиции в списке категорий.

Что касается бюджетной сферы, в 1917 году она упоминается на страницах «Вестника...» заметно чаще, чем в 1913 году. Вероятно, это связано со спецификой российского бюджета, заметную часть которого составляли военные расходы государства, увеличивавшие- 
ся во время войны. Как следствие, в 1917 году статьи по проблемам государственного бюджета и кредита занимали на страницах журнала больше места, чем в 1913 г.

Интересно, что категория «промышленность», которая в 1917 году стала одной из ведущих на страницах журнала, в предвоенный 1913 год уступала по частоте встречаемости и финансовым, и торговым вопросам. Статьи по этой проблематике в основном представляли собой обзоры различных отраслей промышленности в России за прошлые годы, а также по смежным темам, связанным с акционерным делом, кредитами, промышленным развитием зарубежных стран, рабочим вопросом и др. Возникает вопрос: почему в 1913 году в период экономического роста падает интерес аналитиков журнала к проблемам промышленного развития, особенно в первой половине года, хотя именно промышленность во многом определяла состояние экономики страны? Это состояние можно измерить с помощью биржевого индекса, построенного на основе стоимости акций ведущих промышленных компаний России. Биржевой индекс для российской экономики был построен Л.И. Бородкиным и Г. Перельманом по аналогии с американским индексом Доу-Джонса [2]. Помесячные данные российского индекса за 1913 г., усреднённые по кварталам, показывают, что индекс в течение этого года постепенно снижается. Однако при этом частота публикации статей по категории «промышленность» к четвертому кварталу 1913 года возрастает. Возможно, это обусловлено тем, что динамика экономических показателей развития разных отраслей промышленности заметно различалась: например, стоимость акций металлургических и машиностроительных предприятий снижалась, тогда как акции нефтяных компаний росли в цене [3]. Скорее всего, благоприятная конъюнктура на нефтяном рынке к концу 1913 года может объяснить растущую частоту категории «промышленность» на страницах «Вестника...», особенно учитывая, что соответствующие статьи посвящены преимущественно нефтяной отрасли.

Сравнительный тематический анализ отражения состояния экономики России в «Вестнике финансов, промышленности и торговли» в знаковые 1913 и 1917 гг. позволил нам выявить отличия в редакционной политике журнала этих лет. Наиболее эффективным для решения этой исследовательской задачи мы считаем обращение к поквартальной динамике тематики аналитических статей и сообщений. 
В 1913 году распределение частоты встречаемости основных категорий было достаточно стабильным: лидерство делили категории «торговля», «кредит», «промышленность». В целом 1913 год в журнале был отмечен превалированием категории «торговля» (с преобладанием в её структуре вопросов внешнеторговой сферы). Это неудивительно для мирного периода развития страны. В русле политики протекционизма лежал интерес редакции и авторов к правовым основам (и ряду других аспектов) государственного регулирования экономики в России и за рубежом.

В 1917 году на фоне продолжавшейся Первой мировой войны заметно повышенное внимание на страницах «Вестника...» к финансам, кредиту, бюджетной политике, организационным вопросам снабжения, влиянию войны на экономику. В этом году на страницах журнала отражаются отголоски социально-экономического коллапса и кризиса власти. Категория «торговля» выходит на главенствующие позиции не в мирных, как в 1913 г., условиях, а как отклик на «торговый голод» и проблемы снабжения. Внимание к социальным проблемам возрастает. Постепенно уменьшаются доли таких категорий, как «промышленность», «государственный бюджет», «транспорт»; почти не публикуются материалы по зарубежным странам.

Таким образом, журнал отражал существующие экономические и социальные проблемы в России и за рубежом, предоставляя свои страницы не только для публикации официальных статистических данных, но и для аналитических статей, в которых давалась оценка этих проблем и рассматривались пути их решения.

\section{Библиография}

1. Кириллов А.К. Электронная публикация исторических источников: проблемы и перспективы (на примере Вестника финансов, промышленности и торговли за 1917 год) // История Сибири, 1583-2006. Проблемы и перспективы: Сборник материалов региональной молодёжной научной конференции. - Новосибирск : ИД «Сова», 2006. C. 14-19.

2. Бородкин Л.И., Перельман Г. Структура и динамика биржевого индекса дореволюционной России: анализ рынка акций ведущих промышленных компаний // Экономическая история. Ежегодник. 2006. - М.: РОССПЭН, 2006. - С. 171-221.

3. Бородкин Л.И., Коновалова А.Д. Российский фондовый рынок в начале XX века: факторы курсовой динамики. - СПб.: Алетейя, 2010. - С. 203-220. 
https://doi.org/10.29003/m1786.978-5-317-06529-4/33-39

Главацкая Е.M.

Уральский федеральный университет, Екатеринбург

Торвальдсен Гуннар

Арктический университет Норвегии - Университет Тромсё

\section{Виновата ли «испанка?»: анализ причин смерти в Екатеринбурге (1917-1919 гг.)}

Аннотация. Пандемия испанского гриппа 1917-1920 гг. по разным подсчетам унесла от 20 до 100 миллионов человек. При этом статистика по ряду стран, включая Россию, не точна, поскольку основана на использовании показателей смертности по другим странам. Данное исследование посвящено анализу причин смертности взрослого населения Екатеринбурга в период испанской пандемии для определения вероятности незамеченного распространения гриппа. В качестве источника использованы базы данных о причинах смертей, зарегистрированных в метрических книгах города в 1917-1919 гг.

Ключевые слова: испанка, испанский грипп, пандемия, причины смерти, база данных, метрические книги, Екатеринбург, историческая демография, Россия.

Glavatskaya E.M. Ural Federtal University.Ekaterinburg

Thorvaldsen Gunnar Arctic University of Norway - Tromsoe University

\section{What role did the Spanish flu play? Analysis of the death causes in Ekaterinburg 1917-1919}

Abstract: The Spanish flu pandemic of 1917-1920 killed, according to some researchers, up to 100 million people while others estimate lower numbers such as 20 million victims. The reason for this uncertainty is that data for a number of countries, including Russia, are rather rough estimates based on mortality rates from other parts of the world. This study analyzes the causes of death in the population of Ekaterinburg during the period of the Spanish pandemic to determine likely signs of the spread of influenza. Databases on the causes of death registered in the city's parish registers were used as a source.

Keywords: Spanish flu, pandemic, causes of death, database, metricheskie knigi, parish records, mortality, Ekaterinburg, history, historical demography, Russia.

Традиционно считалось, что пандемия испанского гриппа, прокатившаяся по миру несколькими волнами в 1918-1920 гг., унесла от

\footnotetext{
${ }^{1}$ Работа выполнена при финансовой поддержке гранта РФФИ № 19-29-07154.
} 
50 до 100 миллионов человек. Высокий уровень смертности от испанского гриппа отчасти можно объяснить отсутствием эффективных методов лечения в 1918 г. и тем, что он вызывал серьезные осложнения. Возможности получения медицинской помощи гражданским населением сократились из-за того, что значительное число врачей и мед сестер находилось на фронте. Многие страны в условиях нехватки продовольствия вынуждены были перейти к нормированному распределению, а ослабленное за годы изнурительной войны население оказалось более уязвимо перед лицом инфекционных заболеваний. Проведенный в 2002 г. анализ смертности от испанского гриппа дал основания уточнить число жертв этого заболевания, снизив его до 20 миллионов. При этом авторы обратили внимание на то, что данные по ряду стран, включая Россию, не вполне очевидны [1]. Так, например, число жертв испанки в России, согласно предположительным подсчетам (в условиях отсутствия точной статистики), могло достигать 450 тысяч, а летальность была значительно ниже - менее полпроцента в сравнении с 2,5\% общемировых показателей [2]. Методологическая проблема подобных подсчетов в том, что они проведены на основании предположения, не подтвержденного эмпирически, что показатели летальности были одинаковы во всех странах. Различия в состоянии национальных экономик и медицины наряду с неравномерным распределением иммунитета к вирусу привели к большим колебаниям в географии смертности и летальности. Данное исследование представляет анализ локальной ситуации в России, в Екатеринбурге - городе, расположенном на границе Европы и Азии.

Первые случаи испанского гриппа были зарегистрированы среди военных в США, после чего вспышки заболевания были отмечены в разных частях мира. «Военное» происхождение болезни сделало молодых мужчин, обладавших наиболее сильной иммунной системой, остро реагировавшей на вирус, особенно уязвимыми, а их концентрация в казармах только усугубляла ситуацию. Резкий всплеск эпидемии произошел примерно через неделю после массовых торжеств по поводу заключения мира в ноябре 1918 г. Вирус гриппа распространялся тремя-четырьмя волнами и им предположительно переболела почти треть населения Земли. Он считается самой страшной эпидемией гриппа в истории человечества, а негативные последствия заметны вплоть до нашего времени [3]. Традиционно пандемия испанского гриппа воспринималась как социально нейтральная. Однако исследование, проведенное на основе индивидуальных данных по смертности в двух различных районах Осло (западном - богатом и восточном - бедном), показали, что испанский 
грипп более серьезно поразил именно низшие социальные слои [4]. Использование данных по всему населению Осло позволило бы сделать этот вывод более аргументированным, исключив чисто географический (экологический) эффект.

Точно известно, что в Россию эпидемию принес британский экспедиционный корпус, воевавший против Красной Армии на северозападе страны, где он и распространился, однако по другим частям страны достоверных данных мало. Данная статья посвящена анализу причин смертности взрослого населения Екатеринбурга в период испанской пандемии для определения вероятности незамеченного распространения гриппа. В качестве источника были использованы сведения о причинах смерти, зарегистрированных в метрических книгах пяти православных приходов Екатеринбурга, являвшегося железнодорожным узлом на пути из Европы в Азию и принявшего огромное число беженцев из западных губерний.

Для достижения поставленной задачи был выделен корпус записей о смертях, зарегистрированных в городе с января 1917 по август 1919 гг., после чего ведение метрических книг прекратилось, - всего 1560 записей. Как и следовало ожидать, большинство смертей приходилось на младенцев, особенно мальчиков. Однако доля инфекционных заболеваний, которые чаще всего диагностировали вместо испанки, значительно выше у взрослых (табл. 1).

Таблий 1

Число смертей, наступивших в результате инфекционных заболеваний. Екатеринбург, январь 1917 г. - август 1919 г.

\begin{tabular}{|c|c|c|c|c|c|c|}
\hline Возраст & Женщины & $\begin{array}{c}\text { Инфекц. } \\
\text { забол. }\end{array}$ & $\begin{array}{c}\text { Инфекц. } \\
\%\end{array}$ & Мужчины & $\begin{array}{c}\text { Инфекц. } \\
\text { забол. }\end{array}$ & $\begin{array}{c}\text { Инфекц. } \\
\%\end{array}$ \\
\hline $0-9$ & 304 & 190 & $57.8 \%$ & 369 & 242 & $53.2 \%$ \\
\hline $10-19$ & 28 & 18 & $5.5 \%$ & 36 & 29 & $6.4 \%$ \\
\hline $21-29$ & 52 & 34 & $10.3 \%$ & 69 & 46 & $10.1 \%$ \\
\hline $31-39$ & 35 & 20 & $6.1 \%$ & 68 & 49 & $10.8 \%$ \\
\hline $41-49$ & 49 & 25 & $7.6 \%$ & 74 & 43 & $9.5 \%$ \\
\hline $51-59$ & 49 & 22 & $6.7 \%$ & 70 & 27 & $5.9 \%$ \\
\hline $61-69$ & 64 & 14 & $4.3 \%$ & 61 & 16 & $3.5 \%$ \\
\hline $71-79$ & 49 & 5 & $1.5 \%$ & 32 & 3 & $0.7 \%$ \\
\hline $81+$ & 36 & 1 & $0.3 \%$ & 15 & & $0.0 \%$ \\
\hline Всего & 666 & 329 & $100.0 \%$ & 794 & 455 & $100.0 \%$ \\
\hline
\end{tabular}

Источник: Регистр населения Урала [5]. 
Полученный пул записей метрических книг был отсортирован по причинам смерти, с использованием классификации Chp1876+ [См.: 6; 7].

Таблица 2

Основные классы причин смерти, зарегистрированных в метрических книгах Екатеринбурга в 1917-1919 гг.

\begin{tabular}{|l|c|c|c|c|c|c|}
\hline Год & 1917 & 1918 & 1919 & 1917 & 1918 & 1919 \\
\hline Инфекционные & 255 & 222 & 307 & $49.4 \%$ & $54.0 \%$ & $57.6 \%$ \\
\hline Неинфекционные & 128 & 73 & 109 & $24.8 \%$ & $17.8 \%$ & $20.5 \%$ \\
\hline Внешние причины & 19 & 29 & 24 & $3.7 \%$ & $7.1 \%$ & $4.5 \%$ \\
\hline Устаревшие & 113 & 75 & 80 & $21.9 \%$ & $18.2 \%$ & $15.0 \%$ \\
\hline Непонятн. / Нет информ. & 1 & 12 & 13 & $0.2 \%$ & $2.9 \%$ & $2.4 \%$ \\
\hline Всего & 516 & 411 & 533 & $100.0 \%$ & $100.0 \%$ & $100.0 \%$ \\
\hline
\end{tabular}

Источник: Регистр населения Урала [5].

Как видно из таблицы 2, инфекционные заболевания в качестве причины смерти доминировали в годы пандемии, особенно в 1919 г., когда было зарегистрировано наибольшее число смертей в Екатеринбурге, несмотря на отсутствие данных за сентябрь-декабрь. Однако проблемы с регистрацией смертей в метрических книгах были и во второй половине двух предыдущих лет, что было связано с ходом гражданской войны. Возможно, в 1917 г. испанка еще не добралась до Урала из-за активных военных действий на западе; в 1918 г. - из-за нарушения железнодорожного сообщения в условиях революции. Лишь к 1919 г. ее волна докатилась до Екатеринбурга, что не удивительно, поскольку и в Западной Европе он все еще продолжал свирепствовать. По данным Наркомздрава РСФСР, с августа 1918 г. по весну 1919 г. в Советской России «испанкой» переболело 1,09 млн. человек.

Однако в метрических книгах Екатеринбурга, диагноза «испанский грипп» как такового нет и всего в четырех случаях в качестве причины смерти назван «грипп» или его варианты - «инфлюэнца», «гриппозное воспаление легких, осложнение отеком легких». Это может показаться странным, однако с другой стороны, значительное число смертей было вызвано не собственно гриппом, а осложнениями. Кроме того, в России распространение эпидемия совпало с эпидемиями сыпного тифа и больным гриппом обычно ставили диагноз «тиф». Кстати, в отличие от испанки, летальность от тифа в некоторых губерниях достигала 8-9\% [8]. 
Информация БД позволила оценить поквартальную смертность от основных инфекционных заболеваний, за которыми, учитывая симптоматику, гипотетически могла «скрываться» испанка. Заболевания легких, согласно БД, являлись наиболее частой внесезонной причиной смерти, но особенно - в первой половине 1919 г. На это же время пришелся и рост смертности от тифа, который, как было сказано ранее, часто фигурировал в качестве диагноза умерших от испанки.

Таблица 3

\section{Смертность от основных инфекционных заболеваний} по кварталам 1917-1919 гг.

\begin{tabular}{|c|c|c|c|c|c|c|}
\hline Год & Квартал & $\begin{array}{c}\text { ЖКТ } \\
\text { инфекц. }\end{array}$ & Респир. & Тиф & Др. инфекц. & Неинфекц. \\
\hline 1917 & I & 8 & 35 & 0 & 35 & 68 \\
\hline 1917 & II & 46 & 47 & 2 & 18 & 79 \\
\hline 1917 & III & 11 & 25 & 2 & 13 & 85 \\
\hline 1917 & IV & 0 & 9 & 1 & 3 & 29 \\
\hline 1918 & I & 8 & 32 & 2 & 21 & 52 \\
\hline 1918 & II & 22 & 52 & 4 & 17 & 79 \\
\hline 1918 & III & 14 & 19 & 4 & 11 & 45 \\
\hline 1918 & IV & 0 & 8 & 6 & 2 & 13 \\
\hline 1919 & I & 12 & 68 & 12 & 10 & 87 \\
\hline 1919 & II & 43 & 71 & 23 & 29 & 107 \\
\hline 1919 & III & 21 & 10 & 1 & 10 & 29 \\
\hline 1919 & IV & 185 & 376 & 57 & 169 & 673 \\
\hline Всего & \multicolumn{7}{|l|}{ Нет данных } \\
\hline
\end{tabular}

Сведения БД позволили проанализировать динамику смертности в Екатеринбурге от инфекционных заболеваний, в том числе респираторных, и ее особенности у мужского населения города (см. рис. 1).

Анализ сведений БД показал, что нет оснований предполагать, что какое-то конкретное, в том числе испанка, заболевание являлось причиной сезонных подъемов смертности, но она могла внести свой вклад. Что касается молодых мужчин, ставших основной жертвой испанки в Европе, то в Екатеринбурге они подвергались не большей опасности, чем молодые женщины, но в большей степени, чем младенцы и дети (см. рис. 2). 


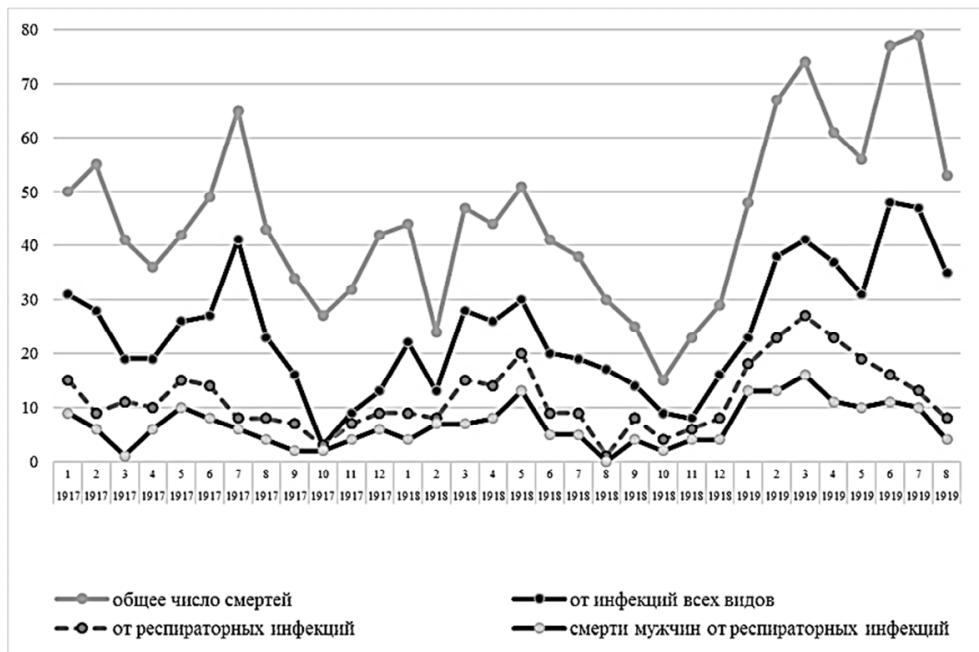

Рис. 1. Динамика смертности от инфекционных и респираторных заболеваний в Екатеринбурге в период пандемии испанки

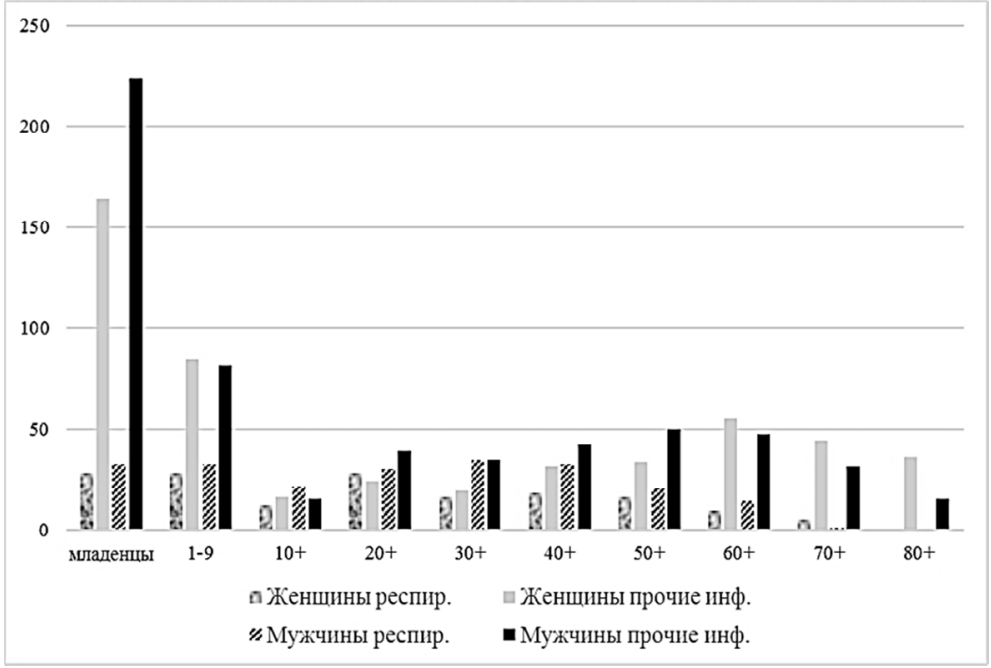

Pис. 2. Смертность от респираторных и других инфекций в Екатеринбурге в период пандемии испанки в зависимости от пола и возраста 
В результате проведенного исследования удалось обнаружить признаки того, что испанский грипп, хоть и со значительным опозданием все-таки, вероятно, добрался до Екатеринбурга и мог повлиять на уровень смертности в городе, особенно в первой половине 1919 г. Он, скорее всего, был у тех, кто умер в периоды всплеска респираторных заболеваний. Вместе с тем, испанский грипп не определял эпидемиологическую ситуацию в городе и не проявился в специфических гендерно-возрастных профилях, как это было в Западной Европе и США. Это может быть связано с тем, что население уже имело коллективный иммунитет из-за более ранних эпидемий гриппа, а именно пандемии «русского гриппа», прокатившейся зимой 1889-1890 гг. и потому, что большинство молодых мужчин находились на западном фронте. Данные по Екатеринбургу косвенно подтверждают гипотезу о том, что испанка, по всей вероятности, поразила Россию в меньшей степени, чем США или Западную Европу, более точные локальные исследования с привлечением данных метрических книг помогут усилить аргументацию и выявить региональную специфику.

\section{Список литературы}

1. Johnson N. \& Mueller J. Updating the accounts: global mortality of the 1918-1920 «Spanish» influenza pandemic // Bulletin Historical Medicine. 2002. - № 76(1). P. $105-115$.

2. Patterson K. David and Gerald F. Pyle. The Geography and Mortality of the 1918 Influenza Pandemic //Bulletin of the History of Medicine. 1991. - № 65(1). - P. 4-21.

4. Barry J. M. The Great Influenza: The Story of the Deadliest Pandemic in History. New York: Penguin Books, 2005. - 546 p.

5. Mamelund S.-E. A socially neutral disease? Individual social class, household wealth and mortality from Spanish influenza in two socially contrasting parishes in Kristiania 1918-19 // Social Science \& Medicine. 2006. - № 62(4). - P. 923-940.

6. Регистр населения Урала [5]. URL: http://urappdataurgi.urfu.ru/ural-populationproject (дата обращения: 10.09.2020).

7. Соммерсет Х., Волхаут Э. Городская смертность в Норвегии во второй половине XIX в. (по материалам приходских книг Тронхейма) // Изв. Урал. федер. ун-та. Сер. 2 : Гуманитар. науки. - 2020. - Т. 22. - № 2 (198). - С. $28-43$.

8. Бахарев Д. С., Главацкая Е. М. Причины детской смертности в Екатеринбурге на рубеже XIX-XX вв.: опыт классификации // Изв. Урал. федер. ун-та. Сер. 2 : Гуманитар. науки. - 2020. - Т. 22. - № 2 (198). - С. 79-96.

9. Сысин А. Эпидемии в России в 1914-22 годах // Врачебная газета, 1922. №10-11. - С. 265-267. 
https://doi.org/10.29003/m1787.978-5-317-06529-4/40-48

Диденко Д.В.

Российская академия народного хозяйства и государственной службы при Президенте Российской Федерации, Москва

Гринева Н.В.

Финансовый университет при Правительстве

Российской Федерации / Российская академия народного хозяйства и государственной службы при Президенте Российской Федерации, Москва)

\title{
Методологические подходы к моделированию роли институтов и технологий в экономическом росте позднего СССР (середина 1950-х - конец 1980-х гг.) ${ }^{1}$
}

Аннотация. На исторических данных тестируются производственные функции, модифицированные на основе экзогенной модели роста Mankiw, Romer, Weil (1992) и на основе идей эндогенного роста Romer (1990). Помимо физического и человеческого капитала, введены прокси-индикаторы, характеризующие институциональную и технологическую среды, а также эндогенный источник роста - затраты на НИОКР. Представлены предварительные оценки роли этих факторов в экономическом росте позднего СССР в межстрановом сравнении.

Ключевые слова: (4-6) новые теории роста, производственная функция, институты, технологии, НИОКР, советская экономика.

Didenko D.V.

Russian Academy of National Economy and Public Administration under the President of the Russian Federation, Moscow

Grineva N.V.

Financial University under the Government of the Russian Federation / Russian Academy of National Economy and Public Administration under the President of the Russian Federation, Moscow

\section{Methodological approaches to modeling the role of institutions and technologies in the economic growth of the late USSR (mid-1950s - late 1980s)}

\begin{abstract}
Based on historical data, we test our modified production functions, derived from exogenous growth model by Mankiw, Romer, Weil (1992) and theoretical ideas by Romer (1990). Besides physical and human capital, we augment them with proxy indicators for institutional and technological environ-
\end{abstract}

${ }^{1}$ Исследование проводится при поддержке гранта РФФИ, № 19-010-00680. 
ments, and with a source of endogenous growth, i.e. R\&D expenditures. We present our preliminary assessments of the role of these factors in economic growth of the late USSR in inter-country comparison.

Keywords: new growth theories, production function, institutions, technologies, R\&D, Soviet economy.

Цель исследования заключается в разработке новых методик, основанных на творческой адаптации моделей, апробированных в мировой научной литературе последних лет, к изучению советской экономики, с операционализацией институциональной и технологической динамики посредством ряда прокси-индикаторов, по которым доступны исторические данные. Разработанные методики используются для проверки содержательных гипотез в отношении роли институциональной и технологической динамики в замедлении экономического роста позднего СССР.

Выдвигаются гипотезы:

- В середине 1950-х - начале 1960-х гг. советская экономика имела предпосылки для перехода к модели роста на основе вложений в сектор научных исследований и разработок, однако впоследствии эти предпосылки оказались нереализованными.

- В 1960-1980-х гг. снижалась эффективность взаимодействия между институтами управления экономикой (во времени и относительно других референтных стран).

- Технологический режим в СССР был связан со сравнительно слабыми изменениями сочетания основных факторов производства.

В предшествовавшей литературе предпринимались попытки квантифицировать институциональную среду и технологический уровень производства, ввести соответствующие прокси-индикаторы и проанализировать их динамику. Однако в известных нам работах они не включались в эконометрический анализ методом производственной функции.

В качестве основного методологического подхода нами применена классическая производственная функция Кобба-Дугласа, которая подвергалась модификациям в [1] и в [2], в первом случае - за счет интерпретации нераспределенного остатка факторов производства как общетехнологического уровня экономики, во втором случае - посредством включения в нее человеческого капитала.

Согласно исследователям, аффилированным со Всемирным банком, невещественную часть национального богатства, наряду с иностранными финансовыми активами, составляют человеческий и ин- 
ституциональный капиталы [3, p. 91-98; 4, p. 96-102]. Соответственно, институты могут не только быть выделены как фактор среды, влияющий на производственные возможности экономической системы, но и введены в состав производственной функции [3, p. 93-98].

На их основе нами предложена модификация производственной функции, аналогичной по форме экзогенной модели роста [2] с физическим и человеческим капиталом, посредством введения переменных, характеризующих институциональную и общетехнологическую составляющие.

В другом направлении анализа, в развитие теоретических идей П. Ромера [5], разработана модель, в которую, помимо указанных переменных, включен эндогенный источник роста - финансирование научных исследований и разработок.

Указанные производственные функции тестировались с использованием собранных статистических данных по СССР и референтным странам: США, Великобритания, Франция, Германия, Испания, Япония, Бразилия, Китай.

Источниковая база:

- Официальные советские статистические данные, в тех аспектах, в которых они могут быть признаны достаточно достоверными, основываясь в том числе на результатах предшествующих исследований $[6 ; 7]$.

- Существющие в литературе расчеты и оценки по реконструкции показателей исторических национальных счетов СССР [6-13], финансирования науки в СССР [14], человеческого капитала и демографических показателей $[15 ; 6 ; 16]$; уровню преступности [17], военным расходам [18; 19].

- Тематические межстрановые наборы данных в формате электронных ресурсов: прежде всего, данные по агрегированным показателям исторических национальных счетов Penn World Tables - PWT, представленные в [20], документированные также в [21]; в качестве источников для сверки - Extended Penn World Tables (EPWT), документированные в [22]; поддерживаемая Еврокомиссией Атесо [23]; финансированию науки в странах ОЭСР [24]; демографические данные [25]; данные по военным расходам [26]; данные о выработке электроэнергии [27]; латентный индекс демократии [28].

Нами выбраны прокси-индикаторы, имеющие доступные и относительно достоверные статистические данные и оценки.

- Выбранные прокси-индикаторы институциональной среды советской экономики: 
Уровень насильственной преступности.

Уровень военных расходов.

Латентный индекс демократии.

- В качестве релевантных для индустриальной экономики выбраны следующие прокси-индикаторы технологического уровня:

Износ физического капитала (накопленная амортизация).

Энергоемкость ВНП (по электроэнергии).

Уровень младенческой смертности.

Доля энергоносителей (в первую очередь, нефти и газа) в экспорте.

При тестировании экзогенной модели анализ проводился по трем группам линеаризованных (посредством логарифмирования) регрессий, относящихся к отдельным странам: 1) классическая модель для каждой из исследуемых стран с двумя независимыми переменными (физический и человеческий капиталы как факторы производства); 2) частные модели с постоянным присутствием двух основных независимых переменных и поочередным включением одного проксииндикатора либо институционального, либо технологического блока; 3) обобщенная модель с несколькими прокси-индикаторами по каждой из анализируемых стран, которые обладали в ее составе статистической значимостью.

Обобщенная экзогенная модель для каждой из анализируемых стран имеет следующий вид:

$$
\begin{aligned}
& Y_{t}=A_{0} F K_{t}^{a_{1}} E L_{t}^{a_{2}} I M_{t}^{a_{3}} E E_{t}^{a_{4}} K_{t}^{a_{5}}(H L)_{t}^{a_{6}}(M R)_{t}^{a_{7}}(L D I)_{t}^{a_{8}} M E_{t}^{a_{9}}+u(t) \\
& Y_{t}=A_{0} F K_{t}^{a_{1}} E L_{t}^{a_{2}} I M_{t}^{a_{3}} E E_{t}^{a_{4}} K_{t}^{a_{5}}(H L)_{t}^{a_{6}}(M R)_{t}^{a_{7}}(L D I)_{t}^{a_{8}} M E_{t}^{a_{9}}+u(t) \\
& \ln Y_{t}=\ln A_{0}+a_{1} \ln F K_{t}+a_{2} \ln K V T_{t}+a_{3} \ln I M_{t}+a_{4} \ln E E_{t}+a_{5} \ln K_{t}+a_{6} \ln (H L)_{t} \\
& \ln Y_{t}=\ln A_{0}+a_{1} \ln F K_{t}+a_{2} \ln E L_{t}+a_{3} \ln I M_{t}+a_{4} \ln E E_{t}+a_{5} \ln K_{t}+a_{6} \ln (H L)_{t}
\end{aligned}
$$

где:

$Y$ - объем ВНП/ВВП (в постоянных ценах по паритету покупательной способности - ППС);

$A_{0}$ - свободный член;

$K$ - объем физического капитала (в постоянных ценах по ППС);

$H$ - индекс человеческого капитала;

$L$ - численность рабочей силы (тыс. чел.);

$F K$ - степень износа физического капитала, \%;

$E L$ - энергоемкость ВНП/ВВП по выработке электроэнергии (кВт*ч на единицу ВВП); 
IM - уровень младенческой смертности (на 1000 живых новорожденных в возрасте до 1 г.);

$E E$ - доля энергоносителей в экспорте (\%);

$M R$ - уровень умышленных убийств (на 100000 жителей в год);

$L D I$ - латентный индекс демократии;

$M E$ - расходы на оборону (\% ВВП);

$a_{n}-$ коэффициенты при независимых переменных регрессии;

$u$ - остатки.

Модель эндогенного научно-технического прогресса также имеет в основе производственную функцию:

$$
Y=A(Q) \cdot F(C, L)
$$

где:

$C$ - объем расширенного капитала (физический и человеческий);

$F(C, L)$ - производственная функция;

$Q$ - суммарный объем вложений в сектор производства научных знаний (текущих и капитальных);

$A(Q)$ - мультипликатор, показывающий эффективность затрат на науку.

Мультипликатор научно-технического прогресса предполагается равным:

$$
A(Q)=\varepsilon \cdot e^{\lambda t}[Q(t)]^{\gamma}, \quad 0 \leq \gamma \leq 1
$$

Обобщенная эндогенная модель для анализируемых стран имеет следующий вид:

$$
\begin{aligned}
& \frac{Y_{t}}{L_{t}}=A_{0} e^{\lambda t} Q_{t}^{\gamma} \frac{K_{t}^{\alpha}}{L_{t}^{\alpha}}(h){ }_{t}^{\beta} P I 1_{t}^{\mu 1} P I 2_{t}^{\mu 2}+u(t) \\
& \ln \frac{y_{t}}{y_{t-1}}=\ln A_{0}+\lambda t+\gamma \ln q_{t}+\alpha \ln \frac{k_{t}}{k_{t-1}}+\beta \ln \frac{h_{t}}{h_{t-1}}+\sum_{i=1}^{n} \mu_{i} \ln \frac{P I i_{t}}{P I i_{t-1}}+u_{t}
\end{aligned}
$$

где:

y- объем ВНП/ВВП на 1 занятого в национальной экономике (в постоянных ценах по ППС);

$t$-время (год);

$k$ - объем физического капитала на 1 занятого в начиональной экономике (в постоянных ценах по ППС);

$h$ - индекс человеческого капитала, сформированного в сфере образования, на 1 занятого в национальной экономике;

$q$ - объем внутренних затрат (государства и предприятий) на НИОКР на 1 занятого в начиональной экономике за год $t$ (в постоянных ценах по ППС); 
PI1 - прокси-индикатор институциональной среды;

РI2 - прокси-индикатор технологического уровня;

и-остатки.

При тестировании эндогенной модели регрессионный анализ для каждой страны проводился по основной модели (включала только независимые переменные $t, q, k, h)$ и по обобщенным моделям. Последние включали 12 комбинаций, состоявших из основной модели и набора двух прокси-индикаторов (институциональной среды и технологического уровня) за период 1965-1990 гг. (за который доступны данные по объему финансирования науки в большинстве выбранных стран), оптимальная комбинация которых подбиралась по критериям статистической значимости переменных и точности модели.

Результаты тестирования экзогенной модели лишь частично подтверждают гипотезу об ухудшении институциональной среды в СССР: негативный вклад институтов не был более сильным и значимым, чем в других странах группы с их ухудшением. Эффекты технологических прокси-индикаторов оказались более значимыми и всегда вносили отрицательный вклад в экономический рост. По результатам тестирования эндогенной модели гипотеза об определяющей роли институциональных факторов в замедлении экономического роста СССР также не подтверждается.

При том, что в основе советского экономического роста лежало накопление физического капитала, вклад человеческого капитала также был положительным и статистически значимым.

Для СССР установлена тенденция к снижению предельной нормы замещения физического капитала человеческим. Это интерпретируется как проявление снижения гибкости в управлении экономикой. Кроме того, включение прокси-индикаторов технологического уровня производства в страновые частные и обобщенные модели показало, что технологический режим в СССР был связан со сравнительно слабыми изменениями сочетания основных факторов производства.

Не полностью подтверждается часто выдвигаемая в русле институционального подхода гипотеза «ресурсного проклятья»: показатель доли энергоносителей в экспорте СССР в экзогенной модели оказался с положительным коэффициентом, при этом статистически незначимым. Напротив, в эндогенной модели производная данного показателя имела положительные коэффициенты и была статистически значимой. 
На протяжении рассматриваемого периода объем расходов на науку в СССР имел явно выраженную тенденцию к возрастанию, что можно интерпретировать как создание предпосылок для перехода к эндогенной модели роста за счет научно-технического прогресса. В то же время, результаты исследования свидетельствуют о сравнительно слабом влиянии этих затрат на экономический рост в СССР в период 1965-1990 гг. При том, что накопление сформированного в сфере образования человеческого капитала в рамках нашей эндогенной модели выступало положительно значимым фактором экономического роста СCCP.

Изучение опыта СССР в межстрановом сопоставлении позволило уточнить ряд эмпирических закономерностей в теоретическом контексте экономики развития. В межстрановом контексте отечественная экономика предстает как особый случай развития, имевший как общие черты с референтными странами, так и особенности, характерные для отдельных из них (прежде всего - Японии и Китая, в ряде аспектов Испании и Бразилии). В наибольшей степени модель эндогенного роста соответствует динамике экономики Японии, другой страны догоняющего развития, сравнительно успешно решавшей задачи позднеиндустральной модернизации.

\section{Библиография}

1. Solow R.M. Technical Change and the Aggregate Production Function // Review of Economics and Statistics. - 1957. - Vol. 39. - No. 3. - P. 312-320.

2. Mankiw N.G., Romer D., Weil D.N. A Contribution to the Empirics of Economic Growth // Quarterly Journal of Economics. - 1992. - Vol. 107. - No. 2. - P. 407-437.

3. Hamilton K., Ruta G., Bolt K., Markandya A., Pedroso-Galinato S., Silva P., Ordoubadi M.S., Lange G.-M., Tajibaeva L. Where is the wealth of nations? Measuring capital for the 21 st century. - Washington, D.C.: World Bank, 2005. - URL: http://documents.worldbank.org/curated/en/287171468323724180/Where-is-the-wealth-ofnations-measuring-capital-for-the-21 st-century (дата обращения: 14.08.2020).

4. World Bank. The Changing Wealth of Nations: Measuring Sustainable Development in the New Millennium. Environment and Development. - Washington, D.C.: World Bank. 2011. - URL: https://openknowledge.worldbank.org/handle/10986/2252 (дата обращения: 14.08.2020).

5. Romer P. M. Endogenous Technological Change // The Journal of Political Economy. - 1990. - Vol. 98. - No. 5. - Part 2. - P. S71-S102.

6. Didenko D., Földvári P., Van Leeuwen B. The spread of human capital in the former Soviet Union area in a comparative perspective: Exploring a new dataset // Journal of Eurasian Studies. - 2013. - Vol. 4. - No. 2. - P. 123-135. + Supplementary data. - URL: https://www.sciencedirect.com/science/article/pii/S1879366513000122 (дата обращения: 14.08.2020).

7. Van Leeuwen B., Didenko D., Földvári P. Inspiration versus perspiration in economic development of the Former Soviet Union and China (ca. 1920-2010) // Economics of Transition. - 2015. - Vol. 23. - No. 1. - P. 228-230. 
8. Воскобойников И.Б., Дрябина Е.В. Историческая статистика основных фондов российской промышленности в 1970-2004 годах // Вопросы статистики. - 2010. № 3. - C. 28-45.

9. Becker A.S. Soviet national income, 1958-1964: National accounts of the USSR in the seven year plan period. - Berkeley: Univ. of California Press, 1969. - 608 p.

10. Bergson A. Real National Income of Soviet Russia since 1928. - Cambridge (Mass.): Harvard University Press, 1961. - 472 p.

11. Easterly W., Fischer S. The Soviet economic decline: Historical and Republican data // World Bank Economic Review. - 1995. - Vol. 9. - No. 3. - P. 341-371. - URL: https://datacatalog.worldbank.org/dataset/wps1284-soviet-economic-decline).

12. Moorsteen R., Powell R. The Soviet Capital Stock, 1928-1962. - Homewood (Illinois): Richard D. Irwin, Inc., 1966. - 671 p.

13. Steinberg D. The Soviet Economy 1970 - 1990: A statistical analysis. - San Francisco: Intern. Trade Press, 1990. - 338 p.

14. Наука и высокие технологии России на рубеже третьего тысячелетия (социально-экономические аспекты развития) / Руководители авт. колл. В.Л. Макаров, А.Е. Варшавский. - М.: Наука, 2001. - 636 с.

15. Андреев Е.М., Дарский Л.Е., Харькова Т.Л. Население Советского Союза 1922-1991. - М.: Наука, 1993. - 143 с.

16. Karabchuk T., Kumo K., Selezneva E. Demography of Russia: From the Past to the Present. - London: Palgrave Macmillan, 2017. - 334 p.

17. Лунеев В.В. Преступность XX века: Мировые, региональные и российские тенденции. Изд. 2-е перераб. и доп. - М.: Волтерс Клувер, 2005. - 912 с.

18. Brada J.C., Graves R.L. Slowdown in Soviet Defense Expenditures // Southern Economic Journal. - 1988. - No. 54. -P. 969-984.

19. Ofer G. Soviet Economic Growth: 1928-1985 // Journal of Economic Literature. 1987. - Vol. 25. - No. 4. - P. 1767-1833.

20. Maddison Project Database, version 2018. Bolt J., Inklaar R., de Jong H., van Zanden J.L. Rebasing 'Maddison': new income comparisons and the shape of long-run economic development. Maddison Project Working Paper 10. - URL: https://www. rug.nl/ggdc/historicaldevelopment/maddison/releases/maddison-project-database-2018 (дата обращения: 14.08.2020).

21. Feenstra R.C., Inklaar R., Timmer M.P. The Next Generation of the Penn World Table // American Economic Review. - 2015. - Vol. 5. - No. 10. - P. 3150-3182. - URL: www.ggdc.net/pwt (дата обращения: 14.08.2020).

22. Marquetti A., Foley D. Extended Penn World Tables v. 4.0 - EPWT 4.0, March 2012. - URL: https://sites.google.com/a/newschool.edu/duncan-foley-homepage/home/ EPWT (дата обращения: 14.08.2020).

23. AMECO. Annual macro-economic database of the European Commission's Directorate General for Economic and Financial Affairs (DG ECFIN). - URL: http:// ec.europa.eu/economy_finance/db_indicators/ameco/zipped_en.htm (дата обращения: 14.08.2020).

24. Joint OECD-Eurostat international data collection on resources devoted to R\&D. URL: http://stats.oecd.org/ (дата обращения: 14.08.2020).

25. Human Life Table Database. 2019. Max Planck Institute for Demographic Research. - URL: https:/www.lifetable.de/cgi-bin/data.php (дата обращения: 14.08.2020). 
26. SIPRI Military Expenditure Database 2019. - URL: https://www.sipri.org/ databases/milex (дата обращения: 14.08.2020).

27. Comin D., Hohijn B. Cross-Country Technological Adoption: Making the Theories Face the Facts // Journal of Monetary Economics. - 2004. - Vol. 51. - No. 1. - P. 3983. - URL: http://www.nber.org/hccta/hcctad.xls (дата обращения: 14.08.2020).

28. Foldvari P. A latent democracy measure 1850-2000. CGEH Working Paper Series. Working paper No. 59. June 2014. - URL: www.cgeh.nl/sites/default/files/WorkingPapers/ cgehwp59_foldvari.pdf (дата обращения: 14.08.2020).

https://doi.org/10.29003/m1788.978-5-317-06529-4/48-56

Жуков Д.С., Канищев В.В., Лямин С.К. Тамбовский государственньй университет им. Г.Р.Державина

Соотношение фрактального моделирования и кластерного анализа социальных процессов в России XVII-XX вв. ${ }^{1}$

Аннотация. Рассмотрены эвристические возможности фрактального моделирования и кластерного анализа в исторических изысканиях. Представлены примеры приложения этих исследовательских инструментов к изучению демографических процессов в крестьянских поселениях в XIXXX вв., освоения фронтирных территорий в XVII - XIX вв. Авторы приходят к выводу, что упомянутый инструментарий является эффективным средством типизации объектов.

Ключевые слова: историческая демография, история фронтира, фрактальное моделирование, кластерный анализ.

\section{Zhukov D.S., Kanishchev V.V., Lyamin S.K. Derzhavin Tambov State University}

\section{Fractal modeling and cluster analysis of social processes in Russia, 17th - 20th centuries}

Abstract. The article is devoted to the heuristic possibilities of fractal simulation and cluster analysis in historical research. The authors presented examples of the application of these research tools to the study of historical demographic processes (XIX-XX centuries), to the history of the frontier (XVII - XIX centuries). The authors concluded that the mentioned toolkit is an effective means of typing objects.

Keywords: historical demography, frontier history, fractal simulation, cluster analysis.

\footnotetext{
${ }^{1}$ Статья подготовлена при финансовой поддержке Российского фонда фундаментальных исследований, проект № 18-09-00313а.
} 
В ходе многолетней работы с моделями социальных процессов перед авторами не раз возникала проблема выбора оптимальных и эвристически продуктивных подходов к осмыслению массовых исторических материалов. В представленном докладе мы стремимся проанализировать накопленный опыт и исследовательские возможности двух мощных инструментов типизации объектов, - фрактального моделирования и кластерного анализа. Обоснованная группировка особенно важна для микроистории: мы должны знать, насколько широко можно распространить наблюдения, сделанные относительно отдельных микрообъектов.

Одним из наших «модельных» проектов является «Демофрактал», в ходе которого построено 8 фрактальных моделей для разных хронологических отрезков второй половины XIX в. - конца XX в. Фрактальное моделирование позволило увидеть разные типы демографического поведения населения одной из характерных аграрных губерний (областей) России, выявить факторы, тенденции и интенции изучаемых процессов. Объяснение математического аппарата фрактальной модели мы уже докладывали на конференции АИК [1].

Используемое в нашей модели четырёхчастное деление фазового пространства оказалось приемлемым для изучения демографических процессов в традиционном обществе. Моделирование для Тамбовской губернии второй половины XIX - начала XX в. показало, что аттракторы поселений собирались в тех зонах фазового пространства, которые обозначали обычные для аграрного общества демографические стратегии, связанные с разными темпами сокращения смертности при сохранении высокой рождаемости.

Изучение последующих периодов ХХ в., в течение которых произошли крупные социально-политические потрясения и демографический переход, потребовало неоднократной корректировки модели. При моделировании демографических стратегий отрезков 1917-1920 и 1920-1926 гг. возник эффект выхода аттракторов некоторых поселений за пределы фазового пространства, которые маркируют физически возможные социальные характеристики. Введение в модель (начиная с 1926 г.) фактора миграции привело к тому, что базовая типология была модифицирована в соответствии с новыми реалиями [2]. При построении модели для 1959-1989 гг. мы учитывали, что аграрный социум подвергся значительной модернизации. Выход системы за рамки приемлемых величин сопровождался «взрывом» аттракторов, которые перемещаются в зону «риска запустения», где находились исчезнувшие после 1959 г. поселения или близкие к «запустению» [3]. 
В ходе моделирования не раз возникал вопрос о целесообразности этой трудоемкой работы ради получения, казалось бы, очевидных результатов. Но всегда мы находили «оправдание» в том, что в некоторых случаях модель демонстрировала контр-интуитивные нелинейные эффекты: интенция к «вымиранию» некоторых селений в условия крестьянского восстания 1920-1921 гг. (эффект бабочек, летящих в огонь), выживание многих «неперспективных» поселений в 1960-1980-е гг. и др.

Фрактальная модель в историко-демографической сфере оказалась целесообразна для исследований на микроуровне.

С другой стороны, кластерный анализ показал бо́льшую целесообразность для изучения демографических процессов мезоуровня (губернии, области, уезды, районы). Кластерный анализ даёт возможность сформировать типологию, которая не является (в отличие от типологии во фрактальной модели) предустановленной. Многомерный кластерный анализ случайности простых группировок [4, с. 8, 21].

Кластерный анализ был использован для выявления регионов России, типологически схожих по основным демографическим показателям. Построение кластеров на разных хронологических срезах показывает, какими темпами и насколько согласованно разные регионы шли по пути демографического перехода. Кластерные группировки сельского населения Центральных и Северо-Западных губерний Европейской России конца 1850 - начала 1860-х гг. образовались сравнительно быстро в процессе кластеризации [5]. На 4-м шаге 15 из 18 изучаемых губерний оказались в одном большом кластере, который состоял из регионов, где крестьянство сохранило традиционные показатели естественного движения. Только сельское население Московской и Санкт-Петербургской губерний сравнительно долго в процессе кластеризации сохраняло особость, но, в конце концов, присоединилось к единой, традиционной в плане демографии группе. Лишь Олонецкая губерния осталась исключительной. Это не было связано с демографической модернизацией, а с резкими отличиями от остальной Европейской России в природно-климатических условиях, этническом и внутрисословном составе крестьянства.

Кластерные группировки тех же губерний в 1902 г. оказались сложнее предыдущих. Только на 10-м шаге 17 губерний объединились в один кластер. Санкт-Петербургская губерния так и не вошла в единую кластерную группировку. Только здесь к началу XX в. проявились заметные признаки демографического перехода у сельского населения. 
Дополнением к фрактальному моделированию демографических процессов 1960-1980-х гг. на поселенном уровне послужил кластерный анализ демографических показателей 156 районов центральночернозёмных и соседних Брянской и Орловской областей по данным 1989 г. Задача кластерного анализа состояла в выявлении групп схожих объектов на основании 5 индикаторов. Были использованы настройки модуля кластеризации в Statistica: метод - древовидная кластеризация; правило объединения - невзвешенное попарное арифметическое среднее; мера расстояния - евклидово расстояние. На каждом хронологическом срезе выделены три уровня кластеров (см. рис. 1). Кластеры уровня С - наиболее мелкие кластеры; В - промежуточный уровень; А - кластеры третьего уровня, включившие в себя кластеры уровня В. Кластеры всех трёх уровней сформировались до последнего скачка в пределах естественной кластеризации, которая даёт основание размышлять о реалистических типах объектов.

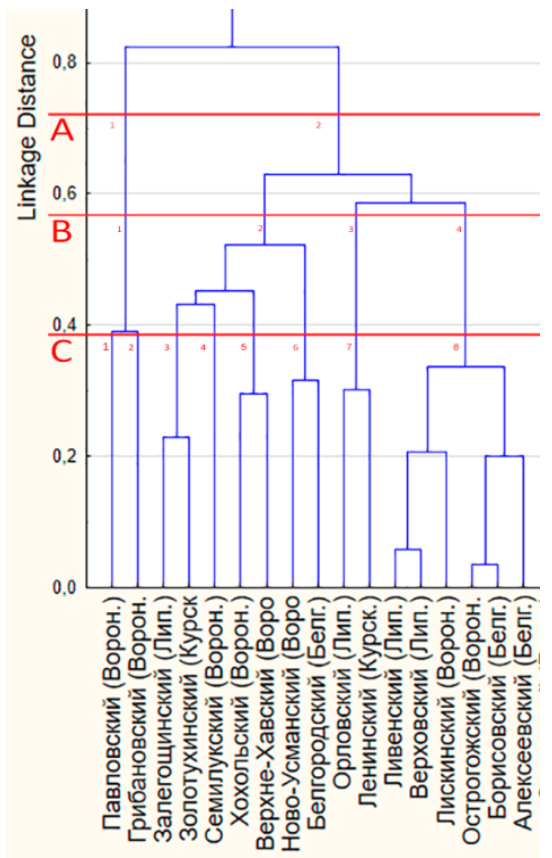

Рис. 1. Дендрограмма, фрагмент 
На уровне А в один кластер объединилось 105 районов (свыше $80 \%$ ), для которых характерно большое сокращение населения в 1960-1980-е гг. при средних темпах экономического развития. Более 30 районов «разбежалось» ещё по 4-м кластерам с заметной разницей в социально-демографических показателях.

Фрактальное моделирование оказалось продуктивным при изучении освоения южнорусского фронтира. Метод позволил проследить, как окраинная территория, на определенном этапе истории нетождественная будущей метрополии, через какой-то исторический отрезок стала однородной частью «материнского» государства и общества.

На рисунках 2, 3 и 4 представлены различных траектории, наглядно отразившие различия в процессе вхождения отдельных фронтирных уездов в состав Русского государства.

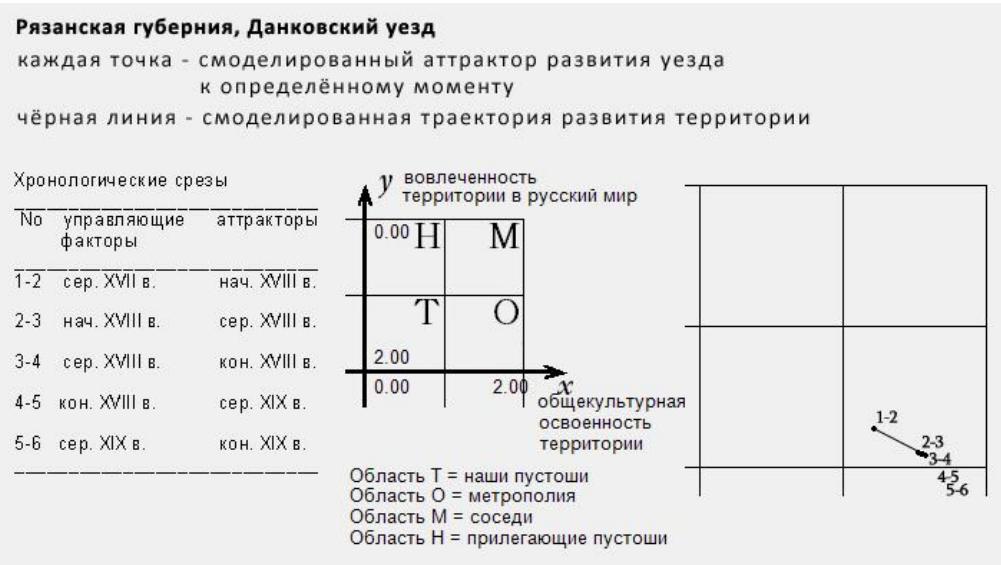

Рис. 2. Эволюция территории, модель (Данковский уезд)

Траектория Данковского уезда Рязанской губернии показывает, что это экс-фронтир. Здесь вовлечённость в русский мир и хозяйственная освоенность по сравнению с Центром были очень велики уже на начальный момент исследования. Подобные траектории характерны для большинства уездов Рязанской и Тульской губерий, некоторых уездов Орловской и Тамбовской губерний.

Изображение для Бобровского уезда Воронежской губернии можно назвать классическим для многих уездов фронтира. Обретение этой территорией основных черт, характерных для метрополии, 
продолжалось до середины XVIII в. Подобный путь проделали почти все уезды Воронежской и Саратовской губернии, часть уездов Орловской, Курской, Тамбовской, Пензенской губерний.

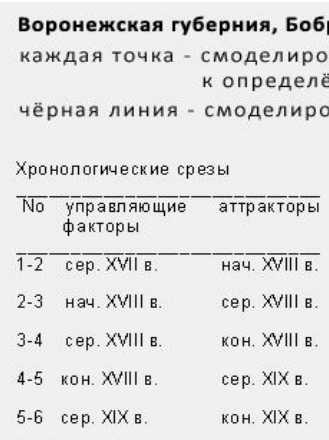

5-6 cep $\times 1 \times$
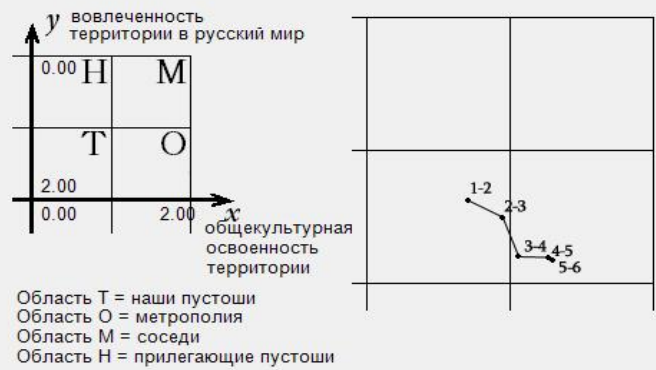

сосед

Область $\mathrm{H}=$ прилегающие пустоши

Рис. 3. Эволюция территории, модель (Бобровский уезд)

\section{Хронологические срезы

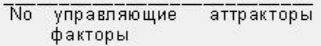 \\ 1-2 cер. ХराI в. - нач. XVIII в. \\ 2-3 нач. XVIII в. \\ 3-4 cep. XVIII в. \\ cep. XVIII в. \\ 4-5 кон. XVIII в. \\ cep. $\mathrm{X} \times \mathrm{X}$ в. \\ 5-6 cep. $\mathrm{XIX}$ в. кон. XIXв.}

область войска Донскоro, Миусский уезд

каждая точка - смоделированный аттрактор развития уезда

к определённому моменту

чёрная линия - смоделированная траектория развития территории

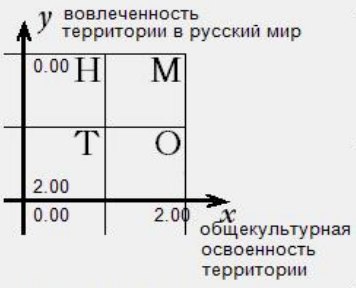

Область $\mathrm{T}=$ наши пустоши

Область О = метрополия

Область $\mathrm{M}=$ соседи

Область $\mathrm{H}=$ прилегающие пустоши

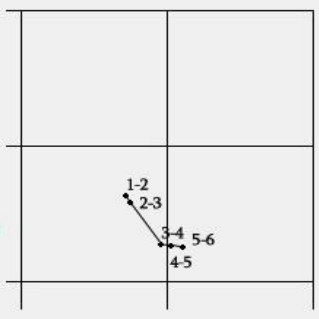

Рис. 4. Эволюция территории, модель (Миусский уезд) 
Траектория для Миусского уезда Области войска Донского показывает длительное пребывание его в зоне фронтира и более-менее заметное вхождение в состав метрополии только в начале XIX в.

Вопреки ожиданиям попытка создать фрактальную модель для фронтира на поселенном уровне оказалась фактически неудачной. Применение в вычислительных экспериментах индикаторов поуездного уровня с небольшим добавлением специфических индикаторов поселенного уровня дало практически те же результаты, что и моделирование уездов.

Понимая трудоёмкость дальнейшей модификации фрактальной модели, мы решили провести кластерный анализ отдельных населённых пунктов на основании 5 индикаторов, которые указывают на фронтирное/нефронтирное состояние поселений. В анализ включено 1640 поселений губернии по состоянию на 1862 г., которые располагались на современной территории Тамбовской области. Кластеризация проведена отдельно для 3-х хронологических срезов: XVII в., XVIII в., первая половина XIX в. На каждом хронологическом срезе выделены 3 уровня кластеров.

Результаты показали неравномерность втягивания отдельных поселений в ядро Русского государства на всех изученных отрезках. На отрезке XVII в. на 3-м уровне сохранилось 5 кластеров. Из 127 сёл этого времени 105 попали в число типичных для зоны фронтира. Но более 20 оказались ещё в 5 кластерах, отразив особости втягивания части поселений в зону фронтира. В кластерных построениях XVIII в. в числе специфичных оказалось только $10 \%$ тамбовских сёл 4-х кластеров, не объединившихся с основным кластером. На основе данных середины XIX в. выстроилось 2 кластера. Подавляющее большинство поселений вошло в кластер, который состоял из сёл, типичных для земель метрополии. Но 3 населённых пункта даже в это время сохраняли «своеобразие».

В итоге, полагаем, были найдены оптимальные параметры кластерного анализа для выбранного массива исходных данных и, вместе с тем, обоснована целесообразность этого исследовательского инструмента.

\section{Заключение}

Совместное использование фрактального моделирования и кластерного анализа дало наблюдения для ответа на ряд «запутанных» исторических вопросов. В частности, появились дополнительные основания для ответа на громко прозвучавший в АИК вопрос «Можно ли увидеть всю Россию из Малых Пупков?» [6; 7]. 
Фрактальное моделирование более тысячи сельских поселений Тамбовской губернии показало, что с. Малые Пу́пки вплоть до начала XX в. было в числе наиболее типичных населённых пунктов по демографическим показателям (более $80 \%$ от общего числа поселений). В результате кластерного анализа установлено, что Тамбовская губерния этого времени вошла в единую группу с другими русскими регионами Европейской России, где явно сохранялось традиционное демографическое поведение крестьянства.

Фрактальное моделирование освоения зоны южнорусского фронтира дало основание говорить, что Козловский уезд, в котором в XVII в. возникло село был типичным для полосы от Белгорода до Пензы и Саратова, уезды которой постепенно вошли в состав метрополии к концу XVIII в. При кластерном анализе село изначально вошло в наиболее типичную группу со служилым населением, занятым земледельческим трудом и характерным для аграрного общества демографическим поведением. Верификация результатов модельных построений другими известными фактами аграрного истории говорит о том, что население М. Пу́пок имело аналоги среди тысяч поселений государственных крестьян средней полосы Европейской России, сотен поселений бывших служилых людей и переселенцев из Центральной России в Поволжье, на Урал, в Западную Сибирь. На этих территориях в начале XX в. проживали десятки миллионов русских православных крестьян. Это не вся России, но очень большая её часть.

\section{Библиография}

1. Жуков Д.С., Канищев В.В. Лямин С.К. Фрактальное моделирование историко-демографических процессов // Бюллетень ассоциации «История и компьютер». 2012. - № 38. - С. 74-75.

2. Жуков Д.С., Канищев В.В. Лямин С.К. Фрактальное моделирование историко-демографических процессов. - Тамбов: Издательский дом ТГУ им. Г.Р. Державина, 2011. -195 c.

3. Жуков Д.С., Канищев В.В. Лямин С.К. Моделирование демографических процессов в поздней советской деревне: 1959 - 1989 гг. // Историческая информатика. 2019. - №4. - С. 43-73.

4. Федоров И.А., Краснова Л.В. Феномен социальной кластеризации. - Тамбов: Издательский дом ТГУ им. Г.Р. Державина, 2010. - 194 с.

5. Канищев В.В. Кластерный анализ демографического поведения сельского населения Европейской России в начале XX в. и в начале XXI в. К постановке вопроса // Ineternum. - 2011. - № 1-2. - C. 43-55.

6. Миронов Б.Н. Можно ли увидеть всю Россию из Малых Пупков? // Круг идей: алгоритмы и технологии исторической информатики: Труды IX конференции Ассоци- 
ации «Историк и компьютер». - М., Барнаул: Издательство Алтайского университета, 2005. - C. 528-543.

7. Дьячков В.Л., Канищев В.В. Послание Б.Н. Миронову о сущности работы отдельных провинциальных историков, или Ответ ученому соседу // Круг идей: алгоритмы и технологии исторической информатики: Труды IX конференции Ассоциации «Историк и компьютер». - М., Барнаул: Издательство Алтайского университета, 2005. C. 544-577.

https://doi.org/10.29003/m1789.978-5-317-06529-4/56-64

Кандаурова Т.Н.

Российский государственный гуманитарный университет, Москва

\section{Социокультурная деятельность российкого предпринимательского сообщества XIX - начала XX вв. в контексте квантитативной истории}

Аннотация. В статье представлен опыт анализа социокультурной деятельности российского предпринимательского сообщества с использованием количественных методов (построение трендовых моделей по материалам динамических рядов годовых отчетов) по развитию Арнольдо-Третьяковского училища, показан вклад предпринимателей в формирование фондов развития и строительства учебного заведения, фондов стипендиальных средств на основе благотворительных практик.

Ключевые слова: российское предпринимательское сообщество, Арнольдо-Третьяковское училище, социокультурные практики, благотворительная деятельность, попечительство, Третьяковы, Боткины, К.Т. Солдатенков.

Kandaurova T.N. Russian State University for the Humanities, Moscow

\section{Sociocultural activities of the Russian business community of the XIX - beginning XX century in the context of quantitative history}

Abstract. The article presents the experience of analyzing the socio-cultural activities of the Russian business community using quantitative methods (building trend models based on the materials of dynamic series of annual reports) for the development of the Arnoldo-Tretyakov school, shows the contribution of entrepreneurs to the formation of funds for the development and construction of educational institutions, scholarship funds based on charitable practices.

Keywords: Russian business community, Arnoldo-Tretyakov school, sociocultural practices, charity work, guardianship, Tretyakovs, Botkins, K.T. Soldatenkov. 
В российской истории пореформенный период характеризуется не только активизацией экономической деятельности предпринимательского сообщества в контексте развития капиталистического производства, но и расширением масштабов и географии социокультурной деятельности. Растет объем вложений в развитие различных социальных и культурных институтов, бо́льшие масштабы приобретает благотворительная, меценатская и попечительская деятельность представителей купеческого, промышленного и банковского сообществ. В сферу социокультурной деятельности включаются не только отдельные представители предпринимательского сообщества, но и их семьи, различные товарищества и объединения, купеческие общества. Активизируется как повседневная благотворительность, так и долговременная или перспективная. Практически во всех попечительных и попечительских советах образовательных, медицинских, культурных учреждений, учреждений призрения представлены отечественные предприниматели. Социокультурная деятельность российских предпринимателей в это время приобретает полифункциональный характер, включая формирование новых социальных и культурных институтов, попечительство, благотворительность, меценатство и деятельность в сферах образования, здравоохранения, искусства, музейного дела, поддержку творческой интеллигенции. Полифункциональная социальная и культурная деятельность характерна была для известных предпринимательских семей Боткиных, Третьяковых, Щукиных, Алексеевых, Абрикосовых, Солдатенковых $[1,2,3,4,14]$ и многих общественных организаций (купеческие общества столиц и регилонов и др.) и предприятий.

Братья П.М. и С.М. Третьяковы и члены их семей помимо создания Третьяковской галереи принимали активное участие в развитии специального учебного заведения для глухонемых детей - Московского Арнольдовского училища. Для П.М. Третьякова, 30 лет возглавлявшего Попечительский совет училища, это был второй масштабный социокультурный проект, по своей значимости равный созданию знаменитой художественной галереи. В знак признательности заслуг П.М.Третьякова в развитии учебного заведения училище получило наименование Арнольдо-Третьяковского. Практически полная сохранность годовых отчетов училища предоставляет возможность проанализировать как вклад семей Третьяковых-Боткиных, К.Т. Солдатенкова и других предпринимателей в развитие образовательного учреждения (микро-уровень), так и сообщества представителей предпринимательских династий в целом (макро- 
уровень). С 1860-х гг. среди жертвователей, почетных членов и членов «Попечительного Арнольдовского общества» были представители известных предпринимательских династий - Алексеевы, Абрикосовы, Боткины, Горбовы, Морозовы, Мамонтовы, Мазурины, Мусатовы, Рукавишниковы, Перловы, Третьяковы, П.П. Сорокоумовский, Щукины, Якунчиковы, Т.Е. Жегин и др. [6, с. 15-16].

Училище для обучения глухонемых детей было открыто в Москве в 1860 г. Основателем этого специального учебного заведения был сурдопедагог Иван Карлович Арнольд, который перевел часть уже существующего училища из Петербурга в Москву. В ноябре 1863 г. обеспечение училища финансовыми и материальными средствами взял на себя «особый Комитет», в состав которого вошли, Д.П. Боткин, П.М. Третьяков, 3.Н. Якунчикова (сестра В.Н. Третьяковой), Э.П. Тиличеева, Н.Г. Лашкарев, М.А. Горбов, А.С. Кампиони. Попечители училища вносили ежегодные взносы и пожертвования на содержание и развитие училища, также формировали сообщество благотворителей училища, привлекая дополнительные финансовые средства на обучение детей в училище. Уже в 1862-63 гг. училище получило 5046 руб. 41/2 к. от жертвователей и в виде ежегодных взносов попечителей, сумма средств, полученных в С.-Петербурге через Г.К. Арнольда составляла тогда 1311 руб. [5, с. 21-29]. Уставные документы Арнольдовского училища в г. Москве и попечительного Общества при нем были утверждены в 1869 г. Общество состояло «под покровительством Московского городского управления». Основная задача Общества состояла в «содержании и развитии Московскаго Арнольдовскаго училища» [6, с. 17]. После ухода из жизни П.М. Третьякова в конце 1898 г. Попечительное общество прекратило свое существование. В мае 1900 г. училище по «приговору Городской Думы», было «принято в ведение Московского Городского Общественного Управления» [13, с. 1].

Статистические материалы годовых отчетов (1862-63, 1867-681899 гг.) позволили проанализировать динамику развития училища за счет пожертвований и благотворительности, трансформацию благотворительных практик предпринимательского сообщества, персональные и корпоративные вклады в развитие училища отечественных предпринимателей, развитие стипендиальных фондов и численность персональных стипендиатов и общественных организаций. Благотворительные практики предпринимателей выражались в ежегодных взносах в фонд училища, в пожертвованиях почетных попечителей финансовых средств в стипендиальный фонд, в передаче материальных средств, в завещании средств училищу по духовным записям, во 
вложении средств на приобретение здания и оборудования и строительство училищного комплекса.

На основе группы динамических рядов (пожертвования в пользу училища; число жертвователей; стипендиальный фонд; число учащихся-стипендиатов; средства Московской купеческой управы; вклады почетных попечителей; персональные и корпоративные пожертвования) были построены трендовые модели, отражающие различные аспекты благотворительности по отношению к училищу и учащимся в третьяковский период (1867-1898 гг.) и тенденции ее развития. Тренд, представляющий объемы пожертвований благотворителей на училище с 1867 по 1899 гг., имеет ниспадающую динамику со среднегодовым показателем уменьшения жертвований 55,05 руб. Рост вложений отмечается на этапе 1867-1885 гг., на этапе 1886-1899 гг. проявляется обратная тенденция (3125 руб. в 1886 г. и соответственно 2155 руб. - в 1899 г.). Самые высокие показатели отмечаются в 1872-1873 гг. Подобная же тенденция проявляется и в динамике численности жертвователей средств на развитие училища в этот более чем 30-летний период (среднегодовой показатель сокращения численности составляет $-2,5)$ (рис. 1 и 2).

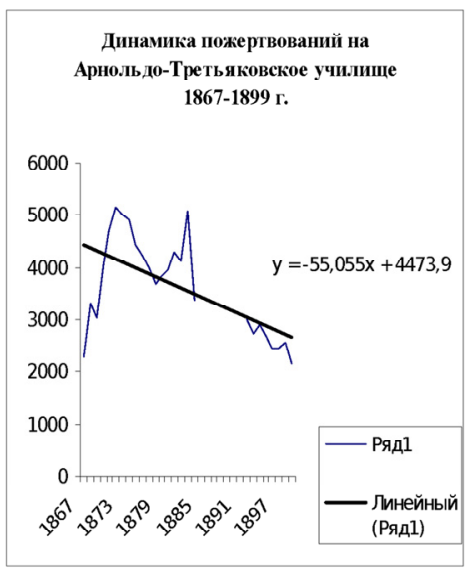

Рис. 1.

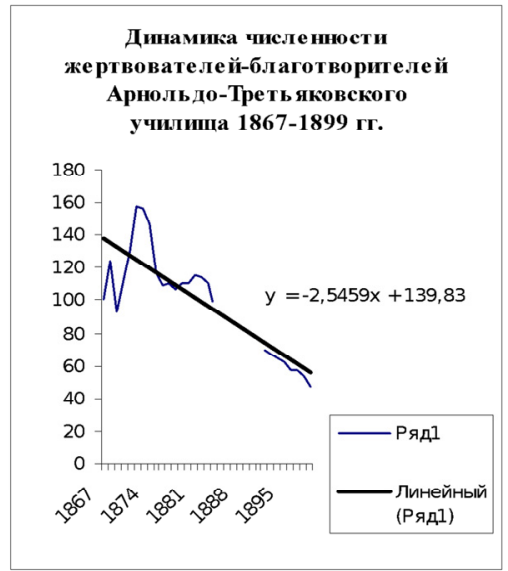

Pис. 2.

По мере формирования основного неприкосновенного капитала училища, который пополнился по завещанию П.М. Третьякова 200.000 руб. в 1899 г. и достиг почти 400.000 руб., [12, приложение c. 10] отмечался ежегодный рост процентов с него, которые употреб- 
лялись на развитие учебного заведения. Эти суммы, как и рост других вложений, компенсировали сокращение с годами пожертвований благотворителей.

Положительная динамика отмечается в объемах пожертвований средств на развитие училища от Московской купеческой управы. Изначально училище получало от управы 1000 руб. ежегодно с 1872 г. по 1876 гг., затем 2000 руб. в 1877-1880 гг., 3500 руб. в 1881-1884 гг. и по 4000 руб. в 1886-1899 гг. В трендовой модели среднегодовой прирост вложений купеческой управы составляет $+124,88$ руб. В динамике пожертвований почетных попечителей Арнольдо-Третьяковского училища также наблюдается положительная тенденция. Среднегодовой показатель роста составляет $+188,73$ руб. (рис. 3 и 4). Пожертвования почетных членов попечительного Общества училища были бо́льшими по свом объемам, чем консолидированные вклады членов-благотворителей.

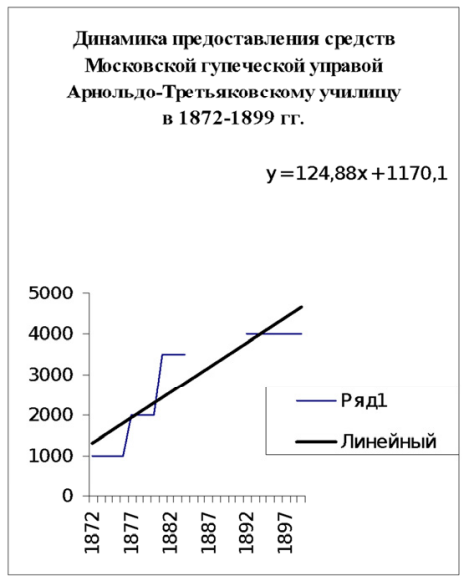

Pис. 3

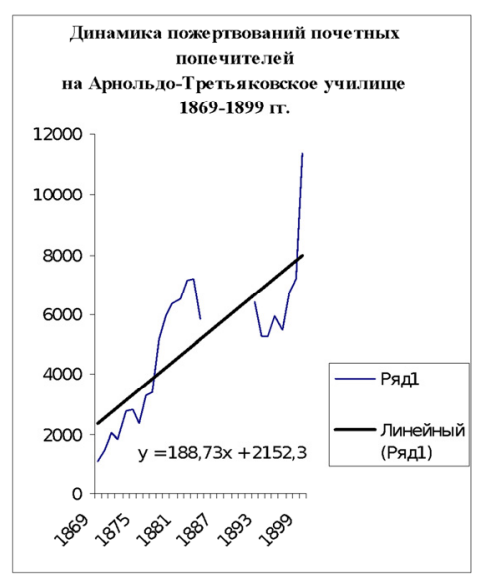

Pис. 4

При анализе состояния и пополнения стипендиального фонда училища по годовым училищным отчетам на основе трендовой модели обнаруживается также восходящая динамика со среднегодовым показателем прироста +278 руб. Одновременно определяется положительная динамика и в численности именных стипендиатов, обучаемых на средства отдельных предпринимателей, городского общества, Московского Технического училища, почетных членов «Попечительного об училище общества» [4, с. 90-91] со среднегодо- 
вым показателем прироста в трендовой модели $+1,4$ (рис. 5 и 6). П.М. Третьяков постоянно активизировал сбор средств на развитие училища. Тренд, представляющий динамику объемов сбора средств на содержание училища, отражает положительную в целом тенденцию, несмотря на снижение размеров сборов по отдельным годам. Среднегодовой показатель прироста здесь составляет чуть более 49 руб. при начальном показателе 2.970 руб. 50 коп. и показателем 1892 г. в сумме 2400 руб. Наибольший размер сборов приходится на 1875 г. 6920 руб. 16 коп. и в 1877 г. -5860 руб. 50 коп. [8, с. 11; 9, с. 7].

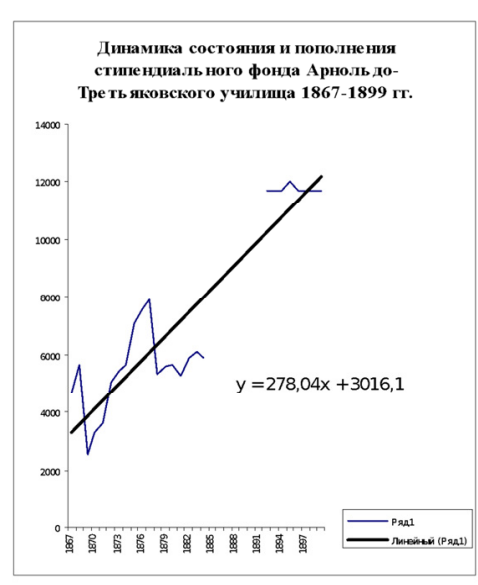

Рис. 5

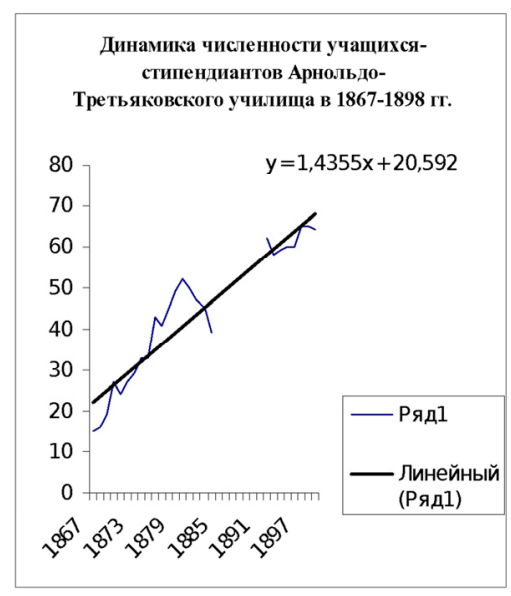

Pис. 6

При анализе персональных и семейных вложений в развитие Арнольдо-Третьяковского училища на основе благотворительных социокультурных практик отдельных представителей предпринимательского сообщества отмечаются также положительные тенденции по трендам. Известный российский предприниматель, благотворитель и меценат К.Т. Солдатенков за третьяковский период (18691899 гг.) передал училищу более 23.200 руб. как почетный попечитель в стипендиальный фонд, и как благотворитель он выделял училищу по 500 руб. ежегодно. [7, с. 15]. Помимо этого Козьма Терентьевич оставил в пользу училища по завещанию 20.000 руб. [12, с. 22]. Представители семьи известных предпринимателей чаеторговцев Боткиных (родственники Третьяковых) также оказывали финансовую помощь училищу на протяжении третьяковского периода. За это время они передали училищу более 8.000 руб. (без учета 5 лет). 
Братья Петр Петр. и Дмитрий Петр. Боткины входили в состав Попечительного совета училища. Член-благотворитель училища Василий Петр. Боткин завещал училищу 5.000 руб. серебром. [7, с. 9] (16.500 рус. ассигнациями) (рис. 7).

Самыми значительными вложениями в развитие училища были вложения семьи Третьяковых. Трендовая модель, представляющая благотворительные пожертвования средств на училище представителями семьи Третьяковых, отражает восходящую тенденцию в период 1867-1899 гг. Практически все члены семьи братьев Третьяковых были членами-благотворителями Арнольдо-Третьяковского училища. Благотворительные пожертвования Третьяковых, в том числе членов семей сестер Павла и Сергея Михайловичей - Гартунгов, Каминских, В.Д. Коншина - за этот период составили более 46,5 тыс. руб., включая средства на стипендии учащихся. Помимо этого по завещанию Сергея Мих. Третьякова училище получило 20.000 руб. Он являлся «Членом-Благотворителем с 1863 года и много способствовал обезпечению Училища в материальном отношении как своими пожертвованиями, так и привлечнием к тому других Благотворителей» [10, с. 10]. В 1875 г. он выделил 5.000 руб. на постройку нового дома для училища [8, с. 11] Авторитет братьев Третьяковых в предпринимательской среде и в московском обществе и их пример, безусловно, способствовал привлечению благотворителей и жертвователей финансовых и материальных средств в фонды училища. (рис. 8).

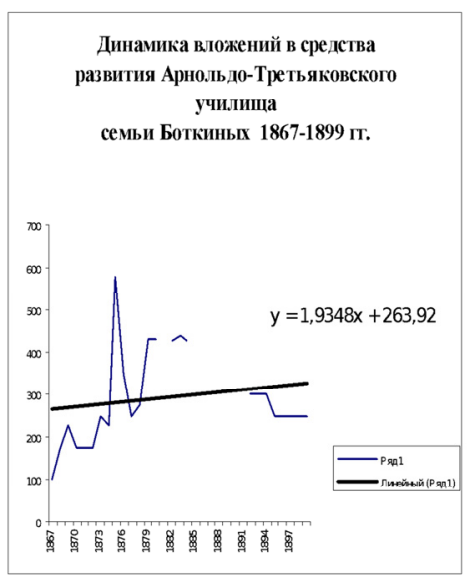

Рис. 7

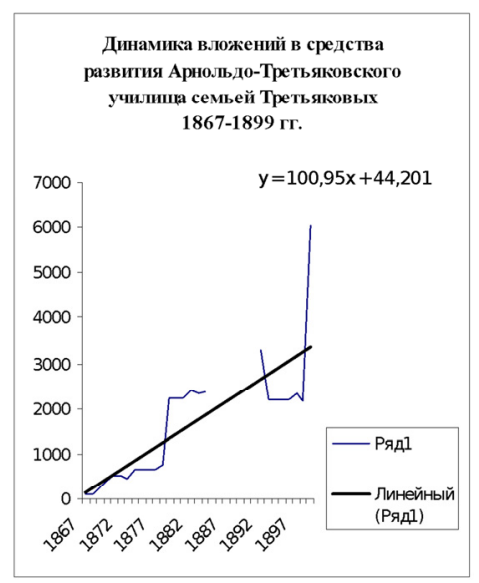

Рис. 8 
Показательным был и их пример служения на поприще попечительства и благотворительности, общественной деятельности и в деле развития одного из значимых специализированных учебных заведений г. Москвы. По подсчетам Г.Н. Ульяновой, П.М. Третьяков выделил «более 340.000 руб. на нужды Арнольдо-Третьяковского училища» [14, с. 470]. «В 1880-1890-х гг. взносы почетных членов Попечительного об училище Общества «на содержание их пансионеров» от членов семьи Третьяковых составляли около одной трети или более чем одну треть от общей суммы по данной приходной статье (в 1880 г. - 33,33\%; 1882-1883 гг. - 31,46\%, 1986 г. - 37,81\%; 1892 г. $-37,5 \% ; 1893$ г. $-40 \% ; 1894$ г. $-40 \%$; 1895 г. $-35,29 \%$; 1896 г. $-37,83 \%$; 1897 г. $-33,45 \% ; 1898$ г. $-29,16 \%) »$. [4, с. 88]. П.М. Третьяков более 30 лет занимался вопросами развития училища, которое стало его одним из главных социокультурных проектов, привлекая к благотворительной деятельности многих членов своей семьи и семей предпринимательского сообщества, наращивая его потенциал, что подтверждается количественным анализом статистики источников и результатами определения тенденций развития. Он значительно расшил училище, что позволило увеличить контингент обучавшихся и проходивших социализацию детей, сформировал современный учебный комплекс, привлекал средства предпринимательского сообщества на поддержку и развитие училища, формирование стипендиального фонда и развития института именных стипендий, что способствовало увеличению числа учащихся, проходивших обучение на бесплатной основе.

\section{Литература и источники}

1. Аронов А.А. Золотой век русского меценатства. - М.: Моск. гос. ун-т кул-ры, 1995. $-115 \mathrm{c}$.

2. Бурышкин П.А. Москва купеческая. - М.: Столица, 1990. - 352 с.

3. Барышников М.Н. Деловой мир России: Историко-биографический справочник. - С.-Петербург: Искусство-СПБ, Logos, 1998. - 448 с.

4. Кандаурова Т.Н. Социокультурные практики российских предпринимателей пореформенного периода: Арнольдо-Третьяковское училище // Историкопсихологические аспекты образования в России и в мире. Материалы XXXVII Международной научной конференции. Санкт-Петербург, 18 мая 2015 г. / Под. ред. С.Н. Полторака. - СПб.: Изд-во «Полторак», 2015. - С. 84-93.

5. Отчет Московскаго учебнаго для глухонемых заведения, основаннаго и содержимаго Эдуардом Арнольдом. За 1862 и 1863 г. - М., 1864. - 29 с.

6. Отчет Московскаго Арнольдовскаго училища для глухонемых детей обоего пола. За 1867 и 1868 годы. - М., 1869. - 20 с.

7. Отчет Московскаго Арнольдовскаго училища для глухонемых детей обоего пола. За 1869 год. - М., 1870. - 15 с. 
8. Отчет Московскаго городского Арнольдовскаго училища для глухонемых детей обоего пола за 1875 г. - М., 1876. - 23 с.

9. Отчет Московскаго городского Арнольдовскаго училища для глухонемых детей обоего пола за 1877 год. - М., 1878. - 28 с.

10. Отчет Московскаго Арнольдовскаго училища для глухонемых детей обоего пола за 1892 год. - М., $1893 .-25$ с.

11. Отчет Московскаго городского Арнольдо-Третьяковскаго училища глухонемых за 1900 год. - М., 1901. - 52 с.

12. Отчет Московскаго Городского Арнольдо-Третьяковскаго училища глухонемых за 1901 год. - М., 1902. - 25 с.

13. Отчет Московскаго городского Арнольдо-Третьяковскаго училища глухонемых за 1903 год. - М.,1904. - 23 с.

14. Ульянова Г.Н. Благотворительность московских предпринимателей: 1860 1914. - М., Изд-во «Мосгорархив», 1999. - 512 с.

https://doi.org/10.29003/m1790.978-5-317-06529-4/64-70

Кузьмин Ю.В.

Центральный аэрогидродинамический институт, Москва

\title{
Конструкторские школы как акторы истории техники. На примере статистического анализа мирового самолётостроения
}

Аннотация. Рассмотрено поведение конструкторских школ в самолётостроении. Эти социальные структуры на протяжении десятилетий сохраняют особенности деятельности, проявляющиеся в специфике создаваемых конструкций. В результате вариативность интенсивности НИОКР, измеряемой как частота появления новых конструкций, намного меньше, чем вариативность выпуска. Впервые показано, что вариации распределения НИОКР по странам также намного меньше, чем вариации выпуска. Это говорит о трудности создания конструкторских школ и необходимости их сбережения.

Ключевые слова: конструкторская школа, стадии развития технологии, динамика НИОКР, развитие самолётов, мировое самолётостроение.

\section{Kuzmin Yu.V. Central Aerohydrodynamic Institute, Moscow}

\section{Aircraft design schools as actors in the history of technology. On the example of the statistical analysis of the world aircraft construction school}

\begin{abstract}
The design schools in airplane manufacturing are considered. For decades, these social structures retain their own features, manifesting in the specifics of the created airplanes. As a result, the variability in R\&D intensity, measured as the frequency of new designs appearing, is much less than the variability in output. It is shown for the first time that variations in the distribution of $\mathrm{R} \& \mathrm{D}$
\end{abstract}


across countries are also much smaller than variations in output. This indicates the difficulty of creating design schools and the necessity to maintain them carefully.

Keywords: design school, technology development stages, R\&D dynamics, airplane development, world airplane manufacturing.

Кораллы растут медленно. Очень медленно растут кораллы. Отломи кусок - и замена появится, в лучшем случае, через десятки лет. Поэтому полиция во многих странах кораллы ломать запрещает. Не у нас. У нас кораллы не растут. А ещё кораллы не любят грязной воды. Впрочем, речь не о них. Речь о конструкторских школах.

Изучение истории мирового самолётостроения показало, что одними из основных акторов при создании новой техники являются не столько конструкторы или отдельные коллективы, не столько отдельные предприятия, а достаточно долгоживущие образования, которые можно назвать «конструкторскими школами». Время жизни таких конструкторских школ может превышать время работы отдельного конструктора.

В каждой школе на протяжении десятилетий сохраняются особенности конструкций. Эти особенности могут «менять знак»: будучи объективно оправданными и эффективными на определённом этапе, позднее они становятся препятствием для создания оптимальных конструкций. Тем не менее, и в новых моделях эти особенности продолжают тиражироваться. Отказ от особенностей школы происходит с большим трудом и значительным - по сравнению с конкурентами, не отягощёнными подобным прошлым - запаздыванием.

Например, в работе автора [1] было проанализировано стремление советских конструкторов создавать лёгкие - по сравнению с

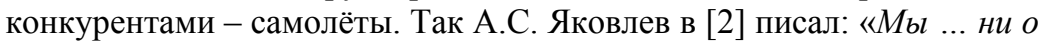
чем не могли думать, кроме одного: сделать новый истребитель самым лёгким из всех воюющих!». Причина понятна и рациональна: мощность советских авиадвигателей перед и во время Второй Мировой войны заметно уступала мощности немецких моторов, не говоря уже об американских. Создать истребитель со сравнимой скоростью можно было только максимально облегчив его.

Маневренность и взлётно-посадочные характеристики (ВПХ) улучшались и при уменьшении связанной с общей массой характеристики - нагрузки на крыло. И в мемуарах советских конструкторов неоднократно, как достижение, повторяется, что нагрузка на крыло у советских самолётов обычно была меньше, чем у немецких машин аналогичного назначения. 
Однако в 1950-1960-х годах был период, когда именно в СССР строились самые мощные в мире реактивные двигатели. Но самолёты продолжали делать лёгкими. Для истребителей это было частично оправдано: например, манёвренность истребителя МиГ-21 заметно превосходила манёвренность американского F-4 Phantom II. Вместе с тем, максимальное облегчение самолёта затрудняло размещение оборудования - тем более что советские изделия электронной промышленности были заметно тяжелее аналогичных европейских и североамериканских.

Но если для истребителей стремление к «лёгкости» и уменьшению нагрузки на крыло имело смысл, то для стратегических бомбардировщиков низкая нагрузка на крыло была противопоказана: она снижает дальность - главный показатель стратегического самолёта. ВПХ же для таких самолётов не важны, они действуют с крупных аэродромов, на которых заранее можно оборудовать длинные взлётно-посадочные полосы. Не нужно бомбардировщикам и интенсивное маневрирование. Однако, по подсчётам автора, во второй половине 1950-х годов (после принятия на вооружение реактивных и турбовинтовых самолётов В-47, B-52, Vulcan, Victor, Valiant, 3M, Ту-16, Ту-95) средняя нагрузка на крыло советских стратегических бомбардировщиков была в полтора раза меньше, чем американских, например в 1956 г. - 476 кг/кв.м. против 741 кг/кв.м. Только в 1980-х годах, с появлением самолёта Ту-160 этот разрыв был ликвидирован. [3].

Конструкторские школы могут передавать традиции многими путями. Стремление «сделать самолёт лёгким» было зафиксировано и в передаваемых при обучении методах проектирования, и в привычных требованиях заказчиков, и в нормативных документах авиапромышленности и конструкторских бюро. Причина исчезла, а традиция осталась.

Этот пример не означает, что долгоживущие конструкторские школы со временем обязательно начинают тормозить процесс: ультимативное стремление максимально облегчить самолёт изначально было вызвано неудовлетворительным состоянием в смежной области двигателестроении - и при «гармоничном» развитии не возникло бы.

В то же время, именно школы поддерживают выполнение работ с нужным качеством. Попытка «рывком» изменить принятый стиль проектирования часто приводит к появлению проблем - иногда, фатальных, в самых неожиданных местах. Например, многие авиационные специалисты связывают катастрофы самолёта Boeing 737 MAX и, главное, затруднения при устранении причин этих катастроф - уже полтора года сотни самолётов прикованы к земле - 
именно ошибками менеджмента компании, резко изменившего процедуры создания новой техники и, как следствие, перечеркнувшего наработки конструкторской школы «Боинг» (см., напр., [4]).

Долголетие научных школ при нормальном развитии событий и трудность образования новых рассмотрена и в работе [5]. Выяснилось, что если в начальной стадии развития технологий (для самолётов - это период 1900-1930-х годов) динамика объёма выпуска и количества разрабатываемых за год моделей коррелируют, то затем график количества новых моделей ведёт себя намного более стабильно, чем график выпуска слабо реагируя и на взлёты, и на падение производства.

Так, не произошло интенсификации конструкторских работ во время Второй Мировой войны и в предшествующие ей годы: в 19411945 годах в миое было создано меньше модификаций, чем, скажем, в 1931-1935 годах, даже если исключить из рассмотрения страны, оккупированные Германией и вынужденно временно прекратившие конструкторскую деятельность. Во время же Первой Мировой войны заметный рост числа создаваемых модификаций самолётов имел место.

В работе [5] на этом основании сделан вывод о конечности и исчерпаемости «творческого резерва» при развитии отрасли техники: если на начальных стадиях развития технологии возможен продуктивный переход специалистов из других отраслей, то позднее, с увеличением сложности создаваемых изделий, он сталкивается со всё большими трудностями. В результате даже в экстраординарных обстоятельствах невозможно быстро увеличить отдачу конструкторских коллективов.

В [5] также показано, что конструкторские школы легко разрушаются при социальных потрясениях, а восстановление происходит очень медленно.

Консервативно не только историческое, но и географическое поведение динамики результативности конструкторских школ, понимаемой как число появляющихся новых модификаций и типов самолётов (тип самолёта - более общее понятие, в одном типе может быть одна или несколько модификаций, определения даны в [5]).

Для оценки концентрации выпуска и НИОКР по странам использован коэффициент Херфиндаля-Хиршмана НН: отношение сумм квадратов показателя для отдельных стран к квадрату суммарного показателя (производства самолётов за год или количества появившихся за год новых модификаций или типов самолётов). 
Коэффициенты НН подсчитаны на основе данных, собранных в созданной автором базе данных самолётов XX века. Сейчас в базе учтены 20260 модификаций самолётов, сконструированных в мире с 1903 по 2000 г. включительно, объединённые в 10800 типов. Результаты публикуются впервые.

При расчёте коэффициентов была введена страна «Россия», представляющая собой Российскую империю до 1917 г., Советскую Россию в 1918-1922 годах, СССР в 1923-1991 годах и РФ в 19922000 годах.

На рис. 1 и 2 видно, что до второй половины 1930-х годов динамика коэффициентов НН для выпуска самолётов по странам и для количества новых модификаций и типов сохраняется. Начиная же с 1940 г. коэффициенты НН для появления новых модификаций и типов ведут себя достаточно устойчиво (превышение НН для модификаций над НН для типов в середине века связано с тем, что именно в ведущих странах создавались наиболее успешные типы, реализованные в большом количестве модификаций) и независимо от значительных колебаний коэффициента для выпуска, связанных, прежде всего, с изменением относительных долей в мировом производстве США и - в меньшей степени - СССР.

Интересно, что момент утраты корреляции на графике 1 - вторая половина 1930-х годов - почти совпадает и с моментом расхождения поведения графиков количества создаваемых новых типов и выпуска самолётов (эти графики приведены в работе [5]).

Таким образом, в истории мирового самолётостроения во второй половине 1930-х годов произошёл «фазовый переход», детектируемый по изменению корреляций графиков выпуска и результативности НИОКР. Анализ по отдельным странам показывает, что, несмотря на очень разные условия, в которых находилась авиапромышленность, например, США, Германии, СССР и Франции, даты «фазового перехода» в отдельных странах очень близки.

Интересно, что этот переход не совпадает по времени с другим переходом, когда перестали расти многие абсолютные характеристики самолётов (например, скорость), а конкуренция технических решений, выражающаяся резкой сменой поколений изделий, сменилась сосуществованием: как в области аэродинамических схем, так и по видам применяемых силовых установок и конструкционных материалов. Этот переход произошёл во второй половине 1950-х годов [6]. 


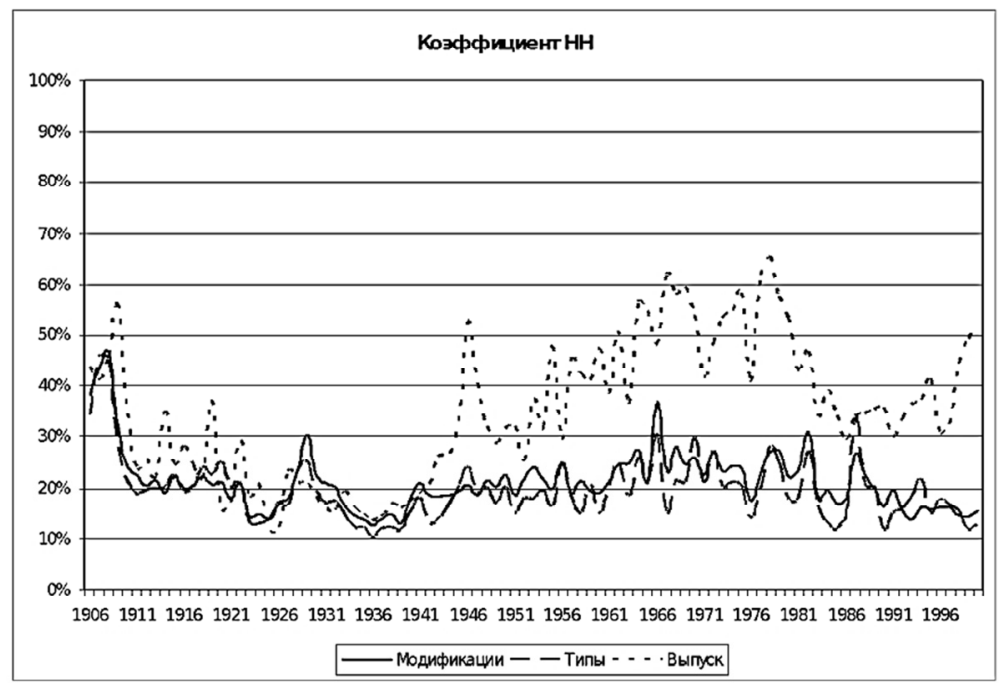

Рис. 1. Погодовая динамика коэффициентов Херфиндаля-Хиршмана для распределения по странам создаваемых модификаций самолётов, типов самолётов и выпуска самолётов

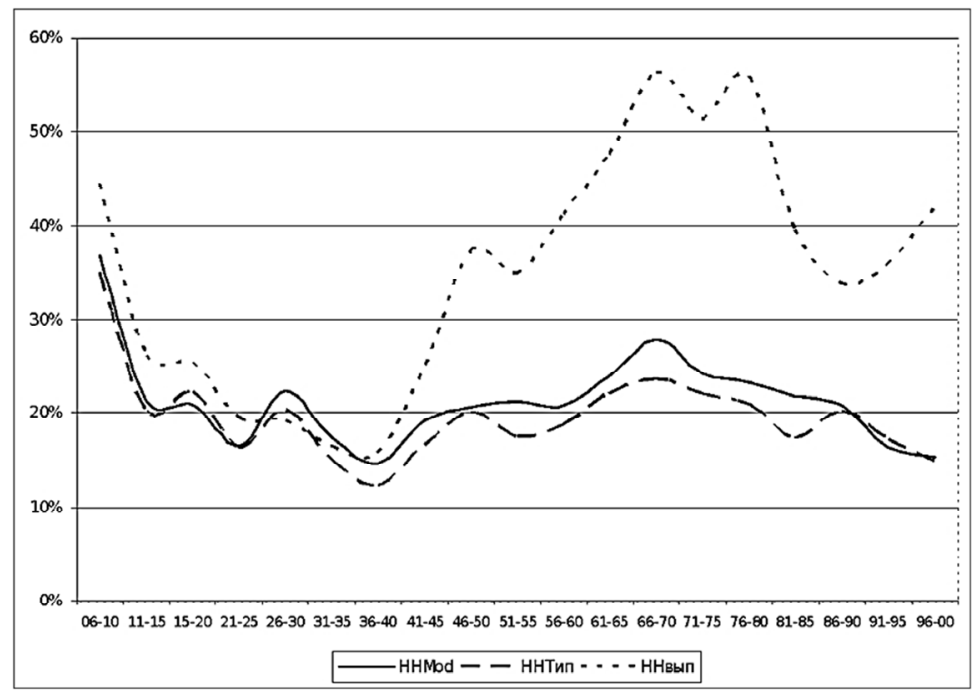

Рис. 2. То же, что рис. 1, усреднённый по пятилетним периодам 
В истории науки понятие «научная школа» давно и плодотворно используется (см., напр., [7]). Появляются и работы, посвящённые конструкторским школам. Однако, в большей части таких работ под «конструкторской школой» понимается коллектив в рамках одной организации или организациях - наследниках (см., напр, [8]. Несмотря на «географическое» название в этой книге используется «фирмоцентрический» подход: рассматриваются, в основном, работы сотрудников ВНИИТМ).

Представляется, что анализ истории техники, выполненный не с точки описания деятельности отдельных конструкторов и/или организаций, а при помощи определения конструкторских школ, характеризуемых количественно измеряемыми характеристиками создаваемых конструкций (как, например, школа создания «лёгких» самолётов в $\mathrm{CCCP}$, и изучения проявления особенностей данных школ, их положительного и отрицательного влияния за всё время существования школы, может стать новым и полезным взглядом на историю техники.

К сожалению, в современной России сохранение конструкторских школ, их традиций и наработок не является приоритетом при «оптимизации» авиастроения. Создание же новых школ, как показывает статистика в работе [5], длится долго - иногда десятки лет - и не может быть обеспечено «волевым» решением даже при неограниченном финансировании.

\section{Библиография}

1. Кузьмин Ю.В. Влияние традиций научных школ на пути развития техники на примере авиастроения // Труды конференции «К.Э. Циолковский. Проблемы и будущее российской науки и техники». - Калуга, 2017. - С. 236-238.

2. Яковлев А.С. Цель жизни. 3-е изд. М.: Политиздат, 1973. - 608 с.

3. Кузьмин Ю.В. Развитие реактивных стратегических бомбардировщиков: влияние конструкторских школ // Труды годичной конференции ИИЕТ РАН. - М., 2012. C. 678-681.

4. Tkacik M. How Boeing's managerial revolution created the 737 MAX disaster // The New Republic. 18.09.2019. - URL: newrepublic.com/article/154944/boeing-737-maxinvestigation-indonesia-lion-air-ethiopian-airlines-managerial-revolution.

5. Кузьмин Ю.В. Соотношение объемов производства и результативности конструкторских работ в мировом авиастроении XX в. Статистический анализ базы данных // Историческая информатика. - 2020. - № 2. - С. 61-82.

6. Кузьмин Ю.В. От истории техники к законам развития техники // Труды годичной конференции ИИЕТ РАН. - М., 2019. С. 276-280.

7. Устюжанина Е.В., Евсюков С.Г., Петров А.Г. и др. Научная школа как структурная единица научной деятельности. - М.: ЦЭМИ РАН, 2011. - 73 с.

8. Космические роботизированные комплексы. Ленинградская - СПб научноконструкторская школа // Под ред В.А. Веселова. - СПб.: БГТУ «Военмех», 2016. $200 \mathrm{c}$. 
https://doi.org/10.29003/m1791.978-5-317-06529-4/71-79

Мазур Л.Н., Бродская Л.И. Уральский федеральный университет, Екатеринбург

\title{
Моделирование жизненного цикла крестьянской семьи (на материалах бюджетных обследований) ${ }^{1}$
}

Аннотация. В статье рассматривается понятие жизненного цикла семьи и методы его изучения. Предложена методика анализа жизненного цикла крестьянской семьи на материалах бюджетных обследований крестьянских хозяйств 1928/1929 г. Методика ориентирована на изучение первичных данных о составе семьи и ее демографических характеристиках, зафиксированных в опросных формах и систематизированных с использованием технологии баз данных. Опираясь на сведения о возрасте главы семьи, наличии детей дошкольного и школьного возраста, составе семьи (демографическом типе) были выделены стадии жизненного цикла, определена продолжительность отдельных стадий и всего цикла в целом.

Ключевые слова: крестьянская семья, репродуктивное поведение, жизненный цикл семьи, моделирование, метод условного поколения.

\section{Mazur L.N., Brodskaya L.I. Ural Federal University, Ekaterinburg}

\section{Modeling the life cycle of a peasant family (on the materials of budget surveys)}

\begin{abstract}
The article discusses the concept of family life cycle and methods of its study. A method for analyzing the life cycle of a peasant family based on the materials of budget surveys of peasant farms in 1928/1929 is proposed. The method is focused on the study of primary data on the composition of the family and its demographic characteristics, recorded in questionnaires and systematized using database technology. Based on information about the age of the head of the family, the number of children of preschool and school age, the composition of the family (demographic type), the stages of the life cycle were identified, the duration of individual stages and the entire cycle as a whole was determined.

Keywords: peasant family, reproductive behavior, family life cycle, modeling, conditional generation method.

«Жизненный цикл семьи» (ЖЦС) - междисциплинарное понятие, которое активно используется в исследованиях, связанных с изучением семьи и закономерностей ее эволюции. Первыми представление о

\footnotetext{
${ }^{1}$ Исследование поддержано грантом РФФИ № 18-09-00592 «Эволюция крестьянской семьи на Среднем Урале в XX веке: опыт реконструкции по материалам бюджетных обследований».
} 
семье как динамической системе, влияющей на экономические показатели семейного хозяйства, сформулировали статистики в конце XIX века. Информационной базой для их выводов послужили бюджетные обследования крестьянских хозяйств [1, с. 91]. В начале XX в. к данному вопросу - изучению семьи в динамике - обратились социологии, анализируя ее через призму изменения семейных функций и ролей $[2,3]$. В демографической науке понятие жизненного цикла семьи утвердилось несколько позднее, в конце 1940-х гг., благодаря статье американского демографа П. Глика [4]. Он рассматривал историю семьи как последовательность этапов роста/сокращения ее численности. «Жизненный цикл», по определению П. Глика, представляет собой ряд социальных и демографических состояний семьи с момента ее образования до момента прекращения существования.

Изучение жизненного цикла семьи опирается на методы когортного анализа [5], к которым относятся:

- метод «реального поколения» - лонгитюдное продольное исследование семьи (совокупности семей) с момента ее образования до распада;

- метод «условного поколения» - поперечное (единовременное) исследование совокупности семей, основанное на выделении когорт.

В нашем распоряжении имеется комплекс первичных материалов (бланков) бюджетных обследований крестьянских хозяйств Уралобласти за 1928/1929 г. (325 семей) [6, д. 39-60]. Он представляет собой естественную выборку: сохранилось чуть больше половины бланков с описаниями хозяйств из первоначального объема. Информация из первичных форм была перенесена в базу данных [7] и послужила основой для изучения семейно-брачного поведения крестьян на Урале в 1920-е гг. [8].

Исходя из особенностей организации и проведения бюджетных обследований, для реконструкции жизненного цикла крестьянских семей был использован метод «условного поколения». Опираясь на данные переписи 1926 г., была разработана поколенческая шкала возраста, которая послужила ориентиром для выделения условных когорт, соответствующих стадиям жизненного цикла крестьянской семьи (см. табл. 1). Затем методом экспертной оценки крестьянские хозяйства, участвовавшие в бюджетном обследовании 1928/1929 г., были распределены по стадиям жизненного цикла. При проведении экспертной оценки помимо возраста главы семьи учитывались дополнительные параметры: наличие в семье детей дошкольного и школьного возраста, взрослых детей и внуков, состав (демографический тип) семьи. 
Для каждой условной когорты был рассчитан средний возраст главы семьи, определен вариационный размах значений и среднее квадратичное отклонение (см. табл. 1, 2). Сопоставление средних возрастов на разных этапах ЖЦС, а также крайних значений возраста на начало смежных фаз, позволило оценить длительность отдельных этапов и цикла в целом [9].

Предварительный структурный анализ крестьянских семей показал сохранение традиционных черт в семейно-брачном и репродуктивном поведении крестьян, в том числе для них свойственна ориентация на многодетность, отсутствие регулирования рождаемости, почти поголовная брачность. И хотя Первая мировая война и Революция 1917-1922 гг. наложили свой отпечаток на демографическую ситуацию, к концу 1920-х гг. происходит восстановление крестьянских хозяйств на традиционных началах. В этом смысле, предложенная в статье модель ЖЦС отражает особенности развития традиционной крестьянской семьи.

Полный жизненный цикл крестьянской семьи включает пять этапов (фаз), различавшихся не только возрастом главы семьи, но и внутренней динамикой: 1 - создание семьи (формирование семейного ядра); 2 - рост; 3 - стабилизация; 4 - сокращение; 5 - распад. Обоснованность выделения этих этапов была проверена путем сравнения средних показателей возраста глав семей условных когорт методом однофакторного дисперсионного анализа (ANOVA). График демонстрирует возрастание среднего при увеличении стадии, за исключением пятой стадии, статистическая оценка которой не вполне корректна из-за малого числа наблюдений (рис. 1).

Первая фаза демографического цикла - создание семьи и ее начальный период существования до рождения первого ребенка. Всего в выборке к данной стадии отнесено 14 семей, преимущественно принадлежащих к демографическому типу «брачная пара без детей» и «брачная пара без детей с родителями и/или родственниками» (см. табл. 1, 2). Средний возраст главы семьи - 27,2 года при вариационном размахе от 22 до 37. В целом, средний показатель возраста свидетельствует о незавершенности восстановительных процессов: наряду с молодыми семьями (возраст главы 22-25 лет), в выборке присутствуют брачные пары, которые можно охарактеризовать как поздний неравный брак (например, мужу - 35, жене 25 лет). Опираясь на сравнение средних показателей возраста и значение среднего квадратичного отклонения, можно оценить продолжительность первой фазы - она составила от 0 до 5. 
Means and 95,0 Percent LSD Intervals

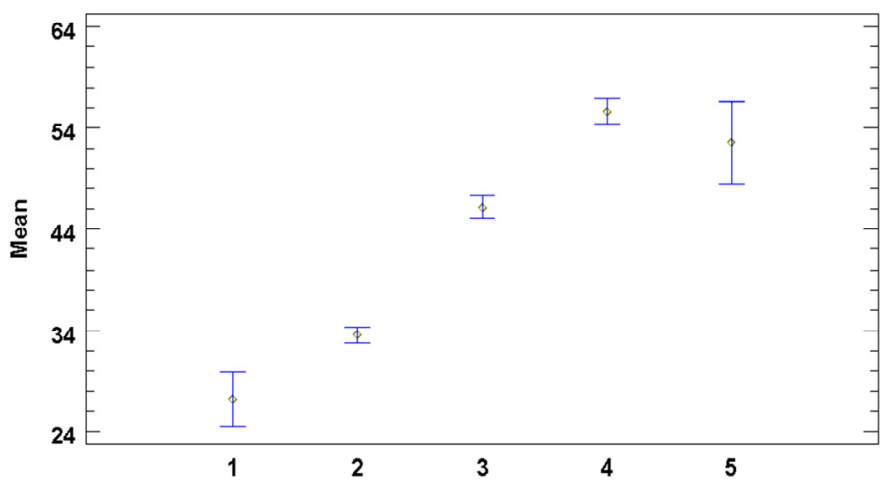

Рис. 1. Зависимость показателя среднего возраста главы семьи от стадии жизненного цикла семьи

Таблицуа 1

Модель жизненного цикла крестьянской семьи (по материалам бюджетных обследований 1928/1929 г.)

\begin{tabular}{|c|l|c|c|c|c|}
\hline \multirow{2}{*}{ Этап } & \multirow{2}{*}{$\begin{array}{c}\text { Характеристика } \\
\text { этапа }\end{array}$} & \begin{tabular}{c} 
Количество \\
семей/ удель- \\
\cline { 4 - 6 }
\end{tabular} & & \multicolumn{3}{|c|}{ Возраст вес в \% } & $\begin{array}{c}\text { Поколенческая } \\
\text { шкала, лет }\end{array}$ & $\begin{array}{c}\text { Интервал } \\
\text { крайних } \\
\text { значений }\end{array}$ & $\begin{array}{c}\text { Средний } \\
\text { возраст }\end{array}$ \\
\hline 1 & Создание семьи & $14 / 4,3$ & До 30 & $21-37$ & 27,2 \\
\hline 2 & $\begin{array}{l}\text { Молодая } \\
\text { растущая семья }\end{array}$ & $160 / 49,2$ & $30-35$ & $22-54$ & 33,6 \\
\hline 3 & $\begin{array}{l}\text { Зрелая стабильная } \\
\text { семья }\end{array}$ & $79 / 24,3$ & $35-50$ & $27-64$ & 46,1 \\
\hline 4 & $\begin{array}{l}\text { Пожилая } \\
\text { убывающая семья } \\
\text { (сокращение }\end{array}$ & $66 / 20,3$ & $50-60$ & $37-81$ & 55,7 \\
\hline 5 & $\begin{array}{l}\text { Старая семья } \\
\text { (распад) }\end{array}$ & $6 / 1,8$ & 60 и более & $40-69$ & 52,5 \\
\hline & Всего & $325 / 100$ & & & \\
\hline
\end{tabular}

Таблица составлена на основе расчетов по базам данных бюджетов крестьянских хозяйств за 1928/1929 г. 
Таблица 2

Возраст главы семьи в статистическом измерении

\begin{tabular}{|l|c|c|c|c|c|}
\hline \multirow{2}{*}{ Показатель } & \multicolumn{5}{|c|}{ Этапы жизенного цикла } \\
\cline { 2 - 7 } & $\mathbf{1}$ & $\mathbf{2}$ & $\mathbf{3}$ & $\mathbf{4}$ & $\mathbf{5}$ \\
\hline Count (объем выборки) & 14 & 160 & 79 & 66 & 6 \\
\hline Average (среднее арифметическое) & 27,2 & 33,6 & 46,1 & 55,7 & 52,5 \\
\hline $\begin{array}{l}\text { Standard deviation (среднее квадратичное } \\
\text { отклонение) }\end{array}$ & 5,25 & 6,23 & 7,77 & 8,66 & 12,04 \\
\hline Coeff. of variation коэффициент вариации), \% & 19,29 & 18,53 & 16,85 & 15,57 & 22,9 \\
\hline Minimum (минимальное значение) & 21,0 & 22,0 & 27,0 & 37,0 & 40,0 \\
\hline Maximum (максимальное значение) & 37,0 & 54,0 & 64,0 & 81,0 & 69,0 \\
\hline Range (вариационный размах) & 16,0 & 32,0 & 37,0 & 44,0 & 29,0 \\
\hline
\end{tabular}

Таблица составлена на основе расчетов по базам данных бюджетов крестьянских хозяйств за 1928/1929 г.

Вторая фаза развития семьи - «рост» (от момента рождения первого ребенка до момента рождения последнего ребенка). В выборке к данной стадии отнесено около половины обследуемых домохозяйств $(49,2 \%)$ - это семьи, в составе которых есть дети младшего (дошкольного) возраста. Подавляющее число семей в условной когорте являются нуклеарными $(65,0 \%)$ и относятся к демографическим типам «брачная пара с детьми»-64,4\% и «брачная пара с детьми и родителями» - 29,4\%. Обращает на себя внимание возрастной интервал главы семьи (от 22 до 54 лет) при среднем значении 33,6 года. Такой вариационный размах является следствием продолжительного репродуктивного периода, а также повторных браков. Продолжительность второй фазы составляет 13 лет.

Третья фаза - период «стабильности» семьи - от момента рождения последнего ребенка до выделения из семьи первого из взрослых детей или вступления его в брак. К данной когорте были отнесены семьи с детьми школьного возраста, их удельный вес в выборке составил $24,3 \%$, из них 74,7\% нуклеарные семьи (преимущественно, «брачная пара с детьми») и 25,3\% - расширенные («брачная пара с детьми и родителями»). На данной стадии растет число неполных семей $(8,8 \%)$, а также повторных браков. В двух семьях мужчины 27 и 28 лет «вошли» в дом жены 48 и 50 лет, соответственно, усыновив их детей [6, оп. 2, д. 42, бюджет 58; д. 47, бюджет 101]. И обратный вариант - глава семьи 64 лет состоит в браке с женой 40 лет и имеет 3 детей школьного возраста (младшему сыну 8 лет) [6, оп. 2, д. 46, бюджет 98]. В рассматриваемой когорте средний возраст главы се- 
мьи 46,1 год, при вариационном размахе от 27 до 64 лет. Продолжительность фазы, связанной с завершением репродуктивного периода, составила в среднем 9 лет.

Четвертая фаза - период «затухания» - до момента выделения последнего из взрослых детей. На этой стадии находится в выборке каждая пятая семья (20,3\%). Особенностью семейной структуры является преобладание расширенной семьи $(89,4 \%)$, относящейся к демографическим типам «брачная пара с детьми и внуками» $(66,7 \%)$ и «мать (отец) с детьми и внуками» (13,0\%). Удельный вес простых семей в условной когорте составил всего 10,6\% (брачная пара / мать (отец) с (взрослыми) детьми). Затухание репродуктивной функции супружеской пары сопровождается структурной трансформацией семьи, направленной на поддержание ее трудового потенциала. В отличии от нуклеарной семьи, для расширенной характерна тенденция роста за счет вступления в брак детей и появления внуков. Средний возраст главы семьи, находящейся на четвертой стадии, составил 55,7 года при вариационном размахе от 37 до 81 года. Продолжительность фазы - 9 лет.

В совокупности третья и четвертая фазы жизненного цикла соотносятся с периодом экономического благополучия, поскольку подрастающие дети включаются в трудовой процесс, снижая уровень трудовой нагрузки на основных работников.

Последняя пятая фаза «распада» семьи (от выдела последнего из взрослых детей до смерти обоих супругов) зафиксирована в $1,8 \%$ семей. В выборке они представлены брачными парами без детей, не охватив одиноких стариков. Незначительное число наблюдений снижает точность статистической оценки данного этапа и не отражает реальную ситуацию. Наблюдаемая погрешность является следствием методики отбора хозяйств для участия в бюджетном обследовании. Продолжительность фазы в среднем 12 лет. Средний возраст главы семьи снизился до значения 52,5 лет при вариационном размахе в 29 лет (от 40 до 69 лет), поскольку в выборку попали бездетные супружеские пары или супруги, потерявшие детей, т.е. семьи с разорванным жизненным циклом [6, оп. 2, д. 40, бюджет 176; д. 45, бюджет 331].

Сближение показателей среднего возраста главы семьи на 4 и 5 фазе может быть свидетельством того, что это момент «развилки»: часть семей задерживается на четвертой стадии, переходя от нуклеарной к расширенной структуре и минуя стадию распада. Другой вариант мы можем проследить у семей, сохранивших нуклеарную структуру: дети отделились и родители остались доживать свой век в «опустевшем гнезде». 
Общая продолжительность жизненного цикла крестьянской семьи от момента ее образования до распада в среднем составила в среднем 40 лет.

Помимо общей модели ЖЦС были проведены расчеты по типическим группам семей - простым (нуклеарным) и расширенным (сложным). В рассматриваемой совокупности простые семьи (однодвухпоколенные) составили 55,8\%, из них 94,5\% - полные, относящиеся к демографическим типам брачная пара без детей $(6,0 \%)$ и брачная пара с детьми (88,5\%); 5,5\% - неполные, относящиеся к демографическому типу мать (отец) с детьми. Расширенные семьи составили $44,1 \%$. В выборку попало также одно хозяйство, где зафиксирован один человек - комсомолец 26 лет. Он был исключен из дальнейшего анализа.

В качестве гипотезы было выдвинуто предположение об отличии жизненных циклов простой и расширенной семьи, поскольку условия ее становления и развития в обоих случаях заметно отличаются, особенно на начальной и заключительной стадиях. Об этом, например, пишет Н.М. Римашевская, подчеркивая, что: а) цикл семьи детей начинается в рамках родительской семьи; б) аналогия циклов относительна, так как он лишь в общем виде повторяет последовательность демографических событий: вступление в брак, рождение первенца, рождение прочих детей, прекращение брака [10, с. 171].

Проведенные расчеты не выявили существенных отличий в ЖЦ простых и расширенных семей ни по показателям среднего возраста, ни по продолжительности этапов. Расхождение заметно в распределении семей по стадиям жизненного цикла и по демографическим типам семей. Так, например, число простых семей, находящихся во второй и третьей фазах (роста и стабильности) почти в два раза больше, чем расширенных. И, наоборот, в четвертой фазе (сокращения) чаще встречаются расширенные семьи. В целом, можно говорить о тесном переплетении жизненных циклов различных типов семей, когда вполне обычной становится ситуация перехода крестьянской семьи из статуса нуклеарной в расширенную и наоборот. На структурные трансформации влияли не только индивидуальные особенности эволюции семей (внутренние факторы), но и историческая обстановка (внешний фактор). В частности, в критических ситуациях, связанных с ухудшением условий жизни, для крестьянских хозяйств характерна тактика консолидации семьи, способствующая выживанию. И напротив, накануне коллективизации фиксировались 
массовые случаи раздела крестьянских хозяйств из-за опасений попасть в число раскулаченных.

\section{Выводы}

Модель ЖЦС, построенная на эмпирическом материале с учетом возраста главы семьи, ее состава и демографического типа, позволяет оценить общие закономерности развития семьи на микроуровне, ее адаптивность к внешним условиям и внутренним обстоятельствами. Необходимость обеспечения крестьянского хозяйства рабочими руками влияла на репродуктивное и семейно-брачное поведение крестьян и в известной степени определяла структуру семьи.

Вместе с тем, предложенная модель содержит погрешности, поскольку однозначно определить границы стадий жизненного цикла затруднительно, особенно для семей со сложной траекторией развития, где присутствуют повторные, неравные браки, процессы разделения и воссоединения семей в результате войн, революций, и других событий, менявших привычный ход вещей. Многое зависит от репрезентативности изучаемой совокупности, в частности ориентация статистиков на изучение «полноценных» хозяйств, занимающихся сельскохозяйственной деятельностью, нарушала принцип пропорциональности. В результате семьи, находящиеся в начале и в конце своего жизненного цикла, представлены в выборке недостаточно полно для статистических обобщений.

\section{Библиография}

1. Чаянов А.В. Крестьянское хозяйство. - М.: Экономика, 1989.

2. Сорокин П.А. Кризис современной семьи // Вестник МГУ. Серия 18. Социология и политология. - 1997. - № 3. - С. 67-70.

3. Антонов А.И. Микросоциология семьи (методология исследования структур и процессов): Учебн. пособие для вузов. - М.: Издательский Дом «Nota Bene», 1998.

4. Glick P. The Family Cycle // American Sociological Review. - 1947. - № 12 (1). Pp. 164-174.

5. Терещенко О.В. Метод когортного анализа в социальных исследованиях // Социология 4М. - 2009. - № 29. - С. 172-185.

6. Государственный архив Свердловской области (ГАСО). Ф. 1812. Статуправление Уралобласти. 1923-1934.

7. База данных «Крестьянские хозяйства Уральской области. 1928/1929». - URL: https://idun.urfu.ru/ru/pro/ehvoljucija-krestjanskoi-semi-na-srednem-urale-v-xx-veke/bazadannykh/baza-dannykh-krestjanskie-khozjaistva-uralskoi-oblasti-19281929/ (дата обращения 10.08.2020).

8. Mazur L., Gorbachev O. The Peasant Family in the Urals in the 1920s-1960s: Reconstruction Based on the Data of Budget Studies // Transylvanian Review. - 2017. - Vol. XXVI. - No. 4. - P. 119-136. 
9. Волков А.Г. Жизненный цикл семьи // Демографический энциклопедический словарь. - М.: Советская энциклопедия, 1985.

10. Римашевская Н.М. Человек и реформы. Секреты выживания. - М.: ИСЭПН PAH, 2003.

https://doi.org/10.29003/m1792.978-5-317-06529-4/79-89

Максимов О.E.

Российская академия народного хозяйства и государственной службы при Президенте Российской Федеращии

Лёгкая промышленность в годы Косыгинской реформы (1965-1970) гг.: анализ темпов роста общего объёма выпуска продукции лёгкой промышленности на основании справочников по советской промышленности и Сводных отчётов ЦСУ при Совмине СССР ${ }^{1}$

Аннотация. В данной статье приводится анализ статистических показателей советской лёгкой промышленности в 1965-1970 гг., таких как валовой выпуск продукции, темпы роста валовой продукции. Данные были взяты из справочников по советской промышленности за соответствующие годы и из фонда ЦСУ при Совмине СССР. Проблематикой исследования является несоответствие одних и тех же показателей в разных источниках. В ходе анализа показателей были посчитаны «компромиссные» значения для каждого показателя и выявлено, данные какого из использованных источников оказались наиболее приближены к этим значениям.

Ключевые слова: валовой выпуск продукции, лёгкая промышленность, восьмая пятилетка, темпы роста общего объёма продукции, тренд.

Maximov O.E.

Russian Academy of National Economy and Public Administration under the President of the Russian Federation, Moscow

Light industry during the years of the Kosygin reform (1965-1970): analysis of the growth rates of the total volume of light industry output based on reference books on Soviet industry and Consolidated reports of the Central Statistical Administration of the USSR Council of Ministers

Abstract. The article represents indices of the Soviet Union's light industry, such as gross output, rate of growth of gross output during the eighth five-year plan. The data for statistical analysis were taken from industrial reference books and the

${ }^{1}$ Исследование проводится при поддержке гранта РФФИ, № 18-00-01687. 
Central Statistical Administration of the Council of Ministers of the USSR's archive fund. Problem of the research is disparity of same indices in different sources. During a statistical analysis arithmetical mean was count for each analysed index, and it was discovered which source's data were the closest to the means.

Keywords: gross output, light industry, the eighth five-year plan, growth rate of total production, trend.

Косыгинская реформа занимает важное место в отечественной истории. Родившаяся в ходе экономической дискуссии конца 1950начала 1960-х гг. концепция предполагала перевод промышленных предприятий на хозрасчёт, создание фондов поощрения, а главное: выделение нового показателя оценки работы предприятия - рентабельности. Старт реформе был дан на сентябрьском пленуме ЦК КПСС 1965 года. В резолюции пленума говорилось о необходимости решительного поворота в сторону экономических методов регулирования предприятий, а председатель Совета Министров СССР А.Н. Косыгин выделил следующие задачи: установить ответственность предприятий за использование оборотных средств, производственных фондов, выделять средства на капиталовложения на кредитной основе [1]. Уже в 1966 г. на новую систему перешли 704 предприятия, которые показали впечатляющие экономические показатели. По сравнению с 1965 г. производительность труда увеличилась на $8 \%$, а прибыль - 23,3\% [1].

В ходе нашего исследования были собраны и проанализированы архивные материалы фонда Центрального Статистического Управления при Совмине СССР, данные статистических справочников «Народное хозяйство СССР в 1970 году» и «Лёгкая промышленность в восьмой пятилетке».

Архивные документы представляют собой сводные отчёты ЦСУ СССР о числе валовой продукции, предприятий, промышленнопроизводственного персонала, стоимости промышленно-производственных основных фондов по отраслям промышленности в целом по СССР и охватывает период 1965-1970 гг. Отчёты имеют одинаковую форму отчётности (форма С-0 по формам подчинения), что позволяет провести адекватный анализ эквивалентных между собой источников. В данном исследовании будут представлены данные подсобных предприятий без предприятий колхозов по промышленности СССР в целом, лёгкой промышленности, а также отдельным отраслям лёгкой промышленности (текстильной, хлопчатобумажной, льняной, меховой, обувной (кроме резиновой)). Валовая продукция исчисляется в оптовых ценах предприятий (тыс. руб.) на 1 июля 
1955 года, 1 июля 1967 года ${ }^{2}$, в ценах, действовавших в отчётном году. Представляет интерес показатель валовой продукции за предшествующий год, рассчитанный по методологии отчётного года. Ключевой показатель, отражённый в документах, темпы роста валовой продукции. Темп роста - относительный показатель и представляет собой отношение отчётного года к предыдущему в процентном выражении. Несмотря на такое детальное и структурированное представление основных показателей советской промышленности, к ним стоит относиться с известной долей критики. Существует вероятность, что данные носят промежуточный характер в расчёте конечных показателей. Данные представлены в табличном формате.

Также были использованы два статистических справочника по промышленности СССР. Справочник «Народное хозяйство СССР в 1970 году» даёт наиболее полную информацию по народному хозяйству СССР в целом, выпускался ЦСУ при Совмине СССР. Нами использовались раздел «Промышленность», включающий в себя подраздел «Лёгкая промышленность». Приведённый раздел располагает такими таблицами, как Темпы роста общего объёма продукции промышленности; Промышленные предприятия, работавшие по новой системе планирования и экономического стимулирования; Темпы роста общего объёма продукции промышленности по отраслям за период 1965-1970 гг. и другими. Данные из таблиц по темпам роста общего объёма продукции по отраслям лёгкой промышленности за период 1965-1970 гг. представляются наиболее интересующими нас. Это объясняется темой статьи, подразумевающей анализ динамики выпуска продукции лёгкой промышленности.

Справочник «Лёгкая промышленность в восьмой пятилетке» подготовлен Министерством лёгкой промышленности и Центральным научно-исследовательским институтом информации и техникоэкономических исследований лёгкой промышленности, что сделало его документом для служебного пользования. Состав справочника во многом идентичен справочнику «Народное хозяйство СССР в 1970 году», за исключением таких специфических для лёгкой про-

\footnotetext{
2 Темпы роста каждого года пятилетки к 1965 г., представленные в Сводном отчёте ЦСУ СССР, рассчитывались по валовой продукции в оптовых ценах предприятий в сопоставимых ценах. Для каждой отрасли был рассчитан коэффициент изменения цен на 01.07.1967 по сравнению с 01.07.1955. Далее валовая продукция, выпущенная в 1965 г., представленная в оптовых ценах предприятий на 01.07.1955, была переведена в цены на 01.07.1967.
} 
мышленности данных, как Производство основных изделий лёгкой промышленности СССР на душу населения, Доля отдельных отраслей промышленности в общем выпуске валовой продукции (в \% к итогу по Минлегпрому СССР) и т.п.

Следует отметить, что данные справочников и архивных документов разнятся между собой. Причём архивные данные в случае с показателем по лёгкой промышленности в целом радикально отличаются в сторону уменьшения данных, нежели справочные материалы, что вызывает ещё больший интерес к проблематике исследования ввиду отсутствия широкой доступности к архивным документам.

Темпы роста валовой продукции лёгкой промышленности СССР в 1965-1970 гг.

В годы восьмой пятилетки лёгкая промышленность показала впечатляющие результаты. Рассчитанные нами темпы роста общего объёма выпускаемой продукции всех предприятий лёгкой промышленности за каждый год по отношению к 1965 году (начало восьмой пятилетки и хозяйственной реформы) демонстрируют это. На построенном графике видно, что данные справочников «Народное хозяйство...» и «Лёгкая промышленность в восьмой пятилетке» (Минасарян) нерадикально отличаются друг от друга (рис. 1).

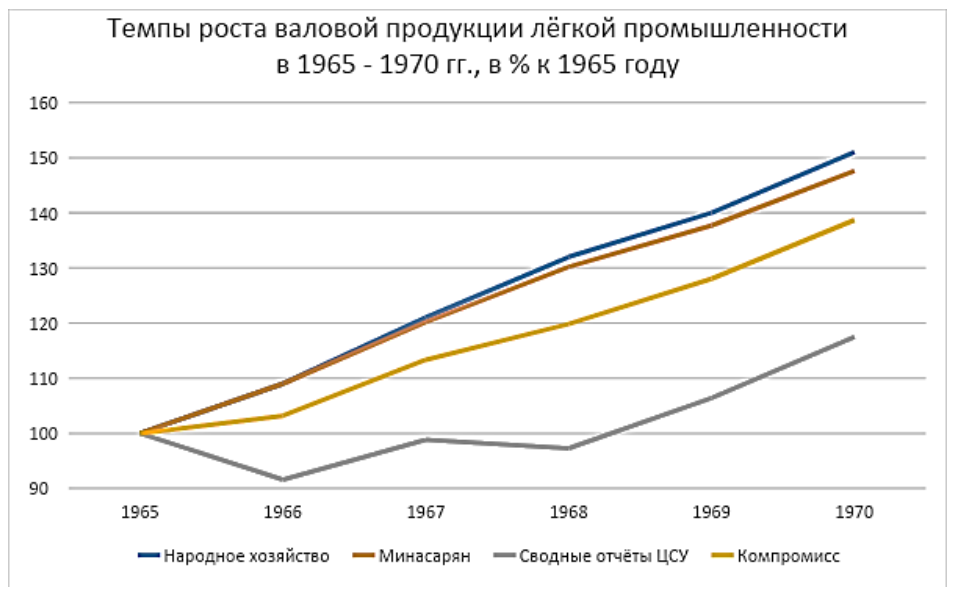

Рис. 1

По данным справочника «Народное хозяйство СССР в 1970 году», темпы роста составили: в 1966 г. - 109\%, 1967 г. - 121\%, 1968 г. 132\%, 1969 г. - 140\%, 1970 г. - 151\% [2]. В «Лёгкой промышленно- 
сти в восьмой пятилетке» (Минасарян) следующие данные за соответствующие периоды: 109\%; 120,2\%; 130,2\%; 137,7\%; 147,6\% [3].

В то же время данные архивных источников $[4,5,6,7,8,9]$ демонстрируют совершенно иной сценарий развития лёгкой промышленности: чередование подъёма и спада в период (1965-1968) гг., и только с 1968 года наблюдается стабильный рост.

Тем не менее рассчитанные по данным трёх источников компромиссные значения показывают стабильную положительную динамику и приближены к «кривой» справочника «Лёгкая промышленность...» (Минасарян). Нетрудно заметить, что самые оптимистичные оценки показывает кривая «Народного хозяйства...».

\section{Текстильная промышленность}

Необходимо заметить, что текстильная промышленность включает в себя следующие отрасли: хлопчатобумажную, льняную, и т.п. промышленности. Мы приведём данные по темпам роста для текстильной, хлопчатобумажной и льняной промышленностям.

На графике (рис. 2) наблюдается положительная динамика развития текстильной промышленности на протяжение всей пятилетки. Наибольшие значения принадлежат Сводным отчётам, наименьшие - «Лёгкой промышленности...»

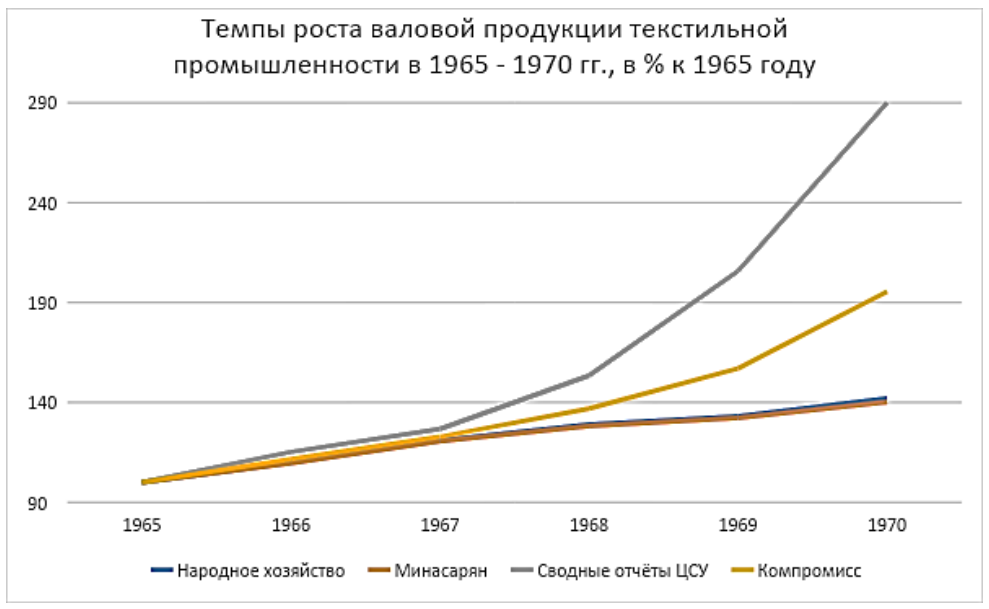

Pис. 2 
Из приведённых расчётов явствует, что значения справочников «Народное хозяйство...» и «Лёгкая промышленность в восьмой пятилетке» разнятся между собой на 0,4-1,8\%, причём данные, собранные для пользования в рамках Министерства лёгкой промышленности, меньше. Выделяются данные из Сводного отчёта ЦСУ, причём в большую сторону. В любом случае, все три источника показывают значительные темпы роста 1970 к 1965 году, что подтверждают и компромиссные значения.

Далее кратко опишем графики для подотраслей текстильной промышленности.

\section{Хлопчатобумажсная промышленность}

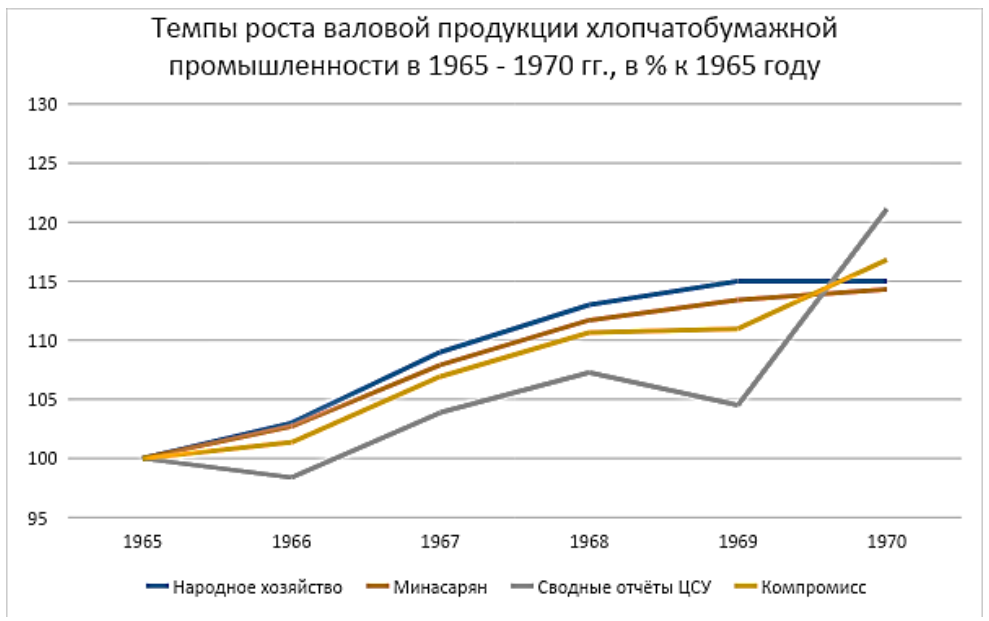

Рис. 3

На рисунке 3 очерёдность расположения кривых такая же, как и на рис. 1, причём кривые «Народного хозяйства» и «Лёгкой промышленности...» едва избегают наложения. Наиболее противоречивые данные показывают Сводные отчёты: здесь наблюдается спад на промежутке (1965-1966) гг. и (1968-1969) гг., а также резкий подъём (1969-1970) гг. Наиболее приближены к компромиссным значениям данные «Лёгкой промышленности...»

\section{Льняная промышленность}

Как в случае с хлопчатобумажной и текстильной промышленностями, на рисунке 4 наблюдаем наложение кривых двух справочников. Данные «Лёгкой промышленности в восьмой пятилетке» вновь 
оказываются наиболее близкими к кривой компромисса. Нам нелегко сказать, чем обусловлена столь малая разница между данными двух источников. Все три источника, включая Сводные отчёты, были подготовлены с помощью Центрального Статистического Управления. Однако почему в таком случае данные отчётов показывают совершенно иную динамику? Возможно, это является следствием промежуточности данных отчётов. С другой стороны, можно предположить, что данные отчётов носят наиболее достоверный характер, а данные справочников ввиду их ориентированности на руководства ведомств («Лёгкая промышленность в восьмой пятилетки») и широкие массы («Народное хозяйство СССР в 1970 году») могли намеренно завышаться или занижаться.

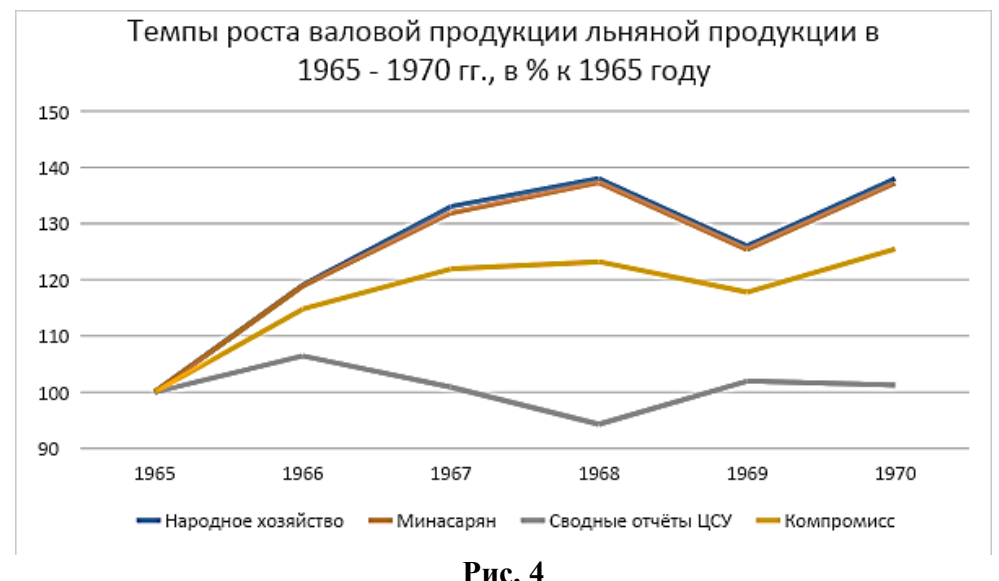

\section{Обувная промышленность}

Показатели темпов роста обувной промышленности также интересуют нас для понимания положения дел в лёгкой промышленности. Одни и те же тенденции в показателях (частичная эквивалентность данных двух справочников, более близкое расположение кривой справочника «Лёгкой промышленности...» к кривой Компромисса, радикальное отличие кривой Сводных отчётов от всех остальных), наблюдаемые в подотраслях текстильной промышленности, могут быть связаны с их одинаковым положением по отношению к главной отрасли - текстильной промышленности. 


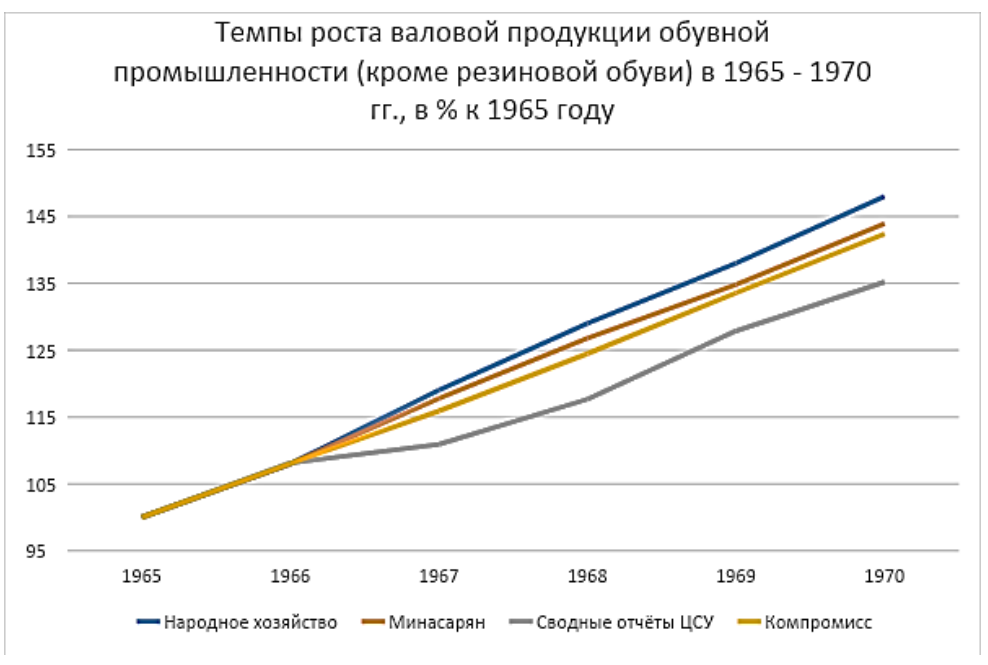

Рис. 5

В самих сводных отчётах $[4,5,6,7,8,9]$ порядок расположения подотраслей текстильной промышленности, а также указание на «собирательность» текстильной промышленности из второстепенных подотраслей свидетельствует о зависимости показателей текстильной промышленности от показателей её подотраслей. С этих позиций интересно исследовать остальные отрасли лёгкой промышленности на предмет сохранения этих тенденций.

Из графика (рис. 5) явствует, что все три источника показывают прогрессивный рост общего объёма реализованной продукции. Как и во всех предыдущих случаях, наиболее близкой к кривой Компромисса оказалась кривая «Лёгкой промышленности...».

\section{Меховая промышленность}

График темпов роста меховой промышленности (рис. 6) в целом показывает те же тенденции, что и на уже описанных графиках. Хотелось бы обратить внимание на факт наибольшего приближения кривой «Народного хозяйства...» к кривой Компромисса, особенно в 1967 году. В первую очередь, это объясняется радикальным отличием положения реперных точек кривой Сводных отчётов на координатной плоскости от положения точек кривых справочников. Конкретно в 1967 году данные темпов роста в Сводных отчётах отличаются от данных справочника примерно на $15 \%$, что, таким обра- 
зом, «вытягивает» кривую Компромисса. Далее, уже начиная с 1968 года участки всех четырёх кривых возрастают, причём происходит наложение кривой «Народного хозяйства...» на кривую Компромисса. Подобные тенденции, как и на остальных графиках, свидетельствуют о ведущей роли кривой Сводных отчётов в вычислении компромиссных значений. «Непохожесть» данных Сводных отчётов, выраженная как в радикальном занижении, так и завышении данных, лишь подтверждает наше предположение, что данные Сводных отчётов могут быть достоверными, что, безусловно, нуждается в дальнейшей проверке, привлекая как классические методы (поиск дополнительной информации об источнике, например, методологии составления отчётов), так и аналитические (на уровне составления и сопоставления графиков).

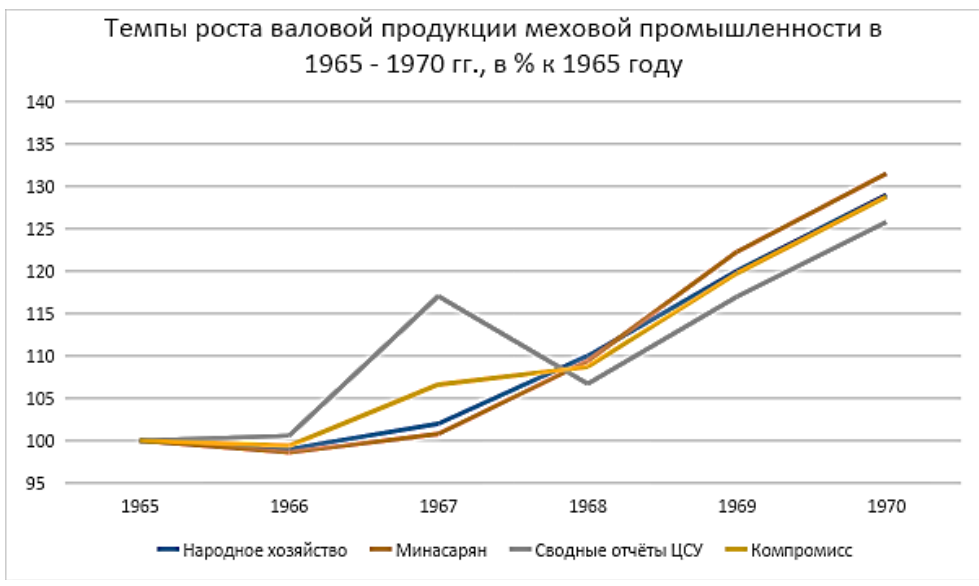

Рис. 6

\section{Выводы}

В нашем исследовании мы проанализировали лишь некоторые отрасли лёгкой промышленности СССР в годы восьмого пятилетнего плана (1965-1970) гг. В их число вошли такие всеобъемлющие отрасли, как текстильная промышленность, хлопчатобумажная, льняная, обувная, меховая. Построенные кривые данных трёх источников по советской лёгкой промышленности указали на частичную эквивалентность данных справочников, при этом в ряде случаев данные справочника «Лёгкая промышленность в восьмой пятилетке» 
(Минасарян) оказались ближе остальных к компромиссным значениям. Данные Сводных отчётов радикально отличались от данных справочников и компромиссных значений, оказывая тем самым влияние на поведение кривой компромисса, а, следовательно, и близость расположения к последней кривой того или иного справочника.

В дальнейшем было бы интересно посчитать темпы роста производства продукции в натуральном выражении каждого года восьмой пятилетки к 1965 году. Это необходимо для проверки на наличие тех же тенденций поведения кривых темпов роста выпуска продукции в натуральном выражении, что и у кривых темпов роста валовой продукции. В случае выделения тех же тенденций поведения кривых по отношению друг к другу наши предположения и надежды касательно достоверности данных в использованных нами источниках могут получить дополнительную поддержку.

\section{Библиография}

1. Голанд Ю., Некипелов А. Косыгинская реформа: упущенный шанс или мираж? // Российский экономический журнал. - 2010. - № 6. - С. 44-66.

2. Народное хозяйство СССР в 1970 г. - М. : Статистика, 1971.

3. Минасарян К. П. Лёгкая промышленность в восьмой пятилетке. - М., 1972.

4. Сводки (ф. С-0 по формам подчинения) ЦСУ СССР о числе предприятий, численности промышленно-производственного персонала валовой продукции, стоимости промышленно-производственных основных фондов по отраслям промышленности в целом по СССР за 1965 г. Т. 2 // РГАЭ. Ф. 1562. Оп. 44. Д. 184.

5. Сводные отчеты (ф. С-0 по формам подчинения) ЦСУ СССР о числе предприятий, численности промышленно-производственного персонала валовой продукции промышленности и стоимости промышленно-производственных основных фондов по отраслям промышленности, министерствам и ведомствам, в целом по СССР за 1966 г. Т. 2 // РГАЭ. Ф. 1562. Оп. 45. Д. 332.

6. Сводные отчеты [ф. С-0 по формам подчинения] ЦСУ СССР о числе предприятий, численности промышленно-производственного персонала, валовой продукции, стоимости промышленно-производственных основных фондов по отраслям промышленности, министерствам и ведомствам в целом по СССР за 1967 г. Т. 2 // РГАЭ. Ф. 1562. Оп. 45. Д. 3679.

7. Сводные отчеты (ф, С-0 по формам подчинения) ЦСУ СССР о числе предприятий, численности промышленно-производственного персонала, валовой продукции, стоимости промышленно-производственных основных фондов по формам подчинения, отраслям промышленности за 1968 г. Т. 2 // РГАЭ. Ф. 1562. Оп. 45. Д. 7085.

8. Сводные отчеты (ф. С-0 по формам подчинении) ЦСУ СССР о числе предприятий, численности промышленного производственного персонала, валовой продукции промышленности, стоимости промышленно-производственных основных фондов предприятий, состоящих на самостоятельном балансе по отраслям промышленности, министерствам и ведомствам в целом по СССР за 1969 г. Т. 2 // РГАЭ. Ф. 1562. Оп. 46. Д. 166.

9. Сводный отчет (ф. С-0 по формам подчинения) ЦСУ СССР о числе предприятий, численности промышленно-производственного персонала, валовой продукции, 
стоимости промышленно-производственных основных фондов предприятий, состоящих на самостоятельном балансе по отраслям промышленности, министерствам и ведомствам в целом по СССР за 1970 г. Т. 2 // РГАЭ. Ф. 1562. Оп. 47. Д. 165.

https://doi.org/10.29003/m1793.978-5-317-06529-4/89-95

Пушков В.П. Московский государственный университет имени М.В. Ломоносова

Завьялов С.М. Музей «Новый Иерусалим»

\section{Уроженцы Смоленской губернии - первокурсники Московского университета 1917-18 гг.}

Аннотация. В 1917 г. Смоленская губ. по числу первокурсников Московского университета занимала второе место после Владимирской губ. (соответственно 158 и 139 чел.). Были представлены 7 уезлов из 11. В основном студентами стали воспитанники гимназий и Духовной семинарии. Впервые студентками стали 8 девушек. По своему сословному составу первокурсники в основном были детьми мещан, духовенства и крестьян. Абсолютное большинство первокурсников пришли на физико-математический факультет (88) и в разы меньше на другие: медицинский - 29, историко-филологический -15 , юридический -7 .

Ключевье слова: 1917 год, Московский университет, Смоленская губерния, первокурсники, сословия.

Pushkov V.P. Moscow Lomonosov State University

Zavjalov S.M. Museum «New Jerusalem»

\section{The natives of Smolensk province - first-year students of Moscow university of 1917}

Abstract. In 1917 Smolensk province stood on the second place by the quantity of sophomores of the Moscow university next to Vladimir province (139 and 158 students correspondingly). 7 districts out from 11 were represented. Mainly graduators of gymnasia and the Seminary entered the university. For the first time 8 girls became students. Principally the social structure of students included petty bourgeoisie, clergy and peasantry. Most part of students entered physics and mathematics department, much smaller part entered medical department and ones of law and of linguistics and history.

Keywords: Moscow state university; Smolensk province; sophomores; strata. 
Не бездарна та природа, Не погиб еще тот край, Что выводит из народа Столько славных - то и знай! Н.А. Некрасов

О дальнейшем процессе демократизации высшей школы в результате Февральской революции 1917 г. убедительно свидетельствует подготовленный университетской канцелярией по студенческим делам «Алфавитный список студентов, принятых в 1917/18 академическом году» [1]. Помимо ФИО первокурсников, документ содержит важные сведения об их сословной принадлежности, вероисповедании, точны датs рождения, а также интересные данные о типе предварительного среднего образования (месторасположение и название гимназий, реальных училищ, семинарий и др.). Вся эта информация в форме электронной таблицы вошла в базу данных «Первокурсники Московского университета 1917 г.» [2].

В 1917/18 академическом году в Московский университет было принято около 2389 первокурсников, хотя по опубликованному 6 июля решению университетского Ученого совета планировалось зачислить в полтора раза меньше - 1450 человек [3]. Впервые на равных правах с мужчинами было принято 154 женщины (6,4\% от общего контингента поступивших). В крайне сложное военнореволюционное время Московский университет не только продолжал оставаться ведущим центром отечественного высшего образования, но даже усилил свои позиции в деле научной мобилизации талантливой российской молодежи. В этот год в его стены пришли самые умные юноши и девушки из 212 населенных пунктов (губернских и уездных городов, сел, аулов и др.) 80 губерний и областей России [2, с. 303, 304] (всего их было 89), тогда как за предыдущее сорокалетие 1877-1916 гг., по которому у нас есть соответствующие данные, таких мест исхода университетских воспитанников было 202 [4, с. 224-226], что однозначно свидетельствует о качественном приращении национального интеллектуального пространства. Максимально широкая география университетских новобранцев позволяет достаточно полно выявить источники формирования отечественного умственного потенциала на переломе исторических эпох, с тем чтобы обеспечить возможность их сравнения с советским временем. И одним из ведущих центров форитрования национального интеллекта, естественно, всегда была Москва, уроженцы которой (вместе с уездными школами) продолжали лидировать и в 1917 г., составляя не более одной трети от всего нового набора -828 чело- 
век; до начала Первой мировой войны москвичей в университете было меньше - около одной четверти), так что провинциальные уроженцы всегда составляли абсолютное большинство университетского студенчества. Ярким подтверждением высокого уровня академической подготовки нового революционного поколения столичного университетского студенчества 1917 г. служат записи «Алфавитного списка» о двух студентах, впоследствии ставших академиками и сменившими друг друга на посту ректора своей «альма матэр». Это будущий химик москвич «сын кандидата права» Александр Николаевич Несмеянов (1899-1980, ректор в 1948-1951 гг.) из частной гимназии П.Н. Страхова и математик «сын купца» Иван Георгиевич Петровский (1901-1973, ректор в 1951-1973 гг.) из Севского реального училища Орловской губернии.

139 смоленских уроженцев занимали второе место среди всех провинциальных университетских первокурсников 1917 г., уступая лишь 158 владимирцам (с большим отрывом за ними следовали 110 рязанцев) [2, с. 303]. Древняя Смоленская земля в этот год была представлена в Московском университете своим центром и семью уездными городами. 62 первокурсника из самого Смоленска оказались воспитанниками восьми государственных и частных учебных заведений, основная доля которых (22 человека) вышла из главной губернской гимназии им. Александра I, двух студентов дала 2-я гимназия и одну первокурсницу подготовила Мариинская гимназия. Смоленская духовная семинария дала университету 18 новобранцев (как правило, они становились медиками), по 5 будущих студентов воспитали гимназия Общества распространения образования и губернское Александровское реальное училище. И 8 университетских новобранцев получили предварительное образование в трех частных гимназиях: Ф.В. Воронина, Е.Г. Швиттау и Е.И. Ровинской (соответственно 4, 3 и 1 человек). Принципиально важным следует признать тот факт, что количество подготовленной уездными городами талантливой молодежи впервые превысило число первокурсников из самого Смоленска - 77 человек $(55,4 \%)$ против 62 . Этот ряд семи уездных городов открывает Вязьма, давщая 32 студента (22 из городской и 10 из гимназии Смоленского земства им. Александра III), 13 первокурсников вышло из Рославльской гимназии, 11 из Дорогобужской, 7 из Гжатского реального училища, 6 из Ельнинской гимназии им. М.М. Глинки, 5 - из Сычевской и 3 человека из гимназии г. Белого (не были представлены Духовщинский, Краснинский, Поречский и Юхновский уезды). 
О весьма высокой академической подготовке смоленских гимназистов убедительно свидетельствуют полученные ими 19 золотых и серебряных медалей: 10 золотых и 9 серебряных - 14\% от всего числа смолян-первокурсников, что было выше среднего уровня по всем губерниям в $10 \%$.

Из восьми смоленских гимназисток, впервые ставших полноправными студентками Московского университета, шесть были из самого губернского центра. Это четыре медички: дочь священника Клавдия Виноградова, «дочь гражданина» Елена Прудникова, дочь статского советника римско-католического вероисповедания Мария Матулянис и дочь губернского регистратора Елизавета Зотова. На физмат из частной гимназии Е.И. Ровинской поступила дочь мещанина Сима Берлин и на юрфак из Мариинской гимназии была зачислена купеческая дочь Вера Гилельс. Из Вязьмы в Москву приехали две «золотые» медалистки: поступившая на историко-филологический факультет дочь статского советника София Сабельникова и на математическом отделении физмата стала учиться дочь мещанина Рива-Лея Кромощь. Как видим, в отличие от молодых людей новоиспеченные студентки-смолянки в основном предпочитали не фундаментальные науки, а медицинское образование. Поскольку же все эти девушки были 1895-1898 годов рождения, то становится ясным, что двери Московского университета для них открыла только образовательная реформа 1917 г. Показательно также, что доля медалистов среди смолянок-первокурсниц была практически вдвое выше, чем у смолян.

Естественно, подавляющее большинство смоленских первокурсников были православными, но примерно каждый пятый из них 30 человек, или 21,5\%, были других верований: 25 иудеев $(18,0 \%)$, четыре католика и один евангелист-лютеранин.

По своему социальному происхождению революционный призыв характеризуется максимальным разнообразием и демократизмом. Чаще всего смоленские первокурсники с их слов регистрировались в канцелярии как «сын» или «дочь мещанина» (соответственно 24 и 3 раза), да к тому же 13 студентов прямо назвались «мещанами», т.е. были главами семей и вели самостоятельное хозяйство (среди них могли быть и рабочие). На второе место после всех 40 мещанских уроженцев с большим отставанием вышли 20 «сыновей крестьянских» и 3 «крестьянина» (всего 23 первокурсника), которым практически не уступали 22 выходца из семей духовенства, среди которых преобладали 16 «сыновей/дочерей священников» (соответственно 15 и 1). Кроме того, в этой группе было 3 «сыновей дьяко- 
нов», 2 - псаломщика и 1 «сын протоиерея». Таким образом, абсолютное большинство (85 первокурсников из 139, или 61,2\%) имели мещанские, церковные и крестьянские корни.

Более состоятельные смоленские уроженцы были представлены разнообразными градациями детей чиновничества, купечества и дворянства (соответственно 19, 16 и 6 студентов). Среди первых 8 человек назвались просто сыновьями чиновников, 4 - статских советников, 2 дочери и 1 сын статских советников, по одной дочери и сыну губернских регистраторов и губернских секретарей, а также по одному сыну коллежского регистратора, статского и действительного статского советника. К благородному сословию принадлежало 6 студентов: 2 «сына потомственных дворян» и 4 «сына дворян». Военные были представлены сыновьями подполковника, прапорщика и «солдата» (3 человека). Удивляет почти полное отсутствие среди первокурсников детей врачей, инженеров и и преподавателей (среди последних нашелся всего лишь один «сын учителя»). Одна девушка назвалась «дочерью гражданина», и один первокурсник оказался «швейцарским подданным» (четыре человека не указали своей сословной принадлежности).

По сути дела, научные приоритеты смолян были заданы их социальным вектором, поскольку явно склонялись в сторону физикоматематических дисциплин: абсолютное их большинство - 88 первокурсников из 139 , или $63,3 \%$ - избрало именно этот факультет, причём некоторое предпочтение было отдано его естественному отделению перед математическим, где изучалась математика, механика и астрономия (47 человек против 41). Втрое ниже оказался интерес смолян к медицинскому факультету, на который пришли 29 первокурсников (20,9\%). По сравнению с медициной историко-филологический факультет привлек вдвое меньше абитуриентов - 15 (10,8\%). И крайне показательно, что всего лишь 7 человек привлёк самый аристократический, но малоперспективный в переломное время юридический факультет (5,0\%). На фоне всех 2389 университетских новобранцев 1917 г. смоленские первокурсники продемонстрировали максимальный удельный интерес к физико-математическому факультету (63,3\% против 53,0\% по генеральной совокупности), что, естественно, означало снижение долей по остальным факультетам: по историкофилологическому $17,5 \%-10,8 \%$, по медицинскому $22,8 \%-10,8 \%$ и по юрфаку - с 9,7\% до 5,0\%. Здесь стоит отметить, что по раскладу университетского Ученого совета максимальное число мест (600) почему-то должно было быть отдано именно юрфаку, на который ре- 
ально пришло в 2,5 раза меньше - 231 первокурсник. Вместо же заявленных 500 мест на физмате туда пришли 1266 человек, а на медицинский - 545 вместо 150 и на историко-филологический - 417 первокурсников вместо планируемых 200. Мы затрудняемся объяснить столь недальновидное отношение университетского руководства к новому набору.

Приведенный ранжир научных интересов нового университетского набора 1917 г. коренным образом отличается от соответствующей картины за довоенное время, когда, наоборот, наиболее привлекательным был именно юридический факультет. В первом приближении катастрофическое падение интереса к юриспруденции можно объяснить малым авторитетом права и законов на переломном этапе истории, тогда как естественнонаучные специальности были остро востребованы военной промышленностью.

В отличие от большинства «коренных» великорусских губерний в фамильной структуре смоленских первокурсников весьма слабо были представлены «птичьи» фамилии (Соколов, Орлов, Лебедев и др.), а также церковно-семинарские маркеры (Никольский, Ильинский, Преображенский и т.п.), Ивановых же оказалось всего два человека. Частотность личных имён и отчеств демонстрирует интересную эволюцию ментальности родителей студентов по сравнению с их дедами. Так, если деды в основном называли их отцов Иванами и Николаями - соответственно 14 и 11 раз, то через одно поколение приоритеты поменялись местами - 17 Николаев против 10 Иванов, что, видимо, свидетельствует о возрастании имперской ментальности родителей смоленских первокурсников по сравнению с их дедами (при этом другое царское имя Александр в этой картине практически не изменило свою частотность - соответственно 4 и 5 случаев).

Большинству смоленских первокурсников было по 18-19 лет, однако десятки из них были гораздо старше - 1892-1897 годов рождения, что свидетельствует о давней мечте стать студентами Московского университета. Самым возрастным оказался ставший медиком 25-летний купеческий сын Борис Черняк, а самым молодым был поступивший на математическое отделение физико-математического факультета воспитанник Гжатского реального училища сын титулярного советника Сергей Эльманович, который родился 13 мая 1900 г.

Конечно, далеко не всем смоленским первокурсникам 1917 г. удалось завершить свое университетское образование - их ждали великие исторические потрясения XX века, но многие из них внесли достойный вклад в науку, образование, культуру и общественнополитическую жизнь страны. Более полные данные о всех 139 смо- 
ленских первокурсниках Московского университета 1917 г. можно получить по адресу электронной почты pushkov@wwwcom.ru.

\section{Библиография}

1. Архив МГУ. Ф. 1. Оп. 14 л. Д. 13312. Машинопись с рукописной правкой, переплетенная в дело стандартного формата.

2. Пушков В.П., Пушков Л.В., Завьялов С.М. Списки первокурсников Московского университета 1917-1918 академического года как массовый источник (по материалам Архива МГУ) // Идеи академика И.Д. Ковальченко в XXI веке. Материалы научных чтений памяти академика И.Д. Ковальченко (Москва, МГУ им. М.В. Ломоносова, 10 декабря 2008 г.). - М., 2009. - С. 302-311.

3. Русское слово, 7 июля 1917 г.

4. Пушков В.П., Пушков Л.В., Завьялов С.М. Профессионально-географический состав выпускников Московского университета. 1877-1916 гг. // История Московского университета: 1755-2004. Материалы V научных чтений памяти профессора А.В. Муравьева (Москва, МГУ им. М.В. Ломоносова, 16 марта 2004 г.). - М., 2004. C. $222-234$.

https://doi.org/10.29003/m1794.978-5-317-06529-4/95-103

Харитонов И.М.

Московский государственный университет имени М.В. Ломоносова

\section{Динамика финансовых операции СССР за рубежом в 1920-е гг.: по архивным материалам Гарантийного и кредитного банка для Востока (Гаркребо)}

Аннотация. Работа посвящена анализу заграничных финансовых операций СССР в 1920-е гг. на примере межбанковских операций банка Garantie- und Kredit Bank für den Osten (Гаркребо) в Германии. Для этого использованы количественные данные из ежемесячной финансовой отчетности банка. Эти данные были унифицированы и преобразованы в динамические ряды. В работе демонстрируется, что инициатором финансовых операций СССР за рубежом был Госбанк. Эти операции были тесно связаны с американским валютным рынком и с контролем курса червонца.

Ключевые слова: совзагранбанк, международный валютный рынок, межбанковские операции, советская финансовая система, Гаркребо, червонец.

\section{Kharitonov I.M. Lomonosov Moscow State University}

\section{Dynamics of USSR's foreign financial operations in 1920: a case study of Garantie- und Kredit Bank für den Osten (Garkrebo) archive materials}

Abstract. The paper analyses the international financial operations of the USSR in the 1920s via the case of interbank transactions of the Soviet foreign 
bank in Germany - the Garantie- und Kredit Bank für den Osten (Garkrebo). The study is based on quantitative data from the archival bank accounting reports. It reveals that the State Bank of the USSR was an initiator of the Soviet financial operations abroad. These operations were aimed to the American foreign currency market, particularly to support of Soviet currency (chervonets) rate.

Keywords: Soviet foreign banks, international currency market, interbank transactions, Soviet financial system, Garcrebo, chervonets.

После Гражданской войны и иностранной интервенции в России дореволюционная банковская система была окончательно разрушена. Вместе с ней был потерян контроль над зарубежными филиалами бывших имперских банков. Кроме того, из-за отказа выплачивать долги царского и Временного правительства на Советское государство были наложены финансовые и экономические санкции. В этих условиях все контакты с иностранными банками были разорваны, и СССР оказался в финансовой изоляции.

При этом, для восстановления экономики государство остро нуждалась в притоке средств из-за рубежа, а также требовалось возобновить внешнеторговые связи. Обязательным условиям для этого было преодоление финансовой изоляции. В 1922 г. на Генуэзской и Гаагской конференциях советские дипломаты пытались выйти из этого положения, но потерпели неудачу. Для преодоления финансовой изоляции было решено создать специальную сеть советских заграничных банков (совзагранбанков). Де-юре банки этой сети являлись обычными акционерными обществами, зарегистрированными в юридическом поле другой страны. Де-факто они напрямую должны были подчиняться советскому руководству: выполнять финансовые поручения и финансировать торговлю. Таким образом, совзагранбанки должны были заменить собой потерянные ранее финансовые учреждения за рубежом и «прорвать» финансовую и экономическую блокаду.

В отечественной историографии уже есть работы Ю.П. Голицына и Н.И. Кротова, посвященные совзагранбанкам $[2,3]$. Однако в них используются преимущественно архивные делопроизводственные материалы, а также источники личного происхождения. Подобный подход позволяет рассмотреть историю совзагранбанков, но проанализировать финансовые операции СССР, проводимые за рубежом, на таких источниках можно только в самом общем виде. Данное исследование призвано закрыть этот пробел.

Для этого используются ранее незадействованные материалы бухгалтерской отчетности совзагранбанка, находившегося в Германии Garantie- und Kredit Bank für den Osten (Гаркребо). Этими материалами 
являются ежемесячные балансы банка, хранящиеся в разных фондах Российского государственного архива экономики (РГАЭ).

Для того, чтобы проанализировать данные, требовалось провести объемную подготовительную работу. В первую очередь, использование ежемесячных балансов вынуждает исследователя оцифровать большой объем количественных данных. Формат ежемесячных балансов Гаркребо менялся, что потребовало их унификации. Кроме того, часть материалов была представлена на немецком языке. Многие немецкоязычные термины, используемые в 1920-е гг., сегодня употребляются иначе, либо не употребляются вообще.

В итоге количественные данные из ежемесячных балансов банка были унифицированы и собраны в динамические ряды, а затем подвергнуты статистическому анализу. На основании этих данных в работе анализируются межбанковские операции, проводимые Гаркребо в 1920-е гг. по поручениям советского руководства.

Гаркребо был одним из первых совзагранбанков. Его основание связано со шведским банкиром Олофом Ашбергом (1877-1960), который еще со времен царского правительства имел тесные связи с Россией, а после стал «красным банкиром», помогая большевикам реализовывать золотые запасы. В период с 1918 по 1922 гг. Ашбергом была создана весьма обширная сеть банковских учреждений, во главе которых стоял его банк в Стокгольме Svenska Ekonomie Aktiebolaget (Свенска-банк). В эту сеть входили несколько банков и их филиалов по всей Европе.

Еще в 1918 г., Ашберг выкупил все акции «старого провинциального банка» в Берлине и открыл там филиал Свенска-банка (SEA) $[5,213]$. В 1922 г., используя этот ресурс, агент Госбанка за границей Илья Давыдович Левин основывает Гаркребо, который попадает в ведомство Госбанка и начинает работу с 1 марта 1923 г. [3, 103]

В 1924 г. вся сеть банков Ашберга была выкуплена Госбанком и Наркоматом внешней торговли и поделена между ними. Таким образом, после объединения банковской сети Ашберга с уже открытыми генеральной агентурой Госбанка банками за рубежом была сформирована система совзагранбанков, которая просуществовала вплоть до распада СССР.

В начале одна группа совзагранбанков попала под контроль Внешторгбанка (создан в 1924 г. из Роскомбанка, принадлежавшего Ашбергу в России). Формально эти банки находились в подчинении Наркомторга. Другая часть загранбанков попала в подчинение Госбанка. Так, совзагранбанки, в числе которых был Гаркребо, находи- 
лись в ведомстве Госбанка до июля 1927 г., когда было принято решение об их передаче Наркомторгу. Последний, в свою очередь, делегировал контрольные функции Внешторгбанку. Изменение системы управления совзагранбанками отразилось на их деятельности лишь спустя несколько месяцев.

Анализируемые в работе межбанковские операции были одним из направлений деятельности совзагранбанков, в частности, Гаркребо. Межбанковскими называют операции между крупными участниками рынка (банками) на денежном, валютном, фондовом рынках, которые проводились через корреспондентские счета. На межбанковском рынке банки выполняли различные поручения друг друга. В отличие от отношений банка с клиентом, где одна сторона всегда должник, а другая - кредитор, в межбанковских операциях обе стороны могут быть по отношению друг к другу как должником, так и кредитором. Для этого банки заключали специальный договор о корреспондентских отношениях, по которому открывался контокоррент - текущий счет, который мог быть как активным, так и пассивным. Подобные счета могли быть «лоро» («их» поручения, т.е. для поручений других банков) и «ностро» («наши» поручения, т.е. для поручений самого банка). Таким образом, банк-комитент (дающий поручения) для банка-корреспондента (выполняющего поручения) является корреспондентом лоро (т.е. дающий их поручения), а банк-корреспондент для банка-комитента является корреспондентом ностро (т. е. выполняющий наши поручения) $[1,18]$.

Таким образом, к межбанковским операциям относятся различные счета лоро, ностро, а также в незначительных объемах счета Госбанка и торгпредства.

В период подчинения Госбанку, удельный вес межбанковских операций колеблется от 30 до $60 \%$, в среднем $42 \%$ баланса Гаркребо. В абсолютном выражении межбанковские операции изменяются от 10 до 20 млн марок, однако за рассматриваемый период наблюдается несколько «всплесков». Первый можно выделить в декабре 1926 г., когда сумма корреспондентских счетов увеличилась с 14 млн до 47 млн марок, после чего постепенно уменьшилась до 23 млн марок в апреле 1927 г. Второй произошел в августе 1927 г., где значение достигло своего экстремума в 59 млн марок (рис. 1).

На эти операции в период подчинения Госбанку именно от него Гаркребо получал большую часть средств («Займы от Госбанка»). Удельный вес средств Госбанка в этот период в среднем составлял $51 \%$ с колебаниями в пределах от 40 до 66\% баланса. При этом займы от Госбанка как источник средств для Гаркребо постоянно росли 
с 14 млн марок в мае 1926 г. до 68,4 млн в августе 1927 г. Этот рост был неравномерным, в нем можно выделить несколько всплесков: декабрь 1926 г. (47,3 млн) и август 1927 г. (68,4 млн) (рис. 2).

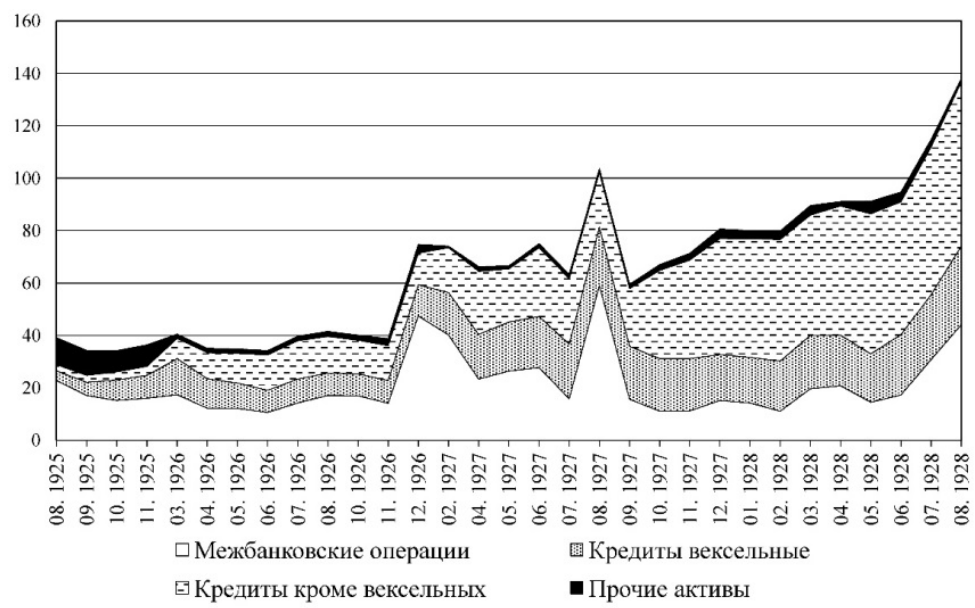

Рис. 1. Активы Гаркребо по балансам на конец каждого месяца, в млн марок Составлено по: РГАЭ. Ф. 7590, Оп. 3. Д. 53, 55, 83, 135, 137, 138, 139, 383, 384; Ф. 7733, Оп. 5. Д. 546.

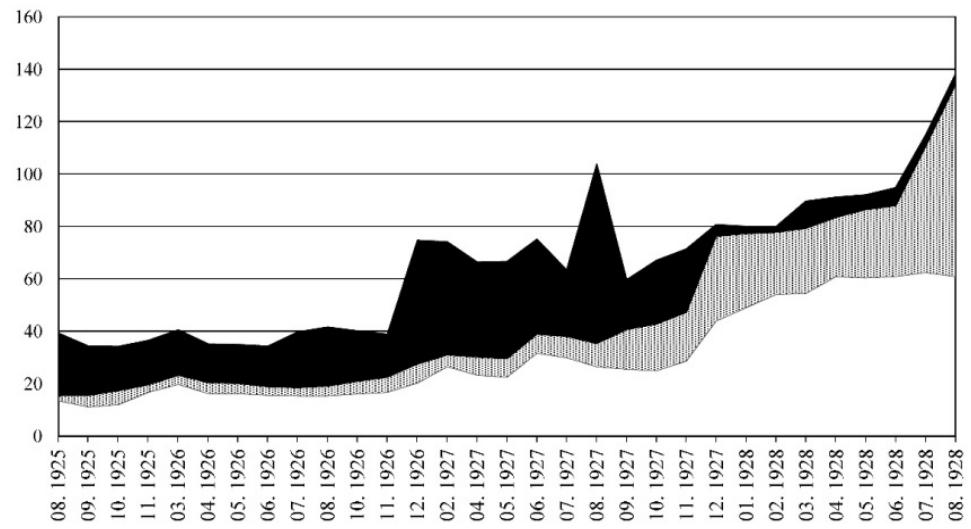

口Остальные пассивы ॠаймы

Pис. 2. Пассивы Гаркребо по балансам на конец каждого месяца, в млн марок Составлено по: см. рис. 1. 
Подобное распределение средств банка показывает, что Гаркребо в период подчинения Госбанку активно использовался последним в качестве посредника для взаимодействия с зарубежными банками (рис. 3). Предположительно, это были активные действия Госбанка на американском валютном рынке. Известно, что первый «всплеск» произошел из-за открытия на средства Госбанка «специальных счетов ностро» в некоторых банках Нью-Йорка (к сожалению, отчетность не отразила, какие конкретно банки были задействованы) [5]. С другой стороны, Госбанк мог использовать эти средства для контроля за курсом червонца. Из раздела «Сообщения о иностранных девизах и рынках ценных бумаг» (Berichte von auswärtigen Devisen und Wertpapiermärkten) главной государственной газеты Германии «Германский имперский вестник» известно, что Гаркребо постоянно осуществлял продажу и покупку червонцев [8]. При этом банк вел мониторинг движения червонцев, о чем отчитывался Госбанку [4].

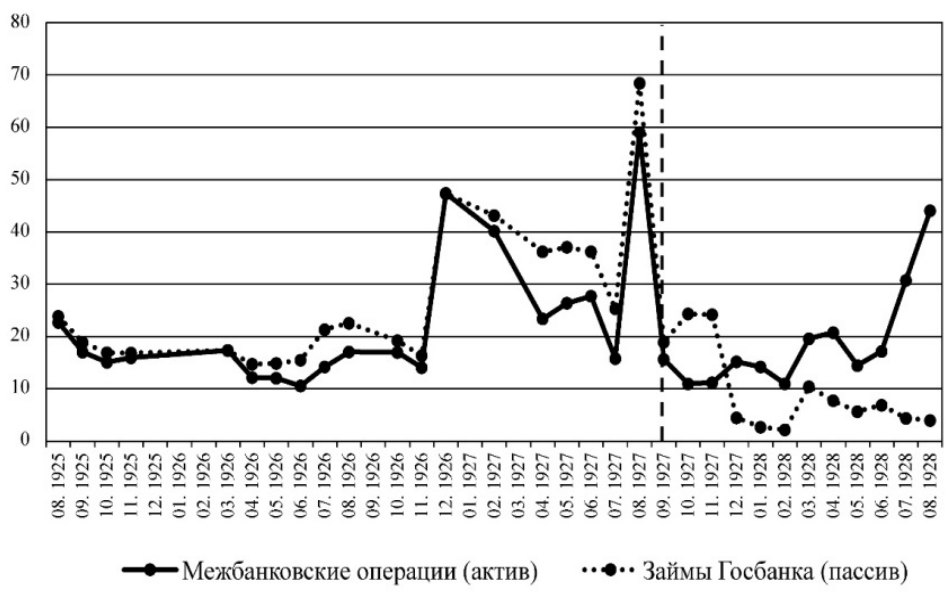

Рис. 3. Источники межбанковских операций до передачи Внешторгбанку в июне 1927 г.*

* Судя по операциям, банк перестроил свою деятельность только к сентябрю 1927 г.

Составлено по: см. рис. 1.

После передачи Гаркребо Внешторгбанку объем средств Госбанка в балансах заметно уменьшается. Если с сентября по ноябрь 1927 г. кредиты от Госбанка составляли уже небольшую, но все еще существенную часть средств Гаркребо (32-36\%), то с декабря их удельный вес не поднимался выше $12 \%$, в среднем 5,8\%. В абсолютном выраже- 
нии средства Госбанка в пассивах Гаркребо составили 19 млн марок в сентябре 1927 г., 3 млн марок в декабре 1927 г., после чего колебались между 4 и 10 млн марок до августа 1928 г. (см. рис. 2).

Уменьшение средств, получаемых от Госбанка, влечет за собой и сокращение межбанковских операций. После передачи Внешторгбанку, с сентября 1927 г. и до июня 1928 г. удельный вес этих операций снижается и находится в промежутке от 16 до $26 \%$, однако в июле и августе повышается до 27 и 32\% соответственно (рис. 4). В абсолютном выражении, однако, межбанковские операции продолжают колебаться между 10 и 20 млн марок. При этом, в этот период в июле-августе 1928 г. происходит третий «всплеск». Значение тогда повысились до 30 и 44 млн марок соответственно (см. рис. 1).

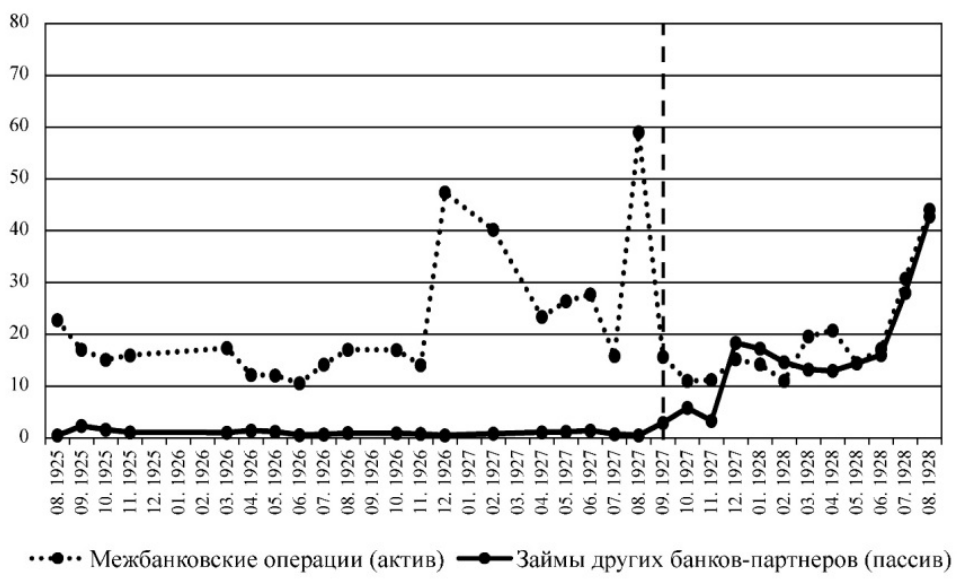

Рис. 4. Источники межбанковских операций после передачи Гаркребо Внешторгбанку в июне 1927 г.*

* Судя по операциям, банк перестроил свою деятельность только к сентябрю 1927 г.

Составлено по: см. рис. 1.

Потеря средств в 1927 г. на первых порах была компенсирована переучетом (перепродажей) векселей и займом от торгпредства. К концу 1927 г. у Гаркребо начинают появляться займы от банковпартнеров. Согласно отчетам, крупнейший из них, размером в 15 млн марок, предоставил Дальбанк в Харбине в декабре 1927 г. [7]. С декабря 1927 г. по июнь 1928 г. займы от банков-партнеров составляли от $25 \%$ до $40 \%$ всех средств Гаркребо (до этого средний 
удельный вес подобных займов составлял 10\%). Так, в декабре Гаркребо получил 32 млн марок займами, после чего эта цифра уменьшилась до 27 млн марок в июне (см. рис. 2).

В июле-августе 1928 г. Гаркребо получает несколько крупных займов от других банков. Таким образом, кредиты от банков увеличились до 48 млн (42\%) в июле и до 73 млн (53\%) в августе (см. рис. 2). Бухгалтерская отчетность банка не диверсифицирует займы от других банков. Однако, как и межбанковские операции, займы между банками оформляются в рамках специального счета - контокоррента. Следовательно, в отчетности они разделены на «лоро» и «ностро». При этом заем от Дальбанка, выданный в декабре 1927 г., проходит по статье «лоро». В июле-августе 1928 г. увеличиваются займы именно по статье «лоро». При этом можно наблюдать, что за счет роста этой статьи и происходит третий «всплеск» межбанковских операций (рис. 4).

Таким образом, в конце 1920-х гг. Гаркребо вновь занимается межбанковскими операциями. В данном случае банк принимал участие в возвращении советского золота из США. [6] Нельзя однозначно сказать, откуда банк брал средства на эту операцию. Однако, как уже отмечено выше, в этот период между Гаркребо и Дальбанком в Харбине установились особые отношения. Кроме того, после июня 1927 г. Дальбанк остался одним из немногих банков, прямо подконтрольных Госбанку. Следовательно, можно предположить, что Гаркребо вновь использовался для выполнения поручений от Госбанка за его счет.

Проанализировав количественные показатели из ежемесячных балансов Гаркребо, можно увидеть, что банк использовался Госбанком в качестве посредника на международных валютных и финансовых рынках. Гаркребо регулярно выполнял различные поручения Госбанка. Кроме того, через Гаркребо Госбанком были оформлены счета в некоторых банках Нью-Йорка. При этом ресурсы Гаркребо регулярно использовались для регулирования курса червонца на иностранных рынках. Предположительно, даже после передачи Гаркребо в ведомство Внешторгбанка, Госбанк продолжал выдавать ему поручения и средства на их исполнение через Дальбанк в Харбине. К примеру, Гаркребо участвует в возвращении советского золота из США летом 1928 г.

Таким образом, судя по деятельности Гаркребо, можно заключить, что финансовые операции Советского государства за рубежом были сильно связаны с американским рынком. Через Гаркребо Госбанк размещал средства в банках Нью-Йорка. При этом, помимо сче- 
тов Гаркребо, в США также было размещено советское золото. Кроме того, советское руководство стремилось регулировать курс червонца. Был налажен постоянный мониторинг состояния червонца и, в случае необходимости, часть валюты выкупалась по поручениям СССР. Важно так же отметить, что важнейшей инстанцией в проведении этой политики был Госбанком, который и давал поручения совзагранбанкам.

\title{
Библиография
}

1. Вейцман Р.Я. Банковское счетоводство в связи с банковской организацией и техникой банковского дела. - М.: ЦЕНТРОСОЮЗ, 1927. - 543 с.

2. ВЭБ: Внешэкономбанк: 75-летию Внешэкономбанка посвящается / [Под общ. ред. А.П. Забазнова; Авт. текста: Ю.П. Голицын, А.Г. Саркисянц]. - М.: Типо Грэфик Дизайн, 1999. - 196 с.

3. Кротов Н.И. Внешэкономбанк. История банка. История страны. - Т. 1. - М.: РОСТ Медиа, 2014. - 376 с.

4. Российский государственный архив экономики (РГАЭ). Ф. 7590. Оп. 3. Д. 82. Л. 57.

5. РГАЭ. Ф. 7590. ОП. 3. Д. 135. Л. 256.

6. РГАЭ. Ф. 7590. ОП. 3. Д. 383. Л. 12.

7. РГАЭ. Ф. 7590. Оп. 3. Д. 383. Л. 26.

8. Deutscher Reichsanzeiger. - 1927 - № 177 - URL: https://digi.bib.unimannheim.de/viewer/reichsanzeiger/film/062-9022/0006.jp2 (Дата обращения:31.08.2020).

9. McMeekin S. History's Greatest Heist: The Looting of Russia by the Bolsheviks. Yale: University Press, 2008. - 302 p.

https://doi.org/10.29003/m1795.978-5-317-06529-4/103-107

\author{
Шиирко С.В. \\ Российский государственный \\ гуманитарный университет, Москва
}

\section{Математическое моделирование иерархичной структуры пространственного размещения средневекового сельского населения}

Аннотация. В качестве предмета исследования рассматривается математическое моделирование пространственного размещения средневекового сельского населения. На основе вариационного подхода разрабатываются две модели иерархии центров, позволяющие с высокой степенью надежности выявить факторы развития поселенческой структуры и описать количественно соотношения между ее важнейшими параметрами, такими как плотность, численность и площадь расселения.

Ключевые слова: квантитативная история, математическое моделирование, теория центральных мест, писцовая книга, система размещения центров, функция плотности населения, оптимальное равновесие, историческая география. 
Shpirko S.V. Russian State University for Humanities, Moscow

\title{
Mathematical modeling of the hierarchical structure of the spatial distribution of the medieval rural population
}

\begin{abstract}
The subject of paper is the mathematical modeling of the spatial distribution of the medieval rural population. On the basis of the variational approach, two models of the hierarchy of centers are being developed, allowing with a high degree of reliability to identify the factors of the development of the settlement structure and to describe quantitatively the relationship between its most important parameters, such as density, population size and area.

Keywords: quantitative history, mathematical modelling, central location theory, scribe book, human settlement system, population density function, optimal equilibrium, population density function, historical geography.
\end{abstract}

\section{І. Модель одноуровневой иерархии центров}

Математическое моделирование пространственного размещения населения является одним из традиционных направлений квантитативной истории. В этой связи достаточно упомянуть исследования А. Чедвика [1] и П. Доорна [2], посвященные реконструкции поселенческой структуры населения эпохи бронзы. Если А. Чедвик в процессе своего моделирования использовал вероятностый подход, то теория В. Кристаллера [3, с. 143], описывая пространственную иерархию городского расселения (центральных мест), использовала оптимизационные принципы. Несмотря на различие в подходах, модели обоих авторов предполагают довольно жесткие ограничения, например, однородность территории, статичность и равномерную распределенность населения, чего в реальной жизни, пожалуй, трудно обнаружить.

Модель размещения центральных мест С.М. Гусейн-Заде [4] призвана разрешить подобного рода затруднения. Главным ее постулатом является отказ от однородности условий, что влечет за собой и признание неравномерного размещения населения, характеризующегося плотностью $\mathrm{p}(\mathrm{x})$ в каждой точке х изучаемой территории. Само расселение представляется в виде динамической системы, каждый из участников которого руководствуется в своей деятельности рядом естественных целей. В качестве таких целей могут выступать, например, свободный доступ к обрабатываемому (контролируемому) участку или максимально близкое размещение к своему центральному поселению. Складываясь вместе, индивидуальные цели каждого из участников формируют общие цели системы. 
Заметим, что выбранные цели системы могут быть взаимно противоположны. Так, указанная ранее минимизация суммарных расстояний до контролируемых участков приводит к равномерному распределению населения по всей территории, и, наоборот, минимизация суммарного расстояния до центров ведет к концентрации населения вокруг них. Варьирование функции плотности населения как раз и призвано уравновесить все выбранные цели, найдя между ними оптимальное соотношение.

Ранее автором настоящего исследования была развита модель одноуровневой иерархии центров [5]. В ней предполагается разделение всей изучаемой территории на совокупность областей, имеющих свой центр (центральное поселение). Взаимодействие население разных областей друг с другом является ничтожно малым и не учитывается. Центры более высокой иерархии отсутствуют. Предполагается, что население при размещении внутри каждой области своих дворов (составляющих отдельные деревни) руководствуется двумя вышеописанными целями. В качестве ближайшей аналогии автором была выбрана погостная система расселения Новгородской земли (Деревская пятина) рубежа XV-XVI веков, отраженная в сохранившихся писцовых книгах и реконструированная Н.В. Пиотух и А.А. Фроловым [6].

Отметим, что согласно модели центральное поселение (поселение-погост) может находиться и за границами своей области (погоста), а сама область может включать в себя и несколько погостовтерриторий. Такую ситуацию отмечал А.Н. Насонов [7, с. 108-112], выделяя на территории средневековой новгородской территории отдельные земли и волости (Лужская, Ладожская, Помостье), и не укладывающиеся в традиционное погостное и пятинное деление.

Следуя в рамках вариационного подхода С.М. Гусейн-Заде, автором настоящего исследования были получены оптимальные соотношения, связывающие между собой параметры системы: плотность населения $p(x)$, расстояние $r(x)$ от точки х до центра, плотность размещение центров $q(x)$, площадь $S$ и население $N$ каждой области. Оказалось, что эти соотношения носят не линейный, а степенной характер. Так, между первыми двумя параметрами они выглядят как $p(x) \approx r(x)^{-2 / 3}$, где отрицательный знак при показателе степени означает взаимообратную зависимость. На естественном языке это можно интерпретировать следующим образом: чем дальше от своего центра, тем меньше плотность населения. Зависимость между средней плотностью и площадью также обратная: $p=\frac{N}{S} \approx S^{-\frac{1}{3}}$, что корре- 
лирует с выводами ряда исследователей [8-9] о том, что областям с большей плотностью населения соответствует их меньшая площадь. Полученные теоретические результаты с весьма высокой степенью надежности соответствуют экспериментальным, приведенным в Историческом Атласе Деревской пятины [6].

\section{II. Модель двухуровневой иерархии центров}

Понятно, что одноуровневая модель не является универсальной. Структура той же Шелонской пятины между погостом и главным городом (Новгородом Великим) включает в себя и промежуточное звено в виде уездов. Более того, для последующего времени мы видим преобладание именно двухуровневой иерархии поселенческой сельской структуры. Погосты, станы, волости составляли ее первый, низший уровень, а включавшие их уезды - второй, высший уровень. Центрами низшего уровня являлись по-прежнему погосты-поселения и владельческие села, а высшего уровня - уездные города.

Руководствуясь этими соображениями, автор настоящего исследования предлагает двухуровневую модель иерархии центров сельского расселения. Согласно этой модели, размещение населения как и расположение центров 1-го и 2-го уровня не является равномерным и характеризуется функциями $p(x), q 1(x), q 2(x)$ соответственно. Развитие поселенческой структуры определяется тремя целями: 1) минимизация суммарного расстояния участников процесса расселения до контролируемых ими участков; 2) минимизация суммарного расстояния участников расселения до своих центров 1-го уровня; 3) минимизация суммарного расстояния от центров 1-го уровня до своих центров 2-го уровня. Варьируемых параметров теперь два: плотность населения $p(x)$ в каждой точке х изучаемой территории и плотность $q 1(x)$ размещения центров 1-го уровня.

Следуя рамкам вариационного подхода, автор получает оптимальные соотношения, связывающие параметры системы, которые как и в ранее представленной модели носят степенной характер. Так, функция плотности размещения центров 1-го уровня и их расстояния до центров 2-го уровня $q 1(x) \approx r(x)^{-6 / 7}$; зависимость между средней плотностью населения области и ее площадью $p=\frac{N}{S}=S^{-1 / 7}$, что вполне согласуется с логикой предыдущей интерпретации.

Проведенное моделирование позволяет с высокой степенью надежности не только выявить факторы (цели) развития системы сельского средневекового расселения, но и описать количественно соотношения между важными ее параметрами. Более того, появляет- 


\section{ся возможность ретроспективной оценки численности населения в случае неполноты данных, что делает полезным данное моделирова- ние для исторической географии и демографии.}

\section{Библиография}

1. Chadwick A.J. A computer simulation of Mycenean settlement// Simulation studies in archaeology/ ed.by I. Hodder. - Cambridge, 1978. - PP. 47-97.

2. Доорн П. Географическое положение, модели взаимодействия и реконструкция исторических поселений и коммуникаций (на примере Этолии, исторической области Центральной Греции) // История и компьютер: новые информационные технологии в исторических исследованиях и образовании / Ред. Л.И. Бородкин, В. Леверманн. - St. Katharen, 1993. - С. 105-139.

3. Бунге В. Теоретическая география / Ред. В.М. Гохман. - М., 1967. - 281 с.

4. Гусейн-Заде С.М. Модели размещения населения и населенных пунктов: дисс... док.физ.-мат. наук: 01.01.09 / Гусейн-Заде Сабир Меджидович. - М., 1990. $218 \mathrm{c}$.

5. Шпирко С.В. О вариационном подходе к моделированию средневекового размещения населения (на примере Деревской пятины Новгородской земли конца XV века) // Историческая информатика. - 2018. - № 4. - С. 22-38.

6. Фролов А.А., Пиотух Н.В. Исторический атлас Деревской пятины Новгородской земли. - М.; СПб., 2008. - Т. 1. -370 с.

7. Насонов А.Н. «Русская Земля» и образование территории Древнерусского государства. Историко-географическое исследование. Монголы и Русь. История татарской политики на Руси. - СПб., 2002. - 269 с.

8. Андрияшев А.М. Материалы по исторической географии Новгородской земли. Шелонская пятина по писцовым книгам 1498-1576 гг. - М., 1914. - 630 с.

9. Платонова Н.И. Погосты и волости северо-западных земель Великого Новгорода // Археологическое исследование Новгородской земли. - Л., 1984. - С. 173-187. 


\title{
КОМПЬЮТЕРИЗОВАННЫЙ АНАЛИЗ ТЕКСТОВЫХ ИСТОЧНИКОВ
}

https://doi.org/10.29003/m1796.978-5-317-06529-4/108-113

Колесник М.О., Баранова Е.В. Балтийский федеральный университет имени И. Канта, Калининград

\author{
Создание информационной системы \\ «Мемориальные доски Калининграда»: \\ контент-анализ коммеморативного текста
}

Аннотация. Статья посвящена исследованию роли мемориальных досок как коммеморативных знаков в создании единого «текста города» Калининграда. На основе американского ресурса Open Plaques была создана наиболее полная на данный момент база мемориальных досок Калининграда. В ходе анализа полученного материала было обнаружено, что созданные доски в Калининграде за последние десятилетия, отличаются от установленных в советский период, тематикой и художественным исполнением, размером невербального компонента текста. Так устанавливаются таблички, связанные с сохранением памяти о героях локальных войн и вооруженных конфликтов. Зачастую на обновленных мемориальных досках невербального компонента становится больше, а вербальный текст дополняется более конкретной информацией.

Ключевые слова: мемориальная доска, коммеморативные практики, база данных, контент-анализ, креолизованный текст.

Kolesnik M.O., Baranova E.V. Immanuel Kant Baltic Federal University, Kaliningrad

\section{Creation of the information system "Memorial plaques of Kaliningrad": content analysis of the commemorative text}

\begin{abstract}
The article is devoted to the study of the role of memorial plaques as commemorative signs in the creation of a single "city text" of Kaliningrad. Based on the American resource Open Plaques, the most complete database of memorial plaques in Kaliningrad has been created at the moment. In the course of the analysis of the obtained material, it was found that the boards created in Kaliningrad over the past decades differ from those established in the Soviet period in thematic and artistic performance, the size of the non-verbal component of the text. This is how the plaques associated with preserving the memory of the heroes of local wars and armed conflicts are installed. Often, on updated plaques, the non-verbal component becomes larger, and the verbal text is supplemented with more specific information.

Keywords: plaque, commemorative practices, database, content analysis, creolized text.
\end{abstract}


Будучи своеобразными «маркерами» городского пространства, мемориальные доски представляют собой элемент историкокультурного наследия - сложной социокультурной системы, активно взаимодействующей со средой и несущей определенную, меняющуюся во времени и пространстве, информацию [1]. История города складывается из свершений отдельных людей, которые находят отражение в тексте мемориальных табличек. Характерной особенностью, присущей советскому искусству вообще и оформлению мемориальных табличек в частности, является лаконичность художественных средств, ясные формулировки текста, предпочтение атрибутов и символов, которые в сознании советского человека должны были рождать определенные ассоциации [2].

Мемориальные доски, установленные в Калининграде, систематизировались, но до сих пор не изучались комплексно, отсутствуют исследования, обобщающие факты, события и явления, а также исследования их места и роли в едином «тексте города», имеющем историческую значимость. В мемориальных табличках просматривается, с одной стороны, история становления Калининграда как советского города, события Второй мировой войны и послевоенного времени, с другой стороны, они ведут нас через прошлые столетия во времена Кенигсберга.

Целью работы стало исследовать роль мемориальных досок как коммеморативных знаков в создании единого «текста города» Калининграда, их систематизация и анализ их социолингвистических характеристик.

Чтобы создать полноценную сводную систему по мемориальным доскам Калининграда, было принято решение использовать интернет-ресурс Open Plaques - проект, который каталогизирует, хранит и продвигает памятные доски и исторические знаки, установленные на зданиях и достопримечательностях по всему миру. Проект через мемориальные доски воплощает историю в жизнь для более широкой аудитории путем создания исчерпывающего и наиболее полного ресурса об этих исторических памятниках. Больше всего мемориальных табличек на сайте размещено в США (19 169) и Великобритании (14 932). В России этот ресурс менее популярен, наибольшую активность можно заметить в Калуге (загружено 157) и в Ульяновске (загружено 74).

Для создания цифровой базы, а также информационной системы «Мемориальные доски города Калининграда» было принято реше- 
ние разбить территорию исследования на три части, по трем административно-территориальным единицам: Центральный, Московский и Ленинградский районы. Основным источником для работы стал «Перечень мемориальных досок, закрепленных на праве оперативного управления за МКУ “Калининградская служба заказчика"».

В процессе исследования была создана база мемориальных табличек города Калининграда в виде таблицы в формате Excel. B нее внесены данные о 138 мемориальных досках, из них по Ленинградскому району - 53, Центральному - 49, Московскому - 36. Таблица состоит из следующих столбцов: порядковый номер, кому посвящена, адрес, состояние, ссылка на страницу на сайте Open Plaques, текст, дата создания, типология (место, личность, событие), кем установлена (администрация, общественность), ВОВ (имеет ли отношение к Великой Отечественной войне). Состояние всех мемориальных досок хорошее, надписи читабельны, сколов нет, многие памятные знаки уже заменены новыми. Стоит отметить, что на обновленных досках чаще можно встретить помимо вербального текста, невербальный (барельеф, портрет и т.д.), т.е. текст большинства мемориальных досок (109 шт.) является креолизованным (сочетание вербальных и невербальных, изобразительных средств передачи информации).

Согласно Решению Городского Совета депутатов от 6 июля 2016 года № 215 «Об утверждении Положения “О порядке установки, содержания и демонтажа мемориальных досок на фасадах зданий и сооружений городского округа "Город Калининград"», на территории городского округа «Город Калининград» могут устанавливаться доски следующих видов: событийные - посвящены знаменательным событиям, связанным с Кенигсбергом-Калининградом; именные посвящены выдающимся личностям, связанным с КенигсбергомКалининградом, отечеством [3].

При анализе текстов мемориальных досок было решено расширить типологию, так как текст мог включать в себя не только информацию о личности, но и одновременно относится к историческому событию или указывать на место, где оно происходило (табл. 1).

Из таблицы видно, что, наибольшее количество мемориальных досок $60 \%$, относятся к типу «личность», на втором месте «место/личность» - 20\%, «место» - 7\%, «личность/событие»- 6\%, «событие» $-4 \%$, «личность/событие/место» $-2 \%$ и «место/событие» $-1 \%$. 
Таблицуа 1

Типология мемориальных табличек

\begin{tabular}{|l|c|c|c|c|}
\hline \multicolumn{1}{|c|}{ Тип } & $\begin{array}{c}\text { Ленинград- } \\
\text { ский }\end{array}$ & Центральный & Московский & Всего \\
\hline «Личность» & 35 & 27 & 21 & 83 \\
\hline «Место» & 6 & 2 & 2 & 10 \\
\hline «Событие» & 5 & 0 & 1 & 5 \\
\hline «Место/Личность» & 5 & 15 & 8 & 28 \\
\hline «Место/событие» & 1 & 0 & 0 & 1 \\
\hline «Личность/событие» & 1 & 3 & 4 & 8 \\
\hline «Личность/событие/место» & 1 & 2 & 0 & 3 \\
\hline
\end{tabular}

Анализируя мемориальные доски, исходя из временного периода, можно отметить, что наибольшее количество 70\%, посвящены событиям и личностям времен СССР, 12\% затронули периоды Советского Союза и Российской Федерации, 9\% относятся к Российской Федерации, $6 \%$ посвящены историческим личностям и событиям Пруссии, 3\% значимым личностям и событиям, которые связывали Кенигсберг и Российскую Империю. При этом в советской тематике $60 \%$ имеют отношение к событиям Великой Отечественной войны.

Частотный анализ полученных текстов выявил, что наиболее употребляемыми словами стали: советский [50], Союз [49], названа [47], 1945 [42], улица [42], год [29], память [27], город [24], год [24] , герой [21] , Великая [19] , Отечественная [19] , апрель [19], честь [19]. Понятно, что большинство языковых единиц несут в себе тематику советского времени и Великой Отечественной войны. Начало истории города, как российского, тесно связано с военной историей. Об этом говорят большинство мемориальных досок города Калининграда. В «языке города», отраженном в мемориальных досках не преобладают ученые, поэты и другие деятели науки и искусства. Транслируется посыл, что Калининград город советской воинской славы, память о немецком прошлом нивелируется.

Доски, посвященные немецким деятелям, истории этого времени начинают появляться только в 1990-е гг. Основная преобладающая тематика - Иммануил Кант, немецкий философ, живший в Кенигсберге в XVIII в.

Русская история досоветского периода, связанна с историей взаимодействия России и Пруссии до революции и отражается в таких 
смысловых единицах как честь [2], Кенигсберг [2], год [2], июнь [2], 1921 [1], знак [1], Пруссия [1], флот [1], операция [1], Петр [1].

При анализе мемориальных досок, посвященных новейшей российской истории, встречаются следующие частоты: честь [5], милиции [5], Калининградской [5], погибшего [5], области [4], жил [4], названа [4], Чеченской [3], исполнении [3], имени [3], честью [3], МОУ [3]. В этом периоде преобладают смысловые единицы, связанные с военными событиями новейшей истории.

Таким образом, стоит отметить, что основной тематикой мемориальных табличек, связанных с городом Калининградом является военная тематика, сначала события имперской истории России $(\mathrm{Ce}-$ милетняя война), затем ВOB, а потом Чеченская компания. Первые мемориальные таблички в городе были установлены в целях увековечивания памяти военных, погибших в годы Великой Отечественной войны при штурме Кенигсберга. С изменением социально-политической обстановки в обществе менялись события и личности, которым посвящались мемориальные таблички. В городе появляются коммеморативные знаки, посвященные немецкому прошлому. Данная тематика типична для конца советского периода и начала периода Российской Федерации.

Мемориальные таблички выступают наиболее массовой формой увековечивания исторической памяти общества наряду с памятниками архитектуры и скульптурными сооружениями. Текст мемориальных досок является неотделимой частью городского текста, способствуя формированию образа Калининграда. На настоящий момент собрана информация о 138 мемориальных табличках Калининграда. Каждая мемориальная доска обладает самодостаточностью, но именно в ансамбле они осуществляют главную содержательную идею - сохранение истории города, увековечение памяти о событиях и выдающихся людях, внесших значительный вклад в становление и развитие города.

\section{Библиография}

1. Беседина Е.А., Буркова Т.В. «В этом здании жил и работал»: мемориальные доски как образ исторической памяти // Труды Исторического факультета СанктПетербургского университета. - 2013. - №16. - C. 48. - URL: https://cyberleninka.ru/ article/n/v-etom-zdanii-zhil-i-rabotal-memorialnye-doski-kak-obraz-istoricheskoy-pamyati (дата обращения: 01.05.2020).

2. Рысаева С.Ф. Мемориальная доска как историческая и художественная память города Кемерово // Вестник Кемеровского государственного университета культуры и искусств. - 2012. - № 21. - C. 188-189. - URL: https://cyberleninka.ru/ article/n/memorialnaya-doska-kak-istoricheskaya-i-hudozhestvennaya-pamyat-gorodakemerovo (дата обращения: 01.05.2020). 
3. Решение Городского совета депутатов Калининграда от 06 июля 2016 года об утверждении Положения «О порядке установки, содержания и демонтажа мемориальных досок на фасадах зданий и сооружений городского округа "Город Калининград”» - URL: http://docs.cntd.ru/document/439097284 (дата обращения: 24.03.2020г.).

https://doi.org/10.29003/m1797.978-5-317-06529-4/113-119

Баранов В.А.

Ижевский государственный технический университет имени М.Т. Калашникова

Гнутиков Р.М. Удмуртский государственный университет, Ижевск

\section{Инструменты извлечения и приемы подготовки лингвистических данных для статистического анализа в историческом корпусе «Манускрипт» ${ }^{1}$}

Аннотация. Рассматривается задача автоматического приведения имеющих неупорядоченную графику и орфографию текстовых форм корпуса «Манускрипт» (manuscripts.ru), содержащего точные транскрипции славянских средневековых рукописей, к одной и только одной лемме, что необходимо для корректного статистического анализа лингвистических данных корпуса. Предлагается несколько способов и приемов сопоставления нормализованных форм, имеющихся в электронном грамматическом словаре корпуса, с формами текстов.

Ключевые слова: исторический текстовый корпус, корпусный менеджер, лемматизация.

Baranov V.A. Kalashnikov Izhevsk State Technical University

GnutikovR.M. Udmurt State University, Izhevsk

\section{Tools of extraction and procedures of preparation of linguistic data for statistic analysis in the historical corpus «Manuscript»}

Abstract. Considered is the task of automatic reduction of the text forms with variable graphics and orthography of the corpus "Manuscript" (manuscripts.ru), comprising exact transcriptions of Slavonic medieval manuscripts, to one and only one lemma, which is necessary for correct statistic analysis of the corpus linguistic data. Several ways and procedures of comparison of normalized forms, which are available in the corpus electronic dictionary, with the text forms are proposed.

Keywords: historical text corpus, corpus manager, lemmatization.

\footnotetext{
${ }^{1}$ Исследование проводится при поддержке гранта РФФИ № 18-012-00463.
} 
Как известно, текстовые корпуса отличаются от коллекций текстов наличием разметки и корпусного менеджера, обеспечивающего манипулирование данными. Современные корпуса на основе русскоязычных текстов, помимо морфологической, снабжаются синтаксической, лексико-семантической, лексико-тематической разметкой, а демонстрация данных в виде перечней с информацией о контекстах и количестве единиц в выборке дополняется возможностями получения сведений о синтаксических структурах, статистических и дистрибутивных характеристиках материала. Наличие электронных грамматических словарей, алгоритмов и программ автоматического стемминга, лемматизации и морфологического и синтаксического анализа позволяет автоматизировать значительную часть работы по подготовке данных.

Особым направлением в корпусной славистике является подготовка и эксплуатация исторических корпусов, содержащих старославянские, древнерусские, старорусские тексты и рукописи. Несмотря на более чем 30-летнюю историю их создания (первые работы, направленные на подготовку славянских исторических корпусов, можно отнести к середине 80 -х годов прошлого века $[1 ; 2])$, и сегодня остаются нерешенными некоторые базовые задачи, в частности, не обеспечен полный автоматический морфологический и синтаксический анализ текстов. Основными препятствиями являются неупорядоченная графика и орфография средневекового письма и существенно иные, чем сегодня, лексические и грамматические системы славянских языков донационального периода. Разметка таких корпусов требует создания специальных процедур нормализации и унификации текстовых форм, а также наличия электронных словарей и/или методов для лемматизации и морфологической разметки.

Тем не менее постепенный перевод все большего количества текстов X-XVII веков в машиночитаемую форму, близкую или идентичную оригиналу, увеличение объема коллекций, постепенно все более проявляющийся интерес специалистов по истории славянских языков к корпусным методам заставляют расширять функциональные и демонстрационные возможности таких корпусов, предоставлять пользователям такие инструменты, которые не только существенно экономят время для поиска материала, но и позволяют ставить и решать задачи, которые уже успешно решаются с помощью больших данных современных текстов.

Одним из существующих в настоящее время исторических корпусов славянских языков является корпус «Манускрипт» (manuscripts.ru), содержащий размеченные машиночитаемые тран- 
скрипции славянских рукописей $\mathrm{X}-\mathrm{XV}$ веков общим объемом около 3,5 миллионов текстовых форм и обеспечивающий с помощью модулей доступа к данным (запросных форм) визуализацию результата как в традиционных формах - в виде конкордансов, прямых и инверсированных перечней текстовых форм, так и в таких, которые позволяют получить информацию о лингвистических единицах на основе применения к ним статистических мер [3].

Пользователям предоставлены различные инструменты для поиска и визуализации лингвистических единиц - стандартные для корпусов формы запросов и демонстрации выборок и специализированные статистические модули (модуль статистики и модуль nграмм $)^{1}$ (о статистических модулях см., например, [4]).

Одним из основных полей запросных форм всех модулей является поле ввода слова - текстовой формы или леммы. Соответствие введенной маски текстовому прецеденту или нормализованной форме словаря может быть установлено значением параметра точность. Маска может быть введена с помощью букв не только старославянского, но и современного алфавита. Последнее позволяет не учитывать при поиске графические варианты одной и той же буквы. Наиболее гибким способом задания маски является использование регулярных выражений.

В целом задачи автоматического распознавания графико-орфографических вариантов одной и той же текстовой формы в корпусе решены несколькими способами:

- использованием правил унификации буквенных символов как без учета, так и с учетом позиции в слове («заглавная $=$ строчная $=$ надстрочная буквы», варианты одной буквы - «ук диграф = ук монограф» и под., варианты разных букв - «фита = ферт» и под., сочетания букв - «согласная $+\mathrm{p} /$ л + ь/ъ + согласная $=$ согласная + ь $/ \mathrm{s}+\mathrm{p} /$ л + согласная» и под., а также, например, «Приравниваются друг другу

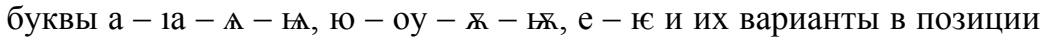
после букв и буквенных сочетаний ш, щ, ж, жд, ч, ц и их вариантов» и др.; всего более 20 правил);

- унификацией или устранением небуквенных символов - диакритики, титл, пробелов, точек, например, при написании порядковых числительных $-\vec{\Gamma} \cdot$ ю;

- использованием транслитерации;

- использованием регулярных выражений;

- использованием нормализованных форм слова;

- приведением текстовых форм к начальным формам и др. 
Понятно, что при большой вариативности первичных данных полнота и точность выборки зависят в том числе и от параметров запросной формы. Вероятные затруднения пользователя в выборе предоставленных ему в корпусе способов унификации текстовых прецедентов, казалось бы, снимаются возможностями извлечения нормализованных начальных форм слов (лемм) с последующим переходом к контекстам. Но, к сожалению, на сегодняшний день морфологический анализатор (лемматизатор) корпуса не обеспечивает однозначную автоматическую разметку всех текстовых форм: некоторые приводятся к нескольким леммам, а некоторые не распознаются из-за отсутствия информации о их парадигмах и начальных формах в грамматическом словаре корпуса (доля нелемматизированных форм колеблется от 7-10 до 23-25 процентов в зависимости от рукописи $)^{2}$. В стандартных модулях при работе с выборками проблемы неснятой омонимии и неполной лемматизации частично снимаются демонстрацией перекрестных ссылок между леммами и возможностью просмотреть контекст в первом случае: вино

вина (3) $\{* * 22.1-17$ см. вино $\},\{* * 28.1-22$ см. вино $\},\{* * 38.2-14$

вино (4) $\{* * 22.1-17$ см. вина $\},\{* * 28.1-22$ см. вина $\},\{* * 38.2-9\}$, $\{* * 38.2-14 \text { см. вина }\}^{3}$

и перечней неразмеченных текстовых прецедентов во втором.

В то же время при количественном и статистическом анализе в модулях статистики и n-грамм эти два фактора принимают критический характер, так как, например, сведения о количестве лемм и текстовых форм в анализируемом подкорпусе существенно отличаются.

Как известно, автоматическое снятие омонимии в современных корпусах осуществляется методами морфологического, синтаксического и семантического анализа. Отсутствие парсера в корпусе «Манускрипт» требует поисков других приемов решения проблемы.

В настоящее время тестируются несколько способов снятия омонимии с целью приведения количества лемм выборки к количеству текстовых прецедентов подкорпуса и морфологической разметки текстовых форм. Особенностью алгоритмов является то, что они применяются не ко всем формам текста, а только к тем, для анализа которых предназначены.

В отношении форм, первоначально распознанных как формы разных лемм, применяются:

- формальные правила, учитывающие, в частности, а) вхождение текстовой формы в парадигму неизменяемого или изменяемо- 
го слова (въ $\rightarrow$ ВЪ1 с вин. / ВЪ2 с местн. $\rightarrow$ ВЪ; да $\rightarrow$ ДА1 союз / ДА2 част. / ДАТИ глаг. $\rightarrow$ ДА), б) совпадение / несовпадение текстовой формы с формой леммы (соугоубо $\rightarrow$ СОУГОУБО нар. / СОУГОУБЪ прил. $\rightarrow$ СОУГОУБО нар.), в) количество установленных связей между формами альтернативных лемм словаря и текстовыми прецедентами (поусти $\rightarrow$ ПОУСТИТИ глаг. [100х] / ПОУСТЬ прил. [50x] $\rightarrow$ ПОУСТИТИ глаг.);

- информация о совпадении грамматических помет находящихся рядом форм (до смьрти $\rightarrow$ ДО предл. с род. + смьрти род. / дат. / местн. $\rightarrow$ СМЬРТЬ смьрти сущ. ед. род.; съ звђздами $\rightarrow$ съ предл. с род. / с твор. + ЗВЂЗДА звђздами сущ. мн. твор. $\rightarrow$ СЪ с твор.);

- учет соседства с другими формами и разделителями текста в меняющемся по ширине окне (свђтомь и теплотою $\rightarrow$ И союз);

- сведения о распределении омонимичных текстовых форм по леммам после ручного снятия омонимии в некоторой части корпуса.

В результате приведенные выше две статьи слов вина и вино получают следующий вид:

вина (1) 281-22 см. вино (И се же нто(с) ли гго смртьнала вина)

вино (3) 22.1-17 см. вина, 38.2-9, 38.2-14 см. вина (вино и масло, хлгбб съ виномь изнесе, хльбъ и вино)

В контексте

- и изгнаша и $\bar{w}$ съборища

свогго вънъ · изгнаша и $\bar{w}$ ненави $[\partial и]-$

маго б[огъ]мь съборища жидовьскаго • (СбТолст, л. 30 [5]) - автоматически однозначно определяются все словоформы:

$u \rightarrow$ И союз.,

изгнаша $\rightarrow$ ИЗГЬНАТИ глаг. изгнаша изъяв. аор. мн. 3,

$\overline{\mathrm{w}} \rightarrow$ ОТЬ предл. с род.,

вънъ $\rightarrow$ ВЪНЪ нар.,

богъмь $\rightarrow$ БОГЬ сущ. муж. богъмь ед. дат.,

$\bar{w}$ съборища $\rightarrow \bar{w}$ [предл. с род.] съборища [сущ. средн. ед. род. / мн. им. / вин. / зват.] $\rightarrow$ СЪБОРИЩЕ сущ. средн. съборища ед. род., съборища своего $\rightarrow$ съборища [средн. ед. род.] своего [мест. притяж. муж. ед. род. / род.-вин. / средн. ед. род. / род.-вин.] $\rightarrow$ СВОИ мест. притяж. своего средн. ед. род.,

$\vec{w}$ ненавидимаго $\rightarrow \bar{w}$ [предл. с род.] ненавидимаго [прич. наст. страд. местоим. муж. ед. род. / род.-вин. / средн. ед. род.] $\rightarrow$ ненавидимаго прич. наст. страд. местоим. муж. ед. род. / средн. ед. род., 
ненавидимаго съборищза $\rightarrow$ ненавидимаго [прич. наст. страд. местоим. муж. ед. род. / средн. ед. род.] съборища [сущ. средн. ед. род. / мн. им. / вин. / зват.] $\rightarrow$ НЕНАВИДЂТИ глаг. ненавидимаго прич. наст. страд. местоим. средн. ед. род. СЪБОРИЩЕ сущ. средн. съборищча ед. род.,

съборища жидовьскаго $\rightarrow$ съборища [средн. ед. род.] жидовьскаго [прил. местоим. муж. ед. род. / род.-вин. / средн. ед. род.] $\rightarrow$ ЖИДОВЬСКЪ прил. жидовьскаго местоим. средн. ед. род.,

изгнаша $u \bar{w} \rightarrow$ изгнаша [глаг. изъяв. аор. мн. 3] $u$ [союз / мест.] $\bar{w}$ [предл.] $\rightarrow$ И мест.

При использовании нескольких приемов важным является очередность их применения, соответствие результатов друг другу, а в случае несоответствия - приоритет результатов.

В отношении группы нелемматизированных форм обсуждаются способы, приемы и алгоритмы а) сопоставления морфологических помет автоматически вычленяемых (псевдо)окончаний и (псевдо)основ с пометами лемматизированных форм контекста (при отсутствии в словаре леммы и ее парадигмы), б) сопоставления приставочных и постфиксальных глаголов с их производящими на основе их анализа в словарной базе данных (при отсутствии в словаре производных), в) неточного сопоставления неизвестной системе текстовой формы с имеющимися в базе данных формами и их словарными эквивалентами с помощью устранения нескольких или всех гласных, кроме конечной (при написаниях под титлом).

Первый прием основывается на возможности нахождения в словарной базе данных корпуса соответствий между хранящимися в ней основами лемм и окончаниями их словоформ и двумя частями текстовой формы, которые последовательно вычленяются изменением границ членения.

Второй способ реализуется в базе данных корпуса, в которой хранятся сведения о леммах, формах их парадигм, их грамматических характеристиках: сопоставление приставочных (в том числе с начальным не-) и бесприставочных, постфиксальных и беспостфиксальных лемм позволяет добавить в словарь отсутствующие леммы и парадигмы.

Третий способ, представляя собой один из вариантов стемминга - приведения слова к основе, позволяет установить словарную форму текстовых форм под титлом. 
Таким образом, эксперименты по приведению того разнообразия текстовых форм, которые мы имеем в транскрипциях средневековых славянских рукописей, показывают, что решение задачи автоматической лемматизации в целом возможно с помощью использования нескольких способов и приемов, примененных к различным лингвистическим компонентам текстов.

\section{Примечания}

1. См., например, запросные формы Остромирова Евангелия 1056-57 гг. (РНБ, F.п.1.5) - http://manuscripts.ru/mns/main?p_text=40921436 и подкорпуса древнерусских рукописей XI века - http://manuscripts.ru/mns/srch.simple?p_ed_id=39250308, а также модуль статистики - http://manuscripts.ru/mns/!cred2.stat и модуль n-грамм http://manuscripts.ru/mns/cred_ngr.stat.

2. Например, в Успенском сборнике кон. XII - нач. XIII в. из собрания ГИМ, Усп. 4, из 133992 текстовых форм один вариант разметки имеют 15140 форм, несколько вариантов - 108 496, не распознаны - 10 226, в Толстовском Апостоле XIV в. из собрания РНБ, Q.п.1.5., из 62981 текстовой формы соответственно 6 019, 42904 , 12890 форм, в Погодинском Евангелии XI|XII|XII-XIII вв., РНБ, Погод. 11, из 45501 формы - 5 716, 32 530, 7255 форм.

4. Где (3) - количество текстовых форм, \{\} - неснятая омонимия, ** - приведение текстовой формы к нескольким грамматическим формам словаря, 22.1.1-17.15 адрес текстовой формы.

\section{Библиография}

1. Corpus Cyrillo-Methodianum Helsingiense. - URL: http://www.helsinki.fi/ slaavilaiset/ccmh/ (дата обращения: 15.08.2020).

2. Thesaurus Indogermanischer Text- und Sprachmaterialien. - URL: http://titus.unifrankfurt.de/indexe.htm / (дата обращения: 15.08.2020).

3. Баранов В.А. Создание и использование исторических корпусов славянских письменных памятников // Scripta \& e-Scripta. - 2019. - Vol. 19. - C. 33-57.

4. Victor A. Baranov, Roman M. Gnutikov. The statistics and n-gram modules of the historical corpus «Manuscript» // Digital and Analytical Approaches to the Written Heritage: Proceedings of the 7th international conference El'Manuscript "Textual Heritage and Information Technologies", 2018 / Compilers and Editors: Anisava Miltenova, Victor Baranov, Heinz Miklas, Kevin Hawkins, Jürgen Fuchsbauer. - Sofia: Gutenberg Publishing House, 2019. - Pp. 9-28.

5. Сборник Толстовский XIII в., РНБ, F.п.I.39, 184 л. - URL: http://manuscripts.ru/ $\mathrm{mns} / \mathrm{main}$ ?p_text=96362255 (дата обращения: 15.08.2020). 
https://doi.org/10.29003/m1798.978-5-317-06529-4/120-126

Корниенко С.И., Исмакаева И.Д. Национальный исследовательский университет «Высшая школа экономики», Пермь

\section{Анализ идейно-политических и агитационно-пропагандистских} дискурсов «красных» и «белых» в годы Гражданской войны: задачи изучения и организации данных для исследования (на материалах Пермской губернской газетной периодики 1918-1919 гг.) ${ }^{1}$

Аннотация. В статье рассматривается необходимость и проблемы организации данных источников для изучения идейно-политических и агитационно-пропагандистских дискурсов «красных» и «белых» в годы Гражданской войны на основе материалов Пермской губернской газетной периодики 1918-1919 гг. Отмечено, что решение этих проблем определяется задачами изучения, необходимостью применения цифровых технологий и сводится в главном к обеспечению машиночитаемости источников данных, необходимого уровня их структурирования и организации на основе форм, позволяющих машинную обработку. В качестве основных путей решения указанных проблем обозначены создание цифровых источниковых комплексов на основе источнико-ориентированных информационных систем, массивов в виде файловых коллекций публикаций в текстовых форматах и данных в табличных формах. Показано, что решение задач организации данных создает необходимые условия для эффективного использования цифровых методов анализа и получения ожидаемых результатов на последующих, аналитических этапах исследования.

Ключевые слова: гражданская война в России, Пермская губерния, Колчак, газетная периодика, дискурсы «красных» и «белых», информационная война, цифровые технологии, организация данных источников.

Kornienko S.I., Ismakaeva I.D. National Research University «Higher School of Economics», Perm

Analysis of the ideological and political, agitation-propaganda discourses of the «red» and «white» during the Civil War: problem of studying and organizing data for research (based on materials from Perm provincial newspaper periodicals 1918-1919)

Abstract. The article discusses the need and problems of organizing sources of data for the study of ideological and political and agitation-propaganda discourses of the "reds" and "whites" during the Civil War based on materials from the Perm province newspapers of 1918-1919. It is noted that the solution to these

\footnotetext{
${ }^{1}$ Исследование проводится при поддержке гранта РФФИ, № 20-09-00443
} 
problems is determined by the tasks of study, using digital technologies and mainly reduced to ensuring the machine readability of data sources, their structuring and organization based on forms that allow machine processing. The main ways to solve these problems are the creation of digital sources of complexes based on source-oriented information systems, arrays in the form of file collections of publications in text formats and data in tabular forms. It is shown that solving the problems of organizing data creates the necessary conditions for the effective use of digital methods of analysis and obtaining the expected results at subsequent, analytical stages of the study.

Keywords: Russian civil war, Perm province, Kolchak, newspaper periodicals, discourses of "Red" and "White", information war, digital technologies, organization of data sources.

Как особый период в жизни общества гражданская война характеризуется особенно высокой степенью военного и идейно-политического противостояния, что находит свое выражение и в остром агитационно-пропагандистком противоборстве. Более того, такое противоборство приобретает относительно самостоятельное значение как средство, обеспечивающее достижение военно-политических целей и задач и носит характер информационной войны. Одним из ее основных инструментов в Гражданской войне в России в период борьбы «красных» и «белых» на Восточном фронте была газетная периодическая печать, которая активно использовалась сторонами для формирования определенных представлений и образов о противоборствующих сторонах, их целях, задачах, характере деятельности. Такие образы и представления можно рассматривать как дискурсы «красных» и «белых». Их изучение важно для понимания самого характера и содержания такого идейно-политического и агитационно-пропагандистского противоборства, его роли и значения в Гражданской войне, понимания возможностей и ограничений газетной периодической печати как исторического источника для изучения этого периода.

Указанное понимание актуальности и значения исследования газетной периодики в период гражданской войны стало основанием для разработки исследовательского проекта «Идейно-политические и агитационно-пропагандистские дискурсы “белых" и “красных” в информационном противоборстве на Восточном фронте Гражданской войны (по материалам газетной периодики 1918-1922 гг.)», поддержанного РФФИ, грант № 20-09-00443». В 2020 году начата его реализация.

Основным источником данных для исследования являются коллекции газет, издававшиеся сторонами на территории Пермской гу- 
бернии в период существования Восточного фронта и борьбы за Пермь. Это достаточно большой массив газет, включающий около 15 изданий и более 500 номеров. Они представляют собой как «красные» - советские официальные губернские, отраслевые и уездные издания, так и «белые» - издания Омского правительства и армии Колчака. Непродолжительным, но заметным и значимым событием в истории пермской периодической печати в годы гражданской войны было издание новых и возобновление выхода некоторых прежних газет в течение оккупации территории Пермской губернии колчаковскими войсками. Происходит частичное возрождение небольшевистской периодической печати. В Перми в это время выходило до 6 наименований газет [1, с. 131-133]. Это были хотя и неоднородные - общественно-политические, земские, епархиальные, но в целом антисоветские газеты, возродившиеся в Перми после ее взятия колчаковскими войсками, разделявшие в целом цели и идеалы и поддерживающие власть и вооруженные силы руководимые адмиралом Колчаком.

Последние издания представляют особый интерес, так как относительно недавно только стали доступны и вводятся в научный оборот исторических исследований. Еще ранее эти газеты были оцифрованы, а их машиночитаемые версии размещены в источникоориентированных информационных системах, созданных в результате реализации соответствующих научных проектов, поддержанных грантами РГНФ на основе пермской газетной периодики периода Гражданской войны «Колчаковские газеты» (kolchak.psu.ru) [2], «Пермская губернская периодика: 1914-1922» (permnewspapers.ru) [3]. История их издания и характеристики даны в специальных статьях, материалах докладов на конференциях, опубликованных в ходе выполнения проектов. В совокупности информация, содержащаяся в массиве газет, позволяет проанализировать все основные стороны идейно-политических и агитационно-пропагандистких дискурсов противоборствующих сторон.

Предмет исследования, а также общая актуальность проблематики анализа данных определили выбор тематики данного сочинения.

В связи с неоднозначностью определения и толкования понятия дискурс следует остановиться на его понимании и некоторых задачах изучения применительно к избранной теме.

В данном случае термин дискурс рассматривается в общем смысле - как речь, процессы языковой деятельности и предполагающие их системы понятий. Как языковая система понятий дискурс 
представляет собой определенный набор словоформ, словосочетаний, взаимных встречаемостей словоформ (коллокаций), упорядоченных в рамках определенной иерархии. На смысловом уровне дискурсы отражают определенные интерпретации терминов, текстов, конструируемых образов, ключевых концептов. Идейно-политические и агитационно-пропагандистские дискурсы в газетной периодике часто содержат идеологические и политические штампы, стереотипы, образы, основанные на определенных моделях ключевых концептов и выраженные совокупностями определённых лексем. В статье, посвященной методологическим проблемам исследования политического дискурса, применительно к характеристике его семантической и формальной сторон, указано, что «центр (ядро) дискурса составляет языковая картина мира, трансформированная модализованным сознанием в речевую реальность с оппозитивной структурой» [4, с. 53]. Таким образом, задачи выявления и анализа идейно-политических и агитационно-пропагандистских дискурсов «красных» и «белых» в годы Гражданской войны означают необходимость системного изучения и представления пропагандистских и агитационных форм публикаций газетной периодики, содержащихся в них определённых лексических наборов словоформ, словосочетаний, коллокаций - агитационно-пропагандистских штампов, шаблонов и стереотипов военного, политического, идеологического, социального и культурного содержания - конструируемых образов власти и властных структур, вооруженных сил и военных действий, военачальников и военнослужащих, образов врага и собственных, образов политических партий, вождей и других стереотипов и объектов и субъектов информационной войны.

Значительный объем информации источников, предмет исследования - дискурсы и задачи их изучения, возможность и целесообразность применить цифровые технологии предъявляют определенные требования к организации данных источников для успешного решения аналитических задач. На первом этапе исследования организация данных для последующего выявления и анализа дискурсов в информационном противостоянии «красных» и «белых» выступает в качестве главной задачи.

В целом организация данных сводиться к решению следующих проблем: обеспечению машиночитаемости источников данных; необходимого уровня их структурирования и организации данных на основе форм, позволяющих их машинную обработку. В значительной степени определенное решение этих проблем обеспечивается 
созданием соответствующих цифровых источниковых комплексов на основе источнико-ориентированных информационных систем. В рамках этой задачи, в целом, как ранее отмечалось, были созданы информационные системы, содержащие машиночитаемые копии необходимых газетных изданий. Системы обеспечили структурирование источников по изданиям, по выпускам (номерам), по публикациям. В свою очередь предусмотрено в них структурирование публикаций и содержащейся в них информации на основе системы описаний. Через инструменты для поиска возможно формирование выборок выпусков и публикаций по различным критериям - по заданному периоду, по рубрикам и тематике. Наиболее информативен расширенный поиск, в котором можно задать сразу несколько атрибутов. Полнотекстовый поиск выполняется по массиву введенных публикаций. Во всех перечисленных случаях формируется таблица с гиперактивными ссылками, из таблицы можно перейти к описанию соответствующего выпуска или публикации. Инструментарий системы позволяет извлечение и группировку статей и других типов публикаций по заданным значениям признаков: газетам, типам публикаций, рубрикам, дате, упоминаемым персонам, упоминаемым географическим объектам, ключевым словам. Таким образом, обеспечивается организация данных различных изданий или публикаций, освещения тех или иных тем и т.п., что весьма существенно и при формирования выборок для исследования дискурсов.

Говоря об организации данных, которые предоставляются самой информационной системой, следует отметить возможность представления информации источников в формате PDF, текст под изображением. Прежде всего, это позволяет обеспечивать одновременное сохранение данных в графическом формате и формате, обеспечивающем машиночитаемость текста. Данное обстоятельство важно из-за особенностей источников данных - газетных изданий, которые в силу условий создания и последующего бытования имеют различного рода физические дефекты не позволяющие распознавать полностью отдельные участки текста. Однако наличие графического изображения в ряде случаев позволяет в ручном режиме восстановить утраченный смысл и использовать такие публикации в исследовании. Другой аспект значимости такого формата хранения данных связан с возможностями их анализа. Использование инструментов поиска программного обеспечения для работы с данными в формате PDF, в частности Acrobat Reader DC, позволяет, применяя технологию контекстного поиска получать данные, в том числе и количественные, о частоте встречаемости словоформ и их контексты. 
В то же время возможности информационной системы не обеспечивают всех потребностей организации данных для анализа информационно-пропагандистских дискурсивных практик газетной периодики «красных» и «белых» в гражданской войне. Поэтому решение задачи организации данных осуществляется и в других направлениях. В качестве основы исследования осуществляется, например, формирование выборок текстов по различным критериям и параметрам для последующего, компьютеризованного контентанализа. Это требует отдельной организации таких массивов в виде файловых коллекций публикаций в форматах, необходимых для обработки в соответствующих программах.

Определенные результаты контент-анализа (частотности встречаемости словоформ, лексем, словосочетаний, коллокаций, контекстов) являются необходимыми данными для применения в исследовании методов построения семантических сетей, n-грамм анализа, других текстометрических методов. Они требуют соответствующей организации в виде тезаурусов, конкордансов, организованных в табличных формах.

Таким образом, осуществления на первом этапе исследовательского проекта по изучению идейно-политических и агитационнопропагандистских дискурсов «красных» и «белых» в газетной периодике Гражданской войны задач организации данных исторических источников позволяет создать необходимую основу исследования, сформировать необходимые для анализа массивы данных. В значительной степени возможности для решения этой задачи и анализа данных предоставляет организация информации источников на основе источнико-ориентированных информационных систем. В то же время задачи организации данных не сводятся только к использованию таких возможностей. Применение таких эффективных при изучении дискурсивных практик противоборствующих в гражданской войне сторон как контент-анализ, сетевое семантическое моделирование, nграмм анализ и другие текстометрические и статистические методы делает необходимым использование и других направлений организации данных. Это и организация данных в виде различных текстовых выборок на основе файловых коллекций, создание тезаурусов, конкордансов, коллокаций, контекстов на основе табличных форм.

Использование указанных средств и способов организации данных позволит на последующих этапах исследования выявить наиболее используемые в газетах агитационно-пропагандистские стереотипы, штампы и образы «красных» и «белых», их особенности для 
каждой из сторон, а также содержащие их типы публикаций, проанализировать тенденции, направления их формирования, динамику; раскрыть содержание, основные направления и тематику агитации и пропаганды; выявить и показать роль газетной периодики как инструмента и среды информационной войны - неотъемлемого процесса войны гражданской и источника для ее изучения; сопоставить представленную стереотипами и образами из газет информацию с соответствующими фактами и знаниями в научной литературе и других исторических источниках, с целью выявления объективности полноты, достоверности, репрезентативности публикаций газетной периодики, возможности и условий их использования как исторических источников.

Организация данных уже сама в определённой мере связана с выполнением аналитических процедур, но еще более она предопределяет возможности и эффективность использования методов анализа данных и получения результатов на последующих аналитических этапах исследования.

\section{Библиография}

1. Обухов Л.А. Периодическая печать как источник по истории Гражданской войны (на примере газет г. Перми периода колчаковщины) // Власть. - 2012. - № 4. C. $131-133$.

2. Колчаковские газеты. - URL: http://kolchak.psu.ru/ (дата обращения: 31.08.2020).

3. Пермская губернская периодика: 1914-1922. - URL: http://permnewspapers.ru/ (дата обращения: 31.08.2020).

4. Краснова Т.И. Анализ политического дискурса: подходы и категории // Политическая лингвистика. - 2013. - № 2 (44). - С. 53-54.

https://doi.org/10.29003/m1799.978-5-317-06529-4/126-134

Ренев Д.А.

Пермский государственный национальный исследовательский университет

\section{Благотворительная деятельность в Пермской губернии в начальный период Первой мировой войны (1914-1915 г.): опыт пространственного анализа (На материалах газеты «Пермская земская неделя»)}

Аннотация. Проанализированы публикации, которые содержат данные о благотворительной активности, связанной с участием России в Первой мировой войне, в выпусках журнала «Пермская земская неделя». Сведения занесены в реляционную базу данных. На основе данной информации создана математико-картографическая модель, отражающая пространственное распределение военизированных благотворительных акций в Пермской гу- 
бернии во время кампаний 1914 и 1915 годов. Наиболее активными оказались экономически развитые города, наименее активными стали уезды, отдаленные от центра губернии, сельскохозяйственные уезды показывают среднюю вовлеченность в благотворительную деятельность.

Ключевые слова: Пермская губерния, благотворительная деятельность, Первая мировая война, Пермская земская неделя, геоинформационные системы, реляционная база данных, геоданные, математико-картографическая модель.

Renev D.A.

National Research University «Higher School of Economics», Perm

Charitable activities in the Perm province in the initial period of the First World War (1914-1915): the experience of spatial analysis (Based on the materials of the newspaper «Perm Zemskaya Nedelya»)

Abstract. The publications are analyzed, containing data on charitable activities in Russia in the First World War, in the issues of the magazine "Perm Zemskaya Week". The information is entered into a relational database. Based on this information, a mathematical-cartographic model was created, that reflects the spatial distribution of militarized charitable actions in the Perm province during the campaigns of 1914 and 1915. The most active were the economically developed cities, the least active were the counties far from the center of the province, and the agricultural counties show an average involvement in charitable activities.

Keywords: Perm province, charity, World War I, geographic information systems, relational database, geodata, mathematical-cartographic modeling.

Широкие возможности для изучения филантропической деятельности период Первой мировой войны открывает периодическая печать, которая активно освещала боевые действия на фронте и агитировали жертвовать в пользу пострадавших людей. С конца июля 1914 г. по июнь 1919 г. было выпущено более двух тысяч номеров периодических изданий Пермской губернии [1, с. 72]. Частота упоминаний в газетах и тип активности регионов Пермской губернии были различны, поэтому применение геоинформационных систем для анализа подобного типа данных, имеющих свою специфику, поможет повысить информационную отдачу источника, визуализировать полученные данные и выявить особенности освещения затрагиваемых проблем. Цель исследования - определить основные направления и результаты военно-организационной и благотворительной деятельности общества, и на основе геопространственного распределения и анализа полученных данных, выявить вклад Перм- 
ской губернии и ее отдельных административно-территориальных единиц, населенных пунктов в решение вопросов, связанных с участием страны в Первой мировой войне.

Для достижения цели данного исследования наиболее подходящим является рассмотрение выпусков журнала «Пермская земская неделя» [2]. Рассматриваемый источник представляет интерес в связи с тем, что помимо упоминания событий, происходящих в Перми и других крупных городах, в газете также активно освещалась и жизнь Пермской губернии в целом, широко раскрывалась деятельность земских организаций, существовала система обратной связи с читателями в виде писем.

Имеющиеся в газете географические пространственные данные (далее - геоданные) делают газету ценным источником для построения математико-картографической модели, которая отражала бы пространственное распределение, виды и периоды благотворительной активности в Пермской губернии в период Первой мировой войны. Под геоданными в настоящем исследовании мы понимаем сведения о совокупности пространственных объектов, которые могут стать основной для информационного обеспечения геоинформационных систем.

В ходе исследования проанализированы выпуски журнала «Пермская земская неделя» за период с 31 июля 1914 г. по 25 декабря 1915 г., которые были размещены в информационной системе «Пермская губернская периодика: 1914-1922 гг.», созданной исследовательским коллективом Центра цифровой гуманитаристики [3].

Первичный сбор данных показал, что наилучшим решением будет создание в реляционной базе данных двух таблиц «Публикации» и «События», которые имели бы между собой связь один-комногим. Изначально информация из газет заносилась в таблицу «Публикации», включающую в себя основные сведения об анализируемой публикации.

Из текстов газетной периодики, данные о которых занесены в таблицу «Публикации», была выделена информация о благотворительных акциях, введенная в таблицу «События». Таблица включает в себя те данные о событии, которые были использованы при создании геоинформационной системы и занесены в слой «События».

Было обозначено три основных типа активности. Критерием для их выделения явились социальные группы, в пользу которых власть и общество организовывали благотворительные акции. Помимо солдат, находящихся на фронте, объектами благотворительной 
помощи становились больные или раненые воины, а также родственники мобилизованных.

Сведения из оцифрованных выпусков периодической печати в соответствии с логикой базы данных были введены в таблицу «Публикации», количество записей в которых превышало 250 единиц. Затем из них выделены благотворительные акции и введены в таблицу «События». Количество записей превысило 500.

Таким образом, были выделены следующие сущности:

1) благотворительность в пользу участников боевых действий, находящихся на фронте;

2) благотворительные акции в пользу больных и раненых;

3) пожертвования семьям мобилизованных.

С целью переноса сведений, содержащихся в таблице «События» реляционной базы данных, в ArcMap был создан слой точечных объектов «События» в системе координат WGS 1984. Помимо этого был подготовлен слой точечных объектов «Населенные пункты». В соответствии с полем «Населенный пункт» таблицы «События» реляционной базы данных в таблице атрибутов слоя «Населенный пункт» находился искомый точечным объект, который далее заносился в слой «События». К каждой записи о благотворительной акции в таблицу атрибутов был введен ряд дополнительных характеристик, описывающих событие. Было получено 5 карт масштаба 1:4000000, отражающих особенности географического распределения благотворительной активности.

Благотворительные акции - мероприятия, которое могли произойти в одном и том же населенном пункте несколько раз, поэтому было необходимо проанализировать соотношение таких населенных пунктов в каждом из уездов, выделить наиболее и наименее активные поселения. Посчитано количество уникальных населенных пунктов с акциями в каждом из уездов губернии. Полученные данные были отображены с помощью количественного фона. Число уникальных акций в каждом из населенных пунктов было показано при помощи увеличения размера символа, отображающего населенный пункт, с нарастанием числа акций, зафиксированных там (Прил. 1).

Вторая карта посвящена распределению акций по типам населенных пунктов. Данные о соотношении количества благотворительных акций по типу населенного пункта (город, село, деревня, завод) в каждом из уездов были показаны в виде круговых диаграмм. 
Количественный фон на карте отражает общее число благотворительных мероприятий в каждом из уездов (Прил. 2).

Для отображения распределения выделенных ранее видов благотворительной активности были созданы три карты. Первая из них отражает соотношение форм благотворительности в деле помощи фронту: денежных отчислений, продовольственной помощи, непродовольственной помощи, акций добровольного ухода на фронт (Прил. 3). Вторая карта показывает соотношение случаев помощи в адрес больных и раненых солдат: денежной помощи, пожертвований в виде продовольствия, непродовольственной помощи, содействия в создании госпиталей и лазаретов, помощь в разрешении проблем размещения раненых солдат (Прил. 4). Третья выражает соотношение между формами активности, связанных с помощью семьям мобилизованных, а именно случаев денежных отчислений, акций помощи в уборке урожая, продовольственной помощи, пожертвований в виде непродовольственных товаров, содействии в создании приютов для детей, осиротивших из-за военных действий (Прил. 5).

Процесс благотворительной деятельности, зафиксированный на страницах журнала «Пермская земская неделя», был пространственно визуализирован при помощи полученной математико-картографической модели, что является основной новизной исследования.

Модель дает широкое поле для интерпретации данных о зафиксированных событиях. Так, по числу задействованных в благотворительных акциях уникальных населенных пунктов лидируют Пермский и Оханский уезды, которые расположены близко к центру губернии. Однако Екатеринбургский уезд, который находился в статусе экономически развитого населенного пункта, показывает также заметный уровень вовлеченности в благотворительность. Наиболее часто акции проходили в экономически развитых городах, таких как Пермь, Екатеринбург, Кунгур, Ирбит, Оханск, которые были связаны между собой сетью дорог (Прил. 1). Географическая близость активных населенных пунктов с центрами может говорить не только о влиянии экономического благополучия и агитации в пользу благотворительности на жителей, что способствовало их вовлеченности в филантропическую деятельность, но и о том, что с данными поселениями были лучше выстроены коммуникации, позволяющие писать о большинстве таких случаев в газете.

Наиболее активными по общему числу благотворительных акций стали центральные уезды губернии с лидирующим Пермским уездом. Наименее активными являются отдаленные от центра уезды, такие как Чердынский, Соликамский и Красноуфимский. Значитель- 
ное число благотворительных акций проходило в Екатеринбургском уезде. Средние показатели имеют прилегающие к нему уезды преимущественно сельскохозяйственной направленности (Ирбитский, Камышловский и Шадринский), которые также выделяются высокой долей акций, проходящих в деревенской и сельской местности, на фоне сравнительно низких значений от городского населения. Иная картина наблюдается в других экономически развитых городах, таких как Пермь и Екатеринбург, где население участвует в благотворительности намного более активно, чем в уездных селах, деревнях и заводских поселениях. При значительной активности сельского населения Оханского и Кунгурского уездов чрезмерно большого разрыва между городом и деревней нет (Прил. 2).

Интерес представляет и соотношение благотворительной деятельности в пользу фронта (Прил. 3). Если высокая доля продовольственного пожертвования в Шадринском, Камышловском, Осинском и Ирбитском уездах кажется очевидной для сельскохозяйственных уездов, то высокий процент денежной помощи в Шадринском и Оханском уездах наравне с аналогичной в Пермском уезде заметно выделяется. Оханск - купеческий город, что может объяснить высокий уровень денежных ассигнований в пользу армии. Аналогичная ситуация в Шадринском уезде объясняется высоким числом населения. С другой стороны, вполне закономерно, что Кунгурский уезд становится лидирующими по непродовольственному обеспечению армии из-за имеющегося кожевенно-обувного производства. Наименее населенный и наиболее отдаленный от центра Чердынский уезд показывает практически нулевую активность. Низкими значениями обладают Соликамский и Красноуфимский уезды, которые также географически удалены от экономического и политического центра.

В деле благотворительности в пользу раненых самым популярным видом пожертвования становятся денежные отчисления (Прил. 4). Такая тенденция наблюдается во всех уездах губернии. Размещение раненых и больных, а также создание госпиталей и лазаретов силами народных масс осуществлялось чаще в западной, чем в восточной части губернии.

Еще одной формой благотворительных акций стала помощь семьям солдат, ушедших на фронт. В данном случае мы также можем наблюдать доминирование денежного пожертвования как формы благотворительной активности. Вторыми по популярности стали акции помощи по части уборки урожая. Причем если в одних сельскохозяйственных уездах (Ирбитский, Камышловский) такая деятель- 
ность находит свое проявление, то в Шадринском уезде, который также являлся преимущественно крестьянским и наиболее населенным в губернии, о такой благотворительности данных нет (Прил. 5).

Таким образом, представленные данные, полученные путем междисциплинарного взаимодействия через алгоритм перевода информации из источника периодической печати в вид математикокартографической модели, раскрывают потенциал пермской губернской периодики с новой стороны. На основе пространственной визуализации данных публикаций получены следующие выводы. В области благотворительности в начальный период Первой мировой войны в Пермской губернии Наиболее активными оказались экономически развитые города, выделяющиеся сильным купеческим сословием. Наименьшее число зафиксированных в периодике благотворительных акции приходится на географически отдаленные от центра губернии, что можно объяснить затрудненностью коммуникации с центрами. Уезды, специализирующиеся на сельскохозяйственной деятельности, в основном показывают среднюю вовлеченность в благотворительность. Городская благотворительность с долей более чем $50 \%$ от общего числа акций характерна только для Пермского уезда, как наиболее территориально-административной единицы, в состав которой входил губернский центр. Шадринский уезд выделяется как уезд с сельскохозяйственной специализацией, в котором, была сильна практика денежных отчислений и практически полностью отсутствовала помощь в уборке урожая в отличие от соседских уездов. Несмотря на уникальное географическое и социально-экономическое положение Пермской губернии, полученные данные могут пролить свет на характерные тенденции в процессе благотворительности в других, но схожих по ряду признаков территориях, а выработанный в ходе исследования алгоритм может быть использован для исследований благотворительной активности в иных регионах.

\section{Библиография}

1. Митина Р.В. Пермские газеты как источник изучения Первой мировой войны: постсоветская историография // Вестник Пермского университета. Сер.: История. 2015. - № 4 (31). - С. 72-81.

2. Пермская земская. - 1914. - № 31-51; 1915. № 1-50.

3. Пермская губернская периодика: 1914-1922 - URL: http://permnewspapers.ru/ (дата обращения: 31.05.2020). 
Приложение № 1

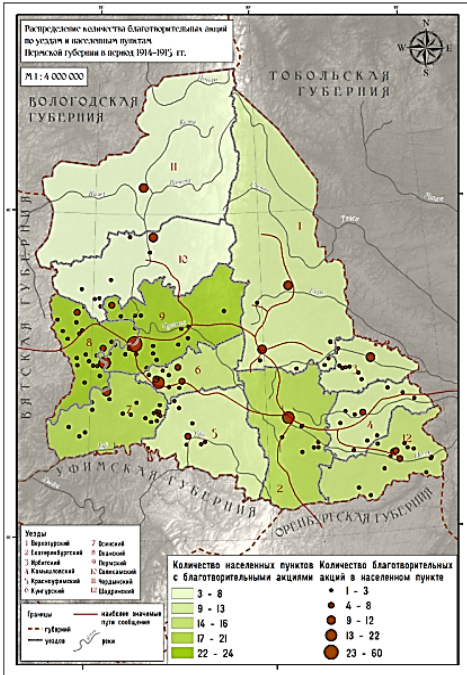

Приложение № 3

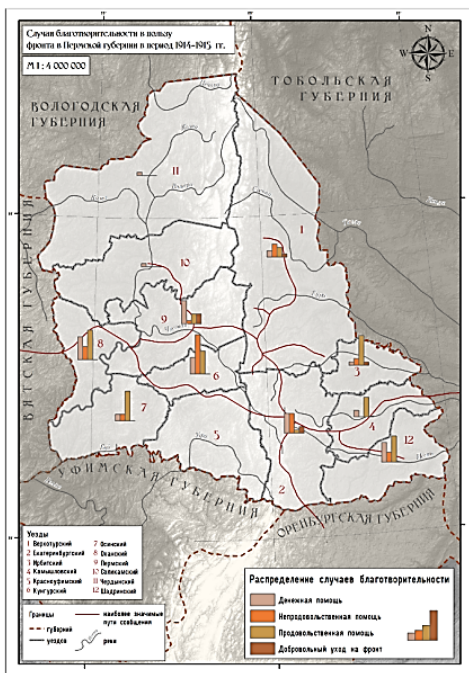

Приложение № 2

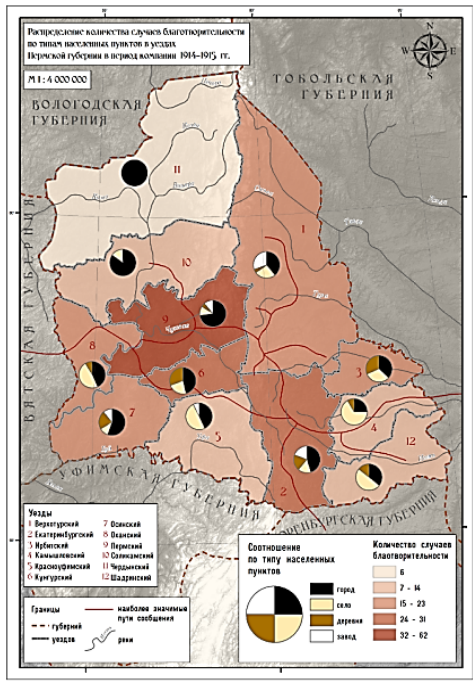

Приложение № 4

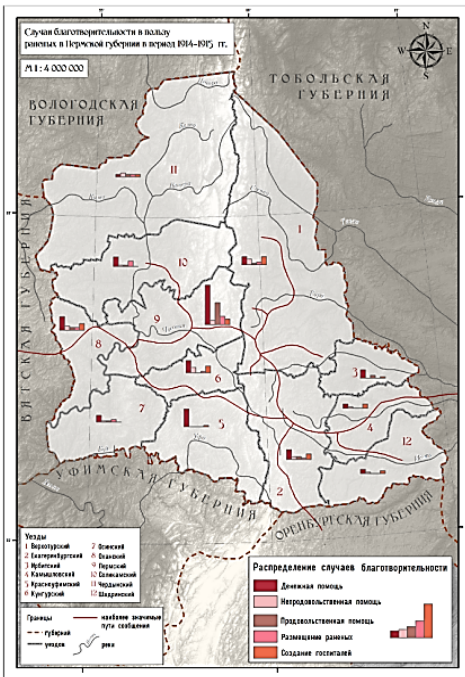


Приложение № 5

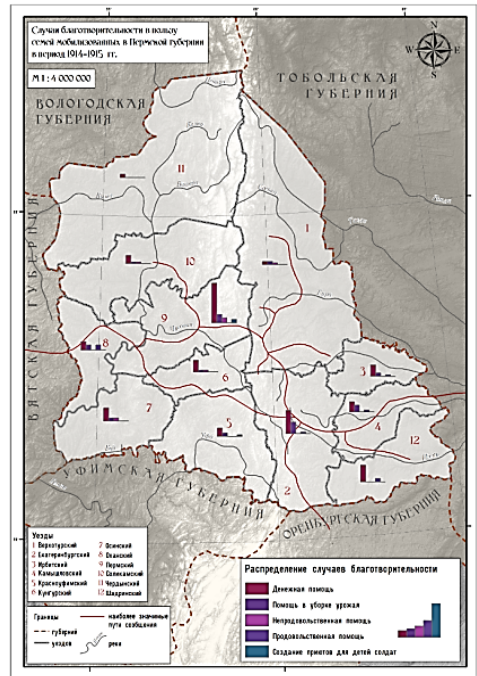

https://doi.org/10.29003/m1800.978-5-317-06529-4/134-139

Саенко А.В. Балтийский федеральный университет имени И. Канта

\section{Проблема освоения историко-культурного наследия Возвращенных земель (Польша) на страницах журнала «Осадник»: опыт контент-анализа ${ }^{1}$}

Аннотация. В результате Второй мировой войны к Польше присоединились бывшие восточные провинции Германии, названные Возвращенными землями. Цель исследования - с помощью методов компьютеризованного анализа текста выявить основные подходы к освоению историкокультурного наследия новых территорий, представленные на страницах польского журнала «Осадник» (1946-1948). Делается вывод, что в политике государства главными были две взаимосвязанные тенденции - удаление из культурного ландшафта «неметчины» и возвращение ему польского облика.

Ключевые слова: контент-анализ, историко-культурное наследие, пресса, Польша, Возвращенные земли.

${ }^{1}$ Исследование выполнено при финансовой поддержке РФФИ и Правительства Калининградской области в рамках научного проекта № 19-49-390003 «Историко-культурное наследие как туристско-рекреационный ресурс Калининградской области». 
Saenko A.V. Immanuel Kant Baltic Federal University, Kaliningrad

\title{
The problem of the development of the historical and cultural heritage of the Returned Lands (Poland) on the pages of the Osadnik magazine: the experience of content analysis
}

\begin{abstract}
After the Second World War the former eastern provinces of Germany, called the Recovered Territories, were joined to Poland. The purpose of the study is to identify the main approaches to the development of the historical and cultural heritage of new territories, presented on the pages of the Polish magazine "Osadnik" (1946-1948), using the methods of computerized text analysis. It is concluded that two interrelated tendencies were the main ones in the policy of the state - the removal from the cultural landscape German features and the return of its Polish appearance.
\end{abstract}

Keywords: content analysis, historical and cultural heritage, press, Poland, Recovered Territories.

После завершения Второй мировой войны и изменения границ в Европе территория польского государства увеличилась за счет приращения на севере и на западе бывших провинций Третьего рейха (Восточная Пруссия, Поморье, Любушская земля, Силезия). Эти территории составили примерно треть площади страны и стали называться «Воссоединенными» или «Возвращенными землями», что должно было подчеркивать их принадлежность Польше в прошлом [2]. Перед новыми властями стояла задача как можно более быстрого включения нового пространства в единый государственный организм в экономическом, политическом и культурном плане. Этому способствовало создание в 1945 году Министерства Возвращенных земель, которое обращало пристальное внимание на идеологическое освещение происходивших процессов.

С августа 1946 г. начал издаваться журнал «Переселенец на Возвращенных землях» (Osadnik na Ziemiach Odzyskanych), который выходил два раза в неделю тиражом 50 тыс. экземпляров, предназначался для новоселов, но знакомил всех польских граждан с положением на Воссоединенных землях. В первые послевоенные годы наиболее остро стоял вопрос экономического освоения территорий, поэтому большинство материалов двухнедельника было посвящено восстановлению промышленности, аграрной реформе, публиковалось много статистики о достигнутых успехах [3, s. 113]. Хотя об историко-культурном ландшафте материалов было немного, именно 
тогда были заложены принципы и подходы к интерпретации «понемецкого» (т.е. оставшегося после немцев) наследия.

Для того чтобы включить Возвращенные земли в орбиту польского государства необходимо было провести процесс «реполонизации», или восстановления польского облика территорий [1, с. 203]. Исходя из этого, для анализа были выделены две ключевые категории - Изменение символического пространства и Историческая пропаганда.

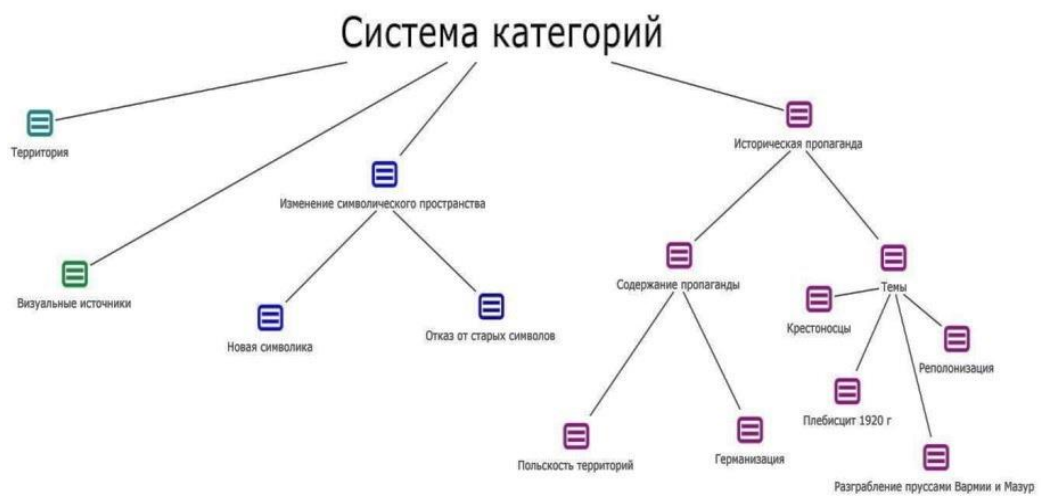

Рис. 1. Система категорий

Изменение символического пространства Возвращенных земель проходило в двух направлениях - отказ от старых, немеиких символов и введение новой национальной и идеологической символи$\kappa u$. Несмотря на важность нивелирования немецкого наследия, «борьбе с неметчиной» посвящено значительно меньшее количество материалов (23\%), чем вопросам введения новых символов (77\%). При этом тема дегерманизации, отношения к немецкому населению (рис. 2) имела ярко выраженный негативный характер. Так, в статье «О чем мечтает женщина на Возвращенных землях», чаяния польских женщин формулируются в нескольких тезисах: забота о детях, собственный дом, общественная гармония и «нежелание видеть немцев» [4, 10-25 wrzesnia 1946, s. 17]. Напротив, утверждение новой символики всегда рассматривалось в позитивном контексте. Газета рассказывала о процессах полонизации территории по нескольким направлениям: в постоянной рубрике «Достижения, планы, цифры...» публиковалась статистика достижений; широко освещалась смена немецкой топонимики на польскую, журнал постоянно призывал к сплочению различных групп населения (рис. 2). На волне 
антинемецких настроений особенно часто обсуждалось отношение к автохтонам - полякам из числа бывших граждан Германии: «Еще чувствуются старые корни, еще чужим считается эта часть новообретённой земли. <..> Вырисовывается новый клубок проблем - отношения с автохтонным населением. Две части польского народа: переселенцы и автохтоны находятся в полном непонимании, не нашли еще они общего языка» [4, 25 wresnia 1948, s. 10].

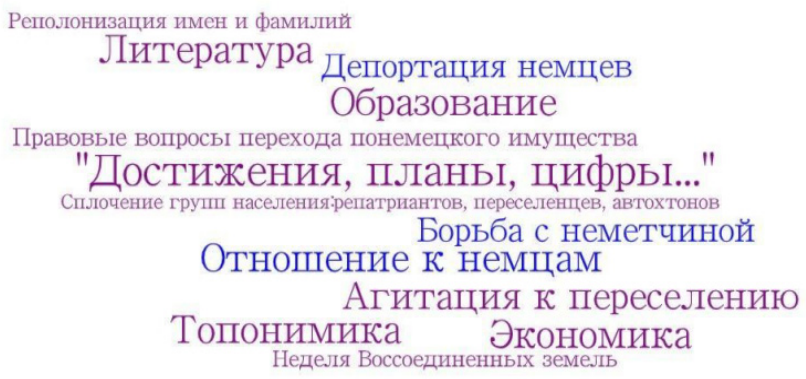

Рис. 2. Инфографическое изображение категории «Изменение символического пространства»

Вопросы переселенческой политики, решение хозяйственных задач, публикация статистических материалов об «успешном освоении земель» не могли отменить потребность в решении вопроса отношения к историко-культурному наследию, что нашло отражение в категории Историческая пропаганда. В номере от 25 февраля 1948 г. сообщалось: «Несмотря на рафинированные методы уничтожения национального польского духа, использованные немцами, неоспоримым является факт, что эти земли сохранили свой польский характер. Это и есть лучшая легитимация польскости данных земель» [4, 25 lutego 1948, s.14]

Принадлежность регионального наследия к польской культуре обосновывалась за счет обращения к событиям общенациональной истории (рис. 3). В некоторых случаях достаточно было показать захватнический характер политики бывших хозяев-немцев, о чем свидетельствует пример описания замка в Любани: «Роскошный замок одного из немецких баронов, где Геббельс укрывал наворованные по всей Европе богатства, сегодня является экономическим центром под управлением Отдела крестьянской взаимопомощи» [4, 10 listopada 1947, s. 10] 


\section{Следы войны \\ Польша времени Пястов \\ Колонизация Восточной Пруссии в XV веке \\ Разграбление пруссами Вармии и Мазур \\ Вторая мировая война \\ Плебисцит 1920 года . Славянские племена \\ Реполонизация RреCTOHOCLЬI \\ Грюнвальдская битва \\ Логово Геббельса \\ Хроника Герборда \\ Поляки в Гермапии \\ Межвоенньй период}

Рис. 3. Инфографическое изображение подкатегории «Темы исторической пропаганды»

Анализ совместной встречаемости категорий Территория и Историческая пропаганда, показывает процесс «закрепления» за территорией определенного исторического сюжета. Для Вармии и Мазур наиболее актуальными являлись темы нашествия крестоносцев, колонизации Восточной Пруссии в XV веке, для Любушской земли в Познаньском воеводстве - разрушений во время Второй мировой войны и др.

В исторической пропаганде делался упор на разоблачение фактов насильственной германизации поляков и перенос внимания на забытые польские корни местного культурного ландшафта. Так, Вармия и Мазуры до первой половины XIX века представлялись областями с преимущественно польским населением, Гданьск - польским портом с навязанным немцами статусом «вольного города», Ольштын - очагом сопротивления рыцарям Тевтонского ордена, городом Н. Коперника.

Отдельного внимания заслуживает анализ визуальных образов. Из 123 изображений за 1946-1948 гг. 40\% показывают жизнь и труд переселенцев или достижения в восстановлении экономики. На втором месте официальные политические новости (21\%). Такая же доля приходится на изображение архитектурного наследия. При этом, как правило, изображения памятников архитектуры никак не связаны с публикуемыми текстами, они представляют самостоятельную рубрику журнала, служат для привлечения внимания читателей. Анализ объектов показывает, что «понемецкая» архитектура (ок. 40\%) становится визуальным символом Возвращенных земель, хотя официальный характер издания предполагал отсутствие такого рода образов (рис. 4). 


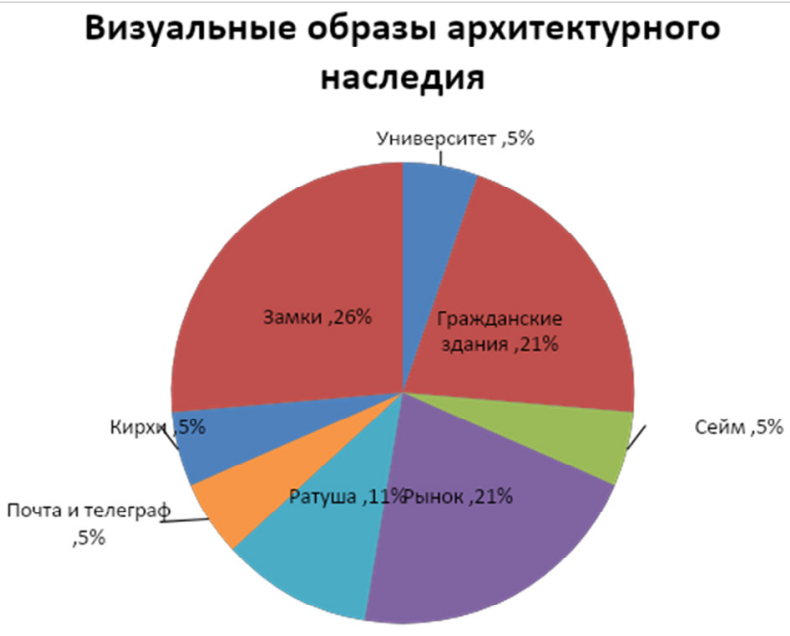

Рис. 4. Визуальные образы архитектурного наследия

Таким образом, контент-анализ журнала позволяет проследить две тенденции в политике государства к историко-культурному наследию в процессе освоения Воссоединенных земель - порицание осуществляемой в прошлом германизации, отрицание ценности немецкого культурного элемента и, напротив, глорификация польской культуры и утверждение «польскости» вновь присоединенной территории. При этом можно проследить определенную эволюцию в содержании журнала. Если в первый год издания большая часть публикаций была связана с исторической пропагандой, обоснованием прав Польши на Воссоединенные земли, то с 1947 года на первый план выходит проблематика изменения символического пространства присоединенных земель.

\section{Список источников и литературы}

1. Костяшов Ю.В. Реполонизация Вармии и Мазур в послевоенные годы // Балтийский регион в Новое и Новейшее время. Калининград. - 2016. - С. 203-220.

2. Костяшов Ю.В., Сергеев В.В. Региональная политика памяти в Вармии и Мазурах (Польша) // Балтийский регион. - 2018. - Т. 10. - № 4. - С. 118-131.

3. Jarosz D., Kachlak T. Obraz chłopa-osadnika na ziemiach odzyskanych w świetle publicystyki krajowej z lat 1945-1948 // Dzieje Najnowsze. - 1989. - T. 21. - №. 2. - S. $113-144$.

4. Osadnik na Ziemiach Odzyskanych: dwutygodnik poświęcony sprawom osadnictwa. 1946-1948. 
https://doi.org/10.29003/m1801.978-5-317-06529-4/140-146

Солощенко Н.В.

Московский государственный университет имени М. В. Ломоносова

\title{
Отраслевая газета пищевой промышленности СССР В 1928-1937 гг. как исторический источник (возможности анализа в программе MAXQDA)
}

Аннотация. Предметом исследования являются источниковедческие особенности отраслевой газеты пищевой промышленности СССР в 19281937 гг. и возможности, которые даёт историкам анализ её текстов в программе MAXQDA. В докладе делается вывод, что изучение отраслевой газеты с помощью применения контент-анализа позволило систематизировать динамику изменения повестки дня одной из крупнейших отраслей промышленности СССР в 1928-1937 гг. и выделить факторы, которые оказывали воздействие на этот процесс.

Ключевые слова: периодическая печать, советские газеты, первые пятилетки, индустриализация СССР, пищевая промышленность, исторический источник, нарративные источники, контент-анализ, MAXQDA.

\section{Soloshchenko N.V. Lomonosov Moscow State University}

\section{The sectoral newspaper of the Soviet food industry in 1928-1937 as a historical source (analysis possibilities in MAXQDA computer program)}

\begin{abstract}
The subject of the research is the features of the sectoral newspaper of the Soviet food industry in 1928-1937 and the possibilities offered to historians by analyzing its texts in the MAXQDA program. The report concludes that the study of the newspaper using content analysis made it possible to systematize the dynamics of changing the agenda of one of the largest industries in the USSR in 1928-1937 and highlight the factors that influenced this process.

Keywords: Periodicals, Soviet newspapers, First Five-Year Plans, Soviet industrialization, Food industry, Historical source, Narrative sources, Content analysis, MAXQDA.

Периодическая печать СССР была одним из самых распространённых каналов, через которые осуществлялось информирование граждан и идеологическое воздействие на общество в период первых пятилеток. Исследователи, изучающие советскую печать 1920 1930-х гг., отмечают, что газеты были «единственным всеохватным средством информации, а следовательно, и эффективным инструментом формирования общественного мнения» [1, с. 37].
\end{abstract}


Проблема формулирования корректных методических подходов для изучения печатных СМИ в качестве исторических источников поднималась в исследованиях И.Д. Архангельской [2], С.А. Красильникова [3], С.М. Поповой [4], А.Г. Голикова [5], О.Н. Блиновой [6], К.К. Любимовой [7], которые активно использовали метод контент-анализа. В работах Л.И. Бородкина и И.Д. Ковальченко приводится наиболее полный обзор исторических исследований с применением этого метода, вышедших в 1970-1980-х гг. [8], [9], [10] Подробный обзор современной историографии даётся в статье И.М. Гарсковой [11].

В настоящее время проблема выработки и апробации корректных методических подходов в изучении периодической печати в целом и советской прессы в частности не теряет своей актуальности. Значительный интерес для историков, в сферу научных интересов которых входит исследование советской индустриализации, представляет отраслевая периодическая печать, под которой понимаются газеты и журналы, предназначенные для работников отдельных отраслей промышленности СССР. В последние годы растёт внимание учёных к подобным изданиям [12], [13], [14].

Следует особо отметить, что печать такой крупной отрасли промышленности, как пищевая, до настоящего времени не исследовалась подробно, хотя вопрос раскрытия информационного потенциала этого источника по истории пищевой индустрии в период первых пятилеток имеет научную значимость.

Целью данного исследования является рассмотреть отраслевую газету пищевой промышленности СССР в 1928-1937 годы как исторический источник и ответить на вопрос, какие возможности для приращения исторического знания несёт в себе анализ текстов этого издания в программе MAXQDA. В частности, с помощью изучения передовиц газеты «Пищевик» («За пищевую индустрию», «Пищевая индустрия») методом контент-анализа автор стремится определить факторы, влиявшие на динамику изменения повестки дня, предлагавшейся этим изданием для всей пищевой промышленности СССР в 1928-1937 гг.

\section{Источниковедческие аспекты исследования}

Первым печатным органом, предназначенным для сотрудников пищевой промышленности СССР, была газета «Пищевик», издававшаяся Центральным Комитетом Всероссийского союза рабочих и служащих пищевой промышленности с 1921 г. С 1 июля 1931 г. газе- 
та получает название «За пищевую индустрию», передаётся в ведение Народного комиссариата снабжения СССР, Народного комиссариата снабжения РСФСР и ЦК Профсоюзов мясо-рыбоконсервной, маслобойной промышленности, мукомольно-хлебопекарной и кондитерской промышленности, сельпромовской промышленности [15, с. 47]. С 21 ноября 1937 г. издание получает заголовок «Пищевая индустрия». Под этим названием оно выходило до июня 1941 г.

Местом издания отраслевой газеты была Москва. Тираж «Пищевика» составлял 42 тысячи экземпляров [16, с. 11] Тираж газеты «За пищевую индустрию» насчитывал 90236 экземпляров [17, с. 302] Газета «Пищевая индустрия» издавалась тиражом 85 тысяч экземпляров $[18$, с. 7$]$. Годовое количество номеров изменялось с течением времени ввиду изменения периодичности выхода этого издания. Цена годовой подписки на газету «Пищевик» составляла 3 руб. [16, c. 11]. Подписка на газету «За пищевую индустрию» стоила 30 рублей за год [17, с. 302]. На газету «Пищевая индустрия» можно было оформить подписку на 12 месяцев по такой же цене [18, с. 7]. Отраслевая газета пищевой промышленности в 1928-1937 гг. выходила в формате $42 \times 60$ см. В каждом номере обычно было четыре страницы.

\section{Методические аспекты исследования}

Изучение содержания отраслевой газеты пищевой промышленности на протяжении довольно длительного периода целесообразно проводить с помощью метода контент-анализа, который хорошо зарекомендовал себя в исторических исследованиях. Этот метод содержит в себе дополнительные возможности для приращения научного знания, так как предполагает, в том числе, изучение внутренних взаимосвязей между элементами содержания текстов исторических источников.

В качестве подготовительного этапа для проведения подобного исследования требуется выработать корректные критерии ограничения того материала, который будет подвергаться анализу. Это означает, что необходимо выбрать рубрики, разделы или тип статей, которые будут изучаться, и сформировать репрезентативную выборку из сохранившихся номеров газеты.

Самым стабильным разделом, который присутствовал в отраслевой газете на протяжении всего периода с 1928 по 1937 гг., являлись редакционные статьи. Их исследование даёт возможность показать смену приоритетов в развитии пищевой промышленности первых пятилеток, а также смену приоритетов в мобилизационной политике государства по отношению к работникам этой отрасли. Таким обра- 
зом, изучение передовиц газеты «Пищевик» («За пищевую индустрию», «Пищевая индустрия») с помощью контент-анализа позволит систематизировать динамику изменения повестки дня, предлагавшейся этим изданием для всей пищевой промышленности СССР в 1928-1937 гг.

Следующим этапом для создания методики анализа содержания газеты в рамках данного исследования стало решение вопроса о выборке. К сожалению, из-за уже упоминавшейся частой смены периодичности выхода газеты число номеров за одни и те же календарные месяцы в разные годы было неодинаковым. Решением этой проблемы стало формирование выборки, в которой равномерно были представлены материалы для всех годов первой и второй пятилеток. Вариантом такой выборки стало изучение передовых статей отраслевой газеты из каждого первого номера каждого календарного месяца. Последующая оцифровка этой совокупности текстов дала возможность провести компьютеризованный анализ в программе MAXQDA 2020.

\section{Анализ частот встречаемости категорий в программе MAXQDA}

Задачей этого этапа анализа было выявление основных тем, которые, по мнению редакции газеты, были связаны с развитием пищевой промышленности и упоминались в выборке за 1928-1937 гг. B программе MAXQDA 2020 была создана система из 30 категорий, разделённых на три блока: производственный, социальный, политический.

C помощью программы MAXQDA было прослежено изменение нагрузки на категории в рамках блоков проблем и на категории по отдельности в течение 1928-1937 гг. В частности, был составлен список из категорий с наиболее высокими относительными частотами встречаемости в указанные годы. В данный список, как правило, входили категории, связанные с производственной и политической проблематикой.

Анализ показал, что изменения, происходившие внутри этого перечня из наиболее частотных категорий, были вызваны сочетанием нескольких факторов. Во-первых, на него влияли реальные политические события из общесоюзной повестки дня. Важными были, например, вопросы внутриполитической и внутрипартийной борьбы. Во-вторых, динамика категорий производственного блока в 19281937 гг. говорит об их связи с ходом индустриализации СССР. Эти категории показывают изменения основных приоритетов развития 
пищевой промышленности в годы первой и второй пятилетки. В-третьих, на содержание редакционных статей влияли общемировые события, например, забастовки рабочих за рубежом и обострение международных отношений. В-четвёртых, изменение наиболее частотных категорий в текстах выборки отражает влияние кризисной социально-экономической ситуации, которая складывалась в СССР к концу первой пятилетки. Об этом говорит появление в списке за 19311932 гг. категорий «питание рабочих» и «обеспечение сырьём».

Таким образом, первый этап анализа текстов выборки в программе MAXQDA позволил определить несколько факторов, оказывавших влияние на динамику категорий в редакционных статьях отраслевой газеты пищевой промышленности.

\section{Анализ внутренних взаимосвязей категорий с помощью программы MAXQDA}

Ещё один фактор, существенно отразившийся на изменении повестки дня, которую газета предлагала своим читателям, был определён в ходе анализа внутренних взаимосвязей категорий в текстах этого издания. Результаты подсчёта частот совместной встречаемости категорий были визуализированы с помощью программы MAXQDA 2020. Использование визуализации в виде графа дало возможность судить об изменениях, происходивших в структуре внутренних связей основных проблем в текстах выборки за период 1928-1937 гг. Одна из наиболее показательных перемен произошла с частотами совместной встречаемости категорий в 1931 г.

Анализ частот совместной встречаемости категорий в текстах газеты за первое и второе полугодие 1931 г. показал, что во втором полугодии происходит значительное усложнение структуры наиболее сильных связей категорий в текстах выборки. Столь резкая перемена в совместных частотах встречаемости категорий объясняется изменением ведомственной подчинённости издания с 1 июля 1931 г. С этой даты данное периодическое издание перешло в совместное ведение Народного комиссариата снабжения СССР, Народного комиссариата снабжения РСФСР и профсоюзных органов.

В первом номере газеты «За пищевую индустрию» было размещено обращение А.И. Микояна, который пояснял, что выпуск нового издания "знаменует собой переход в решительное наступление за реконструкцию отраслей пищевой промышленности в мощную пищевую индустрию, за освоение высших достижений техники и науки» [19]. Нарком указывал: «Газета - важнейший рычаг организаџии и руководства. Газета “За пищевую индустрию” должна мо- 
билизовать передовые слои рабочих, лучших инженеров и хозяйственников вокруг задачи коренной реконструкиии всех отраслей пищевой индустрии, за полное выполнение всей промышленностью Наркомснаба промфинплана третьего, решающего года пятилетки, за окончание в срок всех начатых новостроек, за своевременный ремонт всех заводов, за большевистские темпь хозяйственной работы»» [19].

\section{Заключение}

Таким образом, применение контент-анализа позволило сделать результаты исследования верифицируемыми и предоставило дополнительные возможности для приращения научного знания. Анализ оцифрованной выборки редакционных статей в специализированной программе помог отнести к факторам, влиявшим на динамику изменения повестки дня, предлагавшейся отраслевой газетой для всей пищевой промышленности СССР в 1928-1937 гг., не только события, происходившие непосредственно в пищевой промышленности, но и трансформационные процессы в народном хозяйстве, внутренней и внешней политике страны, а также наглядно показал, какую роль сыграла в этом процессе смена подведомственности издания.

\section{Библиография}

1. Каменская Е.В. Советские газеты как исторический источник: специфика и возможности использования // Человек, общество, власть. К 100-летию Российской революции 1917 года. - Екатеринбург, 2017. - С. 37-44.

2. Архангельская И.Д. К вопросу изучения периодической печати методами контент-анализа // Методы количественного анализа текстов нарративных источников. - М., 1983. С. 110-126.

3. Красильников С.А. Периодическая печать Сибири в период Октября в системе политической пропаганды. К постановке проблемы и методов исследования // Книжное дело Сибири и Дальнего Востока в годы строительства социализма. - Новосибирск, 1984. - С. 154-184.

4. Попова С.М. Контент-анализ в исследовании облика положительного героя на страницах газет 30-х годов // Количественные методы в исследованиях по истории рабочего класса и крестьянства. - Свердловск, 1991. - С. 33-49.

5. Голиков А.Г. Российские монополии в зеркале прессы (газеты как источник по истории монополизации промышленности). - М., 1991. - 205 с.

6. Блинова О.Н. Экономическая концепция КПРФ в 1990-е годы в отражении партийной периодической печати: Источники и методы исследования: дис. ... канд. ист. наук: 07.00.09. - М., 2004. - 218 с.

7. Любимова К.К. История завода, региона и страны на страницах заводской многотиражки // Урал индустриальный. Бакунинские чтения. Материалы VIII Bcероссийской научной конференции. 27-28 апреля 2007 г.: в 2-х т. - Екатеринбург, 2007. T. 2. - C. $162-166$. 
8. Бородкин Л.И. Контент-анализ и проблемы изучения исторических источников // Математика в изучении средневековых повествовательных источников. - М., 1986. - C. 8-30.

9. Бородкин Л.И. Многомерный статистический анализ в исторических исследованиях. - М., 1986. - 188 с.

10. Ковальченко И.Д., Бородкин Л.И. Современные методы изучения исторических источников с использованием ЭВМ. - М., 1987. - 85 с.

11. Гарскова И.М. Новые тенденции в компьютеризованном анализе текстов: концепции, методы, технологии // Электронный научно-образовательный журнал «История», 2015. - T.6. Выпуск 8 (41). - URL: http://history.jes.su/s207987840001255-91 (дата обращения: 22.01.2020). - DOI: 10.18254/S0001255-9-1

12. Раздина Н.В. Газета «За индустриализацию» как источник для изучения промышленной политики государства в годы первых пятилеток (опыт контент-анализа редакционных статей) // Историческая информатика. - 2013. - № 1 (3). - С. 41-60.

13. Раздина Н. В. Газета «Черная металлургия (Индустрия)» как источник для изучения промышленной политики государства в годы третьей пятилетки (контентанализ редакционных статей) // Клио. - 2014. - № 10 (94). - С. 18-25.

14. Раздина Н.В. Первые пятилетки: промышленная политика СССР в отражении газеты «За индустриализацию». - М., 2016. - 224 с.

15. Газеты СССР, 1917-1960: Библиографический справочник. Т. 1. Газеты Москвы, Ленинграда и столиц союзных республик. - М., 1970. - 278 с.

16. Хомский А.П. Газеты и журналы СССР: справочник на 1929 год о всех периодических изданиях, выходящих в СССР. - М., 1929. - 168 с. $801 \mathrm{c}$.

17. Летопись периодических изданий СССР в 1936 г. (на 1 июля). - М., 1937. -

18. Ежегодник периодических изданий СССР за 1938 год. Ч. 2. Газеты. - М., 1939. $-311 \mathrm{c}$.

19. Микоян А.И. На борьбу за пищевую индустрию // За пищевую индустрию. М., 1931. - 1 июля (№ 1). - С. 1.

https://doi.org/10.29003/m1802.978-5-317-06529-4/146-153

Филёв М.В.

Балтийский федеральный университет им. И. Канта,

Калининград

\section{Сельская повседневность на страницах газеты «Колхозная правда» (1950-1961 гг.): опыт контент-анализа}

Аннотация. В рамках микроисторического исследования колхоза «Большевик» Калининградской области изучались публикации районной газеты «Колхозная правда». Целью контент-анализа являлось выявление содержания газетных статей, основных приоритетов и степени адекватности отражения колхозной действительности в сравнении с другими источниками. Делается вывод, что представленная на страницах газеты колхозная жизнь имела мало общего с действительностью.

Ключевые слова: сельское хозяйство, колхоз, Калининградская область, газета, контент-анализ, микроистория. 
Filev M. . Immanuel Kant Baltic Federal University, Kaliningrad

\title{
Rural everyday life on the pages of the newspaper «Kolkhoznaya Pravda» (1950-1961): the experience of content analysis
}

\begin{abstract}
The article examines the publications of the local newspaper "Kolkhoznaya Pravda" as part of a microhistorical study of the kolkhoz "Bolshevik" in the Kaliningrad region. The aim of the content analysis was to identify the content of newspaper articles, the main priorities and the degree of adequacy of the reflection of rural reality in comparison with other sources. The author concludes that the life of collective farmers presented on the pages of the newspaper had little in common with reality.
\end{abstract}

Keywords: agriculture, kolkhoz, Kaliningrad region, newspaper, content analysis, microhistory.

Колхоз «Большевик» был организован в октябре 1946 г., располагался в посёлке Поречье Правдинского района Калининградской области [1, л. 1]. В 1957 г. переименован по названию посёлка. В рамках микроисторического исследования данного колхоза был предпринят анализ районной газеты «Колхозная правда». Цель работы заключалась в выявлении содержания публикаций газеты о колхозе и их соотношения с деревенской повседневностью, отраженной в других источниках, прежде всего в фонде колхоза в Государственном архиве Калининградской области (протоколы колхозных [1] и партийных собраний $[2,3])$.

В ходе исследования в программе Microsoft Office Access была создана база данных статей о колхозе. Заголовки из этой базы данных были загружены в редактор Word Art, подсчитывающий, сколько раз было задействовано в названиях статей то или иное слово, и обрабатывающий эти слова в облако заголовков.

Редакция «Колхозной правды» была образована 29 июля 1947 г. [4]. Сайт Калининградской областной библиотеки располагает оцифрованными копиями выпусков газеты с 1950 по 1961 г. [5]. По электронному архиву «Колхозной правды» за 1950-1961 гг. было выявлено 492 публикации, посвящённых изучаемой сельхозартели.

«Колхозная правда» издавалось три раза в неделю, тиражом от 1300 до 2100 экземпляров, на четырёх страницах. Первая освещала события в стране, во время посевной или уборочной кампании сюда попадали заметки о выполнении плановых показателей. Вторую и третью страницы заполняли статьи о жизни в районе корреспонден- 
тов газеты и письма в редакцию читателей. На последней публиковались тассовские материалы о международной жизни, заметки о культуре, науке, спорте, происшествиях, а также юморески и карикатуры. Примерно пятая часть публикаций была анонимной (106 из 492). Из известных авторов в газету чаще всего писал председатель колхоза, а также другие должностные лица. Штатного или внештатного корреспондента, который на регулярной основе писал бы о колхозе, не было. Приниципиальные различия по тематике, содержанию и стилю между журналистскими публикациями и письмами колхозников отсутствовали, что наводит на мысль о возможной инспирированности читательской активности. Колхозники, как и журналисты, писали о работе клуба [6], успехах артели [7] или плохой работе кого-то из колхозников [8], колхозной молодёжи [9], достижениях Советского Союза [10].

Частота упоминаний колхоза в газетных публикациях то увеличивалось, то шла на спад (рис. 1). По всей видимости, это было связано с местом сельхозартели в районной табели о рангах. В первой половине 1950-х гг. «Большевик» находился в числе аутсайдеров, а когда стал крепким хозяйством, по большинству показателей входившим в тройку лидеров в районе, число статей о нем увеличилось.

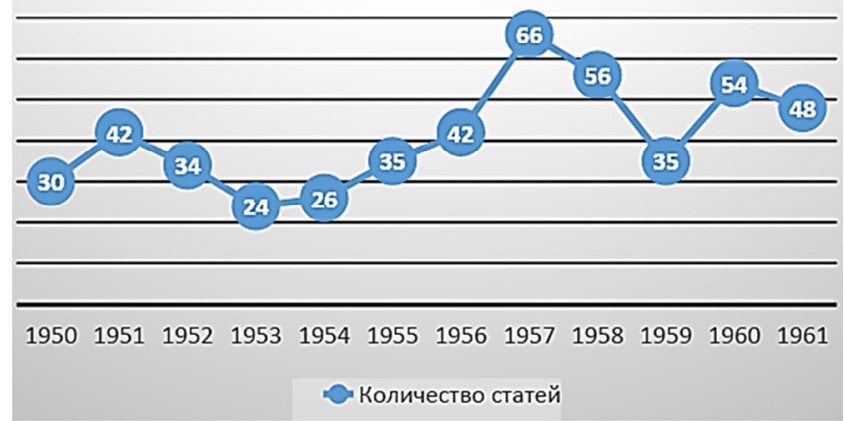

Рис. 1. Динамика изменения количества статей

о колхозе «Большевик»/«Поречье» в газете «Колхозная правда» в 1950-1961 гг.

По содержанию статьи о колхозе «Большевик»/«Поречье» в «Колхозной правде» можно разделить на несколько категорий (рис. 2).

Как видно диаграммы (рис. 2), основной массив публикаций (около2/3) был посвящен производственным вопросам. 


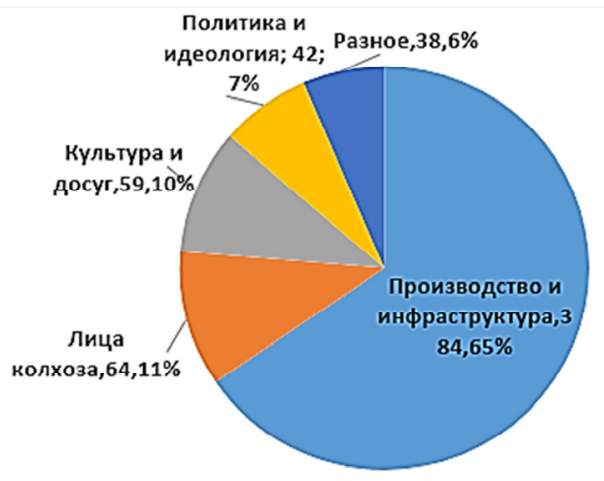

Рис. 2. Тематика публикаций о колхозе «Большевик»/«Поречье» (категория, число и доля публикаций)

Внутри этой категории можно выделить несколько подкатегорий (рис. 3).

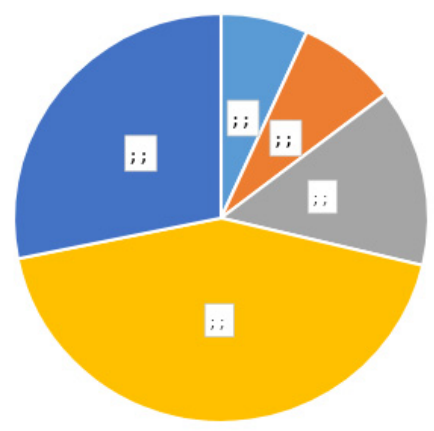

Рис. 3. Распределение тематики статей в категории «Производство и инфраструктура» (количество публикаций и их доля)

Практически все материалы категории «Производство и инфраструктура» были о полевых работах $(42,9 \%)$ или животноводстве $(28,1 \%)$. Третьей по частоте употребления является тема трудовой дисциплины (7,8\%). Количество публикаций о полевых работах и животноводстве показывает изменение специализации артели. До середины 1950-х гг. колхоз позиционировал себя как полеводческий (но и животноводство развивалось), а в конце десятилетия и в начале 1960-х гг. в «Поречье» постепенно стало преобладать животноводство (рис. 4). 


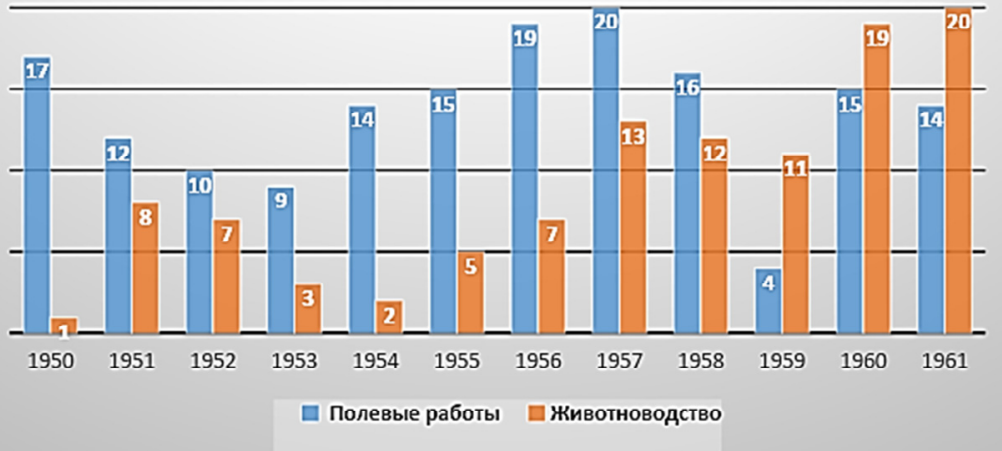

Рис. 4. Динамика изменения количества статей о полевых работах и животноводстве

Облако заголовков (рис. 5) показывает, что через газету крестьянам, как и через другие средства пропаганды (стенгазеты, «боевые листки», лозунги, лекции и кинофильмы) стремились внушить главную идею: необходимость работы в артели. Помимо слов «колхоз» и его производных (89 раз) и «Большевик» (35 раз) в заголовках чаще других встречаются слова, связанные с трудовой деятельностью: работа (21 раз), труд (18 раз), дело (13 раз), урожай (12 раз), ферма (10 раз), поле (9 раз).

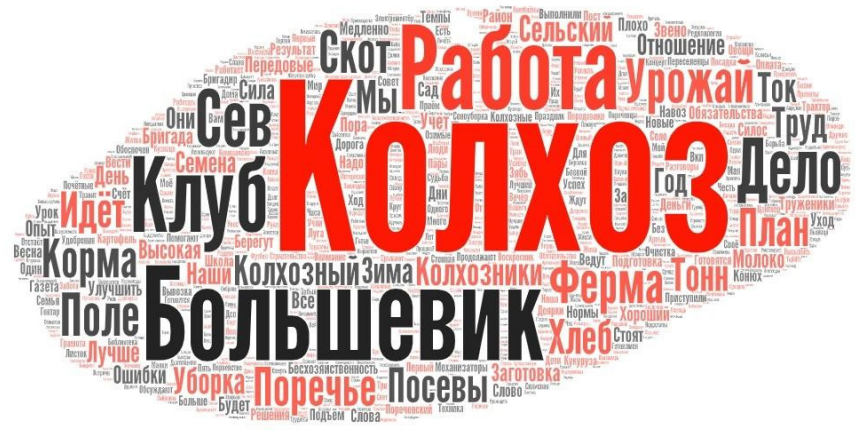

Рис. 5. Облако заголовков публикаций о колхозе «Большевик»/«Поречье»

Облако заголовков демонстрирует заметное дистанцирование «Колхозной правды» от непроизводственных сфер жизни колхоза. Организацию досуга сводили к работе клуба (слово «клуб» 16 раз 
встречается в заголовках). Менялись его заведующие, но организация деятельности клуба практически ежегодно подвергалась критике, что видно из названий статей: «Колхозный клуб на замке» [11], «Клуб не работает» [12], «Почему так получается?» [13].

Проблема получения образования затрагивалась считанное количество раз. Например, колхозник М. Курочкин в своём письме «Ни школы, ни клуба» сообщил о закрытии начальной школы в посёлке Лукино, входившем в состав артели. Автор сокрушается больше всего из-за отсутствия клуба, поскольку «с тех пор кино к нам не привозят» [14], закрытие школы в письме лишь упомянуто. А журналистских заметок о колхозном образовании и здравоохранении не было вовсе.

В конце 1940-х - начале 1950-х гг. «Большевик» испытывал значительные сложности при организации труда колхозников. Нередко члены правления колхоза, несмотря на регулярные заявления о необходимости исправлять положение, занимались улучшением личного состояния путём присвоения общественного имущества. Факты его хищения часто обсуждались на партийных собраниях, но в «Колхозной правде» эта тема так и не была поднята [2, 3].

Важнейшее место в колхозной жизни занимало соотношение личного и общественного хозяйства. В газете личное подсобное хозяйство за 12 лет упоминается всего несколько раз. Например, в статье «В колхозе “Большевик»" не берегут хлеб» автор отмечал, что «из 80 трудоспособных колхозников ежедневно на поля выходят не более 30 человек. Остальные же заняты своими огородами или же торгуют на базаре в г. Правдинске» [15]. Много писали о нарушениях трудовой дисциплины, уклонении от работы в колхозе, но умалчивали, что крестьяне предпочитали в поте лица работать на своих участках, которые обеспечивали им средства для выживания.

В облаке заголовков практически отсутствуют понятия, связанные с политикой и идеологией. Дело в том, что, хотя пропагандистских материалов в газете было более чем достаточно, но они печатались в рубриках, никак не связывались с жизнью отдельных колхозов. Большое внимание уделялось, пожалуй, только избирательным кампаниям, читателей знакомили с кандидатами в депутаты Советов разного уровня в форме шаблонных отчётов с предвыборного колхозного собрания, в ходе которого один из колхозников рекомендовал поддержать чьё-либо предложение об избрании какого-либо кандидата, а другие дружно с этой рекомендацией соглашались [16].

В заключение следует отметить, что газета, которая должна была являться для жителей села главным источником информации, на де- 
ле была одним инструментов официальной пропаганды. В противовес эффективному социалистическому колхозному хозяйству читателям предлагали узнать об постоянных проблемах хозяйства капиталистического.

Содержание публикаций из года в год практически не менялось: клишированными формулировками рассказывалось об успехах сельского хозяйства и скором преодолении имеющихся трудностей. Через прессу государство пыталось мотивировать крестьян ударно работать в колхозе, но их позиция, как и в отношении других агитационно-пропагандистских средств, была индифферентной. Колхозники не проявляли желания выписывать «Колхозную правду», ввиду чего было организовано «размерное чтение газет» вслух на политинформациях, но и эта затея не увенчалась успехом. Интереса не проявили ни ответственные за мероприятие, ни сами колхозники [3, л. 11].

Тот факт, что лишь дважды в 1948 г. на партийном собрании обсуждалась газетная статья [2, л. 27-28 об., л. 32-33], а на колхозных собраниях ни разу, также демонстрирует отношение крестьян к публикациям прессы. Критика в газете была осторожной, часто затрагивая абстрактные проблемы, вроде слабой работы агитаторов или плохой организации культмассовых мероприятий. Насущные же для села проблемы, такие как благосостояние колхозников, справедливый учёт трудодней и оплата труда, обеспечение инвентарём и техникой, состояние социальной инфраструктура, миграция населения в город, отсутствие мотивации к общественному труду - все они в газете появлялись либо эпизодически, либо вообще не затрагивались.

Изученные материалы показывают, что колхозная жизнь, представленная на страницах газеты, имела мало общего с сельской действительностью. Пресса создавала образ колхозника, ответственно трудящегося на производстве, стремящегося исправлять недостатки, проводящего свободное время в клубе или библиотеке. В реальной жизни крестьяне предпочитали общественному хозяйству личное, не проявляя стремления к решению проблем колхоза и заботясь о поисках способов выживания в непростых условиях советской деревни.

\section{Библиография}

1. Государственный архив Калининградской области (ГАКО). Ф. Р-1059. Оп. 2. Д. 1.

2. ГАКО. Ф. П-145. ОП. 1. Д. 1.

3. ГАКО. Ф. П-145. Оп. 1. Д. 2. 
4. Правдинский городской округ / Государственный архив Калининградской области. - URL: http://gako.name/publikatsii/spravochnik-dokumenty-po-lichnomu-sostavu-/ pravdinskiy- orodskoy-okrug/ (дата обращения: 05.08.2020).

5. Колхозная правда / Калининградская областная научная библиотека. Электронный архив. - URL: http://lib39.ru:8082/dsweb/View/ResourceCollection-137 (дата обращения: 19.08.2020).

6. Исакова А., Матвеева Н. Так ли надо относиться к культурному обслуживанию // Колхозная правда. - 1957. - 25 января.

7. Савицкий Г. Трудовой подъём // Колхозная правда. - 1957. - 20 февраля.

8. Смирнов М. Если бы участвовали все... // Колхозная правда. - 1960. - 29 мая.

9. Беспалов И. Дети берут пример с родителей // Колхозная правда. - 1959. 17 июля.

10. Искарадов П. Не удивлён, а восхищён // Колхозная правда. - 1960. - 24 августа.

11. Громов Н. Колхозный клуб на замке // Колхозная правда. - 1954. - 9 июля.

12. Шарай В., Дёмкина В., Пойкова Е. Клуб не работает // Колхозная правда. 1953. - 20 декабря.

13. Иванов А. Почему так получается? // Колхозная правда. - 1957. - 15 сентября.

14. Курочкин М. Ни школы, ни клуба // Колхозная правда. - 1958. - 31 октября.

15. Лохин Н. В колхозе «Большевик» не берегут хлеб // Колхозная правда. 1950. - 2 августа.

16. На собрании колхозников сельхозартели «Большевик» // Колхозная правда. 1955. - 21 января. 


\section{БАЗЫ ДАННЫХ И ИНФОРМАЦИОННЫЕ РЕСУРСЫ}

https://doi.org/10.29003/m1803.978-5-317-06529-4/154-160

Боровик Ю.В.

Уральский федеральный университет

\section{Социальный облик городского православного прихода на рубеже XIX-XX вв. по данным метрических книг Богоявленского собора Екатеринбурга ${ }^{1}$}

Аннотация. В докладе представлены результаты анализа состава приходского сообщества на основе БД по метрическим книгам Богоявленского собора Екатеринбурга. Использованы сведения о сословном статусе и месте приписки родителей, чьи дети были крещены в храме, объединявшем значительную часть деловой и административной элиты крупного регионального города динамично растущего во второй половине XIX - начале XX вв. за счет миграции.

Ключевые слова: городской социум, российская урбанизация, метрические книги, базы данных, Урал.

Borovik Ju.V.

Ural Federal University, Ekaterinburg

\section{The social appearance of the urban Orthodox parish at the turn of the 19th -20 th centuries. according to the metric books of the Epiphany Cathedral in Yekaterinburg}

Abstract. The article presents the results of the analysis of the parish community according to the database of the Epiphany Cathedral of the parish books of the late 19 th - early 20 th centuries. The data on the social status, class, occupation and place of registration / residence of parents, whose children were baptized in this temple in Yekaterinburg, were used. The Epiphany parish united the urbanized business and administrative elite of a large regional city, as well as rural migrants looking for work and a better life.

Keywords: urban society, urbanization, the Russian parish registers, databases, Ural.

База данных по метрическим книгам екатеринбургского кафедрального Богоявленского собора уже неоднократно служила источником для исследований ряда демографических характеристик городского населения [1-4]. Приход собора в начале ХХ в. описывался представителями церковного ведомства как объединяющий исклю-

\footnotetext{
${ }^{1}$ Исследование проводится при поддержке гранта РФФИ, № 20-49660013 р_а «Городские элиты Екатеринбурга конца XVIII - начала XX века: 250 лет социальной и демографической эволюции».
} 
чительно горожан, в отличие от остальных православных приходских церквей города к нему не было приписано никакого населения за пределами Екатеринбурга. В сведениях о Богоявленском приходе указывалось, что в его состав входят мещане, духовенство, военные и гражданские чины, мелкие служащие, купцы [5-6]. Однако, как следует из массива записей о крещениях новорожденных в метрических книгах этого храма, среди почти 6 тыс. детей $45 \%$ родились в семьях выходцев из заводских и сельских местностей (в основном из сословия крестьян). Чтобы ответить на вопрос о динамике пополнения главного городского прихода, а также определить какая часть мигрантов могла входить в число постоянных прихожан, мы проанализировали базу данных, созданную на основе метрик Богоявленского собора за 1880-1919 гг. в составе ресурса «Население Урала» [7].

Массив данных для исследования составил 5902 случая (табл. 1). В это число включены только оригинальные записи о родившихся (в т. ч. мертворожденных) без учета крещенных в ходе присоединения к православию (106 чел.) - оно чаще всего требовалось для заключения брака, без подкидышей и усыновленных (68 чел.) - появление на свет которых не всегда было связано с событиями в границах прихода, а также без записей, внесенных в метрические книги сотрудниками ЗАГС в советский период (11 чел.).

Таблийа 1

Количественные характеристики состава записей о родившихся в метрических книгах Богоявленского собора Екатеринбурга, 1880-1919 гг.

\begin{tabular}{|l|c|c|c|c|}
\hline \multicolumn{1}{|c|}{$\begin{array}{c}\text { Социальный } \\
\text { и территориальный статус }\end{array}$} & $\mathbf{N}$ (чел.) & $\begin{array}{c}\text { Доля } \\
\text { (\%) }\end{array}$ & $\begin{array}{c}\text { Среднее } \\
\text { число } \\
\text { записей } \\
\text { за год }\end{array}$ & $\begin{array}{c}\text { Медианное } \\
\text { значение } \\
\text { за год }\end{array}$ \\
\hline $\begin{array}{l}\text { Горожане } \\
\text { из Екатеринбурга и других } \\
\text { городов }\end{array}$ & 3126 & 53,0 & 78 & 71 \\
\hline $\begin{array}{l}\text { Мастеровые, крестьяне } \\
\text { и другие выходцы из заводских } \\
\text { местностей }\end{array}$ & 1260 & 21,3 & 32 & 22 \\
\hline $\begin{array}{l}\text { Крестьяне и другие выходцы } \\
\text { из сельских местностей }\end{array}$ & 1389 & 23,5 & 35 & 26 \\
\hline Нет данных & 127 & 2,2 & 3 & 1 \\
\hline Всего & $\mathbf{5 9 0 2}$ & $\mathbf{1 0 0}$ & $\mathbf{1 4 8}$ & $\mathbf{1 1 8}$ \\
\hline
\end{tabular}


Изучение данных о социальном статусе и месте приписки производилось на основе сведений о родителях из соответствующего раздела метрики («Звание, имя, отчество и фамилия родителей и какого вероисповедания»). Разнородные определения источника были сначала транскрибированы в базу данных в оригинальном виде, а затем обработаны и классифицированы по трем группам, связанным с сословием и местом происхождения: горожане, выходцы из горнозаводской местности (к каковым относились многие из сопредельных Екатеринбургу территорий) и выходцы из сельской местности (табл. 2). В составе последних двух групп преобладающим большинством были крестьяне, но изредка встречались мастеровые, служащие заводов, сельское духовенство и др.

Таблица 2

Примеры классификации социальных статусов источника
в группы по сословию и приписке

\begin{tabular}{|c|c|c|c|}
\hline Группы & Горожане & \begin{tabular}{|c|} 
Мастеровые, \\
крестьяне и другие \\
выходцы из \\
заводской местности \\
\end{tabular} & $\begin{array}{c}\text { Крестьяне и другие } \\
\text { выходцы из } \\
\text { сельской местности }\end{array}$ \\
\hline $\begin{array}{c}\text { Обозначение } \\
\text { социального } \\
\text { статуса в } \\
\text { метрических } \\
\text { записях }\end{array}$ & $\begin{array}{c}\text { Временный купец; } \\
\text { Дворянин; } \\
\text { Диакон сего собора; } \\
\text { Купец г. Яранска; } \\
\text { Личный почетный } \\
\text { гражданин; } \\
\text { Мещанин; } \\
\text { Отставной } \\
\text { канцелярский } \\
\text { служитель; } \\
\text { Потомственный } \\
\text { почетный } \\
\text { гражданин; } \\
\text { Преподаватель } \\
\text { реального училища; } \\
\text { Сын коллежского } \\
\text { советника; } \\
\text { Титулярный } \\
\text { советник; } \\
\text { Цеховой; }\end{array}$ & \begin{tabular}{|c} 
Губернский \\
секретарь в Нижне- \\
Исетском заводе; \\
Крестьянин \\
Ревдинской \\
волости и завода; \\
Обыватель \\
Миасского завода; \\
Мастеровой \\
Васильевского \\
завода; \\
псаломщик \\
Успенской церкви \\
Верх-Исетского \\
завода \\
Рекрут \\
Сысертского \\
завода; \\
Сельский \\
обыватель \\
Ижевского завода;
\end{tabular} & $\begin{array}{c}\text { Крестьянин } \\
\text { Вятской губ. } \\
\text { Вятского уезда } \\
\text { Вязовской волости } \\
\text { деревни Калины } \\
\text { Макаровой; } \\
\text { Унтер-офицер } \\
\text { Люблинского } \\
\text { жандармского } \\
\text { управления села } \\
\text { Люблино } \\
\text { Колонист } \\
\text { Самарской } \\
\text { колонии } \\
\text { Екатериненштадт; } \\
\text { Числящийся в } \\
\text { запасе рядовой } \\
\text { Клевакинской } \\
\text { волости } \\
\text { Камышловского } \\
\text { уезда; }\end{array}$ \\
\hline
\end{tabular}




\begin{tabular}{|c|c|c|c|}
\hline Группы & Горожане & $\begin{array}{c}\text { Мастеровые, } \\
\text { крестьяне и другие } \\
\text { выходцы из } \\
\text { заводской местности } \\
\end{array}$ & $\begin{array}{c}\text { Крестьяне и другие } \\
\text { выходцы из } \\
\text { сельской местности }\end{array}$ \\
\hline & $\begin{array}{c}\text { Чиновник особых } \\
\text { поручений Министра } \\
\text { финансов; } \\
\text { Швейцарский } \\
\text { подданный кантона } \\
\text { Берн }\end{array}$ & $\begin{array}{c}\text { Солдат } \\
\text { Верхнесергинского } \\
\text { завода; } \\
\text { Сосланный в } \\
\text { Сибирь из } \\
\text { Березовского } \\
\text { завода; } \\
\text { Учитель } \\
\text { ревдинской школы }\end{array}$ & $\begin{array}{c}\text { Священник села } \\
\text { Мостовского } \\
\text { Екатеринбургского } \\
\text { уезда } \\
\text { Состоящий в } \\
\text { запасе армии } \\
\text { фельдфебель } \\
\text { Владимирской губ. } \\
\text { Вязниковского } \\
\text { уезда Нагуевской } \\
\text { волости деревни } \\
\text { Третьяковой }\end{array}$ \\
\hline
\end{tabular}

Часть данных (о 127 родившихся - 2,2\%) интерпретировать не удалось, большинство таких случаев приходится на рубеж 18801890-х гг. и мы предполагаем, что они связаны с вынужденным и временным перемещением не городских семей под угрозой голода, когда отец ребенка при взаимодействии с екатеринбургскими властями предпочитал говорить о своем статусе, связанном с отбыванием воинской повинности: «старший запасный писарь», «отставной рядовой», «Туркестанской 1 роты новобранец» и т.п., не указывая при этом место своего происхождения.

Проанализированный динамический ряд абсолютных значений показал, что на протяжении рассматриваемого периода приток выходцев из горнозаводской и сельской местности, обращавшихся в Богоявленский собор был особенно заметным в уже упоминавшийся период неурожая в начале 1890-х гг. (рис. 1). Трудности с продовольствием ощущались не только в Зауралье (особенно в сельскохозяйственном Камышловском уезде), но и на горных заводах. Часть ищущих заработок и пропитание в городе после завершения кризиса возвратилась на родину и новая волна, хотя уже не столь значительная, возникает в условиях переселенческого движения 1910-х гг., а также мобилизации и вынужденной миграции в период Первой мировой войны. На протяжении многих лет на Урал и далее на восток идет немало крестьян из европейской части страны, главным образом из центрального Нечерноземья, особенно из Вятской губернии. 


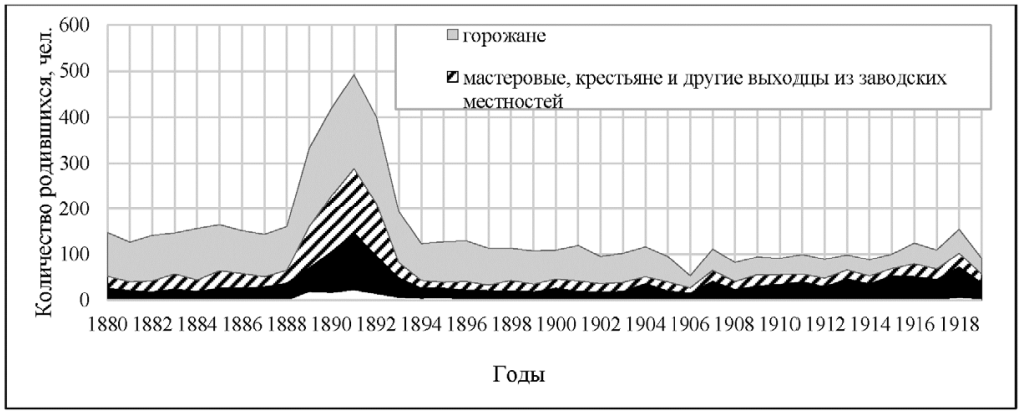

Рис. 1. Количество родившихся в группах прихожан Богоявленского собора Екатеринбурга в 1880-1919 гг. (на основе 5902 записей о родившихся)

Расчет относительных величин - вклада каждой из групп («горожане», «мастеровые, крестьяне и другие выходцы из заводской местности», «крестьяне и другие выходцы из сельской местности») по годам уточнил последовательность изменения в их соотношении (Рис. 2). Доля крестьян только из сельской местности среди обращавшихся в Богоявленский собор увеличивается во второй половине 1900-х гг., превосходя цифры голодного 1891 г., и становится сопоставимой со всеми городскими стратами вместе взятыми.

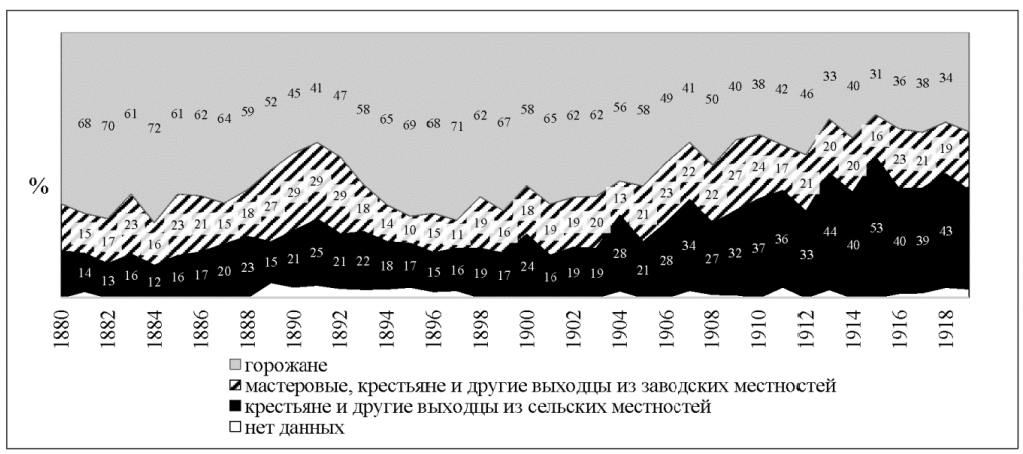

Рис. 2. Соотношение групп прихожан Богоявленского собора Екатеринбурга в 1880-1919 гг. (на основе 5902 записей о родившихся)

Часть выходцев из горнозаводской и сельской местности могла долгое время сохранять свой прежний сословный статус, но при этом проживать и работать в городе, устраивать свою семейную жизнь и становиться постоянными посетителями Богоявленского прихода. Уже в 1880-х гг. такие пары, формально не включенные в 
состав прихода, но неоднократно обращавшиеся к причту, были причиной более половины всех крещений новорожденных - на них приходились 212 из 414 записей (табл. 3).

Таблица 3

Крещения детей в семьях, не причисленных к городским сословиям, 1880-е гг.

\begin{tabular}{|c|c|c|c|}
\hline Год & $\begin{array}{c}\text { Общее количество } \\
\text { крещений в семьях, } \\
\text { приписанных } \\
\text { за пределами города }\end{array}$ & $\begin{array}{c}\text { В том числе семьи, } \\
\text { обращавшиеся } \\
\text { неоднократно (крестили } \\
\text { от 2 до 8 своих детей) }\end{array}$ & $\begin{array}{c}\text { Доля семей, } \\
\text { обращавшихя } \\
\text { неоднократно, } \\
\text { \% }\end{array}$ \\
\hline 1880 & 40 & 18 & 45 \\
\hline 1881 & 27 & 15 & 55,6 \\
\hline 1882 & 29 & 21 & 72,4 \\
\hline 1883 & 42 & 21 & 50 \\
\hline 1884 & 31 & 19 & 61,3 \\
\hline 1885 & 51 & 27 & 52,9 \\
\hline 1886 & 45 & 26 & 57,8 \\
\hline 1887 & 42 & 25 & 59,5 \\
\hline 1888 & 52 & 25 & 48,1 \\
\hline 1889 & 55 & 15 & 27,3 \\
\hline Всего & $\mathbf{4 1 4}$ & $\mathbf{2 1 2}$ & $\mathbf{5 1 , 2}$ \\
\hline
\end{tabular}

В разные годы доля семей, которые договаривались со священником об обряде после рождения очередного ребенка составляла от 30 до 70\% всех крещений среди тех, кто не относился к городским сословиям. Мы предполагаем, что регулярность их контактов с местным духовенством указывает на длительное пребывание в городе и ставит таких условных «мигрантов» на один уровень с простыми мещанами по занятиям, доходам и образу жизни.

В итоге можно констатировать, что среди прихожан самого «городского» прихода Екатеринбурга на протяжении четырех десятилетий, в 1880-1910-е гг., доля представителей городских слоев постепенно уменьшалась, доля выходцев из уральских горнозаводских поселков изменялась незначительно, а часть тех, кто был связан припиской с сельской местностью последовательно росла и отражала постепенный процесс включения крестьян в состав постоянного городского населения. Учет более сложного состава православного прихода позволит взвешенно подходить к изучению социально- 
демографических аспектов российской урбанизации в дальнейших микро-исторических исследованиях.

\section{Библиография}

1. Главацкая Е.М., Бахарев Д.С., Заболотных Е.А. База данных «Метрические книги Богоявленского собора Екатеринбурга»: опыт создания и перспективы использования // Церковь. Богословие. История. - 2020. - № 1. - С. 305-311.

2. Заболотных Е.А. Метрические книги Богоявленского прихода Екатеринбурга: критика и информационные возможности источника // Уральский историко-архивный форум. Материалы Всероссийского научного форума с международным участием, посвященного 50-летию историко-архивной специальности в Уральском федеральном университете. Екатеринбург, 11-12 сентября 2020 г. - Екатеринбург: Изд-во Урал. унта, 2020. - C. 49-54.

3. Glavatskaya E., Thorvaldsen G., Borovik I., Zabolotnykh E. Mixed Marriages in Late Nineteenth to Early Twentieth Century: Comparing Russia and Norway // Journal of Family History. - 2020. - DOI: 10.1177/0363199020945215

4. Бахарев Д.С., Главацкая Е.М. Причины детской смертности в Екатеринбурге на рубеже XIX-XX вв.: опыт классификации // Известия Уральского федерального университета. Серия 2: Гуманитарные науки. - 2020. - Т. 22. - № 2 (198). -С. 79-96.

5. Справочная книжка для прихожан Богоявленского кафедрального собора г. Екатеринбурга / Сост. свящ. Пономарев А.Р. - Екатеринбург: тип. Я.Ф. Шубина, 1911.

6. Приходы и церкви Екатеринбургской епархии. Екатеринбург: Братство Св. Праведного Симеона, Верхотурского Чудотворца, 1902. - С. 4-6.

7. Население Урала (конец XIX - начало XX вв): [Электрон. ресурс] - URL: http://urappdata-urgi.urfu.ru/ural-population-project (дата обращения 31.08.2020).

https://doi.org/10.29003/m1804.978-5-317-06529-4/160-166

Бочаров А.В. Национальный исследовательский Томский государственный университет

\section{Проект исторического предметного рубрикатора-тезауруса на базе конструктора комбинаторных поисковых запросов Inspert в контексте перспектив корпусной историографии}

Аннотация. В статье проанализированы актуальность и проблемы развития корпусной историографии в контексте принципов и методов корпусной лингвистики. Представлен проект предметного рубрикатора для разметки текстов с учетом специфики предмета исторической науки на примере различных отраслевых тезаурусов и поисково-аналитических сервисов. Состав рубрикатора и функции корпуса исторических текстов соотнесены с методами автоматизированной обработки естественного языка: извлечении именованных сущностей и извлечение фреймов.

Ключевые слова: корпусная историография, исторический рубрикатор, поисковые системы, онтологии и тезаурусы. 


\title{
Bocharov A.V. National Research Tomsk State University
}

\section{The project of a historical subject heading-thesaurus based on the constructor of combinatorial search queries Inspert in the context of the prospects of corpus historiography}

\begin{abstract}
The paper presents the topicality and problems of the development of corpus historiography in the context of the principles and methods of corpus linguistics. A project of a subject heading thesaurus for marking up texts, taking into account the specifics of the subject of historical science is presented on the example of various industry thesauri and search and analytical services. The structure of the rubricator and the functions of the corpus of historical texts are correlated with the methods of automated natural language processing: Named-entity recognition, Frame-Based NLP System.
\end{abstract}

Keywords: corpus historiography, historical rubricator, search engines, ontologies and thesauri.

В филологических науках за последние полтора десятилетия произошла так называема корпусная революция и лидирующие позиции заняла корпусная лингвистика. Появление крупных (свыше миллиарда словоупотреблений) репрезентативных компьютеризированных корпусов за последнее десятилетие позволило перевести изучение языковых и текстовых материалов на принципиально иной уровень продуктивности, верифицируемости и эвристичности [1].

За последние годы создано большое количество специализированных корпусов на русском языке, как и на всех европейских языках. В 2004 г. по адресу http://ruscorpora.ru открыт сайт «Национального корпуса русского языка», который с тех пор активно пополняется и развивается. Это кардинально изменило облик исследований не только в области языка, но и в области литературоведения. Может ли, и должна ли в этом же направлении двигаться историография? Может ли возникнуть новая субдисциплина - корпусная историография? Нужен ли специализированный корпус исторической литературы? Как он может быть устроен? Попытаемся рассмотреть эти вопросы в методологическом плане, оставив за скобками организационно-технические аспекты.

Корпус - это не просто массив текстов, это тексты, в которых все языковые единицы размечены по множеству грамматических, семантических, тематических и прочих признаков, и снабжены многофункциональным поисковым и статистическим интерфейсом. От простых электронных библиотек, корпус отличает именно глубокая 
разметка самого текста, а не просто сопровождение его библиографическим метатекстом типа ключевых слов, аннотации и т.п. В отличие от индексирования содержания для полнотекстового поиска, разметка не просто повышает релевантность - она превращает поисковые механизмы в инструменты многомерного моделирования предметной области.

Сбалансированность состава национального корпуса означает представленность всех типов и жанров текстов, распространенных в данном языке, по возможности пропорционально их доле в языке соответствующего периода. Именно поэтому в НКРЯ почти нет научных статей и монографий по истории. Очевидно, что первый шаг к корпусной историографии - это разработка национального корпуса исторической литературы, куда начнут входить все русскоязычные тексты с исторической тематикой, в том числе переведенные тексты с билингвальным сопровождением. Исторический корпус может создаваться либо как подкорпус НКРЯ, либо как самостоятельный корпус на такой же или подобной технологической платформе. Сбалансированность для корпуса исторической литературы будет означать пропорциональность и достаточность представленности всех жанров и тематик историописания.

Второй шаг - разработка рубрикаторов для разметки текстов с учетом специфики предмета исторической науки. Третий шаг - разработка методов и алгоритмов этой разметки с учетом специфики лексико-семантических и стилистико-синтаксических особенностей исторических текстов. Наша статья посвящена в наибольшей степени второму шагу, а именно предварительному анализу особенностей исторического рубрикатора для автоматизированной разметки корпуса исторических текстов.

Автоматизация рубрикации нарративов на современном этапе наиболее успешно и активно реализуется в информационных агентствах, занимающиеся сбором и анализом медиатекстов и новостных сообщений. Методы и подходы в автоматизированном анализе медиатекстов могут быть перенесены в сферу исторической информатики и соотнесены с задачей развития корпусной историографии. В рамках методов обработки естественного языка (Natural language processing) решаются несколько типовых задач, обеспечивающих авторубрикацию, в частности, извлечении именованных сущностей (Named-entity recognition) и извлечение фреймов (FrameBased NLP System). Ниже будет рассмотрено, как данные задачи применимы к перспективам корпусной историографии. 
В рамках развития когнитивного подхода к историографии автором разрабатывается исторический предметный рубрикатор Historical Subject Headings (HiSH), апробируемый на базе конструктора комбинаторных поисковых запросов Inspert, который был создан и запущен автором данной статьи в 2015 г. по адресу http://www.lib.tsu.ru/inspert.

Для внутридисциплинарного рубрикатора наиболее подходящей представляется фасетная систематизация семантического содержания предметной области. Фасетная классификация - это совокупность нескольких независимых классификаций, осуществляемых одновременно по различным признакам в разных множествах. Внутри одного фасета может использоваться иерархическая рубрикация.

Из русскоязычных фасетно-иерархических рубрикаторов самым крупным является ГРНТИ. Рубрикатор ГРНТИ обеспечивает отнесение каждого документа к минимально необходимому числу рубрик $[2$, c. 54.]. Следует отметить что данный принцип минимизации не походит для предлагаемого исторического рубрикатора $\mathrm{HiSH}$, поскольку его задачей является максимальное вычленения всех возможных исторических и смежных с историей тематик, а не просто отнесение к одной из областей знания или деятельности, как в ГРНТИ.

В качестве наиболее успешных образцов и ориентиров фасетных научных предметных рубрикаторов автором был взят опыт тезауруса Art \& Architecture (AAT), используемый для описания предметов искусства, архитектуры и материальной культуры [3] и опыт тезауруса Медицинских предметных рубрик (MeSH - Medical Subject Headings).

Тезаурус Art \& Architecture косвенно связан с исторической тематикой, и его в первую очередь стоит рассмотреть в качество сравнительного образца. ААТ на базовом уровне содержит 7 фасетов: «Ассоциированные понятия», «Физические свойства», «Стили и периоды», «Агенты (люди и организации)», «Деятельность», «Материалы», «Объекты». Каждый фасет подразделяется на иерархии (всего 33 иерархии) и содержит общие термины, такие как «собор», но не имена собственных, такие как «Собор Нотр-Дам». Общий объем структурированного словаря в 2020 году составлял ок. 131000 терминов и 55661 концептов.

B тезаурус HiSH предварительно предлагается включить 19 фасетов (общетематических категорий или гиперонимов): 1) Концепции и теории, 2) Научные дисциплины, 3) Исторические категории, 4) Взаимосвязи событий, 5) Исторические персоналии, 6) Исторические факторы, 7) Конфликты, 8) Социальные группы, 9) Религии, 
10) Научные методы, 11) Идеологии, 12) Цивилизации, 13) Физические метафоры, 14) Материальная культура, 15) Ментальная культуpa, 16) Этносы, 17) Исторические регионы, 18) Исторические тексты, 19) Исторические периоды. В 2020 году на базе сервиса Inspert peaлизовано 15 из 19 перечисленных пунктов. При этом в HiSH в отличие от ААТ используются имена собственные, так как без них невозможно описать историческую предметную область. В сервисе Inspert на сегодняшний день задействовано более 2500 понятийных рубрик, и ещё ок. 3 тыс. исторически значимых персоналий. В дальнейшем рубрикатор и тезаурусы будут расширяться за счет корректировки и расширения тематических словарей.

В интерфейсе сервиса Inspert фасеты комбинируются в различных визуальных поисковых формах, названных клиограммами. Каждый фасет (категория) содержит иерархический список понятий, доступных в клиограмме. Например, категория «Социальные группы» всего содержит ок. 400 наименований по подгруппам: «Правители», «Земледельцы», «Светские титулы и чины», «Светские сословнопрофессиональные группы», «Военные сословно-профессиональные группы и чины», «Религиозные группы и титулы», «Территориальные группы», «Поло-возрастные группы».

Для того, чтобы обосновать преимущества принципов поиска, на которых основан Inspert, далее кратко сопоставлены подходы к выделению ключевых слов в текстах. Различные авторы по-разному именуют и определяют феномен ключевых слов [4]. Один из самых известных пионеров составления электронных тезаурусов-рубрикаторов Г. Сэлтон (Gerard Salton) [5] указывал, что для одних тематических областей словари могут быть «слабыми» (т.е. недостаточно стандартизированными и неоднозначными), тогда как в другой области - «сильными» [5, с. 67.]. Очевидно, что по историческим тематикам словари пока являются «слабыми». Комбинаторный поиск предназначен для снятия неоднозначности понятий в корпусах социогуманитарных текстов.

Выделим четыре возможных концептуальных подхода к выделению ключевых слов для предметных областей, в том числе для научных дисциплин:

1. Авторское субъективное решение о назначении ключевых слов.

2. Пользовательская интуиция и эрудиция «наедине с поисковой строкой».

3. Статистический частотный контент-анализа с автоматизированным извлечением ключевых слов и исключением неинформативных стоп-слов. 
4. Дисциплинарно-отраслевые онтологии, отображающие предметную область в форме иерархических структурированных тезаурусов, описывающих лексические родовидовые, синонимические, омонимические, антонимические и ассоциативные аспекты понятийно-терминологического аппарата.

Что касается статистического подхода, то формализованные алгоритмы полностью или частично игнорируют смысловые контексты и тематическую специфику. Кроме того, доказано, что важные для тематики текста слова не всегда являются самыми частотными, а уникальные термины часто в первую очередь сигнализируют о главной смысловой специфике текста и его информационной новизне [6]. Обзоры частотных подходов даны в некоторых отечественных работах [7].

Наиболее подходящим для корпусной историографии представляется четвертый онтологический подход. При этом структура и содержание онтологии должна быть встроена в пользовательский интерфейс поиска.

Одной из наиболее сложных задач автоматизированного анализа текстов является извлечение событийных фреймов (Fact Extraction). Фрейм может быть интерпретирован в данном случае как устойчивая комбинация семантических сущностей. Например, универсальный фактологический фрейм (в авторской интерпретации) может состоять из слотов: 1) Наименование (обозначение) события, 2) Даты события, 3) Место события (геолокация), 4) Участники события (люди, группы, организации и т.д.), 5) Объекты (материальные) связанные с событием.

Для проекта корпусной историографии рубрикатор должен содержать систематизированные перечни типов исторических событий, процессов и факторов. В сервисе Inspert в клиограмме фактологии представлен авторский список исторических факторов. Здесь представлен список из почти 300 исторических факторов, сгруппированных по типам: «Демографические», «Культурные и социальные», «Политические», «Природные», Хозяйственные (экономические)». Факторы разбиты по бинарным оппозициям - противоположно направленным явлениям и показателям. Например, увеличение численности населения / уменьшение численности населения; пополнение казны / разорение казны; расширение империи / распад империи и т.д. Каждый из пунктов при поисковом запросе сопровождается списком синонимов.

Кратко подводя итог, констатируем два ключевых заявления.

Первое. Возможность и необходимость разработки национального корпуса исторических текстов является актуальной задачей, кото- 
рая нуждается в активном обсуждении и разработке коллективных проектов в данном направлении.

Второе. Изучение комбинаторики всех понятий из различных тематических блоков Исторического предметного рубрикатора открывает новые перспективы, как для исследовательских проектов, так и для организации рубрицирования и аннотирования текстов с социальной или исторической тематикой в образовательных практиках или наукометрических сервисах.

\section{Библиография}

1. Плунгян В.А. Корпус как инструмент и как идеология: О некоторых уроках современной корпусной лингвистики // Русский язык в научном освещении. - М., 2008. - № 2 (16). - С. 7-20.

2. Гиляревский Р.С., Шапкин А.В., Белоозеров В.Н. Рубрикатор как инструмент информационной навигации. - СПб.: Профессия, 2008. -352 с.

3. Art and Architecture Thesaurus. Second Edition. 5 vols. / Toni Petersen, Director. New York: Oxford University Press, 1994.

4. Виноградова Н.В., Иванов В.К. Современные методы автоматизированного извлечения ключевых слов из текста // Информационные ресурсы России. - 2016. № $4-$ C. $13-18$.

5. Сэлтон Г. Автоматическая обработка, хранение и поиск информации. - М., 1973. $-560 \mathrm{c}$.

6. Salton G., Yang C.S. On the Specification of Term Values in Automatic Indexing // Journal of Documentation. - 1973. - Vol. 29. - No. 4. - Pp. 351-372.

7. Ванюшкин А.С., Гращенко Л.А. Методы и алгоритмы извлечения ключевых слов // Новые информационные технологии в автоматизированных системах. - 2016. № 19. - C. $85-93$.

https://doi.org/10.29003/m1805.978-5-317-06529-4/166-172

Житин Р.М., Топильский А.Г. Тамбовский государственный университет им. Г.Р. Державина

\section{«Усадебные библиотеки Тамбовской губернии конца XVIII - начала XX века»: методика создания информационного ресурса ${ }^{1}$}

Аннотация. В статье проанализированы основные подходы к созданию информационного ресурса «Усадебные библиотеки Тамбовской губернии конца XVIII - начала XX века». Проанализирована источниковая база, определены способы систематизации книжных собраний тамбовских дворян

${ }^{1}$ Исследование выполнено при финансовой поддержке РФФИ в рамках научного проекта № 19-09-00484. 
XVIII-XIX веков на русском, французском, греческом, латинском, английском и немецком языках, их значение для изучения книжной культуры региона.

Ключевые слова: усадебные библиотеки, культурное наследие, реконструкция, информационный ресурс, Тамбовская губерния.

Zhitin R.M., Topil'skiy A.G. Derzhavin Tambov State University

\section{"Manor libraries of the Tambov province of the late 18th - early 20th centuries": a method of creating an information resource}

Abstract. The article analyzes the main approaches to creating an information resource "Estate libraries of the Tambov province of the late XVIII - early XX century_. The author analyzes the source base, identifies ways to systematize book collections of Tambov nobles of the XVIII-XIX centuries in Russian, French, Greek, Latin, English and German, and their significance for the study of book culture in the region.

Keywords: manor libraries, cultural heritage, reconstruction, information resource, Tambov province.

«Усадебные библиотеки Тамбовской губернии конца XVIII начала XX века» - комплексный информационный ресурс, направленный на комплексное и всестороннее текстологическое, археографическое, источниковедческое изучение проблемы возникновения, бытования книжных собраний усадебных библиотек Тамбовской губернии как элементов провинциальной книжной культуры.

Актуальность изучения книжных собраний дворянских библиотек Тамбовской губернии обусловлена, в первую очередь, их ценностью как памятников книжной культуры XVIII-XIX веков. Среди коллекций региона имеются издания, которые могут заинтересовать зарубежных и отечественных архивистов, библиографов. В числе особо ценных памятников - издания из личных библиотек Г.Р. Державина, Воейковых, Норцовых, Волконских и других влиятельных дворянских родов России [1].

Уникальность их собраний определяется личностью самих владельцев - выдающихся государственных и общественных деятелей Российской Империи. В своих имениях они смогли аккумулировать огромные собрания, по разнообразию репертуара не уступающие библиотекам Феофана Прокоповича, Д.М. Голицына, М.В. Ломоносова, высокое значение которых неоднократно актуализировалось как отечественной, так и зарубежной историографией. 
Исследование реализовывалось на богатой источниковой базе, основой которой стали документы Государственного архива Тамбовской области (Ф. 4, Ф. 17, Ф. 181, Ф. 186, Ф. 212, Ф. 893), Государственного архива древних актов (Москва) (фонды: Ф. 1255, Ф 1261, Ф. 1263, Ф. 1289, Ф. 1375, Ф. 1379 и др.), Российского государственного исторического архива (Санкт-Петербург) (Ф. 648, Ф. 655 , Ф. 707, Ф. 840), отдела рукописей Российской государственной библиотеки (Москва) (Ф. 350, Ф. 336, Ф.334, Ф. 575, Ф.311, Ф. 486, Ф. 665, Ф. 030 и др.). Многие из источников впервые введены в научный оборот. Особого внимания заслуживают неописанные собрания книг из хранилищ Тамбовской областной универсальной научной библиотеки им. А.С. Пушкина (7510 единиц хранения). Этот массив поступил в библиотеку в начале 1920-х гг. по решению распределительной комиссии. Из-за недостатка специалистов, способных работать с иностранной литературой, дальнейшая систематизация фонда охватила только книги на русском языке. Однако их оказалось не более $10 \%$ от общего объема. Изучение и разбор остального репертуара, анализ имеющихся книжных знаков и маргиналий не производились. Об уникальности указанного собрания говорит наличие вкладных, владельческих и другие записей (в том числе на иностранных языках), характеризующих историю бытования, историко-культурную и мемориальную ценность каждого издания.

В качестве метода изучения книжных собраний региона использовался метод поэкземплярного анализа. На основании владельческих знаков (экслибрисы, маргиналии) было систематизировано неописанное ранее книжное собрание Тамбовской областной универсальной научной библиотеки им. А.С. Пушкина (7510 единиц хранения). Результаты анализа заносились в базу данных «Книжные редкости усадебных библиотек Тамбовской губернии XVIII - начала $\mathrm{XX}$ века», сочетающей разные способы представления исторической информации. Основой системы стала источникоориентированная база данных, в которой максимально полно отражается информация по книжным коллекциям. В качестве программной среды для разработки БД выбрана СУБД MS Access. Мы отказались от двухмерной структуры и выбрали вариант реляционной системы, позволяющей в простых таблицах предоставить списки соответствующих объектов. (основные элементы библиографического описания книги, принадлежность к книжной коллекции, владельческие признаки и т.д.). Для ряда объектов предусматривались дополнительные характеристики (книжный состав по содержанию и внешнему виду, владельческие 
записи, экслибрис, объем коллекции); источники комплектования (книги каких издательств преобладали, время издания книг)), представленные в виде стандартизированных списков. Применительно к характеристике читательской культуры помещиков в базе данных предусмотрены возможности внесений результатов контент-анализ нарративных источников (воспоминания и мемуары помещиков), отражающих особенности литературных предпочтений и личные характеристики владельца. Работа с книжным фондом Тамбовской областной универсальной научной библиотеки им. А.С. Пушкина позволила занести информацию о 7510 изданиях XVIII - начала $\mathrm{XX}$ века на русском, французском, греческом, латинском, английском и немецком языках, их владельческих признаках (экслибрисы, маргиналии).

Для выявления особенностей состава, развития усадебных библиотек была начата работа по контент-анализу нарративных источников (биографические данные, воспоминания и мемуары, переписка). В основе отобранных признаков (категорий) для контентанализа - выражения самих помещиков о литературных предпочтениях, степень практической значимости книжного собрания (оценка ее хозяином, современником), личные характеристики владельца (уровень образования, возраст, социальная группа и т.д.). Результаты контент-анализа будут закончены на заключительном этапе работы над проектом.

В качестве основного метода анализа происхождения и бытования книжных собраний были выбраны технологии мультипрофильного моделирования. Подход предполагает изучение усадебных коллекций с точки зрения заранее определенных ракурсов исследования (для нас это: персонологическое, аксиологическое, количественное направления). Персонологический анализ способствует разработке проблемы формирования книжных коллекций в личностном плане: исследование биографий владельцев, побудительных мотивов книгособирательства. Количественный анализ ориентирует к использованию конкретных данных о преобладающем авторском и тематическом составе собраний. Аксиологический подход предполагает изучение ценности коллекции как памятника культурного наследия, выявления значения коллекции для владельца.

Анализ дворянских библиотек в контексте отдельных профилей сочетался со сравнительно-диахроническим подходом и методом структурно-компонентного исследования. Сравнительно-диахрони- 
ческий подход помогает выявить особенности различных частных книжных коллекций региона в пространстве разных временных границ, в контексте качественных характеристик окружающей социокультурной среды.

Общенаучные методы познания применялись в работе как основание для выявления моделей развития частных библиотек Тамбовской губернии. С точки зрения системного подхода библиотеки региона исследовались с трех позиций: 1) как самостоятельный и сложный объект; 2) как компонент региональной и национальной культуры; 3) как фактор развития усадебной культуры в регионе. Аналитико-интерпретативный метод помогал «вписать» личные библиотеки (или их фрагменты) края в общую панораму научных представлений о феномене личной библиотеки. Структурно-компонентный метод позволил представить собрания владельцев как сложную коммуникационную систему, основу которой составляла взаимосвязь книги и читателя.

В ходе исследования применялись библиотековедческие подходы к изучению библиотечно-усадебной культуры. Среди них: 1) библиотековедческий системный подход, разработанный Ю.Н. Столяровым; 2) теория документальных потоков, наиболее полно разработанная в трудах Г.Ф. Гордукаловой; 3) результаты категориального анализа библиографического знания, предпринятого В.А. Фокеевым. Применение библиотековедческих знаний обуславливалось рядом обстоятельств. Несмотря на множество историко-археографических трудов, посвященных описанию и комментированию конкретных явлений личных библиотек, живое бытование этих книг в помещичьей среде, т.е. собственно библиотечная сторона дела, обычно остается за рамками исследований. Это приводит, во-первых, к изучению, главным образом, текстов в отрыве от книги как целостности и, во-вторых, к игнорированию общественных и культурных отношений, складывающихся вокруг собраний.

Другая важная причина библиотековедческого подхода в целом обуславливалась тем, что хотя формой самоорганизации помещика как общественной системы в принципе является усадебный быт, вместе с тем помещичья библиотека на протяжении большей части истории также могла претендовать на такой центральный статус. Со временем дворянская библиотека постепенно начинала представлять смысловое ядро, вокруг которого концентрировалась хозяйственная деятельность, и полицентричность, когда традиционные домашние формы приобщения к чтению становились определяющими в любом 
векторе направлений многоплановой жизни человека. Усадебная книжность в течение столетий имела определенную систему функционирования и массового использования, обладающую собственными устойчивыми чертами. В этой ситуации библиотеку можно рассматривать одним из важнейших элементов усадебного быта и жизни.

В ходе проведенной работы был выявлен и проанализирован массив опубликованных и архивных документов, удалось выполнить научное описание и анализ 7510 экземпляров книг на русском французском, греческом, латинском, английском и немецком языках, системные сведения о которых на сегодня отсутствуют в историографии и фигурировали лишь в качестве отдельных упоминаний в трудах местных краеведов. Анализ выбранного собрания по чертам владельческого пользования (экслибрисы, маргиналии) позволил создать новые и дополнить уже существующие книжные коллекции. В общей сложности были созданы 28 новых книжных коллекций владельцев усадеб Тамбовской губернии (в том числе Вышеславцевых, Петрово-Соловово, Бенкендорфов и др.), дополнены новыми изданиями собрания Л.А. Воейкова, Г.Р. Державина, А.Д. Хвощинского, А.Н. Норцова, Кугушевых, Поленовых. Практически полностью реконструирована библиотека А.В. Вышеславцева, состоящая из 343 книг на иностранных языках, купленных в 50-80-х годах XIX века в странах Западной Европы [2]. Об историко-культурной ценности собранных коллекций говорит тот факт, что многие книги личных библиотек владельцев имений Тамбовской губернии являются раритетами и числятся в крупнейших библиотеках зарубежных стран в единичных экземплярах.

Результаты работы были обощены в рамках действующей модели информационно-поисковой системы «Усадебные библиотеки Тамбовской губернии конца XVIII - начала XX века» с удобными инструментами поиска, визуализации данных, а также с достаточным для работы в пилотом режиме объемом информационного контента. При разработке системы использовались следующие технологические решения: клиент-серверная технология распределенной обработки данных, программная среда для разработки веб-приложений PHP, свободная объектно-реляционная СУБД MySQL. B качестве веб-сервера задействован веб-сервер Арасhе под управлением операционной системы Linux. При создании клиентской части использованы технологии HTML и CSS с поддержкой JavaScript. Пользовательский интерфейс обеспечивает возможности высокоско- 
ростного интеллектуального поиска данных в разделах ресурса. Вся актуальная информация помещена в едином хранилище данных (СУБД объектно-реляционного типа) и с помощью специальных алгоритмов выводится на отдельные страницы ресурса. Таким образом, за счет создания хранилища данных, в работе был реализован принцип единства контента.

Структура ресурса построена на основе взаимосвязанных разделов (модулей), доступ к которым осуществляется через навигационное меню, наследуемое на всех страницах сайта (http://tambov.ru.net/ libraries/). Структура сайта включает в себя информацию о целях и задачах реализации проекта, методике предпринятого исследования, раздел с библиографическими описаниями 7510 книг, проанализированными в ходе реализации проекта, научными статьями первого этапа реализации проекта, анализом выявленных книжных коллекций. Аналитические возможности ресурса позволяют систематизировать книжное собрание по заглавию, автору, месту выпуска, издательству, году издания, тематике книги или по всем полям одновременно, принадлежности к владельческой коллекции. К концу 2020 года структура сайта будет дополнена: 1) полнотекстовой библиотекой изданий ряда книжных коллекций региона; 2) галереей выявленных экслибрисов с описанием их историко-культурной ценности и художественных особенностей.

Создание ресурса актуально с точки зрения популяризации культурного наследия Тамбовщины, имеющего не только локальнорегиональное, но и федеральное значение. Разработанный ресурс способен стать опытной площадкой для интернет-представительства ранее неизвестных книжных памятников, поможет привлечь внимание к проблеме изучения книжной культуры региона в прошлом.

\section{Библиография}

1. Патрина Л.Н. Книжные собрания дворянских библиотек Тамбовской губернии конца XVIII - начала XX века. Проблема реконструкции и анализа книжного наследия / Л.Н. Патрина, Р.М. Житин // Румянцевские чтения - 2019: материалы международной научно-практической конференции (23-24 апреля 2019). - М., 2019. C. $277-280$.

2. Патрина Л.Н. Личная библиотека как отражение истории жизни и творчества А.В. Вышеславцева / Л.Н. Патрина, М.В. Сабетова // Неофилология. - Тамбов, 2019. T. 5. - № 20. - C. 549-557. 
https://doi.org/10.29003/m1806.978-5-317-06529-4/173-177

Ильин А.Ю.

Тамбовский филиал Российской академии народного хозяйства и государственной службы при Президенте РФ)

Лямин С.к.

Тамбовский государственный университет им. Г.Р. Державина

\section{Электронная Тамбовская энциклопедия:}

\section{функциональные возможности и перспективы развития проекта}

Аннотация. В статье представлены результаты реализации проекта по созданию электронной Тамбовской энциклопедии. Особое внимание уделено анализу возможностей Wiki-платформы, на которой создаётся электронная энциклопедия.

Ключевые слова: электронная энциклопедия, wiki-платформа, краеведение.

Ilyin A.Ju.

Tambov Branch of the Russian Academy of National Economy and Public Administration under the President of the Russian Federation

Lyamin S.K.

Derzhavin Tambov State University

\section{Electronic Tambov Encyclopedia: Functionality and Prospects for Project Development}

Abstract. The article presents the results of the implementation of the project to create an electronic Tambov encyclopedia. Particular attention is paid to the analysis of the capabilities of the Wiki-platform on which the electronic encyclopedia is created.

Keywords: e-encyclopedia, wiki platform, local history.

16 лет назад, в 2004 г. под редакцией Л.Г. Протасова вышло первое издание «Тамбовской энциклопедии». Это уникальное справочное издание, в подготовке которого учувствовали десятки специалистов из различных отраслей знания, востребовано до сих пор. Тем не менее, 15 лет - большой срок. За этот период появилось много новой информации, обнаружились неточности в издании 2004 г. и назрела необходимость переиздания энциклопедии.

4 сентября 2017 г. Администрацией Тамбовской области было подписано постановление «О переиздании Тамбовской энциклопедии и создании постоянно действующего ресурсного информационно-аналитического центра «Электронная энциклопедия Тамбовской области»». Фактически в области при поддержке Администрации 
области была инициирована реализация большого проекта по сохранению историко-культурного наследия и развитию просветительской инфраструктуры региона.

Уже три года идёт большая работа по подготовке переиздания печатной версии Тамбовской энциклопедии. Энциклопедия должна выйти в свет в конце 2020 г. Новая энциклопедия по объёму публикуемого материала, количеству статей и иллюстративного материала вдвое больше первого издания. В ней 6438 статей. Существенно увеличена информация по разделам: административно-территориальное деление, общественно-политическая жизнь, природа, спорт, театр и кино, образование, медицина, религия и церковь, экономика, сельское хозяйство, наука. Если в первом издании почти две трети объёма составляли биографические статьи, то теперь при общем увеличении их количества около половины всего материала -это статьи тематические и обзорные.

В новой энциклопедии содержатся статьи о всех существующих населённых пунктах Тамбовской области. В предыдущем издании использовался критерий «крупное старинное село» и материал был представлен лишь о 364 населённых пунктах. Представлена информация о всех административных единицахТамбовской области в соответствии с Законом Тамбовской области от 21 июля 1996 № 72-3 «Об административно-территориальном устройстве Тамбовской области» (с изменениями на 6 февраля 2019 г.): 8 городах, 23 муниципальных районах, 1741 населённом пункте. Основная часть статей о населённых пунктах невелика по объёму, содержит лишь сведения о дате возникновения, версиях происхождения названия, численности населения. Часть - уже исчезающие поселения, существуют лишь формально. Мы посчитали необходимым зафиксировать их в энциклопедии, дав возможность будущим исследователям расширить информацию. История отдельных сёл освещена на основе опубликованных материалов, а также информации, предоставленной редакционному совету местными администрациями. Весьма интересной в исследовательском отношении мог бы стать проект по пополнению в дальнейшем электронной энциклопедии статьями об исчезнувших населённых пунктов Тамбовского края.

Отдельный пласт информации - материалы по административнотерриториальному устройству региона в разновременном формате. На протяжении столетий административная карта Тамбовщины претерпела немало изменений. Редакция посчитала целесообразным подготовить достаточно подробные разноплановые статьи о Тамбовской губернии и её уездах, Центрально-Чернозёмной области, терри- 
ториальном устройстве Тамбовской области во второй половине $\mathrm{XX}-\mathrm{XXI}$ вв.

В издании относительно широко представлена история края начиная с древнейших времён. Отказавшись от специального отдельного очерка, составители энциклопедии сознательно расширили конкретные исторические сюжеты. Учитывая традиционно высокий интерес общественности к ископаемым древностям, в издании помещены статьи о всех сколько-нибудь изученных археологических памятниках и культурах, тамбовской археологии в целом. Представлены статьи о Древнерусском государстве, Рязанском княжестве, Верхоценской дворцовой волости, в состав которых в XI - первой трети XVII в. входила часть территории современной Тамбовской области. В издании размещена серия материалов о военно-административных единицах XVII в. (оборонительные линии, крепости, военные городки), которые стали остовом, каркасом заселения края.

Особое место в энциклопедии занимают важные, знаковые для Тамбовщины события. Одни из них представляли собой отклик на общероссийские (крестьянские восстания под предводительством С. Разина и Е. Пугачёва). Другие, напротив, имели региональный масштаб, но в силу исторических обстоятельств становились общезначимыми (крестьянское XIX в., столыпинское переустройство деревни в начале XX в., новая экономическая политика 1920-х гг. и др.). Обширный ряд статей посвящён вкладу тамбовчан в общегосударственные военные события от обороны южных рубежей России в XVII в. до Великой Отечественной войны 1941-45 гг.

С конца 2018 года, при поддержке гранта Администрации области, осуществляется проект по созданию wiki-платформы для размещения в сети Интернет Тамбовской энциклопедии [1].

Wiki-платформа представляет собой информационную систему, предназначенную для аккумуляции и структурирования больших массивов знаний из разных источников. Только на wiki-платформе имеется возможность организовать краудсорсинговые кампании, привлекая множество авторов к совместной разработке конечного интеллектуального продукта. Вместе с тем, подобные ресурсы содержат инструменты, которые позволяют редакторам полностью контролировать содержание статей, отслеживая правки и дополнения авторов, историю изменений статей.

Wiki-платформы являются современным и признанным инструментом для создания энциклопедий. Примеры подобных платформ многочисленны, начиная от глобальной Википедии и заканчивая кор- 
поративными базами знаний. Одна из самых известных в мире энциклопедий - Британская энциклопедия (Британника) - сейчас базируется на wiki-платформе: https://www.britannica.com.

В перспективе - по мере заполнения Тамбовской энциклопедии - этот Интернет-ресурс станет наиболее качественным, авторитетным и доступным источником информации о современном состоянии и истории региона, о людях, учреждениях, предприятиях и событиях для преподавателей и учащихся школ, колледжей и вузов Тамбовской области, для всех жителей области, интересующихся современным состоянием и историей региона, для научного и экспертного сообщества.

Wiki-платформа постепенно должна стать основой организации всей редакционной работы. Ведь необходимо создать эффективный механизм для систематизации крупных информационных массивов и для организации сетевого взаимодействия множества авторов и редакторов. Являясь главным фундаментальным комплексным источником сведений об истории, людях, достижениях и современном состоянии региона, энциклопедия нуждается в существенном обновлении и уточнении. Вне энциклопедии накопилось большое количество данных, которые должны быть упорядочены и включены в энциклопедию. Эти трудоёмкие задачи наиболее эффективно могут быть решены при помощи wiki-платформы.

Создание wiki-платформы означает переход энциклопедии в новый формат. Во-первых, в отличие от бумажной версии, это будет постоянно обновляющийся ресурс. Постоянная актуализация сведений в системе, конечно, подразумевает, что работа редакции перестанет быть эпизодической. Во-вторых, к пополнению и уточнению статей энциклопедии можно будет привлечь существенно больше авторов при сокращении организационных усилий как со стороны самих авторов, так и редакторов. Wiki-платформf предоставляет авторам удобные и простые для пользователя инструменты создания статей, обсуждения правок и, в то же время, даёт редакторам возможность видеть все правки, сравнивать версии текстов, выбирать необходимые версии, публиковать готовые статьи и закрывать от читателя статьи, находящиеся на стадии редактирования.

Для создания платформы использована система управления контентом (CMS) TikiWiki CMS/Groupware. Эта CMS обладает рядом характеристик, которые делают её удобной для проекта. Базовая версия CMS бесплатна (включая обновления), поэтому имеется возможность неограниченно использовать её в будущем. TikiWiki CMS/Groupware обладает широким функционалом и даёт возмож- 
ность создавать наиболее сложные и масштабные Интернет-ресурсы. Помимо wiki-функционала, она содержит инструменты для создания и поддержания форумов, блог-платформ, социальных сетей, информационных бюллетеней, проведения опросов и многое другое. Это программное решение позволит проекту развиваться в обозримом будущем, не ограничиваясь рамками исходных задач.

TikiWiki CMS/Groupware имеет довольно обширную поддержку со стороны многочисленного международного сообщества разработчиков (в частности, сама CMS и модули к ней регулярно обновляются, совершенствуются в плане функционала и безопасности).

Среди наиболее интересных и перспективных функциональных возможностей отметим следующие сервисы:

1. Сервис «В этот день» - привязка энциклопедического контента к календарю, позволяющая оперативно подготавливать и осуществлять презентацию отдельных хронологических выборок по событиям, песоналиям, объектам, собранных в энциклопедии.

2. Сервис «Это место» - пространственная локализация энциклопедического контента, позволяющая размещать сведения о событиях, персоналиях и объектах в различных картографических приложениях.

Мы стремились обеспечить максимальную интеграцию электронной Тамбовской энциклопедии в национальное электронное энциклопедическое пространство. Во-первых, статьи Тамбовской энциклопедии содержат гиперссылочный аппарат на статьи ведущих энциклопедий страны (Электронная Большая Российская энциклопедия, Электронная Православная энциклопедия и т.д.). Во-вторых, общий дизайн сайта Тамбовской энциклопедии максимально приближен по своей структуре к Электронной Большой Российской энциклопедии, что облегчает пользователю параллельную работу с двумя разными энциклопедическими контентами.

На данный момент wiki-платформа прошла процедуру тестирования и начала свою работу в сети Интернет и стала доступна пользователям. Процесс аккумуляции справочной информации о регионе станет постоянным процессом, в который будут вовлечены десятки специалистов. Таким образом, в регионе будет сформировано уникальное экспертное сообщество, работающее в рамках постоянно действующего ресурсного информационно-аналитического центра «Электронная энциклопедия Тамбовской области».

\section{Библиография}

1. Тамбовская энциклопедия - URL: https://tambweb.ru) 
https://doi.org/10.29003/m1807.978-5-317-06529-4/178-183

Лuxmep Ю.A.

ООО Археологические изыскания в строительстве, Москва

\section{Статистический и информационный подходы} к изучению древних артефактов и реляционная база данных

Аннотация. Доклад посвящён исследованию древних артефактов по методике Ю.Л. Щаповой. Группировке артефактов с помощью статистических методов предшествует исследование признаков, описывающих эти артефакты. Описание понимается как информационно насыщенная система. Признаки выбираются обобщённые, например, набор конструктивных элементов (часть вещи, выделенная морфологически). Как пример, приводятся два исследования автора, основанные на предложенной методике.

Ключевые слова: информационная система; древние артефакты, археологические типологии; московская керамика, стекло черняховской культуры.

Likhter Yu.A. LLC Archaeological research in construction, Moscow

\section{Statistical and informational approaches to the study of ancient artifacts and a relational database}

Abstract. The topic of the report is the study of ancient artifacts by the method of Yu.L. Shchapova. The grouping of artifacts using statistical methods is preceded by the study of the features that describe these artifacts. Description is understood as an information-rich system. Generalized features are chosen, for example, a set of constructive elements (a part of a thing, distinguished morphologically). As an example, two studies of the author are cited based on the proposed methodology.

Keywords: information system; ancient artifacts, archaeological typologies; Moscow ceramics, glass from Chernyakhov culture.

При проектировании любой базы данных возникает вопрос, по каким принципам вводить данные. В археологии, как правило, компьютерные технологии подключают не просто после описания материала, но после первичной обработки материала - материал вводят, подчиняясь определенной задаче. На этом настаивает, к примеру, А.С. Смирнов [1, с. 6]. Однако такой подход лишает исследователя возможности использовать созданную БД для решения других проблем.

Следствием этого подхода можно также считать то, что большинство исследователей при изучении археологического материала, в первую очередь вещественных источников (артефактов), используют для их группировки различные статистические пакеты, основанные на комбинировании множества признаков, но эти признаки выбирают произвольно. 
Можно предложить и другой подход. Вводить весь материал, не интерпретированный, но структурированный и описанный в соответствии с определенными правилами. То есть вводятся не созданные автором классификации, а аналитические описания каждого объекта.

Язык такого описания и алгоритм классификации вещей был разработан участниками семинара «Морфология древностей», который работал на кафедре археологии исторического факультета МГУ под руководством профессора Ю.Л. Щаповой с 1989 по 2006 гг. [2, $3,4,5,6,7,8,9,10,11,12,13.14,15,16,17,18,19,20,21]$.

После ввода в базу полного описания из него можно выбирать признаки, необходимые для решения задачи, которую исследователь перед собой поставил. Из них создается дополнительная таблица, которая может быть импортирована в любой статистический пакет. Принципы отбора этих признаков представляют отдельную методическую проблему.

Дифференциация, то есть отбор признаков, необходимых для исследования, по мнению Ж.-К. Гардена, - одна из важнейших исследовательских операций [22. с. 208]. Как правило, при этом наибольшее внимание уделяется выбору диагностических, или, как их еще называют, работающих признаков, по которым можно группировать артефакты [23, с. 26]. Разным исследователям существенными кажутся разные признаки. Не существует общепринятого представления, какие признаки являются существенными, какие нет. Л.С. Гераськова считает, что такие признаки каждый исследователь интуитивно выбирает сам [24, с. 31].

Полученные в результате такого подхода группировки (по археологической терминологии - типологии), как правило, нельзя использовать в дальнейшем исследовании. К такому выводу, критически рассмотрев разнообразные типологии, пришёл Л.С. Клейн. Поэтому автор предложил вовсе отказаться от формально-типологического рассмотрения материала и перейти к изучению типов внутри культуры [25, с. 85].

Однако, изучение типов внутри культуры во многих случаях недостаточно. Существуют научные проблемы, неразрешимые с точки зрения отдельной культуры. К примеру, типы, выделенные внутри одной культуры, сложно состыковать с типами в другой. В то же время импорты могут быть одними и теми же в разных культурах, несмотря на то, что они играют там разную роль. Если одинаковые вещи (импорты) внутри разных культур - это разные культурные типы, где место того, что их объединяет? Играет ли какую-нибудь 
роль общность происхождения? Кроме того, замена формальнотипологического метода культурно-историческим подходом не отменяет необходимости выбора признаков для сравнения, поскольку сравнение необходимо проводить по каким-то признакам.

Очевидно, для решения этой задачи недостаточно привычных археологических методов. Ю.Л. Щапова предложила иной путь. По её мнению, группированию и исследованию вещей необходимо предпослать исследование признаков, а статистическому определению веса признака необходимо предпослать его логический анализ. Статистический подход, при котором редко встречающиеся признаки отметаются как несущественные, Ю.Л. Щапова предложила предварять информационным, когда учитывают наличие признака как таковое, вне зависимости от частоты встречаемости. Полный набор признаков выражает информационное разнообразие выборки, а сам признак - это своего рода единица информации. [6. с. 105].

Ещё одной особенностью создания типологий можно считать то, что при этом используют большое количество признаков, описывающих мелкие детали. В результате получающиеся группы не обобщают, а выделяют индивидуальности. По мнению Ю.Л. Щаповой, на первоначальном этапе исследования надо использовать немногие крупные, обобщённые признаки.

Так, в частности, при изучении морфологии вещей, по мнению Ю.Л. Щаповой, помимо формы (внешнего контура) существенное значение имеет конструкция, которая складывается из конструктивных элементов (часть вещи, выделенная морфологически), каждый из которых имеет ту или иную форму [26, с. 23-24].

Для посуды Ю.Л. Щапова наметила следующий путь изучения конструкции. У сосуда можно выделить десять конструктивных элементов: край, венчик, горло, тулово, дно, поддон, ручка, ножка, подножка, носик.

Край, тулово и дно составляют основу сосуда, остальные конструктивные элементы к ней добавляются. Число возможных сочетаний основы с другими конструктивными элементами может быть вычислено по формуле $2^{\mathrm{n}}$, где $\mathrm{n}$ - число конструктивных элементов, прибавляемых к основе. У сосудов $\mathrm{n}=7$, то есть $2^{7}=128$. Простейший конструктивный класс состоит из одной основы, а наиболее сложный из основы, венчика, горла, поддона, ручки, ножки, подножки и носика $[14$, с. 9-10; 3, с. 170-177].

Предложенную классификацию можно рассматривать как генеральную для всех возможных сосудов. В конкретной культуре будет представлена только какая-то их часть. Однако сопоставление выде- 
ленного набора с генеральной классификацией поможет точнее выявить его специфику. Как примеры применения предложенного подхода, приведём два исследования.

Рассматривая с этой точки зрения конструкции московской керамической посуды, мы учли классы от 1 до 80, так как последующие, включающие различные комбинации поддона, ножки и подножки друг с другом, в московской керамике не встречаются и вообще очень редки. На схему, предложенную Ю.Л. Щаповой, мы наложили определения конструкций вещей, опубликованных у Р.Л. Розенфельда [27]. Из возможных восьмидесяти классов здесь представлено 26.

Эти конструкции можно сопоставить с функциональными формами, такими как горшок, миска, кувшин. Однозначного соответствия здесь не наблюдается, каждой конструкции может соответствовать несколько форм. Дальнейшее упорядочение таблицы по функциональным формам сосудов дает возможность установить, что более сложные конструкции, соответствующие какой либо из функциональных форм - хронологически более поздние. Если взять, к примеру, миску, то соответствующие ей номера конструкций будут иметь следующие даты: № 1, основа: XII-XIII века; № 2, основа с венчиком: XV-XVI века; № 6, основа с венчиком и поддоном XVIII век.

Появление новых, более сложных конструкций имеет скачкообразный характер. Скачки происходят в XII веке, в XIV, XV, XVI веках. Наибольшее число новых конструкций появляется в XV веке.

Сопоставление времени появления новых конструкций, со временем появления тех или иных типов керамики, на основе гистограммы, составленной С.3. Черновым [28, рис. 2, с. 58], позволяет сделать вывод, что скачки в конструктивном разнообразии совпадают с появлением новых типов керамики.

Таким образом, изучив конструкции московской керамики XII$\mathrm{XV}$ веков, и сопоставив их с видом керамического теста, авторы пришли к выводу, что каждый скачок в улучшении качества теста и обжига приводил к появлению новых, все более сложных конструкций. По-видимому, московское керамическое ремесло находилось на этапе освоения керамической технологии. [29, с. 91].

Другой пример использования этой методики - изучение стеклянных сосудов на территории черняховской культуры. Среди них преобладают простые конструкции - основа (класс 1), к которой 
прибавлены поддон и венчик - либо по отдельности (классы 2 и 5), либо вместе (класс 6). Формы с горлом единичны (класс 8). То есть преобладают сосуды для питья.

При этом по форме низа их можно разделить на две группы: сосуды с неустойчивым (сферическим и коническим) дном и устойчивые сосуды (плоское дно, поддон). Можно предполагать культурную детерминированность этих форм. Сосуды с неустойчивым дном характерны для варварских форм пира, устойчивые сосуды использовались на античных симпосиях [30, с. 92].

Для московской керамической посуды - существенно соотношение конструкции и материала, для черняховской стеклянной - соотношение конструкции и функции. В обоих случаях для группировки не потребовались сложные статистические процедуры. Достаточно характеристики на качественном уровне, но при этом существенным оказывается учёт всех вариантов рассматриваемого признака вне зависимости от частоты встречаемости.

\section{Список литературы}

1. Смирнов А.С. Компьютерные базы данных в археологии. // Базы данных в археологии. - М., 1995. - С. 3-9.

3. Щапова Ю.Л. Древнее стекло. Морфология, технология, химический состав. М.: Изд-во МГУ, 1989. - 120 с.

4. Щапова Ю.Л. Программа изучения керамики //Древнерусская керамика. - М.: Наука, 1992. - С. 170-177

5. Щапова Ю.Л. Описание, классификация и эволюционные закономерности в развитии вещей // Российская археология. - 1994. - № 2. - С. 81-91

6. Щапова Ю.Л. Можно ли построить общую классификацию древнего вещного мира? // История и эволюция древних вещей. - М.: Изд-во МГУ, 1994. - С. 43-49.

7. Щапова Ю.Л. Лингвистическое обеспечение баз данных по археологии. // Компьютеры в археологии. - М.: ИА РАН, 1996. - С. 104-108.

8. Щапова Ю.Л., Лихтер Ю.А., Столярова Е.К. Морфология древностей. - Киев: Общество «Знание» Украинской ССР, 1990. - 92 с.

9. Щапова Ю.Л., Лихтер Ю.А., Сарачева Т.Г., Столярова Е.К. Основные принципы изучения древних материалов и технологий // Вестник МГУ Сер. 8. История. 2000. - № 4 - C. 102-109.

10. Щапова Ю.Л., Лихтер Ю.А., Сарачева Т.Г., Столярова Е.К. Морфология украшений. Морфология древностей, вып. 4. - М.: Книжный дом Университет, 2007. $100 \mathrm{c}$.

11. Кокорина Ю.Г., Лихтер Ю.А. Проникающее оружие и орудия. Морфология древностей, Вып. 3. 2-ое издание - М.; Тула: Гриф и К., 2009. - 126 с.

12. Кокорина Ю.Г., Лихтер Ю.А. Логическая система изучения декора // Вестник МГУ Сер. 8. История. - 1999. - № 2. - С. 113-120

13. Кокорина Ю.Г., Лихтер Ю.А. Морфология декора. 2-ое изд. - М.: URSSкнижный дом «Либраком», 2010. - 199 с. 
14. Лихтер Ю.А. Структура базы данных для описания вещей // Круг идей: развитие исторической информатики. - М.: Мосгорархив, 1995. - С. 357-369.

15. Лихтер Ю.А., Щапова Ю.Л. Замечания и пояснения к машинной версии программы «Сосуды» // Артефакт, программный продукт по археологии. - М.: СП Диалог, центр в МГУ. - С. 3-33. (не опубликовано).

16. Лихтер Ю.А., Столярова Е.К. Конструктивная классификация некоторых предметов материальной культуры древности // Теория и практика классификации и систематики в народном хозяйстве. Тезисы. - М., 1990 - С.149-150.

17. Осипов Д.О, Лихтер Ю.А. Системное описание и классификация кожаной обуви. Методические рекомендации. - М.: ИА РАН, 2004. - 66 с.

18. Сарачева Т.Г. Металлические перстни Днепровского Левобережья // История и эволюция древних вещей. - М.: Изд-во МГУ, 1994. - С. 85-99.

19. Столярова Е.К. Конструктивная классификация крестов // История и эволюция древних вещей. - М.: Изд-во МГУ, 1994. - С. 80-84.

20. Черных Е.М. Классификация построек // История и эволюция древних вещей. М.: Изд-во МГУ, 1994. - С. 50-54.

21. Черных Е.М. Жилища Прикамья. Эпоха железа. - Ижевск: УдмГУ, 2008. $271 \mathrm{c}$.

22. Фалькович Ю.А. Древнеегипетские амулеты // Щапова Ю.Л., Лихтер Ю.А., Столярова Е.К. Морфология древностей. - Киев: Общество «Знание» Украинской CCP, 1990. - С. 61-65.

23. Гарден Ж.-К. Теоретическая археология. - М.: Прогресс, 1983. - 294 с.

24. Каменецкий И.С., Маршак Б.И., Шер Я.А. Анализ археологических источников. - М.: Наука, ГРВЛ, 1975. - 172 с.

25. Гераськова Л.С. О создании базы археологических данных на Украине // Компьютеризованные банки данных музейной и археологической информации. Материалы межведомственного рабочего совещания. Тбилиси, 22-26 февраля 1988 г. Тбилиси: Мецниереба, 1988. - С. 31-34.

26. Клейн Л.С. Археологическая типология. - Л.: ЛФ ЦЭНДИСИ, 1991. - 447 с.

27. Щапова Ю.Л. Естественнонаучные методы в археологии. - М.: Изд-во МГУ, 1988. - $150 \mathrm{c}$.

28. Розенфельд Р.Л. Московское керамическое производство XII-XVIII вв. - М.: Наука. 1968. - 123 с.

29. Чернов С.3. К хронологии московской керамики XV-XVI веков // Московская керамика. Новые данные по хронологии. - М.: ИА РАН, 1991. - С. 50-61.

30. Лихтер Ю.А., Осипов Д.О. Московская керамика и керамическое ремесло // Российская археология. - 1995. - № 3. - С. 77-91.

31. Лихтер Ю.А. Стеклянная посуда черняховской культуры // Вещь в контексте культуры. Материалы научной конференции. - СПб: ИИМК РАН, 1994. - С. 91-92. 
https://doi.org/10.29003/m1808.978-5-317-06529-4/184-190

Ловцов В.А.

Тамбовский государственный университет им. Г.Р. Державина

\section{«Губернаторский корпус при П.А. Столыпине: 1906-1911 гг.»: первые результаты работы с базой данных ${ }^{1}$}

Аннотация. В статье рассмотрены этапы создания просопографической базы данных «Губернаторский корпус при П.А. Столыпине: 1906-1911 гг.», ее исследовательский потенциал и первые результаты работы с базой данных. Проанализирована динамика назначений губернаторов в европейской России при П.А. Столыпине. Сделаны выводы о том, что большая часть назначенных при П.А. Столыпине губернаторов заняли этот пост впервые. Отмечена роль вице-губернаторской должности как этапа в карьере губернатора при П.А. Столыпине.

Ключевые слова: губернаторский корпус, губернатор, база данных, П.А. Столыпин, Российская империя.

Lovtsov V.A.

Derzhavin Tambov State University

\section{«The Governor's Corps under P.A. Stolypin: 1906-1911»: the first results of working with the database}

Abstract. The article discusses the stages of creating a prosopographic database «The governor's corps under P.A. Stolypin: 1906-1911», its research potential and the first results of working with the database. The dynamics of the appointment of governors in European Russia under P.A. Stolypin is analyzed. It is concluded that most of the governors appointed under P.A. Stolypin took this post for the first time. The role of the vice-governor's office as a stage in the career of the governor under P.A. Stolypin is noted.

Keywords: governor's corps, governor, database, P.A. Stolypin, Russian Empire.

В просопографической базе данных «Губернаторский корпус при П.А. Столыпине: 1906-1911 гг.» объединена биографическая и карьерная информацию о чиновниках, занимавших должность гражданского губернатора с апреля 1906 г. по сентябрь 1911 г. в губерниях, управляемых по Общему учреждению губернскому [1, с. 2-149]. Финалом составления базы данных станет формирование сплошных рядов данных о служебных биографиях губернаторов.

Целью создания базы данных стало выявление через количественный анализ профессиональных качеств, предъявляемых к кан-

\footnotetext{
${ }^{1}$ Исследование проводится при поддержке гранта РФФИ, № 20-39-90026.
} 
дидатам в губернаторы в этот период, факторы формирования губернаторского корпуса и особенности карьерной динамики чиновников, занимавших этот пост. База данных поможет понять, каким образом произошедшие в Российской империи изменения общественно-политической жизни и осуществление программы реформ П.А. Столыпина могло отразиться на подходах к формированию провинциальной администрации. Помимо этого, будет реконструирован социальный облик губернаторов этого периода.

Для создания базы данных использовалась программа MS Access.

Источниками информации для составления списка губернаторов и их ротаций в этой должности между губерниями послужили биографические справочники: «Губернии Российской империи. История и руководители. 1708-1917» [2], «Высшее чиновничество Российской империи. Краткий словарь» [3], «Государственные деятели Российской империи. Главы высших и центральных учреждений. 1802-1917» [4].

Остальная необходимая информация содержится в формулярных списках губернаторов. Перемещение чиновников по должностям на всех этапах карьеры можно уточнить при помощи служебных адрескалендарей различных ведомств Российской империи.

На первом этапе создания базы данных при помощи справочной литературы были сформированы списки губернаторов, занимавших пост в период с апреля 1906 г. по сентябрь 1911 г. в губерниях, управляемых по Общему учреждению губернскому.

Затем была собрана биографическая информация о губернатоpax, такая как фамилия, имя, отчество, даты и места рождения и смерти, наличие дворянского титула и вероисповедание.

На следующем этапе в базу данных были внесены сведения о наименовании законченных губернаторами учебных заведений, уровне и типе полученного образования.

Карьера каждого чиновника была разложена на ряды данных, содержащих информацию о продвижении по классным чинам Табели о рангах, с привязкой к последовательности занимаемых в каждом чине должностей.

Для каждого чина отмечена дата присвоения, номер класса чина и его тип: статский, военный или придворный.

Каждая запись о должности содержит в себе информацию о хронологических рамках нахождения в должности, конкретной организации, в которой работал чиновник, ее ведомственном подчинении и географической локализации. 
Таким образом, база данных позволяет проанализировать вертикальную мобильность в бюрократической иерархии Российской империи - динамику повышения в должности и повышения в чине, и горизонтальную мобильность - динамику перемещения в равных по классу чина должностях, а также типизировать модели карьер чиновников, достигнувших уровня губернатора.

Повышение в должности не всегда соответствовало повышению в чине, а повышение в чине не гарантировало повышения в должности [5, с. 17]. Это связано с тем, что должностей высокого класса чина было меньше, чем низкого, в то время как количество претендентов на них не уменьшалось из-за особенностей сроков выслуги чинов по Табели о рангах. В таких случаях роль в назначении играли дополнительные факторы, такие как личные и деловые качества, а также принадлежность к влиятельным сетевым группам бюрократии. Выявление наиболее успешных чиновников с помощью анализа представленных в базе данных сведений позволит обратить более пристальное внимание на их карьеры и проанализировать сопутствующие успеху факторы.

На основе анализа представленных в базе данных рядов данных создано несколько классификаций, позволяющих лучше понять функционирование губернаторского корпуса и чиновного мира начала XX в. В первую очередь, губернаторы разделены по критерию продолжительности службы в губернаторском корпусе и вхождению в него до или после того, как П.А. Столыпин возглавил МВД. Подобная классификация помогает выявить те критерии, которые предъявлялись к губернаторам непосредственно во время службы, какие их действия приводили к отставке, а какие практики службы способствовали дальнейшему карьерному продвижению.

Кроме того, карьеры губернаторов классифицированы по типам занимаемых на предшествующей службе должностей: был ли губернатор провинциальным деятелем или служил в центральных столичных ведомствах, были ли это военные или гражданские должности. Вся информация систематизирована и проанализирована в динамике как для отдельных губерний и хронологических отрезков, так и для всей совокупности в целом.

Первым результатом работы с базой данных стало формирование рядов данных по губернаторским назначениям, которые включают себя название губернии, даты начала и окончания службы, а также о занимаемых каждым чиновником постах вице-губернатора.

Анализ этих данных позволил описать динамику назначений губернаторов при П.А. Столыпине. Также был рассмотрен вопрос о 
наличии у кандидатов в губернаторы предшествующего опыта вицегубернаторской службы.

Эти аспекты функционирования губернаторского корпуса, но в несколько других хронологических и географических рамках рассмотрены в исследованиях Л.М. Лысенко [6], С.В. Любичанковского [7] и А.С. Минакова [8].

П.А. Столыпин был министром внутренних дел с 26 апреля 1906 г. по 5 сентября 1911 г., соответственно хронологические рамки анализа назначений охватывают период с мая 1906 г. по август 1911 г. для 49 губерний европейской России, управляемых по Общему учреждению губернскому.

Общее количество новых назначений в этот период составило 62, в них было задействовано 55 чиновников. Для 41 из них это было первое губернаторское назначение, повторное назначение в этот же хронологический период получили 7 из них. До прихода П.А. Столыпина в губернаторском корпусе уже состояли 14 чиновников, из них 10 занимали пост в европейской России, 2 - в Польше, 1 - в Сибири и 1 был военным губернатором в Средней Азии.

В процентном соотношении период управления МВД П.А. Столыпиным большая часть (66\%) губернаторских назначений пришлась на чиновников, впервые занимавших этот пост. Повторные назначения (34\%) складывались из двух компонентов: ротации чиновников, пришедших в губернаторский корпус при П.А. Столыпине $(11 \%)$ и перемещение губернаторов, состоявших в губернаторском корпусе до П.А. Столыпина (23\%).

Губернаторский корпус при П.А. Столыпине был практически полностью обновлен, из 55 чиновников, получивших назначение, большая часть (75\%) получила назначение впервые. При этом (25\%) уже состоявшие в губернаторском корпусе чиновники в большинстве случаев предыдущим губернаторским назначением имели губернию европейской России.

Опыт, схожий с губернаторской службой, будущим губернаторам могла предоставить вице-губернаторская должность. Это особенно важно для чиновников, впервые занявших губернаторский пост, а таких при П.А. Столыпине было 41. Из них 24 (59\%) были вице-губернаторами. Для тех, кто уже находился в губернаторском корпусе до П.А. Столыпина, этот показатель несколько выше (64\%).

Рассмотрение динамики назначений на каждый год позволяет выявить дополнительные результаты. 
В 1906 г. было назначено 18 новых губернаторов, из них 12 занимали этот пост впервые, а имели вице-губернаторский опыт только 4. При этом из 5, получивших повторное назначение, вицегубернаторами служили 4. И еще одно назначение было выполнено за счет перевода начавшего губернаторскую службу при П.А. Столыпине А.П. Веретенникова из Киева в Кострому из-за конфликта с генерал-губернатором В.А. Сухомлиновым [9, С. 74-75].

В 1907 г. произошло 10 губернаторских назначений, из 8 назначенных впервые чиновников 6 проходили вице-губернаторскую службу. Из 2, получивших повторное назначение, вице-губернатором служил 1.

В 1908 г. состоялось 5 назначений, впервые стало губернаторами 4 чиновника и 2 из них имело за плечами вице-губернаторскую службу. Единственный получивший повторное назначение губернатор вице-губернатором не служил.

В 1909 г. зафиксировано 9 назначений, из 8 вошедших в губернаторский корпус чиновников 4 имели опыт вице-губернаторства, 1 получивший повторное назначение губернатор его не имел.

В 1910 г. впервые сравнивается количество привлеченных в губернаторских корпус новых чиновников и назначений, выполненных за счет внутренних перестановок. Всего отмечено 11 назначений, из них в первый раз стали губернаторами 6 чиновников, 5 из которых служили вице-губернаторами. Повторные назначения получили 5 губернаторов, 3 из которых были привлечены в губернаторский корпус непосредственно при П.А. Столыпине, а из 2 оставшихся вице-губернатором служил 1.

В 1911 г. внутренние ротации начали преобладать над привлечением новых чиновников. Из 8 назначений впервые заняли губернаторский пост только 2 чиновника, оба имели вице-губернаторский опыт, 3 назначения получили губернаторы, занявшие этот пост при П.А. Столыпине. И еще 3 назначения получили состоявшие в губернаторском корпусе до П.А. Столыпина чиновники, все три несли вице-губернаторскую службу.

Таким образом, анализ назначений в динамике позволяет увидеть, что несмотря на общее преобладание губернаторов с первым губернаторским сроком в целом эта тенденция снижалась с пика 1906 г. и достигла минимума к 1911 г. Причем, если в 1906 г. большинство губернаторов не имели опыта не только губернаторской, но и вице-губернаторской службы, то к 1911 г. большинство губернаторов пришли на повторные назначения, а новые губернаторы имели вице-губернаторский опыт. 
Существует несколько губерний, которых не затронули губернаторские перестановки. Это Витебская, Казанская, Ковенская, Лифляндская, Московская, Подольская, Смоленская и Тверская губернии. Три смены губернатора произошли в Вятской, Екатеринославской, Киевской, Нижегородской, Пензенской и Симбирской губерниях. В 10 губерниях смена губернаторов происходила дважды и в 25 губерниях губернаторы сменялись один раз.

Можно сделать вывод, что губернаторский корпус при П.А. Столыпине прошел несколько этапов развития. Если первые губернаторские назначения пришлись на чиновников, не имеющих губернаторского и вице-губернаторского опыта, то к концу службы П.А. Столыпина ситуация изменилась в обратную сторону. Наибольшее количество назначений в год пришлось на 1906 г., наименьшее на 1908 г., в остальные годы количество назначений держалось примерно на одном уровне.

Таким образом, динамика губернаторских назначений при П.А. Столыпине имела следующую модель: на первом этапе производились быстрые смены губернаторов без оглядки на их служебный опыт, но постепенно изменения в губернаторском корпусе становятся более редкими, а предпочтение отдается более опытным чиновникам. При этом губернаторский корпус Европейской России достаточно замкнут, и вхождение в него губернаторов из других регионов, таких как например Польша и Сибирь, производились крайне редко. В половине губерний губернатор сменялся лишь один раз, а восемь губерний губернаторские перестановки при П. А. Столыпине не затронули вовсе.

\section{Библиография}

1. Свод законов Российской империи. Издание неофициальное // под ред. И.Д. Мордухай-Болтовского. - Кн. 1. - Т.2. - СПб.: Русское Книжное Товарищество «Деятель», 1912. - 737 с.

2. Губернии Российской империи. История и руководители. 1708-1917 / Под общ. ред. Б.В. Грызлова; гл. ред. Н.Ф. Самохвалов. - М.: Объединенная редакция МВД России, 2003.

3. Высшее чиновничество Российской империи: краткий словарь / С.В. Волков. М.: Ун-т Дмитрия Пожарского, 2016. - 798 с.

4. Государственные деятели Российской империи. Главы высших и центральных учреждений. 1802-1917 : Биобиблиогр. справ. / Д.Н. Шилов. - СПб.: Дмитрий Буланин, 2001. -830 с.

5. Шепелев Л. Е. Титулы, мундиры, ордена в Российской империи. - Л.: Наука, 1991. $-222 \mathrm{c}$.

6. Лысенко Л. М. Губернаторы и генерал-губернаторы Российской империи (XVIII - начало XX века). - М.: Изд-во МПГУ, 2001. - 357 с. 
7. Любичанковский С. В. Губернское правление в системе губернаторской власти в последнее десятилетие существования российской империи (на материалах Урала): автореф. дис. канд. ист. наук. - Оренбург, 2003. - 27 с.

8. Минаков А. С. Губернаторский корпус и центральная власть: проблема взаимоотношений (по материалам губерний Черноземного центра второй половины XIX начала XX вв.). - Орел: Орлик, 2011. - 487 с.

9. Курлов П.Г. Гибель Императорской России. - М.: Современник, 1992. -255 с.

https://doi.org/10.29003/m1809.978-5-317-06529-4/190-196

Стрекалова Н.В., Рахманов П.С. Тамбовский государственный университет имени Г.Р. Державина

\section{«Бывшие» в социальной структуре провинциального города в 1917-1919 гг.: опыт создания и обработки баз данных (на материалах Тамбова)}

Аннотация. В статье на микроуровне, на основе массовых персонифицированных источников, через призму судеб конкретных людей рассматриваются проблемы региональных особенностей социального положения и социальных траекторий, обусловленных революционными преобразованиями в России, представителей бывших имущих слоев провинциального города в 1917-1919 гг. Охарактеризованы источники, структура и исследовательский потенциал источнико-ориентированных баз данных.

Ключевые слова: «бывшие», имущие слои населения, Тамбов, социальная мобильность, революция, базы данных.

Strekalova N.V., Rakhmanov P.S. Derzhavin Tambov State University

\section{«Former people» in the social structure of a provincial city in 1917-1919: experience in creating and processing databases} (based on materials from Tambov)

Abstract. The article considers the problems of regional peculiarities of social status and social trajectories caused by the revolutionary transformations in Russia, representatives of the former propertied strata of a provincial city in 19171919 on the micro level, based on mass personalized sources, through the prism of the destinies of specific people. The sources, structure and research potential of source-oriented databases are described.

Keywords: «former people», wealthy individuals, Tambov, social mobility, revolution, databases.

Вопросы влияния революционных изменений на социальную структуру провинциального общества стоят в центре внимания ряда исторических исследований, посвященных революции 1917 г. в Рос- 
сии. В большей степени изучены изменения социальной структуры российского общества, обусловленные событиями октября 1917 г., значительно меньше исследовано влияние революционных преобразований февраля-марта 1917 г. на данный процесс.

Локализация объекта исследования на уровне конкретного города позволяет детальнее изучить региональные особенности революционных преобразований через призму судеб конкретных людей и отдельных социальных групп. Особый интерес представляет анализ положения представителей бывших привилегированных и имущих слоёв дореволюционного российского общества. В отношении этой группы населения употреблялся термин «бывшие», который не был закреплен каким-либо специальным законодательным документом, но имел место в повседневной жизни и идеологическом дискурсе [1].

Для исследования проблемы были использованы массовые источники, которые содержат персонифицированную информацию о представителях бывших привилегированных и имущих слоёв населения дореволюционного российского города в переломный для страны исторический период: адрес-календари и справочные книжки, окладные книги на недвижимые имущества, списки избирателей в Государственные Думы Российской империи, списки избирателей в Учредительное собрание за 1917 г. (по г. Тамбову), анкеты «бывших помещиков, капиталистов и лиц, занимавших ответственные должности при царском и буржуазном строе» (данные за 1919 г. по г. Тамбову). На основе указанных источников в СУБД MS Access были созданы источнико-ориентированные базы данных (далее БД): «Население Тамбова в начале XX в.», «Списки избирателей по г. Тамбову в Учредительное Собрание (1917 г.), «Бывшие» 1919 г.». Сравнительный анализ аккумулированной информации баз данных позволяет проследить изменения, произошедшие с представителями привилегированных, имущих слоёв населения дореволюционного города на персональном уровне во время и после революционных событий.

БД «Население Тамбова в начале ХХ в.» содержит данные о принадлежности конкретного человека к той или иной социальной страте населения губернского центра до революции. В БД «Списки избирателей по г. Тамбову в Учредительное Собрание (1917 г.) представлена информация, которая отражает изменения, произошедшие в социальном статусе конкретного горожанина к осени 1917 г. БД «Бывшие» 1919 г.» создана на основе информации анкет «бывших помещиков, капиталистов и лиц, занимавших ответственные долж- 
ности при царском и буржуазном строе», которые по данным на 1919 г. проживали в Тамбове.

Структура баз данных «Население Тамбова в начале XX в.» и «Списки избирателей по г. Тамбову в Учредительное Собрание (1917 г.) уже была описана в рамках других исследований одного из авторов статьи [2-3]. Источнико-ориентированная база данных «Бывшие» 1919 г.» на данный момент содержит информацию о более 250 (включая членов семей) представителях имущих слоёв дореволюционного губернского центр по следующим полям: фамилия, имя, отчество, возраст главы и членов семьи, дореволюционное общественное, служебное и имущественное положение, род деятельности на момент составления анкеты применительно к каждому члену семьи, источник дохода, адресе проживания [4].

Информация, включенная во все указанные БД, персонифицированная, что позволяет объединить ее применительно и конкретному человеку и провести сравнительное изучение его социальных траекторий от февраля к октябрю 1917 г., а затем и в Советской России.

Социальная стратификация тесно связана с господствующей системой ценностей. В разных стратификационных системах она различна. Революционные преобразования изменили шкалу социального ранжирования в провинциальном городе.

Большинство представителей имущих слоев населения губернского центра относительно спокойно восприняли события февралямарта 1917 г., рассматривая Временное правительство в качестве законной верховной власти. Так, в 1917 г. большинство представителей дореволюционной тамбовской элиты по-прежнему были широко представлены в органах местного самоуправления, и, прежде всего, в городской думе. Хотя были и те, кто отказался от дальнейшего участия в работе данных структур [5, с. 276].

Сравнительный анализ информации окладных книг на недвижимое имущество г. Тамбова свидетельствовал, что факты смены местожительства и продажи недвижимой собственности в городе представителями элиты в первые месяцы революционных событий 1917 г. были единичными. 54\% владельцев недвижимости дореволюционного города остались в Тамбове и сохранили свое имущество к осени 1917 г. [6, с. 146]. Более того, количество крупных собственников, особенно среди чиновников и дворян, увеличилось.

В то же время сравнительный анализ совокупной информации «Списков избирателей в Учредительное собрание» и сведений, зафиксированных в источниках в предреволюционное десятилетие, позволил установить, что только около трети представителей элиты 
и средних слоев губернского центра осенью 1917 г. оставались в городе. Для части мужчин - представителей данных социальных страт городского населения причиной отсутствия была мобилизация и участие в Первой мировой войне.

Сложившееся в предреволюционное десятилетие социальное ранжирование претерпело отдельные изменения, последовавшие за революционными преобразованиями февраля - марта 1917 г. Это, в свою очередь, нашло отражение и в изменении самоидентификации конкретного горожанина. В «Списках избирателей в Учредительное Собрание часть указывала свое прежнее занятие с использованием прилагательного «бывший» («бывший городничий», «бывший судья»), что могло свидетельствовать об изменении социального статуса в новой системе социального ранжирования. Часть представителей этих социально-профессиональных групп Тамбова в исследуемый период утратили прежние занятия и не приобрели новые.

К событиям октября 1917 г. большинство представителей имущих слоев Тамбова отнеслись как к «большевистской авантюре», но уже весной 1918 г. новая власть в полной мере заявила о себе, в том числе национализацией имущества, которое принадлежало состоятельным жителям губернского центра [5, с. 277]. В собственность государства перешло большинство предприятий, банки, торговые и развлекательные заведения, трактиры, аптеки и др. По мнению исследователей, большевики буквально сразу же стали реализовывать доктрину о ликвидации «буржуазии» (как крупной, так и мелкой) путем установления над ней контроля и национализации, принадлежавшей этому классу собственности [7]. Уже в апреле 1918 г. были национализированы предприятия, земля, дома и иное имущество ряда крупных предпринимателей и богатейших жителей губернии среди которых Асеевы, Можаровы и др. «Бывшие» облагались рядом дополнительных налогов [8, л. 8, 22].

Часть представителей элиты губернского центра покинула город, переселивших в столичные города, где, очевидно, легче было затеряться. Другие выехали за пределы страны, как например, большинство членов многочисленного семейства М.В. Асеева.

Однако и в этих условиях значительная часть состоятельных горожан осталась жить в Тамбове. Некоторые из них поступили на службу в учреждения новой власти. Работа в различных учреждениях позволяла, во-первых, уклониться от привлечения к трудовой повинности в рамках политики «военного коммунизма», во-вторых, 
влияла на продовольственное обеспечение, в связи с введенной на территории РСФСР дифференцированной системы снабжения населения [9, л. 21].

С одной стороны, большевиками был провозглашен курс на строительство бесклассового общества и борьба с пережитками прошлого, но с другой - на начальном этапе социалистического строительства кадровый потенциал дореволюционной России им был необходим. В сентябре 1919 г. для выявления лиц, чьи профессиональные навыки могли бы оказаться полезными и для экономического и политического контроля, был принят декрет «Об обязательной регистрации бывших помещиков, капиталистов и лиц, занимавших ответственные должности при царском и буржуазном строе» [10, с. 124-126]. Анализ информации материалов регистрации бывших в г. Тамбове, включенных в базу данных «Бывшие «1919», показал, что средний возраст зарегистрированных мужчин был 58,9 лет, женщин - 47,2, детей - членов семьи - 20,2 года.

В качестве дореволюционных занятий «бывших» были указаны следующие виды деятельности: землевладельцы, домовладельцы, частная торговля, представители администрации (включая вицегубернатора Т.А. Липинского) руководители и рядовые служащие разного рода учреждений, геолог, профессор и др.

По данным на 1919 г. 26,7\% из списка «бывших» г. Тамбова числились безработными. В числе безработных были указаны, например, бывший князь Н.Н. Чолокаев, бывший землевладелец и частный торговец Н.В. Григорьев и др. 5,6\% были зафиксированы как пенсионеры. 9,8\% указали, что занимаются домашним, а 2,8\% - сельским хозяйством. 22,5\% утратили должности руководителей и стали рядовыми служащими учреждений. $21,1 \%$ занимали должности руководителей или их помощников в учреждениях города. 11,2\% сохранили прежние профессиональные занятия, а отдельные лица из числа «бывших» даже сумели подняться по карьерной лестнице. Например, М.А. Гедеонов, ранее занимавший должность секретаря губернского статистического комитета дослужился до заведующего демографической секцией тамбовского Губстатбюро. 7\% «бывших» были зафиксированы по рабочим специальностям. Например, бывший землевладелец С.М. Шульгин стал слесарем, а бывший вице-губернатор Тамбовской губернии Т.А. Липинский - сапожником.

Большинством анкетируемых не указывались данные о дореволюционном положении своих жен или мужей (в случае если главой семьи в 1919 г. была записана женщина). Согласно данным за 1919 г. 
$46,6 \%$ из них занимались домашним хозяйством, $4,4 \%$ были указаны как нетрудоспособные в силу болезни, 4,4\% - безработными, 4,4\% работали в школе, 2,2\% состояли на службе, 2,2\% были зафиксированы как кустари, одна выполняла обязанности сестры милосердия, муж второй был священником, о 26,6\% информация отсутствовала. Таким образом, значительное число «вторых половин» являлись так называемым «нетрудовым элементом». Отдельные «лица, жившие за счет нетрудовых доходов» оказались на принудительных работах «в лагерях» [11, л. 5, 57].

Персонифицированный характер источника позволил проследить межпоколенную профессиональную мобильность. В БД «Бывшие 1919 г.» представлена информация о дочерях и сыновьях - членах семей «бывших».

О занятиях 22,9\% сыновей и дочерях «бывших» информация отсутствовала, 31\% были указаны как служащие различных учреждений (включая руководящие должности), 6,7\% служили в Красной армии (включая двух красных командиров), 4,3\% указали, что были заняты домашним хозяйством. 2,5\% были зафиксированы как «нетрудоспособные по болезни», 2,5\% трудились чернорабочими, 1,8\% работали в медицинской сфере, $1,2 \%$ - в системе образования, 1,2\% были техническими специалистами. Среди детей «бывших» числилась балерина, плотник и др. В списки попал и партработник - сын бывшей землевладелицы Д.Н. Селезнев. 22,9\% были детьми дошкольного возраста, $8 \%$ - школьниками, 3,1\% - студентами, 1,8\% учащимися профессиональных учебных заведений. Большинство детей «бывших» получали образование в школах и иных учебных заведениях. Таких, кто вынужден был с ранних лет работать, было немного $(1,8 \%)$.

Таким образом, представители имущих слоёв дореволюционного провинциального российского города, которые не хотели или не смогли покинуть страну, должны были приспосабливаться, пытаться «вписаться» в новые условия жизни.

Информация баз данных позволяет проследить изменение социального статуса «бывших», изучить возможности и степень их интеграции в новое общество, исследовать влияние прежнего социального положения на их судьбу и судьбы членов их семей, проанализировать эволюцию политики власти в отношении свергнутых классов в послереволюционный период и особенности ее реализации в провинции. 


\section{Библиография}

1. Смирнова Т.М. «Бывшие люди» в социальной структуре и повседневной жизни советского общества (1917-1936 гг.).: Автореф. дис. док. ист. наук. - М., 2010. - 53 с.

2. Стрекалова Н.В. Социальная стратификация и социальная мобильность средних слоев Тамбова в 1907-1917 гг. // Информационный бюллетень Ассоциации «История и компьютер». - 2002. - № 30. - С. 23-25.

3. Стрекалова Н.В. Профессия как объект изучения по материалам «Списков избирателей в Учредительное собрание» Тамбова за 1917 г.: проблемы технологии и адаптации HISCO // Информационный бюллетень Ассоциации «История и компьютер». - 2008. - № 35. - С. 114-115.

4. ГАТО (Государственный архив Тамбовской области). Ф. Р-6. Оп. 1. Д. 120. Л. 1-3, 10-16, 18-19, 23-30, 32-52, 54-58, 60-75об, 77-79, 81-83, 85-87, 90.

5. Зайцева О.М., Стрекалова Н.В. Элита и средние слои провинциального губернского центра в революционном изломе 1917 г. (на материалах Тамбова) // Великая Российская революционная трансформация: взгляд через 100-летие. Материалы научно-экспертных сессий и Международной научной конференции (Москва, 20162017 гг.) / Отв. ред. П.М. Петров, В.Э. Багдасарян. - Тверь: ООО «СФК-офис», 2017. C. $272-282$.

6. Стрекалова Н.В. Влияние революционных событий 1917 г. на изменения социальной стратификации и социальной мобильности средних слоев провинциального российского города (на материалах Тамбова) // Вестник Тверского государственного университета. Серия: история. Выпуск 1. - 2011. - № 6. - С. 144-145.

7. Канищев В.В. Городские средние слои в период формирования основ советского общества. Октябрь 1917 - 1920 гг. (по материалам центра России): Автореф. дис. док. ист. наук. - М., 1998. - 36 с.

8. ГАТО (Государственный архив Тамбовской области). Ф. Р-394. Оп. 1. Д. 108.

9. ГАТО (Государственный архив Тамбовской области). Ф. Р-6. Оп.1. Д. 51.

10. Декреты советской власти. 1 августа - 9 декабря 1919 г. Том 6. - М.: Государственное Издательство политической литературы, 1973. - 590 с.

11. ГАТО (Государственный архив Тамбовской области). Ф. Р-398. Оп. 1. Д. 138.

https://doi.org/10.29003/m1810.978-5-317-06529-4/196-202

Ульянова С.Б., Аладышкин И.В. Санкт-Петербургский политехнический университет Петра Великого

\section{Проект «Цифровая история Санкт-Петербургского политехнического университета» и перспективы моделирования институциональной истории высшей школы}

Аннотация. В докладе представлены результаты реализации проекта «Цифровая история Санкт-Петербургского политехнического университета» и связанные с ним возможности репрезентации и изучения институциональной истории высшей школы. Дано описание и характеристика разрабатыва-

${ }^{1}$ Исследование проводится при поддержке программы «5-100» СанктПетербургского политехнического университета Петра Великого. 
емого в рамках проекта онлайн-ресурса, который представляет собой виртуальную динамическую структуру университета в виде интерактивного «генеалогического древа», дополненного справочными материалами, полнотекстовыми историческими источниками, научным комментарием.

Ключевые слова: институциональная история, цифровые гуманитарные науки, цифровая история, Санкт-Петербургский политехнический университет.

Ulyanova S.B., Aladyshkin I.V. Peter the Great St.Petersburg Polytechnic university

\title{
The Project «Digital History of St.Petersburg Polytechnic University» and Prospects for Modeling the Institutional History of Higher Education
}

\begin{abstract}
The report represents the implementation of the project «Digital History of St.Petersburg Polytechnic University» and analyzes related opportunities in the representation and the study of the institutional history of high schools. The authors dwell on the description and characteristics of the online resource that represents a virtual dynamic structure of the University in the form of an interactive genealogical tree, supplemented by reference materials, full-text historical sources, scientific commentary.

Keywords: institutional history, digital Humanities, digital history, St.Petersburg Polytechnic University.

Сегодня редкое научно-образовательное учреждение обходится без собственного онлайн-ресурса, который содержит, среди прочего, справочную историческую информацию. Если к этому прибавить еще и размещенные в интернете разнородные материалы по истории высшей школы в целом и отдельным вузам, в частности, то может сложиться представление о сложившейся цифровой истории высшего профессионального образования в России. Между тем, следует признать, что научные разработки в данной области находятся в зачаточном состоянии.

Безусловно, достижения в области оцифровки материалов могут служить аргументом в пользу «цифрового перехода» в современной исторической науке. Однако сами по себе подобные материалы еще не являются цифровой гуманитаристикой, для которой характерны определенные принципы и методы проведения исследований и получения результатов. По сути, на разноформатной оцифровке документов и объектов историко-культурного наследия, которые могут быть размещены в глобальной сети, в настоящее время основаны любые исторические исследования, в том числе и вполне традиционные.
\end{abstract}


Следует согласиться с теми, кто утверждает, что специфика цифровой истории заключается не столько в оцифровке и онлайнрепрезентации документов, сколько в проектном подходе к решению научных проблем, предполагающем в качестве итога исследовательского труда конкретный информационный цифровой продукт, например, электронный онлайн-ресурс [1;2]. Digital history ориентирована на создание цифровых архивов, интерактивных презентаций, карт и виртуальных миров. Большие массивы данных требуют новых подходов, специализации технологических решений для целей исторического исследования [3]. Исходя из такого подхода, следует признать, что история профессионального образования делает лишь первые шаги в овладении средствами и методами цифровой гуманитаристики.

Между тем, именно эти средства и методы могут открыть новые перспективы институциональной истории высшей школы. Использование приемов и методов цифровой истории позволяет не только создать нарратив по истории вуза, но и по-новому проанализировать, визуализировать его. В результате тексты оказываются в одном ряду с изобразительными, аудиовизуальными и прочими мультимедийными источниками. Любой объем информации становится более наглядным и вызывает больше интереса у конечного потребителя. Представление результатов исследования в формате Digital history расширяет аудиторию, повышает интерес к истории университетов.

Перспективы использования средств и приемов цифровой гуманитаристики в институциональной истории высшей школы побудили нас реализовать проект «Цифровая история Санкт-Петербургского политехнического университета». Его цель заключается в исследовании истории одного из крупнейших технических вузов страны с одновременной разработкой интерактивного онлайн-ресурса. Ресурс создается коллективом сотрудников вуза (как историков и архивистов, так и ITспециалистов) под руководством авторов данной статьи.

Идея создания цифровой истории Политеха соответствовала провозглашенной концепции СПбПУ как «цифрового университета». Толчком к разработке нашего проекта стала подготовка к 120 летию университета, основанного как Петербургский политехнический институт в 1899 году. Уже в 2018 г. были намечены основные задачи проекта, получившего поддержку руководства университета, Гуманитарного института и Попечительского совета СПбПУ:

- разработка принципов построения ресурса;

- формирование документальной базы исследования;

- создание общего дизайна проекта с цветовыми и графическими компонентами; 
- конструирование динамической структуры СПбПУ;

- формирование документального и просопографического контента;

- подбор изобразительных материалов;

- разработка англоязычной версии ресурса;

- разработка адаптивной версии ресурса.

В настоящий момент выполнены первые шесть пунктов намеченного плана работы. Ресурс, в целом, готов и пока действует с временным доменным именем http://p2.orlime.ru/. В ближайшее время с некоторыми дополнениями ресурс будет перенесен на серверы СПбПУ с обретением нового постоянного адреса. Осталось добавить англоязычную версию ресурса, а также «подправить» его адаптивную версию.

Разработка ресурса и его наполнение тесно связаны с проводимым исследованием по восстановлению общей «генеалогии» Санкт-Петербургского политехнического университета и преемственной связи всех его структурных подразделений. В процессе работы с архивными документами удалось выявить и устранить многочисленные ошибки и неточности в «официальной» истории СПбПУ. Исследование базируется на материалах Центрального архива, Фундаментальной библиотеки и музейного комплекса СПбПУ, дополненных документами из центральных и местных архивов (Российский государственный исторический архив, Центральный государственный исторический архив Санкт-Петербурга, Центральный государственный архив Санкт-Петербурга, Центральный государственный архив историко-политических документов Санкт-Петербурга, Российский государственный архив Военно-морского флота, архив Российской академии наук).

Созданный на основании нашего исследования онлайн-ресурс представляет собой виртуальную динамическую структуру университета в виде интерактивного «генеалогического древа», дополненного справочными материалами, полнотекстовыми историческими источниками, научным комментарием. Большая часть архивных документов специфическим образом визуализирована и размещена на ресурсе, дополняя тем самым варианты динамического древа университета и его структурных подразделений.

Использование методов цифровой истории позволило «упаковать» большой массив данных, в том числе, архивных источников, наглядно показать динамику развития университета, связи между отдельными его подразделениями, проследить происхождение ин- 
ститутов, кафедр, лабораторий и научных школ. Таким образом, данный ресурс объединяет достоинства цифрового архива и виртуальной реконструкции исторических процессов, наглядно показывая максимально широкой аудитории интернета историю СанктПетербургского политехнического университета.

Созданный ресурс соответствует стандартам подачи информации в интернете - Digital storytelling. Его преимущества по сравнению с традиционным нарративом (научные статьи и монографии, сборники документов): погружение в историю, ощущение духа времени за счет широкого использования документов; более быстрый поиск нужной информации; интерактивность, возможность для пользователя взаимодействовать с материалом и др.

Еще одним достоинством разрабатываемого онлайн-ресурса является возможность перманентного дополнения, обновления и редактирования материалов, включая своевременное внесение корректив в саму динамическую модель университета. Частые, особенно в последнее время, структурные преобразования в вузе приводят к быстрому «устареванию» информации в традиционных публикациях по истории университета. Наш же ресурс позволяет не только зафиксировать очередные изменения, например, появление нового института, высшей школы, кафедры, научного центра, но и визуально отразить их в динамической структуре университета. Поэтому можно утверждать, что ценность проекта для университета со временем будет увеличиваться.

Следует отметить, что в разработке онлайн-ресурса особый упор был сделан на удобную навигацию, а режимы информационного поиска позволяют реализовать нелинейные механизмы исследования исторического материала.

Вот некоторые базовые технические характеристики ресурса:

- «Flat дизайн», проектирование UI/UX;

- адаптивное масштабирование на разных экранах с валидным HTML5;

- плавное анимационное сопровождение при изменении состояний объектов;

- асинхронная передача данных по технологии АJАХ;

- минимальное количество обновлений и переходов по страницам. Интерактивное/динамическое изменение содержимого с обновлением URL через JavaScript и его обработки при переходе в приложение с GET параметрами для возможности «поделиться» текущей информацией; 
- гибкая система управления для добавления элементов/блоков древа (институты, кафедры и пр.), автоматического построения структуры, хранения и обновления информации на сопутствующих страницах/блоках, поддержки проекта собственными силами модераторов без вмешательств в программный код;

- удобное управление информацией отдельных страниц/блоков с возможностью полноценного форматирования текста и добавления фото-галерей, видео-плееров и пр.;

- динамическое обновление содержимого (структурной зависимости и элементов) при непосредственном взаимодействие с древом: zoom/click/scroll/move.

Важную роль в работе с онлайн-ресурсом «Цифровая история Санкт-Петербургского политехнического университета» играет его оформление, которое сопряженно с фирменным стилем СПбПУ. Содержательные заголовки, структурирование текста, схемы, подборка шрифтов и т.п. делают материал современным, увлекательным и предельно наглядным. Динамическое «древо» каждого института выделено фирменным цветом, дополнительная информация раскрывается благодаря, всплывающим комментариям, гиперссылкам и удобными переходами на связанные страницы ресурса. По этим схемам можно «бродить», открывая для себя все новые и новые повороты в истории вуза.

Безусловно, разрабатываемый проект можно рассматривать и как ценный справочный ресурс, используемый при проведении юбилейных мероприятий, для уточнения тех или иных событий в истории отдельных факультетов / институтов и кафедр. Однако, кроме наглядной и современной подачи история вуза, удобного справочника, в онлайн-ресурсе «Цифровая история СПбПУ» заложен серьезный научно-исследовательский потенциал.

В ресурсе реализована своеобразная модель истории СанктПетербургского политехнического университета, которая, наряду с размещенными на нем архивными и справочными материалами, представляет собой самостоятельное научное значение. Ведь выбранный формат визуализации истории университета позволяет проследить трансформации его структуры в ответ на социальноэкономические изменения в стране, развитие отдельных отраслей промышленности, внедрение новых технологий в производство или смещение курса государственной политики в области образования. Материалы онлайн-ресурса и способы их визуализации помогают 
выявить изменения в направлениях подготовки инженерных кадров и осуществления научно-исследовательской работы, изменение структуры административного управления университета, выделить институциональные аспекты его экономической активности (выполнение государственных заказов на прикладные исследования, создание собственных высокотехнологичных предприятий и т.д.) [4; 5].

В заключение стоит отметить, что все ведущие университеты России и мира уделяют большое внимание изучению своей истории. Как правило, руководство вуза понимает значимость историкокультурного наследия для повышения узнаваемости бренда, привлечения абитуриентов, образовательных и научных партнеров, укрепления университетской корпорации, повышения лояльности студентов и работников университета за счет осознания их причастности к институции, имеющей давнюю и славную историю. Между тем историко-культурное наследие и традиции того или иного вуза требуют адекватного текущим реалиям, современного, доступного и наглядного формата их репрезентации. И в данном контексте проект «Цифровая история Санкт-Петербургского политехнического университета» выступает одним из перспективных вариантов как визуальной репрезентации, медиатизации, так и анализа институциональной истории высшей технической школы с опорой на методы и технологии цифровой гуманитаристики.

\section{Библиография}

1. Бородкин Л.И. Digital History: применение цифровых медиа в сохранении историко-культурного наследия? // Историческая информатика. - 2012. - № 1. C. 14-21.

2. A New Companion to Digital Humanities / S. Schreibman, R. Siemens, J. Unswort (ed.). - Oxford: Blackwell, 2016. -592 p.

3. Manning P. Challenges of Big Data in History // Manning P. Big data in history. Palgrave Macmillan, 2013. - P. 1-13.

4. Аладышкин И.В., Ульянова С.Б. Цифровому университету - цифровая история: новые подходы к изучению истории Санкт-Петербургского политехнического университета // История политехнического образования в России. - СПб.: ПОЛИТЕХПРЕСС, 2019. - С. 83-89.

5. Aladyshkin I., Anosova N., Kulik S., Ulyanova S. Digital humanities: prospects for knowledge transfer // Proceedings of the International Conference on Digital Technologies in Logistics and Infrastructure (ICDTLI 2019). - 2019. - P. 380-384. 


\title{
МЕТОДЫ И ТЕХНОЛОГИИ СЕТЕВОГО АНАЛИЗА В ИСТОРИЧЕСКИХ ИССЛЕДОВАНИЯХ
}

https://doi.org/10.29003/m1811.978-5-317-06529-4/203-208

Владимирова А.В.

Институт востоковедения РАН, Москва

\author{
Особенности диагностики пропущенных данных \\ при проведении историко-экономических исследований \\ сетей внешней торговли
}

\begin{abstract}
Аннотация. По мере развития исторического сетевого анализа, появления новых информационных ресурсов и методов, возрастает важность вопросов, касающихся качества данных, среди которых особое место занимают проблемы с моделями, возникающие из-за наличия пропусков. В представляемой работе на примере зеркальной статистики экспорта и импорта стран Юго-Восточной Азии демонстрируется значение правильно проведенной диагностики для историко-экономических исследований сетей внешней торговли, а также обозначаются соответствующие перспективные методологические подходы.

Ключевые слова: оценка качества данных, пропуски в данных, историческая информация, зеркальная статистика, внешняя торговля, сетевой анализ, Юго-Восточная Азия.
\end{abstract}

Vladimirova A.V. Institute of Oriental Studies of the Russian Academy of Sciences

Features of diagnostics of missing data when conducting historical and economic research of foreign trade networks

\begin{abstract}
With the emergence of new resources and methods, issues related to data quality are getting even more crucial. As for the recent rise of historical network research, no doubts, that missing data problems attract the special attention of scholars. In this paper mirror statistics on exports and imports of the Southeast Asian countries are used as a case to demonstrate the importance of properly conducted diagnostics.

Keywords: data quality assessment, missing data, historical information, mirror statistics, international trade, network analysis, Southeast Asia.

Распространение практики использования информационных технологий в исторической науке с одной стороны дало исследователям много новых возможностей и методов, привело к формированию и развитию таких «успешных междисциплинарных направлений» $[3$, с. 25], как историческая информатика, но с другой стороны, вызва-
\end{abstract}


ло появление ряда новых вызовов и рисков. Среди опасений, высказываемыми академическими историками, есть и те, что связанны именно с вопросами управления данными. Авторы отмечают как общие для разных дисциплин проблемы обработки быстро появляющихся больших объемов информации, так и специфические: например, пути интеграции ресурсов, создаваемых объединениями специалистов, преимущественно состоящих не из профессиональных историков, или опасности «размывания» границы между науками, которые могут повлиять на нежелательный переход к нетрадиционным способам изучения источников [1, с. 21]. Очевидно, вопросы, касающиеся проблем качества исторических источников и информации, не только остаются на повестке дня, но и становятся все более актуальными.

Основной задачей проведенной работы было рассмотреть различные подходы к определению количества пропущенных данных при проведении оценки качества источника статистики внешней торговли, а также обозначить перспективные методологические подходы, которые могут использоваться при построении исторических сетевых моделей внешней торговли. В качестве примера были взяты показатели экспорта и импорта стран Юго-Восточной Азии (ЮВА) базы данных «Комтрейд ООН» [7], поскольку в этом регионе всего 11 стран, но с точки зрения их роли и вовлеченности в международные торговые сети они сильно различаются. Кроме того, неравность развития наблюдается также и в плане создания инфраструктуры, необходимой для эффективного сбора и обработки статистики. Так, несмотря на то, что проект Ассоциации государств Юго-Восточной Азии «Единое окно АСЕАН», одной из главных целей которого как раз является управление данными по торговым отношениям, находится в списке приоритетных, у организации годами не получается реализовать его в полной мере и отчасти это происходит именно изза трудностей «цифрового разрыва» [2].

Очевидно, что изучение вопросов, касающихся истории формирования внешнеторговых связей неразрывно связано с решением проблемы пропущенных данных даже если речь идет всего о нескольких странах, как в случае исследования государств ЮВА (рис. 1). Между тем база данных «Комтрейд ООН» содержит более 3 млрд записей и имеет достаточно разветвленную структуру кодов, поэтому диагностику пропусков гораздо эффективнее проводить, используя функционал соответствующих пакетов в программной среде вычислений $\mathrm{R}$, особенно когда речь идет о лонгитюдном исследовании сетей внешней торговли. 


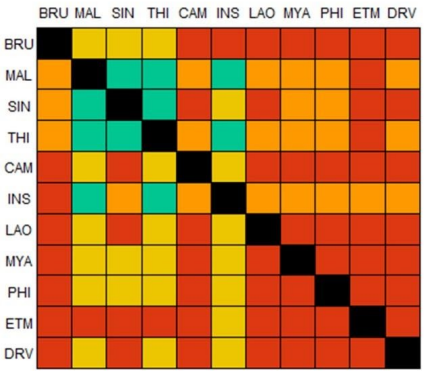

1990

BRU CAM INS MAL PHI SIN THI DRV LAO MYA ETM

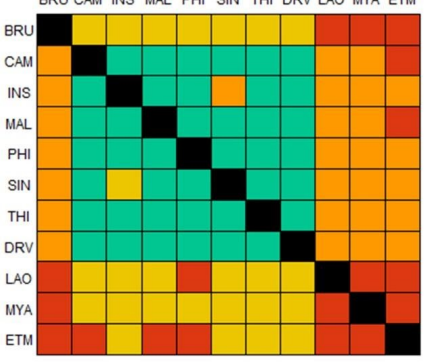

2000
BRU MAL SIN THI CAM INS LAO MYA PHI ETM DRV

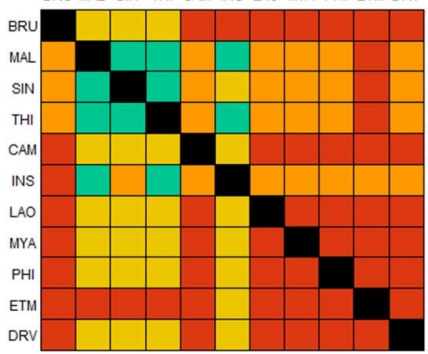

1995

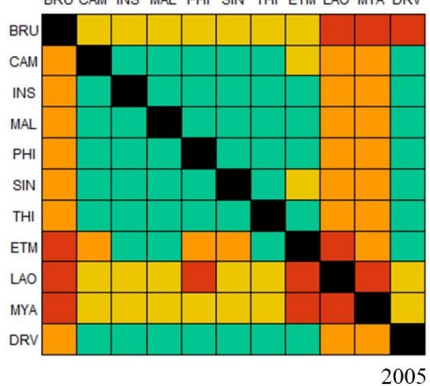

2005

данные отсутствуют

$\square$ данные предоставлены экспортером

$\square$ данные предоставлены импортером

данные предоставлены экспортером и импортером

Рис. 1. Пропуски в данных по внешнеторговым отношениям между странами Юго-Восточной Азии (источник: «Комтрейд ООН»)

Что касается методологии, на основе которой пишутся скрипты для оценки качества данных, то в настоящее время в литературе представлено два основных подхода к работе с пропусками: традиционный «структурный», как явно следует из его названия, фокусируется на их структуре и механизмах порождения. Приверженцы же второго, «функционального» [9], подхода настаивают, что основное внимание следует уделять тому, как недостающая информация влияет на процедуры и результаты конкретных инструментов и методов анализа данных с точки зрения валидности, надежности и возможности генерализации сделанных выводов.

Но какой подход не был бы выбран, одно не меняется: собираемые людьми данные о явлениях или процессах в подавляющем 
большинстве случаев не бывают полными и вопрос о пропусках поднимается тогда, когда за ними стоит значимая для исследования информация. Между тем, науке известно достаточно примеров, когда в определённом контексте отсутствующая информация не играет роли, например, при проведении медицинского эксперимента пропуски в данных о выживаемости пациентов крайне важны, а вот в переменной, отражающей удовлетворенность жизнью - нет [8]. При этом, вспомним, что в рамках анализа истории события (event history analysis) направление развития статистических методов, таких как семи-параметрическая регрессия Кокса (Cox proportional hazards model), во многом определяется необходимостью правильно обрабатывать цензурируемые данные (censured data), т.е. для которых из-за ограничения наблюдения во времени у ученых нет записей о наступлении изучаемого события. Таким образом, получается, что для целого ряда областей работа с неполными данными считается нормальной практикой. Очевидно, что историческая наука является типичным представителем этого списка, но отрывочность извлекаемой из исторических источников информации хотя и является серьезным вызовом для историков, не останавливает их на пути приращения важнейших знаний о прошлом.

В следствии того, что изначально научные работы по пропускам в данных публиковались социологами, более того, специалистами по опросным методам, базовая классификация подразумевает их разделение на две основные группы: недостижимое наблюдение (unit nonresponse, unit missingness) и неполное наблюдение (item nonresponse, partial nonresponse). В первом случае речь идет о ситуации, когда, например, респондент, случайным образом включенный в выборку телефонного опроса, не берет трубку вообще, а во втором - когда он отказывается отвечать на ряд вопросов в анкете. Однако, эта классификация вполне подходит и для других областей, включая статистику внешней торговли. Так, в исторических данных, используемых для анализа динамики развития торговли стран ЮВА, Восточный Тимор, ставший в 2002 г. первым суверенным государством нового тысячелетия, по очевидным причинам будет представлять собой недостижимое наблюдение, а работа со статистикой членов группы КЛМВ (Камбоджа, Лаос, Мьянма и Вьетнам) вообще уже традиционно ведет к увеличению доли неполных наблюдений.

Причины, по которым не удается получить полные наблюдения (full response), могут быть весьма разнообразными. Так, существуют вопросы, на которые люди просто не любят отвечать, в частности, 
раскрывать свой доход или наличие собственности, но проблемы могут быть и с анкетой в целом: ее заполнение может требовать больше времени и усилий, чем респонденты готовы уделить. Впрочем, после распространения телефонных и онлайн опросов, пропуски, начинающиеся после определённого вопроса, стали возникать и по причине проблем со связью, тогда в зависимости от количества успешно записанных ответов, анкета респондента классифицируется либо как неполное, либо как недостижимое наблюдение.

Расширяемые с годами опыт проведения массовых опросов и знания о подобных ситуациях, привели появлению специфического типа пропусков, которые образовываются согласно дизайну (missing by design). Иначе говоря, в ходе разработки инструментария они изначально запланированы самими исследователями. Действительно, изменение исходной анкеты для сбора данных у разных групп респондентов является нормальной практикой и использование функциональных вопросов-фильтров давно не вызывает нареканий у специалистов [6].

Для аналитика понимание возможных причин отказа предоставить информацию крайне важно, но, установить их бывает сложно. C решением этого вопроса отчасти может помочь изучение структуры пропусков. Для этого удобно воспользоваться уже созданными достаточно универсальными типологиями, например, Рубин предлагает выделять 6 основных паттернов [5]. Что касается отечественной литературы, то хотелось бы отметить, что и российские ученые не обходят стороной тему развития процедур повышения качества данных, в частности, сравнивая и анализируя их возможности разных алгоритмов [4]. Тем не менее, в русскоязычной литературе наблюдается явное преобладание публикаций на тему проблем восстановления и анализа данных с пропусками, поэтому имеет смысл также осветить и классификацию, используемую для подобных работ. С того момента, как Рубин представил этот подход, она стала, пожалуй, самой известной в области изучения пропусков, однако, применять ее следует тогда, когда важен механизм появления пропусков.

Несомненно, основой эффективной работы с данными является хорошо проведенная диагностика их качества, в ходе которой могут изучаться как традиционные вопросы о количестве (amount), структуре (patterns) и механизмах порождения пропусков (mechanisms), так и специфические вопросы, касающиеся причин (reasons), источников (sources), измерений (dimensions) или уровней (levels). 
В настоящее время в специализированной литературе по диагностике пропусков можно найти уже достаточно много методов, среди которых к основным причисляются следующие: анализ полных наблюдений, анализ полных переменных, анализ доступных наблюдений, разреженные матрицы с возможным их использованием для вычисления соотношений пропусков в наблюдениях и переменных. Таким образом, сейчас существуют различные подходы и процедуры, базирующиеся на логических размышлениях, статистике и визуальном анализе, из которых исследователь может подобрать комплекс, отвечающий его личным предпочтениям, структуре его данных и особенностям используемой им методологии.

\section{Список литературы}

1. Владимиров В.Н. Историческая информатика: прошлое, настоящее и будущее // Цифровая гуманитаристика: ресурсы, методы, исследования: материалы Междунар. науч. конф. (г. Пермь, 16-18 мая 2017 г.): в 2 ч. / под ред. С.И. Корниенко. - Пермь: Перм. гос. нац. исслед. ун-т., 2017. - С. 19-22.

2. Владимирова А.В. Становление цифровой экономики и новые аспекты региональной интеграции: анализ основных итогов 32-го саммита АСЕАН // ЮгоВосточная Азия: Актуальные проблемы развития. - 2018. - Т. 1. - № 1 (38). С. 62-75.

3. Гарскова И.М. Историческая информатика: сравнительный анализ национальных моделей // Информационный бюллетень Ассоциации «История и компьютер». - 2018. - № 47. С. 25-26.

4. Зангиева И.К., Тимонина Е.С. Сравнение эффективности алгоритмов заполнения пропусков в данных в зависимости от используемого метода анализа // Мониторинг общественного мнения: экономические и социальные перемены. - 2014. № 1 (119). - С. 41-55.

6. Литтл Р.Дж.А., Рубин Д.Б. Статистический анализ данных с пропусками. М.: Финансы и статистика, 1990. - 336 с.

7. Ядов В.А. Стратегия социологического исследования. Описание, объяснение, понимание социальной реальности. - М.: Омега-Л, 2007. - С. 567.

8. Commodity Trade Statistics Database (COMTRADE) // United Nations Statistics Division [Электронный pecypc]. - URL: https://comtrade.un.org/ (дата обращения: 24.04.2019).

9. Little R.J.A., Rubin D.B. Statistical Analysis with Missing Data. - Hoboken, NJ: Wiley, 2019. 464 pp.

10. McKnight P.E., McKnight K.M., Sidani S., Figueredo A.J. Missing Data: A Gentle Introduction. - New York: The Guilford Press, 2007. - 251 pp. 
https://doi.org/10.29003/m1812.978-5-317-06529-4/209-217

Владимирова А.В.

Институт востоковедения РАН, Москва

\title{
Изучение эволюции международных торговых сетей: обзор проблем предварительной обработки данных
}

Аннотация. На протяжении последних десятилетий методы сетевого анализа успешно используются учеными при изучении эволюции системы международной торговли, что позволяет существенного обогащать исторические знания о динамике экспортных и импортных потоков. Однако существует целый ряд проблем с качеством торговых данных, слишком часто не упоминаемых даже в научных публикациях. Представляемая работа фокусируется именно на таких вопросах, связанных со спецификой препроцессинга данных и с оценкой их качества перед построением сетевых моделей.

Keywords: сетевой анализ, качество данных, внешняя торговля, асимметрия данных, зеркальная статистика, пропущенные данные, API.

\section{Vladimirova A.V. Institute of Oriental Studies of the Russian Academy of Sciences}

\section{Exploring Evolution of International Trade Networks: Overview of Data Preprocessing Issues}

\begin{abstract}
For decades network analysis methods have been successfully used by scholars to investigate international trade evolution and to substantially enrich existing body of knowledge on dynamics of export and import flows. However, there is a range of problems with international trade data too often not mentioned even in scientific publications. Thus, this paper aims to address a discussion among historians on the pitfalls of data preprocessing and its quality assessment before building network models.

Keywords: Network Analysis, Data Quality, International Trade, Data Asymmetry, Mirror Statistics, Missing Data, API.
\end{abstract}

\section{Introduction}

For decades analysis of international trade evolution has been an inevitable part of global development studies and, as various publications in cliometrics show, trade relations can be considered one of the most important factors [3]. With the rise of historical network research, we have got new models that can help to substantially enrich existing body of knowledge on dynamics of export and import flows, and luckily the relational data needed for such methods are becoming more available now.

Interesting, that global trade indicators are usually characterized by specialists as methodologically advanced and with the high availability of 
data, for instance, the Inter-Agency and Expert Group on SDG Indicators (IAEG-SDGs) has placed almost all of them in Tier 1 of the classification developed for the UN [10]. However, there is a range of problems too often not mentioned even in scientific publications. Thus, this paper aims to address discussion among historians on the pitfalls of data preprocessing and its quality assessment before building network models. Using the United Nations Commodity Trade Statistics Database (UN Comtrade) as a case, we would like to draw the attention of researchers to the specifics of international trade data management and to propose a revision of existing practices of reporting a preprocessing stage of analysis.

\section{Preprocessing of International Trade Data}

The global replication crisis and discourses on transformations connected to the Data Age were among factors that supported an increase of publications that reveals a variety of existing and emerging problems of quality at all levels of the historical information hierarchy. Thereupon practice of research data management is also changing as scholars starting to work with new types of sources and information systems such as those developed to deal with big data. Even though not all historians agree that such data have a place in the field [1], however, all of them believe that discussion on these new tools and approaches is crucial.

\subsection{Availability of International Trade Data}

A long time before the inventions of computers and relational databases, it was already evident how important and difficult to collect data on international trade. International organizations have been putting enormous effort into developing methodological approaches and information resources to increase their coverage, accuracy, and availability. Certainly, a special role was devoted to the United Nations and now the UN Comtrade is one of the most widely used sources to analyze international trade networks.

The UN has already introduced a few versions of the UN Comtrade website [11] and it indeed follows modern trends in data science including the integration of specific tools such as Tableau dashboards. As for data management, the UN allows to access its data using an application programming interface (API) which is an extremely useful option considering that this dataset now consists of more than three billion records[9]. Most certainly, not all of them are needed for a particular study but even to build a network based on the total volume of commodity flows requires downloading quite a huge volume of data (Fig. 1). 


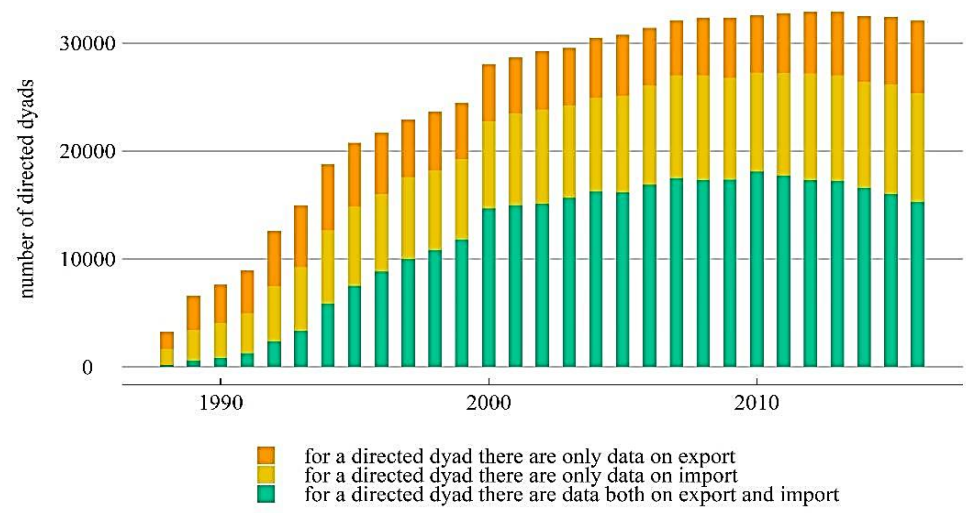

Fig. 1. Availability of data on total international trade of goods: UN Comtrade

Nevertheless, there are a few issues any scholar who is willing to access data from this API should be aware of. First of all, the UN Comtrade is a dynamic database and it means that records can be added, altered, or deleted at any moment without declaring a new version. Thus, a script must include a check for duplicates as well as a researcher need to decided whenever to keep all data or to follow the UN decision to exclude some cases. But what is much more crucial is that this API can be a source of missing data. And this amount can be quite significant (Tab. 1).

Table 1

Using the UN Comtrade data API with R: share of missing data

\begin{tabular}{cccccc}
\hline Year & $\begin{array}{c}\text { Downloaded } \\
\text { Records } \\
\text { Maximum }\end{array}$ & $\begin{array}{c}\text { Missing } \\
\text { Records } \\
\text { Maximum }\end{array}$ & Year & $\begin{array}{c}\text { Downloaded } \\
\text { Records } \\
\text { Maximum }\end{array}$ & $\begin{array}{c}\text { Missing } \\
\text { Records } \\
\text { Maximum }\end{array}$ \\
\hline $\mathbf{1 9 9 1}$ & 11,055 & $19 \%$ & $\mathbf{2 0 0 1}$ & 46,296 & $4 \%$ \\
$\mathbf{1 9 9 2}$ & 15,899 & $1 \%$ & $\mathbf{2 0 0 2}$ & 46,984 & $2 \%$ \\
$\mathbf{1 9 9 3}$ & 19,615 & $7 \%$ & $\mathbf{2 0 0 3}$ & 48,393 & $9 \%$ \\
$\mathbf{1 9 9 4}$ & 26,142 & $0 \%$ & $\mathbf{2 0 0 4}$ & 50,066 & $3 \%$ \\
$\mathbf{1 9 9 5}$ & 29,946 & $6 \%$ & $\mathbf{2 0 0 5}$ & 50,643 & $7 \%$ \\
$\mathbf{1 9 9 6}$ & 32,306 & $4 \%$ & $\mathbf{2 0 0 6}$ & 51,964 & $5 \%$ \\
$\mathbf{1 9 9 7}$ & 34,809 & $2 \%$ & $\mathbf{2 0 0 7}$ & 53,357 & $7 \%$ \\
$\mathbf{1 9 9 8}$ & 36,264 & $13 \%$ & $\mathbf{2 0 0 8}$ & 53,806 & $7 \%$ \\
$\mathbf{1 9 9 9}$ & 38,191 & $0 \%$ & $\mathbf{2 0 0 9}$ & 53,794 & $15 \%$ \\
$\mathbf{2 0 0 0}$ & 45,437 & $0 \%$ & $\mathbf{2 0 1 0}$ & 55,201 & $22 \%$ \\
\hline
\end{tabular}

Note: Accessed from May 1, 2018 to May 31, 2018. 
We had written an R code according to "UN Comtrade API" documentation published on the official website[12] and for more than two years we have been monitoring how it works. Our conclusions are that the API must be used with caution and a scholar needs to introduce a range of solutions not mentioned by the UN to ensure consistency of the data. Obvious, it is not enough just to refer in a paper that the UN Comtrade was the source; for a replication of a study the exact date of access matters.

\subsection{Accuracy of International Trade Data}

To set a weight of an arc could be quite a challenging task as well. According to the UN Comtrade principles of data collection, any country can be presented as a reporter and as a partner, so, for each commodity flow we can potentially get numbers from two sources, and they can be extremely controversial. To show the problem we suggest looking at data on trade relations between Denmark and Singapore (Tab. 2). As we can see, the value of this edge can be significantly bigger if we take the number provided by Singapore.

Table 2

Data on the total commodity flow from Singapore to Denmark

\begin{tabular}{|c|c|c|c|c|c|c|}
\hline \multirow{2}{*}{ From } & \multirow{2}{*}{ To } & \multirow{2}{*}{ Year } & \multicolumn{2}{|c|}{ Source } & \multirow{2}{*}{$\begin{array}{c}\text { Trade Value } \\
\text { Total (USS) }\end{array}$} & \multirow{2}{*}{ Difference } \\
\hline & & & Database & Reporter & & \\
\hline \multirow{6}{*}{ Singapore } & \multirow{6}{*}{ Denmark } & \multirow{6}{*}{2000} & IMF & Singapore & $205,430,000$ & \multirow{2}{*}{0.56} \\
\hline & & & DOTS & Denmark & $115,660,000$ & \\
\hline & & & $\mathrm{UN}$ & Singapore & $205,234,971$ & \multirow{2}{*}{0.53} \\
\hline & & & COMTRADE & Denmark & $109,709,887$ & \\
\hline & & & NBER & - & $108,428,000$ & - \\
\hline & & & CPEII & - & $145,365,168$ & - \\
\hline
\end{tabular}

This phenomenon of discrepancies is usually called 'asymmetry in mirror trade statistics' in the specialized literature and compared to problems with big data management, it has been discussed for decades. One can find methodological publications on this issue dating back to the middle of 19th century [4], as well as, works by many famous scholars, for example, Sir Arthur L. Bowley [5], the pioneer of modern statistics, or C. Gini [6], which name is well-known outside of economics because of the popular index.

Meanwhile, in the recent scientific papers of such a leading journal like Social Networks we can see a statement that mirrored import and export flows in 2001-2010 are presented by «slightly different numbers 
due to country differences in reporting standards» [7]. It is true, that the factor mentioned above can lead to discrepancies, however, there are many other sources of asymmetry (Fig. 2) and as our analytical survey shows [2], they create a combination of causes specific for a particular country and a historical period. Thus, in general, these differences are neither small, neither should be resolved by calculation an average of two numbers.

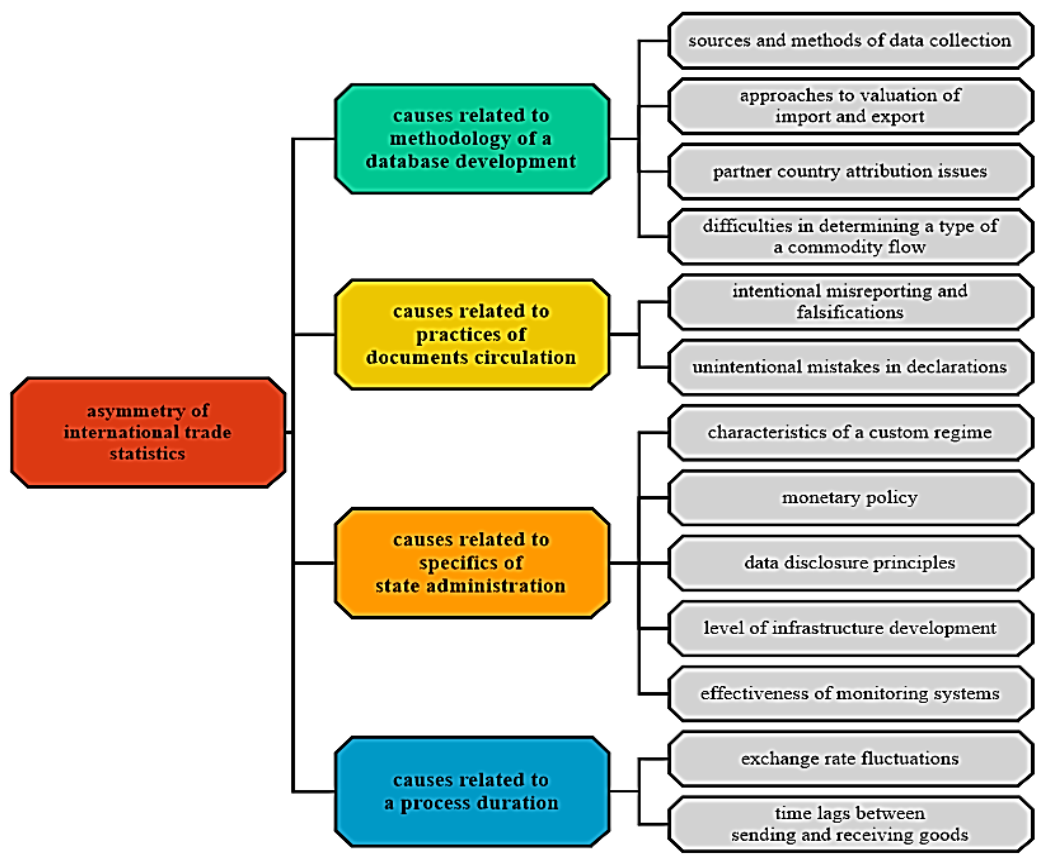

Fig. 2. Asymmetry in mirror trade statistics: a classification of sources

To demonstrate that it is a correct observation we are suggesting to look at Table 3, which presents descriptive statistics of discrepancies in data provided by national agencies to the UN. Even though there are a lot of records characterized by a low level of asymmetry, there are also a significant number of countries in dyads that strongly contradict each other. 
Table 3

Asymmetry in mirror trade statistics

\begin{tabular}{|c|c|c|c|c|c|c|c|c|}
\hline Year & $\begin{array}{c}\text { Number of } \\
\text { Asymmetric } \\
\text { Dyads }\end{array}$ & Mean & SD & Variation & P25 & P50 & P75 & Histogram \\
\hline 1991 & 1,230 & 0.37 & 0.29 & 0.78 & 0.13 & 0.28 & 0.56 & \\
\hline 1992 & 2,238 & 0.37 & 0.30 & 0.81 & 0.12 & 0.28 & 0.59 & \\
\hline 1993 & 3,199 & 0.39 & 0.30 & 0.77 & 0.14 & 0.30 & 0.62 & \\
\hline 1994 & 5,675 & 0.39 & 0.30 & 0.77 & 0.14 & 0.32 & 0.62 & \\
\hline 1995 & 7,078 & 0.42 & 0.31 & 0.74 & 0.15 & 0.35 & 0.67 & \\
\hline 1996 & 8,342 & 0.43 & 0.31 & 0.72 & 0.16 & 0.37 & 0.71 & \\
\hline 1997 & 9,230 & 0.44 & 0.31 & 0.70 & 0.17 & 0.39 & 0.71 & \\
\hline 1998 & 10,060 & 0.44 & 0.31 & 0.70 & 0.16 & 0.39 & 0.72 & \\
\hline 1999 & 11,291 & 0.45 & 0.31 & 0.69 & 0.17 & 0.39 & 0.73 & \\
\hline 2000 & 14,344 & 0.47 & 0.32 & 0.68 & 0.18 & 0.42 & 0.76 & \\
\hline 2001 & 14,652 & 0.47 & 0.32 & 0.68 & 0.19 & 0.43 & 0.76 & \\
\hline 2002 & 14,793 & 0.47 & 0.32 & 0.68 & 0.19 & 0.43 & 0.76 & \\
\hline 2003 & 15,342 & 0.48 & 0.32 & 0.67 & 0.19 & 0.43 & 0.77 & \\
\hline 2004 & 15,938 & 0.47 & 0.32 & 0.68 & 0.18 & 0.43 & 0.77 & \\
\hline 2005 & 15,833 & 0.47 & 0.32 & 0.68 & 0.18 & 0.42 & 0.76 & \\
\hline 2006 & 16,523 & 0.47 & 0.32 & 0.68 & 0.18 & 0.42 & 0.77 & \\
\hline 2007 & 17,161 & 0.48 & 0.32 & 0.67 & 0.19 & 0.43 & 0.78 & \\
\hline 2008 & 16,992 & 0.48 & 0.32 & 0.67 & 0.19 & 0.44 & 0.79 & \\
\hline 2009 & 16,965 & 0.48 & 0.32 & 0.67 & 0.19 & 0.44 & 0.78 & \\
\hline 2010 & 17,732 & 0.47 & 0.32 & 0.68 & 0.18 & 0.43 & 0.77 & \\
\hline
\end{tabular}

Source: UN Comtrade

Moreover, as datasets on international trade are becoming more complex and consist of a bigger number of records, this problem is getting worse (see Fig. 3). We believe it allows us to argue that this problem of statistics accuracy should be addressed as a more serious one by network scientists and that papers have to include details on data quality assessment, implemented solutions, and possible reduction in the precision of estimates with a focus on methods selected for a study.

No doubt, a greater degree of caution is required in drawing conclusions from network models based on data which is described by high levels of asymmetry. This problem's potential influence on analysis results differs starting from the basic methods and a researcher should carefully consider which data on international trade to select for a study. 


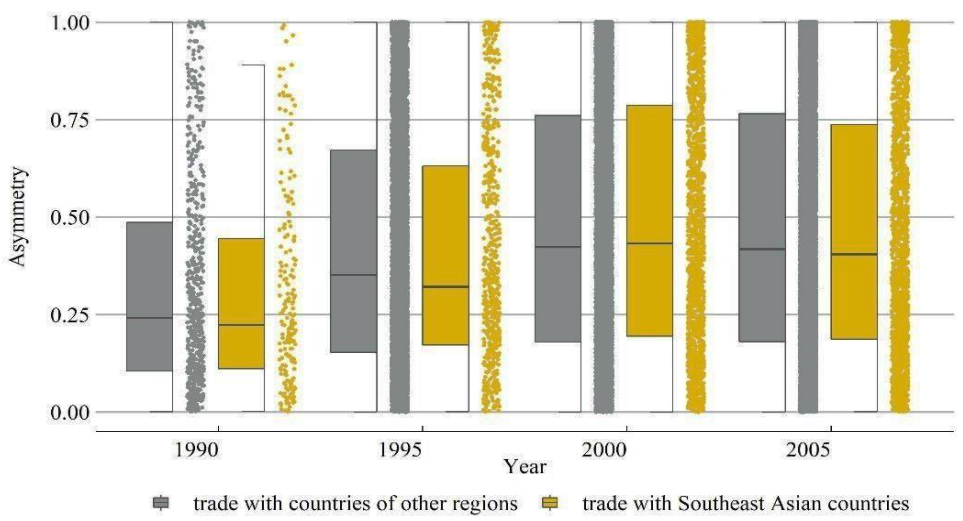

Source: UN Comtrade

Fig. 3. An increase in the level of trade statistics asymmetry

In this conference paper, we show just two traditional measures of weighted degree and betweenness centralities (see Fig. 4 and Fig. 5) calculated based on datasets provided by authoritative international organizations; the United Nations (UN), the International Monetary Fund (IMF), and the Organisation for Economic Co-operation and Development (OECD).

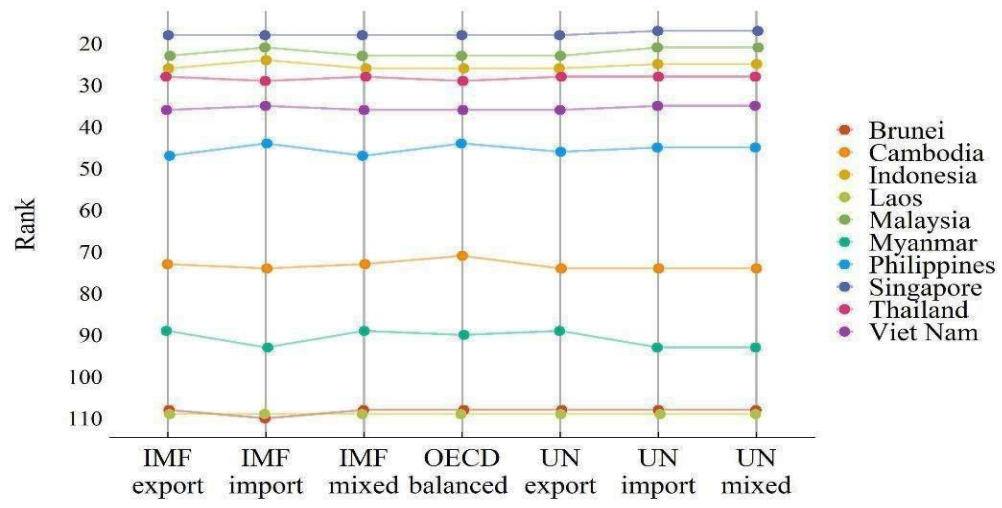

Fig. 4. Comparing datasets: weighted degree centrality 


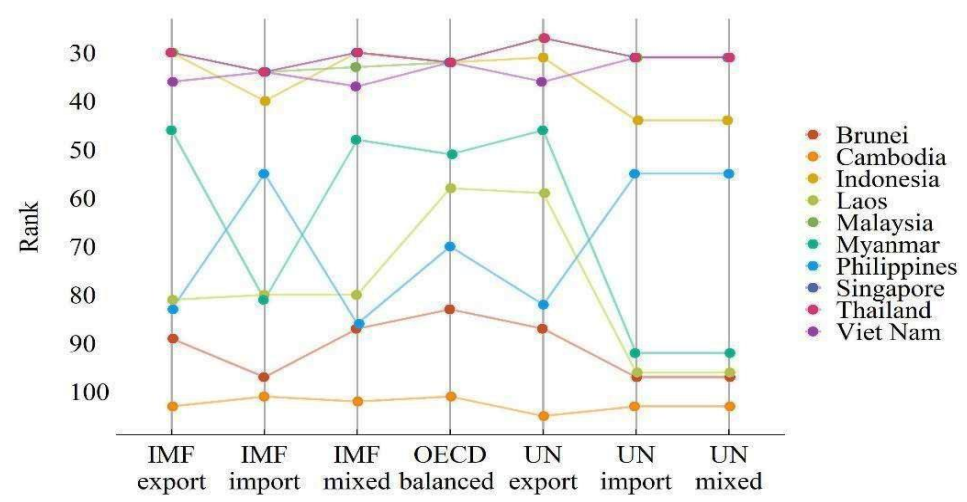

Fig. 5. Comparing datasets: weighted betweenness centrality

The first two sources, UN Comtrade and DOTS [13], are the most popular among scholars now, while the last one [8] was specially designed to lower the number of discrepancies and thus can be used as a reference. To exclude the effect of missing data we have subsetted only edges that are present in all these datasets.

\section{Conclusion}

In closing, we would like to emphasize that a high level of asymmetry found in databases such as UN Comtrade can't be considered as a sufficient reason for an accusation in falsifications and therefore leads to an exclusion of this source from an analysis. Historically, there were many causes of discrepancies in mirror trade statistics and not all of them are possible to obviate. Unfortunately, despite the great efforts of international organizations and scholars worldwide, there is no single database that is ideal in terms of quality, consequently, it is so crucial for researchers to include in their publication a section dedicated to data quality issues and their possible impacts on the results of a conducted analysis. Finally, it is also important to note that for some research questions, it is possible to select a source of international trade data, which is characterized by a greater asymmetry with fewer missing edges.

\section{References}

1. Бородкин Л.И. Историк и мир (больших) данных: вызовы цифрового поворота // Историческая информатика. - 2019. -№ 3 (29). - С. 14-30.

2. Владимирова А.В. Аналитический обзор основных факторов, влияющих на рост асимметрии показателей экспорта и импорта стран Юго-Восточной Азии // ЮгоВосточная Азия: Актуальные проблемы развития. - 2020. - Т. 1. - № 1 (46). - С. 45-68.

3. Зинькина Ю.В., Шульгин С.Г., Коротаев А.В. Эволюция глобальных сетей: Закономерности, тенденции, модели. - М.: ЛЕНАНД, 2016. - 280 с. 
4. Alex J. Memorandum Indicating Some of the Causes to Which the Discordancy of the Commercial Statistics of Various Countries in Chiefly to be Attributed // Journal of the Statistical Society of London. - 1861. - T. 24. - № 2. - C. 229-234.

5. Bowley A.L. Some Tests of the Trustworthiness of Public Statistics // Economica. 1928. - № 24. - C. 253-276.

6. Gini C. Le statistiche delle esportazioni // Rivista di Politica Economica. - 1928. T. 18. - № 5. - C. 389-700.

7. Zhou M., Wu G., Xu H. Structure and Formation of Top Networks in International Trade, 2001-2010 // Social Networks. - 2016. - T. 44. - C. 9-21.

8. Balanced Merchandise Trade Statistics (BIMTS)// Organisation for Economic Cooperation and Development (OECD) [El. resource]. - URL: http://stats.oecd.org/Index.aspx? DataSetCode=BIMTS_CPA (дата обращения: 03.05.2018).

9. About the Data. UN Comtrade Analytics// Commodity Trade Statistics Database (COMTRADE) [El. resource]. - URL: https://comtrade.un.org/labs/data-explorer/ (дата обращения: 05.05.2020).

10. IAEG-SDGs Tier Classification for Global SDG Indicators// United Nations [E1. resource]. - URL: https://unstats.un.org/sdgs/iaeg-sdgs/tier-classification/ (дата обращения: 07.05.2020).

11. United Nations Statistics Division - Commodity Trade Statistics Database (COMTRADE) [El. resource]. - URL: https://comtrade.un.org/db/mr/rfglossarylist.aspx (дата обращения: 23.11.2017).

12. API Portal // UN Comtrade: International Trade Statistics [El. resource]. - URL: https://comtrade.un.org/data/dev/portal/ (дата обращения: 11.12.2018).

13. Direction of Trade Statistics (DOTS)// International Monetary Fund [El. resource]. URL: http://data.imf.org/?sk=9D6028D4-F14A-464C-A2F2-59B2CD424B85 (дата обращения: 17.01.2019).

https://doi.org/10.29003/m1813.978-5-317-06529-4/217-229

Гарскова И.М.

Московский государственный университет имени М.В. Ломоносова

\section{Методика сетевого анализа в исторических исследованиях: специфика проблематики и источниковой базы исследования}

Аннотация. В данной работе делается попытка выявить некоторые особенности и тенденции применения сетевого анализа в отечественной историографии применительно как к проблематике исследований, так и к видам источников. Показано, что в последние годы повышается интерес к работе с большими по объему тематическими текстовыми коллекции данных, что предполагает применение комплекса методов и технологий, включающего создание табличных и полнотекстовых баз данных, контент-анализ, сетевой анализ и визуализацию данных и результатов.

Ключевые слова: сетевой анализ, источниковая база, методы и технологии, контент анализ, географические информационные системы. 


\title{
Garskova I.M. Lomonosov Moscow State University
}

\section{Methodology of network analysis in historical research: the specificity of the topic and the source base of the research}

\begin{abstract}
In the research, an attempt is made to identify some of the features and trends in the application of network analysis in Russian historiography in relation to both research problems and types of sources. It is shown that in recent years there has been an increase in interest in working with large-scale thematic textual collections of data, which implies the use of a set of methods and technologies, including the creation of tabular and full-text databases, content analysis, network analysis and visualization of data and results.
\end{abstract}

Keywords: network analysis, sources, methods and technologies, content analysis, geographic information systems.

Быстро набирающие популярность, особенно в связи с ростом электронных коммуникаций в современном обществе, междисциплинарные методы сетевого анализа активно используются в социально-гуманитарных науках, прежде всего, в социологии, которой они обязаны своим появлением.

В исторических исследованиях примеры применения сетевого анализа пока немногочисленны, можно сказать, что эта область пока находится в стадии формирования. Например, до недавнего времени у историков не было профильного научного журнала по сетевым исследованиям, он появился на Западе только в 2017 году - Journal of Historical Network Research (http://historicalnetworkresearch.org/). Тем не менее, в последние 15-20 лет сетевой анализ в исторических исследованиях активно развивается и превращается из периферийного направления в достаточно популярную методологию, вышедшую за рамки метафорического ощущения понятия «сети». Этой эволюции во многом способствуют и расширяющиеся междисциплинарные контакты, и растущий объем оцифрованных источников, особенно - текстовых источников, хотя с ростом объема материала растут и сложности работы с ним: это проблемы полноты, точности, репрезентативности, с которыми гораздо реже сталкиваются специалисты в области социальных наук, имеющие дело с анкетами, опросами и другими более структурированными источниками.

Сетевой анализ в исторических исследованиях адаптирует теорию и методы, разработанные в социальных науках, к конкретноисторической проблематике. Область, в которой преобладали традиционные просопографические исследования, заметно расширяется. 
В экономической истории сетевой анализ используется для анализа финансовых связей, сетей средневековой торговли, в политической истории - для изучения элит, политических институтов (например, парламента), оппозиционных движений, анализа дипломатических и военных союзов и конфликтов, в социальной истории и просопографии - для изучения социальной структуры общества, миграционных потоков, формирования систем образования и др. Используется широкий круг источников, от античной литературы до современных газет и журналов, судебно-следственной документации, коллекций фотодокументов, завещаний, частной переписки.

В данной работе делается попытка выявить некоторые особенности применения сетевого анализа в отечественной историографии применительно как к проблематике исследований, так и к видам источников.

Помимо классических сетей, представляющих собой связи между персоналиями (акторами) на основе отношений дружбы, доверия, родства (т.н. аффективных отношений), порождающих матрицы смежности (социоматрицы), не менее широко распространены аффилиативные сети - сети, построенные по критерию участия акторов в некоторых событиях или принадлежности к определенным группам. В отличие от традиционных сетей такие сети включают два множества элементов - акторов и события. В этом случае в основе сетевого анализа находится матрица инцидентности - более сложная матрица связей акторов и событий, в которых акторы принимают совместное участие. Строки такой матрицы соответствуют вершинам графа - акторам, столбцы - ребрам (дугам) графа, т.е. событиям. $\mathrm{C}$ точки зрения формата данных матрица инцидентности может быть создана непосредственно на основе источника в виде электронной таблицы или получена из базы данных в результате выполнения перекрестного запроса, а затем преобразована в электронную таблицу. Электронная таблица, в свою очередь, импортируется в программу сетевого анализа и трансформируется, чаще всего, в матрицу смежности - связи между акторами.

Хронологически первым исследованием, в котором фактически была поставлена задача выявления в 1914 г. сетевых связей между крупными акционерными предприятиями тяжелой промышленности через изучение состава правлений, была работа В.И. Бовыкина и К.Ф. Шацилло, источником для которой послужили справочники «Акционерно-паевые предприятия в России» (1910-1917 гг.) [1]. 
Эта работа о личных униях, опубликованная еще до появления концепций и программ сетевого анализа в исторических исследованиях, содержит много таблиц, содержащих информацию об аффилиативных связях.

Та 6 лица 14

Предприятия, связанные личными униями с участниками Русской Генеральной нефтяной корпорации (РГНК)

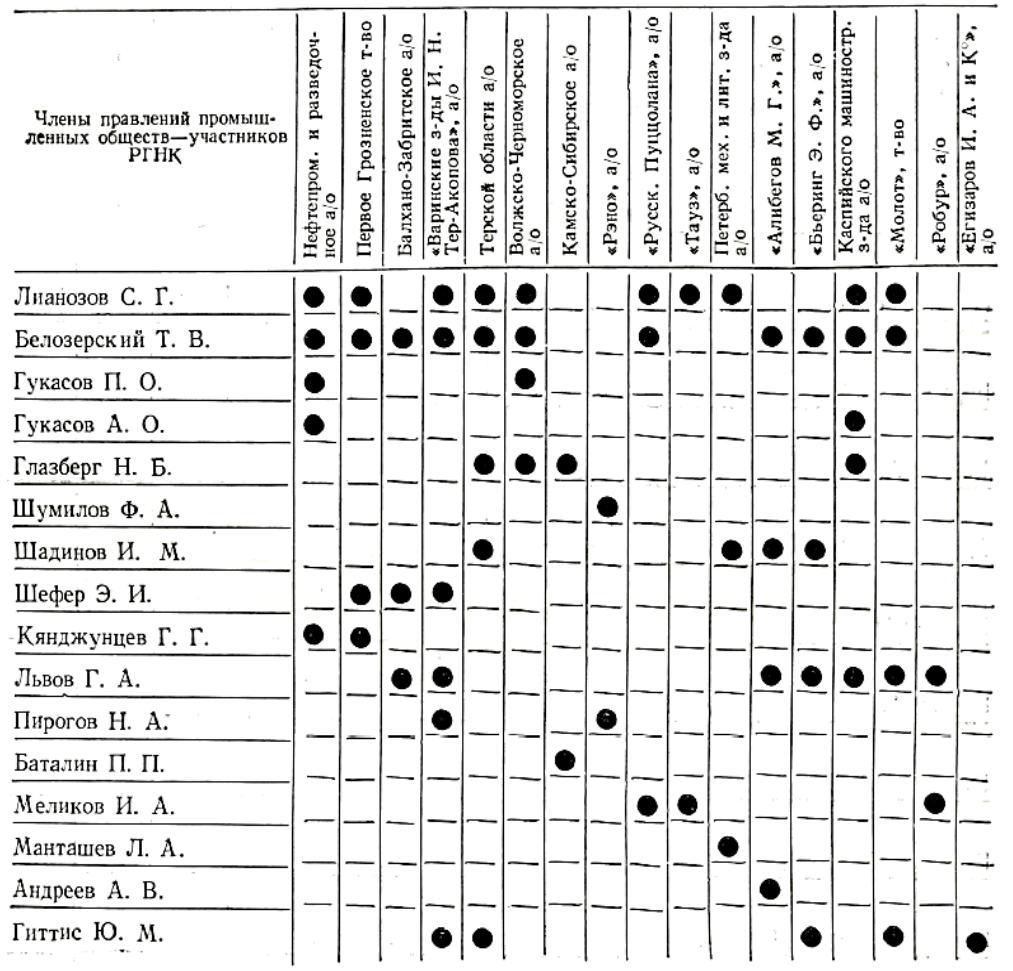

В качестве примера организации информации в этом исследовании здесь приведена таблица, которая демонстрирует связи предприятий группы Русской генеральной нефтяной корпорации (РГНК) через личные унии с группой нефтедобывающих и нефтеперерабатывающих предприятий, а также заводов, производящих нефтяное оборудование и стройматериалы. Статья снабжена таблицами, которые сегодня воспринимаются как практически готовые данные для представления их в формате MS Excel и последующего экспорта в программу компьютеризованного сетевого анализа. 
После значительного перерыва на рубеже XX и XXI вв. проблематика уний в банковском секторе вновь привлекает внимание историков и изучается уже с помощью статистических методов, в частности, кластерного анализа, но по-прежнему, без обращения к специализированным программам SNA [2]. В несколько ином ракурсе возможности применения современных концепций сетевого анализа рассматриваются в связи с прикладными аспектами теории бизнес-сетей [3].

В начале 2010-х гг. в социальной и социально-политической истории отечественные исследователи начинают ставить задачи изучения социальных и профессиональных структур и обсуждать в качестве инструментов для решения этих задач возможности использования методов SNA, см., например [4], [5].

Разумеется, одним из основных направлений сетевого анализа в исторических исследованиях остается его применение на материалах баз данных, прежде всего, просопографических. Биографические сведения о социально-профессиональных группах людей дают много информации для построения социальных сетей. В качестве примера можно назвать одну из первых работ в этом жанре - сетевой анализ просопографической базы, посвященной созданию коллективной биографии архитекторов Московского метро. Это исследование выполнено на материалах архива ГНИМА им. А.В. Щусева с привлечением материалов СМИ, монографий и статей, которые выходили в годы строительства московского метро [6].

На приведенном сетевом графе (рис. 1) видны основные подгруппы - компоненты сети профессиональных связей архитекторов, складывавшиеся в первый (т.н. «сталинский») период строительства метрополитена. В этой работе уже в полной мере видны результаты работы с компьютеризованными инструментами сетевого анализа и визуализации сетей. В данном случа сеть строится на основании сведений о совместном участии архитекторов в создании проектов станций и вестибюлей метрополитена, с использованием перекрестных запросов к таблицам базы данных.

Внимание российских исследователей привлекают и возможности сетевого анализа для изучения политических организаций и институтов власти. Этой проблематике посвящен ряд публикаций по материалам деятельности Государственных Дум начала XX в. Для изучения политических группировок помимо биографических сведений привлекаются полнотекстовые коллекции документов - выступления депутатов, депутатские запросы, законодательные предложения. 


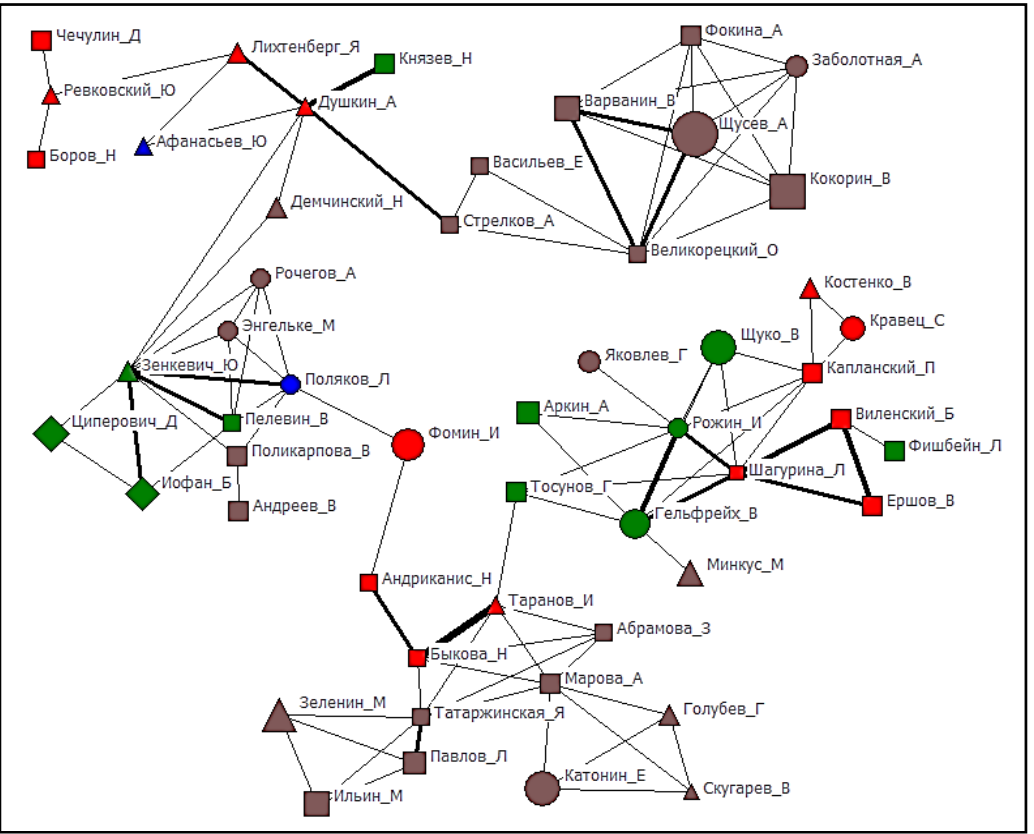

Рис. 1. Сеть профессиональных связей архитекторов в первый период строительства

На основе изучения этих источников выявлялось и измерялось сходство (с применением корреляционного анализа) политических и социально-экономических взглядов депутатов, а затем выполнялся сетевой анализ: например, [7], [8]. На губернском уровне, на материалах журналов губернских земских собраний изучалась возможность построения сетевых связей, как проявление фракционности, то есть публичной поддержки мнений единомышленников, и возможность выявления устойчивых группировок в земских собраниях [9].

Сетевой анализ используется в историографических и библиографических исследованиях. Так, в работе И.М. Гарсковой по анализу формирования профессиональных сетей в области исторической информатики использована уже не просопографическая, а библиографическая база данных, содержащая описания более 3 тыс. публикаций. Сеть научных связей между исследователями, работающими в русле одного направления, строится на понятии соавторства. Были выявлены более двух десятков региональных центров и групп исследователей и 4 школы исторической информатики, центральной из 
которых является московская школа, объединенные в единую межрегиональную группу [10].

На рис. 2 показаны 4 ведущие школы с научными связями как внутри каждой из них, так и со связями между школами, которые обеспечиваются наличием акторов, которые играют роль посредников, «мостов», без которых сеть распадается на отдельные изолированные компоненты, как это бывает на начальных этапах формирования научного направления. Подход, основанный на анализе соавторства публикаций как показателе научных связей, позволяет изучать формирование как формальных, так и «виртуальных» научных коллективов, процесс появления научных центров и школ.

Современные программы сетевого анализа позволяют проводить «двухуровневый» анализ: изучение динамики складывания групп, их концентрации выявляет центральные фигуры, вокруг которых формируются компоненты, которые называются эго-сетями; их визуализация характеризует позиции лидеров сетевого сообщества и их связи с сетевым окружением.

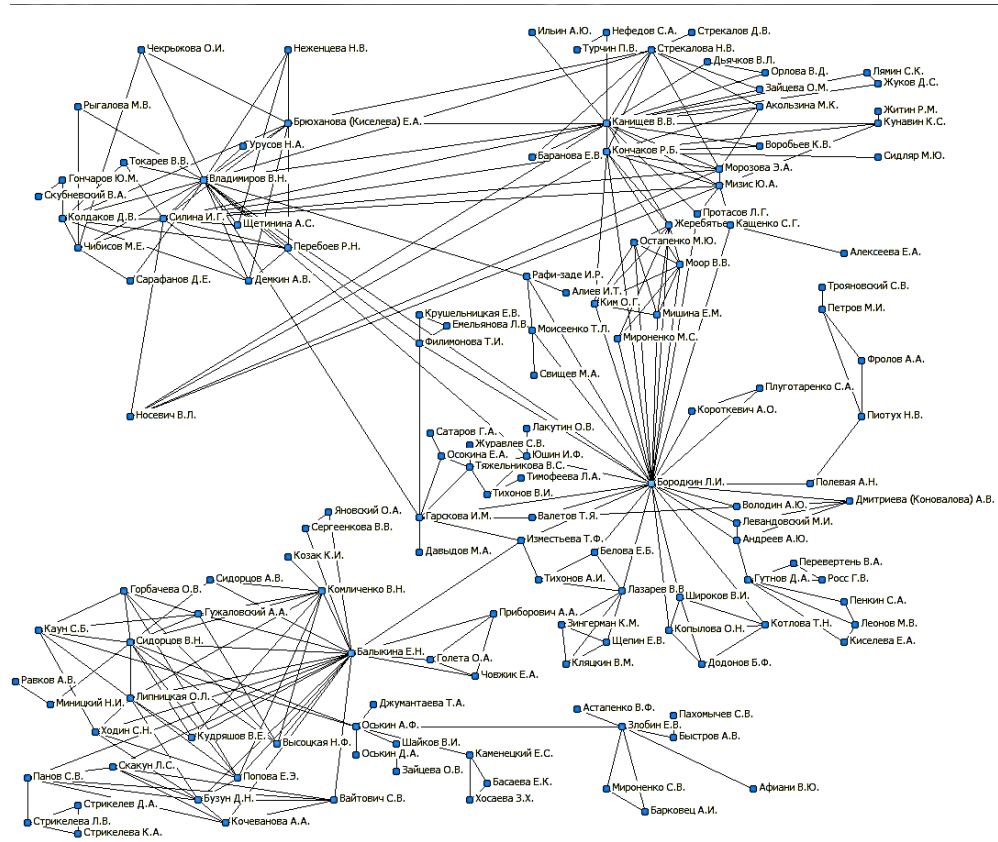

Рис. 2. Ведущие научные школы в области исторической информатики 
Более того, связывая информацию о группах с тематическими рубриками публикуемых работ, можно выявлять специфику научных интересов этих групп, их сходство и различия.

Теоретико-графовый метод использовался и при изучении «генеалогии» исторического научного сообщества, т.е. фактически - сетевых связей между поколениями историков, хотя в этих публикациях терминология SNA еще не использовалась [11].

На основе аффилиативных сетей можно строить не только традиционные сети, т.е. отношения между элементами одного множества (акторами), обусловленные их связями с элементами другого (событиями). Здесь можно использовать две стратегии анализа: с одной стороны, изучать связи акторов между собой, с другой стороны - связи событий между собой, т.е. в определенном смысле акторы и события можно менять местами; например, уже у В.И. Бовыкина унии рассматриваются не только как связи между членами правлений, но унии в определенном смысле - это и связи между акционерными предприятиями

Такой поворот можно продемонстрировать на примере построения сетей, акторами в которых являются события (в широком смысле слова), а связывают их между собой люди, принимающие в них совместное участие. Например, можно строить сети, представляющие собой связи между различными направления научной проблематики в рамках определенной научной области или в структуре публикаций в научном журнале. На рис. 3 можно видеть связи между основными тематическими блоками публикаций в изданиях под эгидой Ассоциации «История и компьютер» в первый период становления отечественной модели исторической информатики, когда мы наблюдаем наиболее сильные связи конкретно-исторических исследований, с одной стороны, с формирующимися информационными ресурсами (коллекциями источников в машиночитаемой форме), с другой стороны, с математическими методами анализа данных.

Выходя за рамки традиционного понимания сетей как отношений между акторами-людьми, отметим, что широкое поле для сетевого анализа представляет изучение несимметричных связей между точками отправления и получения информационных, товарных, финансовых, миграционных потоков. Здесь изначально анализируется не совместное участие или совместная принадлежность к некоторым группам или событиям, а направленные связи между объектами одного уровня (отправителями и получателями). 


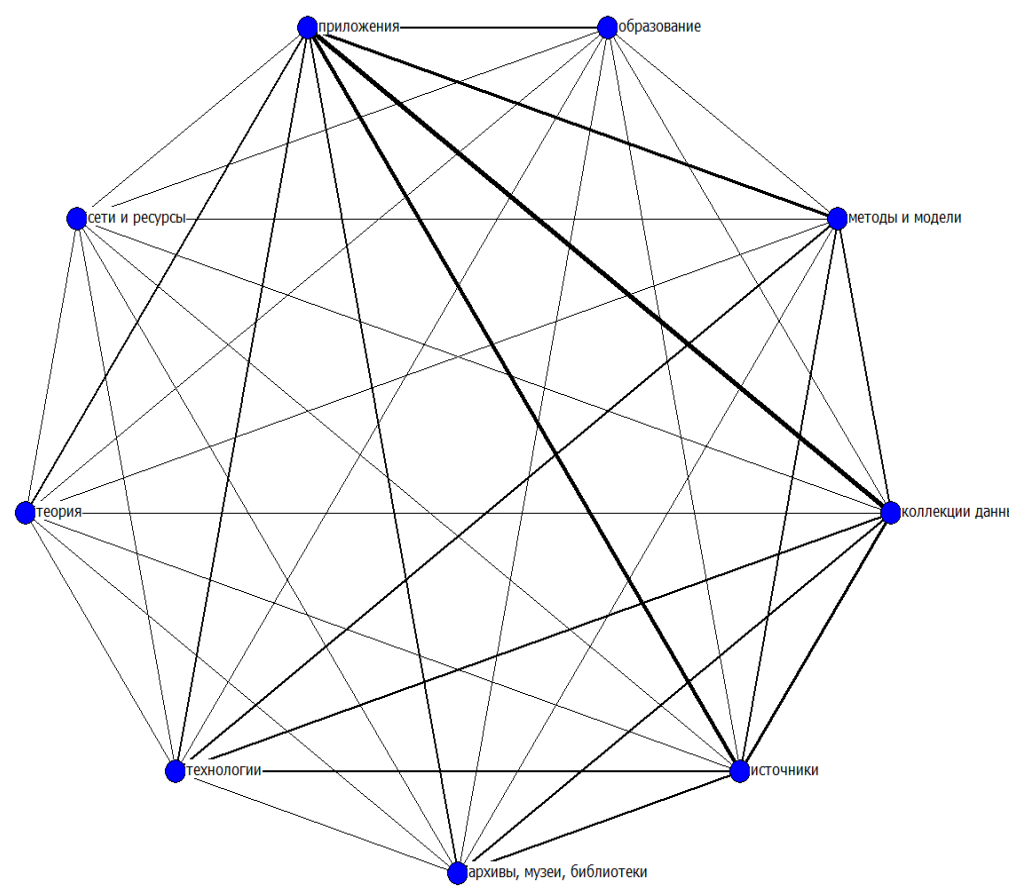

Рис. 3. Связи между основными тематическими блоками публикаций в изданиях под эгидой Ассоциации «История и компьютер» в 1992-1996 гг.

Источники демографических данных в исследованиях на макроуровне часто представлены как электронные таблицы, обеспечивающие удобный инструмент для трансформации данных о потоках в формат файлов программы SNA. Если речь идет о пространственных процессах, в таких исследованиях, кроме графов, хорошей иллюстрацией являются карты. Пример миграционных потоков представлен на карте, иллюстрирующей структуру укрупненной сети крестьянских миграций. Основным источником для проведения сетевого анализа структуры миграционных потоков послужили сведения Всесоюзной переписи населения 1926 г. На карте (рис. 4) показаны восемь кластеров, состоящих из районов со схожей структурой миграционных потоков [12]. 


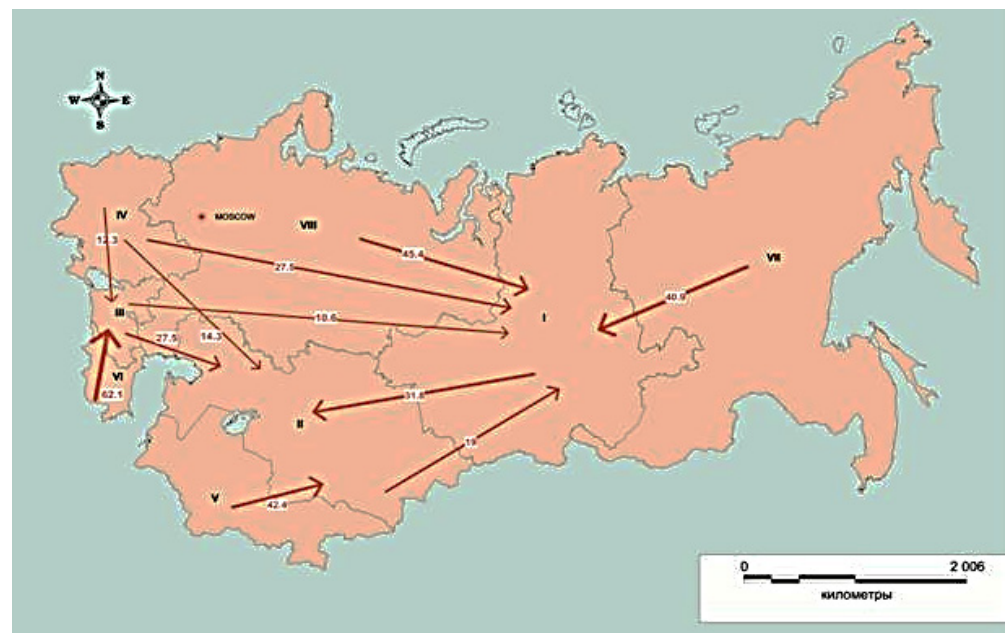

Рис. 4. Сеть крестьянских миграцийпо данным переписи 1926 года

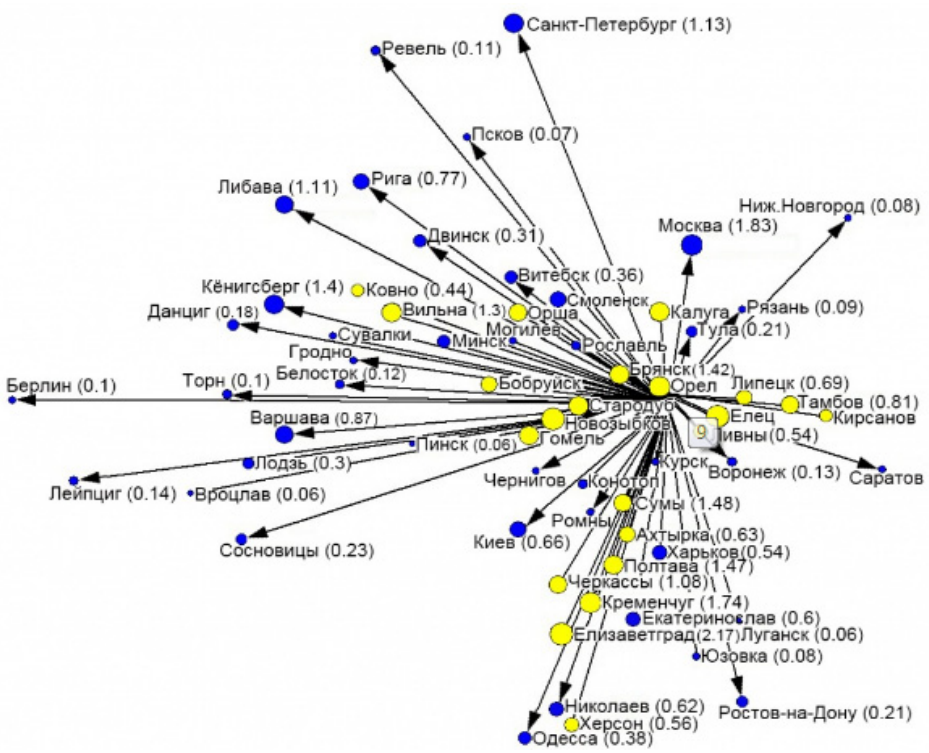

Рис. 5. Товарно-денежные потоки из Центрального Черноземья и в противоположном направлении (1901 г.) 
Другим примером может служить проект, в котором проводится сетевой анализ товарно-денежных потоков Центрального Черноземья на статистических материалах межрегиональных платежей Орловского коммерческого банка за 1874-1901 гг. На рис. 5 показаны товарно-денежные потоки из Центрального Черноземья, которые были ориентированы на вывоз товаров в западном направлении, и товарно-денежные потоки в противоположном направлении, связанные с ввозом товаров в Центральное Черноземье из всех основных торгово-промышленных центров Российской империи. Расположение объектов соответствует их географическим координатам [13].

Интересные возможности сетевого анализа открываются при обращении к материалам нарративных источников, преобразованных в ходе исследования в формат полнотекстовых баз данных. Это, как правило, большие по объему текстовые коллекции источников личного происхождения (мемуары, дневники, переписка) или материалы прессы [14]. Необходимая для сетевого анализа структура привносится в такие источники с помощью формирования системы семантических категорий и индикаторов и последующего частотного анализа их совместной встречаемости, дающего в результате таблицу сопряженности этих семантических категорий, отражающую основные их взаимосвязи. Полученные сети позволяют изучать эволюцию редакционной политики печатного издания или проводить сравнительный анализ позиций различных источников информации в освещении событий, например, сравнивать воспоминания бывших заключенных и подцензурную лагерную прессу [15].

В работе с полнотекстовой базой данных можно дополнительно включить в анализ просопографическую информацию. Современные программы компьютеризованного контент-анализа позволяют дополнять тексты атрибутами, характеризующими биографии авторов, их профессиональную и институциональную принадлежность. Это открывает возможность для сравнительного анализа отдельных групп текстов (авторов), выявляя особенности восприятия событий в источниках личного происхождения, присущие этим группам. Такой подход выявляет «сетевой портрет» каждой группы как основу для интерпретации ее особенностей [14].

Если же в число семантических категорий контент-анализа включаются имена персоналий, например, авторов воспоминаний и тех, о ком они пишут, мы получаем некоторый аналог аффилиативных сетей и возможность построения связей не только между категориями, но и между персоналиями [16]. 
Таким образом, работа с такими массовыми источниками, как большие по объему тематические текстовые коллекции предполагает применение комплекса методов и технологий, включающего создание табличных и полнотекстовых баз данных, контент-анализ, сетевой анализ и визуализацию сетей, а если имеется картографическая информация, то построенные сети можно размещать на карте с использованием ГИС-технологий.

\section{Библиография}

1. Бовыкин В.И., Шацилло К.Ф. Личные унии в тяжелой промышленности России накануне Первой мировой войны // Вестник МГУ. Серия История». - 1962. № 1. - C. 55-74.

2. Белова Е.Б., Лазарев В.В., Рудюк И.В. Банковские унии в России на рубеже XIX - XX вв. // Экономическая история. Ежегодник. 1999. - М., 1999. - С. 397-416.

3. Саломатина С.А. Теория бизнес-сетей и российское банковское дело, вторая половина XIX - начало XX вв. // Роль информации в формировании и развитии социума в историческом прошлом. М., 2004. С. 253-266.

4. Лямин С.К. Фрактальная имитационная модель социально-культурных сетевых связей в русском городе второй половины XIX - начала XX вв. // Информационный Бюллетень Ассоциации «История и компьютер». - 2010. - №36. - С. 103-104.

5. Кончаков Р.Б., Стрекалова Н.В. К проблеме изучения сетевых связей государственных служащих в провинциальном городе начала XX в. методами SNA // Информационный Бюллетень Ассоциации «История и компьютер». - 2012. - № 38. - С. 111-113.

6. Ермошин А.Д. Сетевой анализ просопографической базы данных об архитекторах Московского метрополитена 1935-1991 гг. // Историческая информатика. 2017. - № 4. - C. 130-142.

7. Сметанин А.В. Институт фракций в Государственной Думе Российской империи (1906-1917): Дис. ... канд. ист. наук. - Пермь, 2016.

8. Сметанин А.В. Семантический контент-анализ выступлений депутатов Государственной Думы Российской империи: методологические аспекты // Вестник Пермского университета. Серия «История». - 2014. - Вып. 3 (26). - С. 57-66.

9. Поврозник Н.Г., Сметанин А.В. Сети земских гласных: К вопросу об истоках «партийности» в местном самоуправлении // Историческая информатика. - Электрон. журнал. - 2020. - №1. - C. 94-110. - URL: https://nbpublish.com/library_read_article. php?id=31884.

10. Гарскова И.М. Историческая информатика: эволюция междисциплинарного направления. - СПб.: Алетейя, 2018.

11. Гутнов Д.А., Перевертень В.А. ГНС-граф как абстрактная структура для визуализированного анализа «генеалогических» отношений в научных сообществах // Информационный Бюллетень Ассоциации «История и компьютер». - 1997. - № 21. C. $14-16$.

12. Бородкин Л.И. Сетевой анализ в исторических исследованиях: микро- макроподходы // Историческая информатика. - Электрон. журнал. - 2017. - №1. - С. 110124. - URL:https://nbpublish.com/library_read_article.php?id=22842.

13. Саломатина С.А., Гарскова И.М., Валетов Т.Я. Межрегиональные расчеты Орловского коммерческого банка во второй половине XIX в.: сетевой анализ // Историческая информатика. - Электрон. журнал. - 2019. - №4. - С. 122-147. - URL: http://e-notabene.ru/istinf/article_31020.html/ 
14. Гарскова И.М., Симонженкова Е.М. О формализованной методике анализа комплексов мемуарных источников // Историческая информатика. - Электрон. журнал. - 2019. - № 1. - С. 169-188. - URL: https://e-notabene.ru/istinf/article 29390.html.

15. Зингис К.А. Мемуары узников Соловецкого лагеря особого назначения: результаты контент-анализа // КЛИО. - 2020. - № 10. - С. 13-26.

16. Гребенченко И.В. Взаимодействие создателей советской космонавтики: контент-анализ воспоминаний // Аналитические методы и информационные технологии в исторических исследованиях: от оцифрованных данных к приращению знания. Материалы международной конференции. - М. : МАКС Пресс, 2018. - С. 51-52.

https://doi.org/10.29003/m1814.978-5-317-06529-4/229-235

Головашина О.В., Кунавин К.С. Тамбовский государственный университет имени Г.Р. Державина

\title{
Сетевая модель межличностных связей высшего чиновничества Российской империи. Проблемы и решения ${ }^{1}$
}

Аннотация. В статье перечисляются некоторые эвристические перспективы применения методов сетевого анализа межличностных отношений высшей бюрократии Российской империи. Озвучивается основная проблема построения такой модели - неопределенность понятия «связь». Предлагаются пути концептуального осмысления этого понятия, приемлемого для конкретно-исторического исследования. Описывается алгоритм выявления межличностных связей на основе различных по качеству источников без необходимости привлечения микроанализа.

Ключевые слова: бюрократия, Российская империя, сетевой анализ, связь.

Golovashina O.V., Kunavin K.S. Derzhavin Tambov State University

\section{Network model of interpersonal links of Russian empire high bureaucracy. Problems and solutions}

\begin{abstract}
In the article some heuristic perspectives of usage of the methods of network analysis of interpersonal relations in the high bureaucracy of Russian empire network analysis are listed. The main problem of building such a model ambiguity of the concept "link" - is stated. The ways of conceptual comprehension of this term are suggested to be acceptable for concrete-historical research.

${ }^{1}$ Исследование проведено при финансовой поддержке Российского фонда фундаментальных исследований. Проект № 19-09-41034 «Культурная и политическая деятельность России в Святой Земле по документам фонда Б.П. Мансурова (1850-1880-е гг.)».
\end{abstract}


The interpersonal links detection algorithm, based on different quality sources with no need of microanalysis, is described.

Keywords: bureaucracy, Russian empire, network analysis, link.

Наиболее распространенными способами изучения высшего чиновничества Российской империи являются два подхода, иногда взаимодополняющие друг друга. В первом случае высшее чиновничество рассматривается как галерея сложных, ярких и влиятельных личностей. Во-втором, в едином феномене под общим названием «бюрократия» выделяются и описываются различные группы, «партии», «клики» личностей. Несмотря на обоснованность и продуктивность таких подходов, каждому из них присущи определенные эпистемологические ограничения.

Для первого подхода, которому следует большинство биографических исследований, характерна одна из двух логик, заложенных в структуре повествования: либо бюрократ, используя ресурсы своей должности, стремится улучшить общество во благо государства [см. напр. 1]; либо бюрократ берет в свои руки функции управления, чтобы облегчить для общества груз государства [см. напр. 2]. Такая дуалистичность закономерна и вытекает из не совсем определенного положения российской имперской бюрократии в ландшафте социальных групп и институтов: кто такой чиновник - агент государства или представитель общества, вживленный в систему служебных отношений? Несводимость этих двух категорий возможна только в том случае, если мы проводим четкий водораздел между государственными и общественными институтами, но такой водораздел сам задается дискурсом и сложившимися моделями описания, так как на протяжении значительной части истории общество и государство стремились управлять друг другом и нередко идентифицировали себя оппозиционно по отношению друг к другу. В исторической реальности, скорее, можно констатировать существование определенного государственнообщественного континуума, в котором чиновник будет занимать различное положение в зависимости от своих задач и/или социального окружения. Адекватное отражение этой ситуации требует другой исследовательской оптики, которая позволяла бы проследить не только биографии конкретных персоналий, а построить систему их (индивидуальных и конкретных) взаимоотношений.

Представители второго направления, хотя и акцентируют внимание на групповых объединениях, (чаще всего в работах, посвященных биографиям чиновников или эпизодам разработки и осуществления реформ), как правило, избегают строгих дефиниций 
терминологии и опираются на различные подходы в использовании понятийного аппарата, поэтому компилятивное или компаративное сопоставление их исследований и выводов затруднено. Наибольшая сложность в определении универсальных и приемлемых для истории имперской России категорий наблюдается у таких ключевых понятий как «партия», «клика», «группа» и т.п. Более того, «партии» и «клики» рассматриваются как сформированные конструкции в социальном пространстве. За пределами анализа почти всегда остаются их зарождение, эволюция (как в узком смысле - эволюция конкретной группы, так и в широком - эволюция самого явления), распад. Мало работ, рассматривающих различные чиновные «партии» в общей совокупности, во взаимных отношениях и соотношениях, в динамике. Нет точного представления о количестве «партий» на протяжении XVIII и XIX в. и их реальном составе. Не ясна доля лиц, входивших в «партии», но не являвшихся государственными служащими. Неизвестна степень преломления установленной бюрократической иерархии должностей и отношений внебюрократическими или околобюрократическими сетевыми структурами, через которые также циркулировала важная информация и посредством которых могли разрабатываться и осуществляться некоторые решения. Мы предполагаем, что эти проблемы могла бы устранить разработка динамической сетевой модели межличностных отношений представителей высшей бюрократии Российской империи.

На наш взгляд, преодолению этих недостатков двух проанализированных выше подходов может способствовать привлечение аппарата сетевого анализа. Метод сетевого анализа уже стал традиционным для социологии и не так давно зарекомендовал себя в истории [см. напр. 3; 4; 5]. В основе метода лежит построение сетевого графа, представляющего собой совокупность вершин (точек) и ребер (соединений). Точками, в нашем случае, выступают персоны, ребрами их межличностные связи. Граф может быть динамическим, то есть менять количество вершин и архитектуру связей между ними каждую единицу времени. Его анализ осуществляется специальным математическим аппаратом, раскрывающим многие качества как графа в целом, так и вершин или их кластеров в отдельности.

Сетевой граф межличностных отношений высшей бюрократии, по нашим предположениям, должен содержать как следы регулярных (государственных) структур, так и следы иррегулярных, стохастических (общественных в широком смысле) систем. Таким образом, сете- 
вой граф позволяет преодолеть противоречия двух существующих подходов и органически вписывает в них каждого бюрократа.

Предлагаемый метод имеет эвристическую продуктивность только в случае учета в сетевой модели значительного, подавляющего числа высших бюрократов, присутствовавших в ландшафте государственных учреждений в течение XVIII-XIX вв. (например, словарь С.В. Волкова «Высшее чиновничество Российской империи» (2017г.) насчитывает около 22 тыс. персон.). Большой объем вершин (персон) в итоговой модели не кажется существенным методическим препятствием. Однако определенные сложности могут быть связаны со вторым компонентом предлагаемой модели - со связью. Во-первых, наиболее точный подход к определению личных связей исторических деятелей - микроанализ их биографий - не будет продуктивен в нашем случае. Во-вторых, есть большая концептуальная неопределенность понятия «связь». Что целесообразно считать связью при моделировании сетевой структуры высшей бюрократии? Факт знакомства? Близкие служебные отношения? Личные дружеские отношения? Родственные отношения? Комбинацию нескольких типов отношений? Четкость определения понятия «связь» будет влиять на построение графа, его структуру, а значит, на полученные в результате нашего исследования выводы. Дополнительные сложности могут быть связаны с тем, что разнообразие типов отношений порождает необходимость привлечения разнообразных комплексов источников, что в условиях больших объемов информации может являться существенным препятствием. Мы предполагаем, что именно сложности с концептуализацией того, что именно мы называем «связью», оказываются причиной, по которой при растущей популярности сетевого анализа и доступности технической возможности обработки больших массивов данных, нами не наблюдаются попытки построения карты связей высшей бюрократии в масштабах империи.

На первом этапе нашего исследования мы провели различение между понятием «отношение» (межличностное отношение) и понятием «связь». Такое различение позволит избежать риска включения в сетевую модель любого факта межличностной коммуникации или намека на продолжающиеся взаимоотношения (которыми, естественно, изобилует исторический нарратив). В нашем понимании «отношение» - более общее понятие. Не каждые отношения перерастают в связь, но каждая связь является продуктом отношений. В отличие от отношений, в нашей модели связь обладает агентностью, поэтому их фиксация в сетевой модели имеет эвристический смысл. 
Для атрибутации отношений и выделения из них связей нам нужен некий формализованный алгоритм, который был бы потенциально применим к информации из разных источников и реализовывался с помощью компьютерных средств. Этот алгоритм на входе должен получать достаточно скромную информацию; подробные данные о взаимоотношении двух персон, приемлемые, например, в рамках биографического метода, не соответствуют поставленным задачам. Мы допускаем, что в этом случае будет иметь место некое обобщение, следовательно, огрубление данных, однако считаем, что за счет большого объема проанализированных связей эвристичность модели сохранится.

Таким образом, мы не столько постулируем наличие каких-либо связей между чиновниками на материале различных источников, сколько считаем, что эти связи должны быть выявлены предлагаемой нами моделью. Опираясь на то, что связь - это агентное проявление устойчивых отношений, на втором шаге нашего исследования мы предлагаем алгоритм, направленный на разложение некоторых измеряемых характеристик отношений в фазовом пространстве. Наиболее важными, на наш взгляд, из таких характеристик являются их продолжительность и интенсивность совместных практик.

При выборе именно этих пунктов мы опирались на работу Г. Зиммеля «Социальная дифференциация», в которой он различает «связи, основанные на внешнем сосуществовании» (отношения в нашей терминологии) и «связи, основанные на отношениях содержательного характера» (то есть, то, что мы выше обозначили как собственно связь) [7, с. 409]. Зиммель подчеркивает, что в процессе взаимодействий происходит «установление ассоциативных отношений между гомогенными составными частями, принадлежащими к гетерогенным кругам» $[6$, с. 410]. То есть, тот или иной социальный круг, с точки зрения Зиммеля, может быть случаен, однако, продолжительность возникающих отношений и интенсивность каких-либо взаимодействий (практик), делает ассоциацию, основанную на внешнем сосуществовании, содержательной [6, там же]. Если использовать терминологию, которую мы выявили на предыдущем шаге, продолжительность и интенсивность взаимодействия позволяют говорить о каких-либо отношениях как о связи.

На третьем шаге нашего исследования мы обозначили каждое отношение в качестве точки на координатной плоскости, образуемой по $\mathrm{X}$ - шкалой продолжительности отношений, а по Y - шкалой индекса интенсивности практик. Если категория продолжительности 
отношений не вызывает особых сложностей, так как мы можем использовать сложившиеся хронологические единицы (месяц, год), то категория практик является одной из самых размытых в современных социальных дисциплинах. В зависимости от целей исследователей практикой могут называться как каждодневные привычные действия индивидов, так и целесообразные попытки преобразования мира (П. Бурдье); при этом практика может отождествляться с социальным действием (Э. Гидденс) или фоновым знанием (этнометодология). Большинство из существующих дефиниций практик и связанных с ними классификаций не может быть нами использовано в предлагаемом исследовании, так как их авторы или акцентируют внимание на разнообразии практик самих по себе на уровне микроанализа и этнометодологии, или говорят о социальном порядке вообще, конструируемом и изменяемом при помощи практик. Так как в нашем исследовании интенсивность практик оказывается операционным понятием, нам представляется достаточным рассматривать их как определенный вид взаимодействий, который целесообразно различить по дихотомичному принципу. В основе такого различения мы предлагаем использовать ключевые для исследуемого периода и интересующей нас проблематики социальные сферы: семья, учеба, работа, общественные организации, неформальные салоны. Интенсивность практик, в соответствии с вышесказанным, будет определяться на модели количеством дихотомий.

Таким образом, факт связи фиксируется в том случае, когда точка отношений пребывает в определенной зоне координатной плоскости. Это позволяет не только отличать связь от простого отношения, но и делает модель динамической. Параметры могут (и должны) обновляться на каждый год, соответственно имитируется динамика межличностных отношений и допускаются случаи, когда отношения со временем перерастают в связь, а затем могут также «затухать» и терять этот статус в определенный момент хронологической шкалы.

Мы предполагаем ряд сложностей, с которыми можем столкнуться при дальнейшей разработке предлагаемой модели.

1. Как вычисляется индекс интенсивности практик? Целесообразно ли решать эту задачу через типологию разных отношений с определением весовых коэффициентов для этих типов?

2. Целесообразно ли фиксировать определенные отношения в качестве связи, не прибегая к алгоритму (например - отношения между двумя родными братьями)?

3. Достаточно ли двух характеристик практик (продолжительность и интенсивность) для корректного различения отношений и связей? 
4. Общий вопрос калибровки и разметки координатной плоскости. Какие показатели продолжительности и интенсивности отношений являются пограничными? Статичны ли они или могут претерпевать эволюцию на протяжении двух сотен лет?

Ответ на эти непростые вопросы - дело дальнейших изысканий. Тем не менее методы сетевого анализа имеют чрезвычайную ценность для анализа феномена имперской бюрократии, а результаты и способы решения озвученных вопросов важны не только в пределах данной проблематики.

\section{Список литературы}

1. Полунов А.Ю. Победоносцев: русский Торквемада. - М.: Молодая гвардия, 2017. $-335 \mathrm{c}$.

2. Стафёрова Е.Л. А.В. Головнин и либеральные реформы в просвещении (первая половина 1860 гг.). - М.: Канон+РООИ «Реабилитация», 2007. - 512 с.

3. Бородкин Л.И. Сетевой анализ в исторических исследованиях: микро- макроподходы // Историческая информатика. - 2017. - № 1. - C. 110-124. - DOI: 10.7256/ 2306-0891.2017.1.22842. - URL: https://nbpublish.com/library_read_article.php?id=22842

4. Поврозник Н.Г., Сметанин А.В. Сети земских гласных: К вопросу об истоках «партийности» в местном самоуправлении // Историческая информатика. - 2020. № 1. - C. 94-110. - DOI: 10.7256/2585-7797.2020.1.31884 - URL: https://nbpublish.com/ library_read_article.php?id $=31884$

5. Фергюсон Н. Площадь и башня. Сети и власть от масонов до Facebook. - M.: Издательство АCT: CORPUS, 2020. - 736 c.

6. Зиммель Г. Социальная дифференциация // Г. Зиммель. Избранное. - М.: Юристь, 1996. - Т. 2.

https://doi.org/10.29003/m1815.978-5-317-06529-4/235-242

Гребенченко И.В. Московский государственный университет имени М.В. Ломоносова

\section{Сетевой анализ личных и профессиональных контактов создателей советской космонавтики по материалам просопографической и полнотекстовой} баз данных

Аннотация. В работе изучается формирование взаимодействия членов «Совета главных» методом сетевого анализа на основе просопографической базы данных и контент-анализа воспоминаний создателей советской космонавтики.

Ключевые слова: космонавтика, Совет Главных, базы данных, сетевой анализ, контент-анализ. 
Grebenchenko I.V. Moscow Lomonosov State University

\title{
Network analysis of personal and professional contacts of the creators of Soviet cosmonautics based on prosopographic and full-text databases
}

\begin{abstract}
In the study the formation of interaction among the members of the "Chief Council" by the method of network analysis based on a prosopographic database and content analysis of the memories of the designers of Soviet cosmonautics.
\end{abstract}

Keywords: cosmonautics, Chief Council, databases, network analysis, content analysis.

Один из основоположников практической космонавтики в СССР Михаил Клавдиевич Тихонравов писал: «Все без исключения работы в области ракетной техники в конце концов ведут к космическому полёту» [3, с. 131]. Это действительно так. От Первого Спутника к первому полёту человека и выходу в открытый космос, затем к автоматическим межпланетным и орбитальным станциям. Уже в самом начале космической эры С.П. Королёву становилось очевидным, что «космонавтика имеет безграничное будущее, и ее перспективы беспредельны, как сама Вселенная» [2].

В СССР за создание и запуск ракет-носителей с космическими аппаратами отвечал неформальный руководящий орган - Совет Главных Конструкторов - группа ученых и инженеров, стоявших У истоков советской космонавтики.

Совет Главных Конструкторов изначально насчитывал всего 6 человек, так называемый «королёвский» [3], по имени негласного руководителя. Конечно, всего шесть человек, безусловно талантливых и опытных, не смогли бы реализовать столь технологически сложные объекты, как корабли, спутники и ракеты-носители, в составе которых множество различных систем, каждую из которых создает отдельное космическое бюро или научно-исследовательский институт во главе с руководителем. Так, постепенно, Совет Главных расширялся и уже к концу 1950-х годов насчитывал 34 человека.

Уточним, что в данном случае подразумевается общий круг конструкторов в составе 34 человек и их совместная работа, несмотря на то, что уже с 1960-го года формально существовало несколько параллельных Советов [4].

Важную роль в деятельности высшего звена руководителей такой сложной научной и инженерной отрасли, как советская космо- 
навтика, безусловно, играли персональные контакты ее создателей. Цель данного исследования - анализ личных и профессиональных контактов членов Совета Главных конструкторов, для чего были использованы методы контент-анализа и сетевого анализа, а также создана просопографическая база данных, которая призвана систематизировать биографическую информацию, полученную при помощи текстовых источников.

Сетевой анализ в данном исследовании выполнялся с двумя целями. Во-первых, для выявления контекстуальной близости упоминаний конструкторов и их характеристик (как профессиональных, так и личных) в текстах, составляющих источниковую базу исследования. Для этого использовались таблицы частот совместной встречаемости категорий, полученные в результате контент-анализа.

Во-вторых, для выявления сети профессиональных (рабочих) контактов между конструкторами, для чего использовалась просопографическая база данных.

Сетевой анализ выполнялся в программе UCINET 6.

Первым этапом сетевого анализа стало построение и последующее изучение сети на основе матрицы совместной встречаемости «персональных» категорий, полученной с помощью программы компьютеризованного контент-анализа MAXQDA 12.

Полученный в программе контент-анализа результат через преобразование таблицы в формат MS EXCEL импортировался в сетевую программу UCINET для построения сети (матрицы смежности).

На уровне связи с частотой больше нуля появляется максимально плотная сеть, в которой каждый член Совета связан со всеми своими коллегами.

С повышением минимального уровня частоты связи сеть сеть становится менее плотной и уже на уровне 30 из нее выпадают Ф.А. Востоков, О.Г. Газенко, О.Г. Ивановский, А.Г. Иосифьян, С.А. Косберг, Н.С. Лидоренко, А.С. Мнацаканян, А.Д. Надирадзе, М.Ф. Решетнёв и Г.И. Северин.

На уровне совместной встречаемости 100 в сети остаются В.П. Бармин, Л.А. Воскресенский, М.В. Келдыш, Г.А. Тюлин и Б.Е. Черток, связанные напрямую с С.П. Королёвым. Что касается В.П. Глушко, А.М. Исаева, В.И. Кузнецова, Н.А. Пилюгина, В.П. Мишина, М.С. Рязанского, В.Н. Челомея и М.К. Янгеля, то, кроме связи с С.П. Королёвым, они также часто встречаются друг с другом.

Наиболее высокая частота встречаемости у членов Совета Главных с С.П. Королёвым, т.е. наиболее часто С.П. Королёв встречается 
в одном контексте с В.П. Глушко, А.М. Исаевым, М.В. Келдышем, В.П. Мишиным, Н.А. Пилюгиным, В.Н. Челомеем, Б.Е. Чертоком и М.К. Янгелем. Данная связь относится к типу «звезда».

Важно отметить связь В.Н. Челомея и М.К. Янгеля не только с С.П. Королёвым, но и друг с другом, что образовывает треугольник (в терминах сетевого анализа это «клика», т.е. часть сети, в которой каждый узел связан с каждым). Эти три Главных конструктора, председатели Совета Главных, создавшие свои конструкторские школы, взаимодействовали регулярно, зачастую являясь прямыми конкурентами друг друга.

Несколько особняком стоит связь Н.А. Пилюгина и М.С. Рязанского, занимавшихся вопросами управления полётами: более высокая совместная встречаемость у М.С. Рязанского - не с С.П. Королёвым, а с Н.А. Пилюгиным.

Постепенно из сети выпадают почти все конструкторы, пока не остаётся самая прочная связь С.П. Королёва и В.П. Глушко (частота совместной встречаемости больше 420), что объясняется не только давним знакомством этих двух Главных конструкторов космической техники, но и совместной работой еще с 1933 года.

Важным выводом, полученным при сетевом анализе частот совместной встречаемости, является выявление конфигурации сети на уровне наиболее высоких частот (190 и выше). На этом уровне сеть приобретает и в дальнейшем сохраняет форму «звезды», центром которой является С.П. Королёв.

К сожалению, в сформированной полнотекстовой базе данных отсутствуют чёткие упоминания космических проектов, в которых задействованы члены Совета Главных. Поэтому для изучения структуры профессиональных контактов в СУБД Microsoft Access 2016 создана табличная база данных, куда вошла информация об этих проектах.

База данных состоит из восьми таблиц, две из которых являются главными, пять - подчинёнными и одна - связывающей две главные таблицы. Первая из главных таблиц, «Люди» включает базовые сведения о 34 конструкторах и состоит из трех полей: «номер», «ФИО» и «даты жизни». Вторая главная таблица «Проекты» содержит необходимую информацию о 28 крупных и зачастую первых в своем роде космических проектах, реализованных под руководством тех или иных членов Совета Главных конструкторов. Таблица состоит из полей «Номер», «Название» и «Дата первого успешного полёта».

Связь главных таблиц между собой обеспечивает подчинённая таблица «Участники - проекты», где посредством связи двух ключевых полей главных таблиц задано соответствие между реализован- 
ными проектами, с одной стороны, и конструкторами, принимавшими участие в реализации данных проектов, - с другой. Данная таблица состоит из 553 записей.

На основе просопографической базы данных был проведен сетевой анализ профессиональных связей.

Сетевой анализ базы данных также выполнялся в программе UCINET 6. В качестве главного объекта для анализа были выбраны сведения о профессиональных взаимосвязях между членами Совета Главных Конструкторов: в данном случае примером такой взаимосвязи может служить любой случай соавторства конструкторов при работе над одним и тем же проектом, начиная от первых баллистических ракет и заканчивая автоматическими межпланетными станциями.

Первым этапом построения сетей стало формирование перекрёстных таблиц формата «конструктор - проект», где в строках таблицы указывался полный список членов Совета Главных периода 1946-1967 гг., а в столбцах - название или главное событие космического проекта. Если конструктор участвовал в разработке аппарата, в таблице на пересечении строки и столбца ставилась единица, если не участвовал - поле оставлялось пустым.

Результат перекрестного запроса импортировался в формат MS Excel, из которого с помощью специальной функции UCINET создавался файл в формате сетевой программы. В данном случае это был файл двумодальной таблицы «конструктор - проект» (матрицы инцидентности).

На следующем шаге двумодальная перекрёстная таблица трансформирована в квадратные одномодальные таблицы (матрицы смежности), где и в строках, и в столбцах таблицы стоят в одном случае только конструкторы, в другом - только проекты, а на пересечении- частота их совместной встречаемости, соответствующая числу раз, когда различные конструкторы становились соавторами. В случае с таблицей «конструкторы» - это частота их «соавторства» в проектах, а в случае с «проектами» - число участников каждого проекта.

В первую очередь мы рассмотрели одномодальную таблицу «проекты», чтобы увидеть, в каких из первых реализованных космических проектов приняло участие наибольшее количество конструкторов. Программа для визуализации графов NetDraw показывает, что наиболее сильные связи имеет проект с общим названием «Восток», а конкретнее - полёты космических кораблей «Восток-1» - «Восток-6». 
Уровень связи в данном случае (28) означает минимальное количество конструкторов, занятых в указанном проекте.

Только два проекта их шести названных имели большее число участников - 29, это подготовка полётов двух самых первых «Востоков» - с Ю.А. Гагариным и Г.С. Титовым на борту, соответственно.

Данная связь обусловлена тем, что впервые в мире запускался в космос пилотируемый человеком космический аппарат, который являлся сложным с конструкторской точки зрения и требовал для своей реализации немалых усилий широкого круга конструкторов.

Следующим этапом работы стало создание сети на основе двумодальной матрицы «конструкторы - проекты», узлами которой являются как конструкторы, так и проекты.

Используя двумодальную таблицу «конструкторы-проекты», можно увидеть состав участников проектов серии «Восток».

Построенная сеть конструкторов показывает, что во всех первых и наиболее важных для советской космонавтики космических проектах участвовали 9 человек - В.П. Бармин, В.П. Глушко, М.В. Келдыш, С.П. Королёв, В.И. Кузнецов, В.П. Мишин, М.С. Рязанский, Г.А. Тюлин и Б.Е. Черток. Характерно, что 5 из 9 человек являются членами «великолепной шестерки» [4] - первого состава Совета Главных конструкторов, начавшего свою деятельность еще в 1946 году. Это говорит о том, что рабочие контакты сохранялись и оставались приоритетными.

Что касается остальных, представляется очевидным участие в этих проектах М.В. Келдыша - Главного Теоретика космонавтики [1], В.П. Мишина и Б.Е. Чертока, еще в Германии работавших с С.П. Королёвым и являвшихся его заместителями, и Г.А. Тюлина, прошедшего долгий путь от простого инженера до первого заместителя С.А. Афанасьева - первого «космического» министра. Это «ядро» оставалось неизменным на протяжении всей успешной «космической» истории 1950-1960-х гг.

Следующим этапом анализа стало изучение сети, построенной программой NetDraw из одномодальной матрицы «конструкторы». В данном случае нас интересует, какие профессиональные связи между членами Совета Главных являются самыми сильными. Под сильными связями подразумевается совместное участие в большом количестве проектов.

Изначально мы видим максимально плотную сеть, в которой каждый член Совета связан со всеми остальными. Однако нас интересуют самые сильные связи (уровень связи в данном случае означа- 
ет максимальное количество проектов, реализованных в соавторстве указанными конструкторами).

Анализ показывает сеть (клику, в которой каждый узел связан с каждым), включающую все тех же 9 человек - В.П.Бармина, В.П. Глушко, М.В. Келдыша, С.П. Королёва, В.И. Кузнецова, В.П. Мишина, М.С. Рязанского, Г.А. Тюлина и Б.Е. Чертока. Они наиболее плотно взаимодействуют друг с другом в космических проектах, что подтверждает полученные ранее выводы о влиянии этих людей на советскую космонавтику в первые два десятилетия ее существования.

Подводя итог анализа сети профессиональных взаимосвязей между членами Совета Главных конструкторов 1946-1967 гг., отметим, что наиболее масштабными проектами с наибольшим количеством участвующих в их реализации членов Совета являются проекты серии «Восток» - «Восток 1-6», то есть первые пилотируемые космические корабли и ракеты-носители, необходимые для вывода кораблей на орбиту. Помимо корабля и ракеты, было необходимо также спроектировать спускаемый аппарат, систему жизнедеятельности космонавта и скафандр, что расширяло список предприятий, участвующих в реализации проекта, и соответственно, конструкторов, возглавлявших данные предприятия.

$$
* \quad * \quad *
$$

Итак, в процессе исследования методом сетевого анализа мы построили и проанализировали графы, отражающие состояние сети профессиональных взаимосвязей между членами Совета Главных Конструкторов 1946-1967 гг., а также графы для частот совместной встречаемости конструкторов в рамках контекста.

Важным выводом является различие результатов сетевого анализа, проведенного для сети профессиональных контактов, и сетевого анализа контекстуальной близости (частот совместной встречаемости) упоминаний в полнотекстовой базе данных членов ведущей группы конструкторов на основе их профессиональных и личных качеств. Для профессиональных контактов мы видим максимально плотную сеть типа «клика», подтверждающую, что Совет Главных это в первую очередь единый коллектив, работа которого невозможна без участия любого из «Главных». Для сети, основанной на совместной встречаемости, на достаточно высоком уровне встречаемости, получается сеть типа «звезда» вокруг личности С.П. Королёва. 


\title{
Библиография
}

1. Голованов Я.К. Королёв: факты и мифы. - M.: Наука, 1994. - URL: http://royallib.com/book/golovanov_yaroslav/korolev_fakti_i_mifi.html

2. Ивановский О.Г. «Наперекор земному притяженью». - М.: Политиздат, 1988. - URL: http://epizodsspace.airbase.ru/bibl/ivanovskiy/naperekor/naperekor-88.pdf

3. Космос. Время московское: сб. документов. - М., РГГУ, 2011. - 691 с.

4. Черток Б.Е. Ракеты и люди. Книга 1. - М.: Машиностроение, 1999. - URL: http://militera.lib.ru/explo/chertok_be/index.html

https://doi.org/10.29003/m1816.978-5-317-06529-4/242-251

Саломатина С.А., Гарскова И.М., Валетов Т.Я. Московский государственный университет имени М.В. Ломоносова

\section{Иерархия финансовых центров Российской империи в конце XIX в.: сетевой и геоинформационный анализ межрегиональных банковских переводов ${ }^{1}$}

Аннотация. В статье исследуется финансовая система Российской империи как денежные потоки между крупнейшими финансовыми центрами по статистике коммерческих переводов Государственного банка в 1898 г. с применением методов сетевого и геоинформационного анализа. В итоге доказывается, что в финансовой системе страны типично доминировали рынки высшего общенационального уровня (Санкт-Петербург и Москва), а межрегиональные рынки более низкого уровня были более сильными на западе и юго-западе (Одесса, Киев, Варшава) по сравнению с Ригой, Харьковом, Нижним Новгородом, Ростовом-на-Дону и Баку.

Ключевые слова: финансовые центры, межрегиональные платежи, сетевой анализ, геоинформационный анализ, Российская империя

Salomatina S.A., Garskova I.M., Valetov T.Ya. Lomonosov Moscow State University

\section{The hierarchy of financial centers in the Russian Empire at the end of the nineteenth century: network and geoinformation analysis of interregional bank transfers}

\begin{abstract}
The article examines the financial system of the Russian Empire as a set of cash flows between the largest centers based on the commercial transfers statistics of commercial transfers of the State Bank in 1898 and network and geoinformation analysis. As a result, the study proves that the national financial system was typically dominated by the highest national level markets (St. Peters-
\end{abstract}

${ }^{1}$ Исследование проводится при поддержке гранта РФФИ № 20-09-00342. 
burg and Moscow), whereas the interregional markets of the lower level were stronger in the west and southwest (Odessa, Kiev, Warsaw) compared to Riga, Kharkov, Nizhny Novgorod, Rostov-on-Don, and Baku.

Keywords: financial centers, interregional payments, network analysis, geoinformation analysis, Russian Empire.

В эпоху индустриализации XIX века финансовая система была одним из факторов экономического роста во многих национальных экономиках [1, p. 388-398]. Для понимания того, как финансовая система перераспределяла ресурсы в XIX веке, необходимо учитывать движение денежных потоков между регионами. От налаженной работы этих каналов зависело, насколько легко средства из одного региона могли перемещаться в другой для эффективного применения. Косвенным источником данных об архитектуре финансовой системы XIX века является даже самая общая статистика финансовых институтов, например, более-менее известно распределение банковских активов по финансовым центрам. В данном исследовании реализован другой подход: архитектура финансовой системы XIX века анализируется на примере Российской империи как сеть денежных потоков между регионами, что позволяет уточнить возможности финансовой системы обслуживать экономику страны.

Ценным источником данных о межрегиональных финансовых потоках является статистика межбанковских платежей, если в ней есть географическая детализация, т.е. данные о местах отправки и приема денег. В частности, статистика переводов денег банками по поручениям клиентов - это информация о денежных потоках, противонаправленных движению товаров и услуг (если товар вывозится из региона, деньги приходят в регион, и наоборот). Таким образом, по географии переводов можно выявлять межрегиональные экономические связи.

В финансовых системах XIX века платежная система поддерживалась в первую очередь банками, через которые деньги из одной географической точки можно было переслать в другую. Переводы могли перемещаться между отделениями одного банка, либо из одного банка в другой банк в рамках корреспондентского договора. Переводами занимались не все банковские учреждения, а прежде всего коммерческие банки, в которых были сосредоточены все виды банковского обслуживания фирм, компаний, предпринимателей, а также депозитная и переводная операция для широкой публики. 
К коммерческому банкингу в Российской империи относились акционерные коммерческие банки, общества взаимного кредита, банкирские дома и конторы, а также частично операции Государственного банка Российской империи (далее - Госбанк) и сберегательных касс, городских общественных банков. Коммерческий банкинг - это примерно 50\% банковской системы России в конце XIX в., потому что были еще ипотечные, ломбардные учреждения и система мелких кредитных кооперативов. Однако благодаря системе коммерческих банков в России были равные возможности для перевода денег между достаточно большим числом географических точек.

Переводы распределялись по банковской системе очень неравномерно, что отражало спрос на межрегиональные расчеты в разных географических точках. Хорошо известно, что есть крупные денежные рынки общенационального уровня, есть финансовые центры, связывающие регионы, а есть центры внутри региона. Через переводы можно выявить эту иерархию финансовых центров, примером такого подхода к изучению финансовых потоков является статья М. Денцеля [2]. Для этих целей хорошо подходит сетевой анализ, в котором финансовые центры рассматриваются как узлы сетевого графа, а направления денежных потоков между каждой парой центров - как дуги между узлами. Если к атрибутам узлов добавить географические координаты финансовых центров, то эти узлы можно расположить на географической карте, что добавляет пространственный аспект в сетевой анализ, и такой подход уже реализован в статье С.А. Саломатиной, И.М. Гарсковой и Т.Я. Валетова [3].

Данные о географии банковских переводов встречаются в разных опубликованных и архивных отчетных материалах российских коммерческих банков разного типа. Однако самый представительный комплекс - это данные о географии коммерческих переводов по сети отделений Госбанка с 1860-х гг. до 1900-х гг. Для нашего исследования выбран 1898 г., потому что это последний полный год благоприятной конъюнктуры перед кризисом 1899-1903 г., т. е. данные за этот год позволяют оценить рост услуг в филиальных сетях Госбанка за период экономического подъема 1890-х гг. и за всю вторую половину ХІХ в. в целом.

В 1898 г. у Госбанка было 122 отделения (из них 114 постоянных, остальные временные - на ярмарках или курортах), которые довольно равномерно распределялись по всей стране, почти по всем губернским городам и по многим уездным. 
Система коммерческих операций, в которой Госбанк действовал как обычный коммерческий банк, обслуживавший клиентов, - это примерно 30\% коммерческого банкинга в России в конце XIX в., т.е. анализируемая статистика относится к довольно крупному фрагменту банковской системы.

Важно отметить, что в эту статистику переводов Госбанка не входят переводы денег за счет бюджета. Операции казначейств явно отделены от коммерческих операций в отчете 1898 г. Таким образом, в этой статистике переводов отражены в первую очередь крупные расчеты предпринимателей. Мелкие переводы обывателей также включены в этот массив, но их объем заведомо меньше объемов бизнес-расчетов.

Данные о переводах между отделениями опубликованы в «Особых приложениях» к годовому отчету Госбанка (Приложение 12. Ведомость о суммах, переведенных в конторы и отделения Государственного банка по переводным билетам и телеграммам с распределением по месту платежа за 1898 г. (в тысячах рублей)) [4, с. 57-81]. Для каждого отделения есть информация: 1) сколько переводов, на какую общую сумму и в какие отделения они были выписаны из этого отделения; 2) о переводах, присланных в это отделение из других отделений, есть аналогичные данные. В такой таблице 122 строки и 122 столбца (по числу отделений как мест отправки и мест получения переводов). Финансовые потоки, или связи между отделениями по этим данным выглядят, например, так:

\begin{tabular}{|c|c|c|}
\hline $\begin{array}{c}\text { Место отправки } \\
\text { переводов }\end{array}$ & $\begin{array}{c}\text { Сумма переводов за год, } \\
\text { тыс. руб. }\end{array}$ & $\begin{array}{c}\text { Место получения } \\
\text { переводов }\end{array}$ \\
\hline Рига & 2788,1 & Москва \\
\hline Москва & 3107,4 & Рига \\
\hline
\end{tabular}

У такого массива данных о переводах между 122 точками внушительный объем, потому что это 14884 потенциальные связи между всеми парами точек. Такой массив сложно качественно визуализировать методами сетевого анализа, поэтому для дальнейшей работы выбраны 10 отделений (финансовых центров) с наибольшим объемом переводов в 1898 г. Эти центры представлены в таблице 1 в двух вариантах: когда они являются местом отправки и местом выплаты переводов. 
Таблицча 1

Крупнейшие отделения Госбанка по сумме переводов в 1898 г., млн руб.

\begin{tabular}{|l|c|c|}
\hline $\begin{array}{c}\text { Финансовый центр } \\
\text { (отделение Госбанка) }\end{array}$ & $\begin{array}{c}\text { Как место отправки } \\
\text { переводов }\end{array}$ & $\begin{array}{c}\text { Как место получения } \\
\text { переводов }\end{array}$ \\
\hline Санкт-Петербург & 328,3 & 135,3 \\
\hline Москва & 129,4 & 205,1 \\
\hline Варшава & 40,8 & 52,4 \\
\hline Киев & 24,0 & 56,4 \\
\hline Одесса & 17,8 & 61,2 \\
\hline Рига & 25,3 & 39,3 \\
\hline Баку & 22,1 & 39,0 \\
\hline Нижний Новгород & 14,6 & 38,2 \\
\hline Харьков & 19,3 & 31,8 \\
\hline Ростов-на-Дону & 15,0 & 25,6 \\
\hline Итого по 10 центрам* & 636,6 & 684,3 \\
\hline В \% от ВСЕГО & 44,6 & 48,0 \\
\hline ВСЕГО по 122 центрам** & 1425,8 & 1425,8 \\
\hline
\end{tabular}

* Исключая переводы внутри отделений (внутри города), в сумме 21,2 млн руб. по отправкам и столько же выплатам. Информации о внутригородских переводах не опубликовано по Одессе.

** Сумма отправленных переводов равна сумме предназначенных к выдаче.

Из таблицы 1 следуют два основных вывода. Во-первых, объем сделок Санкт-Петербурга и Москвы значительно превосходит другие города. Это известно и по другим источникам, например по объему банковских активов двух столиц [5, с. 205-215, 385-390, 416-443; 6, c. 180-182]. Этот факт свидетельствует о, как минимум, двухуровневой иерархии финансовой сети: два центра общенационального уровня и остальные финансовые центры. В то же время список ведущих финансовых центров Российской империи в конце XIX в., выявленных по объему переводов, хорошо совпадает с общими представлениями об экономическом статусе крупнейших городов, за исключением, пожалуй, только Баку, хотя вероятно, это отражает возраставшее в тот период значение бакинской нефтедобычи.

Во-вторых, почти по всем центрам, кроме Санкт-Петербурга, объемы выплаченных переводов значительно превышают отправленные. Если отправление перевода из центра соответствует покупке товаров и услуг для этого центра, а выплата перевода в центре соответствует продаже товаров и услуг из этого центра в другие центры, то такая статистика переводов указывает на то, что крупные финансовые центры - это в первую очередь центры продажи товаров и услуг. В этом смысле, например, Москва крупный оптовый центр 
продаж для всей России, а, например, Варшава или Киев, - для своих регионов. Только из Санкт-Петербурга денежный поток в регионы преобладает над обратным потоком, т.е. столица в первую очередь закупает товары и услуги по всей стране. Эта особенность СанктПетербурга в платежной сети еще нуждается в осмыслении, особенно в сравнении с другими историческими периодам и другими банками с большим столичным подразделением.

Суммы переводов из таблицы 1 можно разделить на отдельные финансовые потоки. В таблице 2 представлены эти финансовые связи 10 крупнейших центров. Такая платежная сеть устроена следующим образом: 122 отделения (узла), каждое отделение может поддерживать связи со 121 отделением плюс переводы внутри отделения, когда отправитель и получатель перевода являются клиентами одного отделения. Внутригородские переводы показаны в таблице 2 отдельно и не учитываются в статистике межрегиональных связей. Однако несмотря на эти возможности у многих крупных отделений связей меньше, чем 121.

Таблица 2

Финансовые связи (переводы) 10 крупнейших отделений с другими отделениями Госбанка в 1898 г., количество связей

\begin{tabular}{|l|c|c|c|c|}
\hline \multirow{2}{*}{$\begin{array}{c}\text { Финансовый центр } \\
\text { (отделение Госбанка) }\end{array}$} & \multicolumn{2}{c|}{$\begin{array}{c}\text { Как место отправки } \\
\text { переводов }\end{array}$} & \multicolumn{2}{c|}{$\begin{array}{c}\text { место получения } \\
\text { переводов }\end{array}$} \\
\cline { 2 - 5 } & $\begin{array}{c}\text { Всего } \\
\text { связей }\end{array}$ & $\begin{array}{c}\text { Связей }> \\
\text { 1 млн руб. }\end{array}$ & $\begin{array}{c}\text { Всего } \\
\text { связей }\end{array}$ & $\begin{array}{c}\text { Связей }> \\
\text { 1 млн руб. }\end{array}$ \\
\hline Санкт-Петербург & 121 & 57 & 121 & 47 \\
\hline Москва & 120 & 36 & 121 & 57 \\
\hline Варшава & 112 & 10 & 118 & 14 \\
\hline Киев & 111 & 6 & 117 & 10 \\
\hline Одесса & 113 & 4 & 116 & 13 \\
\hline Нижний Новгород & 115 & 2 & 116 & 8 \\
\hline Рига & 109 & 7 & 114 & 6 \\
\hline Харьков & 107 & 5 & 113 & 6 \\
\hline Ростов на Дону & 108 & 3 & 108 & 5 \\
\hline Баку & 104 & 7 & 101 & 5 \\
\hline Внутригородские потоки** & 9 & 9 & 9 & 9 \\
\hline Остальные отделения*** & 1055 & & 1030 & \\
\hline $\begin{array}{l}\text { Всего связей 10 крупнейших } \\
\text { отделений**** }\end{array}$ & 2184 & & 2184 & \\
\hline
\end{tabular}

* По сумме переводов в 1898 г.

** Переводы в пределах одного отделения, по всем крупнейшим отделениям, кроме Одессы.

*** Только их связи с 10 крупнейшими отделениями, но не между собой.

**** Сумма отправленных переводов равна сумме предназначенных к выдаче. 
Архитектура финансовой сети видна по крупным потокам, поэтому, чтобы ее выявить, нужно убрать из анализа мелкие потоки. В таблице 2 отдельно показаны потоки размером более 1 млн руб. в год. Санкт-Петербург и Москва имеют 36-57 таких связей с другими отделениями (как по отправке, так и по получению переводов). Таких потоков вокруг других финансовых центров значительно меньше - от 3 до 14. Всё это свидетельствует о двухуровневой структуре платежной сети: две столицы и все остальные города.

Часть платежной сети высшего уровня (Санкт-Петербурга и Москвы) можно визуализировать методами сетевого анализа на примере связей 10 крупнейших финансовых центров. Таких связей (центры только между собой) - 93. Самые крупные из них (30) включены в сетевой граф на рис. 1. Среди них 9 связей с размером потока более 10-27 млн руб. в год, 8 связей с потоком 4-10 млн руб., 13 связей с потоком 2-4 млн руб.

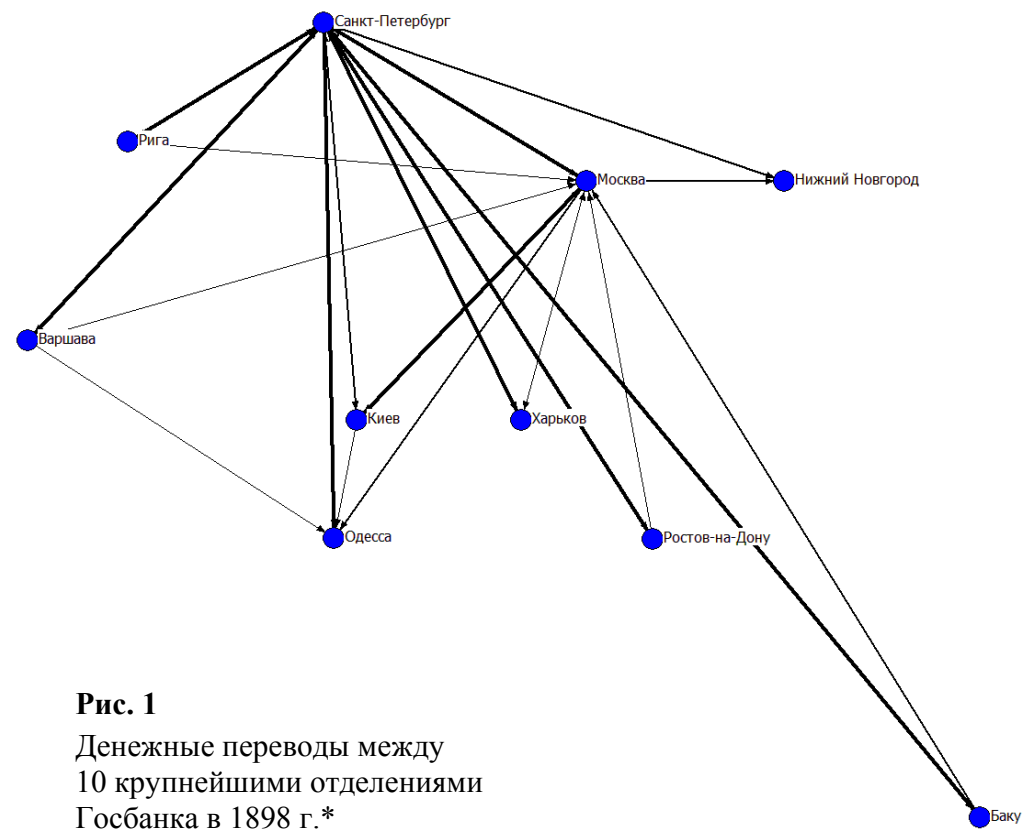

* Отделения, крупнейшие по сумме переводов в 1898 г. В граф включены 30 денежных потоков из 93, размером более 2 млн руб. в год. Три уровня толщины дуг на графе соответствуют суммам от 2 до 4 млн. руб.; от 4 до 10 млн. руб. и более 10 млн. руб. 
Эти 30 связей почти исключительно связанны с Санкт-Петербургом и Москвой. Если считать отдельно 2 потока из СанктПетербурга в Москву и обратно, то остальные потоки распределяются следующим образом:

1) из Санкт-Петербурга в другие города -8 потоков;

2) в Санкт-Петербург - 5 потоков (в порядке убывания размера потока - из Варшавы, Риги, Киева, Баку и Харькова);

3) из Москвы - 6 потоков (в Киев, Одессу, Нижний Новгород, Ригу, Варшаву, Харьков);

4) в Москву - 7 потоков (из Нижнего Новгорода, Баку, Харькова, Варшавы, Ростова-на-Дону, Киева, Риги).

5) только 2 потока из 30 являются «нестоличными», причем достаточно скромными по размеру: в Одессу из Варшавы и Киева (по 3,1 млн руб. каждый).

Таким образом, верхний сегмент этой платежной сети - это связи Санкт-Петербурга и Москвы с другими городами. Связей других финансовых центров между собой на этом уровне почти нет. СанктПетербург и Москва как общенациональные рынки высшего уровня можно исключить из дальнейшего сетевого анализа, чтобы в деталях рассмотреть связи региональных финансовых центров. Это задача следующего этапа исследования, на котором будут анализироваться связи 8 «нестоличных» финансовых центров, причем это будут только крупные связи размером более 1 млн руб.

Предварительно, есть признаки устойчивой региональной сети на западе страны (треугольник Одесса - Киев - Варшава). Остальные центры занимают более слабое положение, присоединяясь лишь к одному из узлов (Баку и Ростов-на-Дону к Одессе, Харьков к Киеву, Рига к Варшаве). Нижний Новгород вообще слабо интегрирован в эту систему и связан лишь с Баку. Если исключить из анализа и эти связи между крупными центрами, становятся заметны региональные рынки (по потокам более 1 млн руб. в год):

- Киев - Полтава, Чернигов, Екатеринослав, Житомир, Каменец-Подольский, Минск;

- Одесса - Каменец-Подольский, Кишинев, Елизаветград, Николаев, Севастополь, Тифлис и связь с другим отдаленным портом Владивосток;

- Варшава - Лодзь, Калиш, Люблин, Петроков, Плоцк, Радом, Ченстохов, Вильно, Ковно, Гродно;

- Рига - Либава, Ревель Вильно, Витебск; 
- Харьков - Екатеринослав, Курск, Полтава, Юзовка;

- Ростов-на-Дону - Ставрополь, Тифлис, Новороссийск;

- Баку - Астрахань, Асхабад, Тифлис, а также «дальний контакт» - Лодзь;

- Нижний Новгород - Вятка, Кострома, Казань, Пермь, Владимир.

Выводы текущего этапа исследования заключаются в том, что поскольку финансовые потоки, связанные с обслуживанием клиентов коммерческими банками, отражали реальный спрос на межрегиональные расчеты, филиальная сеть Госбанка, как сеть крупнейшего коммерческого банка, должна отражать реальную иерархию финансовых центров внутри страны. В этой сети был ярко выраженный высший общенациональный уровень - это Санкт-Петербург и Москва. Их финансовые потоки выглядели как две сети типа «звезда», в которых связи как лучи расходились из двух столиц по всей стране. Именно здесь концентрировались самые крупные денежные потоки (как в центр, так и из центра). Такая архитектура свидетельствует о том, что российские финансы функционировали прежде всего вокруг столиц, что было довольно типичным для той эпохи [7, p. 279$282 ; 8$, p. 1-30; 9, p. 17-84].

Межрегиональная сеть более низкого уровня была только на западе (Одесса - Киев - Варшава), а в центре и на востоке страны этот уровень фактически отсутствовал, поэтому региональные рынки были напрямую связаны в Санкт-Петербургом и Москвой. Видимо, не стоит переоценивать межрегиональный статус Риги, Нижнего Новгорода, Ростова-на-Дону, Харькова. Неожиданным фактом является высокий статус Баку в 1890-е гг., хотя скорее всего это объясняется ростом нефтедобычи.

Таким образом, несмотря на возможности переводить деньги между любыми географическими точками, где есть банковские подразделения, финансовая система XIX века действительно была иерархичной и тяготела к столицам, что в самом общем виде объясняется концентрацией капиталов на ведущих рынках, но конечно же заслуживает более детального изучения на российских данных.

\section{Библиография}

1. Rousseau P.L., Sylla R. Financial Systems, Economic Growth and Globalization // Globalization in Historical Perspective / M.D. Bordo, A.M. Taylor and J. G. Williamson (eds.). - Chicago: University of Chicago Press, 2003. - P. 373-415.

2. Денцель М. Международная система безналичных расчетов и интеграция в нее Российской империи. Вклад в становление мировой экономики // Экономическая история: ежегодник. 2005. - М., РОССПЭН, 2005. - С. 76-107. 
3. Саломатина С.А., Гарскова И.М., Валетов Т.Я. Межрегиональные расчеты Орловского коммерческого банка во второй половине XIX в.: сетевой анализ // Историческая информатика. - 2019. - № 4. - С. 122-147. $83 \mathrm{c.}$

5. Особые приложения к отчету Государственного банка за 1898 г. - СПб., 1899. -

6. Гиндин И.Ф. Русские коммерческие банки: из истории финансового капитала в России. - М.: Госфиниздат, 1948. -454 с.

7. Саломатина С.А. Банковский кредит в Российской империи в 1860-1914 гг.: современные концепции и новые данные // Российская история. - 2018. - № 4 (18). C. $170-187$.

8. Cassis Y. Capitals of capital: a history of international financial centres, 17802005. - Cambridge: Cambridge University Press, 2006. - 385 p.

9. The emergence of organizations and markets / J.F. Padgett and W.W. Powell (eds). Princeton: Princeton University Press, 2012. - 583 p.

10. Sassen S. The global city: New York, London, Tokyo. - 2nd ed. - Princeton, N.J.: Princeton University Press, 2001. - 447 p.

https://doi.org/10.29003/m1817.978-5-317-06529-4/251-256

Сметанин А.В.

Пермский государственный национальный исследовательский университет

\section{Реконструкция ценности товаров \\ в период российского экономического транзита на основе бартерных объявлений}

Аннотация. В исследовании предлагается способ моделирования потребительских представлений граждан позднесоветского периода и нач. 1990-х гг. на основании газетных объявлений о прямом обмене товаров. Для моделирования используется инструментарий социально-сетевого анализа. Созданные семантические сети позволяют определить круг статусных товаров и особенности экономического поведения граждан, переходящих из эпохи дефицита в эру рыночных отношений.

Ключевые слова: бартер, социально-сетевой анализ, потребительские предпочтения, экономический транзит, позднесоветская экономика, экономическая история.

Smetanin A.V. Perm State University

\section{Value of Goods During the Period of Russian Economic Transit Based on Barter Ads Analysis}

Abstract. The study proposes a method for modeling consumer perceptions of citizens during the late Soviet period and early 1990s based on newspaper ads for direct exchange of goods. The toolkit of social network analysis is used for 
modeling. To determine the range of status goods and the economic behavior features of citizens moving from the era of shortage to the era of market relations is possible thanks to created semantic networks.

Keywords: barter, social network analysis, consumer preferences, economic transit, late Soviet economy, economic history.

Экономическая наука достаточно давно пришла к пониманию, что экономические действия не объясняются всецело стимулами рационального выбора, важными факторами оказываются социальная структура, институциональные нормы и психологические установки акторов $[1,2]$. Исследования в сфере обмена и потребления, пожалуй, ранее всего обнаружили эти закономерности: понятия статусного и этического потребления, табуированных товаров стали общеупотребимыми. Подобный подход является необходимым применительно к изучению потребительского поведения позднесоветского периода и периода 1990-х гг., когда при жизни одного поколения происходило смещение социальных и экономических ценностей, большую роль в жизни общества стал играть свободный рынок и исчезал фактор товарного дефицита. Кроме того, ощущается недостаток системных эмпирических исследований по данному вопросу, имеющиеся работы акцентируют внимание лишь на отдельных сторонах советского консумеризма $[3,4,5]$.

Настоящее исследование пытается структурировать товарные предпочтения граждан в кон. 1980-х - нач. 1990-х гг., реконструировать потребительский идеал и его трансформацию. Работа исходит из двух гипотез. Первая заключается в том, что ценность, полезность товаров была в глазах граждан неодинакова и эти статусные различия возможно выявить с помощью газетных объявлений о прямом бартере. Вторая гипотеза заимствована у Дэвида Андерсона, полагающего, что в России эпохи экономического транзита существовали вложенные (nested) сообщества обмена [6, p. 342], т.е. локальные экономические системы, обеспечивавшие относительную стабильность и выживание, где экономическую ценность могли приобретать достаточно неожиданные товары и услуги.

Основным источником для работы служат газетные объявления о прямом обмене товаров. Объявления позволяют отследить как представления о равноценности вещей, так и степень их желанности. Данный источник имеет ряд ограничений: редакторская политика, платность объявления, недоверие многих граждан к подобному способу поиска контрагентов и т.д. Однако лучшей замены для источника нет - более массовые и репрезентативные «объявления на забо- 
ре» безвозвратно утеряны, личный опыт граждан менее надёжен для реконструкции ввиду свойств памяти.

Формализация сведений из объявлений производилась в таблице MS Excel, создана несимметричная направленная матрица (столбцы и строки означают одни и те же названия товаров, в том же порядке). Строки означают товары, которые пытались поменять, в столбцах товары, на которые пытались выменять имеющееся. Не фиксировались следующие обменные операции: «автомобиль-автомобиль», «жильё - жильё», «автомобиль - жильё» (и наоборот). Эти объявления составляют более $90 \%$ всего источникового корпуса, но достаточно однотипны и малоинформативны для понимания ценности товаров. Исключение делалось лишь для операций обмена чего-либо третьего на автомобиль или жильё (квартира, дом). На текущий момент выделено более 60 категорий товаров, кодификация осуществлена экспертным путём, исходя из возможностей и ограничений источника. На пересечении двух обмениваемых товаров в таблице отражается значение - число объявлений, где зафиксировано желание обменять товар А на товар Б, т.е. частота такой бартерной операции.

Далее матрица анализируется с помощью инструментария социально-сетевого анализа. Фактически, мы можем визуализировать потребительские представления граждан, определить статус вещей на основании их субъективной оценки. Всё множество повторяющихся обменных операций можно представить как семантическую сеть, узлами которой являются товары, а связями - желание обменять один товар на другой. Такой подход, по сравнению с простым частотным анализом, позволяет выявить ядерные и периферийные товары, определить узлы с невысокой частотой упоминания, но значимые в общественной картине материальных ценностей.

Сетевая модель оказывается достаточно тонкой, поскольку матрица имеет направленный вид и узлы (товары) с высокими индексами центральности определяются более точно. Центральность рассчитывалась с помощью метрики directed betweenness (центральность по посредничеству с учётом направления связей) [7, p. 55]. Смысл метрики в том, что узлы, через которые проходит наибольшее число кратчайших путей между двумя любыми узлами сети, рассматриваются как более важные. В случае бартерных отношений это означает более высокую меновую стоимость товаров, большую ценность материального блага для обменных операций.

Принципиально важно, что для каждой локальной экономической системы создаётся своя матрица и отдельная сеть, что вытекает 
из принятой ранее гипотезы Д. Андерсона. Единая общероссийская (общесоюзная) сеть не моделируется. В настоящем исследовании в качестве условных локальных экономических систем воспринимаются города.

Был произведён пилотный анализ бартерных объявлений в г. Иркутск (газета «Восточно-Сибирская правда» [8]) за 1992 г. Год интересен одновременно либерализацией торговли и гиперинфляцией. С одной стороны, потребительский рынок оказался насыщен новыми, полезными вещами, с другой стороны, происходило быстрое обесценивание рубля и наблюдался дефицит наличности, что придавало бартерным отношениям особую актуальность. Пилотное исследование позволило сделать ряд наблюдений.

1. В большинстве случаев менялись вещи со схожими функциями: одежда на одежду, бытовая техника на другую бытовую технику, автозапчасти на автозапчасти и т.д. Мы видим, стратегию снижения риска. Граждане с трудом соотносили ценность товаров различного назначения, сегментировали потребительский рынок на специализированные отделы, где несложно сравнить два товара (по качеству материала, новизне и т.д.). Людям в 1992 г. было сложно измерить ценность разнородных вещей в денежной форме и на этом основании совершить обмен. Однако обмены, вроде «покрышки - спальный гарнитур» также фиксируются и не являются единичными.

2. Выдающийся экономический статус в рамках сети (на основании метрики directed betweenness) имели лишь три товара. Автомобиль - потребительский идеал советского времени абсолютно выделяется в иркутской сети, на него готовы менять десяток товаров, тогда как обладатели авто редко предлагали обмен на что-либо. Достаточно неожиданно высокий экономический статус имели пиломатериалы, вероятно, для обустройства дачи (другого компонента советской мечты). Наконец, третий товар, видеомагнитофон - окно в мир досуга и западной культуры, явно выделяется как новое явление в статусном потреблении.

3. За исключением указанных трёх товаров, рациональная стратегия обмена менее ценных товаров на более статусные и дорогие, скорее не соблюдается. Граждане стараются менять что угодно на то, что нужно или хочется.

4. Можно согласиться с тезисом Кэролин Хамфри о том, что бартер в условиях социального недоверия рождает краткосрочное экономическое мышление, сужает интересы в пользу доступного [9, р. 259]. Российский бартер 1992 г. - это мир доступных вещей; 
за исключением видеомагнитофона, товары обмена вполне характерны для домохозяйств 1980-х гг., товары новой эпохи (микроволновая печь, компьютер и т.д.) встречаются в единичных объявлениях и находятся на периферии представленной сети. С одной стороны, гражданам была не всегда ясна ценность этих вещей, а с другой стороны их полезность.

5. Бартер занимал в экономике несколько иную роль, нежели отношения купли-продажи. Анализ объявлений в той же газете показал, что обладатели статусных товаров (пиломатериалы, видеомагнитофоны, шубы) чаще пытались продать их, чем выменять на что-либо.

Семантические сети, отражающие потребительские идеалы позволяют концептуализировать ряд вопросов экономической истории России 2 пол. ХХ в.

1. Принципы функционирования бартера как системы. Можно ли воспринимать его как структуру, обусловленную общественными идеалами, ценностями и заблуждениями, либо бартер - это совокупность независимых друг от друга сделок, формирующих случайные сети?

2. Квантификация потребительского идеала и динамики его изменения. Наложение сетевых моделей обменных операций одного города за разные годы позволит построить динамические сети, определить стабильные и изменчивые приоритеты граждан на потребительском рынке.

3. Связь потребительских предпочтений и ценообразования. Сравнение индексов центральности узлов и среднерыночной стоимости товаров за то же самое время позволяет выявить статусные товары, уточнить неоклассическую модель рационального выбора. Также целесообразно исследовать пары товаров, где обмен явно неравнозначен с точки зрения рыночной стоимости.

4. Географические различия потребительских предпочтений и факторы, определяющие эти различия. Сравнение моделей, построенных для разных городов, позволит более аргументировано постулировать наличие или отсутствие региональных факторов в развитии рыночной экономики.

\section{Библиография}

1. Коулман Дж. Введение социальной структуры в экономический анализ // Классика новой экономической социологии / сост. В.В. Радаев, Г.Б. Юдин. - М.: Изд.дом Высшей школы экономики, 2014. - 381 с.

2. Kahneman D., Knetsch J. L., Thaler R. Fairness as a Constraint on Profit Seeking: Entitlements in the Market // American Economic Review. - 1986. - № 76. - 728-741 pp. 
3. Reid S.E. Cold War in the Kitchen: Gender and the De-Stalinization of Consumer Taste in the Soviet Union under Khrushchev // Slavic Review. - 2002. - Vol. 61. - No. 2. Pp. 211-252.

4. Chernyshova N. Soviet Consumer Culture in the Brezhnev Era. - New York: Routledge. -2013 . -280 p.

5. Иванова А. Магазины «Березка». Парадоксы потребления в позднем СССР. М.: Новое литературное обозрение, 2018. - 304 с.

6. Anderson D.G. Surrogate currencies and the 'wild market' in Central Siberia // The vanishing rouble: barter networks and non-monetary transactions in post-Soviet societies / ed. by P. Seabright. - Cambridge, 2000. - 383 p.

7. Alhajj R., Rokne J. Encyclopedia of Social Network Analysis and Mining. - New York: Springer, 2018. $-3504 \mathrm{p}$.

8. Восточно-Сибирская правда. - 1992. - № 1-242.

9. Humphrey C. How is barter done? The social relations of barter in provincial Russia // The vanishing rouble: barter networks and non-monetary transactions in post-Soviet societies / ed. by P. Seabright. - Cambridge, 2000. -383 p. 


\section{ИСТОРИЧЕСКАЯ ГЕОИНФОРМАТИКА: ТРАДИЦИИ И ТРАНСФОРМАЦИИ}

https://doi.org/10.29003/m1818.978-5-317-06529-4/257-264

Брюханова Е.А., Чекрыжова О.И. Алтайский государственныий университет, Барнаул

\section{Проблемы on-line реконструкции}

городского пространства Сибири на рубеже XIX-XX вв. (на примере города Тобольска) ${ }^{1}$

Аннотация. Целью исследования является реконструкция социального пространства сибирских городов в конце XIX - начале XX веков на основе привлечения различных источников и их комплексного анализа, а также репрезентация исторических данных в интерактивной геоинформационной системе. В рамках реализации проекта была создана web-ГИС по социальной топографии отдельных городов Тобольской губернии рубежа XIXXX вв., в том числе была проведена реконструкция более 50\% городской застройки г. Тобольска на основе изучения исторических карт, переписных листов 1897 г., фотодокументов и других источников.

Ключевые слова: городское пространство, Сибирь, объекты городской застройки, web-ГИС, on-line репрезентация данных, историческая топография, перепись 1897 года, фотодокументы.

Brukhanova E.A., Chekryzhova O.I. Altai State University, Barnaul

\section{The problems of the Siberian urban space reconstruction} at the turn of the XIX-XX centuries (on the example of Tobolsk city)

Abstract. The aim of the study is the Siberian cities' social space reconstructiong in the late 19th - early 20th centuries based on the various sources and their comprehensive analysis, as well as the historical data representation in the interactive geoinformation system. As part of the project, the web-GIS of social topography of Tobolsk province's cities at the turn of the XIX-XX centuries was created, including the reconstruction of more than $50 \%$ of Tobolsk's urban development based on the study of historical maps, materials of the 1897 Census, photographic documents and other sources.

Keywords: urban space, Siberia, urban development objects, web-GIS, on-line data representation, historical topography, 1897 Census, photographic documents.

Работа по реконструкции социальной топографии городов Сибири на рубеже XIX-XX вв., ведется на основании анализа целого комплекса источников. Большое внимание уделяется анализу соци-

\footnotetext{
${ }^{1}$ Исследование выполнено за счет гранта Российского научного фонда, проект № 19-78-10020.
} 
альной принадлежности и статуса, занятости, уровня благосостояния населения и влиянии этих факторов на формирование городского пространства [1, с. 347]. Город рассматривается как социальный, культурный, экономический феномен. Акцент делается на анализе городского пространства с точки зрения застройки и заселения, формирования городской среды, зафиксированной в исторических планах городов и картах. Такой подходделает города перспективными объектами пространственного изучения целого ряда факторов, в том числе размещения населения.

Оптимальным инструментом для реконструкции социального пространства городов является геоинформационная система, которая позволяет интегрировать данные разных источников. Основная идея исследования состоит в создании интерактивной on-line карты по социальной топографии сибирских городов и «синхронизации» данных разных временных периодов, в том числе пространственной идентификации объектов городской застройки как на исторических планах, так и на современных картографических ресурсах [2].

Создание картографических онлайн ресурсов на основе сопоставления исторических и современных данных реализовывалось в ряде проектов. Например, проекты на основе кадастровых данных о собственниках недвижимости по городам Антверпен [3] и Казань [4], а также проект по материалам переписи населения города Тарту [5]. По российским данным аналогичные онлайн проекты привести сложно. Сопоставление сведений разных временных срезов в России использовалось для проектов по созданию онлайн карт историкокультурного наследия [6].

Проблемы по идентификации объектов на исторических картах и подходы к их решению представлены в работах C. Gordon [7, с. 3], E. Diamond, [8, с. 41], I. Gregory, [9, с. 7] и других.

Для реконструкции социальной топографии города Тобольска рубежа XIX-XX вв. использовалсякомплекс массовых, статистических, описательных и визуальных источников, в числе которых переписные листы переписи 1897 г. по городам Тобольской губернии, списки дворовых мест г. Тобольска, карты и планы городов Сибири второй половины XIX - начала XX вв., фотографии с видами города Тобольска рубежа XIX-XX вв.Основными источниками стали переписные листы Первой всеобщей переписи населения Российской империи 1897 г., содержащие не только социально-демографические данные, но и сведения о месте проживания и собственниках здания и «План губернского города Тобольскасоставленный в 1860 году». План представляет 
отдельный источниковедческий интерес, поскольку содержит более поздние относительно даты издания городские объекты (ориентировочно до 1890 г.). По всей вероятности, отпечатанный в 1860 году типографским способом план служил основой для внесения изменений и дополнений по мере развития города, что мы можем проследить по рукописным правкам, внесенным очевидно в разное время, т.к. они выполнены разными чернилами.

Дополнительными источниками являются списки домохозяев с планами счетных участков переписи 1897 г. [10], списки историкокультурного наследия Тюменской области [11], содержащие данные о сохранившихся объектах городской застройки и их современного адреса, исторические и современные фотографии с видами города Тобольска, материалы периодической печати, отражающие сведения в том числе об утраченных зданиях и сооружениях [12], современные картографические ресурсы (Yandex.Map, OpenStreetMap, Sas.Planet).

В процессе создания исторической web-ГИС по социальной топографии городов Сибири на рубеже XIX-XX вв. (на примере города Тобольска) исследовательский коллектив столкнулся с проблемами связанными с пространственной идентификацией объектов городской застройки для решения которых работы были распределены на этапы.

Основным инструментом создания ГИС являлся программный продукт MapInfo, однако результат трансформирования и геопривязки исходных картографических материалов не обеспечивал требуемой точности. Поэтому для решения отдельных задач проекта использовались другие технологии. Например, в проекте использованы векторные слои, полученные в результате оцифровки в современной системе координат на основе источников: Дубль ГИС on-line, OpenStreetMap Россия [13], а также растровые подложки, загруженные с использованием сервиса SAS.Planet.

Для размещения исторической карты в современной системе координат WGS84 применялась программа ArcGIS, а для создания онлайн версии проекта необходимо было выбрать технические и инструментальные средства, которые позволяют публиковать интерактивные исторические карты. В результате для представления информации в Web-ГИС выбрана платформа NextGISWeb. В настоящее время ресурс функционирует, на нем представлена информация по реконструкции городского пространства Тобольска рубежа XIX$\mathrm{XX}$ вв. до уровня квартальной застройки и конкретных сооружений. 
Идентификация исторических объектов городской застройки заключается в определении их расположения на современной карте, присвоении им идентификационного номера (ID) и географических координат. Объекты городской застройки для реконструкции социальной топографии города Тобольска на рубеже XIX-XX вв. можно условно разделить на три группы.

Объекты, сохранившиеся до настоящего времени - некоторые церкви, мечеть, каторжная тюрьма, здание губернского музея и пр. Работа по идентификации объектов этой группы позволяет наиболее полно восстановить исторический облик города и использовать эти объекты в качестве опорных точек для дальнейшего процесса визуализации. К этой группе относится дом наследников Неудачина, сохранившийся до наших дней и представленный на некоторых фотографиях (рис. 1, 2).

Объекты, утерянные относительно недавно, но сохранившие достаточное количество источников и сведений для восстановления их местоположения и координат. Например, мы имеем возможность определить современный адрес где некогда располагалось известное в Тобольске фотоателье Марии Уссаковской, (дом на углу Пятницкой, сейчас - улица Мира и Почтовой, сейчас - Ершова, в котором на рубеже XIX-XX вв. В настоящее время здесь находятся руины, однако фотографии буквально конца XX века позволяют идентифицировать координаты расположения некогда двухэтажного здания мастерской.

Объекты, не сохранившиеся до наших дней. Для определения местоположения учреждений анализируются исторические планы городов. В качестве вспомогательных источников выступают фотодокументы и письменные свидетельства. Для этой группы объектов наибольшую сложность в пространственной идентификации вызывают не учреждения, а частные лавки, магазины, мастерские и жилые застройки, данные о которых фиксировались достаточно редко.

Для решения проблем идентификации объектов последней группы используются дополнительные картографические, описательные и фото источники. Наиболее точные сведения содержатся в списках домохозяев с планами счетных участков переписи 1897 г. обнаруженных фонде Тобольской окружной переписной комиссии Государственном архиве г. Тобольска. Списки «домохозяев и квартирантов» некоторых переписных участков г. Тобольска, составлены в апреле 1897 г. к сожалению, сохранились сведения, только по двум из четырех частей города Тобольска. Эти данные позволили нам восстановить информацию о частной жилой застройке максимально точно. Объекты застройки двух других частей города на данном эта- 
пе проекта можно восстановить лишь частично. При этом сохранившиеся, или уже идентифицированные объекты выступают в качестве опорной точки для дальнейшей работы по сопоставлению объектов представленных в визуальных и письменных источниках.

Визуальные источники в контексте изучения и реконструкции пространства города на рубеже XIX-XX вв. представляют значительный интерес, т.к. содержат информацию, которую невозможно получить из других групп источников. В процессе работы над реконструкцией городского пространства Тобольска использовались коллекции фотоснимков фотографов С.M. Прокудина-Горского, С.П. Паутова, В.А., М. Уссаковской, И. Шустер и др.

Сопоставление исторической и современной карты позволило определить координаты утраченных церквей, например, Благовещенской, располагавшейся недалеко от дома Уссаковской по улице Пятницкой. Изучая фотографии улицы Кузнецкой (сейчас - Алябьева), сделанной Сергеем Прокудиным-Горским в начале XX в., и сопоставляя изображения с планами счетных участков и списками домохозяйств удалось восстановить расположения некоторых жилых домов, например, дом отставного чиновника Розова и мещанина Блажевича. Место расположения некоторых объектов, например, дома известного сибирского художника Михаила Знаменского, удалось восстановить по упоминаниям в местной прессе.

Таким образом, удалось осуществить реконструкцию более $50 \%$ городской застройки города Тобольска рубежа XIX-XX вв., включая государственные, общественные и религиозные учреждения, а также частные лавки, магазины, жилые постройки и другие объекты. Методика реконструкции городского пространства заключается в сопоставлении картографических, номинативных, описательных и фотоисточников разных временных срезов, присвоении каждому объекту идентификационного номера (ID) и современных географических координат.

В результате саздана геоинформационная система и историкокартографический on-line pecypc (рис. 3.), позволяющие представить результаты проведенного исследования, в интерактивном формате и визуализировать историческое пространство городов Сибири рубежа XIX-XX вв. Такой формат представления данных исследуемого комплекса источников, позволяет получить уникальные сведения об отдельных строениях, городских районах, особенностях проживания тех или иных социальных групп, факторах, определяющих выбор места жительства, в исторической ретроспективе. 


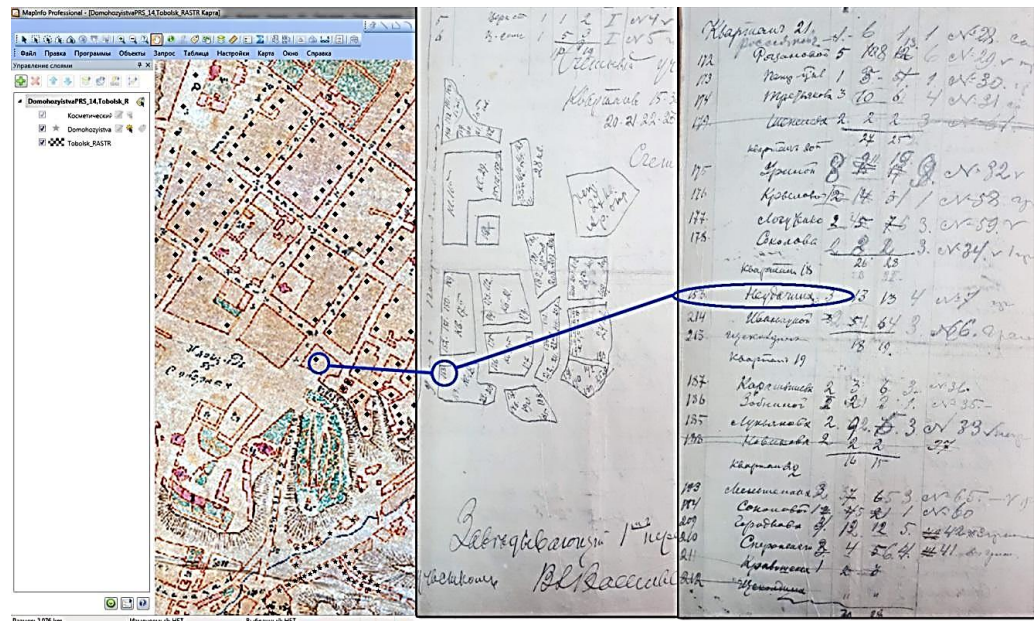

Рис. 1. Идентификация объекта застройки методом совмещения данных современного и исторического плана города и сведений содержащихся в Списке домохозяйств города Тобольск

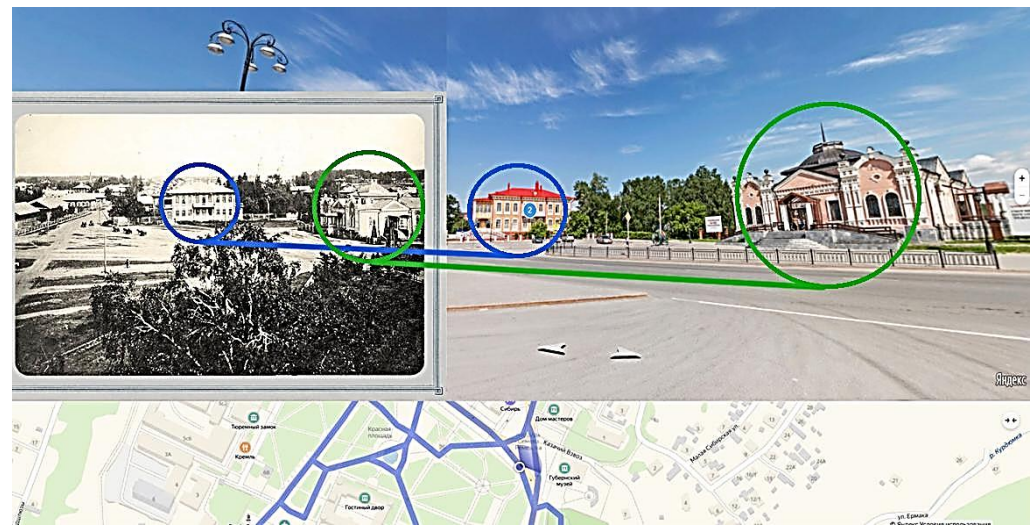

Рис. 2. Сопоставление изображений дома Неудачина и Губернского музея, представленные на фотографии С.П. Паутова (ХІХв.) 
三 Население городов Сибири на рубеже XIX-XX вв.

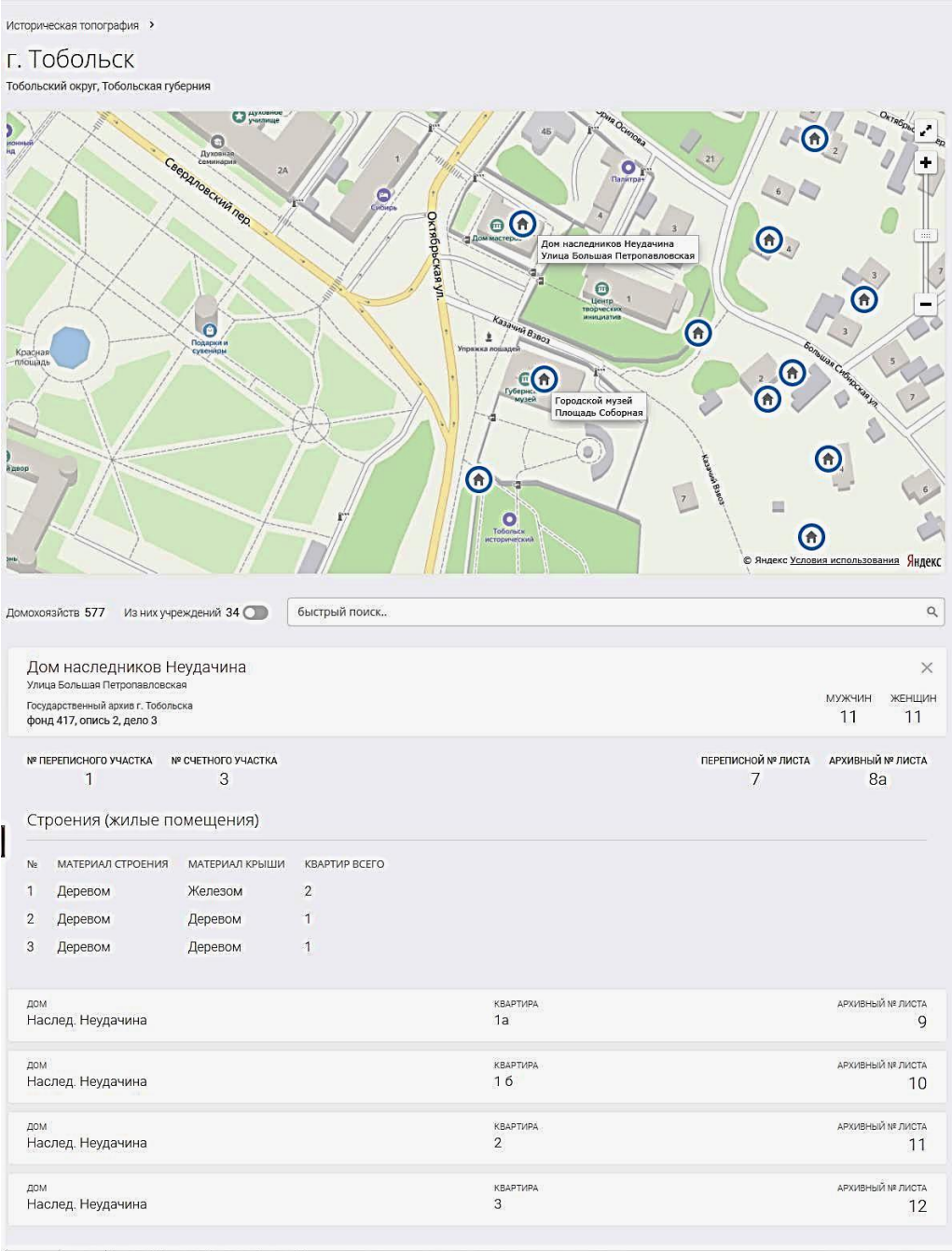

Рис. 3. Итоговая репрезентация данных в историко-картографическом on-line pecyрсе по городскому пространству Сибири на рубеже XIX-XX вв. (дом Неудачина) 


\section{Список источников и литературы}

1. Richer Z. Toward a Social Topography: Status as a Spatial Practice // Sociological Theory. - 2015. - Vol. 33(4). - Рp. 347-368.

2. Население городов Сибири на рубеже XIX-XX вв. По материалам переписи 1897 г. - URL: http://person1897.histcensus.asu.ru/

3. GIStorical Antwerp II (1500-2000) (2017). - URL: http://www.hisgis.nl/hisgis/ gewesten/antwerp/antwerpenkaarten.

4. Kazan 19th c. - URL: https://kazan19c.com/kazan_map

5. Tartu 1867. - URL: http://www.ra.ee/tartu1867/

6. Город Вологда в XVIII - начале XXI века: планировка, застройка, топонимика, объекты культурного наследия. - URL: historymaps35.ru.

7. Gordon C. Lost in space, or confessions of an accidental geographer // International Journal of Human-ities and Arts Computing. - 2011. - Vol. 5. - No. 1. - P. 1-22.

8. Diamond E., Bodenhamer D.J. Race and the decline of mainline Protestantism in American cities: a GIS analysis of Indianapolis in the 1950s // History and computing. 2001. - Vol. 13. - No.1. - P. 40-44.

9. Gregory I.N., Kemp K.K., Mostern R. Geographic Information and Historical Research: Current Progress and Future Directions. // History and Computing. - 2001. Vol. 13. - Pp. 7-21.

10. Государственный архив города Тобольска (ГАТО) - Ф. И571 Оп. 1. Д. 2.

11. Перечень объектов культурного наследия, расположенных в г. Тобольске (здания и сооружения) [Электронный ресурс] - URL: http://admtyumen.ru/ogv_ru/ society $/$ culture $/$ object $/$ more.htm? id $=10532547 \% 40 \mathrm{cms}$ Article

12. Панишев Е. А. Прогулка по старой улице Мира //Тобольская правда. - № 179 (16617). - 21.11.2002 г.

13. OpenStreetMap Россия - URL:http://openstreetmap.ru/

https://doi.org/10.29003/m1819.978-5-317-06529-4/264-272

Владимиров В.Н., Сарафанов Д.Е., Крупочкин Е.П. Алтайский государственный университет, Барнаул

Численность населения в пространстве приходов Колывано-Воскресенского горного округа во второй половине XVIII в.: возможности ГИС для анализа массивов данных

Аннотация. Рассмотрен вопрос создания исторических ГИС, позволяющих проводить анализ распределения данных о населении по церковным приходам. Предложена модель построения границ приходов. На основе сосредоточенных в ГИС статистических данных разработана серия карт, отражающих численность населения в границах приходов по нескольким временным срезам. Выделены существующие в Барнаульском духовном правлении типы приходов (городские, при заводах, сельские, при военных укреплениях, при рудниках), проанализирована динамика численности населения как в рамках отдельных приходов, так и в границах выделенных типов.

Ключевые слова: пространственный анализ данных, ГИС-технологии, церковный приход, население. 


\section{Vladimirov V.N., Sarafanov D.E., Krupochkin E.P. Altai State University, Barnaul}

\section{Population size in the space of parishes of the Kolyvano-Voskresensky mountain district in the second half of the 18th century: GIS capabilities for analyzing data sets}

Abstract. As a key task, the authors consider the issue of creating historical GIS that allow analyzing the distribution of data on the population by church parishes. As well as a model for constructing the boundaries of parishes is proposed. Based on statistical data concentrated in GIS, a series of maps has been developed that reflect the population size within the boundaries of parishes for several time periods. The types of parishes existing in the Barnaul spiritual government (urban, at factories, rural, at military fortifications, at mines) are highlighted, the dynamics of the population size is analyzed both within the framework of individual parishes and within the boundaries of the selected types.

Keywords: spatial data analysis, GIS technologies, parish, population.

Данные источников Русской православной церкви имеют огромное значение для историко-демографических исследований. Однако, для их полноценного использования, обработки и интерпретации необходима большая подготовительная работа. Настоящее исследование направлено на анализ динамики численности населения в пространстве приходов Колывано-Воскресенского горного округа во второй половине XVIII в. Вопросы локализации территории церковных приходов решаются с помощью геоинформационных технологий.

Первые упоминания в источниках термина «приход» относят к концу XV в. [1, с. 235; 2, с. 5] В этот период приход выступает не как территориальная общность, а как паства священника, регулярно приходящая на исповедь и причастие. Большое значение имела связь духовного лица и его прихожан. C середины XVI в. духовенство для расчета налога в пользу архиерея - начинает готовить описания приходов с указанием количества дворов, прихожан и пр. В Синодальный период (в XVIII - начале XX вв.) приход являлся низовой единицей церковной организации, среднее звено в которой составляли духовные правления, высшее - консистории. В этот период времени термин употреблялся в нескольких значениях: 1) низовой церковно-административный округ (с церковью и без нее); 2) население, приписанное к округу, т.е. прихожане; 3) церковное сообщество - прихожане и причт, во главе с настоятелем церкви; 4) только клир (понятие использовалось реже) [2, с. 6].

Таким образом, приход - это церковный территориальный округ, включающий населенные пункты, причисленные к конкретной церк- 
ви, а также община людей, которые молятся и удовлетворяют иные религиозные потребности в этом храме. Хотя приходы формировались по территориальному принципу (принадлежность человека к приходу определялась местом его проживания), их реальные границы на планах и картах того времени не фиксировались (авторам не встречались). Поэтому наш интерес - реконструкция системы приходов с использованием средств и возможностей ГИС. Это очень важно, поскольку на протяжении XVIII - начала XX вв. формируется обширная документная база, включающая массивы первичных источников, позволяющая проводить историко-демографические исследования на уровне приходов с применением компьютерных технологий. ГИС при этом помогает решать не только задачу пространственной привязки данных, но и, по сути, является инструментом реконструкции и пространственно-временного анализа.

Основой построения сети приходов, а точнее - границ приходов, является построение такой ГИС-модели или модели статистической поверхности, в которой учитывается расположение сети исходных опорных точек в виде системы населенных пунктов с расположенными в них церквями. С точки зрения геоинформатики определение центров не является сложной задачей. Однако более интересной и сложной задачей является построение моделей поверхностей, на основе которых можно определить набор оптимальных расчетных параметров - границ, расстояний, площадей и др.

Для этого необходимо не только вычисление «центров», но и построение моделей интерполяции и аппроксимации [3] по приходам, показывающим, например, миграцию населения, его социальный и профессиональный состав, формирующим, по сути, систему расселения. Для этого возможно использование метода геополей, основанного на применении алгоритмов построения полигонов Тиссена. Из условий триангуляции Тиссена, что в наибольшей степени соответствует задачи выделения границ приходов, две точки соединяются линией, если их полигоны имеют общую границу. Данный алгоритм позволяет получить систему непересекающихся треугольников с центрами внутри каждого из них. Недостатком такого разбиения является построение сети остроугольных треугольников. Но такого недостатка лишена триангуляция Делоне, так как для каждого ребра треугольника образуются серединные перпендикуляры, формирующие ребра полигонов Тиссена. В итоге получают не сеть треугольников, а сеть топологически корректных полигонов, ребра которых проходят через равноотстоящие точки относительно исходных центров (рис. 1). 


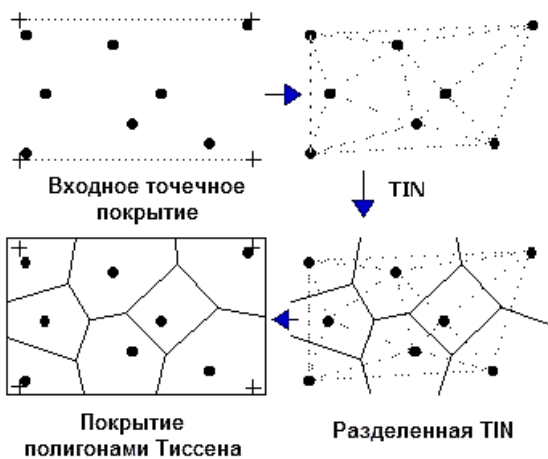

Рис. 1. Схема построения полигонов Тиссена по точечно распределенным данным [4]

Особое внимание мы уделяем анализу распределения данных по церковным приходам. Исходная статистика подключается к ГИС посредством операции геокодирования, под которой понимается присоединение статистических данных к конкретным пространственно определенным объектам, имеющим четкое географическое положение и координаты [5]. Функция геокодирования будет выполняться при условии наличия связи с файловой базой данных в виде структурированных реляционных таблиц в формате MS Excel (рис. 2).

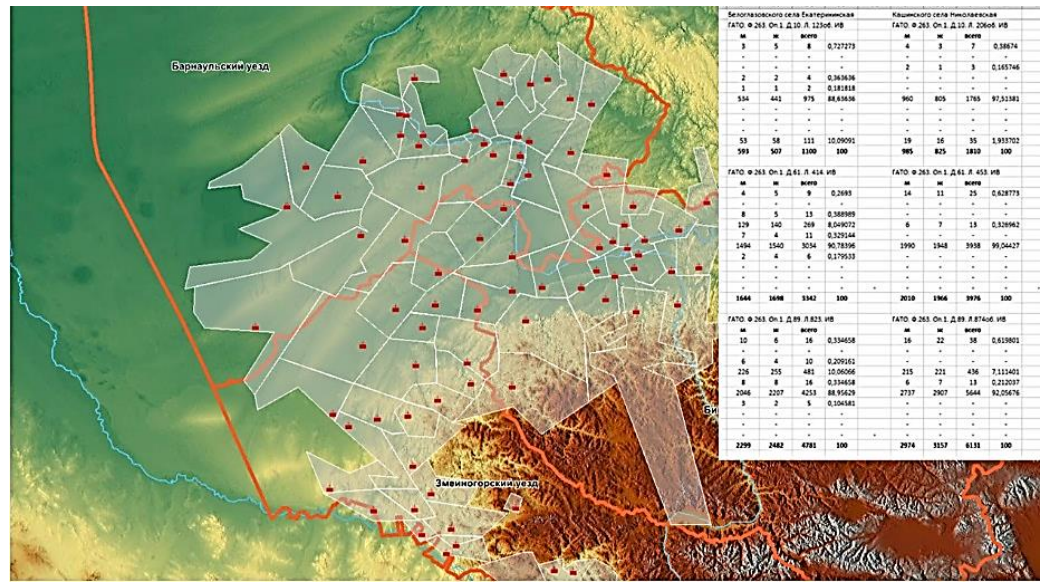

Рис. 2. Схема расположения приходов в ГИС с фрагментом файловой базы данных MS Excel [6] 
Архивы содержат обширное количество первичных церковных источников, данные которых могут быть представлены в пространстве церковных приходов. При этом в центре внимания оказываются демографические и социальные процессы, изучение которых ведется на основе связанных между собой технологии баз данных и геоинформационных технологии $[6,7]$. В зарубежной исторической демографии ГИС нашли применение гораздо раньше [см., например: 8].

\section{Анализ полученных результатов}

На территории Колывано-Воскресенского горного округа система церковных учреждений возглавлялась Барнаульским заказным духовным правлением, образованным в 1750 г. Духовное правление на 1752 г. включало 14 приходов, на 1774 г. - 17 [9, с. 34-35, 40-41]. В последующем их количество возрастало.

Настоящая работа, проведенная в рамках второй половины XVIII в., основана на материалах исповедных росписей, отложившихся в фондах Государственного архива Томской области. На основе указанных источников была создана база данных, реализованная в MS Excel. Отметим, что за 1750-е годы документы выявлены пока только за один год (1755 г.) по 12 церквям духовного правления. Источники за период с 1760 по 1799 г. сохранились значительно лучше - созданный массив электронных данных включает сведения за 23 года. Отметим, что по данным исповедных ведомостей на 1760 г. в Барнаульском заказном духовном правлении насчитывалось 16 приходов, к 1799 г. их количество возросло до 24.

На территории округа существовало несколько типов приходов: городские, при заводах, сельские, при военных укреплениях, при рудниках. Можно предположить, что подобная группировка учитывает не только административный статус населенного пункта, но и отражается на особенностях (различии) социального состава населения, демографических процессов в рамках пространства отдельных типов приходов.

На основе материалов базы данных нами были рассчитаны средние показатели численности населения в границах четырех десятилетий (4 временны́х среза). Средства ГИС использовались для визуализации данных. Распределение приходов по типам в рамках Духовного правления показало следующие результаты:

- семь заводских приходов (Барнаульского завода Петропавловский, Барнаульского завода Одигитриевский, Барнаульского завода Захарьевский, Колыванского завода Воскресенский, Ново-Павлов- 
ского завода Введенский, Нижне-Сузунского завода Вознесенский, Шубинского завода Николаевский);

- тринадцать сельских приходов (Тальменского села Архангельский, Белоярского села Петропавловский, Новоенисейской слободы Дмириевский, Кособоко-Белоглазовского села Екатерининский, Кашинского села Николаевский, Касмалинского села Введенский, Малышевской слободы Христорождественский, Чингисского села Петропавловский, Ирменского села Екатерининский, Крохалевского села Введенский, Кривощековского села Николаевский, Гутовского села Петропавловский, Легоставского села Архангельский);

- три прихода «при военных укреплениях» (Бийской крепости Петропавловский/Успенский, Смоленского редута Одигитриевский, Берского острога Сретенский);

• один приход «при рудниках» (Змеиногорского рудника Преображенский).

Отметим, что во второй половине XVIII в. административный статус отдельных населенных пунктов изменялся: в частности, Бийск с 1782 по 1796 гг. имел статус окружного города; по данным А.В. Контева Барнаул в XVIII в. был окружным городом в 1780 1782 гг. [10, с. 66], Берский острог (наименование используемое в церковных источниках) в период существования Колыванского наместничества приобрел статус города (именовался Колыванью) и считался таковым с 1782 г. по 1797 гг. Указанные приходы нельзя однозначно отнести только к одному определенному типу.

Среди заводских наиболее многочисленным был приход Петропавловской церкви Барнаула. В 1760 -е гг. численность его прихожан в среднем составляла 2 тыс. чел., а в 1790-е гг. $-5,4$ тыс. чел. (т.е. возросла в 2,7 раза). Здесь и далее мы оперируем средними числами, рассчитанными за десятилетние периоды (если прирост рассчитывать на основе данных «крайних» дат, то он будет выше). Следует учитывать, что население барнаульского завода и сельской округи «обслуживалось» духовенством еще двух церквей. Большое количество прихожан числилось в Ново-Павловского завода Введенском и Нижне-Сузунского завода Вознесенском приходах. Указанные заводы были запущены в 1764-1766 гг., в силу этого источники за 1760-е гг. по ним отсутствуют. Обе церкви (Введенская и Вознесенская) имели примерно равное количество прихожан. Их число возросло в 2 раза за 1770-1790-е гг., составив за последнее десятилетие XVIII в. более 4 тыс. чел. (средние значения). Приход Колыванского 
завода Воскресенской церкви, уступавший по численности населения примерно в два раза вышеуказанным, можно отнести к малочисленным среди заводских приходов (наряду с Захарьевским и Одигитриевским Барнаула). Николаевский приход (Шубинского завода) числился в составе Барнаульского заказного духовного правления всего несколько лет, в середине 1760-х гг. он перешел в ведение Омского духовного правления.

Среди сельских приходов самыми многочисленными можно назвать четыре - Тальменского села Архангельский, Белоярского села Петропавловский, Малышевской слободы Христорождественский и Чингисского села Петропавловский приходы. Численность их населения варьировалась к концу XVIII столетия от 5,5 до 7,7 тыс. человек (средние значения за 1790-е гг.). К средним по количеству прихожан можно отнести Кособоко-Белоглазовского села Екатерининский, Кашинского села Николаевский, Ирменского села Екатерининский и Легоставского села Архангельский приходы. Они насчитывали 3-4 тыс. человек на 1790-е гг. Меньшими по численности населения были приходы: Новоенисейской слободы Дмириевский, Касмалинского села Введенский, Крохалевского села Введенский, Кривощековского села Николаевский и Гутовского села Петропавловский. Средние показатели численности населения в границах последнего десятилетия XVIII в. варьировались в них от 1,4 до 2,3 тыс. человек.

Наибольший прирост населения среди сельских приходов наблюдался в Чингисского села Петропавловском приходе: если в 1760-е гг. численность его прихожан в среднем составляла 1,7 тыс. чел., то в 1790-е гг. - уже 7,7 тыс. чел. (т.е. возросла в 4,5 раза). Наименьший отмечен в Касмалинского села Введенском приходе (1,1 раза).

В существующих трех приходах при военных укреплениях Бийской крепости Петропавловском/Успенском, Берского острога Сретенском, Смоленского редута Одигитриевском - к концу изучаемого периода численность населения была сопоставимой (4,4-5 тыс. чел.). При этом к 1760-м годам в первых двух приходах количество прихожан составляло более 3 тыс. человек, в то время как первые упоминания о селе Смоленском относятся только к 1759 г., а исповедные ведомости сохранились только с 1769 г. В силу указанного обстоятельства, темпы роста числа прихожан Одигитриевской церкви Смоленского редута были выше.

Многочисленным был приход Преображенской церкви Змеиногорского рудника (само поселение при руднике появилось в 1744 г.). 
В 1760-е гг. численность прихожан Преображенской церкви в среднем составляла 1,8 тыс. чел., а в 1790-е гг. - 8,5 тыс. чел. (т.е. возросла в 4,7 раза).

Мы видим, что наиболее многочисленным был приход Преображенской церкви Змеиногорского рудника. Стоит, однако учитывать, что население Барнаула и сельской округи «обслуживалось» в этот период духовенством трех церквей. Значительная часть сельских приходов к концу XVIII в. была больше по численности населения или сопоставима с заводскими приходами и приходами при военных укреплениях.

Таким образом, результаты анализа могут быть использованы для сравнительной характеристики аналогичных явлений и процессов. Следует учитывать, что на протяжении всего времени происходили изменения границ приходов на территории Сибири, связанные с церковным строительством. Предложенная методика выделения границ приходов и построения топологически корректных территорий приходов, реализованная в ГИС, позволяет получить новые возможности исследования историко-демографических и социальных данных. Между тем, используемый ГИС-инструментарий и алгоритмы разбиения полигонов, нельзя назвать инновационными, т.к. это довольно давно используется при решении подобных задач (например, в региональной экономике и территориальном планировании). Для получения более точных данных по реконструкциям приходов мы будем исходить из расширения периода наблюдений, аналитической базы и применения центрографического метода, что в совокупности позволит перейти к более точным результатам.

\section{Библиография}

1. Стефанович П.С. Приход и приходское духовенство в России в XVIXVII веках. - М.: «Индрик», - 2002. - 352 с.

2. Бернштам Т.А. Приходская жизнь русской деревни: очерки по церковной этнографии. - СПб.: Петербургское Востоковедение, $-2005 .-416$ с.

3. Jonathan E. Campbell. Geographic Information System Basics // UCLA, Michael Shin. April 28, 2014 - Updated: May 9, 2019. - URL: https://2012books. lardbucket.org/books/geographic-information-system-basics/index.html (дата обращения: 25.08.2020).

4. Как работает инструмент Тиссен (Thiessen) (набор инструментов Покрытие) // ArcGIS Desktop - URL: https://desktop.arcgis.com/ru/arcmap/10.3/ tools/coverage-toolbox/how-thiessen-works.htm (дата обращения: 25.08.2020)

5. Michael Schmandt, Ph.D. GIS Commons: An Introductory Textbook on Geographic Information Systems // Initial author and Associate Professor of Ge- 
ography. Department of Geography. Sacramento State University - URL: https://giscommons.org/ (дата обращения: 25.08.2020)

6. Владимиров В.Н., Силина И.Г., Чибисов М.Е. Приходы Барнаульского духовного правления в 1829-1864 гг. (по материалам клировых ведомостей): монография. - Барнаул: Изд-во Алт. ун-та, -2006. - 140 с.

7. Владимиров В.Н., Сарафанов Д.Е. Информационные технологии в изучении метрических книг (население Барнаула в конце XVIII - начале XX в.): монография. - Барнаул: Изд-во Алт. ун-та. - 2013. - 114 с.

8. Alves D.R. Using a GIS to reconstruct the nineteenth century Lisbon parishes // Humanities, Computers and Cultural Heritage. Proceedings of the XVIth international conference of the Association for History and Computing. - Amsterdam: Royal Netherlands Academy of Arts and Sciences. - 2005. - Pp. 12-17.

9. Документы по истории церквей и вероисповеданий в Алтайском крае (XVII - начало XX в.). - Барнаул: Управление архивного дела Администрации Алтайского края, 1997. - 408 с.

10. Контев А. В. История Алтайского края XVIII-XIX веков: учебник для вузов. - Барнаул: АлтГПУ, 2017. - 232 с.

https://doi.org/10.29003/m1820.978-5-317-06529-4/272-277

Воробьева Е.M.

Тамбовский государственный университет им. Г.Р. Державина

\section{Анализ градостроительной реформы Екатерины II средствами ГИС}

Аннотация. В работе анализируется одна из составляющих градостроительной реформы Екатерины II, а именно создание и приведение в исполнение планов, конфирмованных для городов Российской империи. Источниковая база исследования: планы Рязани, Екатеринбурга и Тамбова. Цель определение города, менее всего затронутого реновацией. Применяя ГИС, были оцифрованы планы и проведены расчеты, результатом которых стали показатели «активной доли» перестройки. Менее всего переустройству был подвержена Рязань ее показатель 4,1\%.

Ключевые слова: город, план, градостроительная реформа, Екатерина II, городское планирование.

Vorobyova E.M. Derzhavin Tambov State University

\section{Analysis of the urban planning reform of Catherine II by means of GIS}

Abstract. The paper analyzes one of the parts of the reform of the city of Catherine II, namely, the creation and implementation of plans confirmed for the cities of the Russian Empire. Source database of research plans of Ryazan, Yekaterinburg and Tambov. The goal is to identify the city least affected by renovation. 
Using GIS, plans were digitized and calculations were made, which resulted in indicators of the "active share" of perestroika, the least affected by perestroika was Ryazan with its indicator of $4.1 \%$.

Keywords: city, plan, urban planning reform, Catherine II, urban planning.

Город - формируемая система, в ее развитии принимают участие различные «социальные агенты» [1]. Распределение их влияния неравномерно и зависит от многих факторов. Один из основных - это «период времени» в который происходит воздействие.

В исследовании проанализированы три антропосистемы, локализованные в городских пространствах Тамбова, Рязани и Екатеринбурга, начавшие свое формирование в разное время. Все эти системы пережили коренной слом во второй половине XVIII века. Коренным сломом можно назвать градостроительную реформу Екатерины II начало которой положил указ 1763 года «О сделании всем городам, их строению и улицам специальных планов, по каждой губернии особо» $[2$, с. 320$]$.

Три города, взятые за основу в данном исследовании: Рязань, Тамбов, Екатеринбург имеют множество различий. Каждый был основан в свою эпоху, а как следствие на этот процесс имели влияние разные факторы. К ним можно отнести: политико-административные интересы государства, состав населения, их занятия, специализацию региона, ближайшее соседство и многое другое.

Информация о заложении крепости Рязань датируется 1095 годом [3, с. 2]. Город, до 1778 года именовался - Переяславль-Рязанский в связи с тем, что название Рязань носил другой населенный пункт, который был разорен в результате монгольского нашествия. Цель основания Переяславля-Рязанского - защита от кочевых народов границ государства. Позже уже в XIV веке он приобрел свое административное значение и продолжил развитие сначала в виде центра княжества, а далее наместничества и губернии.

Тамбов был заложен как крепость, также для обороны от кочевников спустя практически шесть веков в 1636 году [4, с. 57-65]. Основная его задача - это защита границ государства. Одним из существенных отличий крепости Тамбов от Рязани является процесс ее заселения, в случае с Переяславлем-Рязанским население увеличивалось плавно, тогда как в Тамбов служилые люди были централизовано направлены [5, с. 31].

Екатеринбург, был заложен незадолго до упомянутой реформы в 1723 году как завод-крепость по инициативе Василия Никитича Та- 
тищева и изначально имел не только оборонное, но и промышленное значение. В следствии чего приобрел отличную от Рязани и Тамбова структуру населения, а также принцип организации городского пространства. Важным моментом является принципиально иное расположение точек притяжения. В Тамбове такими точками можно назвать церкви и центральную площадь, в Екатеринбурге же - это еще и заводские помещения. На плане можно заметить, что город располагался вокруг Екатеринбургского завода.

Тамбов и Рязань не раз подвергались реновации, и прошли долгий путь формирования под влиянием различных факторов. Екатеринбург же имел сравнительно не богатую на тот момент историю, а потому предположительно подвергся не столько переустройству, сколько регламентации.

На момент воцарения Екатерины II многие города имели лишь формальный статус в реальности же представляли собой скорее крупные села [6, с. 375]. Правительство стремилось наполнить пространство тем, что способствовало бы развитию промыслов и торговли [7, с. 31]. Стихийная застройка рассматривалась как препятствие развитию транспортной инфраструктуры и противоречила основам логистики, которая была крайне важна для переориентации города и создания из него центра промышленности и торговли.

Большая часть городов Российской империи получила планы, которые призваны были регламентировать переустройство. Все они имели схожий внешний вид и единую систему обозначений. Важным признаком этой группы источников является присутствие на планах как старых, не затронутых перестройкой кварталов, так и новых привнесенных градостроительной реформой. Существенный минус отсутствие картографической точности, что не позволяет проводить точные подсчеты размеров территории, поэтому расчеты ведутся в условных единицах.

Источниковая база исследования: «План Губернского города Рязани» 1780 года, «План губернскому городу Тамбову» 1781 года, «План Пермского наместничества городу Екатеринбургу» 1776 года.

Наибольший интерес для нас представляет конфликт старого и нового в рамках градостроительной реформы. Как уже упоминалось ранее столкновение отражено и в используемых источниках, оно проявляется в виде «наложения» сети новых кварталов на уже существующую городскую структуру. В результате чего части старых кварталов в рамках реформы должны были стать широкими улицами или площадями. Что могло реализовываться путем сноса построек, находящихся в этих местах. 
Любое вторжение в жизнь города требует дальнейшего долгого процесса адаптации жителей к новым условиям. Потому перепланировку города следует рассматривать как коренной слом. Цель работы - проанализировать три города каждый из которых является продуктом градостроительной политики определенного периода. В рамках этого исследования мы ставили задачу понять какой из этих продуктов наиболее «бескровно» мог быть адаптирован к новым потребностям государства в рамках проводимой во второй половине XVIII века реформы. «Бескровность» определяется малой долей урона городской и личной собственности, уровнем сохранности культурного наследия и т.п.

Чтобы ответить на этот вопрос необходимо подсчитать площадь «противостояния» старого стихийного и нового регулярного. Оцифровка планов и расчёты были выполнены средствами Географической информационной системы (далее - ГИС).

На основе планов трех городов в ГИС были созданы отдельные проекты каждый из которых имеет идентичный набор векторных слоев. Слои далее будут именоваться следующим образом:

1. «Pre_Reform»- старая стихийная застройка, на планах отмечена пунктиром, а также карминовой заливкой.

2. «Post_Reform»- реформированный образ города, на планах обозначены светло карминовой и желтой заливкой.

Получив для каждого плана единую структуру доступную для компьютерной обработки, мы вычислили приблизительную долю затронутых реновацией территорий.

Для каждого города проведены аналогичные вычисления. Из геометрии слоя «Pre_Reform» вычтен слой «Post_Reform», полученный результат преобразован в векторный слой «Crash_Area». C целью определения общей площади всех полигонов «Crash_Area» была использована функция «Базовая статистика для полей». При этом полем расчета статистики назначена «площадь полигона», которая перед этим была найдена для каждого из них в калькуляторе полей с использованием функции «\$area»/1000 000000.

Таким образом в каждом из проектов получена суммарная площадь всех полигонов для слоя «Crash_Area*название города*». При этом важно понимать, что площадь, представленная в условных единицах, относительна, поскольку слои были сориентированы только в локальной системе координат. 
Определение реального соотношения размеров городов между собой в опоре на масштабы, указанные на планах не имеет смысла в контексте данного исследования и использованной источниковой базы. Основной причиной этого является картографическая неточность присутствующая на планах XVIII века. Для сравнения необходимо было стандартизировать данные, чтобы минимизировать различия в размерах городов. Для этого проведены следующие вычисления: $(«$ Crash_Area»/«Pre_Reform»)*100. Таким образом для расчетов использованы слои, в рамках одного проекта находящиеся в единой системе координат, а данные представленные в процентах стали доступны для сравнения.

В результате проведенных подсчетов объемы зоны «конфликта» нового и старого составили: для Рязани 4,1\%; для Тамбова 27,7\%; для Екатеринбурга $14 \%$.

В случае Тамбова необходимо внести некоторые уточнения. На плане пунктирной линией отмечены кварталы за рекой Гаврюшка на месте которых располагалась городская Полковая слобода. Принимая во внимание расположение новой квартальной сетки можно предположить, что слобода входит в зону «активной перестройки». При этом под зоной «активной перестройки» понимается части кварталов, вероятно разрушенных для расширения улиц и площадей. В реальности Полковая слобода просто перестала являться частью города, в силу чего план не регламентировал ее внешний вид. Исходя из вышесказанного площадь данных кварталов не была включена в вычисления.

Из полученных данных можно сделать вывод что более всего «перестройка» затронула Тамбов и Екатеринбург, а менее - Рязань. В опоре на результаты исследования возможно выдвинуть несколько гипотез.

1. Рязань меньше всего подверглась перестройке поскольку при реновации необходимо было сохранить культурное наследие города.

2. Екатеринбург легче было подстроить под новые потребности нежели Тамбов, поскольку при его основании в проект уже были привнесены часть необходимых для нового города особенностей.

Стоит подчеркнуть, что любая выдвинутая гипотеза требует дополнения ее информацией об особенностях переустройства.

Изначальной целью исследования было сравнение эпох, являвшихся пиками градостроительства путем сопоставления продукта их деятельности - городов. Поставленная цель имеет долгосрочную перспективу, планируется охватить большее количество антропосистем для обретения более точного и объективного результата. 
Полученные данные неизбежно влекут за собой множество вопросов социального и административного толка. Важно определить, как проходил процесс переустройства города, какие учреждения в нем были задействованы, были ли конфликты и судебные изыскания между жителями и представителями власти на местах по поводу утраченной земли. Как вмешательство государства перестроило быт и привычки населения? Все эти вопросы имеют не только социальную, но и экономическую подоплеку, поскольку несмотря на неразвитость института частной собственности споры за землю между горожанами уже имели судебные прецеденты.

Кроме того, важно понимать, что исследование не столько нацелено на решение конкретной задачи, сколько на представление действенного механизма осуществления анализа информации, содержащейся в картографических источниках, средствами ГИС. Использование такой формы обработки данных возможно при анализе градостроительства в других городах Российской империи. Также большую перспективу имеет «экспорт» рассчитанных показателей в другие исследования, социально-экономической и политологической направленности.

\section{Библиография}

1. Бурдье П. Социология социального пространства/Пер. с. франц.; отв. ред. перевода Н.А. Шматко. - М.: Институт экспериментальной социологии; СПб.: Алетейя, 2007. $-288 \mathrm{c}$.

2. Полное Собрание Законов Российской Империи: Собрание первое: С 1649 по 12 декабря 1825 года. - СПб.: Тип. ІІ Отд-ния собств. Е. И. В. канцелярии, 1830. 48 т.: указ. Т. 16.

3. Празднование 800-летия (1095-1895 гг.) г. Рязани. 20-22 сентября 1895 года / под ред. чл. комис. С.Д. Яхонтова. - Рязань: Рязанская ученая архивная комис., 1896. $126 \mathrm{c}$.

4. Ляпин Д.А. Урбанизация Центрально-Черноземного региона в конце XVI начале XVIII вв // Гуманитарные и юридические исследования. - 2017. - №3 - С. 57-65.

5. Черменский П.Н. Прошлое Тамбовского края. - Тамбов: Кн. изд-во, 1961. $199 \mathrm{c}$.

6. Дитятин И.И. Устройство и управление городов России / [Соч.] И.И. Дитянина. Т. 1-2. - Санкт-Петербург: тип. П.П. Меркульева, 1875-1877. - Т. 2. - 507 с.

7. Белов А.В. Реформа города Екатерины II: (по материалам губерний Центральной России) / А.В. Белов; Институт российской истории Российской академии наук. М.: Институт российской истории РАН: Центр гуманитарных инициатив, 2019-613 с.

8. План Губернского города Рязани [Электронный ресурc] - URL: http://www.etomesto.ru/map-ryazan_1780/ (дата обращения: 15.07.2020).

9. План Пермского наместничества городу Екатеринбургу [Электронный ресурс] URL: http://www.etomesto.ru/map-ekaterinburg_1776/ (дата обращения: 15.07.2020). 
https://doi.org/10.29003/m1821.978-5-317-06529-4/278-284

Карпова М.В., Степанова Ю.В. Тверской государственный университет

\section{Историко-географическое исследование Торопецкого уезда XVI в. с применением геоинформационных технологий}

Аннотация. В статье представлены результаты историко-географического исследования Торопецкого уезда XVI в. с применением гис-технологий. Произведена локализация и оценка заселенности волостей и специфических территориальных единиц уезда - перевар, связанных с развитием бортного промысла по данным писцовой книги 1540 г. Внутри перевар зафиксированы «гнезда» сельских поселений. Бортные угодья Торопецкой земли в период ее нахождения в составе Великого княжества Литовского (ВКЛ) являлись частью великокняжеского хозяйства, а в московское время постепенно приходили в упадок. Здесь происходило формирование поместного землевладения, что и зафиксировала писцовая книга.

Ключевые слова: гис-технологии, статистика, историческая география, уезд, волость, перевара, расселение, Московское государство.

Karpova M.V., Stepanova Y.V. Tver State University

\section{Historical and geographical study of the Toropetsky uezd of 16th century using geographic information technologies}

Annotation. The article presents the results of a historical and geographical study of the Toropetsky uezd of the 16th century using GIS technologies. The volosts and specific territorial units of the uezd - perevara, associated with the development of wild-hive beekeeping were localized according to the scribe book of 1540 . The settlement of the territories was estimated. The "nests" of rural settlements were recorded inside perevara. The wild-hive beekeeping in Toropetsky uezd during the period of the Grand Duchy of Lithuania was the part of the Grand Duke's household, and gradually fell into decline in the Moscow State. Here the estates were formed, which were recorded by the scribe book.

Keywords: GIS, statistics, historical geography, uezd, volost, perevara, settlement, Moscow State.

Территориально-административное устройство и поземельная организация отдельных регионов Московского государства имели как общие, так и специфические региональные черты. Изучение и поиск причин этих различий позволяет проследить отдельные элементы более ранней территориальной организации и яснее представить себе процесс централизации земель вокруг Москвы. Настоящее исследование посвящено территории Торопецкого уезда XVI в., находившегося на западных границах Московского государства и 
обладавшего специфическими чертами территориальной организации, расселения и хозяйства.

Для исследования экономики и хозяйственной жизни западнорусских территорий, граничивших с Великим княжеством Литовским, в том числе Торопецкого уезда, важное значение имеет писцовая книга письма Александра Давыдовича Ульянина и Тимофея Степанова сына Бибикова 1540 г. - основной источник исследования. Книга была опубликована дважды: впервые - в 1963 г. [1], более полно - в 2005 г. [2].

Особенности территориально-административного устройства, землевладения и хозяйства Торопецкой земли и сопредельных Торопцу территорий рассматривались в работах М.В. Довнар-Запольского [3], М.К. Любавского [4, 5], И.И. Побойнина [6], М.Н. Тихомирова [7], В.Л. Янина [8], В.Н. Темушева [9], А.А. Фролова [10, 11]. Целью настоящего исследования является историко-географическая характеристика Торопецкого уезда по данным описания 1540 г., локализация населенных пунктов, волостей и специфических территориальных образований уезда - перевар, изучение характера сельского расселения и землевладения в уезде. Исследование является частью программы историко-географического изучения территории Тверской области в эпоху позднего средневековья, осуществляемой Тверским государственным университетом совместно с Институтом всеобщей истории РАН, в рамках которой разработаны исторические ГИС, в частности, по территории Тверского [12] и Ржевского [13] уездов, карельского расселения в Верхневолжье в XVII в. [14].

Исследование проведено с применением геоинформационных технологий. Для локализации топонимики Торопецкой писцовой книги 1540 г. использовались материалы Генерального межевания второй половины XVIII в., в том числе экономические примечания Торопецкого уезда, а также статистические описания и картографические материалы XIX-XX вв. Расположение северной границы уезда уточняется благодаря локализации смежных территорий Деревской пятины Новгородской земли [10].

Особенностью структуры сельского расселения Торопецкого уезда является специфический характер размещения населенных пунктов - деревень, которые объединялись в своеобразные «гнезда» под обобщающим названием. Образовывавшие «гнезда» деревни не имели названий, в писцовом описании они обозначаются по именам крестьян (например, «дрв. Федька Максимова», «в Оке ж Демеховская Мясцова» и т.п.). 
В целом, обобщающие названия «гнезд» охватывают небольшое количество поселений, от 2 до 20. В основном это малодворные деревни, в которых насчитывалось от 1 до 3 дворов, но иногда встречаются упоминания о 6-7 дворах в поселении. Например, в Сережской переваре выделяются следующие «гнезда» поселений: «на Лугу», «озера Говья», «над Любишом», «Долгая», «в Столбове», «в Сосновице». Местность, объединяющая в себе несколько мелких поселений, могла осознаваться жителями окрестных деревень как одно поселение.

Зафиксированный писцовой книгой 1540 г. способ обозначения поселений через обобщающие названия связан с расселением и формированием общин черносошного крестьянства [11, с. 153-201]. Он служил надежным средством идентификации объекта налогообложения. Наличие обобщенного названия для целого ряда поселений упрощало поступление средств в казну великого князя. В сопредельных с Торопецким уездом территориях Деревской пятины Новгородской земли встречаются обобщающие собирательные наименования подобного типа. В Обонежской пятине, где встречается аналогичная система обозначения селений, соответствующие деревни были населены ближайшими родственниками [10, с. 86,87$]$. Похожее явление зафиксировала Торопецкая писцовая книга 1540 г. Так, в Збуцкой переваре имелись деревни со сходными названиями, в которых проживали близкие родственники: (дрв) Овжа Зела городского человека, (дрв) Овжа ж Зелова ж Онисимка Голашова сына городского человека, (дрв) Шерепино Ортемка Зелова брата [2, с. 554].

В связи с отсутствием названий у значительной доли поселений их точная локализация оказалась затруднена. Однако, местонахождение «гнезд» поселений было определено в 90\% случаев благодаря известным крупным поселениям и указаниям на гидронимы. В результате были локализованы территории волостей и перевар Торопецкого уезда и получено представление о размещении «гнезд» поселений. Определена площадь волостей, произведено ее сопоставление с численностью населенных пунктов, дворов и мужского населения.

Торопецкий уезд делился на следующие волости: Торопецкая, Любута, Тура, Нежелская, Данковская, Старцева, Столопенская, Казаринская. Перевары зафиксированы в Торопецкой, Данковской и Старцевой волостях Торопецкого уезда (рис. 1). Не ясным остается соотношение Стрежинской перевары с волостным делением. Возможно, Стрежинская перевара образовывала самостоятельную Стрежинскую волость. В писцовой книге также отсутствует четкое соотнесение территории в районе оз. Бойно на северо-востоке с административными единицами уезда. 


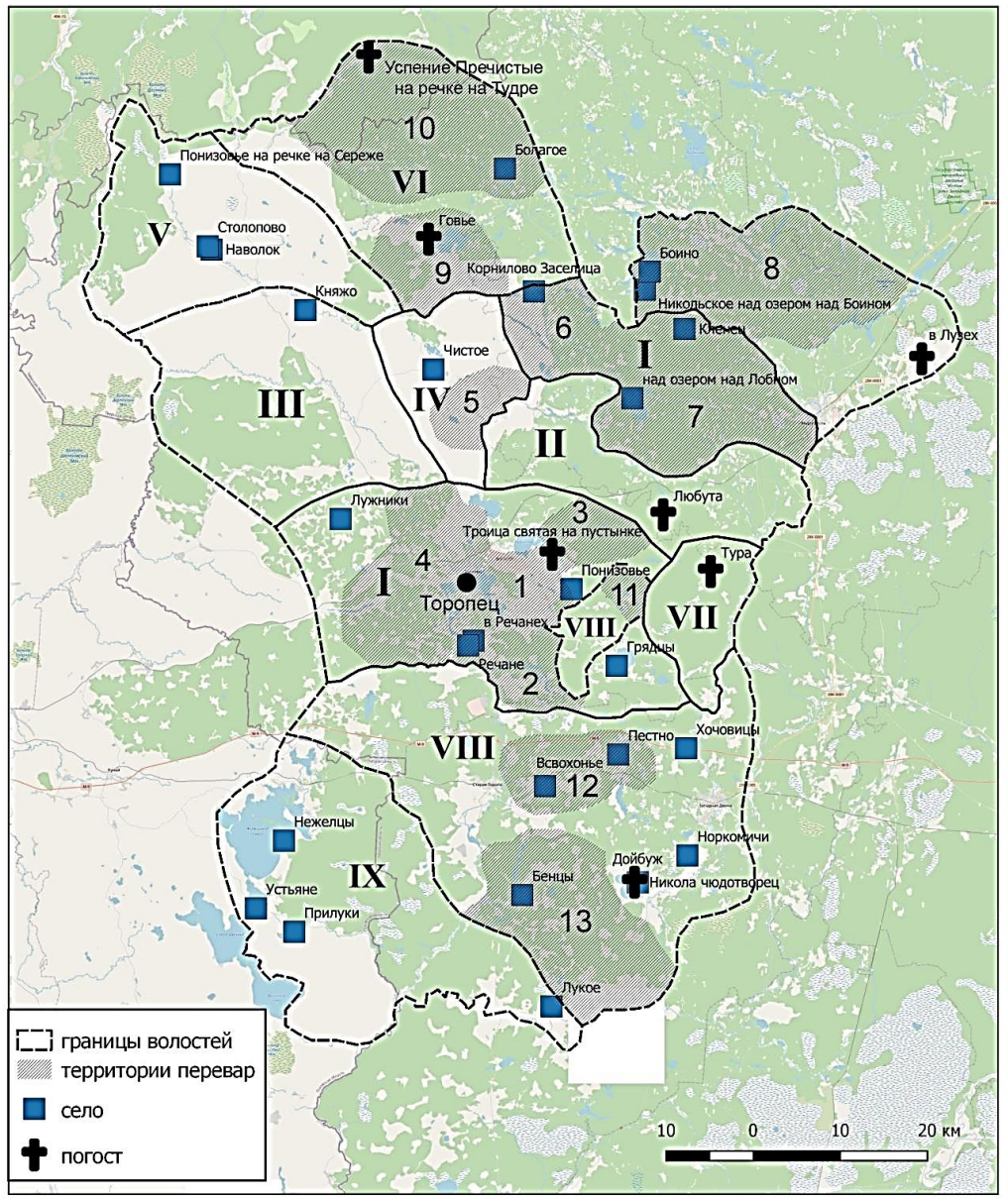

Рис. 1. Торопецкий уезд по данным писцовой книги 1540 г.

Волости: I - Торопецкая, II - Любута; III - Казаринская, IV - Стрежинская, V - Столопенская, VI - Данковская, VII - Тура, VIII - Старцева, IX - Нежелская. Перевары: 1 - Торопецкая, 2 - Порецкая, 3 - Лаширская и Кудинская и Меденская и Язвецкая, 4 - Збутцкая, 5 - Стрежинская, 6 - Желинская, 7 - Лобинская, 8 - Замошская, 9 - Сережская, 10 - Данковская, 11 - Зимецкая, 12 - Всвохонская, 13 - Соловская

Торопецкая волость располагалась вокруг самого Торопца и включала в себя обширную территорию, включавшую шесть перевар: Порецкая (с приписанной Зимецкой), Збутцкая, Струская, Торо- 
пецкая, Жалинская и Любинская. Данковская волость включала две перевары - Данковскую и Сережскую; Старцева - 3 (Зимецкую, Всхонскую, Соловскую). Установлено, что перевары являлись более мелкими территориальными образованиями и входили в состав волостей.

Наиболее обширными по территории волостями Торопецкого уезда являлись Торопецкая, Нежелская и Старцева. Наименьшую площадь имели волости Тура и Стрежинская. Было также установлено, что территории Торопецкой и Старцевой волости, повидимому, были разделены на два самостоятельных анклава. Подобное явление известно по материалам Новгородской земли и Ржевского уезда изучаемого периода и объясняется процессами развития феодального землевладения и налогообложения. Наиболее густо населенными, с учетом площади, представляются Торопецкая, Тура, Казаринская волости, наиболее близко располагавшиеся к Торопцу (рис. 2).

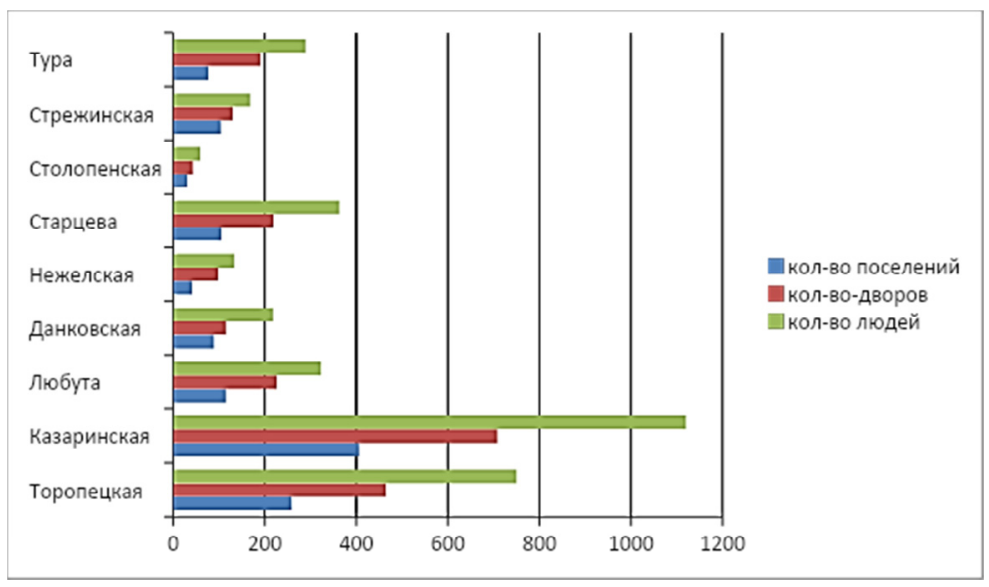

Рис. 2. Количество населенных пунктов, дворов и численность мужского населения в волостях Торопецкого уезда по данным писцовой книги 1540 г.

Обращает на себя внимание малое количество крупных сел в Торопецком уезде, что резко отличает его от соседних территорий, в частности, Тверского уезда [12, с. 117]. По-видимому, это связано с небольшим количеством поместных владений в уезде в XVI в. Административными центрами волостей являлись погосты. Как правило, это один погост с единственным храмом (волости Тура, Нежелская, Столопенская). Центром Торопецкой волости являлся г. 
Торопец. В некоторых волостях существовало более одного погоста с храмами. Так, в волости Любута существовало два погоста - Георгиевский и Воскресенский, которые в XVIII в. имели одинаковые названия - погост Любута.

С 1320 г. Торопец находился в составе ВКЛ, в связи с чем на территории волости получило развитие господарское (великокняжеское) хозяйство, в том числе бортное, доход с которого составлял важную часть всех налоговых поступлений [5, с. 98]. В восточных и южных волостях, отдаленных от центра ВКЛ, бортные промыслы облагались повышенным сбором дани (в денежном или натуральном (медовый сбор) виде). С задвинских волостей, в том числе с Торопца, дань шла в казну великого князя, находящуюся в Смоленске: «Великий князь Александр в 1496 г. велел побрать дань писарю Ивашку Яуковичу с Торопецких волостей...» [4, с. 287, 343].

Совокупность всех бортных земель, входящих в состав великокняжеского хозяйства, в Торопце объединялась под названием «перевар». Однако, бортным промыслом могли заниматься не только жители перевар. Подтверждением этому служат бортные знамена, принадлежавшие как жителям г. Торопца, так и близлежащих волостей [2, с. 547].

Торопецкая писцовая книга зафиксировала начальный период формирования поместной системы землевладения. Они зафиксированы на территории перевар - Желинской, Болобинской, Замошской, Данковской, Сережской переварах. Поместные деревни в переварах были несколько больше (3-6 дворов), чем на черносошных землях, где преобладали однодворки. Выяснено, что территории поместий иногда не имеют соотношения с волостями, но соотносятся с «гнездами» поселений. Таковы, например, поместные владения на северовостоке уезда, расположенные в местности «в Лузех» и в районе о3. Бойно.

Разработанная ГИС по данным Торопецкой писцовой книги 1540 г. наглядно отражает территориальное устройство Торопецкого уезда и концентрацию населения в центральной и западной части Торопецкого уезда, в относительной близости к г. Торопец. Писцовая книга 1540 г. зафиксировала упадок бортных угодий в первой половине XVI в. и постепенное формирование поместного землевладения в уезде после его вхождения в состав Московского государства. Локализация в ГИС показала, что поместное землевладение концентрировалось на окраинах уезда, преимущественно в его северной части, в том числе на территориях перевар. Предположи- 
тельно, бортное хозяйство в переварах с черносошным населением дольше сохранялось в южной части уезда, в Старцевой волости. Дальнейшее исследование с привлечением более ранних источников и писцовых описаний XVI-XVII вв. позволит изучить историкогеографические особенности региона в динамике, от нахождения в составе ВКЛ до нового времени.

\section{Литература}

1. Торопецкая книга 1540 г. // Археографический ежегодник за 1963 г. M., 1964. - C. 279-357.

2. Писцовая книга Торопецкого уезда письма Александра Давыдовича Ульянина и Тимофея Степанова сына Бибикова // Писцовые книги Новгородской земли. Т. 4: Писцовые книги Деревской пятины $1530-\mathrm{x}-1540-$ х гг. / сост. К.В. Баранов. - М.: Древлехранилище, 2004. - С. 501-682.

3. Довнар-Запольский М.В. Государственное хозяйство Великого княжества Литовского при Ягеллонах. - Киев: Тип. Императорского университета, 1901. - 935 с.

4. Любавский М.К. Областное деление и местное управление ЛитовскоРусского государства ко времени издания первого Литовского статута. - М.: Универ. типография, 1892. - 884 с.

5. Любавский М.К. Очерк истории Литовско-Русского государства до Люблинской унии включительно. С приложением текста хартий, выданных княжеству Литовскому и его областям. - М.: Московская художественная печатня, 1915. - 414 с.

6. Побойнин И.И. Торопецкая старина: ист. очерки г. Торопца с древнейших времен до конца XVII в. - Торопец: б.и., 2004. - 383 с.

7. Тихомиров М.Н. Россия в XVI столетии. - М.: Издательство АН СССР, 1962. $584 \mathrm{c}$.

8. Янин В.Л. Новгород и Литва. Пограничные ситуации XIII-XV веков. - М.: Изд-во Моск. ун-та, 1998. - 216 с.

9. Темушев В.Н. Таропецкая воласць // Вялікае княства Літоўскае: Энцыклапедыя. У 2 т. Т. 2: Кадэцкі корпус - Яцкевіч. - Мн.: БелЭн., 2006. - С. 659-670.

10. Фролов А.А. Историко-географическое своеобразие новгородских волостей Буйцы и Лопастицы в XV-XVII веках // Очерки феодальной России. - 2012. - Вып. 15. C. $84-88$.

11. Фролов А.А. Волости Буйцы и Лопастицы: опыт соотнесения топонимов обыскной книги 1562 г. со сведениями письма 1495-1496 гг. и проблема «домосковского» земельного кадастра // Очерки феодальной России. - 2013. - Вып. 16. C. $153-201$.

12. Кутаков С.С., Степанова Ю.В. Тверской уезд в XVI веке по данным писцовых описаний: опыт создания геоинформационной системы // Информационный бюллетень ассоциации «История и компьютер». - 2013. - № 40. - С. 115-120.

13. Писцовая приправочная книга 1588-1589 годов уезда Ржевы Володимеровой (половина князя Дмитрия Ивановича) / Подгот. А.А. Фролов. - М.; СПб.: АльянсApxeo, 2014. - $488 \mathrm{c}$.

14. Степанова Ю.В., Савинова А.И. Расселение карел в Верхневолжье в середине - второй половине XVII в.: опыт изучения с применением ГИС-технологий // Историческая информатика. - 2018. - № 4(26). - С. 57-72. 
https://doi.org/10.29003/m1822.978-5-317-06529-4/285-291

Крупочкин Е.П., Воробъев Д.А., Суханов С.И. Алтайский государственный университет, Барнаул

\section{Пространственно-временны́е аспекты исследования археологических памятников Юстытского археологического микрорайона: теория, методика, результаты ${ }^{1}$}

Аннотация. Предложена технология геоинформационного картографирования и геоархеологического анализа памятников археологии, позволяющая проводить анализ распределения данных о расселении населения АМР Юстыт. Разработана и протестирована новая программа вычисления пространственной корреляции. Построены интегральные ГИС модели отражающие закономерности расселение населения.

Ключевые слова: ГИС-технологии, интегральная ГИС модель, пространственный анализ, расселение населения

\section{Krupochkin E.P., Vorobiev D.A., Sukhanov S.I. Altai State University, Barnaul}

\section{Spatio-temporal aspects of the study of archaeological monuments of the Yustyt archaeological microdistrict: theory, methodology, results}

Abstract. The technology of geoinformational mapping and geoarchaeological analysis of archaeological monuments is proposed, which makes it possible to analyze the distribution of data on the settlement of the population of the archaeological microdistrict Yustyt. A new program for calculating spatial correlation has been developed and tested. Integral GIS models have been built that reflect the patterns of population settlement.

Keywords: GIS technologies, integral GIS model, spatial analysis, population resettlement.

\section{Введение}

Уникальной долиной, расположенной на территории Горного Алтая, где в скифскую эпоху происходило интенсивное движение кочевников и заселение территории, является долина Юстыт, особенно верховье и средняя часть поймы. Долина Юстыта является одной из самых необычных археологических областей России.

Она раскинулась на высоте от 2000 до 2300 м над уровнем моря и состоит из довольно недоступной в верхней части холмистой морены, и в то же время широкой и открытой нижней части (пойма и надпойменная терраса). Огромная концентрация памятников распо-

\footnotetext{
${ }^{1}$ Работа выполнена при финансовой поддержке РФФИ, грант № 18-05-00864.
} 
ложена именно на обширных террасах, причем как на левом, так и на правом берегу реки. В низовье река выходит в Чуйскую степь, пока не сливается с Бар-Бургазы и образуется Чуя.

Климат здесь отличается, как и много лет назад, низкими средними годовыми температурами, продолжительной и очень холодной зимой, коротким, относительно сухим и прохладным летом. Климат района резко-континентальный, это самое холодное место в Республике Алтай. Для района характерны резкие перепады температуры в течение суток. Зима очень малоснежна и длится более 7 месяцев. По своим геоморфологическим и природно-климатическим условиям район является высокогорным и приравнен к Крайнему Северу [1].

В административном плане район расположен в юго-западной части республики, он граничит с Республикой Тыва, Улаганским, Усть-Коксинским и Онгудайским районами (внутренние границы), а также с Монголией, Китаем и Казахстаном (государственные границы). Ввиду большого разнообразия и высокой концентрации археологических памятников данный район правомерно называть археологическим микрорайоном - АМР Юстыт.

Юго-Восточный Алтай в целом и долина Юстыт в частности, вплоть до конца 60-х гг. прошлого столетия оставались «белым пятном» для археологов. Наиболее существенные археологические изыскания в советское время здесь были проведены с конца 1960-х до 1980-х гг. экспедицией Института археологии СО РАН под руководством В.Д. Кубарева [1, 2].

С 2004 г. изучением и сплошным картографированием правобережной части Юстыта занималась группа бельгийских ученых под руководством проф. Жана Буржуа (Гентский университет). Учеными из Бельгии была зафиксирована высокая плотность археологических объектов, особенно в средней части долины. Высокая часть террасы правого берега имеет ширину 200 м, но расширяется до 1,5 км и более в нижнем течении и переходит в Чуйскую степь. Ж. Буржуа и В. Гейле обнаружили и зафиксировали 2400 объектов (структурных частей памятников). Как отмечает В. Гейле, некоторые из них было довольно трудно идентифицировать и хронология большинства выявленных структур неизвестна. В отношении хронологии остальных объектов - херексуры и связанные с ними каменные кольца, ученые относят их к бронзовому веку (40\% относительно всего археологического наследия). Другие типы памятников относят к скифской эпохе вместе с тюркскими оградками (соотношение составляет $24 \%$ и $17 \%$ ). 
За период с 2005 г. По настоящее время изучением археологического наследия левобережной части занимались И.Ю. Слюсаренко, Е.С. Богданов, Е.П. Крупочкин и др. Однако это происходило точечно - выделялись отдельные участки (площадки), для которых постепенно производили геодезическую съемку в масштабах 1:500-1:2000. В последние годы для обнаружения новых объектов внутри выявленных площадок и за их пределами мы стали применять космические снимки и БПЛА. Однако ввиду накопления огромного массива данных единственным эффективным инструментом их обработки, картографической визуализации и пространственно-временной интерпретации являются ГИС.

Целью наших исследований является изучение пространственновременных закономерностей распределения археологических памятников с помощью методов математико-картографического моделирования. Задачи исследований:

1. Изучение пространственных закономерностей распределения археологических памятников.

2. Выделение основных этапов в истории освоения долины АМР Юстыт.

3. Применение аппарата пространственной корреляции для выявления ключевых факторов в системе расселения кочевников в разные исторические периоды.

\section{Методы и технологии исследований}

Несмотря на предпринимаемые попытки, до сих пор ЮгоВосточный Алтай и АМР Юстыт недостаточно подробно изучены, т.к. исследования проводятся выборочно - в пределах отдельных территорий, так называемых условных площадок. Это правомерно отнести и к Юстыту. Множество могильников и тем более отдельно стоящие археологические объекты (херексуры, ритуальные оградки, выкладки и т.д.) до настоящего времени не имеют четкой географической и координатой привязок. В особенности это относится к левобережной части.

Отсюда концептуальной основой наших междисциплинарных исследований стала сквозная (типовая) технология, ориентированная на ГИС, ДЗЗ и картографический метод исследования, а также современный арсенал полевых и камеральных археолого-географических методов.

Предлагаемая технология базируется на концептуальной схеме геоинформационного картографирования и геоархеологического анализа памятников археологии. Она предусматривает разработку 
и активное применение геоинформационных систем и технологий, включая непосредственно разработку археологических ГИС, анализ и интерпретацию материалов с помощью специальных видов моделей, называемых математико-картографическими $[3,4]$.

Следует отметить, что инструментальной основой сбора и анализа археолого-географической информации на исследуемую территорию является геоинформационная система «Археологические памятники МАР Юстыт», которая объединяет данные об объектах, отличающихся друг от друга как по пространственным (с учетом ландшафтных особенностей), так и по временным признакам - культурной и временной принадлежности. В общем итоге только на одном левом берегу р. Юстыт мы подготовили и внесли в базу геоданных более 2000 объектов. Кроме того, эти объекты показаны на картах планах и тематических картах.

Вместе с тем, мы не ставим целью анализировать все виды математико-картографических моделей, использование которых возможно в археологии. В основе наших экспериментов использованы скорректированные данные SRTM (версия 2.0) с пространственным разрешением 90 м. Так, например, данные SRTM были использованы для создания интегральных модели теплообеспеченности, охватывающей следующие этапы:

- разработка базы геоданных (БГД);

- наполнение БГД растровыми данными SRTM;

- создание мозаики на заданную территорию;

- нормализация шкалы - перевод значений в метры;

- замена пропущенных пикселей и вычисление их средних значений;

- разработка блока производных тематических растров;

- классификация полученных растров по заданным критериям;

- калькуляция растров с целью создания синтетических карт.

Если первые пять этапов являются общими (однотипными) при работе с данными SRTM, то последние три (6-8) довольно специфические, они полностью зависят от исходных условий и алгоритмов решения поставленных задач. Так на этапе разработки блока производных карт с помощью программы ArcGIS строились модели крутизны склонов и экспозиции. Дальнейший анализ и синтез этих показателей сводился к интеграции и вычислению синтетических показателей теплообеспеченности.

Логика такого синтеза основана на следующих предпосылках. Поскольку крутизна склонов есть проявление гравитации (имеется в 
виду ее природного генезиса), а экспозиция есть проявление инсоляции в виде солнечной энергии, физический смысл интегрального показателя теплообеспеченности сводится к совместному анализу гравитации и инсоляции. Ранее предполагалось - чем выше освещенность или теплообеспеченность, тем комфортнее условия для проживания [5, 6]. Таким образом, поиск участков территории с наиболее комфортными условиями стал одним из базисных принципов нашего эксперимента.

Следующая часть эксперимента заключалась в решении задачи пространственной корреляции для выявления взаимосвязей между природно-географическими факторами, т.е. параметрами среды, и распределением археологических объектов. Для перехода от просто анализа к более строгому - количественному. Нами предложен алгоритм расчета пространственной корреляции, характеризующей не массив (модель) в целом, а значения локальных областей.

Алгоритм «пространственной корреляции» и программа «Spatial Correlator» работает следующим образом: на входе указываются два массива/изображения А и В с одинаковым количеством значений, что соответствует равенству двух массивов. Далее с помощью функции corr_2 (A, B) в программе MatLAb выполняется вычисление коэффициента корреляции в начальной позиции $\mathrm{R}_{\mathrm{Xi}, \mathrm{Yi}}$, где $\mathrm{X}_{\mathrm{i}}, \mathrm{Y}_{\mathrm{i}}$ соответствуют центральному элементу скользящего окна - маски. После этого полученное численное значение присваивается результирующему массиву в позиции $\mathrm{R}_{\mathrm{Xi}}$, зом завершается первый цикл. Далее следует новый цикл, который повторяется до тех пор, пока не будут обработаны все элементы массива/матрицы. Результирующая матрица - I, представляет по сути численную модель, но в то же время - модель пространственную, т.е. адаптированную для работы в ГИС-среде.

\section{Результаты анализа}

Пространственный анализ полученных в ходе апробации математико-картографических моделей на примере Юстытского археологического микрорайона, показал следующие результаты. В распределении могильников ключевую роль играют - экспозиция склонов, освещенность, крутизна и др. Большая часть могильников эпохи железа расположена на склонах южной и юго-западной экспозиции, что объясняется фактором освещенности. Исходя из данного условия можно предположить, что зимние могильники размещались на склонах южных экспозиций таким образом, чтобы продлить солнечное 
освещение, особенно в утренние и вечерние часы. Однако мы не можем утверждать об исключительности данного правила, поскольку более полутора тысяч объектов расположены на левом берегу Юстыта, а это все-таки склоны северной экспозиции.

Интегральная ГИС-модель, учитывающая одновременно два фактора (крутизну и экспозицию) показала наряду с участками южной экспозиции, участки склонов северной экспозиции с высокой концентрацией памятников скифской эпохи. Таким образом, есть основания предполагать, что летние могильники также были ориентированы на более ранний восход Солнца и более поздний его заход, для чего выбирались склоны северных экспозиций. Интегральная модель теплообеспеченности показала зависимость распределения археологических памятников от количества получаемого тепла склонами разных экспозиций и крутизны. Причем максимальная концентрация объектов наблюдается в шестом (S) и седьмом (SW) диапазонах, что соответствует наибольшей теплообеспеченности.

Авторами также предложен новый алгоритм, разработана и протестирована новая программа вычисления пространственной корреляции на основе обнаружения параметрической связи внутри скользящего окна/маски. Уникальность предложенного аппарат состоит в следующем. Во-первых, с помощью модели пространственной корреляции появляется возможность перейти от обобщенного уровня анализа причинно-следственных связей к локальному или местному, выявляющему локальные «ядра» повышенных значений пространственной корреляции. Это дает основание говорить о том, что, к примеру, несмотря на преобладающие низкие или близкие к нулевым, значения корреляции связь между двумя наблюдаемыми явлениями присутствует в обнаруженных очагах. Отметим, что такой механизм практически никогда не использовался. Как правило, в расчетах, в том числе с использованием современных ГИС-технологий, принимался во внимание один общий коэффициент корреляции, рассчитанный между матрицами. Однако для более тщательного, глубокого анализа такой механизм ничего не дает. Во-вторых, результирующая корреляционная матрица является одновременно и изображением и численной моделью (т.е. массивом данных). Такие универсальные свойства позволяют выполнять аналитические процедуры в программах математической обработки и в то же время - в геоинформационных системах. Например, появляется возможность настройки, классификации и группировки классов пикселей, соответствующим заданным порогам. Автоматически это находит свое отражение в легенде. В-третьих, при условии географической при- 
вязки, обеспечивающей строгое математическое соответствие заданной системе координат, появляется возможность реализации оверлейных функций в ГИС - от простого соответствия с наборами векторных и растровых слоев, до математической обработки с использованием калькулятора растров и других инструментов http://journal.asu.ru/st/article/view/7152.

Интегральные модели, построенные для АМР Юстыт показали наличие высокой корреляционной связи в распределении археологических памятников от интегрального фактора теплообеспеченности. Большинство памятников сконцентрированы именно в таких участках. Если исходить из предположения «чем теплее, тем комфортнее», в долинах крупных рек это действительно подтверждается максимальной концентрацией археологических объектов на склонах южной и юго-западной экспозиции. Такие участки соответствуют наибольшей теплообеспеченности, на них сконцентрированы более 2/3 от общего количества археологических памятников, сосредоточенных преимущественно берегах рек. Вторым фактором, не менее важным, является близость к воде, что подтверждается практически на всех ГИС-моделях.

\section{Библиография}

1. Кубарев В.Д. Курганы Юстыда. - Новосибирск: Изд-во «Наука» СО РАН, 1991. $-186 \mathrm{c}$.

2. Быкова В.А. Природные условия Юго-Восточного Алтая и их роль в жизни общества в пазырыкское время: монография / В.А. Быкова, Н.И. Быков; АлтГУ. Барнаул: Изд-во Алт. Ун-та, 2014. - 186 с.

3. Крупочкин Е.П., Быков Н.И. Теоретико-методические аспекты ГИСкартографирования археологических памятников (на примере Чуйского бассейна, Юго-Восточный Алтай) // Историческая география России: ретроспектива и современность комплексных региональных исследований: Материалы V Междунар. конф. по исторической географии (Санкт-Петербург, 18-21 мая 2015 г.). Ч. І. - СПб.: ЛГУ им. А.С. Пушкина, 2015. - С. 95-99.

4. Крупочкин Е.П., Суханов С.И. Программный комплекс «Detection Artifacts»: функциональные возможности и перспективы использования (на примере геоархеологических исследований) // ИнтерКарто/ИнтерГИС 23. Геоинформационное обеспечение устойчивого развития территорий в условиях глобальных изменений климата: Материалы Междунар. конференции. - Т. 1. - М.: Издательство Московского университета, 2017. - С. 199-208.

5. Зольников И.Д., Постнов А.В., Лямина В.А., Славинский В.С., Чупина Д.А. ГИС-моделирование условий обитания, благоприятных для проживания древнего человека в горах Алтая // Археология, этнография и антропология Евразии. - 2013. № 3. - C. 40-47.

6. Червяков В.А. Крупочкин Е.П. Теория и технология регионального картографического моделирования: монография. - Изд-во Алт. ун-та, 2005. 
https://doi.org/10.29003/m1823.978-5-317-06529-4/292-297

Кунавин К.С.

Тамбовский государственный университет имени Г.Р. Державина

Гришин Е.C.

Российская академия народного хозяйства и государственной службь при президенте Российской Федерации

\title{
Применение данных дистанционного зондирования Земли для изучения хозяйственной деятельности в Новое время ${ }^{1}$
}

Аннотация. Статья посвящена проблеме разработки и апробации методов использования данных дистанционного зондирования (спутниковые снимки и многоканальные ортофотопланы) для изучения природно-экологических аспектов хозяйственной деятельность в России в Новое время на примере небольшой территории на юге Тамбовской области. Описывается процедура поиска визуальных аномалий, результаты их конкретно-исторической интерпретации и перспективы автоматизации части процедур.

Ключевые слова: ДЗЗ, экологическая история, хозяйственная деятельность, антропогенный фактор, ГИС.

Kunavin K.S. Derzhavin Tambov State University

Grishin E.S. The Russian Presidential Academy of National Economy and Public Administration

\section{Usage of the data of remote sensing of the Earth for researching economic activity in modern times}

\begin{abstract}
The article discusses the problem of development and testing of the methods of remote sensing data (satellite photos and multichannel orthophotomaps) usage for researching the natural-ecological aspects of economic activity in Russia in modern times by the example of a small territory in the south of Tambov region. The procedure of the searching for visual anomalies is described as well as the results of their concrete-historical interpretation and the

Keywords: remote sensing of the Earth, ecological history, economic activity, anthropogenic factor, GIS.

\footnotetext{
${ }^{1}$ Исследование проведено при финансовой поддержке Российского научного фонда. Проект 19-18-00322 «Сравнительно-историческое изучение антропогенных ландшафтов различных регионов средствами беспилотных летательных аппаратов (Тамбовская область и Удмуртия, середина XVIII начало XX вв.)».
} 
Изучение природно-экологических аспектов хозяйственноэкономической деятельности в России Нового времени часто встречает определенные препятствия со стороны источниковой базы. Для слабо освоенных регионов они заключаются в недостатке информации (низкая степень картографического, статистического и текстового описания). Напротив, для хорошо освоенных территорий часто можно найти подробное описание, но при этом нередки случаи, когда один источник в некоторых деталях противоречит другому источнику. В обоих случаях возникает стремление подвергнуть ретроспективному анализу современное состояние изучаемой местности. До недавнего времени это можно было осуществить путем привлечения современных (более подробных и качественных, чем старые) топографических карт или с помощью реконгсценировки в интересующей зоне. В последнее время к этим инструментам добавились данные дистанционного зондирования Земли (ДЗ3).

Данные ДЗ3 уже давно активно используются в археологических исследованиях, но применительно к Новому времени они практически не задействуются. Связано это, в первую очередь, с разным масштабом поиска. Если археологическая разведка с помощью ДЗЗ в основном заключается в поиске больших объектов на большой территории, то поиск следов хозяйственной деятельности в Новом времени как правило сводится к обнаружению небольших признаков на небольших пустых/заброшенных территориях вокруг населенных массивов.

Наше исследование сфокусировано на небольшом участке $\left(12,5\right.$ км$\left.^{2}\right)$ в средней полосе России - в Знаменском районе Тамбовской области. Его хозяйственное освоение началось в XVIII в. Этот участок выбран как довольно типичный для русской лесостепи и, кроме того, обеспеченный достаточными историческими источниками. Хозяйственное освоение этой земли имеет довольно протяжённую историю. Участок, несмотря на скромные размеры, демонстрирует разнообразие: лес, остатки степи, пашни, крупные сёла, дороги, реки и ручьи. Всё это обещает сделать его рассмотрение эвристически продуктивным и даёт надежду, что полученные результаты и разработанные методики могут быть расширены на значительно более протяжённые территории.

На рассматриваемой территории располагалось два крупных имения, основанных в XVIII в. представителями знатных российских родов Воронцовых и Загряжских. Эти имения в последующие десятилетия переходили к разным владельцам. Наиболее известными из новых владельцев были Строгановы и Щербатовы в Знаменке. 
В течение XIX века наблюдался резкий рост населения в крупных сёлах. Это стимулировало увеличение числа выселок. Но даже после выселения части крестьян в Знаменке до реформы 1861 г. шел бурный рост населения. После крестьянской реформы численность крестьян сократилась в связи с тем, что Строгановы предоставили крестьянам небольшие дарственные наделы, недостаточные для нормального ведения хозяйства. В итоге значительная часть молодого населения выехала из села. Темпы роста населения Воронцовки в предреволюционные годы были невысоки в сравнении со средними по губернии. Поэтому можно говорить об относительно невысокой демографической нагрузке на природную среду изучаемой территории в начале $\mathrm{XX}$ в.

Более того, во второй половине XIX - начале XX вв. воронцовское и знаменское имения в хозяйственном отношении относились к образцовым, широко вводились элементы рационального природопользования. Важно учесть, что здесь происходило не только истощение природных ресурсов в процессе сельскохозяйственной деятельности, но и их частичное восстановление, что было редким явлением в России того времени.

Рост населения Знаменки в XX в. связан с превращением села в райцентр и поселок городского типа со сравнительно большим для сельской местности индустриальным сектором и, соответственно, с возросшим влиянием на природную среду. Численность населения Воронцовки в 2010 г. являлась сравнительно высокой: втрое превышала среднюю численность тамбовских сел. Появление большого по размерам и числу жителей поселка Первомайское на прежде безлюдной территории, конечно, привело к существенным изменениям природной среды.

Обширная литература, посвящённая методам анализа исторических карт в сопоставлении с данными дистанционного зондирования земли (ДЗ3), создана в рамках истории ландшафта. Однако в Новое и, особенно, Новейшее время одним из ключевых драйверов изменения среды стал антропогенный фактор. Поэтому соответствующие методологические наработки могут быть адаптированы для целей исторических исследований. Для этого необходимо «перефокусировать исследовательскую оптику истории экологии - со среды, в которой, среди прочего, живёт и действует человек, на человека, который живёт и действует в некоторой среде» [1].

Ключевой источник - ортофотопланы местности, сделанные в 2019 году. Они фиксируют изучаемую территорию в двух состояниях: с молодой низкой растительностью (май) и развитым раститель- 
ным покровом (июнь). Каждый временной срез снимался как в видимом цветовом диапазоне, так и в отдельных цветовых спектрах. В результате, все данные были скомбинированы в 21 канал.

Для рассматриваемой территории можно выделить четыре поколения картографических съемок, материалы которых могут быть привлечены в качестве базовых пространственно-ориентированных источников. Съемочные работы представлены следующими картографическими материалами:

1. План генерального межевания по Тамбовскому уезду, созданный в конце XVIII века (ПГМ-XVIII).

2. Топографический межевой атлас был создан в конце 1840-х в 1850-е гг. под руководством генерал-лейтенанта А.И. Менде.

3. Карта Красной армии (Рабоче-крестьянской Красной армии) $1941 \Gamma$.

4. Топографическая карта СССР/России с поправками от 1992 г.

Наличие четырех разновременных срезов картографического изучения местности позволяет не только проследить характер её развития, но и провести хронологическую атрибуцию дешифрируемых объектов. Последняя проблема как раз и составляет специфику использования данных дистанционного зондирования в сегменте Новой истории: отсутствие возможности проводить датировку выявленных объектов путем ассоциирования с памятниками материальной культуры. В этом смысле картографические источники выполняют компенсирующую роль; кроме того, они позволяют уточнить типологическую принадлежность обнаруженных пространственных аномалий.

Методология ручной и компьютерной интерпретации аэрофотоснимков довольно подробно представлена в ряде обзоров [2; 3]. Определённым недостатком ручной интерпретации является необходимость привлечения высокопрофессиональных специалистов. Кроме того, этот метод, в значительной степени, зависит от личного опыта и знаний интерпретатора, а также от его представлений о том, что следует ожидать на данном участке. Однако субъективность ручной интерпретации компенсируется высокой способностью человека различать разного рода сложные, нетривиальные образы.

Среди множества методов обработки данных Д3З для этого исследования был избран поиск визуальных аномалий. Под аномалиями понимаются объекты, отличающиеся по морфологии и отра- 
жающим способностям от остальных объектов такого же типа, расположенных поблизости. Мы сфокусировали внимание на таких аномалиях, которые могли быть следами антропогенного воздействия на исходную среду или, наоборот, следами поглощения природной средой антропогенных ландшафтов в результате запустения. Таким образом, полагаем, в аномалиях могут быть закодированы исторические сведения.

В литературе обычно приводятся три основных типа демаскирующих признаков, которые указывают на аномальный объект: (1) характеристики света, тени и контрастности (Iight - shadow - contrasts); (2) растительные признаки (cropmarks, vegetation patterns) и (3) почвенные признаки (soil marks) [4].

Поскольку нас интересовали, главным образом, аномалии, имеющие антропогенное происхождение, особое внимание уделялось геометрически правильной форме аномалий, а также несоответствию контексту.

Сопоставление исторических картографических источников, письменных материалов с обнаруженными аномалиями позволяет, во многих случаях, определить время возникновения или исчезновения аномалий. Следы человеческой деятельности обычно весьма сильно привязаны к контексту - ландшафту и природным ресурсам, хозяйственной инфраструктуре, дорожной сети, системообразующим объектам и пр. Человек и его деятельность зависят от геометрии пространства - как в силу объективных обстоятельств, так и в силу инерции мышления. Поскольку контекст весьма быстро менялся, то, как правило, можно установить, в какой контекст какого периода вписывается та или иная аномалия.

Для более глубокого анализа обнаруженные аномалии были классифицированы по четырем показателям:

1. «Стабильность» - отражает устойчивость аномалии. Вычисляется как количество каналов, на которых данная аномалия видна.

2. «Класс» - морфология объекта, задаваемая, в основном, геометрической формой внешнего контура. В нашем случае аномалии были разбиты на 10 классов.

3. «XY-Cluster» - результат кластерного анализа расположений геометрических центров аномалий, задаваемых географическими координатами широты и долготы. Выделено 23 кластера.

4. «C-Cluster» - результат кластерного анализа совокупности показателей видимости/невидимости каждой аномалии на каждом канале. Было определено 12 кластеров. 
Полученная классификация является важным этапом, предшествующим главной задаче - составлению репрезентативного атласа аномалий. Данный атлас является продуктом содержательного анализа каждой аномалии, определения её причины и исторического контекста. Предполагается, что такой атлас может стать полезным инструментом, позволяющим обеспечить автоматический или полуавтоматический поиск конкретных следов антропогенных процессов на пустых/заброшенных территориях в более широком масштабе.

Однако, даже без репрезентативного атласа, поиск аномалий даёт содержательные и конкретно-исторические результаты. Так, на изучаемом участке были обнаружены признаки проселочной дороги, которая утратила свое значение во второй половине XIX в. На одной из её сторон, видимо, располагались выселки из соседнего села, не обозначенные ни на одном источнике. Можно предположить, что они оказались заброшенными после того, как проселочная дорога была перерезана в результате заболачивания части территории на правом берегу Цны.

Показана принципиальная возможность использования аэрофотоснимков и спутниковых снимков в исторических изысканиях, относящихся к XIX - XX векам. Анализ и сопоставление планов и исторических карт, современных материалов аэрофотосъёмки, полевых исследований и некартографических исторических источников является полезным инструментом понимания социальной истории и её движущих сил.

\section{Список литературы}

1. Жуков Д.С., Лямин С.К., Кунавин К.С. Опыт использования аэрофотосъемки и исторических карт в исторических исследованиях. Литература, методы, кейсы // Инноватика и экспертиза: научные труды. - 2019. - № 3 (28). - С. 44-63. - DOI: 10.35264/1996-2274-2019-3-44-63.

2. Morgan J.L., Gergel S.E., Coops N.C. Aerial Photography: A Rapidly Evolving Tool for Ecological Management // BioScience. - 2010. - Vol. 60. - № 1. - P. 47-59. DOI: $10.1525 /$ bio.2010.60.1.9.

3. Журбин И.В., Борисов А.В., Назмутдинова А.И., Милич В.Н., Петров Р.П., Иванова М.Г., Модин Р.Н., Князева Л.Ф., Воробьева Н.Г., Зинчук С.В. Комплексное использование методов дистанционного зондирования, геофизики и почвоведения при изучении археологических памятников, разрушенных распашкой // Археология, этнография и антропология Евразии. - 2019. - Т. 47. - № 2. - С. 103-111. - DOI: 10.17746/1563-0102.2019.47.2.103-111.

4. Коробов Д.С. Применение ГИС и данных дистанционного зондирования в археологии // Междисциплинарная интеграция в археологии: сборник статей / Ред. Е.Н. Черных, Т.Н. Мишина. - Москва: Институт археологии РАН, 2016. - С. 280-311. 
https://doi.org/10.29003/m1824.978-5-317-06529-4/298-303

Петров Р.П., Журбин И.В., Васина Т.А., Пислегин Н.В., Чураков В.С. Удмуртский федеральный исследовательский иентр УрО РАН, Ижевск

\section{Исторические картографические материалы XVIII-XIX вв. для оценки антропогенного воздействия на территории горноза- водских округов (Пудемский железоделательный завод) ${ }^{1}$}

Аннотация. Исторические картографические материалы XVIII-XIX вв. позволяют оценить структуру и тенденции расселения на территории, прилегающей к Пудемскому железоделательному заводу Глазовского уезда Вятской губернии. Экстенсивных характер использования природных ресурсов и динамику их освоения демонстрируют планы заводских дач. Выполнена трансформация к современной топооснове серии исторических карт и планов дач завода, что обеспечило сопоставимость представительного массива разновременных источников.

Ключевые слова: Пудемский завод, исторические карты, планы дач, природные ресурсы, антропогенное воздействие, трансформация карт, оценка точности привязки.

Petrov R.P., Zhurbin I.V., Vasina T.A., Pislegin N.V., Churakov V.S Udmurt Federal Research Center of the Ural Branch of the RAS, Ixhevsk

Historical cartographic materials of the XVIII-XIX centuries to assess the anthropogenic impact on the territory of mining districts (Pudemsky ironworks)

Abstract. Historical cartographic materials of the XVIII-XIX centuries allow us to assess the structure and trends of settlement in the territory adjacent to the Pudemsky ironworks of the Glazovsky district of the Vyatka province. The extensive nature of the use of natural resources and the dynamics of their development are demonstrated by the ironworks districts plans. The transformation of a series of historical maps and plans of the ironworks districts to a modern topo-base was performed, which provided comparability of a representative array of differenttime sources.

Keywords: Pudemsky ironworks, historical maps, ironworks districts plans, natural resources, anthropogenic impact, transformation maps, accuracy assessment of referencing.

${ }^{1}$ Исследование выполнено при финансовой поддержке РНФ, проект № 1918-00322 «Сравнительно-историческое изучение антропогенных ландшафтов различных регионов средствами беспилотных летательных аппаратов (Тамбовская область и Удмуртия, середина XVIII - начало XX вв.)». 
Исследование регионов, где современные ландшафты сложились под влиянием многовекового хозяйственного воздействия общества, становится заметным явлением в современной науке. Возникновение территорий с антропогенно-преобразованной природной средой может быть следствием формирования горнозаводских округов - особой формы организации металлургической промышленности Урала. Горнозаводской округ является одним из центральных понятий, под которым понимается единый хозяйственно-территориальный (социально-экономический) комплекс со сложной многоотраслевой и многоукладной системой хозяйства мануфактурного типа, в XVIIIXIX вв., как правило, отличавшейся экстенсивным характером освоения природных ресурсов. Горнозаводской округ мог состоять из одного или нескольких предприятий, каждое из которых имело собственную заводскую дачу - обширные земельные угодья с промышленными сооружениями (плотиной и фабриками), рудными месторождениями, лесными массивами, пашнями и лугами, усадьбами рабочих, дорогами, речными пристанями и т.д.

В Удмуртии во второй половине XVIII-XIX вв., в период промышленного освоения края, складывались горнозаводские округа, входившие в территориальную, социально-экономическую и административную систему уральской горнозаводской промышленности. В Сарапульском уезде Вятской губернии функционировали крупные железоделательные (сталеплавильные) государственные заводы Камско-Воткинский (1759 г.) и Ижевский (1760г.). В Глазовском уезде был основан Пудемский железоделательный завод (1759 г.). В Елабужском уезде в 1756-1882 гг. действовал Бемышевский медеплавильный завод. Каждое металлургическое предприятие представляло собой центр обширной территории. Металлургическая отрасль Удмуртии на протяжении XVIII-XIX вв., в период своего становления и развития, активно использовала природные ресурсы: лес топливо (древесный уголь) и строительный материал, недра - источники руды и минералов, водоемы - реки и пруды с плотинами (водные потоки давали энергию и служили транспортными путями). Экстенсивный характер природопользования привел к истощению природных ресурсов (истреблению лесов, выработке рудников) и, в сочетании с архаичными системой управления, социальными отношениями и оборудованием, стал в начале XX в. причиной кризиса уральской горнозаводской промышленности, не исключая и предприятия Вятской губернии. 
Комплекс производственных строений Пудемского завода в конце XVIII в. включал молотовую, кузнечную, меховую фабрики и лесопилку. Предприятию принадлежали 40 рудников; земельные владения к середине XIX в. насчитывали свыше 23 тыс. десятин и охватывали территорию заводского поселка с усадьбами и огородами рабочих, пруд, реки и болота, поля и луга, дороги, леса, лесосеки и курени, места добычи известкового камня. Основными транспортными коммуникациями для Пудемского завода служили Глазовский тракт, проселочные дороги и р. Чепца, по которой сплавлялся груз до Лаишевской пристани на р. Каме; а с начала XX в. в 14 верстах стала действовать станция Яр Пермской железной дороги.

Следовательно, изучение антропогенного воздействия на территории горнозаводского округа включает два взаимно дополняющих направления: оценка структуры и тенденций расселения на территории, прилегающей к структурообразующему предприятию, а также определение специфики использования природных ресурсов и динамики их освоения. Оценка системы расселения базируется на серии исторических карт, отражающих распределение населенных пунктов на различных этапах заселения региона: до начала формирования горнозаводского округа, после возникновения предприятия и на всех стадиях его функционирования. Специфика и направленность использования природных ресурсов может быть прослежена по планам заводских дач, на которых отражены основные природные ресурсы, необходимые для производства: леса (строительный материал и топливо), реки (транспортные пути и источник энергии), недра (рудные месторождения), дороги (коммуникации), а также усадьбы, пашни, луга заводских крестьян. Безусловно, полноценная реконструкция всех аспектов антропогенного воздействия требует привлечения и письменных источников (данных ревизий, исповедные росписи и пр.), но в данной статье рассмотрен лишь один тип источников исторические картографические материалы.

\section{Принципы и методика трансформации картографических материалов}

Необходимым условием корректного использования пространственных данных, нанесенных на исторические карты, является приведение их к современной картографической основе. В качестве основы использована векторная цифровая схема муниципальных образований Удмуртской Республики (универсальная поперечная проекция Меркатора (UTM), 39 зона северного полушария), созданная в 2007 г. по данным кадастрового учета, материалам космической съемки и полевого трассирования основных дорог с помощью 
GPS-аппаратуры (картографические материалы предоставлены 3АО НТП «Ижтехинформ», г. Ижевск).

Трансформация всех видов картографических материалов осуществлялась с использованием аффинных преобразований в геоинформационной системы MapInfo. Очевидно, что исторические картографические материалы содержат искажения. Учитывая, что в архивах карты хранились длительное время (иногда в ненадлежащих условиях), их бумажная основа может быть деформирована. Другой причиной возникновения погрешностей является исходная некорректность геодезической съемки. Размер локальной области исторических карт, связанной с Пудемским заводом и прилегающей территорией, составляет $25 \times 27$ км, что допускает компенсацию искажений. Привязки локальной области исторических карт осуществлялись за счет выявления стабильных во времени и пространстве картографических объектов (крупные населенные пункты, стыки рек и т.п.). По множеству контрольных точек производился перерасчет системы координат исторической карты к координатной системе современной топоосновы и соответствующая трансформация исторической карты. Метод наименьших квадратов позволяет подобрать параметры трансформации, которые минимизируют среднюю ошибку привязки множества контрольных точек и в некоторой степени компенсирует искажения фрагмента карты в целом. После трансформации фрагмента исторической карты вычислялись оценки средней ошибки привязки и среднеквадратическое отклонение контрольных точек, которые определяли точность трансформации исторических карт.

\section{Трансформация исторических карт региона}

На данный момент выявлены две карты, относящиеся к начальному периоду заселения территории, до создания Пудемского железоделательного завода: Ландкарта Казанской губернии Вятской провинции (1731 г.) и Ландкарта Вятской провинции (1741 г.). Трансформация первой из них практически невозможна ввиду высокой степени генерализации. Например, p. Чепца - основная водная артерия региона прорисована практически прямой линией от д. Глазовой до д. Елово. Населенные пункты, расположенные на правобережной части р. Чепцы «смещены» к реке, то есть нарушены геометрические соотношения между объектами. Тем не менее, это самая ранняя из известных карт региона, на которой отражена информация о существующих населенных пунктах и их взаимном расположении. Ландкарта Вятской провинции 1741 г. в большей степени соответствует географической ос- 
нове. Масштаб карты - в одном градусе 104,5 русских версты. В окрестностях Пудема (пока еще не существующего), на этой ландкарте показано большее, по сравнению с ландкартой 1731 г., количество населенных пунктов и рек. Так как обе карты созданы в промежутке между I и II ревизиями, сложно предположить отражает ли этот факт расширение сети населенных пунктов или демонстрирует халатность геодезистов, создавших карту 1731 г. Трансформация карты 1741 г. основана на 10 контрольных точках, средняя ошибка их привязки составляет 384 м, а среднеквадратическое отклонение - 59 м.

Генеральная геометрическая карта Вятской губернии 1805 г. включает карту губернии и зарамочный текст, в котором размещена статистическая информация по 10 уездным городам и 2 городам, не имеющим статуса уездных. Масштаб карты в 1 английском дюйме 16 верст. Трансформация карты основана на 8 контрольных точках, средняя ошибка привязки составляет 341 м, а среднеквадратическое отклонение - 185 м.

План генерального межевания Вятской губернии Глазовского уезда (ориентировочно - 1830-е гг.) составлен в масштабе в 1 английском дюйме 1 верста. Он содержит множество населенных пунктов, в том числе хуторов, однодворок, постоялые дворы, мельницы, починки, дороги, тракты и прочие объекты. Трансформация карты основана на 11 контрольных точках, средняя ошибка привязки составляет 40 м, а среднеквадратическое отклонение - 18 м.

На Специальной карте Вятской губернии 1868 г. показаны границы казенных, удельных и заводских земель, а также земель других ведомств и частных владельцев. Показаны основные дороги. Масштаб карты - в одном английском дюйме 10 верст. Трансформация карты основана на 12 контрольных точках, средняя ошибка их привязки составляет $300 \mathrm{M}$, а среднеквадратическое отклонение - $116 \mathrm{~m}$.

\section{Трансформация планов заводской дачи}

Планы дач являются наиболее детальными картографическими источниками, отображающими границы и качество земельных и лесных угодий, специфику землепользования, расположение географических и промышленных объектов. Планы и чертежи владений Пудемского завода составлены в период проводившегося в Вятской губернии Генерального межевания (1805-1835 гг.).

План дач Пудемского завода 1825 г. составлен в масштабе в 1 английском дюйме 2 версты. Трансформация картографических материалов основана на 11 контрольных точках, средняя ошибка привязки составляет 42 м, а среднеквадратическое отклонение - 13 м. 
План дач Пудемского завода 1832 г. составлен в масштабе в 1 английском дюйме 2 версты. На нем особое внимание уделено участкам вырубок леса в 1828, 1829, 1830, 1831 и 1832 годах. Трансформация картографических материалов основана на 12 контрольных точках, средняя ошибка привязки составляет 48 м, а среднеквадратическое отклонение - 26 м.

Таким образом, трансформация исторических материалов позволяет оценить степень антропогенного влияния, обусловленную возникновением горнозаводского округа Пудемского железоделательного завода, и тенденции его развития. Преобразованные карты обеспечивают достаточную точность для характеристики процессов расселения в регионе и влияние на эти процессы созданного в 1759 году Пудемского завода. Максимальная погрешность в определении расположения населенных пунктов не превышает 400 м. Существенно меньшая погрешность привязки координат контрольных точек (не более 50 м) достигнута при преобразовании планов заводской дачи. Это позволяет с высокой степенью достоверности определить расположение участков локального антропогенного влияния (лесосеки, пашни и сенокосные угодья) и оценить динамику изменения их конфигурации и площади.

https://doi.org/10.29003/m1825.978-5-317-06529-4/303-310

Самойлов Д.В. Вологодский государственный университет

\section{Геоинформационный анализ отхожих промыслов и локальных миграций крестьян Вологодского уезда в пореформенный период ${ }^{1}$}

Аннотация. Статья посвящена отхожим промыслам и локальным миграциям крестьян Вологодского уезда в пореформенный период. Анализ этих процессов демонстрирует, что традиционное объяснение отхожих промыслов, утверждающих, что крестьянин уходит на сторонние заработки из-за кризиса сельского хозяйства, не подтверждаются локальными сведениями. Исследование основано на ГИС, отображающей демографические изменения и миграционную активность каждой деревни Вологодского уезда в 1859-1914 гг.

Ключевые слова: крестьяне, Вологодский уезд, ГИС, отходники, крестьянские миграции.

${ }^{1}$ Исследование проводится при поддержке гранта РФФИ, № 18-00-01687. 
Samoilov D.V. Vologda State University

\title{
Geographic information analysis of seasonal works and local migrations of peasants in the Vologda district during the post-reform period
}

\begin{abstract}
The paper deals with seasonal work and local migrations of Vologda uyezd peasants after the abolition of serfdom in Russia. It has been found that traditional explanation which claims agricultural crisis as main reason of peasants leaving their villages for seasonal work was not confirmed by the information from local documents. The research is based on GIS displaying demographic change and migration activities in every village of Vologda uyezd in 1859-1914.
\end{abstract} tions.

Keywords: peasants, Vologda uyezd, GIS, seasonal workers, peasant migra-

Во второй половине XIX века значительно увеличивается число крестьян, уходящих на заработки из своих деревень, что фиксируется как статистикой выдачи паспортов, так и наблюдениями современников. С 1870-1880 годов отхожие промыслы регулярно освещались в публицистике, а также были включены в форму губернаторских отчетов, которые ежегодно составлялись для извещения столичных властей о состоянии дел в губернии.

Публицист Ленский (Онгирский), рассматривая неземледельческие отхожие промыслы, констатировал: «следует сознаться, что здесь мы имеем пред собой совершенно непобедимое зло» [1, 217]. Эту точку зрения разделяло большинство исследователей, отхожие промыслы рассматривались как индикатор неблагополучия сельского хозяйства. К примеру, исследователь земледельческих отхожих промыслов Чаславский пришёл к выводу: «эти передвижения народа не выгодны никому: ни самим крестьянам, ни частным владельцам, ни наконец государству» [2, 209]. Первые исследования опирались в основном на мнения помещиков, земств и доступную статистику, как правило, на уровне губерний. Качественно новая работа была создана сельским доктором Жбанковым, чьё исследование основывалось на собственных наблюдениях в Солигаличском и Чухломском уездах Костромской губернии. Он одним из первых отмечает, что отхожие промыслы оказывают некоторое положительное влияние на грамотность и образованность крестьян, прививают им городские привычки. Тем не менее, само явление отхожих промыслов он считает ненормальным и вредным [3, 5]. Ему резко оппонировал Ленин, утверждая, что отхожие промыслы представляют 
собой «явление прогрессивное», то есть приближающее крестьян к пролетариату, а Жбанков и прочие «представители народнической экономии» лишь идеализируют сельскую жизнь $[4,569]$.

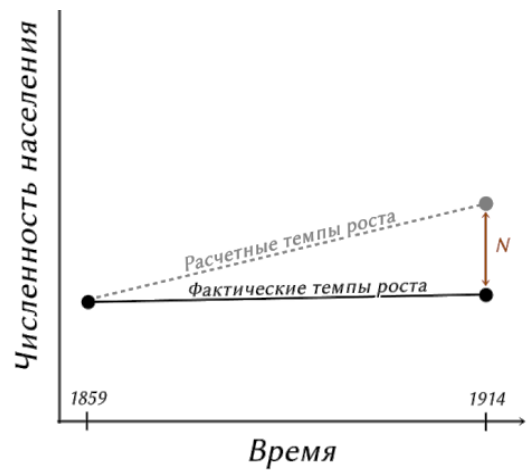

Рис. 1. График расчета прироста населения, относительно темпов по губернии:

$\mathrm{N}$-разница в численности населения

Большинство исследователей сходилось в том, что отхожие промыслы помогают крестьянам мигрировать в города и другие местности, но объяснительные модели появления и развития отхожих промыслов варьировались: малоземелье, низкая урожайность, непредсказуемость земледелия, из-за слабого развития местных промыслов, из-за высокого развития местных промыслов и прочее. Следует отметить, что большинство объяснений появились умозрительно или из личных наблюдений, мнением самих крестьян почти никто не интересовался. Негативистский взгляд на отхожие промыслы, то есть такой, при котором считается, что крестьяне покидают свои деревни не от хорошей жизни, сохранился после появления земской статистики, а также встречается и в современных работах [5, 11]. Удалось найти кейс, где земские статистики по итогам подворной переписи прямо писали, что связи между земледелием и промыслами обнаружить не удалось [6, II], но все равно продолжали поставлять для губернаторских отчетов информацию, где причиной отхожих промыслов указывалось неудовлетворительное состояние земледельческого хозяйства $[7,15]$.

Данные противоречия, по мнению автора настоящей статьи, дали основания полагать, что изучение отхожих промыслов и миграций на локальном уровне может принести интересные результаты. Было 
решено сделать это в рамках одного уезда - территории, где в большинстве случаев статистика собиралась одинаково, что не всегда происходит со статистикой губернского уровня. Был выбран Вологодский уезд, который охвачен земскими исследованиями, располагается на северной границе зоны крепостного права, что даёт возможность сравнивать между собой разные категории крестьян, а также охвачен губернской и городской прессой, полностью оцифрованной.

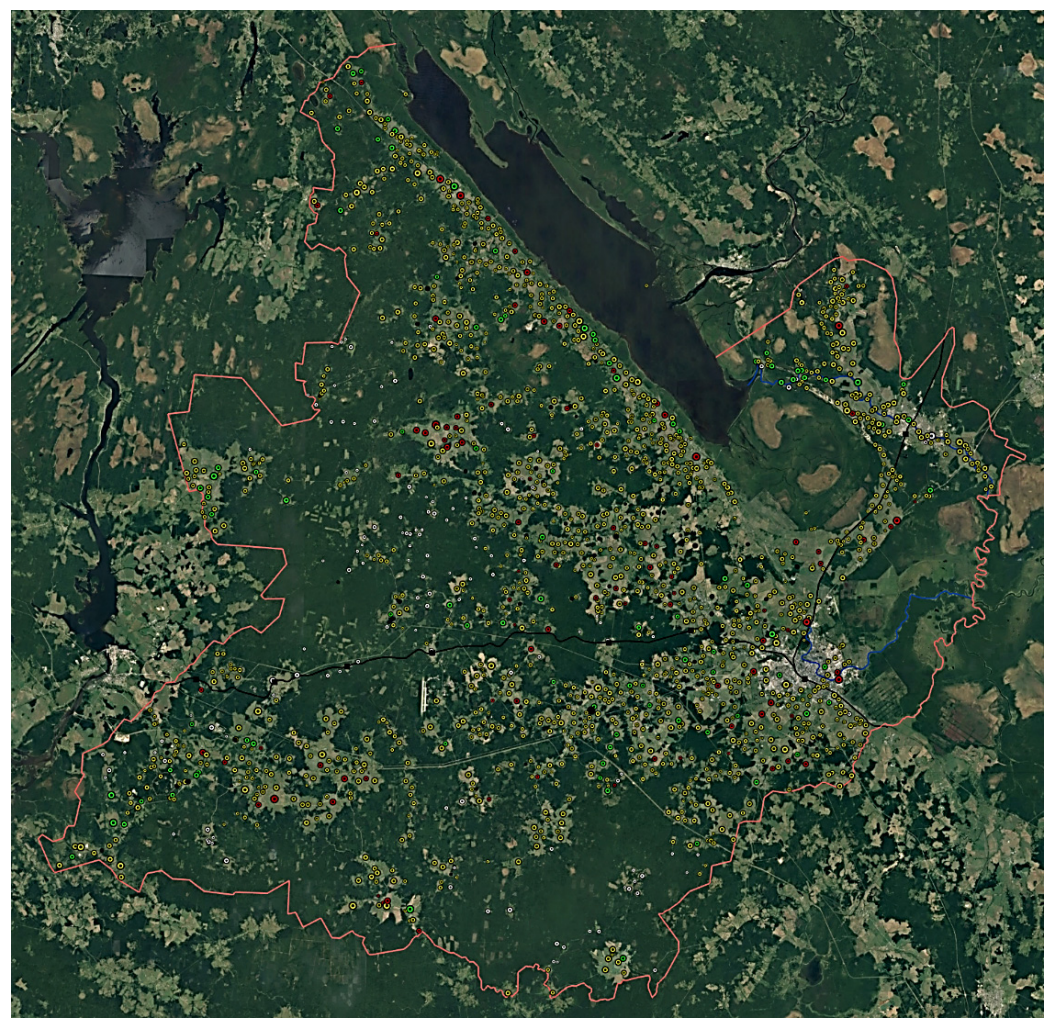

Рис. 2. Демография населенных пунктов Вологодского уезда в 1895-1914 гг.:

Черным обозначены вымершие населенные пункты, красным - с выраженным оттоком населения, белым - новые деревни, зеленым - с выраженным притоком населения, желтым помечены деревни средней демографической динамики, без выраженных признаков. Красной линией показаны границы уезда, черной - железные дороги и станции, а синей - судоходные реки 
В начале работы перед автором встала проблема различения в источниках одноимённых деревень, коих в уезде насчитывался не один десяток. Для этого были расшифрованы и переведены в электронный вид списки населенных мест Вологодского уезда 1859 года [8] и 1914 года [9], а также указатель деревень к материалам подворной переписи 1901 года [6, 832]. Списки населенных мест, как правило, включают в себя минимальную информацию о численности населения с разбивкой по полам, количестве дворов и примерном местоположении. Однако из подобных данных можно извлечь информацию для анализа, если сопоставить их с другим временным слоем. Удалось установить соответствия для 98\% деревень во всех трех списках, а также установить их географические координаты по картам генерального межевания 1789 года и карте Вологодского уезда 1906 года. Прирост населения в период 1859-1914 гг. был неравномерно распределен по населенным пунктам уезда. Взяв за основу информацию о среднегодовом приросте населения в этот период по всей губернии, для каждой деревни была рассчитана степень отклонения от этого показателя, выраженная в разнице численности населения, которую можно было ожидать по средним темпам роста, и фактической численности к 1914 году. Автором было специально уточнено, что последний список населения был составлен в июне 1914 года, то есть демографические сведения ещё не были искажены массовым призывом. Таким образом в рамках уезда удалось установить деревни с наибольшим и наименьшим приростом населения, а также исчезнувшие и новые населенные пункты.

Крайние случаи, то есть деревни с наибольшим приростом и убылью населения, по мнению автора, могут быть объяснены только с помощью миграционных процессов.

К примеру, в деревне Гвоздево Воронцовской волости Вологодского уезда на 1859 год проживало 104 человека, когда к 1914 году там числилось 272 человека. Это затруднительно объяснить только естественным приростом, особенно с учетом того, что данная деревня не отличалась этническим или религиозным составом от уезда в целом, где на 1897 год проживало 99,4\% великороссов и 99,2\% православных.

В общей сложности из 1805 деревень, упомянутых в списке 1859 года, в 603 деревнях темпы роста опережали средние по губернии, а в 978 были ниже. Деревни, в которых разница между прогнозируемыми темпами роста и фактическими превышала 60 человек (с учетом поправки на изначальную численность населения в 1859 году), 
были соответственно отнесены к теряющим и притягивающим население. Эта черта была взята с запасом, чтобы в число этих деревень достоверно попали деревни с выраженным миграционным оттоком/притоком населения.

Кроме этого, были собраны и систематизированы качественные источники по крестьянским промыслам Вологодского уезда.

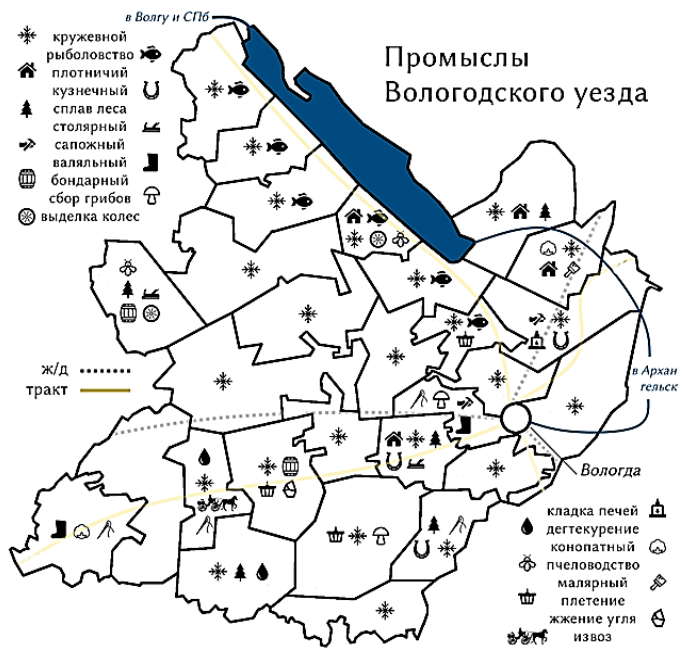

Рис. 3. Промыслы Вологодского уезда

Подобного рода данные обычно описывались на уровне волости, в которых уже складывались определенные промысловые особенности. К примеру, если в газетах упоминались плотники, то обычно писали про плотников из Боровецкой волости, про каменщиков из Семёнковской волости, а единственным промыслом, который встречался повсеместно, можно было назвать только кружевоплетение. Но нужно учитывать, что в источниках такого рода наибольшее внимание уделялось тем промыслам, которые встречаются в городах, поскольку в большинстве случаев авторы письменных свидетельств проживают в городах. Например, в подворной переписи 1901 года наибольшая распространенность отхожих промыслов наблюдается в самой северной волости - Нефёдовской - откуда крестьяне уходили работать в Петербург землекопами. В издании 1903 года сведений об этом нет совсем, видимо, потому что этот поток отходников проходил мимо уездного города, где проживал автор той работы. 
Сопоставление демографической динамики населенных пунктов Вологодского уезда в 1859-1914 годах с данными земской статистики 1901 года позволило сделать несколько наблюдений. В частности, положение деревни внутри уезда на миграционную активность влияет слабо, а именно не влияют: близость к железной дороге (бралось расстояние до ближайшей станции), близость к уездному центру, а также и близость к волостному центру.

Также в материалах подворной переписи для каждой деревни была обозначена одна из семи почвенных групп в порядке убывания благоприятствования сельскому хозяйству. Для первых пяти, от «среднеподзолистого лесовидного суглинка» до «супеси и суглинка» миграционный баланс оказался схожего уровня и нейтральным по значению, а для последних двух групп, «заболоченных почв» и «хрящеватого суглинка и глинистого песка», положительным, что скорее всего объясняется простым совпадением, поскольку деревни этих двух групп представляют собой маленькую выборку. Тем не менее, можно заключить, что положительной связи между оттоком населения из деревни и неблагоприятными почвенными условиями, которые напрямую влияют на урожайность, нет.

Проверить наличие связи между отхожими и местными промыслами оказалось довольно сложно. Дело в том, что в земской статистике не сложилось общепринятого деления между этими двумя разновидностями промыслов, в вологодском земстве было принято считать местными все промыслы внутри уезда, а отхожими - все промыслы за его пределами. В результате крестьянские заработки на одинаковом расстоянии от дома могли классифицироваться разным образом.
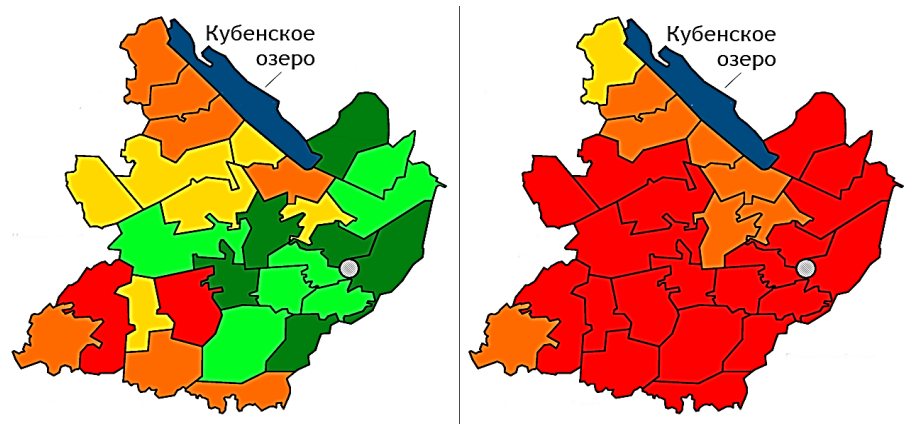

Рис. 4. Слева показаны доли хозяйств по волостям Вологодского уезда с местными промышленниками, справа - с отхожими 
Распространенность отхожих промыслов по посевным группам показала, что хозяйства без посева занимаются отхожими промыслами также мало (4-5\%), как и хозяйства с шестью и более десятинами посева, а основная доля отхожих промышленников приходится на промежуточные группы. Кроме того, выяснилось, что само влияние отхожих промыслов на миграцию, по всей видимости, переоценено, так как места с наибольшим оттоком населения не совпадают с местами с наибольшим распространением отхожих промыслов.

Большинство этих наблюдений не согласуются с традиционным описанием отхожих промыслов и являются очередным свидетельством тому, что с написанными не-крестьянами источниками по крестьянской истории нужно обращаться осторожно, поскольку стереотипы образованных слоев населения о крестьянах могут внести в источник существенные искажения.

\section{Библиография}

1. Ленский Б. Отхожие неземледельческие промыслы в России // Отечественные записки. - СПб. 1877. № 235.

2. Чаславский В.И. Земледельческие отхожие промыслы в связи с переселениями крестьян // Сборник Государственных знаний. - СПб., 1875.

3. Жбанков Д.Н. Бабья сторона. Статистико-этнографический очерк. - Кострома: Губ. типография, 1891.

4. Ленин В.И. Отхожие неземледельческие промыслы // Полное собрание сочинений. 5-е изд. - М.: Издательство политической литературы, 1971. - Т. 3.

5. Лурье Л. Я. Питерщики. Русский капитализм. Первая попытка. - СПб.: БХВПетербург, 2011.

6. Материалы для оценки земель Вологодской губернии. Т. 2. Вологодский уезд, вып. 1. Таблицы. Крестьянское хозяйство / Оценочно-стат. отделение Вологод. губ. зем. упр. Вологодский уезд. - Вологда: Тип. Н. Знаменского и П. Цветова, 1907.

7. Обзор Вологодской губернии за 1913. - Вологда: Тип. губ. правл., 1914.

8. Список населенных мест Вологодского уезда за 1914 год. Государственный архив Вологодской области. Ф. 17. Оп. 2. Д. 126.

9. Списки населенных мест Российской империи, составленные и издаваемые Центральным статистическим комитетом Министерства внутренних дел. - СПб.: изд. Центр. стат. ком. Мин. внутр. дел, 1861-1885. Вып. 7: Вологодская губерния: по сведениям 1859 года / сост. и изд. Центр. стат. ком. М-ва внутр. дел.; обраб. Е. Огородниковым, 1866.

10. Внеземледельческие промыслы Вологодской губернии / Под ред. Я.Н. Масленикова; Изд. Вологод. Губ. Земства. - Вологда: Типо-литогр. Шахова и Клыкова, 1903. 
https://doi.org/10.29003/m1826.978-5-317-06529-4/311-316

Санжаров В.А. Донеиккий национальный университет

Комплексная цифровая модель параллельных франко-бургундских итинерариев

(Людовика XI, Филиппа Доброго и Карла Смелого) как инструмент изучения управленческих институтов, военно-политической и дипломатической активности

Аннотация. Статья посвящена ГИС-картографии королевского и герцогских итинерариев Людовика XI, Филиппа Доброго и Карла Смелого (1461-1477). Итинерарий не просто календарный перечень посещенных мест, а источник характеризующий реализацию управленческих стратегий «манеру править». Итинерарий позволяет пошагово удовлетворить интерес к проблемам власти, механизмам ее осуществления, определения пространств реальной власти. Статья предлагает подходы к созданию комплексной цифровой модели параллельных франко-бургундских итинерариев.

Ключевые слова: итинерарий, ГИС картографирование, Людовик XI, Филипп Добрый, Карл Смелый, ордонансы.

Sanzharov V.A. Donetsk National University

\title{
A complex digital model of parallel Franco-Burgundian itinerarii (Louis XI, Philip the Good and Karl the Bold) \\ as a tool for studying administrative institutions, military-political and diplomatic activity
}

\begin{abstract}
The article is devoted to the GIS cartography of the royal and ducal itineraries of Lous XI, Philip the Good and Charles the Bold (1461-1477). The intinerary is not the simple calendar list of visited places but the source characterizing the implementation of the government strategies - 'the style of governing'. The itinerary allows to satisfy step by step the interest in problems of power, the mechanisms of its implementation, the definition of spaces of real power. The article proposes approaches to creating a complex digital model of parallel Franco-Burgundian itineraries.

Keywords: itinerary, GIS cartography, Lous XI, Philip the Good, Charles the Bold, ordonnances.

Событийная и институциональная история периода оформления этно-национального государства во Франции изучены достаточно полно $[1 ; 2 ; 3]$. Франко-бургундское противостояние представителей королевской и герцогской ветвей рода Валуа в XV в., череда гражданских войн и перемирий, иностранных интервенций сопровожда-
\end{abstract}


ют процесс формирования État moderne. Завершающая фаза противостояния приходится на правление Людовика XI, Филиппа Доброго и Карла Смелого [4]. Для короля, согласно его итинерарию, вторым по частоте посещений и времени пребывания регионом является территория от Арраса до Компьеня: это связано с военными кампаниями против его основного противника внутри королевства - герцога Бургундии.

Исследовательский интерес последних десятилетий к проблеме королевского и сеньориальных дворов стимулировал новые подходы к изучению властных итинерариев [5, с. 57-58; 6; 7]. Это прежде всего проблемы механизмов личного влияния на ключевые процессы управления страной вне прежней поведенческой парадигмы (личном неучастии в военных сражениях, в заседаниях парламента и штатов, ассамблеях отдельных сословий); выбор «точек контроля» за ситуацией, характер оперативного вмешательства монарха и коррективы собственных решений; организации работы и значимость отдельных служб двора, влияние «движущегося двора» на весомость тех или иных придворных должностей и лиц из королевского окружения; места расположения и передвижения ордонансных рот, их участие/неучастие в обеспечении безопасности королевских поездок по стране и т.д. Непосредственное физическое присутствие суверена является релевантным и определяющим в реализации управления.

Документальные источники позволили составить полные итинерарии герцогов Бургундии дома Валуа [8; 9]. Это, в свою очередь, обусловило появление работ, которые пытаются дать математическое описание данных [10, с. 102-103]. С итинерарием французского короля $[11 ; 12$, с. 143 , табл. 1 , с. 144 , табл. 3] дела обстоят несколько сложнее. Из 8074 дней правления Людовика XI (1461-1483) места пребывания монарха и маршруты перемещений королевского двора известны для 2/3 времени. Французские исследователи пока ограничились попыткой картографирования и анализа итинерария, опубликованного в 1909 г. Бернаром Мандро, на базе карт Кассини и Луи Капитана XVIII в. [13]. Но, во-первых, традиционная исследовательская база (5 томов ордонансов, перечень ордонансов, зарегистрированных парламентом Парижа, 10 томов писем, 3 тома актов по Дофине) $[14$, с. $391-468 ; 15$, с. 48-88; 16; 17] может быть существенно расширена за счет привлечения новых документов, опубликованных в «Исторических архивах» по отдельным провинциям [18; 19; 20], либо изданий отдельных документов из архивных коллекций, в том числе отечественных [21; 22]. Во-вторых, современные возможности исторической цифровой картографии позволяют внести ряд уточне- 
ний в моделирование маршрутов и сделать на их основе важные наблюдения.

Одной из важнейших задач в области изучения средневековых итинерариев является преодоление «картографической пустыни». Источники официального происхождения наряду с нарративными один из основных носителей пространственной информации: они содержат массу эмпирических данных по локализации конкретных географических объектов, административно-политических областей, пространственной активности отдельных групп населения, интегрированности конкретных регионов в историческом пространстве. Информативность подобного рода приобретает особую ценность применительно ко времени, предшествующему появлению полноценных картографических источников. Подготовка и изучение королевского итинерария требует междисциплинарного подхода и тщательной проработки картографической основы, которая должна включать в себя объекты рельефа и гидрографии, населенные пункты, границы феодальных владений. К сопутствующим вопросам картографирования итинерариев относятся типология населенных пунктов, пути сообщений, условия снабжения.

Для актуализации отдельных географических объектов привлекалась карта почтовых станций Франции 1690 г. Несмотря на значительную хронологическую удаленность от изучаемого периода и ожидаемые проблемы с математической основой, указанная карта позволяет уточнить морфологию и относительное местоположение многих картографируемых объектов. Например, было установлено, что наиболее часто используемые маршруты Людовика XI в промежутке между Пуатье и Парижем соответствуют одной из основных почтовых дорог.

Фактографическую основу составляют два массива данных - индексированный перечень локаций и связанная с ним таблица местопребываний короля. Последняя содержит в себе обобщенные сведения из королевских грамот, включая начальные и конечные даты вхождения в локацию, индекс объекта, общую длительность пребывания. К настоящему моменту учтено 493 локализации (как однодневных, так и продолжительных) королевского итинерария за первые десять лет правления Людовика ХІ. В цифровой модели картографической основы учтено 426 населенных пунктов различных типов (города, шато, монастыри, отдельные поместья) и 292 объекта феодальных владений. Накопленный массив картографируемых объектов достаточен для построения всех доступных по источникам маршрутов за 
указанный период. После индексирования и локализации точек местопребывания было осуществлено построение отдельных скетчей маршрутов, которые затем сводились в единые маршруты месячной и годичной протяженностей.

При построении маршрутных линий основную проблему составляли лакуны в датах локализаций, когда между отдельными опорными точками имелся значительный хронологический интервал. Решение состояло в построении буферных зон с центром в опорных локациях; радиус буферной зоны определялся в виде произведения расстояния полуперехода (около 13 километров) на количество пропущенных дней; по следующей точке маршрута проводились те же действия, после чего становилась возможной примерная интерполяция для недостающих дат. Сложнее складывается ситуация в тех эпизодах, где король проявлял особую активность и мог менять локации, например, побывав за одни сутки в Божанси и Орлеане.

Очевидна важность масштабирования не только пространства, но и времени: пространственная активность Людовика XI в течение диапазона нескольких лет, за один год, месяц или несколько дней дают материал для разноуровневых выводов и наблюдений. Ареал годичных перемещений короля обычно соответствует региону основных сюжетов политических событий, в то время как более дробная хронологическая атрибуция позволяет вскрыть пространственную конъюнктуру конкретных территорий, решить вопросы логистики и стиля управления государством. Людовик XI продолжает придерживаться традиции «путешествующих» королей, предпочитая личное пребывание на месте событий осуществлению своей воли через исполнителей. Отсюда можно говорить об отсутствии столицы и постоянных резиденций как центра управленческих функций. Вместе с тем, выявлены вполне выраженные пространственные области предпочитаемых перемещений короля в периоды между пиками политической и военной активности. При этом указанные области представлены не одной конкретной локацией, а кластером нескольких близко расположенных населенных пунктов. К таковым можно отнести группы Тур, Монтиль-ле-Тур, Плесси, Анжер; Амбуаз, Монришар, Тур; Орлеан, Божанси, Сюлли и некоторые другие. Территориальное ядро географической мобильности короля составляет треугольник Орлеан, Сомюр, Бурж, основное направление перемещений соответствует течению Луары с выходом на северовосточное направление - Париж и течение Уазы.

Важный источниковедческий аспект построения цифровой модели итинерариев состоит в том, что она позволяет проводить вери- 
фикацию используемых данных и вносить уточнения в сведения нарративных источников. Так, построение сплошных маршрутов дает возможность выявить те грамоты, которые были подписаны без участия короля (если локализация грамоты не соответствует его местопребыванию по созданной модели).

Содержательная сторона представленных материалов позволяет детальнее изучить историческое пространство французской монархии XV века: основные векторы дипломатической, военно-политической, административной, церемониальной активности Людовика XI. Маршруты дипломатических вояжей французского короля для личных встреч с Великим герцогом Запада (1465, 1468 гг.), кастильским, арагонским (1462, 1463 гг.), английским (1475 г.) монархами есть возможность сопоставить с перемещениями других участников переговоров.

\section{Библиография}

1. Favier J. Louis XI. - Paris: Tallandier, 2012. - 1019 p.

2. Этносы и «нации» в Западной Европе в Средние века и раннее Новое время / под ред. Н.А. Хачатурян. - СПб: Алетейя, 2015. - 344 с.

3. Цатурова С.К. Формирование института государственной службы во Франции XIII-XV веков. - М.: Наука, 2012. - 622 с.

4. Brusten C. Les itinéraires de l'armée bourguignonne de 1465 à 1478 // Publication du Centre Européen d'Études Burgondo-médianes. - Bâle: Centre européen d'études bourguignonnes (XIVe-XVIe s.). - 1960. - Vol. 2. - P. 55-67.

5. Санжаров В.А. Прелаты Дофине перед лицом «императорской» политики Людовика II // Вестник Донецкого национального университета. Серия Б: Гуманитарные науки. - 2017. - № 4. - С. 56-63.

6. Гришин Е.С. Пространственный анализ нарративных источников. Некоторые методические замечания // Testis Temporum. Международный открытый электронный журнал о проблемах истории и гуманитарных наук в цифровую эпоху. - URL: http://www.rfbr.ru/pics/22394ref/file.pdf (дата обращения: 29.08.2020).

7. Гришин Е.С. Пространственная мобильность Генриха IV в 1063-1073 гг. как фактографическая основа для анализа распространения информации в средневековой Германии // Историческая информатика. - 2018. - № 3. - С. 106-122.

8. Vander Linden H. Itinéraires de Philippe le Bon, duc de Bourgogne, 1419-1467, et de Charles, comte de Charolais, 1433-1467. - Brussels: Palais des Académies, 1940. - 533 p.

9. Vander Linden H. Itinéraires de Charles, duc de Bourgogne, Marguerite d'York et Marie de Bourgogne, 1467-1477. - Brussels: Maurice Lamertin, 1936. - 88 p.

10. Ewert C. Itinerar und Herrschaft im Spätmittelalter: ein wirtschaftstheoretischer Ansatz und empirische Ergebnisse für die burgundischen Herzöge im 15. Jahrhundert (1419-1477) // Historical Social Research. - 1996. - Vol. 21. - Issue 4. - P. 89-114.

11. Itinéraire de Louis XI roi de France // Lettres de Louis XI, roi de France / éd. J. Vaesen, B. de Mandrot. - Paris : Société de l'histoire de France, 1909. - T. XI. - P. 3-236.

12. Санжаров В.А., Смагин М.Р., Леонова Е.Б. Возможности статистической обработки формализованных данных на материале итинерария Людовика XI (1461-1483) // Мир Евразии: от древности к современности: сборник материалов Всероссийской научно-практической конференции. - Уфа: РИЦ БашГУ, 2020. - Т. 1. - С. 141-146. 
13. Costa L., Bove B., Kolk C. zum Construire et utiliser un SIG pour l'analyse des données sur les itinéraires logiciel Qgis // le 20 Juin 2017, Maison Max Weber, Université de Paris Nanterre. - URL: https://abp.hypotheses.org/files/2017/05/2017_Exo_BP-20-062017_V1.pdf (дата обращения: 28.08.2020)

14. Pardessus J.M. Table chronologique des ordonnances des rois de France de la troisième race jusqu'au règne de Louis XII inclusivement. - Paris: Imprimerie royale, 1847. VIII, $607 \mathrm{p}$.

15. Stein H. Inventaire analytique des ordonnances enregistrees au Parlament de Paris jusqu'a la mort de Louis XII. - Paris : Impremerie nationale, 1908. - XII, 132 p.

16. Lettres de Louis XI, roi de France, publiées d'après les originaux pour la Société de l'histoire de France / éd. J. Vaesen, É. Charavay. - Paris : H. Laurens, 1883-1908. - 10 vols.

17. Pilot de Thorey E. Catalogue des actes du dauphin Louis II, devenu le roi de France Louis XI, relatifs à l'administration du Dauphiné. - Grenoble: V. Truc, 1899. 2 vol. - XXVII, 536, 472 p.

18. Archives historiques du Département de la Gironde. - Bordeaux, 1859-1936. 59 vols.

19. Archives historiques du Poitou. - Poitiers, 1872-2005. - 64 vols.

20. Archives historiques de la Saintonge et de l'Aunis. - Saintes, 1874-2019. - 69 vols.

21. Nosova E. Chartes et lettres inédites de Louis XI (1461-1483) aux Archives de l'Institut d'histoire de Saint-Pétersbourg // Annuaire-Bulletin de la Société de l'Histoire de France. - 2014. - P. 41-68.

22. Nosova E. L'expertise de la signature du roi Louis XI à l'aide des méthodes judiciaires // Le Moyen Age. - 2020/1. - T. CXXVI. - P. 45-57.

https://doi.org/10.29003/m1827.978-5-317-06529-4/316-323

Степанова Ю.В., Фролов А.А. ИВИ РАН

Гаврилов П.В. Тверской государственный университет

\section{Землевладение в Тверской половине Бежецкой пятины в конце XV - первой половине XVI в.: представление в ГИС ${ }^{1}$}

Аннотация. В статье рассматриваются результаты локализации землевладения на территории погостов Тверской половины Бежецкой пятины конца XV - первой половины XVI в. Указание в писцовой книге 1545 г. на землевладельцев последней трети XV и первой трети XVI в. позволило рассмотреть характер землевладения в домосковский период и проследить разделение крупных волостей новгородского боярства между служилыми землевладельцами первой половины XVI в. после вхождения Новгородского государства в состав Московского великого княжества. Уточнено местоположение погостов и волостей, проанализировано размещение поселений.

Ключевые слова: ГИС, историческая география, землевладение, пятина, погост, волость, Новгородская земля.

${ }^{1}$ Исследование проведено при поддержке гранта РФФИ, проект № 20-09-00278. 
Stepanova Y.V., Frolov A.A. Institute of general historyof $R A S$

Gavrilov P.V. Tver State University

\section{The land tenure in the Tver half of the Bezhetskaya pyatina at the end of the 15th - the first half of the 16th century: presentation in GIS}

Annotation. The paper considers the results of the localization of land ownership of the parishes of the Tver half of the Bezhetskaya pyatina at the end of the 15 th - the first half of the 16th century. The indication in the scribe book of 1545 of the landowners of the last third of the 15th and first third of the 16th century allowed to consider the land ownership before 1478 and trace the division of large volosts of Novgorod boyars between service landowners of the first half of the 16 th century. The location of parishes and volosts was clarified, the settlement was analyzed.

Keywords: GIS, historical geography, land tenure, pyatina, parish, volost, Novgorod land.

Целью настоящего исследования является выявление особенностей землевладения в Тверской половине Бежецкой пятины Новгородской земли в исторической динамике, от последний десятилетий самостоятельности Новгородского государства до ее вхождения в состав Московского великого княжества.

Бежецкая пятина занимала восточную и юго-восточную часть Новгородской земли и граничила на юге с Новоторжским и Тверским уездами, на востоке - с Бежецким Верхом, на севере с Обонежской пятиной, и на западе - с Деревской пятиной. Историко-географические особенности этой территории рассматривались в работах К.А. Неволина [1], В.Л. Янина [2], Г.В. Абрамовича [3, 4], А.А. Фролова [5]. Впервые локализация погостских центров Бежецкой пятины была произведена К.А. Неволиным. Храмы Тверской половины Бежецкой пятины были локализованы А.А. Фроловым по данным приходной книги новгородского архиепископа 1576/77 г. [6]. Размещение территорий погостов и землевладений до недавнего времени оставалось слабо изученным.

Основным источником исследования является писцовая книга 1545 г. письма И.Д. Вельяминова и А.Г. Соловцова [7]. Это наиболее полное из ранних описаний, составленное в середине 1540-х гг. по результатам полевого описания конца 1530-х гг., но книга содержит данные только о поместных землях. 
Локализация средневековых топонимов, производившаяся с применением ГИС-технологий, позволила уточнить расположение границ Тверской половины Бежецкой пятины, центров и территорий 47 погостов и отдельных волостей в составе погостов. Получены предварительные результаты картографирования территории погостов [8]. В общей сложности в писцовой книге 1545 г. насчитывается 4 села, 35 селец, 3223 деревни, 1542 починка, 5 рядков, в общей сложности 4809 пунктов. Погосты локализованы с разной полнотой, что объясняется сохранностью топонимики в источниках XVIII$\mathrm{XX}$ вв., а также утратами в писцовой книге.

Наиболее полно локализованы территории западных погостов, а также северная часть Богородицкого Павского и Покровского в Слезкине погостов, в среднем от 60 до 90\%. Меньше процент локализации топонимов восточной части рассматриваемой Тверской половины, в среднем от 45 до 60\%. Слабее всего локализованы пункты компактно расположенных Покровского Полянского, Петровского Тихвинского, Михайловского Трестенского, Богородицкого в Замутье, Богородицкого Плавского, Никольского в Забрусье, Спасского в Клину погостов (до 45\% топонимов). Выделяются также отдельные наиболее полно локализованные по количеству топонимов волости, например, волость Матвеевская в Егорьевском Чудинском погосте, Мушино и Еваново в Богородицком и Никольском в Поддубье Удомельских погостах, Боярщина в Никольском Удомельском погосте, Малинец, Коства и Лощемля в Михайловском Костовском погосте, Леганец, Перхово, Поляна в Никольском Молдинском погосте.

Структура писцовой книги 1545 г. позволяет выделить три группы землевладельцев Тверской половины Бежецкой пятины:

- представители новгородского боярства и духовенства, последние владельцы земли накануне или вскоре после вхождения Новгорода в состав Московского государства (им соответствуют территории волостей) - в общей сложности 124 землевладения;

- представители служилого класса, получившие землю после 1478 г. - в начале XVI в. после конфискаций земли у новгородских владельцев великим князем московским, всего 324 землевладения;

- владельцы поместий на момент описания начала 1540-х гг.; как правило, это потомки помещиков из предыдущей группы, всего 489 землевладений.

В общей сложности писцовая книга 1545 г. зафиксировала 124 землевладения домосковского периода. Среди землевладельцев первой группы (новгородцев) - представители крупного боярства: Еси- 
повы, Овиновы, Лошинские, Грузовы, Посохновы, Юрьевы, Доможировы, Скомантовы и др.; новгородские монастыри (Аркажский и Спасский Хутынский) и архиепископ новгородский.

Среди землевладельцев второй и третьей групп - князья и дети боярские, служившие московскому великому князю: Мещерские, Пужбольские, Кавские, Черкасские, Загряжские, Кутузовы, Кандауровы, Юреневы, Забелины, Родичевы и др. Среди них - перешедшие на службу в Москву представители аристократии из соседних Тверского княжества и Бежецкого Верха: Дорогобужские, Холмские, Оплечуевы, Волынцовы, Курцовы и др.

Учет в ГИС имеющихся в книге 1545 г. данных о землевладельцах позволил локализовать территории землевладений как новгородского боярства конца XV в., так и служилых землевладельцев Московского государства первой половины XVI в. В настоящее время определяется местонахождение около 90\% новгородских волостей и $80 \%$ поместий. Для визуализации землевладений в ГИС точки локализованных селений были преобразованы в полигоны Вороного, объединенные по признаку принадлежности к тому или иному землевладельцу. Полученная картина дает общее представление о размещении землевладений домосковского периода (рис. 1).

Около 60\% приходится на крупные землевладения Есиповых, Овиновых, Грузовых, Лошинских, Кузьминых, Тучиных, Юрьевых, Посохновых. К крупнейшим компактным землевладениям новгородского боярства можно отнести обширную территорию Ивана Лошинского на севере Тверской половины в погостах в Слезкине и Ивана Кузьмина в Осеченском Воскресенском погосте. Меньшие по размерам компактные территории - Федора Юрьева в Никольском Удомельском погосте, Луки и Якова Федоровых в Михайловском Костовском, Никифора Хмелева в Егорьевском Млевском погосте. Компактную волость обр азовывали земли Спасского Хутынского монастыря в Забрусье (Никольский Толмачевский погост).

Прочие же владения новгородского боярства располагались отдельными анклавами. Так, Андрею Посохнову принадлежали земли в Покровском в Сорогошине и Михайловском Костовском погостах, Ивану Ящинскому - в Никольском Быстром и Никольском Молдинском, Василию Кузьмину - в Покровском Полянском, Никольском Молдинском, Егорьевском Удомельском в Илове погостах. Земли Матрены Есиповой располагались двумя анклавами в Никольском погосте на Вышнем Волочке; Офросиньи Лаврентьевой - в Васильевском Кострицком и Богородицком в Замутье погостах. 


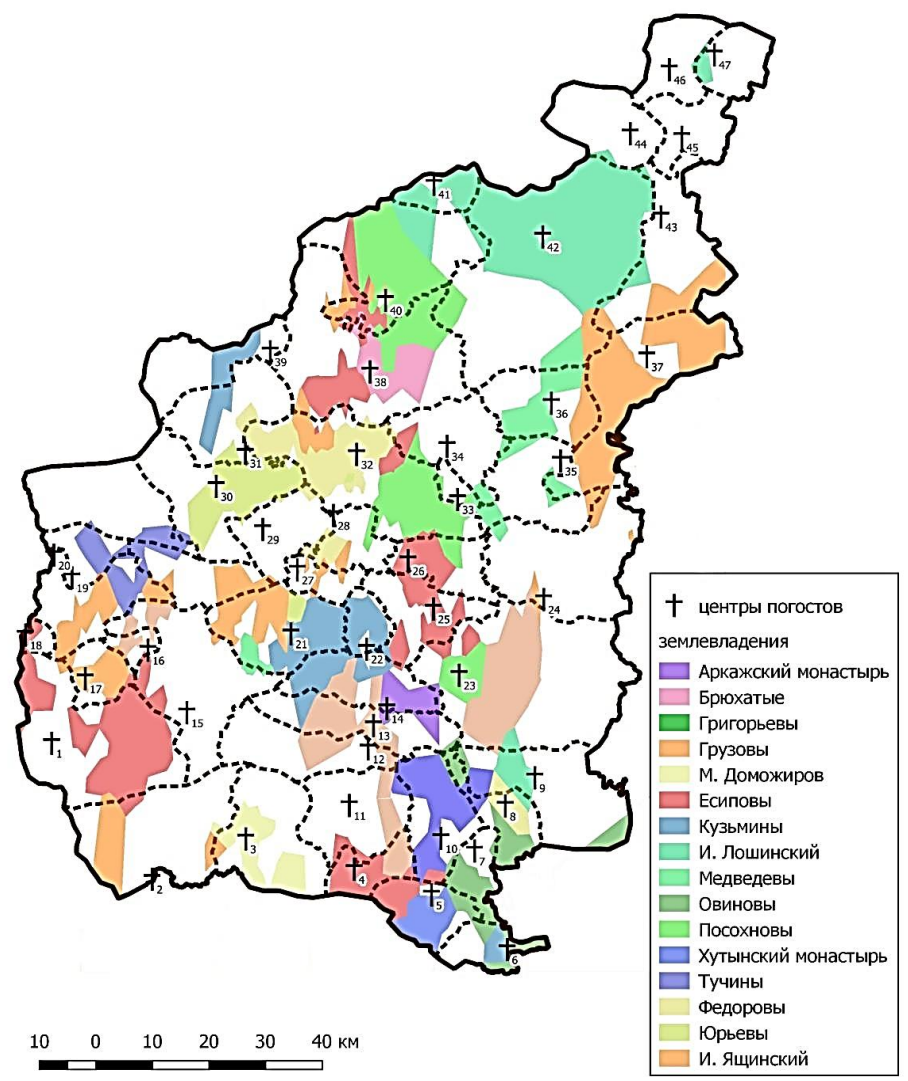

Рис. 1. Землевладения новгородского боярства и монастырей в Тверской половине Бежецкой пятины до присоединения Новгорода к Московскому государству по данным писцовой книги 1545 г.

Картину новгородского землевладения в Тверской половине Бежецкой пятины дополняют сведения почти не сохранившейся писцовой книги 1499 г., в которой имеется описание земель новгородского архиепископа в Удомельских погостах [9]. В общей сложности в нем насчитывается 554 населенных пункта (локализовано 344), расположенных компактно в Никольском, Егорьевском, Спасском, Ильинском, Никольском в Дуброве Удомельских погостах (рис. 2). 


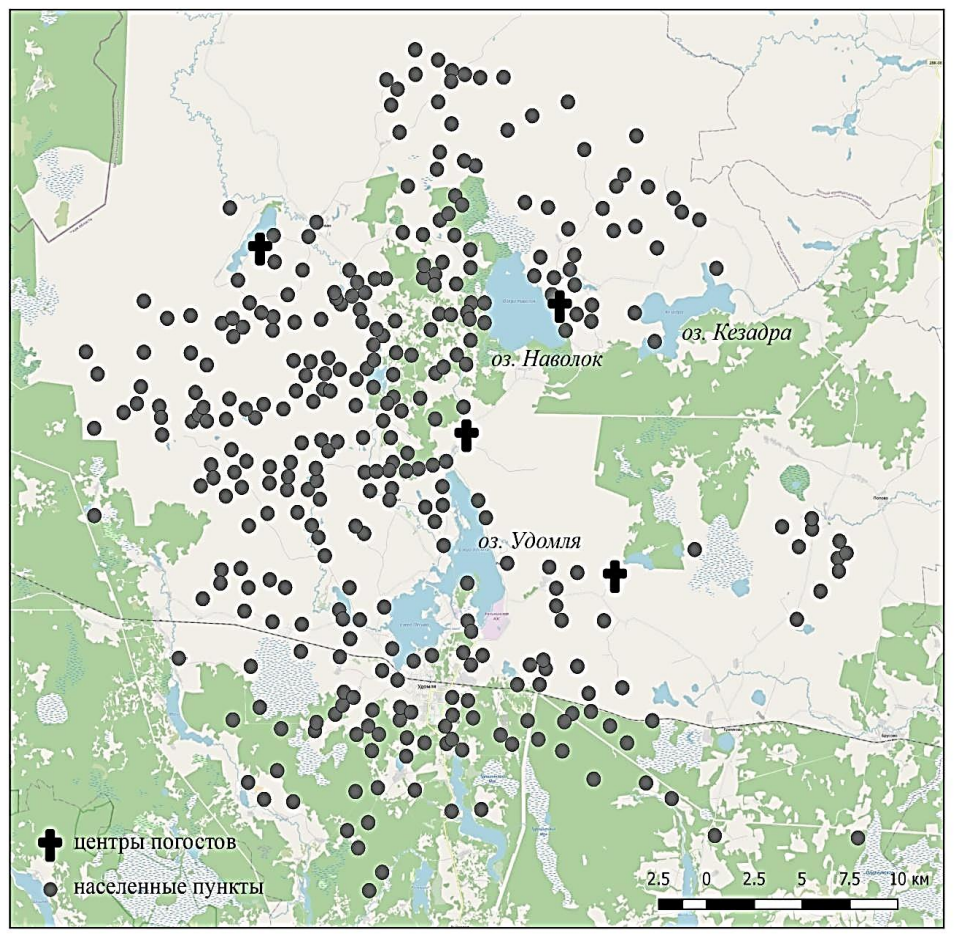

Pис. 2. Владения новгородского архиепископа в Удомельских погостах

Тверской половины Бежецкой пятины по данным писания 1499 г.

После вхождения Новгорода в состав Московского государства боярские волости и волостки были разделены между служилыми землевладельцами Московского государства первой половины XVI в. ГИС позволяет проследить динамику изменений в землевладении от конца XV в. до середины 1540-х гг. Так, волость Боярщина в Никольском Удомельском погосте, принадлежавшая Федору Юрьеву, была разделена между служилыми людьми Юреневыми, Посоховыми, Колачевыми. Земли волости Лощемля в Михайловском Костовском погосте Андрея Посохнова перешли князю Даниилу Дмитриевичу Холмскому, а затем его детям, а также Семенским и Черкасским. Волостью Малинец Никиты Грузова в 1540-х гг. владеют Лаговчины и Лыковы. Волость Коства Луки и Федора Юрьевых была разделена между помещиками Оникеевыми, Юреневыми, Гло- 
товыми; волость Леганец Ивана Ящинского - между Загряжскими, Лутовиниными, Лодыгиными, Ватутиными, Корсаковыми; волость Поляна Федора Юрьева - между Курцовыми, Паисовыми, Коротневыми. Практически везде наблюдается сильное дробление крупных волостей на относительно мелкие поместья.

В ряде случаев можно проследить процесс перехода владений и их дробления. Например, волость Перхово Михаила Медведева в Никольском Молдинском погосте, в соответствии с текстом книги 1545 г., была отдана в поместье Владимиру Паисову, а в дальнейшем разделена между его сыновьями. Волостка Микшино в Никольском в Дорке погосте, принадлежавшая Захарию Овинову, перешла к князю Осипу Дорогобужскому, а после его смерти в 1530 г. перешла Б.Ф. Волынцову, а затем к представителям служилого рода Кандауровых.

В целом, приведенные количественные показатели и наблюдения над динамикой землевладения свидетельствуют о дроблении землевладений и уменьшении их размеров от последней четверти $\mathrm{XV}$ до 1540-х гг. Наиболее резкий рост числа поместных владений, произошел, по-видимому в $1530-\mathrm{x}$ - начале 1540 -х гг., что согласуется с выводами М.М. Бенцианова [10].

Полученные результаты позволят в дальнейшем более детально изучить сельское расселение и динамику землевладения на территории Тверской половины Бежецкой пятины в конце XV-XVI в.

\section{Литература}

1. Неволин К.А. О пятинах и погостах новгородских в XVI веке, с приложением карты / Записки Императорского русского географического общества. Кн. VIII. СПб.: Тип. Имп. Акад. наук, 1853. - 415 с.

2. Янин В.Л. Новгородская феодальная вотчина. - М.: Наука, 1981. - 296 с.

3. Абрамович Г.В. Бежецкая пятина // Аграрная история Северо-Запада России. - Л.: Наука, Ленингр. отд-ние, 1971. - С. 227-250.

4. Абрамович Г.В. Бежецкая пятина // Аграрная история Северо-Запада России XVI века. - Л.: Наука, Ленингр. отд-ние, 1974. - С. 184-240.

5. Фролов А.А. Административная система центральных районов Новгородской земли в X - начале XVII века в контексте истории территориальных юрисдикций // Историческая география. - М., 2012. - Том 1. - С. 110-154.

6. Приходная книга новгородского Дома Святой Софии 1576/77 г. («Книга записи софийской пошлины») / сост. И.Ю. Анкудинов, А.А. Фролов. - М.; СПБ.: АльянсApxeo, 2011. - 280 c.

7. Писцовая книга 1545 г. // Новгородские писцовые книги, изданные Императорской археографической комиссией. - СПб.: Тип. Безобразова, 1910. - Т. 6: Книги Бежецкой пятины. - Стб. 35-564.

8. Степанова Ю.В., Гаврилов П.В. Локализация погостов Тверской половины Бежецкой пятины по данным писцовой книги 1545 г. // Новгородский архивный вестник. - 2019. - Вып. 15. - С. 79-85. 
9. Писцовые книги Новгородской земли. Т. 1: Новгородские писцовые книги 1490-х гг. и отписные и оброчные книги пригородных пожен Новгородского дворца 1530-х гг. / Сост. К. В. Баранов. - М.: Древлехранилище, 1999. - С. 145-238.

10. Бенцианов М.М. Дети боярские «наугородские помещики». Новгородская служилая корпорация в конце XV - середине XVI в. // Проблемы истории России. Екатеринбург: Банк культурной информации, 2000. - Вып. 3: Новгородская Русь: историческое пространство и культурное наследие. - С. 241-277.

https://doi.org/10.29003/m1828.978-5-317-06529-4/323-329

Уманский Л.А. Большая Российская энциклопедия, Москва

Грииин Е.C.

Российская академия народного хозяйства и государственной службы при президенте Российской Федерации, Москва

\section{Историческая морфология преступности в российской империи XIX в.}

\section{как компонент комплексных и тематических карт}

Аннотация. На примере данных уголовной статистики в статье описывается апробация методики изучения социально-экономического развития поздней Российской империи с применением единой пространственновременной цифровой картографической модели.

Ключевые слова: история преступности, Российская империя, цифровая картография, ГИС.

\section{Oumansky L. \\ Great Russian Encyclopedia, Moscow}

Grishin E.S.

The Russian Presidential Academy of National Economy and Public Administration, Moscow

\section{Historical Morphology of Crime in the Late Russian Empire as a Component of Complex and Thematic Maps}

\footnotetext{
Abstract. On the crime studies data set example the article describes an approbation of the new method for researching the social and economic development of the late Russian Empire. This method is based on the usage of the unified by the land- and timescape digital GIS model.

Keywords: crime studies, Russian Empire, digital cartography, Geographic Inform93ation Systems (GIS).
} 
Обращение к наборам геоданных, которые охватывают значительные территории, предполагает использование качественной картографической цифровой модели, которая служит основой для их обработки. Создание цифровой картографической основы по азиатской части Российской империи позволило совместить её с аналогичным ресурсом по европейской части в единую цифровую модель, которая предназначается для тематических историко-картографических исследований. В качестве апробации возможностей использования подобного ресурса были выбраны некоторые исследовательские вопросы географии российской преступности. Известно, что самый наглядный материал для изучения любых социально-экономических процессов это периоды затрагивающих их кризисов. История же преступности есть в некотором роде история одного непрерывного кризиса.

$\mathrm{B}$ настоящей работе уголовная статистика и описываемые ею явления рассматриваются с трёх точек зрения с опорой на работы:

- Б.Н. Миронова, писавшего о преступности как о «барометре свободы в обществе» [Миронов 2009];

- А.М. Эткинда и его наследующей С.М. Соловьёву концепции «России как страны, которая непрерывно колонизуется» [Эткинд 2013]. Сибирская каторга оказывается наиболее ярким примером «внутренних колоний» Российской империи, а побеги из мест «не столь отдалённых» - прекрасным образцом их влияния на метрополию, т.е., европейские губернии;

- Б. Андерсона, рассматривавшего музей, карту и перепись населения как институты осмысления и «созерцания» колониальными империями своей периферии. В этом же ряду совершенно естественно смотрятся и подробнейшие таблицы, приводимые авторами используемых нами источников, с этнографической дотошностью о параллельном и взаимосвязанном развитии криминалистики и антропологии см., например, [Крылова 2017] - описывавшие Сибирь и её обитателей.

К преимуществам этого материала применительно к его пространственному анализу можно отнести обширный территориальный охват - губернии европейской части демонстрируют распространенность отдельных видов преступлений, азиатские территории - места ссылок и направления на каторжные работы. Разнообразие данных позволяет использовать различные прием картографического анализа: от простых картограмм по губернской статистике и до построения маршрутов и детального картографирования объектов сибирской каторги. 
Специфика тематической нагрузки цифровых карт распространения преступности позволяет эффективно совмещать их с картами других тематик, в том числе, по исторической демографии и социально-экономическому развитию.

Корпус источников представлен тремя изданиями (полу)официального происхождения:

- «Сибирь и каторга» известного по публикациям в «толстых» журналах этнографа и беллетриста С.В. Максимова, в 1871 году собравшего под одной обложкой свои заметки, написанные в ходе предпринятого в первой половине 1860 -х годов по просьбе Морского ведомства изучения сибирских мест заточения;

- «Исследования о проценте сосланных в Сибирь в период 1827-1846 годов: материалы для тюремной статистики России», опубликованные в 1873 году членом Императорского географического общества Е.Н. Анучиным;

- «Итоги русской уголовной статистики за 20 лет (18741894 гг.)» под редакцией Е.Н. Тарновского, выпущенные в 1899 году министерством юстиции, в котором же младшим делопроизводителем служил и составитель сборника.

Сведения в источниках дают возможность проследить привлечь различные показатели статистики преступления, к которым может быть приложен картографический анализ: сословная принадлежность преступников, вид преступлений, назначенное наказание (каторга, поселение, житье). Из всего многообразия описываемых видов преступлений - совершаемых, к примеру, на религиозной почве или общественных выступлений - отдельно стоит выделить совмещенные группы преступлений, как, например, убийство помещиков или «дурное поведение крепостных по мнению помещиков». Обозначим, что преступность здесь рассматривается строго как историческое явление - многие виды преступности в настоящее время таковыми не считаются: такие категории преступление, как неповиновение помещику актуально лишь для конкретных исторических условий. Соответственно, историческая статистика преступлений представляет собой материал не столько по истории преступности вообще, сколько проявления более общих процессов, затрагивающих население империи.

К основным требованиям к картографической основе, необходимой для работы с конкретной тематикой, относятся наличие административно-территориального деления, актуализированного на изуча- 
емый период; значимые населенные пункты, пути сообщений, основные общегеографические объекты. Используемая цифровая модель была адаптирована соответственно указанным требованиям.

Картографическая обработка данных по преступности уже предпринималась: Е.Н. Анучин сопроводил свою работу несколькими картограммами, отражающими процент преступников по отдельным категориям от общей численности населения губернии; подобной же реализации придерживался Е.Н. Тарновский. Уже по их материалам можно сделать некоторые наблюдения в пространственном сегменте, однако приемы, использованные этими авторами, не исчерпывают всю информативность используемого ими материала.

Преступность, будучи сопутствующим признаком населения, может рассматриваться как количественный признак сплошного распределения; соответственно, для её изучения необходимо применять районирование с дазиметрической дифференциацией. Однако объяснение самого результата районирования, а также привязанность данных к губернскому уровню, предполагают также использование типологического картографирования.

Для прояснения методики картографической обработки данных было выделено три основных вида распространенности явлений и процессов в историческом пространстве в приложении к видам преступности:

- Очаговое распространение: явление имеет выраженный источник, от которого происходит движения по различным направлениям. Для пространственнойобработки подобных проявлений очаговых процессов хорошо подходит прием изохронов, однако его применение может быть ограничено информативностью и наличием источников;

- Распространенность в связи с одинаковыми условиями: процессы возникают в различных регионах независимо друг от друга в силу подобия сложившейся ситуации;

- Ограниченная распространенность, привязанная к локализации или мобильности других объектов: в этом случае процесс имеет локализованный характер, но - без выраженной направленности.

Очевидно, что перечисленные виды распространения могут сочетаться: возникновение нескольких локальных очаговых процессов в силу схожести условий может привести к синхронизации и даже объединению этих очагов в один. Однако для осуществления пространственного анализа важно выявить преобладающий характер распространения (или локализации), чтобы определиться с методически- 
ми приемами обработки данных. Выраженный очаговый характер имеют побеги из Сибири (выделены как особая группа преступлений) и побеги «за пределы отечества». Определенную «очаговость» демонстрируют некоторые виды преступлений на конфессиональной почве, особенно связанные с деятельностью религиозных общин (сект). Локализованный, региональный характер прослеживается лишь у двух групп преступлений: кража золота на приисках и контрабанда. Все прочие виды преступлений относятся к первому виду распространения.

Если для «очаговых» процессов важно выявить векторы и отдельные особенности распространения, то для прочих ситуаций важно привлекать дополнительную тематическую нагрузку. Картограммы и карты районирования в зависимости от поставленных задач могут отвечать на различные вопросы: в одном случае вопрос звучит - «Где определенное явление было распространено?», в другом - «Насколько это явление было развито в конкретном регионе?». Реализация этих вопросов и составляет основное содержание рассматриваемых данных.

Основные положения настоящей работы сформулированы следующим образом: сходные социально-экономические условия демонстрируют соответствующие показатели по статистики преступности и её распределению в пространстве; распространенность определенных видов преступлений ассоциирована с населением, соответственно, показателя одного административного региона оказывают давление на положение в другом регионе в той же степени, в какой осуществляются контакты населения между этими регионами.

Дополнительную проблему составляет сцепленность некоторых видов преступлений или конкретные их проявления в рамках одной группы. Так, бродяжничество в Пермской и Оренбургской губерниях было представлено беглыми каторжниками, что позволяет ассоциировать этот вид преступлений с другим - «бегством из каторги». Стоит отметить, что бродяжничество имеет выраженный региональный характер, мало затронув центральные и северные губернии. Подделка документов закономерно оказалась частым явлением именно в губерниях с высокими показателями бродяжничества. Уголовные преступления, напротив, распространены более равномерно, без четких пространственных аномалий.

Определенный интерес представляет совмещение данных по статистики по различным видам преступности с картами этнографической нагрузки. Например, по наблюдению С.В. Максимова традици- 
онное сочувствие беглецам среди татарских народов, сказалось в сторону повышенного показателя по «пристанодержательству» укрыванию беглецов от преследования.

Ещё один вид связей прослеживается между соотношением сельского и городского населения с определенными видами учитываемых преступлений. Некоторые виды нарушений закона на религиозной почве (особенно «святотатство») демонстрируют зависимость от доли городского населения в конкретном регионе.

Динамика пространственного распределения статистики преступлений в европейской части России представляет собой устойчивую систему с обратной связью: движения осужденных на каторгу и в ссылку в сибирские губернии приводило к их дальнейшему преобладанию в Пермской и Оренбургской губерниях, от которых в дальнейшем распространяются на прочие губернии, пропорционально повышая в них уровень регистрируемой преступности. Таким образом, картографическую обработку данных по преступности стоит рассматривать как частный случай дазиметрического картографирования, который значительно дополняет традиционные историкодемографические карты.

\section{Библиография}

1. Анучин Е.Н. Исследования о проценте сосланных в Сибирь в период 1827-1846 годов: материалы для тюремной статистики России. - СПб.: тип. Майкова, 1873. - 508 с.

2. Баяндин В.И. Организация пересылки ссыльных в восточные районы Сибири и Дальнего Востока во второй половине XIX - начале XX в. // Сергеев О.И. (ред.) Исторический опыт открытия, заселения и освоения Приамурья и Приморья в XVII-XX вв. (к 35-летию начала похода В.Д. Пояркова на Амур). - Владивосток: Институт истории, археологии и этнографии народов Дальнего Востока ДВО РАН, 1993. - С. 71-74.

3. Бортникова О.Н. Сибирь тюремная: пенитенциарная система Западной Сибири в 1801-1917 гг. - Тюмень: Тюменский юридический институт МВД РФ, 1999. - 304 с.

4. Горюшкин Л.М. (ред.). Ссылка и каторга в Сибири (XVIII - начало XX вв.). Новосибирск: Наука, 1975. - 303 с.

5. Детков М.Г. Наказание в царской России. Система его исполнения. - М.: Интерправо, 1994. - 119 с.

6. Крылова Н. Нерчинская каторга: этнографический взгляд на Российскую империю в фотографиях "видов и типов" последней четверти XIX века // Новое литературное обозрение. - 2017. - № 2 (144). - С. 285-311. Ч. 1-3.

7. Максимов С.В. Сибирь и каторга : В 3-х ч. - СПб.: тип. А. Траншеля, 1871. -

8. Миронов Б.Н. Историческая социология. - СПб.: Издательский дом С.-Петерб. ун-та; Интерсоцис, 2009. - 536 с.

9. Остроумов С.С. Очерки по истории уголовной статистики дореволюционной России - М., 1961. - 303 с. 1975.

10. Ссылка и каторга в Сибири (XVIII - начало XX в.). - Новосибирск: Наука, 
11. Тарновский Е.Н. Итоги русской уголовной статистика за двадцать лет: $1874-$ 1894 гг. - СПб.: Типография Правительствующего Сената, 1899. - 414 с.

12. Филиппов М.А. (ред.). История и современное положение русских карательных учреждений. Записка № 2 // Тюремные преобразования в России: доклад комиссии, записки, сводная ведомость, исторические очерки. 1872-1874 гг. -Ч. 1.

13. Эткинд, А. Внутренняя колонизация. Имперский опыт России - М.: Новое литературное обозрение, 2013. - 448 с.

https://doi.org/10.29003/m1829.978-5-317-06529-4/329-339

\section{Фролов А. $A$. Институт всеобщей истории РАН}

\section{Оценка средствами геоинформатики параметров координатной системы арабских географов XIII-XIV вв. Абу-л-Фиды и Ибн Са'ида о побережье Средиземного моря ${ }^{1}$}

Аннотация. В статье проанализированы значения широт, приведенные для городов африканского и азиатского побережий Средиземного моря в компилятивном труде XIV в. по сирийского географа Абу-л-Фиды и заимствованные им из сочинения арабо-испанского путешественника XIII в. Ибн-Са'ида. Средствами геоинформатики оцениваются параметры той координатной системы, которая фактически легла в основу использованной ими системы координат.

Ключевые слова: средневековая арабская география, системы координат, Средиземноморское побережье, длина дуги меридиана, историческая геоинформатика.

Frolov A. A.

Institute of General History RAS

\section{Assessment by means of geoinformatics of the parameters of the coordinate system of the Arab geographers of the XIII-XIV centuries Abu-l-Fida and Ibn Sa'ida about the Mediterranean coast}

Abstract. The article analyzes the latitude values given by the Syrian 14th century geographer Abu-1-Fida for the cities of the African and Asian coasts of the Mediterranean Sea and deriving from manuscript the manuscript of the $13^{\text {th }}$ century Arab-Spanish traveler Ibn Sa'id. The parameters of the coordinate system that actually formed the basis of the coordinate system is estimated by means of geoinformatics.

Keywords: medieval Arabic geography, coordinate systems, Mediterranean coast, meridian arc length, historical geoinformatics.

${ }^{1}$ Исследование проводится при поддержке гранта РФФИ № 20-09-00207 (рук. И.Г. Коновалова). 
Традиция арабских средневековых географических сочинений, испытав воздействие работ Птолемея, тем не менее, обладает значительным своеобразием. Одним из видных представителей арабской географии является эмир сирийского города Хама Абу-л-Фида, известный двумя сочинениями - преимущественно компилятивными по своей природе. Одно из них посвящено всемирной истории (до 1329 г.). Второе же является сочинением по всемирной географии (годы создания 1321-1331). За первые столетия своего существования оно стало очень хорошо известно в ученом мире Западной Европы и по популярности в рейтинге арабских сочинений уступало только Корану и «1001 ночи» [1, с. 392]. «Таквим ал-булдан» («Упорядочение стран») с описанием Земли и всех известных к тому времени в арабском мире стран и народов содержит данные о географических координатах десятков пунктов - главным образом городов. На русском языке изданы фрагменты сочинения, касающиеся Восточной Европы (перевод И.Г. Коноваловой и характеристику источника см.: [2]).

Прямая интеграция значений этих координат с современными геоданными невозможна, но вычленение различных групп пунктов, координаты которых находятся в некотором соответствии друг другу, открывает путь для выяснения способов вычисления приведенных Абу-л-Фидой координат. Естественные группы такого рода образованы координатами, происходящими из одного источника и относящимися к пунктам одного региона. Теоретически это могут быть как самостоятельно полученные данные астрономических наблюдений, расчеты по результатам промеров расстояний или оценка длины пути, так и заимствованные из сочинений того или иного предшественника, который, в свою очередь, тоже мог получать значения координат разными способами. «A priori» вариант астрономических наблюдений кажется маловероятным - в силу существенных отличий значений приведенных координат от современных. Однако установить степень связи между координатами пунктов внутри одной группы и судить о возможных способах получения координат не всегда возможно, оперируя лишь методами традиционного источниковедческого анализа. Перспективным представляется моделирование системы координат, которая фактически оказалась в основе представленной в этих группах координатной сетки. Привлечение результатов анализа географических данных, выполненного современными средствами геоинформатики, способно сделать решение данной задачи более эффективным и аргументированным. 
Для большинства координат, приведенных в тексте, Абу-л-Фида указывает свой источник, причем для некоторых городов он сообщает несколько вариантов координатных пар, взятых из разных источников. Одним из самых активно используемых Абу-л-Фидой источников было сочинение Ибн Са'ида - арабо-испанского путешественника XIII в. [2]. Сочинения Ибн Са'ида и Абу-л-Фиды никогда не анализировались с точки зрения способов пространственного конструирования, использовавшихся этими авторами, хотя как вспомогательный материал труд Абу-л-Фиды привлекался при анализе значений долготы, приводимых арабскими географами (в основном XVI в.) для Средиземноморья [3].

Не зная параметров, на которых рассчитывались долготы и широты, невозможно напрямую использовать их, чтобы смоделировать соответствующую систему координат. Можно, однако, попытаться рассчитать эти параметры, оценив величину одного «арабского» градуса по меридиану и по долготе, используя значения указанных в источнике координат. Относительно просто посчитать величину градуса по меридиану, поскольку при перемещении от экватора к полюсам она практически не меняется и, следовательно, какова бы ни была ошибка в определении экватора, она практически не влияет на результат. Значительно сложнее то же самое сделать для долготы, поскольку градус долготы становится короче к полюсам. Приблизительно длина «арабского меридиана» (так для краткости назовем расстояние между двумя точками на земной поверхности, широта которых различается ровно на 1 градус, а долготы равны - в системе координат арабского географа) может быть рассчитана, исходя из реальных расстояний между объектами с координатами. Предварительные результаты такого рода оценки (в настоящий момент - только для пунктов на южном и восточном берегах Средиземного моря) средствами информатики составляют основное содержание настоящей статьи. Это первый опыт оценки связности данных арабских географов о координатах через подбор возможных параметров соответствующей системы координат. Основная цель работы - апробация такого подхода, в дальнейшем он может быть развит и применен для других наборов координат с неизвестными параметрами системы.

Характеризуя морское побережье от Танжера до Константинополя, Абу-л-Фида ссылается на Ибн Са'ида при указании координат для 20 пунктов, 19 из которых были локализованы и нанесены на современную карту в проекте QGIS (рис. 1). Это позволило получить положение точек в современной системе координат, определить азимут отрезков, соединяющих каждую пару точек, и рассчитать рас- 
стояние между ними на эллипсоиде, то есть с учетом кривизны земной поверхности. Всего 19 точек комбинируются в 342 пары, а на их основе, соответственно, строится такое же число отрезков. При этом каждая пара точек в расчетах участвует дважды, поскольку между точками А и В создается не только отрезок А-В, но и В-А. Это, однако, никак не искажает точность последующих расчетов и не перегружает вычислительные мощности, поэтому в дальнейшем для расчетов использовалась вся совокупность отрезков.

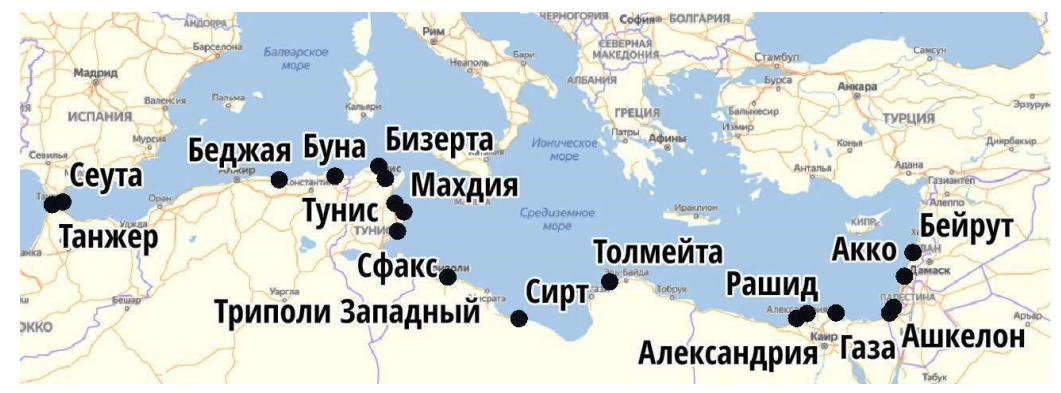

Рис. 1. Города южного и западного побережий Средиземного моря, описанные Абу-л-Фидой, снабженные координатами из сочинения Ибн-Са'ида

В прямоугольном треугольнике, гипотенуза которого образована отрезком между парой картографированных точек, а один из катетов лежит на параллели, второй катет лежит на меридиане, и его длина может быть измерена разницей в минутах между широтными координатами соответствующих пунктов. Таким образом через разницу в минутах Ибн Са'ида можно рассчитать длину катета, лежащего на «арабском» меридиане. Оно, однако, не может быть выражено напрямую в метрах, поскольку длина его одной минуты не известна. При подстановке различных значений длины «арабского меридиана» размер катета будет меняться, а вместе с ним - и углы прямоугольного треугольника. Разница между соответствующими углами «арабского» треугольника и треугольника в реальной системе координат характеризует разницу направлений на север в системе координат Ибн Са'ида и современным направлением на географический полюс.

Пользуясь известным решением прямоугольного треугольника и подбирая различные варианты соотношения длины «арабского» меридиана с соответствующим «арабским» азимутом, мы имеем возможность оценить отклонения «арабского» азимута от современного для каждой из пар точек, снабженных координатами Ибн Са'ида. Для это- 
го все данные о городах и соответствующих координатах Ибн Са'ида были внесены в базу данных (СУБД PostgreSQL 12) с расширением PostGIS, предназначенным для обработки геоданных. На основе этой таблицы было создано представление (view), генерирующее множество ребер графа, связывающих все возможные комбинации пар точек.

Алгоритм задачи выглядит следующим образом (рис. 2, 3). Реализация алгоритма выполнена средствами процедурного программного языка Python 3. Он снабжен модулями, позволяющими конвертировать градусы в десятичные градусы и радианы, что оказывается необходимым, поскольку встроенные функции PostGIS возвращают углы в радианах, а сравнение с «арабским» азимутом требует использования градусов. С другой стороны, «арабские градусы», указанные вместе с минутами, удобнее также преобразовать предварительно в десятичные градусы. Реальная длина дуги одного градуса широты составляет около 111111 м. Для каждой пары точек значения «арабского меридиана» перебирались в диапазоне от 50000 до 150000 м, однако для демонстрации результатов был оставлен только диапазон от 105000 до 125000 - значения азимутов за его пределами еще менее сопоставимы с реальными азимутами соответствующих отрезков. Поскольку координаты арабских географов приводятся с точностью до 1 минуты (в действительности 1 минута меридиана равна примерно 1852 м), нет смысла рассматривать изменения «арабского» меридиана с чрезмерно частым шагом. В цикле, перебирающем различные значения длины «арабского меридиана», его величина на каждой итерации увеличивалась на 1000 м. С заданным значением меридиана вычислялся угол описанного выше треугольника между гипотенузой и катетом, лежащим на меридиане. Таким образом, для каждого из 342 отрезков были сгенерированы значения углов прямоугольного треугольника для 100 вариантов длины «арабского меридиана». В зависимости от того, в каком диапазоне находится азимут отрезка, соединяющего взятую пару точек, «арабский азимут» находился из вычисленного этим способом угла по-разному: при азимуте от 0 до 90 (исключительно) градусов азимут приравнивался к этому углу, в диапазоне от 90 до 180 (исключительно) вычислялся как результат вычитания угла из 180 градусов, в диапазоне от 180 до 270 (исключительно) - как результат сложения угла со 180 градусами, в диапазоне от 270 до 360 (исключительно) как результат вычитания угла из 360. Для настоящего исследования интерес предсталяет не сам «арабский азимут», а величина его расхождения с современным. 


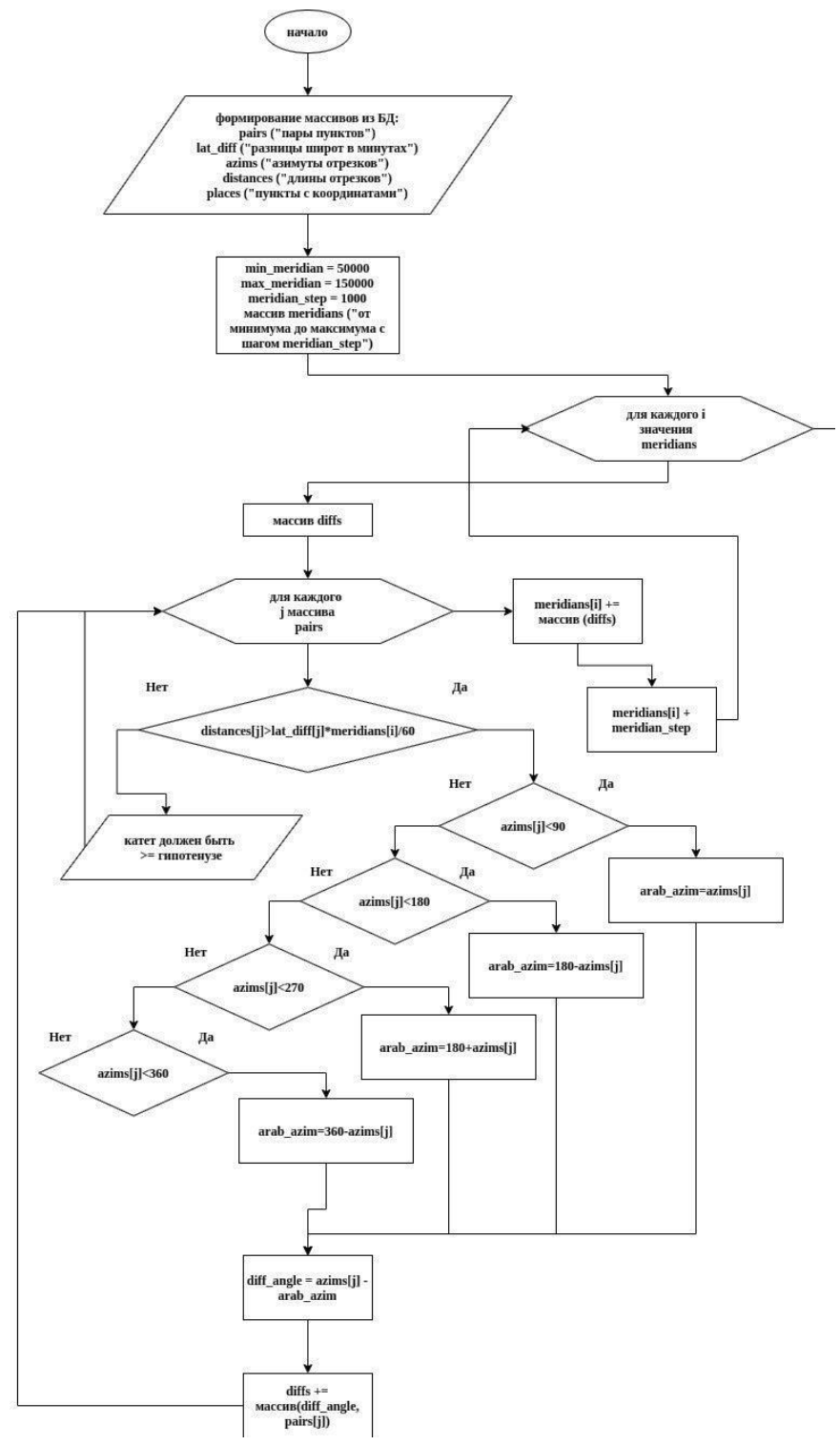

Рис. 2. Алгоритм оценки связности координат из сочинения арабского географа Ибн-Са'ида с подбором различных значений длины дуги градуса меридиана (левая половина) 


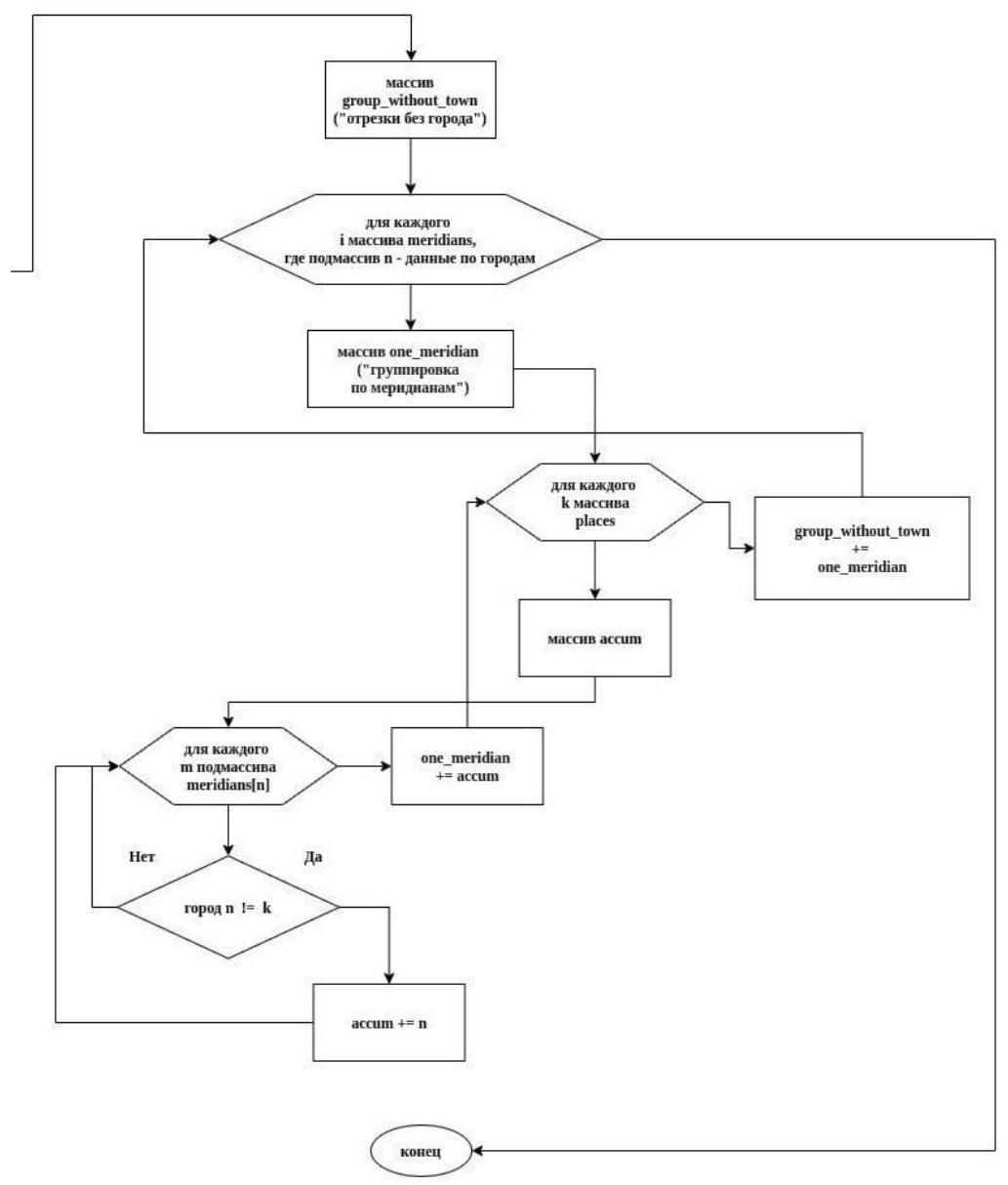

Рис. 3. Алгоритм оценки связности координат

из сочинения арабского географа Ибн-Са'ида с подбором различных значений длины дуги градуса меридиана (правая половина)

В результате для каждого значения «арабского» меридиана был получен набор значений, характеризующих величину отклонения от современного азимута каждого отрезка, связывающего пары точек. Разброс этих отклонений оказался весьма велик, и это побудило к исследованию вопроса о вкладе в величину этого разброса значений координат каждого отдельного пункта, ведь определение координат от- 
дельных пунктов, взятых из одного источника, могло быть выполнено с различной точностью. Определение такого вклада осложняется тем, что элементом, на основе значений которого рассчитывается стандартное отклонение, является отрезок, соединяющий пару точек, а исключение из расчетов какого-то одного пункта требует исключения из выборки не одного, а всех отрезков, в создании которых этот пункт участвует. Поэтому для решения этой задачи теми же программными средствами для каждого значения «арабского меридиана» были сформированы группы отрезков, где все отрезки с участием одного из городов исключены (см. рис. 3). Чем меньше стандартное отклонение в такой группе, тем больший вклад в его увеличение вносил исключенный город. Таким образом были построены вариационные ряды, в которых внутри одного значения «арабского меридиана» города отсортированы по силе влияния их координат на общий разброс отклонений «арабского азимута» от современного. Чем меньше стандартное отклонение в выборке без отдельного географического пункта, тем хуже его координаты согласуются с координатами всех остальных пунктов (рис. 4).

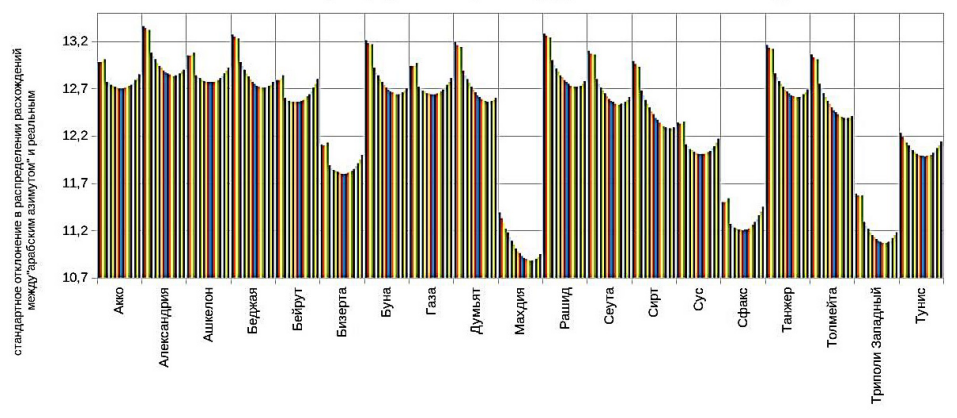

исключенные города

| $105000=106000=107000=108000=109000=110000=111000=112000=113000=114000=115000$ घ $116000=117000=118000=119000$ a $120000=121000=122000=123000=124000=125000$

Рис. 4. Согласованность широт средиземноморских городов из сочинения Ибн Са'ида. Диаграмма

Проведенные расчеты позволяют сделать несколько выводов. 1. Наименьшей согласованностью с остальными координатами, заимствованными Абу-л-Фидой у Ибн Са'ида, обладают координаты городов Махдия, Сфакс и Западный Триполи. 2. Достаточно точные данные о длине дуги 1 градуса земного меридиана арабская география получила еще в правление халифа ал-Ма'муна в результате астрономических измерений, проведенных около 827 г. По одной 
версии, результат соответствует 111815 метрам, по другой 111721 м [1, с. 83]. Однако стандартное отклонение, характеризующее разброс разниц «арабского азимута» с действительным, в ряду, полученном для длины дуги градуса меридиана 112000 м, превышает 11 градусов. Это, по-видимому, означает, что расчет широты из сочинения Ибн Са'ида не опирался на астрономические расчеты. 3. Минимальных значений стандартное отклонение, характеризующее разброс разниц «арабского азимута» с действительным, достигает при длине дуги градуса меридиана 115 000-123 000 м, то есть несколько большей, чем та, которая была рассчитана по результатам астрономических наблюдений. По-видимому, это свидетельствует о том, что в данной системе координат размеры полярного радиуса Земли, независимо от того, как эти широты вычислялись, были несколько переоценены относительно действительных. Но и минимальные значения стандартного отклонения превышают 10 градусов, хотя для каждого города этот минимум находится на своем значении длины дуги меридиана (таблица, рис. 5). Это также подтверждает неастрономическую природу расчетов, положенных в основу исследуемой градусной сетки.

Таблица

Минимальные значения стандартного отклонения (разброс величины расхождения современного азимута отрезков, соединяющих пары городов, с азимутом, который вычислен по широтам Ибн Са'ида)

\begin{tabular}{|l|c|c|}
\hline \multicolumn{1}{|c|}{1} & 2 & 3 \\
\hline Акко & 12,7 & 116000 \\
\hline Александрия & 12,83 & 120000 \\
\hline Ашкелон & 12,77 & 117000 \\
\hline Беджая & 12,71 & 120000 \\
\hline Бейрут & 12,56 & 114000 \\
\hline Бизерта & 11,8 & 116000 \\
\hline Буна & 12,64 & 120000 \\
\hline Газа & 12,64 & 116000 \\
\hline Думьят & 12,56 & 121000 \\
\hline Махдия & 10,88 & 120000 \\
\hline Рашид & 12,72 & 120000 \\
\hline
\end{tabular}


Продолжение таблицьь

\begin{tabular}{|l|c|c|}
\hline \multicolumn{1}{|c|}{1} & 2 & 3 \\
\hline Сеута & 12,53 & 120000 \\
\hline Сирт & 12,28 & 123000 \\
\hline Сус & 12,01 & 116000 \\
\hline Сфакс & 11,2 & 115000 \\
\hline Танжер & 12,61 & 120000 \\
\hline Толмейта & 12,38 & 122000 \\
\hline Триполи Западный & 11,07 & 119000 \\
\hline Тунис & 11,98 & 117000 \\
\hline
\end{tabular}

1 - исключенный город;

2 - минимальное стандартное отклонение;

3 - длина дуги одного градуса.

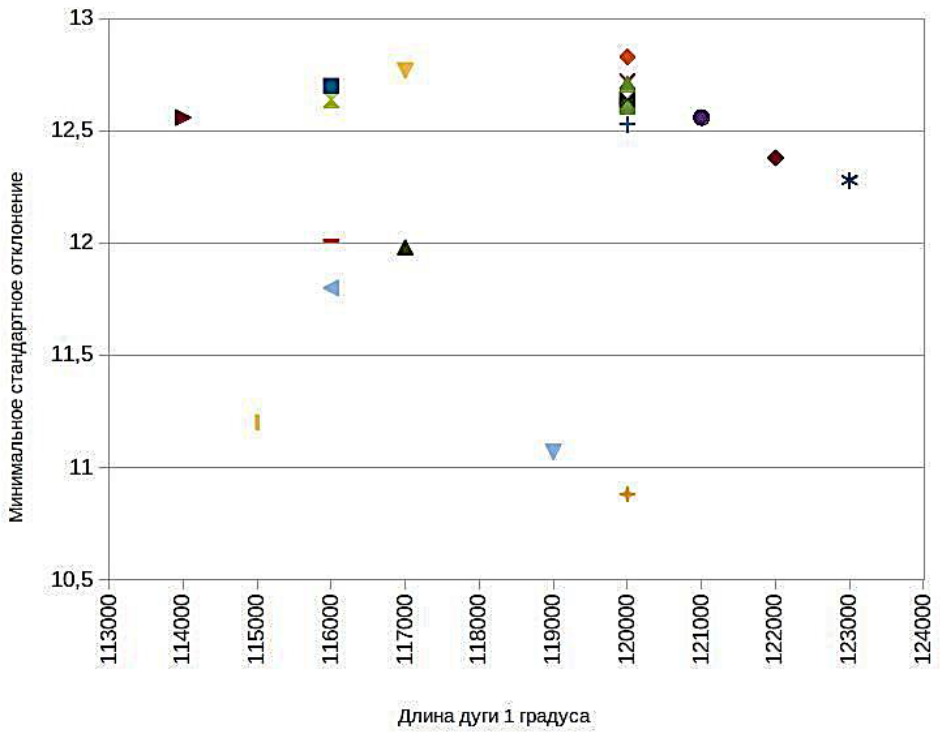

\begin{tabular}{|c|c|c|c|}
\hline 口акко & - Александрия & ₹ Ашкелон & А Беджая \\
\hline йрут & ४ Бизерта & М Буна & х Газа \\
\hline Бят & + Махдия & $\times$ Рашид & + Сеута \\
\hline & - Cyc & I Сфакс & 口 Танжер \\
\hline
\end{tabular}

Рис. 5. Минимальные значения ст. отклонения в группах без указанного города. Диаграмма 2 


\title{
Библиография
}

1. Крачковский И.Ю. Избранные сочинения. Т. IV. - М.; Л., 1957. - 919 с.

2. Коновалова И.Г. Восточная Европа в сочинениях арабских географов XIIIXIV вв. - M., 2009. -223 c.

3. Robles Macías L. The longitude of the Mediterranean throughout history: facts, myths and surprises // E-Perimetron. - 2014. - Vol. 9/1. - P. 1-29.

https://doi.org/10.29003/m1830.978-5-317-06529-4/339-345

Щекотилов В.Г.

РГО

Лазарев О.E.

Тверской государственный технический университет

Методика применения ГИС и архивных материалов при подготовке обоснования для признания погибшими воинов, считавшихся пропавшими без вести ${ }^{1}$

Аннотация. Предложена методика подготовки обоснования для признания погибшими считавшихся пропавшими без вести воинов. Методика основывается на использовании ГИС с архивными и современными картами, а также архивных материалов из баз данных систем и Центрального архива Министерства обороны. В качестве основного документа для принятия решения о гибели воинов использованы книги погребения полков и дивизий.

Ключевые слова: ГИС, карта, захоронение, пропавший без вести, книга погребения, база данных, установление, геокодирование, увековечение памяти.

Shchekotilov V.G. $R G O$, Tver Lazarev O.E. Tver State Technical University

Methodology for the use of GIS and archival materials in the preparation of a justification for the recognition of the dead soldiers who were considered missing

\begin{abstract}
A methodology has been proposed and implemented to prepare a justification for the recognition of missing persons as dead. The methodology is based on the use of GIS with archival and commercial maps, as well as archival materials from the database of the Memory of the People system and the Central Archive of the Ministry of Defense. In the quality of the main document, burial

${ }^{1}$ Исследования выполнены с использованием результатов грантов РФФИ № 14-06-00282, № 14-06-97507 р_центр_а.
\end{abstract}


books were used to decide on the death of warriors, in which records on soldiers were found to be missing.

Keywords: GIS, map, burial, missing, burial book, database, establishment, geocoding, memorialization.

По прошествии 75 лет после окончания Великой Отечественной войны 1941-1945 гг. по оценкам редакций Книг памяти около 40\% [1, с. 1; 2 с. 7] из не вернувшихся с войны числятся пропавшими без вести. Данная ситуация позволяет предполагать, что по многим воинам документы об их гибели существуют [3, с. 14].

В работах [4, с. 123] показана возможность использования технологий географических информационных систем (ГИС) и баз данных (БД) для аргументирования гипотез об обстоятельствах гибели воинов. В частности, была выявлена большая группа пропавших без вести воинов, которые стали таковыми после ранения [5, с. 90].

Предлагаемая методика установления судьбы считающихся пропавшими без вести воинов основана на следующих положениях:

- подготовка материалов для решений о признании погибшими отдельных воинов, которые считались пропавшими без вести (Щекотилов В.И., Теткин П.В. из 46 гв. сп);

- создание практики подготовки материалов по конкретным воинам для признания их погибшими и увековечения их памяти;

- на основе обращений с ходатайствами о признании воинов погибшими в Управление по увековечению памяти погибших при защите Отечества МО РФ, военные комиссариаты, администрации принято решение, что ходатайства, в основном, нужно направлять в военный комиссариат по месту первичного захоронения воина с приложением пакета печатных и электронных материалов;

- исследование документов 46 гв. сп на предмет выявления других воинов, которые числятся пропавшими, но в документах полка учтены как погибшие;

- исследования документов 46 гв. сп других временных периодов (1941-1944 гг.) и документов других стрелковых дивизий (243 сд, 49 гв. сд) на предмет выявления таких же случаев.

Представляемая методика включает следующие этапы:

- формирование исследовательской БД по записям в книге погребения конкретной военной части;

- поиск в БД системы «Память народа» военных топографических карт с данными по территории захоронений для соответствующего периода боевых действий; 
- формирование с использованием ГИС «MapInfo» и «Global Mapper» растровых электронный карт;

- формирование в программе «САС.Планета» векторного слоя мест первичного захоронения воинов с использованием при этом карт современных и периода боевых действий;

- последовательный перебор записей из книги погребения и выявление в БД системы «Память народа» случаев, когда воин считается пропавшим без вести;

- поиск в БД системы «Память народа» подтверждающих документов, что воин считается пропавшим без вести;

- подготовка обоснования, что в разных документах указан один воин;

- нанесение геокодируемых данных в программе «САС.Планета» (места призыва и жительства воина и родственников, места боев части до даты захоронения);

- анализ расположения ныне существующих воинских захоронений (В3) и определение вариантов, куда их могли перезахоронить;

- подготовка комплекта печатных (в том числе и картографических) и электронных документов для ходатайства о признания воинов погибшими;

- после получения из Военного комиссариата положительного решения, размещение информации в сети Интернет, в местных СМИ по месту призыва воинов, передача данных в редакции региональных Книг памяти, в органы местного самоуправления для вручения родственникам воина.

В 2018-2019 гг. были предприняты попытки инициировать принятие решения о признании погибшими в июле и августе 1942 г. в боях в районе д. Полунино Ржевского района Тверской области группы из 68 воинов 46 гвардейского (гв.) стрелкового полка (сп) 16 гвардейской стрелковой дивизии (гв. сд), с которыми после ранения родственники утратили связь [6, с. 9]. Получены отрицательные ответы из районного и областного военных комиссариатов, Управления по увековечению памяти погибших при защите Отечества (Управление) МО РФ, органов власти районного, областного и федерального уровня.

Продолжение исследований по документам в Центральном архиве Министерства обороны (ЦА МО) по воинам, ставшим пропавшими без вести после ранения, позволило выйти на группу пропавших без вести, по которым существует документ об их захоронении. 
Причем среди погребенных в районе боя оказалось несколько воинов из упомянутого выше списка 68 воинов пропавших без вести после ранения $[6$, с. 14$]$ и по ним после этого удалось отстоять решение о гибели.

Например, по Теткину Павлу Васильевичу удалось найти документ 46 гв. сп о его захоронении и 05.08.2019 г. военный комиссариат г. Ржева принял решение о его гибели и захоронении в д. Полунино.

Крылова Василия Ивановича 09.06.2019 г. нашли поисковики из отряда «Пионер» на окраине д. Полунино (https://vk.com/wall-20817 809_10277).

С использованием программы САС.Планета авторами производится аккумулирование различных картографических материалов XIX-XXI вв. [7, с. 81], которые используются при исследованиях.

После выявления в книге погребения 46 гв. сп 16 гв. сд данных по Теткину П.В., этот документ анализировался на предмет выявления данных о считающихся пропавшими без вести воинах.

Документ содержит 102 страницы, 593 записи (групповые захоронения неустановленных воинов не нумерованы) датируются с 20.10.41 г. по 19.07.44 г.

Решение Ржевского комиссариата фактически открыло возможность принятия решений уже по более 170 воинам считающимися пропавшими без вести.

Установленные воины 46 гв. сп (всего 121) погибли в следующих районах:

- в Тверской области в Осташковском -1, в Ржевском р-не - 77;

- в Смоленской обл. в Велижском р-не - 12;

- в Калужской обл. в Ульяновском р-не - 12;

- в Республике Беларусь, Витебская обл. в Витебском - 19.

Исследования по пропавшим без вести воинам, по которым есть данные об их ранении или захоронении, были начаты в 2015 г. с боев июля и августа 1942 г. в Ржевском районе Тверской области. К этому периоду относятся 45 воинов.

Это обусловило начало аналогичных исследований по другим частям, в частности, по 118 сд, которая в составе 31 армии в августе вела бои по освобождению г. Зубцов [8, с. 23]. По данной дивизии в 2019 г. удалось поработать с данными книг призыва Шахунского РВК Горьковской обл. - фактически по месту 2-го формирования 118 сд на станции Шахунья и в поселке Вахтан. По Зуеву Василию Тихоновичу было установлено, что он числится пропавшим без вести, но при этом указан в книге погребения 49 гв. сд [9, с. 1]. 
По представленным документам состоялось решение Ржевского комиссариата, что Зуев В.Т. воевал в 398 сп 118 сд, погиб и захоронен в Ржевском районе.

Таким образом, в исследования был вовлечен документ 49 гв. сд. После представления материалов состоялись решения Ржевского военного комиссариата по 19 воинам, 9 захоронено на В3 в д. Гнилево, 10 - на В3 «Курган» в г. Ржев.

Был произведен поиск оцифрованных книг погребения иных частей, воевавших в Ржевском районе. В частности, была выявлена книга погребений 243 сд [10, с. 1], в которой указаны захоронения с 19.08.41 г. по 08.02.43 г.

Для периода боев в Ржевском районе с 21.08.42 г. по 21.09.42 г. было выявлено 11 захороненных воинов (7 перезахоронены в д. Бахмутово, 4 - в д. Кокошилово).

В результате анализа записей за декабрь 1941 г. выявлено захоронение 16 воинов. Захоронения выполнены с 14 по 17 декабря на северной окраине г. Калинин. Тверской городской военный комиссариат 14.11.19 г. определил, что воины перезахоронены на В3 на ул. 3. Коноплянниковой в г. Тверь.

В таблице в разрезе по воинским захоронениям представлены данные по воинам, признанным погибшими.

В процессе настоящих исследований при Тверском государственном техническом университете был создан поисковый отряд «Возвращение» (руководитель - Лазарев О. Е.).

Продолжающиеся исследования расширяются на анализ документов иных частей, например, погребальной книги 49 гв. сп 16 гв. сд.

С учетом длительной временной задержки при размещении решений комиссариатов в системах «Мемориал» и «Память народа» сканы решений размещаются авторами в ОБД «Мемориал» через механизм «Дополнительная информация», на ресурсах отряда [11, с. 1] и иных.

С начала исследований материалы по воинам передаются в редакции Книги памяти. В частности, по воинам с Горьковской области в редакцию Книги памяти Нижегородской области (в 20-й том). Материалы по воинам публикуются в районных газетах.

На основании документов, сформированных с использованием предлагаемой методики, в 2019-2020 гг. 172 воина (111 в Тверской области) признаны погибшими. Для сравнения в Книге памяти «Имена из солдатских медальонов» Т. 8 , изданной по результатам 
работы десятков поисковых отрядов «Поискового движения России» за 2016-2017 гг. представлены данные о гибели в Тверской области 125 воинов, считавшихся пропавшими без вести [12, с. 8]. Причем среди них около 25\% - это данные за 2000-2015 гг. Данные количественные характеристики характеризуют высокий уровень приращения исторических социально значимых знаний от использования баз данных, ГИС и аналитического сопоставления данных из различных архивных источников.

Таблица

\section{Воинская часть, место и дата захоронения}

\begin{tabular}{|c|c|c|c|c|c|}
\hline № & Захоронение & Область & С даты & По дату & Кол-во \\
\hline & 46 гв. сп 16 гв. сд & & & & 127 \\
\hline 1 & д. Замошье & Тверская & 24.12 .41 & 24.12 .41 & 1 \\
\hline 2 & г. Велиж & Смоленская & 08.03 .42 & 14.05 .42 & 15 \\
\hline 3 & д. Полунино & Тверская & 03.08 .42 & 04.09 .42 & 45 \\
\hline 4 & д. Петуново & Тверская & 06.09 .42 & 14.09 .42 & 5 \\
\hline 4 & д. Бахмутово & Тверская & 10.10 .42 & 15.10 .42 & 17 \\
\hline 5 & д. Погорелки & Тверская & 04.12 .42 & 19.12 .42 & 10 \\
\hline 6 & д. Всходы & Смоленская & 16.03 .43 & 28.03 .43 & 8 \\
\hline 7 & д. Холмищи (Вязовна) & Калужская & 07.06 .43 & 15.07 .43 & 4 \\
\hline 8 & д. Дубна & Калужская & 13.07 .43 & 13.07 .43 & 2 \\
\hline 9 & д. Вязовна & Калужская & 15.07 .43 & 15.07 .43 & 2 \\
\hline 10 & c. Зароново & Витебская & 23.01 .44 & 07.02 .44 & 19 \\
\hline & 49 гв. сд (2 гв. мсд) & & & & 18 \\
\hline 1 & д. Гнилево & Тверская & 24.09 .42 & 01.10 .42 & 8 \\
\hline 2 & г. Ржев & Тверская & 01.10 .42 & 14.10 .42 & 10 \\
\hline & 243 сд & & & & 27 \\
\hline 1 & г. Тверь & Тверская & 14.12 .41 & 17.12 .41 & 16 \\
\hline 2 & д. Кокошилово & Тверская & 01.09 .42 & 07.09 .42 & 4 \\
\hline 3 & д. Бахмутово & Тверская & 21.08 .42 & 21.09 .42 & 7 \\
\hline & Всего & & & & 172 \\
\hline
\end{tabular}

Таким образом, использование технологий БД и ГИС позволило при анализе документов Центрального архива МО РФ формировать гипотезы о судьбе воинов, считающихся пропавшими без вести. Представление в военные комиссариаты результатов исследований, в том числе и с приложением картографических материалов, позволило в 2019-2020 гг. признать погибшими с указанием даты, мест первичного и текущего захоронения 172 воина. 
Авторы выражают благодарность за предметное и внимательное рассмотрение представляемых материалов сотрудникам ЦА МО и военных комиссариатов: Ржевского, Осташковского и Тверского Тверской области, Велижского и Вяземского Смоленской области, Хвастовичского Калужской области.

\section{Библиография}

1. Закон РФ № 4292-1 от 14.01.1993 «Об увековечении памяти погибших при защите Отечества» // Система ГАРАНT. - URL: https://base.garant.ru/1583840/ (дата обращения: 22.08.2020)

2. Книга памяти Нижегородской области. Том 13: Уренский, Чкаловский, Шарангский, Шахунский районы. - Нижний Новгород, 1995. - 656 с.

3. Трушин Александр. Армия безвестных // «Огонек». - 2019. - № 36. - С.14-16.

4. Щекотилов В.Г., Шалаева М.В., Щекотилова С.Н. Использование географических информационных систем и баз данных в исследованиях по установлению места службы и гибели без вести пропавших воинов // Историческая информатика. - 2018. № 3. - C. 123-145.

5. Щекотилов В.Г., Шалаева М.В., Щекотилова С.Н. Применение ГИС в исследованиях установления судьбы пропавших без вести воинов // Вестник ТвГУ. Серия: география и геоэкология. -2019 . - №1. - С. 90-107.

6. Щекотилов В.Г., Щекотилова С.Н., Назоева Е.Г., Шалаева М.В. Имена из солдатского медальона (Ранены - пропали без вести ...). Часть 2. Команды военнопересыльного пункта 81 зсп 30 зсд и данные из писем с фронта. Сборник материалов поиска. - Тверь, 2018. -44 с.

7. Щекотилов В.Г., Щекотилова С.Н. Шалаева М.В. Комплекс баз данных по топографическим межевым картам XIX в. восьми губерний съемки А.И. Менде // Известия высших учебных заведений. Геодезия и аэрофотосъемка. - 2016. - № 5. C. 81-87.

8. Щекотилов В.Г., Щекотилова С.Н., Назоева Е.Г., Шалаева М.В. Имена из солдатского медальона (ранены - пропали без вести ...). Часть 3. По архивным материалам 398 сп 118 сд (249 гв. сп 85 гв. сд). Сборник материалов поиска. - Тверь, 2019. $-56 \mathrm{c}$.

9. ЦА МО: Ф. 1158. Оп. 2. Д. 10, Книга погребения, 49 гв. сд 22.09.42 - 14.10.42. $91 \mathrm{c}$.

10. ЦА МО: Ф. 1525. Оп. 2. Д. 41, Книга погребения, 243 сд 19.08 .41 - 31.03.43. $303 \mathrm{c}$.

11. Поисковый отряд «Возвращение» - URL: https://vk.com/club187562181 (дата обращения: 22.08.2020)

12. Имена из солдатских медальонов. Т. 8 // Сост. Коноплев А.Ю., Салахиев Р.Р., Салахиева М.Ю., Кислицина Т.Н. - Казань: «Отечество», 2018. - 363 с. 
https://doi.org/10.29003/m1831.978-5-317-06529-4/346-351

Щекотилов В.Г.

РГО

Лазарев О.E.

Тверской государственный технический университет Методика формирования атласов
по архивным и современным картам

Аннотация. Предложена методика создания серии атласов для использования в исследованиях многолистного стосаженного плана дачи 1865 г. С учетом масштаба базового картографического произведения в атласах дополнительно используются военно-топографическая карта 1942 г. и топографическая карта начала XXI в. Методика основана на формировании карт в формате Google Map, создании векторной карты страниц и использования программы САС.Планета.

Ключевые слова: атлас, ГИС, карта, план дачи, схема листов, Google Мар, САС.Планета, ГОСГИСЦЕНТР.

Shchekotilov V.G.

$R G O$

Lazarev O.E.

Tver State Technical University

\title{
Methodology for the formation of atlases from archival and modern maps
}

\begin{abstract}
The method of creating a series of atlases is proposed for use in the analysis of a multi-sheet standing plan of 1865 . Taking into account the masheadquarters of the basic cartographic work, the atlases additionally use a militarytopographic map of 1942 and a topographic map of the beginning of the XXI century. The method is based on the formation of maps in the format of Google Map, the creation of a vector map of pages and the use of the program SAS.Planet.

Keywords: Atlas, GIS, map, delivery plan, sheet diagram, Google Map, SAS.Planeta, GOSGISCENTRE.

При практическом использовании картографических материалов в обучении, туризме, краеведческих исследованиях востребованной формой являются печатные атласы $[1$, с. $1 ; 2$, с. $1 ; 3$, с. $1 ; 4$, с. 1]. При использовании атласов возникает необходимость работать с разновременными картами, поэтому актуально наличие атласов на несколько карт.
\end{abstract}

${ }^{1}$ Исследования выполнены с использованием результатов грантов РФФИ № 14-06-00282, № 14-06-97507 р_центр_а. 
Рациональными представляются, в частности, следующие подходы к организации атласов:

- создание разномасштабных атласов в интересах оперативного перехода от обзорного атласа к более детальному;

- создание атласов по разновременным картам в интересах сравнения гидрографии, границ землепользования, расположения населенных мест и урочищ, дорожной сети и т.д. для различных временных периодов.

Создание комплексов атласов приобретает повышенную актуальность при наличии архивных крупномасштабных многолистных (больших по размеру) картографических произведений. Актуальность усиливается, когда архивное картографическое произведение длительное время было недоступно для исследователей и соответственно предстоит его длительное использование в разноплановых исследованиях, образовании, просвещении.

Примером такой ситуации является многолистный план дачи Ветлужского уезда Костромской губернии съемки 1865 г. из 65 листов [5, с. 108].

Исследования показали, что этот план дачи является элементом большого комплекса многолистных планов дач государственных земель в различных губерниях [6, с.99], изданных в середине XIX в.

В 2019 г. усилиями Шахунского «Народного фольклорноэтнографического музея» (НФЭМ, http://shahmuzei.ru/) и краеведов в Российском государственном историческом архиве (РГИА, https://rgia.su/) были куплены отсканированные изображения 43 из 65 листов плана дачи. План дачи выполнен в масштабе 100 саженей в английском дюйме.

Печатный вариант объединения имеющегося состава листов в масштабе оригинала составит по ширине 5 м и по высоте 3 м. Для полного комплекта листов (из 7 строк и 13 столбцов) размер склейки составит 6.5 м на 3.5 м.

С учетом того, что исходный размер квадратного листа составляет $50 \mathrm{~cm}$, а масштаб 1: 8 400, один лист охватывает территорию квадрата со стороной 4.2 км. Созданное в 2019 г. объединение листов содержит 10 столбцов и 6 строк, что составляет на местности с востока на запад 42 км и с юга на север 25.2 км. При использовании масштаба 1: 10000 это составит 4.2 м на 2.52 м.

С помощью специальной методики были рассчитаны параметры сетки листов и сформированы разноформатные растровые электрон- 
ные карты объединения листов [5, с. 108], в т.ч. и в формате Google Map (размещены в Интернете, http://boxpis.ru/gk-g/leaflet/Vetl-18659.php?1=46.316845\&b=57.687247\&mas $=11)$.

В качестве программного инструментария проведения прикладных исследований по архивным картам авторами, в частности, используется программа «САС.Планета» $[7$, с. 1], в которой реализованы функции ГИС.

С учетом освоения исследуемой территории в XIX в., появления большого числа починков, изменения названия населенных мест актуально создание печатного атласа с привлечением разновременных карт.

На данном этапе выбраны следующие разновременные карты:

- план дачи масштаба 1: 8 400, изданный в 1865 г. из 65 листов;

- военно-топографическая карта масштаба 1: 500001942 г. из объединения листов [8, с. 1];

- многолистная карта масштаба 1: 25000 ГОСГИСЦЕНТРа 2000 г. (https://cgkipd.ru/opendata/kartography/).

Для перечисленных карт выполнено макетирование серии атласов под общим заголовком «Атлас Костромской губернии, Ветлужского уезда. Дачи сел Новоуспенского и Хмелевицкого с деревнями. Владения государственных крестьян. Новоуспенской и Хмелевицкой волостей», в которую входят:

- Часть 1. Атлас плана дачи 1865 г. в масштабе 1:10 000.

- Часть 2. Атлас плана дачи 1865 г. в масштабе 1:20 000.

- Часть 3. Атлас плана дачи 1865 г. и карты ГОСГИСЦЕНТРа в масштабе 1: 20000.

- Часть 4. Атлас по карте ГОСГИСЦЕНТРа в масштабе 1:20000.

- Часть 5. Атлас по военно-топографической карте 1942 г. в масштабе 1:40 000.

Целесообразность создания совместного атласа по плану дачи и карте ГОСГИСЦЕНТРа заключается в возможности одновременного использования страниц по этим картам на развороте атласа.

Использование кратных масштабов в 1 см 400, 200 и 100 м позволяет согласовать сетки атласа, т.е. лист масштаба 1:40 000 состоит из 4-х листов масштаба 1:20 000, а он в свою очередь из 4-х листов масштаба 1:10 000.

При создании печатного атласа необходимо создать изображения частей карты, которые соответствуют некоторой сетке страниц и 
обеспечивают взаимное перекрытие картографической части.

Ранее для двухверстной (1:84 000) топографической межевой карты Тверской губернии съемки А.И. Менде 1853 г. была разработана методика создания печатного атласа $[9$, с. $31 ; 10$, с. 81]. Формирование изображений страниц в ней производилось с помощью специально разработанной программы.

В настоящем материале представляется методика формирования изображений карты для страниц атласа с использованием программы САС.Планета. При этом в качестве исходных данных используются растровая электронная карта объединения листов плана дачи в формате Google Мар и векторная карта границ изображений для страниц и границ перекрытия страниц.

В процессе разработки методики был апробирован вариант генерации векторной карты границ страниц в прямоугольной системе координат (СК) «Гаусса-Крюгера, Пулково-42», 8-я зона (текстовый файл формата mif). В результате прямоугольники границ для страниц получались наклонными относительно геодезической системы координат и сформировать точное изображение карты в границах прямоугольника через программу САС.Планета не получилось (программа формирует прямоугольник в геодезической системе координат).

Проблема была решена формированием карты границ страниц в геодезической СК «Широта-долгота. WGS-84» с заданием размеров прямоугольников, обеспечивающих требуемые размеры на местности. Для каждой страницы атласа формируются два объекта: площадной и линейный. Площадной используется при задании области карты для страницы атласа, линейный объект отображается поверх карты и является частью линий, показывающих области перекрытия страниц.

Для формирования текстового файла векторной карты в формате mif использовалась программа FreeMat (http://freemat.sourceforge.net/), можно использовать и VBA Microsoft Office (https://docs.microsoft.com/ ru-ru/office/vba).

Для формирования изображения для страницы атласа используется функция программы САС.Планета «Операция с выделенной областью», которая вызывается при размещении курсора мыши над площадным объектом сетки страниц и кликом правой кнопки мыши.

На окне «Операция с выделенной областью» выбирается вкладка «Склеить».

С учетом исходного масштаба карт и масштаба атласа используются тайлы одного из масштабов 15, 16, 17. 
Для отображения границ перекрытия устанавливается флаг «Накладывать отображаемые метки».

Размеры карты на странице атласов составляют 26 см на 17 см.

Параметры для масштаба 1:10 000:

- размер изображения карты без перекрытия 2.5 км на 1.6 км;

- расширение изображения - 0.05 км;

- общий размер изображения страницы 2.6 на 1.7 км.

Параметры для масштаба 1:20 000:

- размер изображения карты без перекрытия 4.8 км на 3.0 км;

- расширение изображения - 0.2 км;

- общий размер изображения страницы 5.2 на 3.4 км.

Методика формирования серии печатных атласов разновременных карт для исследования многолистного плана дачи 1865 г. состоит из следующих этапов:

- формирования растровых электронных карт, используемых в атласе в формате Google Map;

- определения размеров картографического изображения страницы, например для формата A4, 26 см на 17 см;

- определение размеров перекрытия, например, 0.5 см;

- определение размеров страницы в геодезической системе координат, обеспечивающих данные размеры;

- автоматическое формирование векторной карты в текстовом формате mif страниц атласа и линий перекрытия;

- импорт векторной карты страниц в программу САС.Планета;

- последовательное автоматизированное формирование страниц атласа с использованием функции «Операция с выделенной областью» в программе САС.Планета;

- верстка атласа, например, в программе MS Word, вставка графических изображений страниц.

Таким образом, по предложенной методике удалось сформировать по разновременным и разномасштабным картам комплекс атласов, который может использоваться в исследованиях, образовании и просвещении.

Предложенный подход может быть использован при создании печатных атласов по другим многолистным планам дач середины XIX в. Костромской, Нижегородской, Тверской и иных губерний, а также по топографическим межевым картам губерний съемки А.И. Менде и военно-топографическим картам XIX в. 
Авторы выражают благодарность краеведам городского округа город Шахунья и директору музея г. Шахунья Нижегородской области Чипак И.Н. за приобретение в РГИА листов плана дачи.

\section{Библиография}

1. Адамовский район Оренбургской области : краевед. атлас // под общ. ред. А.А. Чибилева. - Оренбург : Газпромпечать: Оренбурггазпромсервис, 2007. - 40 с. URL: https://project.orenlib.ru/geografija_orenburgskaja/spisok6.html (дата обращения: 28.08.2020).

2. Атлас Демянского района Новгородской области // сост. и гл. ред. В.Г. Васильев. - Гатчина: СЦДБ, 1997. - 33 с. - URL: http://local-atlas.ru/page15.html (дата обращения: 28.08.2020).

3. Курортный район Санкт-Петербурга. Справочные материалы для школы. Гатчина: СЦДБ, 2004. - 27 c. - URL: http://local-atlas.ru/page23.html (дата обращения: 28.08.2020).

4. Ресурс «SASGIS. Веб-картография и навигация». URL: http://www.sasgis.org/ sasplaneta/ (дата обращения: 28.08.2020).

5. Учебные географические атласы административных районов России. - URL: http://local-atlas.ru/page4.html (дата обращения: 28.08.2020).

6. ЦАМО, Ф. 214, Оп. 1437, Д. 2972. Карта войск 32 А, 09.12.1944. - URL: https:/pamyat-naroda.ru/documents/view/?id=100997987 (дата обращения: 28.08.2020).

7. Щекотилов В.Г., Лазарев О.Е. Метод разработки электронных атласов и серий карт-схем на основе крупномасштабных карт губерний // Геодезия и картография. 2010. - № 1. - C. 31-39.

8. Щекотилов В.Г., Щекотилова С.Н. Шалаева М.В. Комплекс баз данных по топографическим межевым картам XIX в. восьми губерний съемки А.И. Менде. // Известия высших учебных заведений. Геодезия и аэрофотосъемка. - 2016. - №5 - С. 81-87.

9. Щекотилов В.Г., Шалаева М.В., Щекотилова С.Н. Методика формирования электронных карт по многолистному плану дач середины XIX в. // Вестник ТвГУ. Серия: География и геоэкология. - 2019. - № 1. - С. 108-122.

10. Щекотилов В.Г., Щекотилова С.Н., Лазарева О.С., Шалаева М.В. Многолистные планы дач XIX в. из фондов библиотеки как элемент автоматизированного геопортала. / Президент. б-ка им. Б. Н. Ельцина. - СПб.: Серия «Электронная библиотека» Вып. 9: Гуманитарные исследования и цифровая среда: наука и практика / Науч. ред. Е.Д. Жабко. - 2019. - C. 99-119. - URL: https://www.prlib.ru/item/1279738 (дата обращения: 28.08.2020). 


\title{
3D-РЕКОНСТРУКЦИИ ОБЪЕКТОВ ИСТОРИКО-КУЛЬТУРНОГО НАСЛЕДИЯ. ВИРТУАЛЬНАЯ И ДОПОЛНЕННАЯ РЕАЛЬНОСТЬ (VR/AR)
}

https://doi.org/10.29003/m1832.978-5-317-06529-4/352-360

Бородкин Л.И., Жеребятьев Д.И., Энтин А.Л. Московский государственный университет имени М.В. Ломоносова

Ким О.Г. Центр культурных исследований и экспертиз, Москва

Чернов С.3. Институт археологии РАН, Москва

Moop B.B.

Севастополь

\section{Цифровые технологии создания \\ виртуальной реконструкции исторического ландшафта и городской застройки Белого города (XVII-XVIII вв.) ${ }^{1}$}

\begin{abstract}
Аннотация. Статья посвящена вопросам методологии и методики виртуальной реконструкции исторического ландшафта городов, имеющих многовековую историю. Это одно из развивающихся направлений современной исторической урбанистики, методической основой которого являются технологии 3D моделирования и трехмерные ГИС. В статье дается описание междисциплинарного проекта создания виртуальной реконструкции ландшафта Белого города XVI-XVIII вв. - исторической местности в центре Москвы. На основе сформированной источниковой базы построена виртуальная реконструкция доминантных объектов Белого города, 3D модели которых «встраиваются» в воссозданный с помощью трехмерной ГИС исторический ландшафт.

Ключевые слова: исторический городской ландшафт, историческая урбанистика, историко-культурное наследие, цифровые технологии, виртуальная реконструкция, 3D моделирование, ГИС, история Москвы, Белый город, рельеф.
\end{abstract}

\footnotetext{
${ }^{1}$ Исследование выполнено при финансовой поддержке РФФИ в рамках научного проекта № 18-00-01641.
} 
Borodkin L.I., Zherebyatyev D.I., Entin A.L. Lomonosov Moscow State University

Kim O.G. Center of Cultural Studies and Expert Examinations, Moscow

Chernov S.Z. Institute of Archeology RAS, Moscow

Moor $\boldsymbol{V} . \boldsymbol{V}$. Sevastopol

\title{
Digital technologies for creating a virtual reconstruction of the historical landscape and urban development of Bely Gorod (17th - 18th centuries)
}

\begin{abstract}
The article is devoted to the issues of methodology and methods of virtual reconstruction of the historical landscape of cities with a long history. This is one of the developing areas of modern historical urban studies, methodological basis of which includes 3D modeling technologies and three-dimensional GIS. The article describes an interdisciplinary project for creating a virtual reconstruction of the landscape of Bely Gorod of the 16th - 18th centuries - a historical area in the center of Moscow. On the basis of generated source base, a virtual reconstruction of the dominant historical objects of Bely Gorod is built, the 3D models of which are "embedded" into historical landscape restored using a threedimensional GIS.

Keywords: historical urban landscape, historical urban studies, historical and cultural heritage, digital technologies, virtual reconstruction, 3D modeling, GIS, history of Moscow, Bely Gorod, relief.
\end{abstract}

Изучение эволюции исторического городского ландшафта привлекает всё больше внимания в контексте растущего интереса к сохранению культурного наследия и ускоряющихся процессов урбанизации. В соответствии с рекомендацией ЮНЕСКО, исторический городской ландшафт представляет собой «городской район, рассматриваемый как результат исторического наслоения культурных и природных ценностей и атрибутов и выходящий за рамки понятия «исторический центр» или «ансамбль» в связи с включением в него более широкого городского контекста и его географических параметров».

В данном проекте рассматривается исследовательская проблематика, касающаяся исторических городских ландшафтов и характерная для большинства городов, основанных много столетий назад. Их ландшафт изменялся на протяжении веков под воздействием природных и антропогенных факторов, и его реконструкция на тех или 
иных временных срезах - одна из задач современной исторической урбанистики. Речь идет, разумеется, о виртуальной реконструкции, в данном случае - о виртуальной реконструкции городского ландшафта Белого города XVI-XVIII вв. - исторической местности в центре Москвы [1].

Учитывая полидисциплинарный характер такого проекта, его коллектив должен включать специалистов из разных областей: истории, археологии, географии, а также архитекторов, реставраторов, IT-специалистов (имеющих опыт работы с 3D-, VR- и ГИС-технологиями). Такой состав и был собран для реализации данного проекта, базирующегося на кафедре исторической информатики исторического факультета МГУ имени М.В. Ломоносова.

Цифровые технологии используются в нашем проекте для создания виртуальной реконструкции исторического ландшафта Белого города и основных (доминантных) элементов его застройки XVIXVIII вв., а также для создания иммерсивных VR-эффектов «погружения» пользователя в воссозданную виртуальную среду. В данной работе мы ограничимся первыми двумя задачами.

Научная реконструкция может быть реализована на базе комплекса исторических источников (археологических, архивных изобразительных, графических, текстовых и др.), характеризующих пространственные изменения территории Белого города в течение трёх веков. Предлагаемая впервые виртуальная реконструкция исторического ландшафта Белого города позволяет оценить роль антропогенного фактора, выявить влияние расширяющейся городской застройки на эволюцию его рельефа и доминатных построек.

На первом этапе проекта была сформирована источниковая база, оцифрован собранный материал, проведен его сравнительный источниковедческий анализ. Укажем основные выявленные нами источники для решения поставленных задач реконструкции исторического ландшафта Белого города.

1. Общегородские планы Москвы и ее центральной части XVII начала XX вв., включая неопубликованные, которые хранятся в фондах РГВИА, РГИА, РГАДА; немаловажное значение имеют геоподосновы Москвы (масштаба 1:2000) с обозначением высотных отметок рельефа и карты города XIX - начала XX вв. с обозначением изолиний рельефа.

2. Планы и чертежи отдельных владений XVIII - начала XIX вв. (хранятся в фондах РГАДА, РГИА, РГВИА, ЦГА Москвы, музейных собраниях). 
3. Текстовые документы, содержащие сведения о владельцах и размерах дворов, строительных работах.

4. Археологические источники, включая данные археологических исследований, проводившихся в течение ряда лет на территории Белого города, а также данные о геологических скважинах и шурфах.

Исходя из состояния источников, в качестве основного временно́го среза в наших реконструкциях берется вторая половина XVIII века, однако в целом ряде случаев рассматриваются и более ранние срезы. На основе сформированной источниковой базы были решены следующие задачи:

- создание базы данных по материалам о сооружениях изучаемой территории Белого города;

- создание виртуальной реконструкции рельефа изучаемой территории Белого города;

- создание виртуальной реконструкции доминатных объектов исторической застройки Белого города (Ивановский монастырь, храмы, палаты, строения городских усадеб);

- размещение (координатная привязка) реконструированных объектов на воссозданном рельефе;

- размещение исторической парцелляции Белого города на воссозданном рельефе;

- использование VR-технологий для «погружения» пользователя в виртуальную среду Белого города.

Решение поставленных задач потребовало использования целого ряда цифровых технологий. Рассмотрим кратко, как использовались эти технологии и какие результаты создания виртуальных реконструкций исторического ландшафта и городской застройки Белого города удалось получить.

$$
* * *
$$

В ходе работы по виртуальной реконструкции исторических сооружений Белого города был освоен одного из методов получения натурных данных о частично сохранившихся архитектурных объектах - технологии 3D сканирования и аэрофотосъемки, с применением современных технических средств (лазерного сканера, коптера). $\mathrm{B}$ качестве примера 3D-моделей, выполненных разными методами, в данной работе представлены реконструкции ряда объектов исторической застройки восточной части Белого города, - церкви князя Владимира в Старых садех (XVII-XVIII вв.), ансамбля Ивановского 
монастыря (XVI-XVIII вв.), а также палат, расположенных по адресу Колпачный пер., 10/7 (в первой половине XVIII в. палаты входили в обширное владение А.Ф. Лопухина, брата царицы Евдокии Федоровны, первой жены царя Петра I; на плане 1769 г. они уже показаны как палаты Голицыных). Речь идет о градостроительных доминантах рассматриваемой территории - культовых сооружениях и крупных усадебных комплексах. Выявленные источники позволяют предложить верифицируемые реконструкции их внешнего облика. Однако в ряде случаев эти модели обладают определенной долей условности, достоверное воссоздание объемно-планировочной композиции зданий может сочетаться с заимствованиями по аналогам [2].

В 2020 г. в рамках проекта было проведено 3D-сканирование фасадов храма Владимира в Старых Садех (существующего в наше время). Для сканирования применялся лазерный сканер Leica BLK 360 с дальностью работы 60 метров. Поле зрения на $300^{\circ}$ по вертикали и на $360^{\circ}$ по горизонтали и большое количество точек съёмки 3D-сканирования (73,7 млн точек) в ходе работы позволили зафиксировать не только точный облик здания, но и большой объём окружающего пространства территории храма, особенности рельефа. Съёмка фасадов храма проводилась с уровня земли с разных точек обзора и с разных ярусов колокольни; полученная по облаку точек реконструкция облика храма использовалась для создания виртуальной реконструкции храма Владимира в Старых Садех на основе методик ретроспекции (рис. 1). В труднодоступных местах съёмки, где возможности лазерного сканера были ограничены (особенно на крыше собора), потребовалось провести комбинированную съёмку храма также и на беспилотном летательном аппарате (БПЛА) DJI Phantom 4 Standart (рис. 2) с последующим построением облака точек по материалам аэрофотосъёмки, совмещением двух облаков точек между собой и созданием 3D-модели современного состояния храма в программе Agisoft Metashape.

Реконструкция храма XVII века выполнена на основе его сложившегося облика, что позволило представить ретроспективную эволюцию памятника от современного состояния до первоначальных форм. В качестве основного программного средства для построения виртуальной реконструкции строений Белого города использовалась программа ArchiCAD (см. 3D-модель храма Владимира в Старых Садех, рис. 3 и палат Лопухина-Голицыных, рис. 4).

Следует отметить, что рельеф местности восточной части Белого города довольно сложный, перепад высот здесь достигает несколь- 
ких десятков метров, что потребовало создания трехмерной карты этого рельефа с помощью программных возможностей QGIS [3] (на основе упомянутых выше источников). На рис. 5 показана виртуальная реконструкция ландшафта восточной части Белого города, отражающая его парцелляцию на вторую половину XVIII в.

Особенности рельефа тщательно учитывались в ходе построения виртуальной реконструкции Ивановского монастыря - основного доминантного объекта (ансамбля) на территории Белого города, расположенного на Ивановской горке (это один их семи холмов Москвы). На рис. 6 приводится визуализация 3D-моделей строений монастыря и всего комплекса в целом. Эта реконструкция воспроизводит облик монастыря XVIII века, который радикально изменился после Отечественной войны 1812 г., когда он был ограблен и сожжен. В 1860-1879 гг. по проекту архитектора М.Д. Быковского был построен новый монастырский комплекс, сохранившийся и в настоящее время.

Завершающий этап проекта связан с использованием технологий виртуальной и дополненной реальности (VR/AR), но это тема следующей статьи.

\section{Библиография}

1. Бородкин Л.И. О виртуальной реконструкции исторического городского ландшафта Белого города // Историческая информатика. - 2019. - № 4. - С. 90-96.

2. Ким О.Г., Моор В.В., Жеребятьев Д.И. Виртуальная реконструкция доминантных объектов исторической застройки Белого города Москвы (XVI - XVIII вв.) // Историческая информатика. - 2020. - №2. - С. 100-134.

3. Энтин А.Л. Возможности использования геоинформационных технологий для реконструкции и анализа исторических поверхностей рельефа // Историческая информатика. - 2019. - № 4. - С. 97-107. 
ПРИЛОЖЕНИЕ

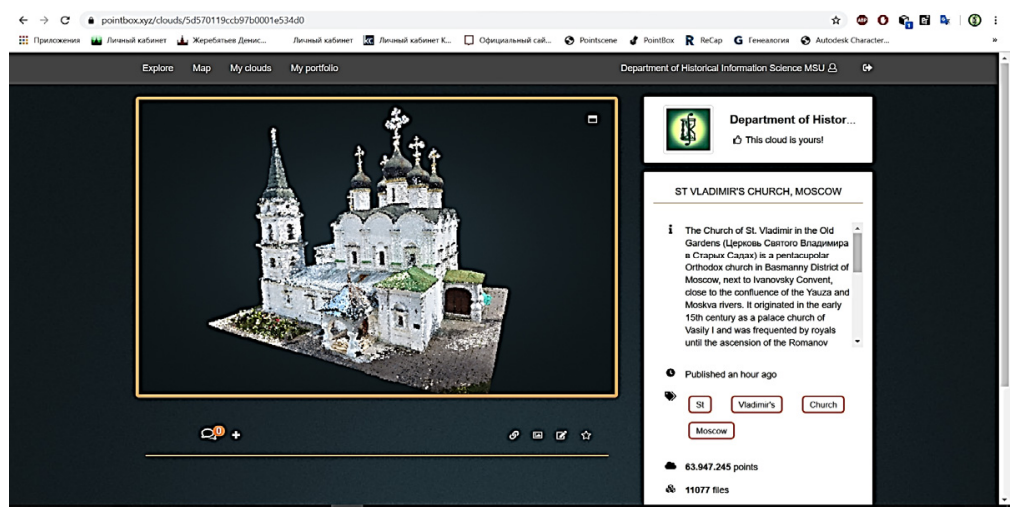

Рис. 1. Реконструкция по облаку точек (лазерное сканирование) храма князя Владимира в Старых Садех на сайте Pointbox

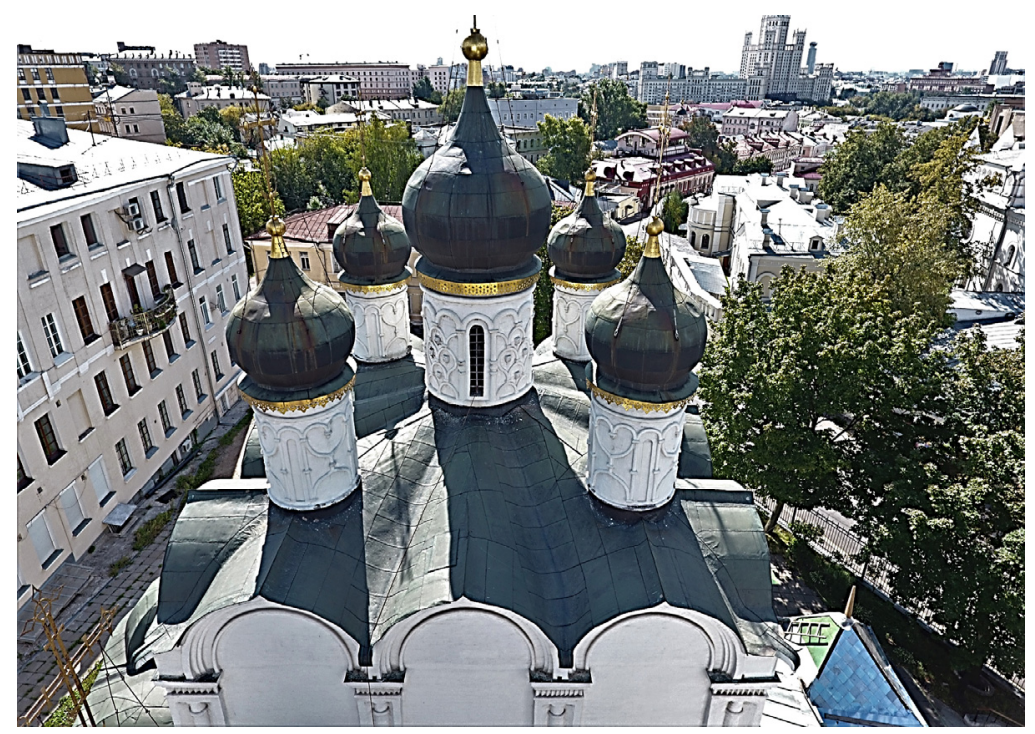

Рис. 2. Вид на купол храма князя Владимира в Старых Садех с квадрокоптера DJI Phantom 4 Standart после обработки в Adobe Lightroom 


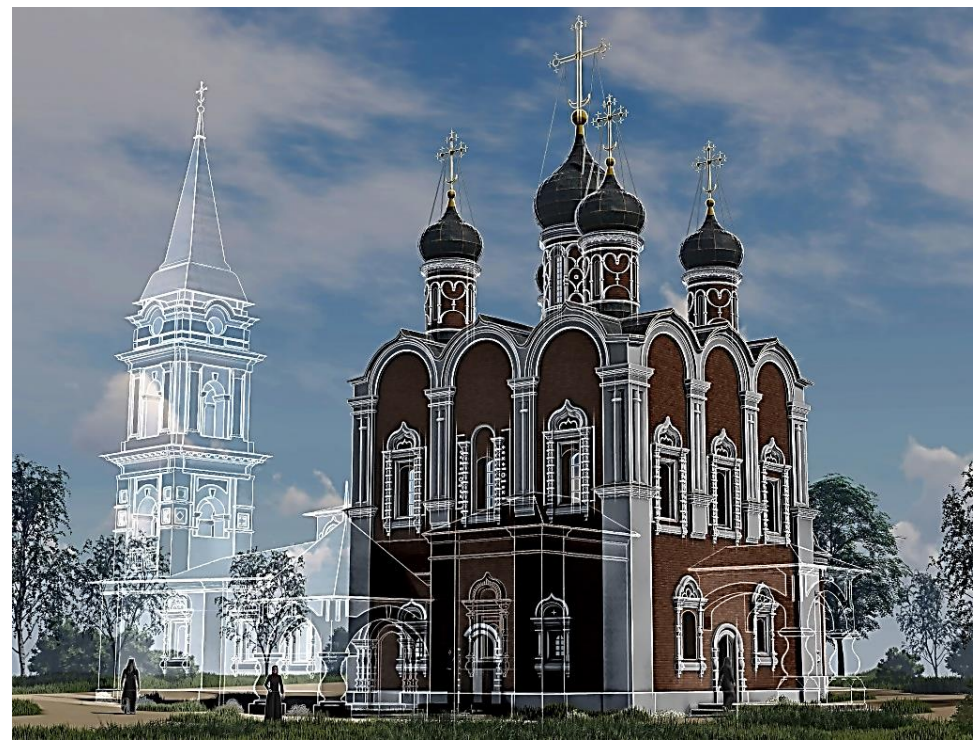

Рис. 3. Визуализация виртуальной реконструкции храма князя Владимира в Старых садех. Вид с юго-запада на XVII в. (основной объем, западный притвор, придел Кирика и Иулитты, южное крыльцо), конец XVIII в. (верхние ярусы колокольни), ХІХ в. (западное крыльцо)

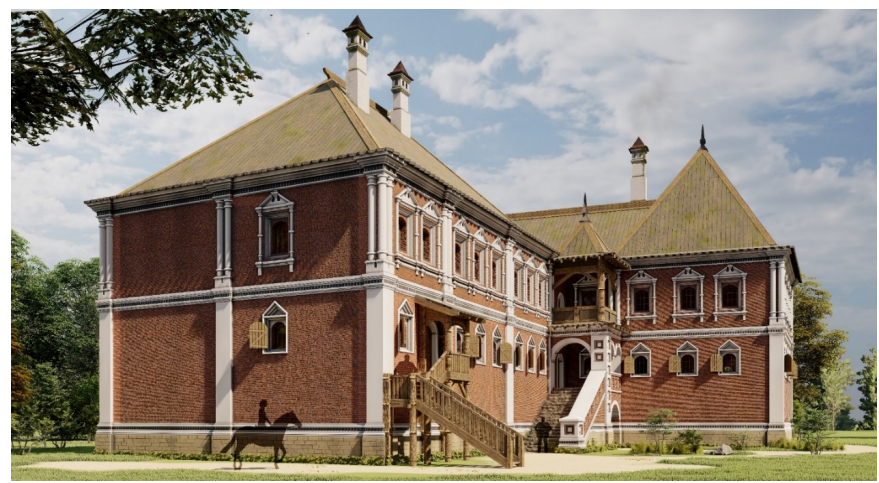

Рис. 4. Визуализация виртуальной реконструкции палат на территории Белого города (Колпачный пер., 10/7). В первой половине XVIII в. палаты принадлежали А.Ф. Лопухину, брату царицы Евдокии Федоровны, первой жены царя Петра I. На плане 1769 г. они уже показаны как палаты Голицыных 


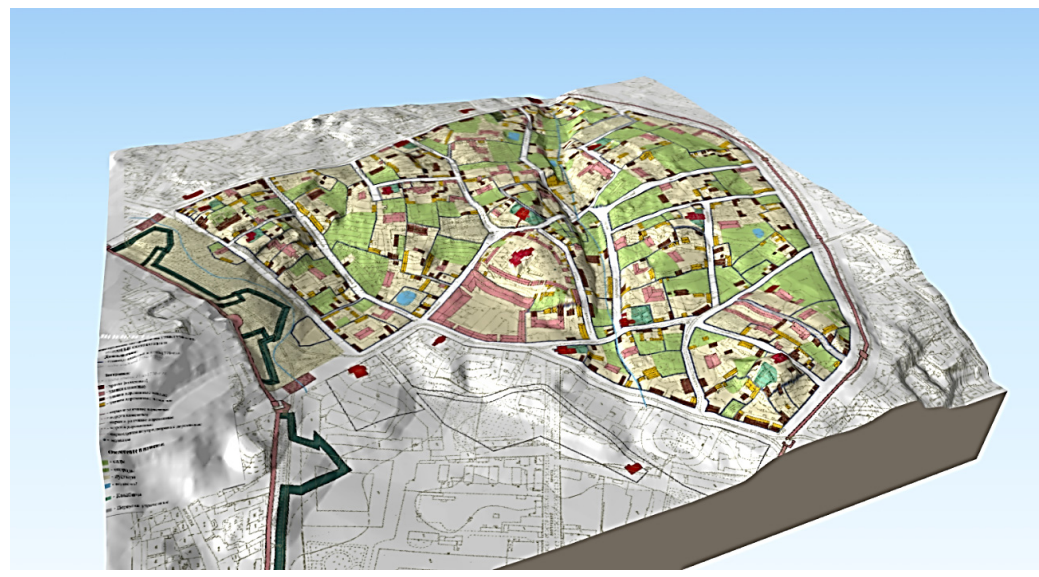

Рис. 5. Виртуальная 3D-реконструкция ландшафта восточной части Белого города, отражающая его парцелляцию на вторую половину XVIII в. (построена в программе QGIS)

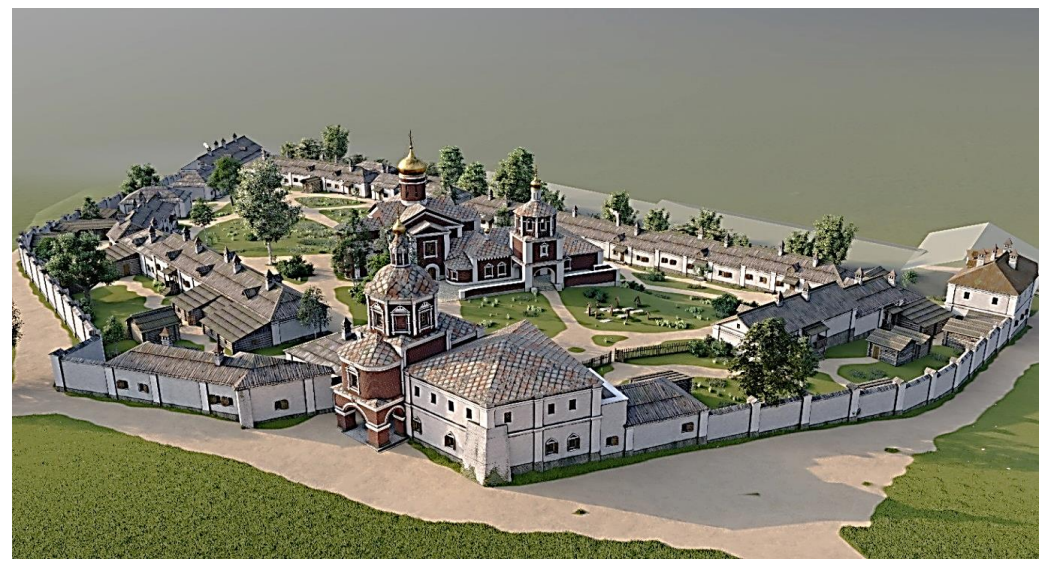

Рис. 6. Визуализация виртуальной реконструкции Ивановского монастыря на середину XVIII в. 
https://doi.org/10.29003/m1833.978-5-317-06529-4/361-365

Баранова Е.В., Верещагин В.А. Балтийский федеральный университет имени И. Канта, Калининград

\section{Виртуальная реконструкция дома Иммануила Канта в Кенигсберге XVIII в.}

Аннотация. Статья посвящена возможностям виртуальной реконструкции исторических объектов на примере дома И. Канта в Кенигсберге. С помощью метода 3D моделирования, на основе письменных и визуальных источников удалось воссоздать реалистичную модель дома И. Канта, его внешнего вида и внутренних помещений. Наша работа как часть большого проекта «Виртуальный Кант» позволила реконструировать один из самых значимых объектов в жизни И. Канта.

Ключевые слова: 3D моделирование, Иммануил Кант, региональная история, Кенигсберг, история быта.

Baranova E.V., Vereshchagin V.A. Immanuel Kant Baltic Federal University, Kaliningrad

\section{Virtual reconstruction of Immanuel Kant's house in Konigsberg of the 18th century}

Annotation. The article is devoted to the possibilities of virtual reconstruction of historical objects on the example of the house of I. Kant in Konigsberg. Using the method of 3D modeling, based on written sources, engravings, paintings, rare photo sources, memories, it was possible to recreate a realistic model of the house of I. Kant, its exterior and interior. Our work as part of the large project "Virtual Kant" allowed us to reconstruct one of the most significant objects in the life of I. Kant.

Keywords: 3D modeling, Immanuel Kant, regional history, Koenigsberg, history of everyday life.

В 2024 г. в Калининграде пройдет Международный Кантовский конгресс на базе Балтийского федерального университета имени И. Канта, такое решение было принято Кантовским обществом Германии. Мероприятие будет посвящено 300 -летию со дня рождения философа. Программа празднования юбилея включает в себя не только проведение научного Кантовского конгресса, будет реализовано множество проектов, связанных с туристической привлекательностью региона: реконструкция «тропы Канта», разработка нового 
туристического маршрута, большая издательская программа, выпуск сувенирной продукции и другое.

В рамках празднования юбилея и подготовки конгресса на базе Научно-исследовательского центра социально-гуманитарной информатики осуществляется проект «Виртуальный дом Канта». К проекту в дальнейшем подключились специалисты Тамбовского государственного университета им. Г.Р. Державина (М.Ю. Сидляр), Московского государственного университета им. М.В. Ломоносова (Д.И. Жеребятьев), Марбургского университета имени Филиппа, Германия (В. Штарк).

Целью проекта является реконструкция с помощью письменных и визуальных источников дома Иммануила Канта в городе Кенигсберг, в котором он проживал и преподавал с 1783 по 1804 год. Виртуальная реконструкция помещения представляет собой визуализацию внешнего вида и некоторых помещений дома И. Канта (кабинет, столовая, библиотека, лекционный зал, спальня), а также интерактивную панораму помещений, воссозданную путем трехмерного моделирования и визуализации помещений и объектов дома И. Канта. Стоит отметить, что в конце XIX в. здание было преобразовано в коммерческое здание с несколькими магазинами, что привело к значительным изменениям внешнего вида (сохранилась фотография этого времени). Помимо рекламных вывесок, в основном это касалось переделки фасадных окон во входные двери и витрины магазинов. Всего через несколько лет после того, как была сделана фотография, на этом месте было построено новое здание.

Основным источником для реконструкции стала работа служащего муниципального строительного управления Кенигсберга Вальтера Курке, который в 1917 г., опираясь на земельные книги, а также воспоминания владельца дома профессора Доббелина, воссоздал внешний и внутренний облик дома [1]. Помимо этого, использовались гравюры, открытки, картины этого периода, работы зарубежных и отечественных кантоведов.

Программным средством, используемым в нашей работе, стал 3ds Maх. Несмотря на всю сложность и трудоемкость работы в этом пакете, именно возможности этой программы позволяют наиболее точно и реалистично смоделировать полигональную сетку объектов, точно наложить текстуру, настроить реалистичное освещение. A плагин VRay для 3ds Max позволяет создавать высокого качества фотореалистичные визуализации. Программа совместима с такими архитектурными программами как AutoCAD и ArchiCAD, есть воз- 
можность импортировать созданные там объекты. Но в отличие от программ CAD, 3ds MAX позволяет создавать не только архитектурные объекты, но и сложные полигональные структуры, различного рода поверхности, жидкости, объекты из ткани и т.д. Что особенно важно для нашей работы - это фотореалистичность 3ds MAX при визуализации.

Первым этапом работы проекта стало составление чертежей и планировки дома И. Канта. Кант приобрел 30 декабря 1783 года дом у наследников портретиста Иоганна Готлиба Беккера при посредничестве лорд-мэра Теодора Готлиба Хиппеля. Это был двухэтажный дом с пристройкой и сводчатым подвалом 54 фута 6 дюймов в ширину со стороны улицы, 23 фута 4 дюйма справа и 26 футов в глубину слева. На нижнем этаже в одном крыле находился лекционный зал, а в другом - квартира повара, на верхнем этаже в одном крыле столовая, библиотека и спальня, в другом - гостиная и кабинет. Кабинет выходил на восток и имел открытый вид на несколько садов, слуга жил на маленьком чердаке. Стены были побелены, мебель простая, предметы домашнего обихода были не в изобилии. После смерти Канта 10 марта 1804 года дом философа был оценен мастером-плотником Келером и мастером-каменщиком Хеллером в 3500 флоринов [2, p. 13]. При реконструкции внешнего облика дома с помощью специалиста Тамбовского государственного университета им. Г.Р. Державина был исправлен ряд неточностей: изменено количество люкарн, сделаны скатные крыши к каждой люкарне, создана крыша ангарного типа, точка деления ската главной крыши была сделана по горизонтали от края правого окна (от края левого окна симметрично), треугольник фронтона поделен по вертикали пополам, крыша ближней пристройки стала совпадать с верхним краем балкона и др.

Следующим шагом стала поэтапная реконструкция столовой, библиотеки и лекционной комнаты. Это работа стала самой сложной. Так, при реконструкции столовой было принято решение ориентироваться на картину Эмиля Дёрстлинга «Кант и его сотрапезники». В 1892 году кёнигсбергский банкир и меценат Вальтер Симон поручил художнику, автору исторических полотен, написать картину, изображающую Канта в его доме в качестве хозяина. Руководствуясь сочинением Кристиана Фридриха Ройша «Кант и его сотрапезники» (1847) Дёрстлинг изобразил известных кёнигсбержцев, бывших частыми гостями Канта. В музее восстановленного Кёниг- 
сбергского кафедрального собора в Калининграде висит копия этой картины. В столовой находились стол, шесть стульев и столовые приборы на шесть персон.

Застольные вечеринки Канта в Кенигсберге были такими же легендарными, как и круглые столы Фридриха Великого в Потсдаме. Как отмечается в источнике, «еда всегда начиналась с супа, смешанного с раскрошенной говядиной, на столе стояла приготовленная самим Кантом английская горчица. В конце обеда приносили фрукты или легкие десерты в зависимости от сезона. На маленьком столике стояли масло и английский сыр. Среди любимых блюд философа были треска, репа из Тельтова, горох со свиными ножками, вино из Грюнштад и Бордо, Кант ненавидел пиво» [3, p. 48]. Все предметы в столовой, посуда, мебель, декор, а также еда нашли отражение в нашей реконструкции.

После реконструкции столовой был воссоздан лекционный зал с двумя окнами и одной дверью. Его площадь равнялась 35 квадратным метрам. Пространство заполнили типичными простыми скамьями, которые широко представлены на картинах XVIII в., была поставлена небольшая кафедра, на стенах повесили подсвечники и карту. Фотоизображения небольшого количества реальных вещей И. Канта, которые хранились в музее в Кенигсберге, также представлены в этой реконструкции. Это сюртук, треуголка, трость, секретер, пуговицы, бокал для шампанского с гравировкой.

Стоит отметить, что наиболее сложная часть - это восстановление библиотеки Канта. В 1922 году кенигсбергский юрист и исследователь Артур Варда опубликовал справочник книг Иммануила Канта [4]. Реконструкция библиотеки Канта сопряжена с некоторыми трудностями, обусловленными историческими особенностями. С одной стороны, инвентарь книг в описи наследия Канта отдельно не числится, а с другой стороны, он всю жизнь владел относительно небольшой библиотекой. На момент его смерти она состояла всего из 500 томов (включая множество небольших брошюр). Большинство книг - физико-математические и философские. Параллельно реконструкции дома наши коллеги трудятся над оцифровкой библиотеки Канта, поэтому просят предусмотреть функцию, которая бы позволяла брать с полок книги и листать их в 3D формате, либо с помощью ссылок попадать на страницу, где можно читать их в режиме электронной библиотеки. 
Наиболее сложной технической частью стало «состаривание» объектов. В источниках часто упоминается, что стены в домах XVIII века нужно было красить как минимум раз в год (обычно только белым мелом). Поскольку Кант не делал этого регулярно, стены его кабинета были черными от дыма печи, так что можно было писать пальцем на стене. Все объекты неровной формы намного сложнее в моделировании и более требовательны к ресурсам ПК. Требуется смоделировать все изгибы, неровности и сделать их максимально реалистично, непосредственно под стену создать сложносоставную текстуру. Получившийся материал нужно наложить на стену, для этого создается развертка, накладывается материал и подгоняется по месту. Все это потребовало очень больших ресурсов ПК, с одной стороны, с другой стороны - такую модель было достаточно трудно выложить на сторонние ресурсы. Поэтому реконструированный дом отличается «новизной» материалов, что иногда вызывает критику специалистов.

Стоит отметить, что реконструкция дома Канта в Кенигсберге в 3D - лишь начальный этап работы. В рамках дальнейшего развития проекта совместно со специалистами МГУ им. М.В. Ломоносова будет создана интерактивная экскурсия по реконструируемым объектам проекта «Эпоха Иммануила Канта» на платформах Twinmotion 2020.2 или Unity, комнаты и отдельные предметы интерьеров будут рахмещены на 3D онлайн платформе Sketchfab.

\section{Библиография}

1. Immanuel Kants Haus in Marburg / Lahn und sein alltägliches Leben (nach Walter Kuhrke, 1917/1924) [Электронный ресурс]. - Sächsisches Staatsarchiv, 1998 - URL: https:/www.archivportal-d.de/item/E3UUEAF2XHKN5JVTM6ZFV7M74D5SXQKZ?is ThumbnailFiltered $=$ false \&rows $=20 \&$ offset $=40 \&$ viewType $=$ list\&hitNumber $=43$ (дата обращения: 03.09.2020)

2. Jachmann R. Immanuel Kant, geschildert in Briefen an einen Freund. - Königsberg, 1804 .

3. Becker W. In der Stadt der reinen Vernunft, Zwei Kulturgeschichtliche Kapitel aus Alt-Königsberg, Kants Tafelrunde, Kants Spaziergang zum Philosophendamm. - Insterburg, 1932.

4. Warda A. Immanuel Kants Bücher. Mit einer getreuen Nachbildung des bisher einzigen bekannten Abzuges des Versteigerungskataloges [1808] der Bibliothek Kants. - Berlin: Martin Breslauer, 1922. 
3D-реконструкции объектов историко-культурного наследия. Виртуальная и дополненная реальность...

https://doi.org/10.29003/m1834.978-5-317-06529-4/366-370

Мироненко М.С.

Московский государственный университет имени М.В. Ломоносова

\section{Модуль верификации 3D-реконструкций объектов историко-культурного наследия в виртуальной и дополненной реальности. Проблема совмещения 2D и 3D-материалов ${ }^{1}$}

Аннотация. Рассмотрены вопросы подготовки и отбора исторических источников для интеграции их в модуль верификации. Представлены примеры использования модуля для разного типа источников. Описаны особенности разработки виртуального интерфейса для подобных задач на примере изобразительных исторических источников XIX века. Затронуты также вопросы интеграции нарративных источников в виртуальное пространство.

Ключевые слова: историческая информатика, виртуальная реальность, 3D-моделирование, культурное наследие, исторический источник.

Mironenko M.S. Moscow Lomonosov State University

\section{Verification module for 3D reconstructions of historical and cultural heritage objects in virtual and augmented reality. The problem of combining $2 \mathrm{D}$ and $3 \mathrm{D}$ materials}

Abstract. The issues of preparation and selection of historical sources for their integration into the verification module are considered. Examples of using the module for different types of sources are presented. The features of the development of a virtual interface for such tasks are described using the example of pictorial historical sources of the 19th century. The issues of integration of narrative sources into virtual space were also touched upon.

Keywords: Virtual reality, 3D modeling, cultural heritage, historical document.

Уже много лет на кафедре исторической информатики исторического факультета МГУ активно ведутся исследования в области применения 3D-моделирования. Наработки сотрудников кафедры нашли свое отражения в статьях $[1,2,3]$, проектах по реконструкции городской пространственной инфраструктуры [4] или исторических ландшафтов [5]. Активно внедряются эти методы и в квалификационные бакалаврские и магистерские работы.

За последние пять лет активно развилось направление виртуальной реальности (VR) в реконструкциях объектов историко-культурного наследия $[6,7,8]$. Пилотным проектом, на котором отраба-

${ }^{1}$ Исследование проводится при поддержке гранта РФФИ: № 18-00-01684. 
тывались подходы к созданию виртуальных пространств стал Страстной монастырь. Именно на его материалах была разработана первая версия модуля верификации для VR-устройств (рис. 1).

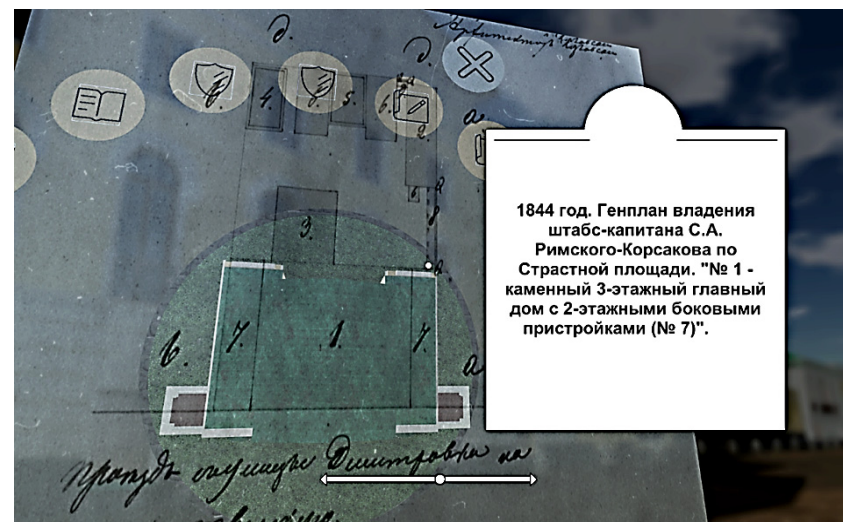

Рис. 1. Модуль верификации для VR-устройств

В рамках работы над проектом по трехмерной реконструкции городской исторической застройки с использованием технологий виртуальной реальности и геоинформационных систем (на примере исторического ландшафта Белого города Москвы XVI-XVIII) разработан прототип модуля второй версии. Важной особенностью которого является масштабируемость интерфейса, под пользователя, в случае использования VR-гарнитур или под размеры экрана устройства, в случае использования мобильных устройств (рис. 2).

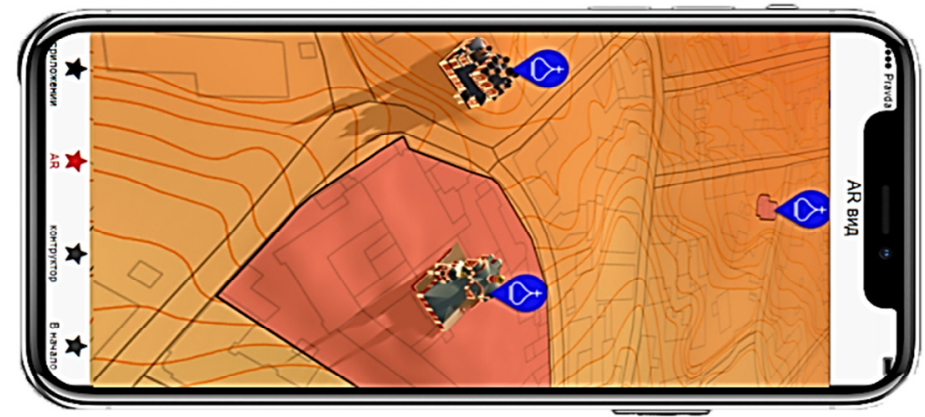

Рис. 2. Прототип интерфейса мобильного AR приложения с модулем верификации 
Сложности возникают при необходимости совмещения исторических источников с 3D-моделью, в.т.ч при работе с декоративными элементами, как, например, происходило в работе над моделью Чудова монастыря. Одна из основных причин, которая приводит к проблемам наложения источника - фокусное расстояние объектива, параметры которого нам неизвестны, дореволюционные источники, как правило, не снабжаются подобной информацией. Для того, чтобы устранить негативные эффекты от этого искажения, мы используем разные подходы автоматизированной и ручной обработки. Чаще всего это модуль lens correction в программе photoshop, но и этот инструмент имеет ряд ограничений, например, устранить такие эффекты как корабление бумаги ему не под силу. При работе с историческими источниками, которые были скопированы методом фотографирования вышеописанные сложности встречаются часто.

Поэтому для восстановления исходного положения мы используем формулу расчета фокусного расстояния.

$$
F=\frac{h \cdot S}{H} \text { или } F=\frac{v \cdot S}{V},
$$

где $S$ - расстояние до исследуемого объекта, $v$ и $h$ - вертикальные и горизонтальные размеры матрицы, которой оснащена камера, $V$ и $H$ - вертикальный и горизонтальный размер исследуемого объекта. Как видно из формулы, нам становится важен новый параметр, расстояние до объекта, который мы можем рассчитать с помощью метода масштабирования объектов на изображении. Для этого мы, с помощью вспомогательных материалов, определяем размер типового элемента, окна, или, например двери, и уже принимая это значение за единицу - создаем масштабную карту объекта.

Вообще, многие проблемы с источниками и сложности получения качественной копии последнего неоднократно в своих работах освещала Ю.Ю. Юмашева [9].

Ниже приведен скриншот модуля верификации на примере Открытки Т-ва Р. Голике и А. Вильборг (Кремль и Китай-город с высоты колокольни Ивана Великого), 1905-1907 г. (см. рис. 3).

Эта иллюстрация показывает, что как источник, с неизвестными параметрами фокусного расстояния совпадает лишь частично со строениями монастыря, особенно это заметно в перспективе на отдалённых и приближенных объектах. При проверке 3D-модели на планах, расхождений с источником не возникало.

Эти моменты сейчас прорабатываются, чтобы автоматизировать процесс адаптации источника к модулю. На данном этапе эту процедуру приходится выполнять вручную вышеописанными инструмен- 
тами. Сейчас удалось поместить в модуль верификации более 30 источников по декоративным элементам монастыря, 20 фотографий и гравюр общего плана.

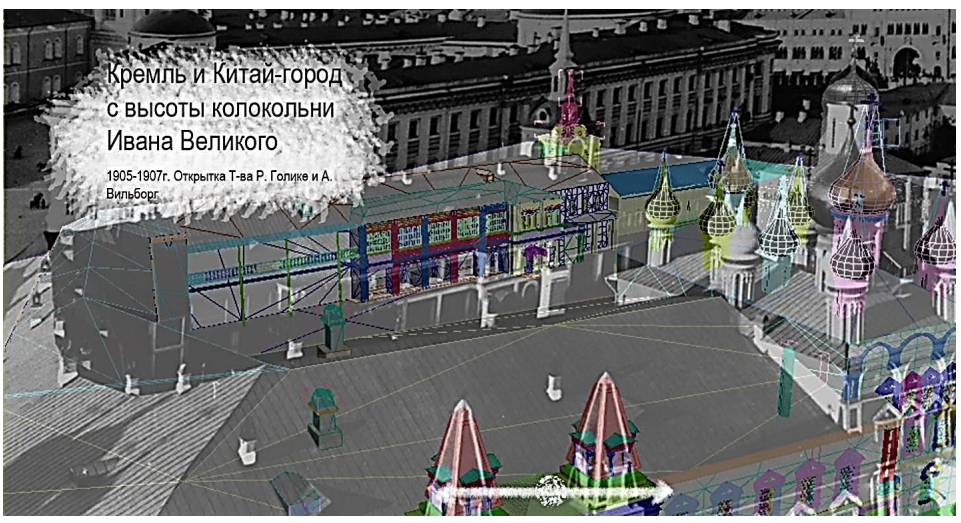

Рис. 3. Кремль и Китай-город с высоты колокольни Ивана Великого. 1905-1907. Открытка Т-ва Р. Голике и А. Вильборг

Отдельной сложной задачей стала интеграция текстовой информации. Большие объемы текста, как в VR-шлемах, так и с экрана мобильного устройства читать неудобно, да и для многих - это второстепенная информация. Поэтому в модуле верификации предусмотрено 2 режима знакомства с документами, а именно, общая информация, описывающий источник до 300 символов и разделение текста на тематические блоки, позволяющие не прочитывать полностью весь документ, а знакомиться непосредственно с интересующей пользователя частью.

Интересный подход по работе с историческими источниками предложил Пётр Курочински, в своей работе он соединил воедино визуализация модели и документацию и все это в Web-интерфейсе [10]. Но его подход не подразумевает прямую проекцию источника на реконструированный объект, но дает интересные инструменты работы с источником и моделью.

Суммируя все вышесказанное, хочется отметить, что использование подобных интерактивных проекционных систем в задачах исторической реконструкции показало свою эффективность. Появляется возможность не вглядываться в небольшие изображения источников, а сразу накладывать их на 3d-объект. В некоторых случаях возникает даже интересная ситуация, когда источники содержат разную инфор- 
мацию об одном и том же объекте или декоративном элементе. Тогда еще на этапе создания модели можно сразу в виртуальной среде их проецировать на прототип объекта, как в совместном режиме, так и поочередно. Неоднократно эта ситуация возникла при работе, как с Собором Чуда Архистратига Михаила в Хонех так и множеством декоративных элементов самого Чудова монастыря, но разбору этих интересных случаев стоит посвятить отдельную работу.

\section{Библиография}

1. Бородкин Л. И. Технологии $3 \mathrm{~d}-$ моделирования и виртуальной реальности в проектах реконструкции исторических городских ландшафтов // Электронный научно-образовательный журнал История. - 2020. - Т. 11. - № 3.

2. Applying numerical optimization to arrangement of elements in spatial interface for historical Moscow center virtual reconstruction / L. Borodkin, S. Lemak, M. Belousova et al. // Proceedings of the 11th Majorov International Conference on Software Engineering and Computer Systems (MICSECS 2019) / Ed. by Sergei Bykovskii, Pavel Kustarev, Dmitry Mouromtsev. S.-Petersburg, December 12-13, 2019. - Vol. 2590 of CEUR Workshop Proceedings (CEUR-WS.org). - CEUR-WS, 2020.

3. Inertial sensor based solution for finger motion tracking / S. Lemak, V. Chertopolokhov, A. Kruchinina et al. // COMPUTERS. - 2020. - Vol. 9. - No. 2. - P. 1-18.

4. Сайт проекта «Виртуальная реконструкция московского Страстного монастыря (середина XVII - начало XX вв.): анализ эволюции пространственной инфраструктуры на основе методов 3D моделирования» - URL: http://www.hist.msu.ru/ Strastnoy/ (дата обращения: 12.09.2020).

5. Сайт проекта по трехмерной реконструкции городской исторической застройки с использованием технологий виртуальной реальности и геоинформационных систем (на примере исторического ландшафта Белого города Москвы XVI-XVIII вв.). - URL: http:/landscape.vrmsu.ru/ (дата обращения: 12.09.2020).

6. Razuvalova, E.; Nizamutdinov, A. Virtual reconstruction of cultural and historical monuments of the Middle Volga // Procedia Comput. Sci. - 2015. - No. 75. P. 129-136.

7. Ferdani, D.; Fanini, B.; Piccioli, M.C.; Carboni, F.; Vigliarolo, P. 3D reconstruction and validation of historical background for immersive VR applications and games: The case study of the Forum of Augustus in Rome // Journal of Cultural Heritfge. - 2020. - Vol. 43. P. 129-143.

8. Virtual Reality Models Based on Photogrammetric Surveys. A Case Study of the Iconostasis of the Serbian Orthodox Cathedral Church of Saint Nicholas in Sremski Karlovci (Serbia) // Applied Sciences. - 2020. - No. 10 (8). - 2743 - Special Issue "Virtual Reality and Its Application in Cultural Heritage" - URL: https://doi.org/10.3390/ app10082743 (дата обращения: 12.09.2020).

9. Юмашева Ю.Ю. Международный опыт решения проблемы самостоятельного цифрового копирования в читальных залах архивов и библиотек // Историческая информатика. - Электрон. журнал. - 2017. - № 2. - С. 95-133. - URL: https://nbpublish. com/library_read_article.php?id $=21905$.

10. Dworak, Daniel \& Kuroczyński, Piotr. (2016). Virtual Reconstruction 3.0: New Approach of Web-based Visualisation and Documentation of Lost Cultural Heritage // EuroMideterranian Conference «Digital Heritage. Progress in Cultural Heritage: Documentation, Preservation, and Protection». Nicosia, Cyprus, October, 2016. - Pp. 292-306 - URL: https://link.springer.com/book/10.1007/978-3-319-48496-9. 
https://doi.org/10.29003/m1835.978-5-317-06529-4/371-377

Чертополохов В.A. Московский государственныий университет имени М.В. Ломоносова

Григорян Г.Л. ООО «Тотал вижн»

\title{
Применение технологии фовеального рендеринга для оптимизации производительности сложных сцен виртуальной исторической реконструкции ${ }^{1}$
}

Аннотация. В докладе рассматривается задача увеличения частоты кадров при рендеринге высоконагруженных сцен виртуальной исторической реконструкции Белого города. Реконструкция воспроизводится в шлеме виртуальной реальности. Для улучшения производительности авторами используется метод фовеального рендеринга: отображение в высоком разрешении только той области сцены, на которую в данный момент смотрит пользователь. Была разработана и протестирована новая система отслеживания направления взора, проведено сравнение частоты кадров для сцены Белого города.

Ключевые слова: виртуальная реальность, оптимизация производительности, фовеальный рендеринг, историческая реконструкция.

Chertopolokhov V.A. Moscow State University named after M.V. Lomonosov

Grigoryan G.L. LLC «Total Vision»

\section{Application of foveal rendering technology to optimize the performance of complex scenes of virtual historical reconstruction}

\begin{abstract}
Authors examine a problem of increasing a frame rate during highload scenes rendering for virtual historical reconstruction of Bely Gorod. The reconstruction is designed to be rendered using a virtual reality headset. To improve performance, authors implemented a foveated rendering technique. It allows to display in high resolution only the area of the scene that the user is currently looking at. A new gaze tracking system was developed and tested, and frame rates were compared for the Bely Gorod scene.

Keywords: virtual reality, VR performance optimization, foveated rendering, historical reconstruction.

\footnotetext{
${ }^{1}$ Исследование проводится при поддержке гранта РФФИ, № 18-00-01684(К) (18-00-01590).
} 


\section{Введение}

В последние годы технологии виртуальной реальности активно внедряются как инструмент наглядного отображения различных объектов и процессов, в том числе в исторических задачах. В рамках совместного проекта исторического и механико-математического факультетов МГУ создается виртуальная реконструкция территории Белого города XV-XVIII вв. Сцены реконструкции включают визуализацию рельефа, растительности и моделей зданий, воссозданных в архитектурной системе автоматизированного проектирования (САПР) по набору источников. При автоматической конверсии САПР-модели в формат, доступный для воспроизведения в шлеме виртуальной реальности, итоговая модель получается недостаточно оптимизированной для рендеринга в реальном времени.

Частота кадров для современных систем виртуальной реальности составляет 60 Гц и более [1], что не всегда достижимо для высоконагруженных сцен. Одно из возможных решений проблемы - использование биологических особенностей человеческого зрения. Известно, что область четкого видения на сетчатке глаза человека находится внутри конуса с углом примерно в 4 [2]. Идея фовеального рендеринга заключается в визуализации с высоким разрешением не всего изображения на экране, а только его небольшой части, которая попадает в область четкого видения. Эта идея прорабатывалась с начала 90-х годов [3, 4], но получила наибольшее распространение с появлением массовых систем виртуальной реальности $[5,6,7]$. Часть сцены, на которую смотрит пользователь, определяется с помощью окулографа (системы отслеживания направления взора).

Анализ движения глаз является достаточно сложной задачей. Возникает ряд ошибок в работе систем отслеживания из-за вращения головы человека, ходьбы, дыхания, смещения системы слежения за глазами. Первые высокоточные комплексы обладали большими размерами, были жестко фиксированными, также фиксировалась голова пользователя. В таких условиях было проведено значительное количество исследований функционирования зрительной системы. В наши дни возникла потребность использовать алгоритмы для новых задач, когда система окулографии размещается на очках или гарнитуре виртуальной реальности.

Авторами предложена и применена новая технология, позволяющая отслеживать движения глаз пользователя с высокой частотой в 1000 Гц. Также было проведено сравнение производительности сцены виртуальной реконструкции Белого города в режиме полного разрешения и режиме фовеального рендеринга. 


\section{Принцип работы окулографической системы}

Зрительное восприятие организовано как последовательная фиксация взора на постоянно меняющихся отдельных точках. Перевод взора с одной точки на другую всегда осуществляется саккадой быстрым совместным движением глаз. Типичная продолжительность движения составляет 0,01-0,1 с., типичная угловая скорость вращения глаза может достигать 500\% [1]. Поэтому, чтобы успеть провести рендер изображения, требуется определить точку остановки взора в середине саккадического движения. Это приводит к требованию обеспечить высокую частоту отслеживания движений глаз (250 Гц., и выше) [8].

Распространенным решением для систем отслеживания движения и окулографии является физически разнесенные фотодатчик и система обработки изображений. Проецируемое изображение с фотодатчика передается на внешний компьютер для обработки изображения и решения задачи отслеживания положения объекта. Отрицательная сторона решения - большой объем данных для передачи и обработки, низкая скорость, высокое энергопотребление. Чтобы устранить эти недостатки, была предложена новая схема типа «видеосистема на кристалле». Система на кристалле была разработана для упрощенного поиска темных или белых объектов на однородном фоне с частотой обработки до 1000 Гц. Она позволяет определять координаты, площадь и яркость точки и может держать в буфере до пятидесяти объектов в каждом кадре с этой частотой. Полученная информация позволяет найти зрачок (темный объект на белом фоне) и определить направление взгляда человека. Система работает в широком спектральном диапазоне, поэтому можно использовать различные конструкции для отслеживания взгляда. В собранном виде устройство имеет достаточно небольшие габариты, массу, высокую точность, низкое энергопотребление, поэтому вполне годится для носимых систем.

Помимо координат зрачка, система на кристалле иногда передает координаты ложных объектов. При этом система позволяет передавать на компьютер полноценный видеоряд с частотой 60 Гц. Чтобы устранить проблему ложных целей, распознавание изображений применяется на компьютере для каждого полученного кадра видео, после чего координаты зрачка вычисляются с высокой частотой по показаниям системы на кристалле в предположении о непрерывности движения глаза. 
По сравнению с другими окулографами, полученное решение сочетает в себе высокую точность и высокую скорость работы, обычно недоступную в портативных системах.

Сами камеры расположены за линзами, поэтому с точки зрения удобства использования гарнитура виртуальной реальности с окулографом отличается от гарнитуры без него только инфракрасной подсветкой вокруг линз. Наконец, возможности системы на кристалле позволяют проводить расчеты даже на слабых портативных компьютерах, таких как Raspberry Pi.

Опытный образец системы был проверен на экспериментальной установке для определения точностных характеристик. Глаз имитировал шар с нарисованным на нем зрачком. Объект был закреплен на высокоточном вращающемся столе. Во время измерения имитатор поворачивался на определенный угол, и положение изображения зрачка на датчике фиксировалось. Для определения координат на датчике использовались внутренние алгоритмы системы на кристалле. Для каждой позиции было выполнено 100 измерений для дополнительной обработки данных и статистических расчетов. Объект освещался источником света в видимом спектральном диапазоне. В этом эксперименте использовалась линза с полем зрения $\pm 20^{\circ}$. Линейное поле зрения линз было немного меньше размера сенсора.

Положение центра пятна можно определить с точностью выше пикселя (за счет усреднения весовых значений освещенности. По результатам экспериментов, чувствительность составила 3,5 угловых минуты. Значение среднеквадратичной ошибки было менее 2,5 угловых минут на уровне $3 \sigma$. Таким образом, по диагонали мы можем получить поле зрения около $35^{\circ}$ с расчетной точностью. Точность измерений можно повысить за счет обработки данных с соответствующим уменьшением частоты кадров. Поле зрения системы можно увеличить с помощью другого объектива с определенным фокусным расстоянием. Точность в этом случае следует масштабировать обратно пропорционально величине поля зрения.

Полученная точность и частота работы позволяет определить быстрое движение глаза. Был предложен алгоритм выполнения предсказания саккады и фовеального рендеринга [8]. Он включает в себя следующие фазы:

- построения определяющих соотношений между амплитудой и временем саккады для различных параметров,

- определения исходных параметров математической модели для небольшого набора выполненных пользователем саккад, 
- подбора подходящей пары определяющих отношений,

- оценки максимальной скорости глаза на саккаде с использованием полученных данных окулографа в реальном времени и смоделированной кривой для саккады,

- оценки амплитуды саккады и определения области рендеринга.

Итоговая область рендеринга высокой четкости регулируется в зависимости от субъективных ощущений пользователей, поскольку возможен случай, когда изменение качества изображения в зоне остановки глаза будет заметно.

\section{Применение фовеального рендеринга при отображении виртуальной реконструкции}

Виртуальная историческая реконструкция была собрана в графической среде Unreal Engine 4.25.1 и включала в себя следующие элементы:

- трехмерную модель ландшафта в виде полигонального меша,

- копию ландшафта с выключенным отображением поверхности, реализованную встроенными методами Unreal Engine,

- размещенные на поверхности «невидимого» ландшафта элементы растительности,

- трехмерные модели фоновой застройки,

- трехмерные модели церкви Трех святителей на Кулишках, церкви Троицы в Хохловке и храма Петра и Павла у Яузских ворот.

Виртуальная камера в сцене была поставлена в фиксированную точку. Общее количество полигонов в сцене с учетом применения уровней детализации для растительности составило 21,8 млн. Значительную часть из общего количества полигонов занимали растительные объекты и храмы, конвертированные из САПР-системы. В то время как для далеко расположенных от камеры растительных объектов есть давно известные методы полуавтоматической оптимизации вроде применения billboard (плоскости из двух треугольников с нанесенной на нее заранее созданной текстурой всего дерева), уменьшение количества полигонов для архитектурных объектов может быть выполнено только вручную. Сцена запускалась на ноутбуке с процессором Intel Core i9-9880Н 2.3 ГГц., 32 Гб. оперативной памяти, видеоадаптер Nvidia GeForce RTX 2080. Изображение выводилось на шлем виртуальной реальности Total Vision VR4 с частотой обновления дисплея 60 Гц. и совокупным разрешением на оба глаза $2880 \times 1440$ пикселей. 
Было проведено 5 сравнительных тестов, каждый из которых состоял из 20 минут нахождения пользователя в виртуальной среде в двух режимах: полного разрешения и фовеального рендеринга. В режиме полного разрешения сцена выводилась в разрешении $2880 \times 1440$ пикселей; для фовеального рендеринга использовалось базовое разрешение $1440 \times 720$ пикселей, и максимальная детализация применялась в квадрате 10 на 10 угловых градусов.

В результате, максимальное количество кадров в секунду для двух режимов получилось одинаковым: 60 Гц. достигались в отдельные моменты изучения сцены пользователем. Разница в средних значениях оказалась существенной: 36,61 кадров в секунду и 54,84 кадра в секунду для полного разрешения и фовеального рендеринга соответственно. Данный тест показывает прирост производительности в $50 \%$ вместе со значительно возросшим процентом времени, когда достигается комфортное для человеческого восприятия значение частоты кадров в 60 Гц. При этом, для различных конфигураций и сцен этот прирост может быть как выше, так и несколько меньше.

Важно отметить, что итоговая версия виртуальной исторической реконструкции будет содержать не только трехмерные модели, но также интерфейс модуля верификации [9]. Модуль верификации позволяет загружать информацию об исторических объектах в виртуальную среду из специализированной базы данных. Полученная информация включает как текстовые описания, так и чертежи, гравюры, фотографии, которые возможно наложить на реконструированный трехмерный объект с целью проверки точности реконструкции и уточнения необходимых деталей. Формат хранения изображений в Unreal Engine предусматривает применение метода МІР-текстурирования, когда помимо текстуры в высоком разрешении хранится набор ее уменьшенных копий.

Загрузка в оперативную и видеопамять всего массива изображений в полном разрешении может приводить к существенному ухудшению производительности трехмерной сцены. Отслеживание взора пользователя позволит подгружать в высоком разрешении только те изображения модуля верификации, на которые пользователь смотрит в данный момент, что также может дать прирост производительности сцены.

Еще одна область применения отслеживания взора - анализ взаимодействия пользователя с виртуальной средой. Построение «карт внимания» с помощью окулографии достаточно широко применяется в задачах нейромаркетинга [10], близкий подход возможно при- 
менять при оценке интереса пользователей к отдельным частям исторической реконструкции и в задаче оптимизации расположения элементов виртуального интерфейса.

\section{Заключение}

Были изготовлены и испытаны прототипы шлема виртуальной реальности с высокочастотной системой отслеживания взора. Частота отслеживания в 1000 Гц позволила использовать обнаружение быстрых движений глаза в задаче фовеального рендеринга. Этот подход показал значительный прирост в частоте кадров по сравнению с отображением сцены реконструкции Белого города в полном разрешении.

В дальнейшем полученная технология отслеживания направления взора будет применена для улучшения взаимодействия пользователя с интерфейсом виртуальной исторической реконструкции.

\section{Библиография}

1. Кручинина А.П., Латонов В.В., Чертополохов В.А. Обзор технологий визуальной имитации в тренажерных системах // Пилотируемые полеты в космос. 2019. - № 3. - С. 89-107.

2. Ярбус А.Л.. Роль движений глаз в процессе зрения. - М.: Наука, 1965. - 166 с.

3. Levoy M., Whitaker R. Gaze-directed volume rendering // ACM SIGGRAPH Computer Graphics. - 1990. - 24(2): 217-223.

4. Ohshima T., Yamamoto H., Tamura, H. Gaze- directed adaptive rendering for interacting with virtual space. // Virtual Reality Annual International Symposium. Proceedings of the IEEE-1996. - IEEE: 103-110.

5. Guenter B., Finch M., Drucker S., Tan D., Snyder J. Foveated 3D graphics. // ACM Transactions on Graphics (TOG). - 2012. - 31 (6). - P. 164.

6. Patney A., Salvi M., Kim J., Kaplanyan A., Wyman C., Benty N. et al. Towards foveated rendering for gaze-tracked virtual reality // ACM Transactions on Graphics. - 2016. 35(6). - P. 1-12.

7. Kim J., Majercik Z., Shirley P., Spjut J., McGuire M., Luebke D., et. al. Foveated AR. // ACM Transactions on Graphics. - 2019. - 38(4). P. 1-15.

8. Kruchinina A., Chertopolokhov V., Grigoryan G., Belyaev V. Prediction of Saccadic Eye Movement for Foveated Rendering // SID 2020 Digest of Technical Papers. 2020. - URL: https://sid.org/Portals/5/pdf/Digest/2020/docs/54-4.pdf (дата обращения: 01.09.2020).

9. Лемак С.С., Чертополохов В.А., Кручинина А.П., Белоусова М.Д., Бородкин Л.И., Мироненко М.С. Задачи оптимизации расположения элементов интерфейса в виртуальной реальности (в контексте создания виртуальной реконструкции исторического рельефа Белого города) // Историческая информатика. - 2020. - № 1. - С. 81-93.

10. Латанов А.В., Королева М.В., Галкина Н.В., Элинзон Д.Л. Нейромаркетинг прикладное применение // Бизнес-анализ и поведенческая экономика / Под ред. И.Р. Дун, М.М. Шарамко, Э.Р. Мубаракшина. - М.: Тезаурус, 2015. - С. 178-195. 


\title{
ИНФОРМАЦИОННЫЕ ТЕХНОЛОГИИ В АРХИВАХ И МУЗЕЯХ: ПРОБЛЕМЫ МЕТОДОЛОГИИ И МЕТОДИКИ В КОНТЕКСТЕ ИСТОРИЧЕСКОЙ НАУКИ
}

https://doi.org/10.29003/m1836.978-5-317-06529-4/378-384

Боброва Е.B.

Российский университет транспорта (РУТ)

\section{Порталы в архивные пространства}

\begin{abstract}
Аннотация. В статье анализируется проблема поиска через Интернет информации об архивах и хранящемся в них документальном наследии. Рассматривается история и роль портала Архивы России, а также дается технологический анализ существующих архивных порталов субъектов Российской Федерации.
\end{abstract}

Ключевые слова: архивы, пользователи, информационное обслуживание, архивные сайты, архивные порталы, научно-справочный аппарат, архивные справочники, доступ к архивным ресурсам.

Bobrova E. $\boldsymbol{V}$.

Russian University of Transport, Moscow

\section{Portals to archive spaces}

Abstract. The article analyzes the problem of searching through the Internet for information about archives and the documentary heritage stored in them. The history and role of the portal Archives of Russia is considered, and a technological analysis of the existing archival portals of the constituent entities of the Russian Federation is given.

Keywords: archives, users, information services, archival sites, archival portals, scientific reference apparatus, archival directories, access to archival resources.

Архивные информационные ресурсы в Рунете начали создаваться двадцать лет назад и продолжают развиваться, но поиск информации об архивах и хранящихся в них документах все еще остается актуальной проблемой.

Это объясняется рядом факторов:

- отсутствие у большей части пользователей базовых знаний об архивном деле в нашей стране, что и где может храниться;

- недостатки сайтов архивных учреждений, многие из которых не содержат нужную информацию; имеют неудобную, непонятную для пользователя систему навигации;

- проблемы с поиском архивных информационных ресурсов в сети Интернет. 
Если пользователь не имеет четкого представления о том, что именно ему требуется, в каком конкретном архиве эта информация может находиться, то поиск через поисковые машины Интернета не приведет к нужному результату.

Если информация, необходимая пользователю, в архивном учреждении есть, но на его сайте об этом не написано, или же информация, размещенная на сайте, не доступна для индексации поисковым машинам Интернета, поиск через них также бесполезен.

Согласно результатам анализа, проведенного нами в июнеавгусте 2019 г., в Рунете была представлена информация обо всех 85 органах управления архивным делом, 15 федеральных и 190 (из 195) региональных архивах [1, с. 30]. Но информация эта рассредоточена по сайтам разного типа.

Если с федеральными архивами все достаточно просто - у каждого есть собственный сайт и свой раздел на портале «Архивы России», то у регионов все сложнее.

Согласно Федеральному закону «Об обеспечении доступа к информации о деятельности государственных органов и органов местного самоуправления» от 09.02.2009 № 8-Ф3 у каждого государственного органа или органа местного самоуправления должен быть свой официальный сайт. И они существуют. Но одна из проблем заключается в том, что во многих регионах управление архивным делом не имеет статуса самостоятельной службы - функции управления архивным делом переданы органам юстиции, культуры и т.д., и их сайты не всегда содержат полную информацию об архивах. Другая проблема в том, что к сайтам госорганов и органов местного самоуправления в плане их информационного наполнения предъявляются стандартные требования, в рамки которых специфическая архивная информация не укладывается. В связи с этим многие сайты (или разделы на сайтах правительства регионов) органов управления малоинформативны и, следовательно, малополезны для пользователей.

Очевидно, что выходом из этой ситуации может быть создание единых точек входа в архивное пространство, максимально аккумулирующих всю архивную информацию по региону.

Ресурсы такого рода существуют и называются порталами. Интернет-порталы в Рунете активно развиваются с 1999 года.

Существуют горизонтальные порталы. Это универсальные порталы, охватывающие все тематики и предлагающие набор сервисов, обслуживающих, по возможности, все темы, ориентированные на 
максимальный охват интересов аудитории, но при этом не претендующие на глубину погружения в предметную область. Пример такого горизонтального портала - поисковая система Яндекс.

Помимо горизонтальных порталов существую вертикальные порталы. Вертикальный портал - это портал узкой тематической направленности, предоставляющий сервисы для пользователей по определенным интересам и ориентированный на полный охват конкретной тематики или сферы деятельности. К такого рода ресурсам относятся архивные порталы.

Первым архивным порталом Рунета стал портал «Архивы России» (rusarchives.ru), открытый 30 января 2001 г. Он изначально задумывался как единая точка входа в архивное пространство страны и в первое десятилетие своей жизни именно эти функции и выполнял. Войдя на сайт, пользователь получал возможность:

- ознакомиться с архивными новостями (как на федеральном, так и на региональном уровнях);

- получить доступ к контактной информации: Росархива, федеральных архивов, региональных органов управления архивным делом и архивов, архивохранилищ федеральных музеев и библиотек. В том числе к кратким описаниям состава и содержания фондов архивохранилищ;

- получить информацию о выложенных Интернете архивных справочниках. Часть справочников размещалась непосредственно на портале «Архивы России», а на все справочники и базы данных, размещенные на сайтах архивных учреждений давались актуальные ссылки;

- ознакомиться с документальными выставками, проводившимися в Выставочном зале федеральных архивов и других выставочных площадках;

- прочитать тексты докладов на архивных конференциях;

- ознакомиться с законодательными, нормативными и методическими документами, регулирующими архивную сферу;

- ознакомится с публикациями (выборочно) архивных СМИ;

- получить информацию о запросах и услугах, доступных для пользователей;

- задать вопросы в гостевой книге сайта или на форуме;

- воспользоваться постоянно обновляющимся каталогом архивных ресурсов (включавшего ссылки на сайты зарубежных национальных архивов и архивных служб); 
- получить доступ к иным информационным ресурсам Росархива (в т.ч.к тематическим проектам, размещенным и на отдельных доменах третьего уровня в домене rusarchives.ru).

В 2004 г. фирмой Ист Вью по гранту Министерства образования США в рамках программы Технологических инноваций и сотрудничества в области информации о зарубежных странах [2] и под патронажем Росархива был создан еще один ресурс портального типа - БД «Путеводители по Российским архивам», позволявший проводить поиск на уровне фондов по путеводителям и кратким справочникам федеральных и региональных архивов. По данным на 2018 г. в БД насчитывалось 34 справочника по фондам федеральных архивов и 93 справочника по фондам региональных архивов [3]. Особенностью это БД было использование технологии XML, которая позволяет эффективно работать со слабоструктурированными данными, характерными для архивного справочника типа путеводителя. По непонятным причинам спустя более чем десять лет существования проекта в Росархиве приняли решение переделать ПО, заменив XML БД на MySQL БД. Новая версия, появившаяся в 2019 г. потеряла большую часть контента (по состоянию на август 2020 г. она насчитывает 19 справочников по фондам федеральных архивов и только 6 справочников по фондам региональных архивов), автоматически создаваемый межархивный указатель фондов и качественный расширенный поиск. Таким образом, портальная суть базы данных в значительной степени была утрачена.

В 2009 г. в связи с изменениями в законодательстве информация о деятельности Росархива была перенесена с портала «Архивы России» на специально созданный для этого сайт archives.ru. В 2010 г. была закрыта Гостевая книга. Ее функции стали выполнять формы для отправки запросов на официальном сайте Росархива.

10 января 2012 г. на портале «Архивы России» была размещена тестовая версия «Центрального фондового каталога» (ЦФК) с информацией о составе и содержании фондов 10 федеральных архивов [4]. К сожалению, это давно ожидаемое портальное решение изначально имело ряд недостатков, которые впоследствии так и не были устранены, несмотря на то, что в октябре 2018 г. появилась его новая версия. Так, в частности, до сих пор не реализована индексация БД поисковыми системами Интернета, отсутствуют сведения о статистике посещаемости ресурса, что мешает оценить его реальную востребованность [5, с. 32]. 
13 января 2015 г. Росархив открыл новую версию портала «Архивы России». По условиям контракта вся информация со старой версии портала должна быть на новую, но этого не произошло.

За бортом остались: архивные справочники, размещенные непосредственно на rusarchives.ru; каталог архивных ссылок; информация об архивохранилищах музеев и библиотек; информация о прошедших в 2000-х годах архивных выставках и конференциях (включая тексты докладов и огромный массив оцифрованных экспонатов выставок) и многое другое, что являлось важнейшей частью именно портального решения. Ситуацию спасало то, что разработчики оставили старую версию сайта и доступ к его ресурсам все еще был возможен по адресу http://portal.rusarchives.ru/ до 6 апреля 2020 года. Однако по состоянию на конец августа 2020 г. ссылка все еще существует, а доступа по ней нет, и огромный пласт информации, накопленный за первые 15 лет архивного сайтостроения, оказался утерянным для пользователей.

Такое важное для коммуникации портальное решение, как общеотраслевой форум, тоже фактически перестал поддерживается. Он существует по прежнему адресу http://forum.rusarchives.ru/, ссылка на него с портала «Архивы России» стоит, но на вопросы пользователей никто не отвечает. За 2020 г. на нем зафиксировано только два новых сообщения - один вопрос и одна реклама услуг по архивному поиску.

Конечно, и в текущей версии портал «Архивы России» можно использовать для поиска контактной информации архивов, однако даже информация по адресам действующих архивных сайтов на нем не всегда актуальна.

По примеру Росархива в ряде регионов были созданы архивные порталы. Они называются по-разному, чаще всего просто «Архивы ... региона».

В некоторых регионах помимо таких порталов существуют и собственные сайты архивных учреждений, на которые на порталах даются ссылки, но пользователям удобнее, когда вся интересующая их информация находится на одном портальном сайте.

По состоянию на август 2020 г. такие архивные порталы созданы в 23 субъектах РФ. К сожалению, некоторые из них, перестали функционировать (например, за последний год исчезли два портальных сайта республики Татарстан и портал Архивы МариЭл).

Яндекс считает самым авторитетным из этих порталов сайт Архивы Санкт-Петербурга (https://spbarchives.ru/). Его индекс качества сайта (ИКС) составляет 940. Два года назад он был 550 [5, с. 35]. Отметим, что ИКС у этого портала растет быстрее, чем ИКС портала 
«Архивы России» - в 2018 г. он составлял 1000, а в августе 2020 1330. Порталы Удмуртии (http:/gasur.ru/) и Воронежской области имеют ИКС 450 (http://www.arsvo.ru/), остальные существенно меньше. К сожалению, ИКС десяти порталов узнать невозможно, так как эти сайты имеют домен третьего уровня, а ИКС считается только для доменов второго уровня.

Согласно данным поисковой системы Яндекс, самое больше количество страниц (более 40 тыс.) проиндексировано ею на сайтах Архивы Прикамья (https://archives.permkrai.ru/), Электронный архив Новосибирской области (http://www.e-archive.nso.ru/), интернет-портал архивной службы Ярославской области (https://af.yar-archives.ru/) и Архивы Санкт-Петербурга. Согласно данным поисковой системы Google, самое больше количество страниц (более 20 тыс.) проиндексировано на сайтах Архивы Удмуртии и Архивы Санкт-Петербурга.

Из 23 порталов субъектов РФ только 4 демонстрируют отличную скорость при загрузке сайта со стационарного компьютера - менее 1,5 секунд, а 8 - низкую скорость (более 2,3 секунд). При загрузке сайта с мобильного устройства хорошую скорость (менее 3 секунд) показывают 3 сайта, а плохую (более 6 секунд) - 12. Быстро загружаются со всех устройств только Архивы Прикамья и интернетпортал архивной службы Ярославской области. Характерно, что оба эти сайта либо созданы, либо обновлены менее года назад и оба поддерживают адаптивные шаблоны для правильного отображения с мобильных устройств и защищенный протокол https, что является важным показателем удобства сайтов для пользователей. Кроме этих двух порталов адаптивные шаблоны и защищенный протокол одновременно также поддерживают Архивы Архангельской области (https://archives.dvinaland.ru/) и Архивы Ямала (https://yamalarchives.ru/).

Как показывает практика, портальные решения, интегрирующие справочную информацию, услуги и обратную связь, являются наиболее эффективной формой для пользователей, для взаимодействия между учреждениями в обслуживании пользователей. Тренд на создание многофункциональных порталов можно увидеть на сайтах Госуслуги, Mos.ru и многих других. Хочется надеяться, что органы управления архивным делом всех уровней будут активно двигатся в этом же направлении.

\section{Список литературы и источников}

1. Боброва Е.В. Организация работы в режиме онлайн с запросами в федеральные и региональные архивы // Отечественные архивы. - 2019. - № 5. - С. 30-39. 
2. О проекте «Путеводители по российским архивам»// EastView - URL: http://guides.eastview.com/help/about.html (дата обращения: 31.08.2020).

3. Киселев И.Н. НСА к архивным документам в Рунете // Отечественные архивы. 2018. - № 1. - С. 33-40.

4. Размещена тестовая версия программного комплекса «Центральный фондовый каталог» // Портал Архивы России - URL: http://www.rusarchives.ru/novosti/ novosti-rosarhiva/razmeshchena-testovaya-versiya-programmnogo-kompleksa-centralnyyfondovyy-katalog (дата обращения: 31.08.2020).

5. Боброва Е.В. Сайты российских архивов: взгляд пользователя // Отечественные архивы. 2018. - № 6. - С. 28-38.

https://doi.org/10.29003/m1837.978-5-317-06529-4/384-390

\section{Гук Д.ю. \\ Государственный Эрмитаж, Санкт-Петербург}

\section{Веб-аналитика как инструмент анализа сетевого ресурса с разновидовыми источниками материалов археологических исследований}

Аннотация. Несмотря на уже введённое в научный оборот понятие вебометрики, основным показателем эффективности интернет-ресурсов музеев до сих пор считается число посещений сайта. В статье приводятся статистические данные Google.analytics и наблюдения, сделанные в ходе работы над пилотным проектом «Электронная Энциклопедия Эрмитажа. Tом 1. Археология», а также в период карантина по COVID-19, когда работа с виртуальными посетителями стала в музеях приоритетной.

Ключевые слова: открытый ресурс, веб-аналитика, вебометрика, электронная энциклопедия, археология, Эрмитаж.

Hookk D.Yu.

State Hermitage Museum, St. Petersburg

\section{Web Analytics as a tool for analyzing a network resource with a variety of sources on the archaeological research materials}

Abstract. Despite the already introduced concept of Webometrics, the visitors counter has considered as a main indicator of the effectiveness of the museum open sources. The article presents the statistical data and observations made during the work on the start-up project "Digital Encyclopedia of the Hermitage. Vol. 1. Archaeology", as well as during the COVID-19 quarantine period, when communication with virtual visitors became a priority in museums.

Keywords: open source, web-analythics, webometrocs museum, digital encyclopedia, archaeology, Hermitage

\section{Вебометрика в исследованиях интернет-ресурсов музеев}

К началу XXI века в сети Интернет появились разноплановые сетевые ресурсы, объединяющие разновидовые источники материалов в области культурного наследия. Структура данных копировала книж- 
ные издания, а интерфейс воспроизводил инструменты управления базами данных, поэтому и запросы можно было осуществлять только по доступным для поиска полям. Несмотря на уже введённое в научный оборот понятие вебометрики [1], основным показателем их эффективности считался в то время счётчик посещений сайта [2]. Вместе с тем, вебометрика изучает количественные аспекты создания и использования информационных ресурсов, структур и технологий в Сети на основе библиометрического и информетрического подхода и включает как минимум четыре основных направления исследований:

- веб-индикаторы (индексы цитирования, наблюдаемость сайтов и т.д.),

- социальные феномены в Сети (социальные сети, сообщества сайтов),

- сбор данных о Сети (поисковые алгоритмы),

- анализ гиперссылок (в частности, связи между сайтами различных организаций).

Если в начале 2000-х годов в банковской сфере для оценки работы сайтов учитывались пять «микроиндексов»: дизайн, содержание, навигация (юзабилити), онлайн-сервис и раскрученность с весовыми коэффициентами $0.2,0.23,0.29,0.16$ и 0.12 соответственно, - то через 10 лет постепенно на первое место стали выдвигать именно последний показатель, зависящий от алгоритмов ранжирования в разных поисковых системах. Значения, получаемые в системах Яндекс и Google, порой различаются на порядок. Эти методики неоднократно менялись, число показателей сначала сокращалось, затем снова увеличивалось. Интересно, что в 2014 году стал учитываться дополнительный показатель, характеризующий видимость ресурса в сетях профессионального общения и сотрудничества учёных. Для улучшения показателей необходимо, чтобы не менее 30\% текстов были переведены на английский язык; при изменении дизайна сайта материалы архивировались, а также осуществлялась связь с другими сайтами посредством гиперссылок. Не все поисковые системы одинаково корректно работают с российскими сайтами, например, Google рассматривает кириллическое имя домена .pф как обычное ключевое слово, и результаты поиска некорректны [3]. В частности, ответ на запрос «что это?» из Wikipedia имеет приоритет над любыми авторитетными русскоязычными справочными изданиями.

Отдельные методики рассчёта показателей эффективности предлагались в архивной отрасли [4; 5], для электронных библиотек [6: 7] 
а также для веб-представительств научных учреждений [8]. Инструменты веб-аналитики для исследования виртуальных посетителей первым использовал Саратовский художественный музей им. Радищева [9]. Дальнейшие опыты по изучению виртуальной аудитории музея также использовали основные показатели, предоставляемые при помощи инструментов веб-аналитики Google $[10 ; 11 ; 12]$. Это был явный прогресс, потому что данные за отчётный период собирались автоматически и были воспроизводимыми. Эти показатели позволяют установить в заданный период общее число посетителей сайта, число уникальных посетителей, среднее время пребывания на сайте, географию пользователей, пол, возраст, тип операционных систем и устройств, с которых осуществлялся доступ, процентное соотношение использования различных языков. Этим, как правило, системные администраторы ограничиваются, других задач им просто не ставят. Музеи вообще учитывают только общее число виртуальных посетителей [13]. Крайне редко, по специальному запросу можно получить информацию о посещении конкретной страницы на сайте, например, раздела панорамных изображений или, так называемого «виртуального визита». Задачи сопоставления запросов пользователей с внешними факторами в принципе не ставилось. Также не принимались в рассчёт и новые подходы к разработке структуры сайтов, ориентированные на работу поисковых машин. Коллеги за рубежом ориентировались на опросы пользователей и многократно переделывали дизайн, о чём сообщали на конференциях; специальных исследований с привлечением инструментов веб-аналитики не проводилось.

С 2014 года стали широко известны данные TNS (www.tnsglobal.ru) о средней длительности пребывания пользователя на сайте, посвящённом культуре. За 1,2 минуты невозможно успеть прочитать все те длинные тексты, которыми заполнены сайты музеев. Технические задания на разработку сайтов перегружены обязательными формальными разделами, но не учитывают запросы реальных пользователей [14]. Повсеместно требуются для работы в пресс-службе музеев SMM-щики, но никто не специализируется на SEO этих ресурсов.

\section{Методические основы построения онлайн энциклопедии по археологии}

Энциклопедический музей нуждался в создании энциклопедии, поэтому была поставлена задача разработать эскизный проект электронного многофункционального издания с низкой себестоимостью. 
Европейские проекты, ставящие перед собой цель создания электронных ресурсов в области культурного наследия, руководствуются директивой Европейского Парламента, регламентирующей беспрепятственное вторичное использование публичной информации [15], а также стандартом описании объектов культурного наследия [16]. Кроме этого были приняты во внимание все актуальные рекомендации по проектированию сайтов в области культуры. Кадровые ресурсы должны были обеспечивать студенты-дипломники и волонтёры. Удалённое наполнение данными (текстами, иллюстрациями, ссылками, трёхмерными моделями) производится постепенно и регулярно, по мере их накопления и организации доступа. По возможности происходит модернизация и доработка некоторых разделов, что не влияет на работу всего ресурса в целом.

\section{Анализ сетевого ресурса в 2017-2020 годах}

Эффективность работы разработанного и поддерживаемого в течение 3 лет электронного ресурса [17] анализировалась при помощи встроенных инструментов Google.analythics. Отсутствие специальной рекламы в СМИ позволило провести эксперимент по выявлению факторов, влияющих на популярность и эффективность информационного ресурса, практически в лабораторных условиях. В самом начале обращали внимание на все обычные показатели, поскольку было непонятно, какие именно являются значимыми. Количество страниц сайта и объём материалов росли, и стало очевидно, что количественные параметры не отражают эффективность так же однозначно, как это происходит в коммерческих приложениях. Единственный из стандартных показателей, на который стоило обратить внимание - это пол. Обычно в соцсетях и на музейных сайтах преобладают женщины, в данном случае с незначительным перевесом, но постоянно преобладают мужчины. Возраст аудитории стандартная метрика делит на значимые для социологов группы, и в последние годы 45+ также разбили на уровни в соответствии с порогом пенсионного возраста.

Прежде всего невозможно расставить приоритеты между равнозначными страницами, как равноценны все статьи энциклопедии, так и все археологические памятники из собрания музея равнозначны независимо от материала и количества находок. Так же и с исследователями, они все в разное время внесли вклад в изучение коллекций. Поэтому условно в качестве достигнутой цели было выбрано 
посещение страницы «Лица» как менее популярной. К страницам с описанием памятников переход осуществляется непосредственно по ссылкам из выдачи по поисковым запросам в браузере.

Рейтинг популярности страниц позволяет контент-менеджеру расставить приоритеты при выполнении работ, например, по переводу на иностранный язык или пополнению ссылочного аппарата. Рост популярности страницы с указанием разработчиков, концепции и использованных источников можно трактовать двояко, но есть положительные отклики, что говорит о выполнении достижении поставленной цели.

\section{Динамика запросов в период карантина по COVID-19}

В период карантина по COVID-19, апрель-август 2020 года, когда работа с виртуальными посетителями стала в музеях приоритетной, появилась возможность обновить содержание страниц и восполнить пробелы, в частности, выполнить перевод на английский язык. В этот период были отмечены следующие позитивные сдвиги:

- органический поиск остался приоритетным среди источников переходов;

- выросла доля посетителей из других стран;

- среднее время нахождения на сайте соответствует этому показателю для сайтов в области культуры и постепенно растёт;

- наконец процент пользователей мобильных устройств стал сопоставим с настольными компьютерами;

- тематика поисковых запросов постоянно варьируется.

Летний период (июнь-июль) по количественным показателям (общее число посетителей, процент новых пользователей, среднее время на сайте, коэффициент конверсии) сопоставим с весенним (апрель-май). Показатель отказов снизился, что свидетельствует о том, что ресурс стал более востребован у целевой аудитории. Самым важным достижением можно назвать обращение к ресурсу сотрудников музея с намерением актуализировать информацию. Это означает, что попадание в первую десятку выдачи по поисковым запросам производит впечатление даже на скептиков.

\section{Выводы}

Как показывают составленные в разное время обзоры, совершенных рейтингов не существует, объективные числовые показатели порой соседствуют с неформализованным мнением экспертов с различным уровнем компетентности и со своими вкусами и интересами. 
Все применяемые методологии составления рейтингов основываются на статистических методах. Поскольку веб-метрики задумывались как средство мониторинга эффективности интернет-ресурса, то и использовать их нужно для проверки тех характеристик, которые изначально были заложены в проект. Для электронной энциклопедии такими метриками являются:

- пол,

- возраст,

- география,

- преобладание органического поиска как источника обращений,

- статистически нормальное распределение числа обращений к страницам,

- разнообразие технических устройств доступа. Какие бы объективные числовые показатели не использовались, необходимо учитывать весь комплекс параметров: качественных, структурных, технических, лингвистических.

\section{Библиография}

1. Almind T.C., Ingwersen P. Informetric analyses on the World Wide Web: Methodological approaches to «webometrics» // Journal of Documentation. - 1997. - № 53 (4). C. 404-426.

2. Фюлес-Убах С. Оценка активности обращений к веб-сайту: о трудностях получения статистических показателей // Научные и технические библиотеки. - 2004. № $10 .-$ С. $55-63$.

3. Поляк Ю.Е. Российский и международный опыт вебометрических исследований // Информационные ресурсы России. - 2010. - № 5. - С. 2-9.

4. Боброва Е.В. Мониторинг архивных сайтов Рунета: методика и результаты анализа // Информационный бюллетень ассоциации «История и компьютер». - 2008. № 35. - C. 13-15.

5. Боброва Е.В. О мониторинге архивных сайтов Рунета // Вестник РГГУ. 2011. - № 18(80). - С. 67-80.

6. Исмагилова А.Х. Оценка качества электронных библиотек // Научные и технические библиотеки. - 2010. - № 5. - С. 60-66.

7. Ударцева О.М., Рыхторова А. Е. Использование инструментов веб-аналитики в оценке эффективности способов продвижения библиотечных ресурсов // Библиосфера. - 2018. - № 2. - С. 93-99.

8. Антопольский А.Б., Поляк Ю.Е., Усанов В.Е. Развитие вебометрического индекса научно-образовательных учреждений России // Информационные ресурсы России. -2013 . - № 4. - С. 16-24.

9. Калинина Л.Л., Пролеткин И.В., Шпак М.Е. Мониторинг Интернет-ресурсов в музейной деятельности // Информационные ресурсы России. - 2007. - № 5. - С. 24-26.

10. Определёнов В.В. Сбор и анализ статистики использования и эффективности информационных ресурсов музея в сети Интернет // Joint International scientific and practical conference "Digital Century of Culture" and "EVA 2013 Moscow", November 
19-22, 2013. - URL: http://www.aselibrary.ru/conference/conference43/conference 434667/_video/4670/ (дата обращения: 01.08.2020).

11. Гук Д.Ю. QR-код Эрмитажа: статистика, посетители, факты // Современные проблемы сервиса и туризма. - 2014. - № 8- С. 43-51.

12. Гук Д.Ю., Определёнов В.В. Методические аспекты анализа и контроля эффективности информационных ресурсов музея в сети Интернет // Информационные ресурсы - футурологический аспект: планы, прогнозы, перспективы : материалы X Всероссийской научно-практической конференции «Электронные ресурсы библиотек, музеев, архивов», 30-31 октября 2014 г., Санкт-Петербург. - Санкт-Петербург : ЦГПБ им. В.В. Маяковского, 2014. - С. 126-137.

13. Об утверждении показателей, характеризующих общие критерии оценки качества оказания услуг организациями культуры : Приказ Министерства культуры Российской Федерации от 05.10.2015 г. № 2515. - URL: http://mkrf.ru/open-ministry/ quality/ detail.php?ID=828006 (дата обращения: 01.08.2020).

14. Методические рекомендации по созданию и эксплуатации сайтов и порталов учреждений культуры музейного типа / В.В. Определёнов, Ю.В. Бузина, M.В. Угольников, Т.Ю. Алейников, Ф.Е. Жерновой. - M., 2017. - URL: http://ebooks.arts-museum.ru/site_method (дата обращения: 01.08.2020).

15. PSI Directive. Directive 2003/98/EC of the European Parliament and of the Council of 17 November 2003 on the re-use of public sector information. OJ L 345, 31.12.2003. p. 90. - URL: http://eur-lex.europa.eu/LexUriServ/LexUriServ.do?uri=CELEX:32003 L0098: En:HTML (дата обращения: 01.08.2020).

16. ISO 21127:2014 Information and documentation. A reference ontology for the interchange of cultural heritage information. - URL: http://www.iso.org/iso/home/store /catalogue_tc/catalogue_detail.htm?csnumber=57832 (дата обращения: 01.08.2020).

17. Гук Д.Ю. Молодые молодым: международное сотрудничество в области создания веб-ресурса по истории археологического собрания Государственного Эрмитажа // Северный археологический конгресс. Ханты-Мансийск, 2019. - С. 407-410.

https://doi.org/10.29003/m1838.978-5-317-06529-4/390-395

Кижнер И.А., Лаптева М.А. Сибирский федеральный университет

\section{Музейные цифровые коллекции и проект «Открытый музей»}

Аннотация. Рассмотрена проблема доступа к закрытым музейным коллекциям в цифровом пространстве. Основное содержание статьи составляет описание концепции «Открытого музея» а также отмечена важность использования открытых лицензий, существующих с целью предоставления возможности многократного использования изображений коллекций. Изложен способ предоставления доступа к культурному контенту на примере реализации серии изданий кафедрой информационных технологий в креативных и культурных индустриях совместно с Издательством Сибирского федерального университета с целью развития культурного канона и популяризации цифрового музейного контента.

Ключевые слова: музейные коллекции, цифровые коллекции, открытый музей, публикация коллекций, ремедиация контента, открытая лицензия, открытый доступ. 
Kizhner I.A., Lapteva M.A. Siberian Federal University

\section{Museum digital collections and the Open Museum project}

Abstract. The problem of access to closed museum collections in the digital space is considered. The main content of the article is a description of the concept of the "Open Museum" and also noted the importance of using open licenses that exist in order to provide the possibility of multiple use of images of collections. A method of providing access to cultural content is described on the example of the implementation of a series of publications by the Department of Information Technologies in creative and cultural industries together with the Publishing House of the Siberian Federal University in order to develop the cultural canon and popularize digital museum content.

Keyword: the Museum's collection, digital collection, an outdoor Museum, the publication of collections, the remediation of content, open license, open access.

Цифровые коллекции музеев увеличиваются, все большее количество музейных предметов публикуются на сайтах музеев и с помощью отечественных и международных платформ, обеспечивающих доступ к произведениям искусства. Многочисленные работы, рассматривающие использование цифровых коллекций музеев, архивов и библиотек в сторонних проектах, касаются как использования изображений общей публикой, так и профессиональными пользователями. Важность открытых лицензий для повторного использования изображений в творческой деятельности для научных исследований подчеркивает ряд исследователей, которые поддерживают подход, связанный с открытостью коллекций и распространением изображений в случае, когда произведения культуры и искусства перешли в общественное достояние $[1 ; 2 ; 3$, с. 754]. Несмотря на то, что использование коллекций учреждений в области культурного наследия как источника данных осложнено вопросами авторского права людей и институций, которые участвуют в создании и ремедиации контента, опыт предоставления доступа к данным и разработки компьютерных средств обнаружения данных, их сортировки и анализа становится частой практикой библиотек, музеев и архивов [4].

Интерес непрофессиональных пользователей, которым необходимы визуальные данные для собственной творческой деятельности, может быть обусловлен поиском культурной и этнической идентичности и онтологической защищенности [5, с. 201]. Людям необходимо чувствовать принадлежность к разным формам культуры, аутен- 
тичность и авторитет которых поддерживают учреждения культуры и организации, поддерживающие цифровые ресурсы в области культурного наследия, и получить возможность творчества, соединенного с культурным наследием этническими, культурными и онтологическими связями.

Цифровые коллекции используются посетителями как источник вдохновения и данных для последующей творческой работы как в профессиональной, так и в непрофессиональной области. Это значит, что пользователям цифровых ресурсов в области культурного наследия часто требуется скопировать и сохранить изображение для повторного использования в собственном проекте. Это особенно важно для исследовательской работы, которая предполагает создание собственных аннотированных коллекций изображений [6], которые впоследствии будут опубликованы.

Концепция «открытого доступа», которой придерживается ряд учреждений культуры [7] для того, чтобы предоставить возможность повторного использования изображений из некоторых разделов своих коллекций, позволяет разным категориям пользователей копировать, изменять и распространять изображения, особенно те произведения, право копирования которых находится в общественном достоянии.

Известно, что в случае, когда авторское право истекло или никогда не существовало, произведения искусства можно копировать, распространять и использовать в дальнейшей работе без ограничений. Однако ряд ограничений, связанных с авторским правом на фотографии или с правом первой публикации, которое принадлежит только тому учреждению, в котором хранится предмет, приводит к тому, что только музей может принять решение относительно того, как он будет распоряжаться изображениями предметов, право копирования которых перешло в общественное достояние. Недавнее распространение принципов «Открытого музея» (Open GLAM) [8] привело к инициативам, в которых музеи руководствуются Открытыми лицензиями (Creative Commons) [9]. Такие лицензии дают возможность музеям, библиотекам и архивам распоряжаться авторским правом, которое принадлежит учреждению культуры, возникло в результате ремедиации аналогового объекта (цифровая съемка, создание файлов, работа над публикацией изображения и т.д.) и связано с исходным аналоговым объектом (например, цифровое изображение произведения искусства, которое находится в общественном достоянии), несмотря на то, что цифровая фотография произведения искусства может быть защищена авторским правом. Отказ от авторского права для цифровых фотографий произведений и объектов из 
общественного достояния (или признание того, что создание цифрового изображения не влечет за собой создание нового авторского права) и использование открытых лицензий становится практикой ряда музеев, архивов и библиотек. Это делается с целью распространения знаний о коллекциях. Лицензии способствуют выполнению миссии музея, которая включает, например, в случае Музея Метрополитен в Нью-Йорке «создание образовательных возможностей, которые демонстрируют важность искусства для всех целевых аудиторий» и «использование информационных технологий в стратегических целях для распространения научных знаний и содержания коллекций и привлечения широкой публики» [10]. К тому же использование открытых лицензий дает возможность музеям вступать в партнерские отношения с технологическими компаниями для проведения исследований в области визуального контента и получать финансирование от тех организаций, условия которых предполагают использование открытых лицензий [11].

Ряд произведений искусства и культуры получают большее распространение по сравнению с другими произведениями. Их включают в коллекции библиотек, музеев и архивов, «их покупает широкая публика, исследования, связанные с этими произведениями, поддерживаются в рамках разнообразных программ финансовой поддержки, их цитируют ученые, ими восхищаются в университетах и за их пределами» [12]. Такие произведения составляют основу так называемого культурного канона.

Идея проекта «Открытый музей» родилась в ходе изучения студентами университета (кафедра информационных технологий в креативных и культурных индустриях) музейных коллекций, находящихся в открытом доступе - практики, еще не получившей широкого распространения в отечественных музеях - и способов предоставления доступа к культурному контенту для дальнейшего творчества, образования и исследований.

В творческом плане изображения, находящиеся в открытом доступе, могут быть использованы для виртуальных музейных проектов, идеи которых нуждаются в визуальном представлении произведений, находящихся в коллекциях разных стран и музеев. Главное в таких проектах - послание, адресованное современнику, и это послание становится убедительнее и достовернее, подтвержденное или сопровождаемое демонстрацией изображений и предметов.

В образовательном поле в рамках проекта «Открытый музей» совместно с Издательством Сибирского федерального университета 
реализуется серия изданий, направленная на расширение культурного канона в результате работы с контентом музеев, которые используют открытые лицензии для распространения своих коллекций. В связи с тем, что музеи лицензируют для копирования и повторного использования только произведения, право копирования которых перешло в общественное достояние, двадцатый век и современная эпоха не были включены в подборки. Издания подготовлены студентами кафедры информационных технологий в культурных и креативных индустриях. В программу обучения студентов кафедры входит обширный курс истории искусства, и у студентов сложилось отчетливое представление и о хорошо известных работах европейских и российских авторов. Работы студентов демонстрируют стремление выйти за пределы известного им канона произведений искусства и расширить его до произведений, которые не входят в курс истории западного и российского искусства. Издания, составленные молодыми исследователями, демонстрируют направления развития канона, показывают те виды работ, которые расширяют канон и, возможно, со временем станут хорошо известны широкой публике.

Таким образом, проект «Открытый музей» направлен на актуализацию цифрового музейного контента и призван демонстрировать возможные современные формы его использования.

\section{Библиография}

1. Kapsalis, E. (2020). 21st-Century Diffusion with Smithsonian Open Access. Smithsonian, 25 February 2020. - URL: https://www.si.edu/openaccess/updates/21st-centurydiffusion (дата обращения: 10.09.2020).

2. Kelly, K. (2013). Images of Works of Art in Museum Collections: The Experience of Open Access. - URL: https://clir.wordpress.clir.org/wp-content/uploads/sites/6/pub157.pdf (дата обращения: 06.09.2020).

3. Terras, M. Opening Access to collections: the making and using of open digitised cultural content // Online Information Review. - 2015. - 39(5). P. 733-752.

4. Allen, L., Frost H., Padilla Th., Potvin S., Roke E.R. and Varner S. (2019). The Collections as Data Framework: A Review from the Always Already Computational Project. - URL: https://tdl-ir.tdl.org/handle/2249.1/156364 (дата обращения: 10.09.2020).

5. Turner, B. The Erosion of Citizenship // British Journal of Sociology. 2001. 52(2): P. 189-209.

6. Fenlon, K. (2019). Modeling Digital Humanities Collections as Research Objects // Proceedings of ACM Joint Conference on Digital Libraries.

7. Kapsalis, E. (2016). The Impact of Open Access on Galleries, Libraries, Museums, \& Archive // Statewide Agricultural Land Use Baseline-2015.

8. OpenGLAM. - URL: https://openglam.org/ (дата обращения: 26.08.2020).

9. Creative Commons. - URL: https://creativecommons.org/ (дата обращения: 10.08.2020).

10. Mission Statement. - URL: https://www.metmuseum.org/-/media/files/about-themet/annual-reports/2014-2015/annual-report-2015-mission-statement.pdf (дата обращения: 02.09.2020). 
11. Kapsalis, E. (2015). The Impact of Open Access on Galleries, Libraries, Museums, \& Archives // Statewide Agricultural Land Use Baseline-2015.

12. Price, Kenneth M. Digital Scholarship, Economics, and the American Literary Canon // Literature Compass. - 2009. - 6.2. - P. 274-90.

https://doi.org/10.29003/m1839.978-5-317-06529-4/395-400

Киселев И.Н.

Москва

\section{Зарубежное ПО на российской архивной почве: два проекта}

Аннотация. Статья посвящена двум международным проектам с участием российских архивов, в которых использовалось зарубежное программное обеспечение. Первый проект: российско-американский проект по вводу описаний фондов четырех российских архивов (ГАРФ, РЦХИДНИ, ГАТО, ТЦДНИ) в БД RLIN. Второй проект - Компьютеризация Архива Коминтерна. Рассмотрены характеристики программного обеспечения, цели и итоги проектов.

Ключевые слова: Архивное программное обеспечение, научно-справочный аппарат, формат MARC AMC, RLIN, российские архивы, РГАСПИ, Архив Коминтерна.

Kiselev I.N.

Moscow

\section{Foreign software on Russian archival soil: two projects}

Abstract. The article is devoted to two international projects with the participation of Russian archives, in which foreign software was used. The first project is the Russian-American project for entering fond descriptions of four Russian archives (GARF, RtSHIDNI, GATO, TtSDNI) into the RLIN database. The second project is the Computerization of the Comintern Archive. The characteristics of software, goals and results of the projects are considered.

Keywords: Archival software, finding aids, MARC AMC format, RLIN, Russian archives, RGASPI, Comintern Archive.

Эти заметки посвящены двум соприкосновениям российских архивистов с зарубежным архивным программным обеспечением. Первое прошло почти незамеченным и не имело никаких практических последствий. Второе оказалось громким и масштабным проектом по оцифровке архивных документов в отечественном архивном деле.

В 1993 г. Росархив согласился с предложением Гуверовского института войны, революции и мира и Группы научно исследовательских библиотек (США) о размещении описаний ряда архивных фон- 
дов российских архивов в онлайновой базе данных Информационной научно-исследовательской библиотечной сети (RLIN). Проект финансировался Национальным фондом гуманитарных наук (США). На трех совещаниях в Калифорнии и в Москве (1993-1995 гг.) были определены основные организационные и технические параметры проекта. В качестве формата описания используется USMARC AMC (Machine-Readable Cataloging for Archival and Manuscripts Control формат машиночитаемой каталогизации для архивных документов и рукописей). MARC изначально создавался как библиографический формат для библиотек, и лишь его десятая версия (1983 г.) была расширена для архивных документов [1, с. 23]. Второй главный параметр проекта - должны быть представлены описания фондов архивов различного уровня - центральных и региональных, при этом критическим условием, поставленным американскими партнерами, является вхождение в проект бывших партийных архивов.

Для проекта были выбраны четыре архива - ГАРФ (фонды учреждений Российской империи, СССР и РСФСР, личные фонды и коллекции), РЦХИДНИ (фонды личного происхождения, материалы по политической и социальной истории стран Западной Европы конца XVII - начала XX вв.), Государственный архив Тверской области (фонды исполкомов губернского, уездных, волостных Советов, уездных военно-революционных комитетов, исполкомов районных и городских Советов, личных фондов), Тверской центр документации новейшей истории (фонды губкома РСДРП (РКП(б)), волостных и уездных комитетов КПСС (РКП(б), ВКП(б), политических отделов при МТС, фракций РКП(б) на некоторых крупных предприятиях, совхозно-колхозных парткомов. обкома КПСС, районных и городских комитетов КПСС, ВЛКСМ).

В декабре 1994 г. в Калифорнии было проведено двухнедельное обучение для российских архивистов, в котором участвовали сотрудники Росархива и четырех упомянутых архивов.

Вначале предполагалось, что ввод описаний будет производиться в онлайн-режиме непосредственно в БД RLIN. Однако выяснилось, что ГАРФ и тверские архивы не могут выходить в связующую с БД сеть Sprintnet, а в РЦХИДНИ идут постоянные перебои со связью. Поэтому американские партнеры установили в архивах периферийное ПО MicroMarc (позаимствованный ими у Мичиганского университета), позволявшее вводить записи в формате, принятом в системе RLIN, в автономном режиме и накапливать их на носителе.

Практически работа состояла в том, чтобы сначала заполнить по каждому фонду рабочие листы, представлявшие собой распечатки со 
структурой полей MARC-формата. Затем архивисты вводили информацию в MicroMarc на автономных компьютерах.

По окончании проекта американским партнерам были переданы описания 3400 фондов на магнитных носителях.

В 1996 г. состоялось итоговое заседание Международного консультативного совета проекта, одобрившего его проделанную работу. Члены Совета единодушно решили начать поиски финансирования следующего проекта - ввода в БД RLIN материалов Центрального фондового каталога Росархива. Однако этот проект не состоялся. Основная причина была даже не в отсутствии финансирования, а в том, что российские архивисты признали нецелесообразным использование формата MARC AMC при создании отечественного автоматизированного научно-справочного аппарата.

Громоздкая структура полей формата, несоответствие представления в нем единиц информации российским правилам, техническое несовершенство его программной реализации вынуждали российских архивистов перерабатывать содержание и преобразовывать вид существующих в архивах элементов описаний фондов, значительно сокращать описания. Наиболее существенные трудности испытывали ГАРФ и РЦХИДНИ с их объемными аннотациями и историями фондов, с множественными переименованиями. Заметим, что аналогичные проблемы с использованием формата MARC AMC возникали и у американских архивистов при описании документов своих архивов [см., например, 2, с. 273].

Как представляется, ущербность формата MARC AMC была заложена уже в подходе к его проектированию. Перед разработкой формата данных для обмена информацией по архивным материалам под эгидой Общества американских архивистов было проведено специальное исследование, которое показало, что наиболее экономичным решением будет не создание нового формата, а адаптация к архивной сфере существующего MARC формата для рукописей. Тем самым предполагалось резко уменьшить расходы на разработку нового формата и одновременно получить интегрированный формат, позволяющий получать сведения о материалах любого типа из одного источника [3, с. 12]. В результате, помимо ограниченного объема записи, в MARC AMC не оказалось возможности формировать иерархическую структуру описаний и взаимосвязи между ними [4, с. 332, 334], то есть исключались принципиально важные свойства архивного НСА.

Краткая информация о проекте содержится только в одной публикации, помешенной в 1998 г в The American Archivist - ведущем 
архивном журнале США [5]. Статью подготовили американская участница проекта Н. Ляндерс и участница проекта из ГАТО О. Леонтьева. Статья содержит краткие общие сведения о проекте и некоторые примеры заполнения ряда полей в американской и российской трактовке. Особенно интересным в статье мог бы стать фрагмент, где сопоставляются корневые понятия в американском и российском архивном деле - фонд (его разновидности, структура), опись, дело, дается характеристика каталогов, затрагивается нумерация фондов в российских архивах, К сожалению, этот сюжет дан поверхностно и с неточностями.

Вынесенная в заголовок статьи весьма претенциозная цель проекта - «развитие международного стандарта по каталогизации архивохранилищ» не была достигнута. Однако близкое знакомство с популярным в то время в США форматом представления архивных описаний и практическая с ним работа были, безусловно, полезны. Американские же партнеры по проекту ввели в структуру формата для БД RLIN дополнительные поля для кириллических и транскирибированных в латиницу записей.

Главным и важным итогом проекта для российской стороны было подтверждение необходимости разработки собственного национального ПО для архивов. Впрочем, это стало нам ясно еще до завершения проекта. В 1995 г. в российские архивы была разослана для опытной эксплуатации первая версия отечественного программного обеспечения «Архивный фонд».

Вторым опытом работы с зарубежным архивным ПО стала компьютеризация Архива Коминтерна.

В 1996-2003 гг. под эгидой Совета Европы по соглашению с Международным советом архивов был реализован международный проект компьютеризации Архива Коминтерна при финансовой и интеллектуальной поддержке национальных архивных служб Германии, Франции, Швейцарии, Швеции, министерств культуры Италии и Испании, Библиотеки Конгресса США. При реализации проекта был положен конец притязаниям ряда государств на документы из Архива Коминтерна, хранившемся в Российском центре хранения и изучения документов новейшей истории (РЦХИДНИ), бывшем Центральном партийном архиве Института марксизма-ленинизма при ЦК КПСС (в настоящее время, после объединения с бывшим Центральным архивом ВЛКСМ - Российский государственный архив социально-политической истории (РГАСПИ)).

В 1996 г. было подписано Соглашение между Государственной архивной службой России и Международным советом архивов о 
принципах проекта Компьютеризации Архива Коминтерна, которое устанавливало, в частности, что Архив Коминтерна является собственностью РФ и входит в состав Архивного фонда РФ (Приложение 1 «Статус Архива Коминтерна»).

В последующим за Соглашением Договоре между Международным советом архивов и РЦХИДНИ (1997 г.) МСА принял на себя обязательство безвозмездно предоставить архиву русифицированную версию программного обеспечения, применяемого в Генеральном архиве Индий (о «Севильской программе» см. [6]).

В испанское ПО «Archidoc» вводились описания документов на уровне фонда, описи, дела, детально структурированные для каждого уровня, к последнему уровню присоединялись сканированные образы документов. Программа обладала развитым и удобным интерфейсом ввода и редактирования данных, механизмом автоматизированного присоединения образов к описаниям, функцией экспорта описаний. Быстрый поиск проводился по восьми видам ключевых слов (дескрипторов): Тема, География, Имена, Статус, Организация, Социум, Название издания, Вид документа. В ходе работ проводилась «нормализация» дескрипторов, то есть поддержка стандартизованных словарей (в западной терминологии - authority files). Оригинальной особенностью программы была возможность вводить составные дескрипторы, то есть состоящие из двух «простых» дескрипторов (перечисленных выше), соединенных между собой связями восьми типов - Alias (Синоним), Чей документ, Кому документ, Отношение к стране, Принадлежность к организации, О чем, Должность, Где (местоположение).

В итоге пятилетней работы была создана база данных описаний документов Архива Коминтерна, содержавшая 240 тыс. записей и около 1,7 миллиона образов документов. Партнерам проекта были переданы коробки с копиями БД на 600 оптических дисках. В БД вошел не весь Коминтерн, а лишь 10\% этого документального комплекса, поскольку описывались и сканировались только документы, связанные с историей стран - участниц проекта.

В настоящее время накопленный в ходе проекта электронный ресурс размещен на сайте Росархива «Документы советской эпохи» [7] в свободном доступе.

О дескрипторах электронного Архива Коминтерна и их использовании можно получить представление на примере его части - фонда 545 «Интербригады Республиканской армии Испании». В 1910 г. компания ИнфоРост разработало платформу для представления в 
Интернете базы данных и коллекции образов Архива Коминтерна. Итогом пилотного проекта стало представление в Интернете документов фонда 545. В ресурс, который доступен по ссылке на сайте РГАСПИ, вошли описания 6 описей, 3365 дел, 397 тыс. образов документов. Представлены все «простые» и «составные» дескрипторы (раздел Указатели). Реализован поиск - простой и расширенный, а также по терминам каждого из указателей.

Испанская программа была полезна в подготовке архивных электронных ресурсов в РГАСПИ, однако не получила распространения в других российских архивах прежде всего по причине ее высокой стоимости (соответственно, дорогой лицензии на сопровождение программы), к тому же ее функционал значительно превышал насущные потребности архивов.

Зарубежное программное обеспечение на российской архивной почве не прижилось. Оно остается у нас, в лучшем случае, параграфом в пособиях по истории архивного дела и в ретроспективных обзорах международного сотрудничества. А быть может, войдет в материалы исследований по сравнительной истории развития архивного научносправочного аппарата в российской и западной традициях.

\section{Литература}

1. Morton K. The MARC Formats: An Overview // The American Archivist - Volume 49. - Issue 1 (Winter 1986). - P. 21-30.

2. Pitti D. Encoded Archival Description: The Development of an Encoding Standard for Archival Finding Aids // The American Archivist. - Volume 60. - Issue 3 (Summer 1997). - P. 268-283.

3. Sahli N. Interpretation and Application of the AMC Format // The American Archivist. - Volume 49. - Issue 1 (Winter 1986). - P. 9-20.

4. Sweetser M. and Orchard A.A. Are We Coming Together? The Archival Descriptive Landscape and the Roles of Archivist and Cataloger // The American Archivist. - Volume 82. - Issue 2 (Fall/Winter 2019).

5. Lyandres N. and Leontieva O. Developing International Cataloging Standards for Archival Holdings: Rosarkhiv-RLG-Hoover Project, 1994-1997 // The American Archivist. - Volume 61. - Issue 2 (Fall 1998). - P. 441-452.

6. Rütimann H., M. Stuart Lynn. Computerization Project of the Archivo General de Indias, Seville, Spain. A Report to the Commission on Preservation and Accessby // The Council on Library and Information Resources. 1992. - URL: https://www.clir.org/ pubs/reports/archivo/archivo/ (дата обращения 29.08.2020).

7. Документы советской эпохи. - URL: http://sovdoc.rusarchives.ru/sections/ organizations/. (дата обращения 27.08.2020).

8. Интербригады Республиканской армии Испании. - URL: http://interbrigades. inforost.org/ (дата обращения 27.08.2020). 
https://doi.org/10.29003/m1840.978-5-317-06529-4/401-407

Поврозник Н.Г.

Пермский государственный национальный исследовательский университет

\section{Веб-архив как источник для изучения современной истории ${ }^{1}$}

Аннотация. Веб-архивы содержат информацию о политической, экономической, социальной и культурной истории, могут являться основой для реконструкции истории информационного общества. Современные вебархивные инициативы направлены на сохранение веба в глобальном, национальном и локальном масштабе и формирование широкого спектра тематических коллекций. В статье представлены возможности использования вебархивных материалов в исторических исследованиях, приведены примеры таких исследований.

Ключевые слова: Веб-архив, Интернет-Архив, национальный веб-архив, исторический источник, веб-ресурс, цифровая критика.

Povroznik N.G. Perm State National Research University

\section{Web Archive as a Source for Studying Contemporary History}

Abstract. Web archives contain information about political, economic, social, and cultural history, and they can be the basis for the reconstruction of the history of the information society. Contemporary web archiving initiatives aim to preserve the web globally, nationally, and locally and to build a wide range of thematical collections. The paper focuses on the possibilities of using web archival materials in historical research and provides examples of such research projects.

Keywords: Web Archive, Internet Archive, National Web Archive, Historical Source, Web Resource, Digital Criticism.

Веб-архивы являются уникальным источником по истории современного общества, которую невозможно рассматривать в отрыве от контекста цифровой революции и развития Интернета, как среды для коммуникации, хранения и передачи информации, ставшей важной частью повседневной жизни современного человека. По образному сравнению Яна Миллигана, если бы не было веб-архивов, мы бы так и изучали прошлое по печатным газетам, полностью упустив как исчезнувшие Интернет-ресурсы, так и способы взаимодействия и коммуникации людей в сети [1].

${ }^{1}$ Статья написана в рамках проекта «Новый учебный курс "Веб-история социума и его институтов"», поддержанного грантом Благотворительного фонда Владимира Потанина. 
Веб в совокупности веб-сайтов в их многообразии представляет собой материалы, созданные изначально в цифровом формате. Являясь хранилищем порций веба, веб-архив представляет только часть всемирной паутины. Современными средствами невозможно даже подсчитать количество созданного на данный момент веб-контента и представленного в Интернете, поэтому и полное сохранение не представляется возможным. Программы веб-архивирования создают источниковую основу, опираясь на которую, историк будущего будет анализировать нашу современность и формировать представление о ней, и поэтому ключевым является вопрос о том, какой контент является более ценным для его сохранения.

Программы сохранения веба действуют на разных уровнях глобальном, национальном и локальном. К глобальным веб-архивным инициативам относится, прежде всего, Интернет Архив [2], крупнейший некоммерческий веб-архивный проект. Инициативы по сохранению национального веба действуют во многих странах, например, в Австрии, Австралии, Великобритании, Финляндии, Новой Зеландии и других стран. К локальным веб-архивам относятся проекты, создаваемые для решения частных задач. Часто их инициаторами становятся университеты, например, веб-архивные проекты университетской библиотеки Братиславы (Словакия), библиотек Стенфордского университета (США) и университета Йорка (Канада). Если посмотреть на карту распространения веб-архивных инициатив [3], то мы все еще видим белые пятна - в Латинской Америке, Африке, Ближнем и Среднем Востоке и в других частях земного шара, где не функционируют программы по сохранению веба, а значит безвозвратно исчезает ценная информация (если она не попала в крупные международные проекты как Интернет Архив, например). Частично эта проблема решается путем ведения веб-архивных проектов институтами из других частей мира, создающих тематические коллекции веба тех стран, где отсутствуют национальные программы по веб-архивированию. Например, Университет Техаса (США) инициировал программу по архивированию веба Латинской Америки LAWAP (Latin American Web Archiving Project) [4], которая функционирует с 2005 г. Часть веб-архивных проектов предоставляют открытый доступ к сохраненному контенту, другие ввиду ограничений по авторскому праву предоставляют возможность работы с материалами только в локальных сетях ответственных организаций.

Веб-архивы как исторические источники могут представлять данные для реконструкции разных слоев информации, возможности изучения которых заложены в инициативных проектах по сохране- 
нию веба. Национальные программы являются масштабными и имеют цель сохранить ресурсы национального домена. Так, например, программа сохранения веба в Австралии сохраняет сайты домена .au и представляет их в открытом репозитории Национальной библиотеки Австралии на платформе TROVE [5]. Национальные веб-архивы дают возможность изучать ресурсы национального веба и его сегментов. В качестве примера таких исследований можно привести проекты по изучению британского национального веба и его эволюции (домен .uk) и развитию университетского веба (субдомен ac.uk) [6], доменным именам и их изменениям [7]. Изучение национального веба и его эволюции способно дать понимание о том, как воспринимались Интернет-технологии обществом, как они проникали в жизнь людей и государства, а также демонстрировать усиление интереса общества и организаций к вебу, оптимизацию веб-ресурсов под нужды пользователей через изменение представлений о его структуре и содержании.

Другие проекты сохранения веба направлены на создание тематических коллекций, отражающих разные стороны современной истории. Тематические коллекции могут быть сфокусированы на разных вопросах политического, экономического, культурного или иного характера. При формировании коллекций ключевыми характеристиками могут являться событие (что существенно для историка) или персона, тема, жанр, формат контента или тип медиаконтента. Форматы контента могут быть различными - текстовый, изобразительный, аудио, видео, мультимедиа и некоторые другие. Интернет Архив, в частности, сканирует контент с платформы Youtube и формирует коллекцию видео [8], а также в указанном вебархиве представлены подборки книг, периодических изданий, фильмов, аудио и программного обеспечения [9].

Веб-архивы позволяют реконструировать историю социума и его институтов разного уровня - государственных (правительственных), образовательных, религиозных, экономических и семейных. История социальных институтов в разрезе веба демонстрирует изменения функциональных особенностей и сервисов, отражает расширение значения информационного пространства в жизни общества. Существенное значение в информационном обществе имеет развитие электронных сервисов - правительственного, общественного, экономического, культурного секторов, развитие которых мы можем проследить, через изменение функциональности сайтов. Так, в исследовании В. Шафер показывается эволюция сервисов, созданных 
французским правительством для общественного использования с 1990-х гг. до настоящего времени [10].

Реконструкция событийной истории современности также возможна благодаря веб-архивам. Особенно значимые события становятся темой для формирования специализированных коллекций и даже осуществления целых веб-архивных программ. Таковым, например, является украинский проект по архивированию вэба, связанного с президентскими выборами 2010 г. и последующими событиями? недоступный на данный момент в живом Интернете, но сохраненный в Интернет Архиве [11]. В данном случае важен сам факт сохранения ресурсов данного типа, а вопрос об ангажированности и критике данных, подходов к сохранению и прочего останется за рамками данной статьи. Другими примерами формирования событийных тематических коллекций являются теракты 9/11 в США [12], ядерный взрыв на Фукусиме [13], президентские выборы в России [14] и многие другие. Следует отметить, что веб-архивные коллекции могут отражать только отдельные точки зрения на происходящее, и это должно приниматься во внимание пользователями этих ресурсов как необходимое звено критики источников.

Веб-архивные материалы позволяют представить и изменение медиапространства, что возможно благодаря созданию архивных коллекций новостных изданий. Новостная повестка, процессы формирования общественного мнения, изменения способов передачи и распространения информации, развитие средств массовой коммуникации, специфика современных новостных лент, формирующихся по новым принципам, могут быть проанализированы на основе создаваемых веб-архивных тематических коллекций. Кроме того, значение этого сегмента веб-архивных коллекций заключается в фиксации и документировании событий и фактов современности. Так, М. Веберу и Ф. Наполи удалось проанализировать эволюцию цифровой журналистики в США [15], которая рассматривается в контексте эволюции веба как такового. Исследовательский проект предполагал создание архивной коллекции местных новостей и 100 сообществ США за 2017 г. В основе исследовательской методики - контент-анализ новостей во взаимосвязи с сетевым анализом демографических характеристик сообществ и их географического расположения.

Веб-архивы позволяют реконструировать историю информационного общества, его особенностей и характерных элементов. С этой точки зрения веб можно рассматривать как культурный феномен, позволяющий с помощью специализированных сервисов транслировать и формировать общественное мнение. Одним исследований 
стало изучения точек притяжения в Лондоне на сайте TripAdvisor [16]. Главная идея исследования заключалась в том, чтобы проанализировать, как популярный сервис передавал культурную значимость тех или иных локаций, как происходило размытие различий между высокой и поп-культурами, а также между коммерческими и некоммерческими местами для посещения туристами.

Другим специфичным элементом информационного общества являются сообщества нового типа. Киберсообщества являются скрытой частью современного общества, невидимой с точки зрения традиционного историка. Поэтому ценность веба как исторического источника заключается возможности представить эту часть современности и эволюцию цифрового пространства, в котором эти сообщества себя проявляют. Так, реконструкции уже исчезнувших к настоящему времени киберсообществ посвящено исследование историка И. Миллигана, который реконструировал пути формирования этих сообществ на примере ресурса GeoCities. Ему удалось показать рост сообщества с 10000 человек в 1995 г. до 1 млн. пользователей в 1997, выявить сообщества и их лидеров, проанализировать интересы лидеров на основе методов дальнего чтения [17].

Социальные медиа являются важной частью жизни современного человека. Они выступают площадками для коммуникации, обмена информацией, местами приобретения товаров и услуг и выполняют массу других функций. Социальные медиа произвели в некотором роде революцию в коммуникации в первую очередь тем, что позволили создавать и публиковать контент широкому кругу пользователей, обладающих минимальным уровнем цифровой грамотности. Вместе с тем, социальные сети являются очень уязвимыми и быстро исчезающими ресурсами, выступающие важным средством документирования культурных и социальных процессов. Сохранение этой части веба весьма проблематично ввиду целого ряда причин, связанных с большими объемами информации, динамичностью контента, постоянно дополняемого и изменяемого, а также с оперированием персональными данными, что накладывает существенные ограничения для проектов по сохранению и анализу социальных сетей в правовом отношении. В последнее время появляются программы, направленные на сохранение этого типа веб-ресурсов для исследователей будущего. Таким, например, является проект сохранения социальных медиа Бельгии BESOCIAL [18]. Главной целью проекта является создание стратегии устойчивого сохранения социальных 
сетей как свидетельств современной истории для обеспечения возможностей их использования исследователями будущего.

Таким образом, веб-архивы хранят уникальные источники, которые позволяют реконструировать историю самого веба, а также политическую, социальную и экономическую, культурную историю, предлагая для анализа огромное количество свидетельств событий этого времени. Важной функцией веб-архивов становится сохранение свидетельств по истории информационного общества, в том числе, динамичного веба социальных сетей. Однако работа с вебархивами требует тщательной критики цифровых источников, понимания способов формирования коллекций, возможностей оценить их полноту и репрезентативность.

\section{Библиография}

1. Milligan, I. Lost in the infinite archive: The promise and pitfalls of web archives // International Journal of Humanities and Arts Computing. 2016. - 10(1). - P. 78-94.

2. Internet Archive. - URL: https://archive.org (дата обращения: 01.09.2020).

3. List of Web archiving initiatives. // Wikipedia. - URL: https://en.wikipedia.org/ wiki/List_of_Web_archiving_initiatives (дата обращения: 01.09.2020).

4. The Latin American Web Archiving Project (LAWAP). - URL: http://lanic.utexas. edu/project/archives (дата обращения: 01.09.2020).

5. TROVE. Национальная библиотека Австралии. - URL: https://rove.nla.gov.au.

6. Meyer, E.T., Yasseri, T., Hale, S.A., Cowls J., Schroeder, R., Margetts, H. Analysing the UK web domain and exploring 15 years of UK universities on the web // N.Brügger, R.Schroeder (Hg.): The Web as History. Using Web Archives to Understand the Past and the Present. - London: UCL Press, 2017. - Pp. 23-44.

7. Brügger, N., Laursen, D. and Nielsen, J. Exploring the domain names of the Danish web // N.Brügger, R.Schroeder (Hg.): The Web as History. Using Web Archives to Understand the Past and the Present. - London: UCL Press, 2017. P. 62-80. - DOI: https://doi.org/10.25969/mediarep/12515 (дата обращения: 01.09.2020).

8. Youtube Videos. Internet Archive. - URL: https://archive.org/details/youtubecrawl (дата обращения: 01.09.2020).

9. Internet Archive Blogs. Internet Archive. - URL: http://blog.archive.org/category/ video-archive (дата обращения: 01.09.2020).

10. Schafer V. From far away to a click away: The French state and public services in the 1990s. // N.Brügger, R.Schroeder (Hg.): The Web as History. Using Web Archives to Understand the Past and the Present. - London: UCL Press, 2017. Pp. 117-133.

11. Центральный державный электронный архив Украины. Internet Archive. URL: https://web.archive.org/web/*/https://tsdea.archives.gov.ua (дата обращения: 01.09.2020).

12. National Disaster and Digital Preservation: $9 / 11$ and the Internet. Archive-It. URL: https://archive-it.org/collections/4486 (дата обращения: 01.09.2020).

13. Japan, Social movements after the Fukushima Nuclear Power Plants crisis, March 11, 2011. Archive-It. - URL: https://archive-it.org/collections/2954 (дата обращения: 01.09.2020).

14. Presidential Elections - Russia-2008. Archive-It. - URL: https://archive-it.org/ collections/901 (дата обращения: 01.09.2020). 
15. Weber M.S. \& NapoliPh.M. Journalism History, Web Archives, and New Methods for Understanding the Evolution of Digital Journalism // Digital Journalism/ - 2018. - 6:9. P. 1186-1205-DOI: 10.1080/21670811.2018.1510293.

16. Hale S.A., Blank G. and Alexander V.D. Live versus archive: Comparing a web archive to a population of web pages // N.Brügger, R.Schroeder (Hg.): The Web as History. Using Web Archives to Understand the Past and the Present. - London: UCL Press, 2017. URL: https://www.jstor.org/stable/j.ctt1mtz55k.8 (дата обращения: 01.09.2020).

17. Milligan I. (2015). Finding Community in the Ruins of GeoCities: Distantly Reading a Web Archive. UWSpace. URL: http://hdl.handle.net/10012/11650 (дата обращения: 01.09.2020).

18. BESOCIAL - towards a sustainable social media archiving strategy for Belgium. URL: https://www.ugent.be/mict/en/research/besocial-towards-a-sustainable-social-mediaarchiving-strategy-for-belgium (дата обращения: 01.09.2020).

https://doi.org/10.29003/m1841.978-5-317-06529-4/407-412

Юмамева Ю.Ю.

ООО «ДИМИ-ЦЕНТР»

\section{Аудиовизуальные архивы \\ в эпоху цифровой трансформации: \\ новые формы представления и исследования}

Аннотация. Статья является кратким изложением выводов, сделанных автором в монографии [1], написанной на основе анализа создававшейся в течение 18 лет базы дынных, в которой регистрировались представленные в сети коллекции электронных копий аудиовизуальных архивов, и посвящена выявлению основных тенденций в вопросах оцифровки, представления онлайн и использования в качестве исторических источников электронных копий аудиовизуальных документов.

Ключевые слова: методы оцифровки, аудиовизуальные архивы, электронные копии, информационные ресурсы, типология, публичный доступ, аутентичная копия, аутентичное описание, методы исследования, хранение цифровой информации.

Yumasheva Ju. DIMI-CENTER, LLC

\section{Audiovisual archives in the era of digital transformation: new forms of presentation and research}

Annotation. The article is a summary of the conclusions made by the author in the monograph, written on the basis of an analysis of the database of data created over 18 years, in which collections of electronic copies of audiovisual archives presented on the network were registered. The article is devoted to identifying the main trends in digitization, presentation online and use electronic copies of audiovisual documents as historical sources. 
Keywords: methods of digitization, audiovisual archives, electronic copies, information resources, typology, public access, authentic copy, authentic description, research methods, storage of digital information.

Революционные изменения, которые переживает человечество на пути к глобальному информационному обществу, оказывают существенное влияние на гуманитарную сферу.

Три составляющих цифровой трансформации - оцифровка, поиск новых исследовательских инструментов на базе цифровых технологий и изменение принципов организации и управления информационными ресурсами - отчетливо заметны в ходе анализа изменений, происходящих в архивно-библиотечно-музейной сферах.

Очевидно, что внедрение методов перевода информации в электронный вид, развитие технологий ее представления в электронной среде, а затем возникновение возможности организации публичного удаленного доступа к созданным информационным ресурсам, стали своеобразным спусковым крючком для начала «цифровой гонки вооружений» в этих областях. Первым «выстрелом» в череде перечисленных процессов стала оцифровка - как «процесс представления в цифровой форме данных, не являющихся дискретными [2]».

В результате применения такой понимания термина хронологические рамки «цифровой трансформации» применительно к аудиовизуальной документации сдвигаются к середине 1980-х гг., к первым опытам оцифровки статичных документов на прозрачных (пленочных) носителях с помощью проекционных сканеров, а фоноваликов (восковых цилиндров) - с помощью археофона. К середине 1990-х эти процессы приобрели массовый характер [3], вовлекая в оцифровку все более разнообразные комплексы документов, а с 2000-х гг. - стали обязательным направлением деятельности всех фондодержателей.

Подтверждением этого тезиса являются статистические данные об изученных информационных ресурсах, коллекция которых формировалась на протяжении последних 18 лет. Так, на сегодняшний момент созданием аудиовизуальных ресурсов на основе перевода в электронный вид аудиовизуальной информации занимаются в 68 странах мира более 560 различных организаций. Всего же выявлено более 3,5 тыс. информационных ресурсов, и их количество растет с каждым днем.

Оценивая в целом положительно взрывной характер появления информационных ресурсов на основе копий аудиовизуальной документации, следует отметить некоторые негативные тенденции. 
1. За почти 35-летнюю историю сканирования аудиовизуальных документов не были разработаны единые методы их оцифровки, не выбраны единые форматы хранения электронной информации [4], что приводит к невозможности адекватного сравнения электронных копий, созданных разными фондодержателями.

2. Возрастание количества оцифрованной информации ставит вопрос о формах ее представления. В середине 1990-х стали издаваться каталоги собраний на $\mathrm{CD}$-дисках, а с появлением и развитием всемирной путины возникли разные формы публикации электронных копий документов (аудиовизуальных в том числе) в сети Интернет. В настоящее время в Интернет сосуществуют фото-, кино и аудиокаталоги коммерческих структур; специализированные электронные архивные порталы; каталоги крупнейших фондодержателей, в которых аудиовизуальная информация является одним из многочисленных видов представленных документов; тематические и мемориальные ресурсы, интернет-выставки и экспозиции, публикации результатов научных проектов, базы данных, персональные «авторские» сайты, блоги, страницы и т.п., на которых представлены электронные копии аудиовизуальной информации.

Такое разнообразие форм и видов публикаций, а также легкость и бесконтрольность создания «электронных копий с электронных копий» с целью их размещения на «собственных» ресурсах, приводит к возникновению серьезных проблем источниковедческого характера.

Первой из них является проблема множественных повторов информации, не дающая возможности установить владельца «твердого» оригинала, физическую природу этого оригинала (особенно для фотодокументов - отпечаток? негатив? позитив?), место первой публикации электронной копии.

Вторая заключается в невозможности определить степень адекватности электронной копии оригиналу, в том числе из-за незнания авторитета автора публикации, уровня ее научности. Впервые эта проблема была сформулирована еще в 1996 г. в выступлении Дж. Веллинга на XI Международной конференции Association for «History and Computing», где он выразился вполне определенно: «[В интернет] практически невозможно проверить качество информации; каждый идиот может выставить то, что он (она) хочет [5]».

К сожалению, создаваемые в настоящее время на основе массовой оцифровки без реализации процедур аутентификации подлинности оригиналов информационные ресурсы несут на себе печать всех нерешенных проблем, которые являются «побочным эффектом» пе- 
ревода архивных документов в цифровой вид (полнота, достоверность и т.п.). Поэтому они могут рассматриваться исключительно в качестве ознакомительных материалов, а не как полноценная замена исторических источников.

Некоторой, весьма ненадежной (поскольку архивы и музеи хранят и подлинники, и подделки и фальшаки, что требует обязательного указания на подлинность в описании), гарантией качества информационных ресурсов может выступать лишь авторитет организации, создающей электронные копии на основе хранящихся у нее документов, и публикующей их в сети [6].

Третья - в отсутствии полного археографического описания оригинала и электронной копии $[7,8]$. На эту тему писалось уже довольно много, однако, понимая всю сложность ее решения, публикаторы не торопятся ее решать.

Четвертая - в огромном количестве «информационного мусора», засоряющего сеть. К сожалению, наличие «вторичных» с точки зрения факта публикации электронной копии ресурсов значительно затрудняет выявление «первоисточника», поскольку большинство поисковых процедур в сети Интернет настроено на отражение результатов поискового запроса по критериям релевантности или частоты обращений к данному ресурсу, которым «первоисточник» может не соответствовать.

И, наконец, пятая - в вале самых разнообразных подделок, появление которых мотивировано незамкнутостью технологического цикла и простотой оцифровки, отсутствием точных и полных описаний, а также огромными объемами уже оцифрованной информации, в которых крайне сложно выявить подделку, и, к сожалению, политическим заказом, реализуемым ныне в виде «войны фейков».

3. Следующая негативная тенденция кроется в проблемах авторского права и интеллектуальной собственности. Она касается не только подлинников архивных аудиовизуальных материалов, защищенных авторским правом, оцифровка которых отложена до истечения срока действия авторского право, но и самих разработанных информационных ресурсов и опубликованных на них электронных копий, которые в отсутствие единых стандартов и методов оцифровки сами становятся объектами авторского права и интеллектуальной собственности. К сожалению, несмотря на ширящееся движение по организации «Открытого доступа» (Open Access) и отслеживанию произведений, переходящих в общественное достояние (The Public Domain), эти вопросы не только не находят своего юридического разрешения на уровне Всемирной организации интеллектуальной собственности (WIPO 
$[9,10])$, a, напротив, усугубляются в законодательстве и нормативной базе отдельных стран (например, в серии ГОСТов «Интеллектуальная собственность», разработанных и принятых в РФ $[11,12,13])$.

4. Эта проблема является основной причиной ограничений доступа к уже оцифрованным и отрекламированным в сети аудиовизуальным архивам и коллекциям, и выражается, прежде всего, в платности оказания услуг доступа к цифровым ресурсам.

Еще одна тенденция связана с хранением и обслуживанием электронной информации. Не секрет, что файлы аудиовизуальной информации значительны по размерам, что создает определенные сложности при их хранении, миграции и конвертации [14]. По подсчетам специалистов Harvard University Library годовая стоимость хранения и обслуживания 9,5 Гб информации составляет около 143 тыс. долл. США, и, к сожалению, способов ее снижения не найдено. Эта финансовая проблема существенно тормозит процессы оцифровки, создания информационных ресурсов на основе аудиовизуальной документации и представления этих коллекций в сети.

5. Следующая проблема выражается в небольшом (на сегодняшний день) количестве удачных попыток разработки новых методов исследования электронных копий аудиовизуальной документации, что, с одной стороны, может быть объяснено спецификой самих видов источников, требующих наличия специальной подготовки у исследователей, а с другой - «болезнью роста», в ходе которой идет внутренний процесс разработки и апробации инструментария.

Рассмотренные в исследовании примеры осуществленных исследовательских проектов наглядно демонстрируют два обозначившихся подхода к выработке научного инструментария. Первый заключается в попытках переноса и адаптации к цифровой среде традиционных методов изучения аудиовизуальных документов. Второй - в применении полидисциплинарного подхода, т.е. в привлечении методов и методик самого широкого спектра гуманитарных и естественнонаучных дисциплин для решения поставленных исследователями задач. Представляется, что существенные успехи в вопросе создания нового инструментария проявятся на стыке двух этих подходов, т.е. при сохранении и реализации в электронной среде традиционных методов исследования и дополнении их современными методиками из сопредельных дисциплин.

Вместе с тем, сам факт существования большого количества аудиовизуальных архивов и коллекций, представленных онлайн, 
свидетельствует о том, что многие проблемы и вопросы могут быть решены или преодолены в самом ближайшем будущем, что создаст возможность полноценного доступа и использования аудиовизуальной информации в исследовательских целях.

\section{Библиография}

1. Юмашева, Ю.Ю. Цифровая трансформация аудиовизуальных архивов. Аудиовизуальные архивы онлайн: монография / Ю.Ю. Юмашева. - Москва; Берлин: Директ-Медиа, 2020. -600 с.

2. ГОСТ Р 52292-2004. Информационная технология. Электронный обмен информацией. Термины и определения.

3. Recommendations for the Evaluation of Digital Images Produced from Photographic, Microphotographic, and Various Paper Formats // Library of Congress. 1996. - URL: http://memory.loc.gov/ammem/ipirpt.html (дата обращения: 17.08.2020).

4. Guidelines: File Format Comparison Projects // FADGI. - URL: http://www.digitizationguidelines.gov/guidelines/File_format_compare.html (дата обращения: 17.08.2020).

5. Веллинг, Дж. История на интернете // Информационный бюллетень АИК. 1996. - № 19. - С. 55.

6. Chassanoff, A. Historians and the Use of Primary Source Materials in the Digital Age // The American Archivist. - Vol. 76 - No. 2 - Fall/Winter, 2013. - Pp. 458-480. URL: https://americanarchivist.org/doi/pdf/10.17723/aarc.76.2.1h76217m2m376n28 (дата обращения: 17.08.2020).

7. Юмашева, Ю.Ю. Электронные копии документов Архивного фонда РФ: источниковедческие проблемы // Вестник МГУ. Серия 8. История. - 2012. - № 5. C. $151-177$.

8. Юмашева, Ю.Ю. Источниковедческие проблемы представления исторических источников в электронной среде // Вестник МГУ. Серия 8. История. - 2014. - № 6. C. $18-36$.

9. Цели и принципы в отношении исключений и ограничений для библиотек и архивов. // Постоянный комитет по патентному праву и смежным правам. Двадцать шестая сессия, Женева, 16-20 декабря 2013 г. - URL: https:/www.wipo.int/ edocs/mdocs/copyright/ru/sccr_26/sccr_26_8.pdf (дата обращения: 17.08.2020).

10. Исключения из авторского права для архивов: типологический анализ. Документ подготовлен доктором юриспруденции, кандидатом наук Кеннетом Д. Крузом // Постоянный комитет по авторскому праву и смежным правам. Тридцать девятая сессия. Женева, 21-25 октября 2019 г. - URL: https:/www.wipo.int/edocs/mdocs/ copyright/ru/sccr_39/sccr_39_5.pdf (дата обращения: 17.08.2020).

11. ГОСТ Р 55386-2012. Интеллектуальная собственность. Термины и определения. С изменениями, вступающими в силу 01.12.2018 г.

12. ГОСТ Р 55385-2012. Интеллектуальная собственность. Научные произведения.

13. ГОСТ Р 56824-2015 Интеллектуальная собственность. Использование охраняемых результатов интеллектуальной деятельности в сети Интернет.

14. Bushey, J. Investigating Sites of Power: Audiovisual Archives and Social Media Platforms // Photographic Powers - Helsinki Photomedia, 2014. - Pp. 264-286. - URL: https://www.academia.edu/16637852/Investigating_Sites_of_Power_Audiovisual_Archives _and_Social_Media_Platforms._pp._264-286 (дата обращения: 17.0̄08.2020). 


\section{ЦИФРОВЫЕ РЕСУРСЫ И ТЕХНОЛОГИИ В ПРОФЕССИОНАЛЬНОМ ИСТОРИЧЕСКОМ ОБРАЗОВАНИИ}

https://doi.org/10.29003/m1842.978-5-317-06529-4/413-420

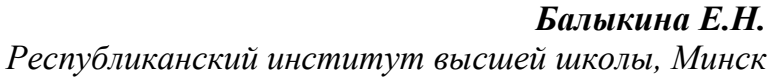

\section{Невербальная поддержка информационного материала в электронном гуманитарном образовании}

Аннотация. Электронные учебные пособия и учебно-методические комплексы, характеризующиеся наглядностью, доступностью, интерактивностью и аттрактивностью, способны пробудить когнитивный интерес студентов. Использование наглядных образов позволяет сфокусировать внимание обучаемых на конкретных символах, понятиях, представлениях. В работе обосновывается необходимость преобразования знаковой информации в образную и рассматриваются этапы трансформации объемного учебного текста в компактный интерактивный мультимедийный конспект.

Ключевые слова: графика, электронное обучение, цифровая трансформация.

Balykina E.N.

Republican Institute of Higher Education, Minsk

\section{Non-verbal support of information material in electronic Humanities education}

Abstract. Electronic teaching aids and teaching and methodological complexes, characterized by visibility, accessibility, interactivity and attractiveness, can awaken cognitive interest of students. The use of visual images allows you to focus the attention of trainees on specific symbols, concepts, representations. The paper substantiates the necessity to transform the sign information into a figurative one and examines the stages of transforming the voluminous text into a compact interactive multimedia abstract.

Keywords: graphics, e-learning, digital transformation.

В начале XXI в. электронное обучение (electronic learning, elearning) стало активно внедряться в традиционное обучение в самых различных организационных формах: как поддержка традиционного очного и заочного обучения, как новый уровень развития дистанционного обучения по программам дополнительного образования детей и взрослых, повышения квалификации преподавателей вузов, первого и второго высшего образования, магистратуры.

Согласно «Концепции цифровой трансформации процессов в системе образования Республики Беларусь на 2019-2025 годы», чрез- 
вычайно важно активизировать внедрение в образовательный процесс использование электронных учебников. Кроме того, необходимо решение следующих задач:

- разработка методик, технологий, ресурсов и сервисов, обеспечивающих формирование и накопление знаний, получение гарантированного эффекта от их использования;

- создание персонального цифрового профиля и построение индивидуальной образовательной траектории [1, с. 7-9].

Для того, чтобы электронные учебные материалы (ЭУМ) обеспечивали формирование и накопление знаний для каждого обучаемого с гарантированным эффектом от их использования по индивидуальной образовательной траектории, они должны создаваться и применяться по определенным правилам.

При проектировании ЭУМ по гуманитарным дисциплинам основное внимание, как правило, уделяется качеству текста и недостаточно статичной графике, визуализации объектов, аудио и видеоматериалам, 2D и 3D-моделированию.

Вербальная информация (verbalis - устный, словесный) - это словесная информация, передаваемая с помощью речи, текста, письма. Невербальное общение - это коммуникационное взаимодействие между индивидами без использования слов (передача информации или влияние друг на друга через образы, интонации, жесты, мимику, пантомимику, изменение мизансцены общения).

При отсутствии или ограниченом объеме анимации, звука и видеоинформации, особое внимание должно уделяеться иллюстративному материалу.

В данной работе акцент ставится на создании и трансформации графического контента при проектировании ЭУМ.

Графика сама по себе привлекает внимание и раскрывает основную мысль быстро и наглядно, что подчеркивают четыре тезиса:

1) фокус - графика концентрирует внимание на ключевой идее лекции;

2) согласие - графика способствует тому, чтобы аудитория согласилась с вашими аргументами (исследования показали, что нейтрально настроенная аудитория, соглашается с текстовой информацией в $58 \%$ случаев, а с графической в $79 \%$ случаев);

3) запоминание - графика способствует лучшему запоминанию информации (человеку свойственно образное мышление, поэтому изображения гораздо быстрее, чем текст, восстанавливаются в памяти); 
4) «использование изображений» не означает применения декоративных элементов (обычно аудитория отрицательно относится к лишним графическим элементам, которые заполняют пробелы на странице и не имеют прямого отношения к делу).

Эффективность e-learning в значительной степени зависит от соблюдения дизайн-эргономических рекомендаций к учебным материалам. В критериях оценки качества электронных учебников среди дизайн-эргономических показателей Главный информационноаналитический центр Министерства образования Республики Беларусь в методических рекомендациях по проведению дизайнэргономической экспертизы выделил группу визуального оформления [2].

А в визуальном оформлении отмечено следующее:

- рекомендации к визуальной среде,

- цветовые характеристики визуальной информации,

- рекомендации по расположению информации на экране,

- оптимальность восприятия текстовой, графической и текстово-графической информации.

Общеизвестно, что всех людей в зависимости от способа восприятия ими информации можно разделить на визуалов, аудиалов и кинестетиков. Визуал - человек, который воспринимает большую часть информации с помощью зрения. Он «видит» информацию. Визуальная среда на экране монитора может быть: комфортная, нормальная, гомогенная, агрессивная. Комфортная визуальная среда - это среда с большим разнообразием элементов. Гомогенная визуальная среда это среда, в которой объект сливается с фоном. Агрессивная визуальная среда - среда, в которой обучаемый одномоментно видит большое число одинаковых элементов. Такая среда вызывает неприятные зрительные ощущения. Если одинаковые микрообъекты разнесены менее чем на 1.2-1.5 см по горизонтали и на 1.7-1.8 см по вертикали в поле зрения, а также их число более пяти, то невозможно зафиксировать взгляд на одном микрообъекте. Возникает агрессивное поле. Нормальной визуальной средой считается среда, в которой иногда встречаются гомогенные и агрессивные поля, оказывающие незначительное влияние на общую визуальную обстановку. Для создания нормальной визуальной обстановки изображения на экране монитора должны соответствовать рекомендациям: расстояние между объектами 2,5 $\left(1^{\circ}\right.$ по вертикали соответствует $0.9 \mathrm{~cm}, 1^{\circ}$ по горизонтали $\left.-0.7 \mathrm{~cm}\right)$ и число однотипных объектов не более 5 . 
Важность графической информации следует сочетать с четырьмя полями ее восприятия:

1) поле высоко значимой информации $\left(15^{\circ}\right.$ во все стороны от оси зрения, т. е $14-16 \mathrm{~cm})$;

2) поле главного объекта $\left(10^{\circ}\right.$ во все стороны от оси зрения, т.е. 9-10 см);

3) поле опознания взаимного расположения объектов (вверх $25^{\circ}$, вниз $35^{\circ}$, вправо и влево по $32^{\circ}$ от оси зрения, т.е. соответственно 24-28 см., 34-40 см, 31-37 см);

4) поле точного восприятия изображения ( $3^{\circ}$ вверх-вниз, $7^{\circ}$ вправо-влево от оси зрения, т.е. 2,6-2,7 см, 4,8-5,2 см соответственно).

Следует учитывать, что при восприятии графической информации сначала анализируются объекты большого размера, затем меньшего в пределах поля высоко значимой информации. Главный объект выбирается в результате логической обработки всего объема графической информации на экране монитора.

На эргономические показатели ЭУМ и комфортность восприятия зрительной информации существенное влияние оказывает степень засоренности поля главного объекта. Рекомендуется размещать в поле главного объекта не более 4-6 второстепенных объектов. Увеличение числа второстепенных объектов может привести к рассеиванию внимания и выпадению главного объекта из области внимания, либо к слиянию второстепенных объектов с фоном.

Соотношение текста, формул и изображений варьируется в зависимости от возраста. Для студентов текста д.б. не больше 45\%, формул - не больше $25 \%$, остальное - изображения (размещение не плотно, на расстоянии $2,5^{\circ}-2,15 \mathrm{~cm} \times 1,75 \mathrm{~cm}$ ).

Формы объектов и элементов фона должны быть похожи на формы реальных предметов, объектов. В противном случае происходит потеря учебного времени из-за возникающих вопросов. Очень часто, к сожалению, проводят непропорциональное масштабирование, искажая «вытягиванием» или «расширением» рисунки до $\pm 30 \%$, а также недопустимое увеличение до 500\%(!) небольшого объекта, значительно теряя при этом в качестве.

Построение изображений на экране монитора следует выполнять по законам гармонии. Это достигается созданием иллюзии разной удаленности объектов, использованием линий разной толщины и контрастности. 
При создании ЭУМ рекомендуется компоновать объекты:

- близко друг от друга, так как чем ближе в зрительном поле объекты друг к другу (при прочих равных условиях), тем с большей вероятностью они организуются в единые, целостные образы;

- с учетом свойств продолжения, так как чем больше элементы в зрительном поле оказываются в местах, соответствующих продолжению закономерной последовательности, тем с большей вероятностью они организуются в целостные единые образы;

- с учетом особенности выделения предмета и фона при выборе формы объектов, насыщенности цвета, и т.п.;

- не перегружая визуальную информацию деталями, яркими и контрастными цветами;

- выделяя учебный материал, предназначенный для запоминания цветом, подчеркиванием, размером и т.п.

Следует применять постоянство используемых цветов для обозначения аналогичности графических конструкций; а также соответствие цветов устойчивым зрительным ассоциациям (цвета объектов изображения похожи на цвета реальных объектов). Рекомендуется соблюдать:

- оптимальность нюанса и контраста изображения по отношению к фону: для графической информации приоритетно использование прямого контраста - на светлом фоне;

- яркость цветов объектов по отношению к фону (необходимо равномерное распределение яркости, яркостный контраст $60 \%$, т.к. меньше - хуже различение, а больше - послеобразы и утомление);

- пропорции «золотого сечения».

Если информация представлена в графическом виде, то зрительный анализатор и мозг способны работать в режиме быстрого панорамного обзора с помощью периферийного зрения и почти мгновенно воспринимать большое количество информации, в отличии от медленного восприятия при чтении текста [3].

Поэтому в теоретических $e$-материалах желательно свести текстовую информацию к минимуму, заменив ее образами, схемами, диаграммами, рисунками, фотографиями, анимационными фрагментами или фрагментами фильмов.

Процессы цифровизации и формирования глобальной информационной среды породили новые способы «упаковки» образовательно значимой информации, более компактные и удобные для использо- 
вания. Эти способы представителями цифрового поколения усваиваются уже на ранних этапах детства, вследствие чего меняется и сам стиль мышления обучающихся. Он перестает быть нарративным (основанным на повествовании, подробном словесном объяснении нового материала, самостоятельном изучении объемных текстов) и становится инфографическим. Инфогра́фика (количественная, пространственная, временная, абстрактная) - это графический способ подачи информации, данных и знаний, целью которого является быстро и чётко преподносить сложную информацию.

Предлагается трансформацию текста и статичной графики производить в два этапа:

1) преобразование тахі-текста в mini-текст; затем mini-текста с графикой в инфографику;

2) изменение статичной инфографики в динамичный интерактивный конспект и создание на его основе раздаточного материала для студентов/слушателей.

На первом этапе необходимо подробно структурировать контент на основе структурно-логических схем, потом преобразовать теоретический курс лекций в конспект лекций, затем конспект минимизировать до тезисов конспекта. Следующим шагом тезисы конспекта разбиваются на фреймы и/или абзацы с выделением основных мыслей, что позволяет добиться существенного сокращение объема текстового материала (не менее 50\%), так как особенностью ЭУМ является их лаконичность и предельная ясность формулировок. Потом во фрейме выделяются ключевые слова и словосочетания, которые можно представить нумерованным/маркированным списком [4] с невербальной поддержкой.

Затем мини-текст трансформируем в текстографику, т.е. преобразовываем текст в графические (иллюстративные) конструкции, схемы, диаграммы, таблицы в следующей последовательности «схема-рисунок-график-таблица-текст». Если информацию можно представить на слайде графическим объектом с использованием сигнального слова или фразы, то следует воспользоваться этим, т.е. лучше показать объект, чем о нем написать. Рекомендуется использовать текст только если все предыдущие способы отображения информации не подошли. Т.е. мы получаем формулу «Лаконичный текст + схемы и рисунки, графики и таблицы, графы и деревья, диаграммы и mind map, sunkey и реконструкции, пиктограммы и блоксхемы, спарклайны и облака тегов = инфографика». 
На втором этапе, по возможности, необходимые элементы статичной инфографики преобразуем в мультимедийные объекты и трехмерные интерактивные образы (можно раскрывать сложную диаграмму или график частями, в определенной последовательности, звуковым треком по ходу объясняя их; показать переход от одной ситуации к другой путем перемещения какого-то объекта с одного места в другое). Таким образом, тезисы конспекта плавно «перетекают» в опорный (опорный конспект - система условных обозначенийсигналов, отражающих необходимую для усвоения информацию, которые раскрываются при их расшифровке), затем динамичный интерактивный конспект.

Статика основы (50-70\%) динамического конспекта в виде конспект-форм (выдачи в MS PowerPoint) предлагалась обучаемым в распечатанном виде. Лекционная тетрадь для e-Learning с готовыми ключевыми слайдами позволяет студенту/слушателю во время лекции акцентировать внимание и подчеркивать только важные моменты: обвести основное понятие, вставить формулу, дополнить схему еще одним элементом или подписью, а так же записывать ответы на вопросы, касающиеся слайда, и дополнительную информацию [5, c. $65-86]$.

Итак, при проектировании графики нужно учитывать:

- сочетание важности графической информации с четырьмя полями ее восприятия,

- четыре основных тезиса (фокус, согласие, запоминание и «ничего лишнего»),

- оптимальное количество однотипных графических объектов на экране и расстояние между ними,

- степень засоренности поля главного объекта,

- порядок анализа объектов на основе их размера,

- форму и цвет объектов, а также их масштабирование,

- соотношение текста, формул и изображений на одном экране,

- правила компоновки графических объектов,

- корректное цветовое решение и др.

Данные подходы к созданию и трансформации графического еконтента реализованы автором в Республиканском институте высшей школы на курсах повышения квалификации преимущественно по Rotation Model и Online Driver Model моделям blended learning в системе дистанционного обучения Moodle и сервисе конференцсвязи Zoom [4, 5, 6]. 


\section{Библиография}

1. Концепция цифровой трансформации процессов в системе образования Республики Беларусь на 2019-2025 годы / Национальный правовой Интернет-портал Республики Беларусь. - URL: http:/www.pravo.by/novosti/obshchestvenno-politicheskiei-v-oblasti-prava/2019/april/33742/ (дата обращения: 30.11.2019).

2. Главный информационно-аналитический центр Министерства образования Республики Беларусь. - URL: http://www.giac.unibel.by/ (дата обращения: 15.05.2019).

3. Леньков С.Л., Рубцова Н.Е. Эргономическое проектирование электронных учебников // Открытое образование. - 2001. - № 2. - С. 10-13.

4. Балыкина Е.Н. Моделирование текстового контента для электронных учебных материалов в историческом образовании // Информационный бюллетень Ассоциации «Истории и компьютер». Специальный выпуск. - 2016. - №45. - С. 223-225.

5. Балыкина Е.Н., Бузун Д.Н. Компьютерное педагогическое тестирование: теория и практика: учеб.-метод. пособие (с приложением CD). 5-е изд. - Минск: РИВШ, 2018. - 104 с.

6. Традиции университета: от Франциска Скорины до современности: сб. материалов Междунар. науч. конф., Минск, 26-27 окт. 2017 г. / редкол.: С.Н. Ходин [и др.]. - Минск: Изд. центр БГУ, 2018. - 285 с.

https://doi.org/10.29003/m1843.978-5-317-06529-4/420-427

Гернович Т.Д. Белорусский государственный университет, г. Минск, Беларусь

\section{Цифровые технологии и их роль}

\section{в современном историко-архивном исследовании и образовании}

Аннотация. В статье рассматриваются основные векторы применения цифровых технологий в архивной сфере. Отмечается, что оцифровка документов и развитие технологий открытого доступа создали благоприятные условия для использования и обеспечения сохранности архивных документов. Создание научно-популярных проектов способствует расширению аудитории архивных пользователей и формирует в обществе уважительное отношение к документальному наследию. Основной тенденцией в применении цифровых технологий в научных исследованиях остается совершенствование методов создания цифровых публикаций документа.

Ключевые слова: архив, оцифровка, цифровая публикация, ресурсы открытого доступа, TEI.

Hiarnovich T.D. Belarusian State University, Minsk, Belarus

\section{Digital technologies in modern historical and archival research and education}

\footnotetext{
Abstract. The article discusses the main vectors of the application of digital technologies in the archival field. It is noted that the digitization of documents and the development of open access technologies have created favorable conditions
} 
for the use and preservation of archival documents. The creation of popular science projects contributes to the expansion of the audience of archive users and forms a respectful attitude towards documentary heritage in society. The main trend in the application of digital technologies in scientific research remains the improvement of methods for creating digital editions.

Keywords: archives, digitization, digital editions, open data, TEI.

Определяя место и роль цифровых технологий в современном историко-архивном исследований и образовании мы часто говорим об их универсальности и многогранности. Пандемия, вызванная вируcoм Covid-19, показала, что в условиях самоизоляции и социального дистанцирования цифровые технологии являются также основным механизмом поддержания общества в активном состоянии и обеспечивают непрерывность образовательного и исследовательского процессов. Благодаря созданным виртуальным коллекциям документов с открытым доступом, несмотря на закрытие посещения по всему миру читальных залов архивов и библиотек, значительная часть информационных ресурсов могла использоваться без ограничений.

Отвечая, на новые вызовы, архивы различных стран смогли в полной мере задействовать ресурсы, связанные с использованием цифровых технологий, которые активно развивались в этой сфере последние десятилетия. Основные векторы их использования в архивной отрасли напрямую отражаются в изменении образовательных курсов университетов различных стран, ведущих подготовку историков-архивистов.

Традиционное архивоведение в настоящее время переживает трансформацию, которую сложно не заметить. Электронный документ и цифровые технологии не только расширили и изменили объект исследования, но и стали причиной ряда дискуссий терминологического и теоретического характера. В этой связи ярким примером является название первого номера журнала La Gazette des archives в 2019 г., которое выбрали французские коллеги: «Вкус архива в цифровую эпоху». Это название отсылает нас к книге французской исследовательницы Э. Фарж «Вкус архива», которая была опубликована в 1989 г., была переведена на многие языки и стала бестселлером. В ней автор описала свои эмоции, переживания, а также наблюдения за реакцией исследователей в читальном зале архива [1]. Редакторы журнала очень точно сформулировали основную парадигму трансформации архива: изменения затронули не только методы работы с документом, но и изменили архив, архивиста и исследователя. 
Одним из основных направлений использования цифровых технологий в архивах является оцифровка архивных фондов и коллекций. Создание цифровых копий одновременно решает несколько проблем: обеспечения сохранности и упрощение использования документов. Основной тенденцией последних лет остается создание ресурсов открытого доступа. Национальные архивы США, Великобритании, стран Европейского Союза, Беларуси, России, Украины, Польши размещают в свободном доступе изображения документов, хранящихся в их фондах на своих сайтах.

Программа ЮНЕСКО «Информация для всех» (IFAP) 2002 г., Рекомендации Европейской комиссии по оцифровке и цифровому сохранению, способствовали разработке национальных стратегий долговременного сохранения цифровых материалов и доступа к ним. Для мониторинга выполнения Рекомендаций в странах Европейского Союза и обмена опытом в 2007 г. была создана Экспертная группа по оцифровке и сохранению цифрового наследия [2].

В последующие годы новая Рекомендация ЕС по оцифровке и онлайн-доступности и цифровому сохранению культурного материала (25 октября 2011) (Recommendation on digitisation and online accessibility and digital preservation of cultural material) и Новая европейская политика в области культуры (New European Agenda for Culture) провозглашают принцип «доступности культуры для всех». Оцифрованное культурное наследие размещается в открытом доступе в Europeana, европейской цифровой платформе культурного наследия [3].

Продвижение решений, которые делают культурное наследие доступным для всех, в том числе с помощью цифровых средств, также было одной из целей Европейского года культурного наследия 2018 года. ЕС инвестировал 265 миллионов евро в исследования и передовые технологии оцифровки, цифровое копирование и инновационные культурные проекты. 9 апреля 2019 г. 24 европейские страны подписали Декларацию о сотрудничестве в продвижении оцифровки культурного наследия. Основными принципами Декларации стали демократизация доступа к культурному наследию, общеевропейское сотрудничество между институтами наследия и содействие взаимодействию и открытому доступу, уважая авторское право [4]. Директива об авторском праве и смежных правах на едином цифровом рынке, которая была утверждена Европейским парламентом в 2019 г., позволит размещать в он-лайн доступе ещё большее количество оцифрованных коллекций. 
Другой стороной оцифровки и принципа открытого доступа к документам архивов стало расширение целевой аудитории и создание с помощью цифровых технологий проектов, ориентированных не только на исследователей, но и на широкую аудиторию (студентов, школьников, обычных граждан, интересующихся историей своей страны, семьи и др.). Несмотря на то, что проекты носят научнопопулярный характер, они имеют большое значение для развития историко-архивного образования и популяризации феномена «архива» в обществе и культуре.

В основном образовательные проекты представляют не только текст документов, но и исторический контекст, биографии людей, которые упоминаются в тексте либо принимали участие в его создании, научные статьи по этой теме. Так, например, такой подход был выбран Национальными архивами США для раздела America's Founding Documents и представления Декларации независимости США, Конституции США и Билля о правах [5]. Национальные архивы Великобритании представляют по каждой исторической эпохе примеры уроков, основанных на тексте конкретных документов, которые учителя могут использовать в образовательном процессе [6].

Научно-популярные проекты, основанные на архивных документах, используют разнообразные приемы подачи контента, в том числе с привлечением игровых элементов и интерактивных технологий. Так, например, Национальные архивы Великобритании в разделе для школьников предлагает интерактивную игру, основанную на информации Книги судного дня - одного из самых известных документов, хранящихся в Национальном архиве Великобритании. Она был написана более девятисот лет назад по приказу Вильгельма Завоевателя, который хотел знать, сколько стоит его королевство и на какие налоги он может рассчитывать. Результатом стало создание подробного описания земель, принадлежащих королю и его людям. В игре предлагается создать вымышленную деревню из объектов и животных, описанных в Книге судного дня и набрать как можно больше очков за счет использования типичных объектов ландшафта Англии XI века [7]. Национальный архив в Кракове предлагает проект «Dawne pismo», который, как отмечают его создатели создан для того, чтобы познавать историю повседневной жизни таких людей, как и мы. В проекте предлагаются различные игры и развлечения со словами, головоломки и кроссворды, составленные из информации архивных документов. Также в проекте предлагается познакомиться с различными типами письма и научиться «чтению» старых писем 
через знакомство с основами палеографии и транскрибирование их текста [8].

В последние годы обучение чтению исторического текста и оказание помощи архивным и научным учреждениям по транскибированию изображений документов стало новым трендом в работе архивов. Такие проекты организовываются как волонтерские и предполагают участие всех желающих. Их основная задача - обеспечить «читабельность» для поисковых машин текста документа, которые в нераспознанном виде являются для поисковых механизмов «белыми пятнами». Существующие программные средства не обладают технологиями, позволяющими автоматически распознавать рукописный текст. Поэтому на современном этапе такие проекты приобретают актуальность.

Одним из последних проектов, который получил особую актуальность в связи с распространением вируса Covid-19 и режима самоизоляции, был проект NARA Citizen Archivist. NARA предлагала всем желающим присоединиться к этому проекту и внести свой вклад в Национальный архивный каталог, транскрибируя и добавляя комментарии к изображениям документов, сделав их таким образом более доступными для поиска. Как отмечалось на страничке проекта «Каждый ваш вклад помогает разблокировать историю» [9].

В рамках портала Europeana также был реализован проект по транскрибированию документов 1914-1918 гг., посвященный Первой мировой войне. В рамках проекта постоянно проводятся конкурсы по транскрибированию. Участники, имеют возможность работать в командах и представлять свои результаты жюри. Те команды, которые набирают больше «миль» во время соревнования, награждаются виртуальными чемпионскими кубками и реальными призами. Первое из этих мероприятий было проведено при запуске веб-сайта в Риге. В 2017 г. состоялся первый тематический конкурс «Любовное письмо» по случаю Дня Святого Валентина. Для транскрибирования был предложен комплекс документов, содержащих личные любовные истории из переписки Первой мировой войны [10].

Среди проектов по транскрибированию комплексов архивных документов следует отметить публикацию: «Завещания парижан солдат Первой мировой войны (1914-1918 гг.)» [11]. В проекте была создана платформа, которая позволяет в он-лайн режиме осуществлять транскрибирование документов. Изображения завещаний солдат были загружены на сайт и систематизированы по авторскому и географическому признаку. После регистрации на сайте любой желающий может ознакомиться с методическими рекомендациями и 
стать участником команды по транскрибированию документов. Благодаря транскрибированию текстов документов создается база данных авторов завещаний, информация о которых связывается в виде геометок с картой. Этот проект, несмотря на свою открытость всем желающим, носит научный характер. Для создания баз данных производится разметка транскибированых текстов с помощью стандарта TEI (инициатива кодирования текста). Формат TEI определяет около 500 различных текстовых компонентов и понятий (слово, предложение, символ, персона, и т.д.), а также позволяет формализовать описания, отражающие физическое состояние, особенности хранения и т.Д. Инструменты TЕI позволяют представлять параллельные элементы (зачеркивание, редакторское прочтение, разные варианты прочтения и т.д.), что расширяет границы критического изучения текста. Благодаря применению разметки текст становится не только «читаемым» для машинного поиска, но и делится на логические элементы, которые позволяют проводить источниковедческий анализ, а также формировать научно-справочный аппарат [12; 13].

Использование такого комплексного подхода стало итогом научных дискуссий о трансформации понятия электронная публикация документа. Петер Робинсон, профессор Бирмингемского университета (Великобритания) и Университета Саскачевана (Канада) в статье «Цифровая революция в академической публикации» приводит пример: за двадцать пять лет до 8 июля 2009 года Британская библиотека позволила только четырем ученым осмотреть 347 листов великого Синайского кодекса IV века. В тот день, когда изображения всей рукописи были опубликованы в Интернет они были просмотрены более миллионом человек за несколько месяцев. Это революция, и очень быстрая. Рассуждая далее П. Робинсон заключает, что размещение изображения памятника в Интернет не является истинной революцией, потому что это событие не стало толчком для появления качественно нового знания и научного открытия [14]. Исследования различных авторов, посвященные проблеме цифровой публикации заключают, что «цифровая публикация» предполагает создание новой плюралистической модели для концепции «текста», целью которой является включение всех различных аспектов научного редактирования, а также декодирования и перекодирования этих текстов в научные издания.

В этом случае «цифровая публикация» должна предусматривать: представление цифровых копий текста, транскрибирование и кодирование текста в формате SGML, XML, TEI; создание массивов дан- 
ных на основе текста, которые через систему гиперссылок будут создавать текстуальные и интертекстуальные связи понятий и значений (географических, именных, предметных и т.д.); предоставление инструментов для возможности поиска и анализа текста [15].

Использование цифровых технологий для создания цифровых публикаций дало толчок к появлению новых научных направлений: компьютерного источниковедения, компьютерной археографии. В образовательном процессе ряд высших учебных заведений, занимающихся подготовкой архивистов выделяют отдельные направления специализации для изучения всех аспектов создания цифровых публикаций документа. Так, например, Национальная Школа Хартий (Франция, г. Париж), одно из старейших европейских учебных заведений, предлагает магистерскую программу «Архивы - цифровые технологии применительно к истории (Archives - Technologies numériques appliquées à l'histoire)». В ходе обучения студентам предлагают курсы по цифровой гуманитаристике, web-проектированию, разметке и описанию структуры документа, созданию цифровых публикаций, баз данных и др. [16].

Таким образом, основной тенденцией последних десятилетий в архивной сфере стало активное использование цифровых технологий в образовательном процессе и архивном деле. Технологии Open data, электронное правительство и электронный документ создали прочный фундамент для развития целого ряда научных и научнопопулярных направлений в изучении и использовании архивных документов. Как нам представляется, такое положение вещей в будущем будет только расширяться. Мы уже сейчас наблюдаем появление «архивов нового поколения», «архивов новых источников»: архивы API, архивы эмоций, которые вызывают наиболее яркие события в социальных сетях и др. Конечно вкус архива в цифровую эпоху изменился, но современные проекты, которые создаются на основании архивных документов, позволяют думать, что он остался таким же притягательным.

\section{Библиография}

1. Farge A. Le goût de l'archive. - Paris: Le Seuil, 1989, 156 p.

2. Рекомендации ЕС по оцифровке и он-лайн-доступности и цифровому сохранению культурного материала (25 октября 2011) // EUR-lex. Access to European Union law [Электронный ресурс]. - URL: https://eur-lex.europa.eu/LexUriServ/LexUriServ.do? uri=OJ:L:2011:283:0039:0045:EN:PDF (дата обращения: 07.08.2020).

3. Новая европейская политика в области культуры // The European Commission [Электронный ресурс]. - URL: https://ec.europa.eu/culture/sites/culture/files/ commission communication_-_a_new_european_agenda_for_culture_2018.pdf. (дата обращения: 03.08.2020). 
4. Декларация о сотрудничестве в продвижении оцифровки культурного наследия // The European Commission [Электронный ресурc]. - URL: https://ec.europa.eu/ digital-single-market/en/news/eu-member-states-sign-cooperate-digitising-culturalheritage?fbclid=IwAR0Bd3o0TlrftoM5PpIXtspK7TEXkONUlBeZx0QDtC1aQqhwASwqB 1zoeYE. (дата обращения: 02.08.2020).

5. America's Founding Documents [Электронный ресурc] - URL: https://www. archives.gov/founding-docs (дата обращения: 02.08.2020).

6. Education and Outreach The National Archives [Электронный ресурс] - URL: https://www.nationalarchives.gov.uk/education/ (дата обращения: 04.08.2020).

7. The National Archives / Exhibitions / Domesday Book / Domesday game [Электронный ресурс] - URL: https://www.nationalarchives.gov.uk/domesday/domesday-game/ (дата обращения: 04.08.2020).

8. Projekt Dawne pismo [Электронный pecypc] - URL: http://dawnepismo.ank. gov.pl/ (дата обращения: 04.08.2020).

9. NARA Citizen Archivist [Электронный ресурc] - URL: https://www.archives. gov/citizen-archivist (дата обращения: 06.08.2020)

10. TRANSCRIBATHON [Электронный ресурc]. - URL: https://transcribathon.com/ (дата обращения: 05.08.2020).

11. Le projet Testaments de Poilus [Электронный ресурс]. - URL: https://testamentsde-poilus.huma-num.fr/\#!/content/17 (дата обращения: 03.08.2020)

12. TEI P5: Guidelines for Electronic Text Encoding and Interchange / Eds. L. Burnard, S. Bauman. S. 1., 2010.

13. TEI: Инициатива кодирования текста [Электронный ресурс]. - URL: https://teic.org/Support/Learn/ (дата обращения: 03.08.2020).

14. Sahle, P. Digitale Editionsformen. Teil I: Das typografische Erbe, Teil II: Befunde, Theorie und Methodik, Teil III: Textbegriffe und Recodierung. / Patrick Sahle; Schriften des Instituts für Dokumentologie und Editorik 7-9. Norderstedt, 2013. Online-Version $7=$ urn:nbn:de:hbz:38-53510, 8 = urn:nbn:de:hbz:38-53523, 9 = urn:nbn:de:hbz:38-53534 [IDEPage on the publication].

15. Гернович Т.Д. Цифровая публикация документа как средство сохранения, изучения и использования культурного наследия // Здабыткі: дакументальныя помнікі на Беларусі / Нацыянальная бібліятэка Беларусі. - Мінск, 2019. - Вып. 22. - С. 190-205.

16. Master «Archives - Technologies numériques appliquées à l'histoire» - URL: http://www.chartes.psl.eu/fr/cursus/master-technologies-numeriques-appliquees-histoire (дата обращения: 03.08.2020).

https://doi.org/10.29003/m1844.978-5-317-06529-4/427-433

Иванова Н.П., Брюханова Е.А. Алтайский государственный университет, Барнаул

\section{Digitaleducation - новые вызовы или чему учить историков?}

Аннотация. Целью публикации является демонстрация опыта внедрения (в рамках дисциплины «источниковедение») обучающих технологий по работе с цифровыми данными (электронными копиями исторических источников, электронным НСА, историческими информационными системами) на примере одного массового статистического источника - Первой всеобщей переписи населения Российской империи 1897 г., а также при овладении технологией баз данных. 
Ключевые слова: Digital education; цифровой поворот; цифровые практики; источниковедение; цифровые и электронные источники; цифровые данные.

\section{Ivanova N.P., Bryukhanova E.A. Altai State University, Barnaul}

\section{Digitaleducation - new challenges or what to teach historians?}

Abstract. The purpose of the publication is to demonstrate the experience of introducing (within the discipline of "source studies") teaching technologies for working with digital data (electronic copies of historical sources, electronic NSA, historical information systems) using the example of one massive statistical source - the First General Census of the Russian Empire in 1897 as well as mastering database technologies.

Keywords: Digital education; digital twist; digital practices; source study; digital and electronic sources; digital data.

Новые реалии нашего времени, признанный многими учеными «цифровой поворот» и переход в «цифровую эпоху» $[1 ; 2 ; 3 ; 4 ; 5]$ требуют новых подходов в обучении современных студентов, особенно на уровне магистратуры. В эпоху digital трансформаций современного общества историческое образование должно принять вызов и давать студентам новые компетенции, а именно умение работать с новыми форматами исторических источников, навыки их поиска, интерпретации и моделирования собственных источникоориентированных систем и/или баз данных. Студенты-историки должны получить полный набор «цифровых практик», включающий «практики цифрового чтения, практики цифрового письма и практики цифрового участия» [6]. В таком контексте заметно меняется роль и место источниковедения в профессиональной подготовке будущих историков, поскольку именно оно играет особую роль в формировании «практике цифрового чтения», как основного исследовательского навыка. Вслед за А.Ю. Володиным под «цифровым чтением» понимаем поиск, оценку степени достоверности и интерпретацию исторических источников, а также навигацию по электронным ресурсам научной информации (архивы, библиотеки, учебные и научные учреждения) [6]. Если в работе с традиционными (текстовые основной вид источников, изучаемых в рамках курса) источниками в источниковедении вполне сложились и наработаны методы атрибуции и оценки степени достоверности (внешняя, внутренняя критика) источников, то появление электронных копий «аналоговых» источников и создание научными сообществами новых форм цифровых 
источников (базы данных, информационные системы, научносправочный аппарат) создает определенные трудности не только у профессиональных исследователей, но и в процессе обучения методам работы с ними студентов, поскольку в профессиональной среде пока не обобщен опыт использования, принципы и методы работы с цифровыми и электронными источниками, не осуществлена их классификация. К тому же из-за отсутствия единых стандартов публикации в информационных ресурсах копий исторических документов, время от времени те или иные исторические информационные ресурсы подвергаются справедливой критике [7]. Это необходимо учитывать при обучении студентов практике и методам работы с цифровыми источниками, электронным научно-справочным аппаратом и электронными копия объектов историко-культурного наследия (в том числе текстовыми). Причем, речь уже ведется не столько о работе (поиске, выявлении, оценке) с исторической информацией, сколько о работе с историческими данными, которые могут существовать в современных реалиях в самых разнообразных форматах (аналоговом, цифровом) [6]. В этом случае встает вопрос, как научить студентов работать с этими данными, как определять степень достоверности информации, извлеченной из цифровых источников. Целью публикации является демонстрация опыта внедрения (в рамках дисциплины «источниковедение») обучающих технологий по работе с цифровыми данными (электронными копиями исторических источников, электронным НСА, историческими информационными системами) для формирования «практики цифрового чтения» [6], который включает несколько последовательных этапов: вводный блок, связанный в определением места исторической науки в рамках «цифрового поворота», формирование digital history и digital humanity; блок, связанный с информационной эвристикой; источниковедческий анализ исторических источников в цифровой среде; технология баз данных в историческом исследовании.

Целью вводного занятия является формирование представления о том, что такое «цифровой поворот», как он отражается на исторической науке, о формировании новых направлений в науке digital history и digital humanity, о том, что такое «цифровой источник» и «электронная копия исторического источника», каковы проблемы их использования в научной практике с источниковедческой точки зрения. Для этого студенты знакомятся с публикациями ведущих экспертов данного направления Л.И. Бородкина, А.Ю. Володина, Ю.Ю. Юмашевой, Н.А. Полевого [4; 5; 6; 7; 8; 9]. Особое внимание 
уделяется на то, что терминологическая база данного направления в науке находится в стадии становления, поэтому трактовки терминов у разных исследователей могут меняться и в практике собственной научно-исследовательской работы необходимо это учитывать.

Задачей второго этапа было обручение студентов методам информационной эвристики. Обучение студентов всем этим методам и технологиям осуществлено на примере такого массового источника как материалы Первой всеобщей переписи населения Российской империи 1897 г. (далее - Переписи). Выбор источника связан с освоением студентами такого вида источников как статистические источники. Кроме того данный источник находится в сфере научных интересов авторов данной публикации. Под материалами Переписи понимаются разные категории источников и данных: номинативные источники (переписные листы, ведомости подсчета населения, обложки и др.), содержащие персональные данные жителей Российской империи рубежа XIX-XX веков и статистика (агрегированные данные). При освоении методов информационной эвристики (с акцентом, в первую очередь, на сетевую «архивную эвристику» [10, c. 6] перед студентами ставится задача поиска материалов по Переписи на сайтах библиотек, архивов, научных и учебных учреждений и др. При этом сетевая архивная эвристика отличается некоторыми особенностями как от интернет-поиска, так и от работы с традиционными справочниками архивов. Выявление архивных материалов с помощью распространенных поисковых систем Yandex, Google и т.п. не приведет исследователя к ожидаемым результатам, а современная система научно-справочного аппарата архивов, доступная пользователям on-line, представляет собой обширную, но разрозненную коллекцию не систематизированных и не связанных друг с другом интернет-ресурсов органов управления архивным делом и отдельных архивов [11, с. 36].

Доступ к оцифрованным статистическим источникам есть на сайтах как российских библиотек и архивов (Национальная электронная библиотека, Государственная публичная историческая библиотека и др.), так и зарубежных Библиотека конгресса США. Относительно недавно обнаружилось, что и номинативные источники по Переписи сохранились, и их тоже можно сейчас найти в сети интернет, на сайтах архивов (крупнейшие электронные коллекции представлены на ресурсах государственных архивов Ярославской области и в г. Тобольске). Кроме сайтов библиотек и архивов данные по материалам Переписи могут содержаться в тематических базах данных, созданных в рамках различных научно-исследовательских про- 
ектов. Поиск и выявление такого рода материалов является важной составляющей процесса обучения. Необходимо обучать пониманию специфики представления данных в сети интернет. Если работа с сайтами архивов требует знания структуры научно-справочного аппарата и системы хранения архивных документов (фонд, опись, дело), то информационные системы и базы данных, созданные исследователями, требуют тщательного предварительного изучения публикаций авторов этих систем и баз, для понимания архитектуры и содержания разделов баз данных. Например, информационная система «Профессии и занятия населения Российской империи конца XIX - начала XX века» (http://stat1897.histcensus.asu.ru/), ориентированная, прежде всего, на аккумулирование и представление данных о занятости населения, содержит также сведения о гендерном, возрастном и этническом составе всех регионов Российской империи.

Следующим этапом является обучение оценке репрезентативности выявленных цифровых источников, которая связана необходимостью сравнительного анализа электронных копий и оригиналов источников. В этом плане с агрегированными источниками по Переписи это легче сделать, т.к. большинство статистических материалов Переписи было опубликовано. Одной из проблем, связанных с оценкой общей репрезентативности электронных копий является установление полноты информации в представленных источниках. Например, на генеалогических сайтах можно обнаружить переписные листы, однако они могут быть выборкой, сделанной либо произвольно, по желанию или интересам создателей сайта, либо естественной выборкой, т.е. представлением доступных для исследователя материалов Переписи. При оценке репрезентативности, необходимо учить оценивать корректность описания источников, представленных в информационнопоисковой системе. Если в информационных системах архивов чаще всего содержится развернутое археографически полное описание подлинника документа (фонд, опись, дело, могут быть комментарии о сохранности дел, о наличии физических особенностей), (было бы хорошо, если бы там еще содержались и описания электронной копии), то, например, на генеалогических сайтах этой информации (библиографической ссылки) можно вообще не найти (https://www.familyspace.ru/), что соответственно не дает возможности найти физический подлинник и определить степень достоверности представленных данных. Кроме того, на этом этапе важным является обучение оценке информационного потенциала выявленных оцифрованных коллекций, оценке возможностей использования дан- 
ных этих коллекций для других исследовательских тем и задач. Также на этапе источниковедческого анализа студентам предлагается выявить структуру первоисточника (например, переписных листов), что поможет им в дальнейшем при разработке структуры собственной базы данных.

Последним этапом в обучении является овладение технологией базы данных при работе с материалами Переписи. Он состоит из двух частей. Первая - декомпиляция исторических данных, осуществляется на примере работы с переписными листами. Студентам предлагается выявить каждый информационный элемент переписного листа. Вторая часть заключается в создании структуры источникоориентированной или тематической (для более продвинутых) базы данных, описание этой структуры и установление системы взаимосвязей между различными элементами структуры и выбор модели представления данных в базе.

Данный опыт был внедрен в рамках дисциплины «источниковедение» на историческом факультете Алтайского государственного университета. Студенты справились со всеми заданиями, а также дали положительную обратную связь, и отметили, что полученные навыки позволяют им лучше ориентироваться в современных тенденциях развития исторической науки.

\section{Библиография}

1. Dougherty J., Nawrotzki K. (ed.) Writing History in the Digital Age. - University of Michigan Press, 2013.

2. Mills K.T. Teaching History in the Digital Age. - University of Michigan Press, 2013.

3. Riley C.L. Beyond ctrl-c, ctrl-v: teaching and learning history in the digital age // Weller T. (ed.) History in the Digital Age. - Routledge, 2013. - C. 149-170.

4. Бородкин Л. И. Digitalhistory: применение цифровых медиа в сохранении историко-культурного наследия? // Историческая информатика. - 2012. - № 1. - С. 14-21.

5. Володин А. Ю. «Цифровая история»: ремесло историка в цифровую эпоху // Электронный научно-образовательный журнал «История». - 2015. - Т. 6. - Выпуск 8(41). - URL: https://history.jes.su/s207987840001228-9-1/ (дата обращения: 20.08.2020).

6. Володин А.Ю. Цифровые практики ученых-гуманитариев: результаты онлайн-исследования // Электронный научно-образовательный журнал «История». 2017. - T. 8. - Выпуск 7(61). Доступ для зарегистрированных пользователей. - URL: https://history.jes.su/s207987840001967-2-1/ (дата обращения: 20.08.2020).

7. Юмашева Ю.Ю. Научное издание исторических документов в электронной среде: проблемы источниковедения и археографии // Историческая информатика. 2017. - № 1. - URL: https://nbpublish.com/library_read_article.php?id=21766 (дата обращения: 20.08.2020).

8. Юмашева Ю.Ю. Влияние информационного общества на методологию исторических исследований // Историческая информатика. - 2019. - № 3. - С. 124-149. - URL: https://nbpublish.com/library_read_article.php?id=3067 (дата обращения: 20.08.2020). 
9. Полевой Н.А. «Цифровой поворот» - новая волна в серфинге исторической информатики по технологическому прогрессу // Историческая информатика. - 2019. № 3. - C. 99-107. - URL: https://nbpublish.com/library_read_article.php?id=30746 (дата обращения: 20.08.2020).

10. Толстова Н.Н. Архивная эвристика: методические рекомендации. - Нижний Новгород, -2015.

11. Брюханова Е.А. Материалы Первой всеобщей переписи населения 1897 года в архивах России и зарубежья: монография. - Барнаул: Изд-во Алт. ун-та, 2019. - 192 с.

https://doi.org/10.29003/m1845.978-5-317-06529-4/433-440

Липницкая О.Л., Попова Е.Э. Белорусский государственный университет, Минск

\title{
Информационные технологии в подготовке историков-архивистов на историческом факультете БГУ: достижения и проблемы
}

Аннотация. В статье рассматриваются проблемы подготовки кадров историков-архивистов в условиях перехода к цифровой экономике. Отмечается резкое сокращение профессиональных образовательных программ, что не соответствует требованиям работодателей и современным тенденциям изменения экономики. Декларируется необходимость владения специалистами в сфере документоведения и архивоведения знаниями и умениями в области информационных технологий, а также наличия у них трудовых функций по проектированию и эксплуатации информационных систем в профессиональной сфере.

Ключевые слова: подготовка кадров, архивоведение, информационные технологии, цифровая экономика.

\section{Lipnitskaya O.L., Popova E.E. Belorussian State University, Minsk}

\section{Information Technologies in the Training of Historians-Archivists at the Faculty of History of BSU: Achievements and Problems}

\begin{abstract}
The article examines the problems of training historians-archivists in the context of the transition to the digital economy. There is a sharp decline in professional educational programs, which does not meet the requirements of employers and modern trends in the economy. The need is declared for specialists in the field of documentation and archival studies to possess knowledge and skills in the field of information technology, as well as the availability of labor functions for the design and operation of information systems in the professional sphere.

Keywords: information technology, personnel training, archival science, digital economy.
\end{abstract}


Информационные технологии оказывают существенное влияние на развитие мировой экономики и особенно ее инфраструктуры.

Учитывая одно из требований цифровой экономики - цифровизация архивов, предусматривающее: модернизацию государственной политики в сфере архивного дела; совершенствование нормативной правовой базы, методического обеспечения архивного дела и делопроизводства; информатизацию архивного дела; формирование кадровой политики; подготовку специалистов, отвечающих требованиям современности, несомненно, что спрос на специалистов, использующих новые технологии в работе с электронными документами, будет расти и, по всей видимости, быстрее, нежели на специалистов, специализирующихся на работе с бумажными документами.

Начать хотелось бы с фрагмента Всеобщей декларации архивов, которую делегаты общего съезда МСА утвердили еще в 2010 году. Декларация признает: многообразие форматов, в которых создаются архивы, включая бумажные, электронные, аудиовизуальные и другие типы документов; роль архивистов как профессионалов с профильным образованием, постоянно повышающих свой квалификацию, служащих своему обществу тем, что поддерживают создание документов, их отбор, сохранность и доступность для использования[1].

Декларация устанавливает ряд правил, которыми должен руководствоваться архивный работник, прошедший соответствующую университетскую подготовку, в своей деятельности: в том числе, объясняет роль архивистов как квалифицированных специалистов, которые заботятся об архивах и предоставляют к ним доступ.

Подобную возможность дает создание единого европейского пространства высшего образования, которое строится на принципе равенства полученных дипломов в странах-участниках Болонского процесса. В том числе, было провозглашено обеспечение равной возможности трудоустройства в любой стране, присоединившейся к инициативе. Однако для обеспечения равенства возможностей трудоустройства, необходимо обеспечить возможность получение качественного образования. Для этого необходимо создать единую образовательную программу подготовки студентов в рамках архивного дела и управления документами.

Вместе с тем, российский ученый, директор Всероссийского НИИ документоведения и архивного дела Федеральной архивной службы России М.В. Ларин отмечает, что «опыт подготовки специалистов в историко-архивном институте РГГУ показывает наличие серьезных проблем в этой сфере» [2]. Одна из них заключается в том, что примерно 40\% дисциплин учебных планов подготовки ар- 
хивистов должны быть информационного плана, иначе под угрозой выполнения заказ практиков, активно использующих в архивах и в делопроизводстве информационные технологии и соответствующую технику.

Эту же проблему авторы видят и в подготовке архивистов Беларуси.

Поскольку важность архивного образования и профессиональной подготовки архивистов заключается и в том, чтобы из числа выпускников, прошедших обучение в стенах истфака БГУ вышло новое поколение специалистов, которые будут продвигать новые идеи и решать актуальные вопросы в будущем, а также готовить профессиональные кадры, способные обеспечить эффективность управления организаций на всех уровнях.

История развития архивного образования в стенах нашей альмаматер начинается с 1992 года, когда на базе исторического факультета БГУ было открыто отделение архивоведения и музееведения с дневной и заочной формами обучения.

Его становление, пришедшееся на время перестройки образования в Республике Беларусь, потребовало поиска новых организационных форм и подходов в системе обучения. К концу 1990-х поставленная задача была решена: разработаны и реализованы новые дисциплины и курсы, причем с учетом национальной специфики, по двум формам обучения, подготовлены первые десятки специалистов для архивоведческой и музееведческой организационно-управленческой и информационно-фондовой работы в государственных и ведомственных архивах и музеях республики.

Параллельно накопленный опыт и общие задачи информатизации определили необходимость введения специальных дисциплин по ИКТ.

В 1992 году на историческом факультете БГУ была введена новая дисциплина «Историческая информатика». Были найдены оптимальные варианты содержания предметной информатики, ориентированные на конкретные специальности (продвинутые курсы) и специализацию (специальные курсы).

Тогда же сложились структуры учебных дисциплин: вводный курс - «Основы информатики и информационные технологии»; базовый курс - «Историческая информатика» и углубленные и специальные курсы, рассчитанные как на конкретные исторические специальности студентов, так и на их специализацию. 
В 1998 г. состоялся первый выпуск историков, архивистов и музееведов со специализацией по исторической информатике (12 чел.).

В 2001 г. произошла реорганизация кафедры. Обновленная кафедра источниковедения стала курировать специальность «Историко-архивоведение».

2008 был ознаменован разработкой и утверждением в республике первого образовательного стандарта нового поколения по специальности «Историко-архивоведение».

Исследования, которые проводились на историческом факультете БГУ, показали еще в начале XXI века достаточную готовность всех студентов-историков, в том числе и архивоведов, к использованию информационных технологий в профессиональной деятельности. И поэтому в 2009 г. открыта специализация «Архивная информатика».

Согласно его требованиям первого образовательного стандарта 2008 г. в период с 2008 по 2013 годы были разработаны и внедрены многоуровневые учебные программы третьего поколения:

I уровень - Основы информационных технологий (вводный курс, 50 часов: OC Windows, MS Word, ABBYY Fine Reader, Internet, E-mail, Adobe Photoshop, MS PowerPoint);

II уровень - Основы информационных технологий (базовый курс, 52 часа: MS Excel, MS Access);

III уровень - углубленные курсы для архивистов (Историческая информатика - 68 часов, Архивная информатика - 68 часов, Технотронное документирование - 68 часов, Технотронные архивы - 68 часов, Географические информационные системы - 38 часов);

IV уровень - специальные курсы для архивистов в рамках специализации «Архивная информатика» (466 часов).

Четвертый уровень включал в себя два блока дисциплин: ИТ в историческом исследовании и ИТ в образовании. В первом блоке студенты изучали семь дисциплин специализации (ДС):

- Обработка и анализ нарративных исторических источников;

- Обработка изобразительных источников;

- Базы данных в исторических исследованиях;

- Основы компьютерного картографирования;

- Обеспечение сохранности электронной документации,

- Объектно-ориентированное проектирование и программирование;

- Количественные методы в историческом познании. 
Второй блок включал:

- Компьютерные технологии обучения,

- Компьютерное дидактическое тестирование,

- Инновации электронной педагогики.

В целом, к 2013 сменилось три поколения учебных планов и программ, изменились количество, структура и содержание основных учебных курсов и спецкурсов, усовершенствовались методы преподавания, расширилась материально-техническая база, пополнился кадровый состав профессорско-преподавательского корпуса.

В 2013 г. был утвержден второй Образовательный стандарт Республики Беларусь «Высшее образование. Первая ступень. Специальность 1-23 0113 Историко-архивоведение». В соответствии со Стандартом начался переход на 4-летнее обучение, который проходил поэтапно с 2013/14 по 2016/17 учебные года.

В связи с реформированием системы высшего образования в Республике Беларусь и переходом на четырехлетнее обучение были открыты магистратуры по специальности 1-26 8002 «Документоведение и архивоведение» с профилизацией «Управление архивами», так как спрос на «междисциплинарных» специалистов растет достаточно быстро.

Образовательный стандарт 2013 г. констатировал следующие профессиональные компетенции (ПК):

ПК-4. Анализировать и оценивать собранные данные.

ПК-7. Использовать глобальные информационные ресурсы.

ПК-8. Использовать современные средства телекоммуникаций.

ПК-15. Выбирать необходимые методы исследования, модифицировать существующие и разрабатывать новые методы, исходя из задач исследования.

ПК-16. Конструировать содержание обучения и воспитания, устанавливать междисциплинарные связи и разрабатывать учебнометодическое обеспечение образовательного процесса (в том числе на основе электронных средств).

ПК-17. Планировать, организовывать и вести научно-методическую, учебно-методическую работу и образовательный процесс, управлять им на основе использования эффективных технологий.

ПК-19. Осуществлять поиск, систематизацию и анализ информации о перспективах развития отрасли, информационных технологий, проектах и решениях.

ПК-26. Использовать возможности и ресурсы новейших информационных средств в профессиональной деятельности. 
Однако поэтапное внедрение второго образовательного стандарта, в связи с переходом на 4-летнее обучение привело к сокращению количества, структуры и содержания основных учебных дисциплин, дисциплин специализации, связанных с использованием ИКТ.

Остались следующие дисциплины:

- Информационные технологии

- Историческая информатика

- Архивная информатика

- Технотронное документирование и архивы

Дисциплины специализации:

- Инновации электронной педагогики.

- Компьютерное педагогическое тестирование.

- Основы компьютерного картографирования.

Исчез набор на специализацию «Архивная информатика».

Исчезло выстроенное годами многоуровневое обучение.

Графически этот процесс представлен двумя гистограммами (рис. 1 и 2).

\section{Распределение учебных часов по программам 3-го поколения}

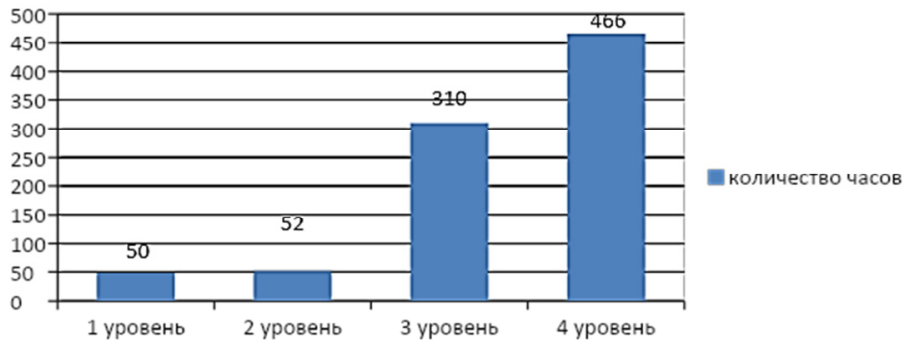

Рис. 1. Распределение учебных часов в 2008-2013 годах

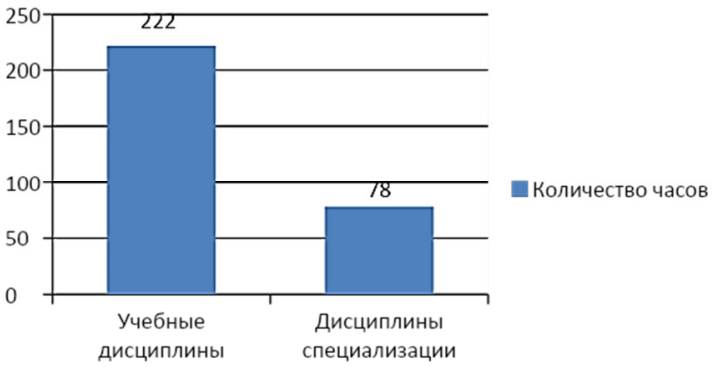

Рис. 2. Распределение учебных часов, начиная с 2016 года 
T.е., количество часов, выделенных на информационные технологии, сократилось на $33 \%$, количество часов на Архивную информатику - к 2013 году подросло на 11\%, но к 2020 упало на 22\%. Историческая информатика потеряла $41 \%$ учебных часов.

Изучение опыта российских вузов, показало, что введение объединенного направление подготовки «Документоведение и архивоведение» на уровень бакалавриата и магистратуры выявило проблему в подготовке квалифицированных документоведов и архивистов, востребованных на рынке труда и получающих достойную зарплату в рамках объединенной программы подготовки. Они ответили: На это просто не хватит объема учебных часов [3, с. 552-553].

В БГУ на историческом факультете эту проблему удалось избежать - документоведы и архивоведы объединены только на уровне магистратуры.

Выше отмечалось, что были открыты магистратуры по специальности 1-26 8002 «Документоведение и архивоведение» с профилизацией «Управление архивами», так как спрос на «междисциплинарных» специалистов растет достаточно быстро. Изучение ИКТ позволяет будущим специалистам, в должной мере подготовиться к процессу получения, накопления и передачи исторических знаний. Привлечение ИКТ для анализа исторических данных дает им возможность внедрить и в будущую научную, и в преподавательскую деятельность в исторической науке разнообразные технологии, методы и приемы.

В магистратуре исторического факультета в уже третий учебный год (начиная с 2018 года) изучается дисциплина «Информационные технологии в документоведении и архивоведении» (84 ауд. часа). Причем, с использованием дистанционного обучения и с приглашенными ведущими специалистами (Англия, Корея, Португалия, Эстония).

Рассмотрев проблемы подготовки кадров в сфере документоведения и архивоведения в условиях перехода к цифровой экономике, российские исследователи отметили неравномерность процессов информатизации в сфере документационного обеспечения управления, документоведения и архивоведения; сохранение недостаточного уровня профессиональной подготовки кадров в сфере информационных технологий, и тот факт, что образовательные программы порой не в полной мере соответствуют нуждам цифровой экономики [4, с. 170].

Таким образом, авторы, как и российские исследователи, считают, что современным образовательным учреждениям, осуществля- 
ющим подготовку специалистов, требуется более оперативно принимать решения по корректировке образовательной траектории с учетом потребностей работодателей и современных тенденций изменения экономики.

Авторам статьи видится необходимым проработка и внесение изменений в программу по подготовке специалистов - историковархивистов на историческом факультете БГУ:

- восстановление системы общенаучных и общепрофессиональных дисциплин, дисциплин специальности, дисциплин специализации, дисциплин по выбору студента, которые вместе с общегосударственным компонентом смогут составить качественное содержательное наполнение подготовки будущих архивистов в области информационных технологий, способствовать формированию их цифровой культуры;

- открытие направления специальности «Цифровые архивы»;

- расширение обмена опытом и лучшими практиками взаимодействия между образовательными учреждениями и архивной отраслью, как внутри Республики Беларусь, так и за ее пределами.

\section{Библиография}

1. Универсальная декларация по архивам. Принята на Генеральной ассамблее Международного совета архивов. Осло, сентябрь 2010 // Международный совет архивов - URL:https://www.ica.org/sites/default/files/20191003_ica_declarationuniverselle_ russian.pdf.

2. Ларин М.В. Архивы в цифровой экономике // Память о прошлом - 2018. VII историко-архивный форум, посвященный 100-летию государственной архивной службы России. Изд-во ФКУ «Российский государственный архив в г. Самаре». Самара, 2018. C. 233-239. - URL: https://elibrary.ru/item.asp?id=36660743.

3. Варламова Л. Н. Пути развития направления подготовки «Документоведение и архивоведение»: взлет или падение? / Л. Н. Варламова // Документ. Архив. История. Современность: Материалы VII Всероссийской научно-практической конференции с международным участием, посвященной 80-летию Исторического факультета Уральского федерального университета. Екатеринбург, 16-18 ноября 2018 г. - Екатеринбург: Изд-во Урал. ун-та, 2018. - С. 548-558.

4. Мишова В.В., Огнева Э.Н. Изменения требований к подготовке кадров в сфере документоведения и архивоведения при переходе к цифровой экономике // Вестник Кемеровского государственного университета культуры и искусств. - 2019. - Вып. 47. C. $170-179$. 
https://doi.org/10.29003/m1846.978-5-317-06529-4/441-446

Можаева Г.В.

Финансовый университет при Правительстве Российской Федеращии

\title{
Интеграция массовых открытых онлайн-курсов \\ в учебный процесс вуза как фактор персонализации исторического образования
}

Аннотация. Рассматриваются 3 модели интеграции массовых открытых онлайн-курсов (МООК) в учебный процесс, позволяющие обеспечить вебподдержку обучения, реализовать смешанное обучение и полностью заменить учебную дисциплину на онлайн-курс. Анализируется потенциал МООК для построения индивидуальных траекторий обучения, позволяющих учесть особенности учебного поведения студентов и нацеленность на достижение образовательного результата. Описаны условия, необходимые для интеграции МООК.

Ключевые слова: массовый открытый онлайн-курс, МООК, модели интеграции онлайн-курсов, индивидуальная образовательная траектория, смешанное обучение.

Mozhaeva G.V. Financial University under the Government of the Russian Federation

\section{Integration of massive open online courses into the educational process of the university as a factor in the personalization of history education}

\begin{abstract}
In this article, three models of integration of massive open online courses (MOOCs) into the educational process are considered. They allow providing web support for training, implementing blended learning and completely replacing the academic discipline with an online course. The potential of MOOCs for individual learning paths is analyzed. They allow taking into account the peculiarities of students' learning behavior and the focus on achieving educational results. The necessary for MOOC integration conditions are described.

Keywords: massive open online course, MOOCs, online-course integration models, individual educational trajectory, blended learning.

Высокие темпы распространения современных технологий оказали существенное влияние на изменение традиционной модели образовательной системы, методов преподавания и обучения. Развитие дистанционных образовательных технологий и использование цифрового контента содействуют расширению доступа к высшему образованию и повышению его качества. Актуальность реализации
\end{abstract}


образовательной программы или части образовательной программы посредством онлайн-курсов одних университетов в других вузах обозначена в национальной программе «Молодые профессионалы» [1] и строится на развитии сетевого взаимодействия университетов и повышении виртуальной академической мобильности обучающихся за счет широкого внедрения онлайн-технологий, что позволяет людям вне зависимости от места обучения и проживания иметь возможность доступа к лучшему мировому образовательному контенту, а наиболее мотивированным из них обеспечить возможность проектирования персональных образовательных траекторий.

Центральным элементом современного онлайн-обучения является массовый открытый онлайн-курс (МООК), представляющий собой логически и структурно завершенную дидактическую единицу, в которой объединены различные элементы учебного деятельности теоретический материал, практические задания, фонды оценочных средств, коммуникации, система поддержки и педагогического сопровождения.

Число слушателей онлайн-курсов в мире в конце 2019 года, по данным агрегатора Class Central, достигало более 110 млн. человек [2]. Пандемия существенно увеличила это число: только на онлайн-платформе Coursera в период с середины марта по середину мая 2020 года зарегистрировались более 10 миллионов новых пользователей [3]. Онлайн-курсы стали активно включаться в вузовские программы, играя значительную роль в развитии моделей смешанного обучения и занимая все более важное место в системе университетского образования. Этому способствовали полное открытие МООК в условиях пандемии мировыми и национальными платформами (например, проект «Coursera for Campus») и стремительный переход вузов многих стран мира на онлайн-технологии.

Основными драйверами развития онлайн-обучения и создания МООК в мире становятся университеты. По оценке проекта «MOONLITE project» к концу 2018 года 55\% образовательных организаций уже предлагали собственные МООКи, а 26\% планировали их разрабатывать [4].

Импульс развитию онлайн-обучения в российских университетах и созданию МООК был дан в 2017 году приоритетным проектом «Современная цифровая образовательная среда в Российской Федерации». В каталоге российского агрегатора онлайн-курсов «ресурс одного окна» содержится 1789 онлайн-курсов от 70 вузов на 44 платформах [5].

Использование МООК в традиционном (кампусном) обучении, как правило, нацелено на расширение вариативности учебно- 
методического обеспечения и свободы обучающихся при выборе индивидуальных образовательных траекторий, предоставление обучающимся возможности освоить разницу учебных планов, возникающую при переводах, или участвовать в виртуальной академической мобильности. МООКи помогают создавать избыточную образовательную среду в университете, решать задачу развития педагогических кадров, имеют высокий потенциал для персонализации обучения.

Механизм интеграции МООК в программы бакалавриата и магистратуры определяется выбором модели интеграции онлайн-курсов в основные образовательные программы. При этом глубина интеграции онлайн-курсов зависит от специфики учебной дисциплины и организации учебного процесса в вузе [6].

Выделим три наиболее распространенных модели интеграции онлайн-курсов в учебный процесс.

1. Онлайн-курс как дополнительный образовательный ресурс, обеспечивающий веб-поддержку любой дисциплины учебного плана в целом и отдельных разделов (модулей). Освоение рекомендуемого МООК происходит в составе группы или индивидуально в соответствии с учебным планом и календарным графиком учебного процесса и осуществляется с целью переноса акцента с контактной на самостоятельную работу по материалу, не требующему подробного анализа или дискуссии в аудитории; систематизации информации из разных источников, в дополнение к имеющимся учебным пособиям для самостоятельного изучения; повышения вовлеченности студентов в аудиторную работу за счет предварительного изучения темы.

МООК становится одним из рекомендованных студентам актуальных учебных ресурсов. Число МООК, посвященных истории, постоянно растет. Так, например, на ведущей мировой онлайнплатформе Coursera на данный момент показано 817 результатов для запроса «history» [7], на платформе FutureLearn - 125 результатов [8]. На «ресурсе одного окна» показан 81 результат для запроса «история» [11].

2. Онлайн-курс как основа смешанного обучения, основанного на сочетании традиционных форм аудиторного обучения с элементами электронного обучения. МООК встраивается в смешанный формат обучения и заменяет собой часть аудиторных занятий, чаще всего лекций. Преподаватели могут вводить в свой очный курс МООК своего и других вузов, в том числе на иностранном языке. Групповое освоение МООК (с частичным или полным перезачё- 
том отдельных тем дисциплины по результатам прохождения онлайн-курса) осуществляется в соответствии с учебным планом и календарным графиком учебного процесса, при котором освоение обучающимся рекомендуемого МООК предусматривает усиление самостоятельности в изучении отдельных тем дисциплины; сокращение аудиторной нагрузки и усиление практико-ориентированного характера дисциплины; обеспечение независимости оценки результатов обучения.

Модель применима для любых дисциплин, как правило, в соответствии с утвержденным до начала учебного семестра перечнем онлайн-курсов, рекомендованных для перезачета. Модель удобна в случае МООК, которые не полностью соответствуют темам рабочей программы учебной дисциплины. Например, при изучении истории России в учебный процесс могут быть включены такие МООК, как «История международных отношений России» [12] или «История» [13], при изучении мировой истории - «The Ancient Greeks» [14] или «Introduction to Ancient Egypt and Its Civilization» [15].

3. Онлайн-курс как замена части дисциплин образовательной программы. Чаще всего, используются собственные МООК университета для замещения нескольких очных курсов или формируется онлайн-программа бакалавриата или магистратуры, в которой все курсы реализуются в формате МООК. Освоение дисциплины осуществляется исключительно через обучение на рекомендуемом онлайн-курсе в составе группы или индивидуально и предусматривает построение индивидуальной образовательной траектории, расширение академической свободы по срокам и интенсивности обучения.

Модель успешно применяется к дисциплинам, содержание которых развивает общекультурные и универсальные компетенции, к элективным дисциплинам, число которых может быть существенно увеличено за счет МООК, что позволяет делать более вариативными индивидуальные образовательные траектории студентов. Баллы за работу в течение семестра могут быть выставлены на основании результатов изучения МООК без обязательного присутствия на учебных занятиях с дальнейшим перезачетом или аттестацией в обычном формате. Одной из сложностей данной системы является отсутствие обратной связи со студентом в течение семестра, что может привести к низким результатам на экзамене. В учебных планах должно быть отмечено, что дисциплина изучается онлайн.

Для организации обучения с применением онлайн-курсов по представленным моделям необходимо определить МООК из числа разработанных в собственном университете или присутствующих на 
внешних онлайн-платформах, утвердить их перечень с указанием модели использования МООК, разместив его на открытом вебресурсе университета. Использование результатов изучения МООС для выставления баллов за работу в семестре должно носить заявительный характер и осуществляться за полгода-год до начала изучения дисциплины.

В большинстве российских университетов реализуется следующая схема перезачета МООК: 1) список онлайн-дисциплин на текущий семестр (по программе); 2) заявление на онлайн-мобильность; 3) включение МООК в индивидуальный учебный план; 4) обучение на МООК; 5) получение подтвержденного сертификата; 6) зачет по дисциплине. Эта схема не регулирует случаи, когда ни один из онлайн-курсов, которые желает изучать студент, не соответствует направлению его подготовки и не может быть включен в индивидуальный учебный план. Схема предполагает сертификацию по результатам обучения на МООК с последующим перезачетом этих результатов [16]. При отсутствии у студента сертификата, подтверждающего обучение на МООК, предусматривается проведение зачета или экзамена.

Использование МООК в качестве элементов основной образовательной программы имеет особое значение при переводе студентов на индивидуальные учебные планы и позволяет персонализировать обучение с учетом специфики научно-исследовательской работы студента, темпа обучения, нацеленности на образовательный результат и др. Важно учитывать, что МООК, предлагая выстраивание персональных стратегий обучения, апеллируют к навыкам тайм-менеджмента и самоорганизации, отсутствие которых не позволит студенту эффективно использовать онлайн-курс.

Использование МООК в учебном процессе позволяет преподавателям не тратить время на создание контента и оценочных средств, поддерживать учебную активность студентов, заданную курсом. Вместе с тем, преподаватель должен адаптировать свои занятия под логику тематического плана МООК, разработать технологическую карту учебной дисциплины, предусматривающую интеграцию онлайн-курса, и помнить, что на открытых онлайн-платформах может не оказаться доступных МООК по нужной теме. Необходимо тщательное проектирование образовательной деятельности, включая подбор МООК на основе сопоставления с дисциплиной по трудоемкости, направлению подготовки, уровню обучения и др., анализ соответствия дисциплине по содержанию и результатам обучения, вы- 
бор модели и построение алгоритма интеграции. Интеграция МООК в уже сложившиеся обучающие практики становится залогом успеха в цифровом образовательном мире.

\section{Библиография}

1. Паспорт федерального проекта «Молодые профессионалы». - URL: https://new.avo.ru/documents/33446/1306658/Молодые+профессионалы.pdf/ff2a38866586-861c-c5d3-5d6332cfса96 (дата обращения: 01.09.2020).

2. Shah, D., 2020. By The Numbers: Moocs In 2019. URL: https://www. classcentral.com/report/mooc-stats-2019 (дата обращения: 01.09.2020).

3. Shah, D., (2020). Moocs Are Back - Even Though They Never Left. URL: https://www.classcentral.com/report/apparently-moocs-are-back/ (дата обращения: 01.09.2020).

4. Ubachs G, Konings L. MOOC Strategies in European Universities. 2018. The Netherlands. European Association of Distance Teaching Universities. ISBN/EAN: 978-9079730-38-4 2018. - URL: https://moonliteproject.eu/wp-content/uploads/2019/08/MOOC _Strategies_in_European_Universities.pdf (дата обращения: 01.09.2020).

5. Ресурс «одного окна». URL: https://online.edu.ru/ru/ (дата обращения: 01.09.2020).

6. Kulik E., Kidimova K.A. Integrating MOOCs in University Curriculum: HSE University Experience // Proceedings of Work in Progress Papers of the Experience and Research Tracks and Position Papers of the Policy Track at EMOOCs 2017. - CEUR Workshop Proceedings, 2017. - P. 118-127.

7. Поисковая система онлайн-платформы Coursera. - URL: https://www. coursera.org/search?query=history\& (дата обращения: 01.09.2020).

8. Поисковая система онлайн-платформы FutureLearn. - URL: https://www. futurelearn.com/search?q=history (дата обращения: 01.09.2020).

9. Поисковая система онлайн-платформы Лекториум. - URL: https://www. lektorium.tv/mooc (дата обращения: 01.09.2020).

10. Поисковая система онлайн-платформы Stepik. - URL: https://stepik.org/ catalog?q=история (дата обращения: 01.09.2020).

11. Поисковая система «ресурса одного окна». - URL: https://online.edu.ru/ public/search?q=история (дата обращения: 01.09.2020).

12. История международных отношений России: онлайн-курс. - URL: https://online.edu.ru/public/course?cid=982234 (дата обращения: 01.09.2020).

13. История: онлайн-курс. - URL: https://stepik.org/course/21476/promo (дата обращения: 01.09.2020).

14. The Ancient Greeks. - URL: https://www.coursera.org/learn/ancient-greeks (дата обращения: 01.09.2020).

15. Introduction to Ancient Egypt and Its Civilization. - URL: https://www.coursera.org/learn/introancientegypt (дата обращения: 01.09.2020).

16. Положение о зачете результатов освоения открытых онлайн-курсов в НИ ТГУ. - URL: https://ido.tsu.ru/normdocs/elearning/perezachet.pdf (дата обращения: 01.09.2020). 
https://doi.org/10.29003/m1847.978-5-317-06529-4/447-453

Оськин А.Ф.

Полочякий государственный университет

Оськин Д.А.

Белорусский государственный экономический университет, Минск

\section{Об учебной программе курса «Data Mining - Интеллектуальный анализ данных» для магистрантов специальности «История»}

Аннотация. В статье рассматривается учебная программа курса «Data Mining - Интеллектуальный анализ данных» для студентов второй ступени высшего образования, обучающихся по специальности «История». Даётся определение термину «Data Mining», перечисляются области применения и подчеркивается важность освоения данных технологий магистрантами этой специальности. Рассматривается содержание лекционной компоненты дисциплины, лабораторного практикума, приводится перечень полезных Интернет-ресурсов.

Ключевые слова: Data Mining, интеллектуальный анализ данных, учебная программа, магистратура.

Oskin A.F. Polotsk State University, Polotsk

Oskin D.A. Belarusian State Economic University, Minsk

\section{About the curriculum of the course "Data Mining - Data Mining" for undergraduates of the specialty "History"}

Abstract. The article discusses the curriculum of the course "Data Mining Data Mining" for graduate students studying in the specialty "History". The definition of the term "Data Mining" is given, the areas of application are listed and the importance of mastering these technologies by undergraduates of this specialty is emphasized. The content of the lecture component of the discipline, laboratory workshop is considered, a list of useful Internet resources is provided.

Keywords: Data Mining, Curriculum, Master Study.

«За последние годы, когда, стремясь к повышению эффективности и прибыльности бизнеса, при создании баз данных все стали пользоваться средствами обработки цифровой информации, появился и побочный продукт этой активности - горы собранных данных: И вот все больше распространяется идея о том, что эти горы полны золота». Эти слова принадлежат известному исследователю в области искусственного интеллекта, автору термина «Data Mining», Григорию Пиатецкому-Шапиро (Gregory Piatetsky-Shapiro). 
В 1989 году он дал следующее определение новому научному направлению [1]: «Data Mining - это процесс обнаружения в сырых данных ранее неизвестных, нетривиальных, практически полезных и доступных интерпретации знаний, необходимых для принятия решений в различных сферах человеческой деятельности». В русском языке эквивалентом английского термина «Data Mining» является словосочетание «Интеллектуальный анализ данных». В дальнейшем в данной статье мы будем использовать термин «Data Mining».

Существует ещё несколько определений данного понятия.

- Data Mining - это процесс выделения из данных неявной и неструктурированной информации и представления ее в виде, пригодном для использования.

- Data Mining - это процесс выделения, исследования и моделирования больших объемов данных для обнаружения неизвестных до этого структур (patterns) с целью достижения преимуществ в бизнесе (определение SAS Institute).

- Data Mining - это процесс, цель которого - обнаружить новые значимые корреляции, образцы и тенденции в результате просеивания большого объема хранимых данных с использованием методик распознавания образов плюс применение статистических и математических методов (определение Gartner Group).

Наиболее удачным, по нашему представлению, является определение, данное автором термина, Пиатецким-Шапиро.

В соответствии с этим определением суть и цель технологий Data Mining можно охарактеризовать так: это технологии, которые предназначены для поиска в больших объемах данных неочевидных, объективных и полезных на практике закономерностей.

- Неочевидных - значит, что найденные закономерности не обнаруживаются стандартными методами обработки информации или экспертным путем.

- Объективных - значит, что обнаруженные закономерности будут полностью соответствовать действительности, в отличие от экспертного мнения, которое всегда является субъективным.

- Практически полезных - значит, что выводы имеют конкретное значение, которому можно найти практическое применение.

Технологии анализа данных, основанные на применении классических статистических подходов, имеют ряд недостатков. Эти методы основаны на использовании усредненных показателей, анализируя которые трудно выяснить истинное положение дел в исследуемой области (классический пример - средняя температура по больнице). 
Прогнозный потенциал методов математической статистики также невысок - исследования специалистов Гарвардского института показали, что на основе имеющейся информации с помощью стандартных статистических методов нельзя было предсказать великую депрессию конца 1920-х годов. Основная область применения этих методов - технологии OLAP (Online Analytical Processing), которые используются для проверки заранее сформулированных гипотез и «грубого» разведочного анализа.

Классические статистические методы имеют ещё один важный недостаток - они пренебрегают аномальными наблюдениями, так называемыми пиками и всплесками. При этом известно, что отдельные нетипичные значения могут составлять самостоятельный интерес для исследования, характеризуя некоторые исключительные, но важные явления. Сама идентификация этих наблюдений, не говоря уже об их последующий анализ, может быть полезной для понимания сущности изучаемых объектов или явлений. Как показывают современные исследования, именно такие события могут стать решающими относительно будущего поведения и развития сложных систем.

Перечисленные недостатки статистических методов послужили толчком к развитию новых методов исследования сложных систем, сочетающих в себе последние достижения искусственного интеллекта, разнообразных математических методов, статистики и эвристических подходов. Эти методы и легли в основу новых технологий анализа данных, получивших название Data Mining.

Нам представляется, что современный уровень развития исторической науки требует от будущих специалистов владения этим важным инструментом научных исследований.

Перейдём к рассмотрению содержания учебной программы дисциплины «Data Mining - Интеллектуальный анализ данных». B соответствии с учебным планом, по данной дисциплине предусмотрено 72 часа аудиторных занятий - 36 часов лекционных и столько же лабораторных занятий.

На рис. 1 приведена интеллект-карта учебной программы с указанием тем лекционных и лабораторных занятий и их объёмом в академческих часах.

Как видно из рисунка, курс «Data Minimg - Интеллектуальный анализ данных» состоит из 5 модулей.

В первом модуле - «Введение. Что такое Data Mining», дается определение понятию «Data Mining», рассматриваются научные дисциплины, на базе которых возникла эта междисциплинарная область, 
проводится сравнение статистики, машинного обучения и Data Mining. На основе проведённого сравнения выявляются отличия Data Mining от других методов анализа данных и обозначаются наиболее перспективные области применения этой технологии.

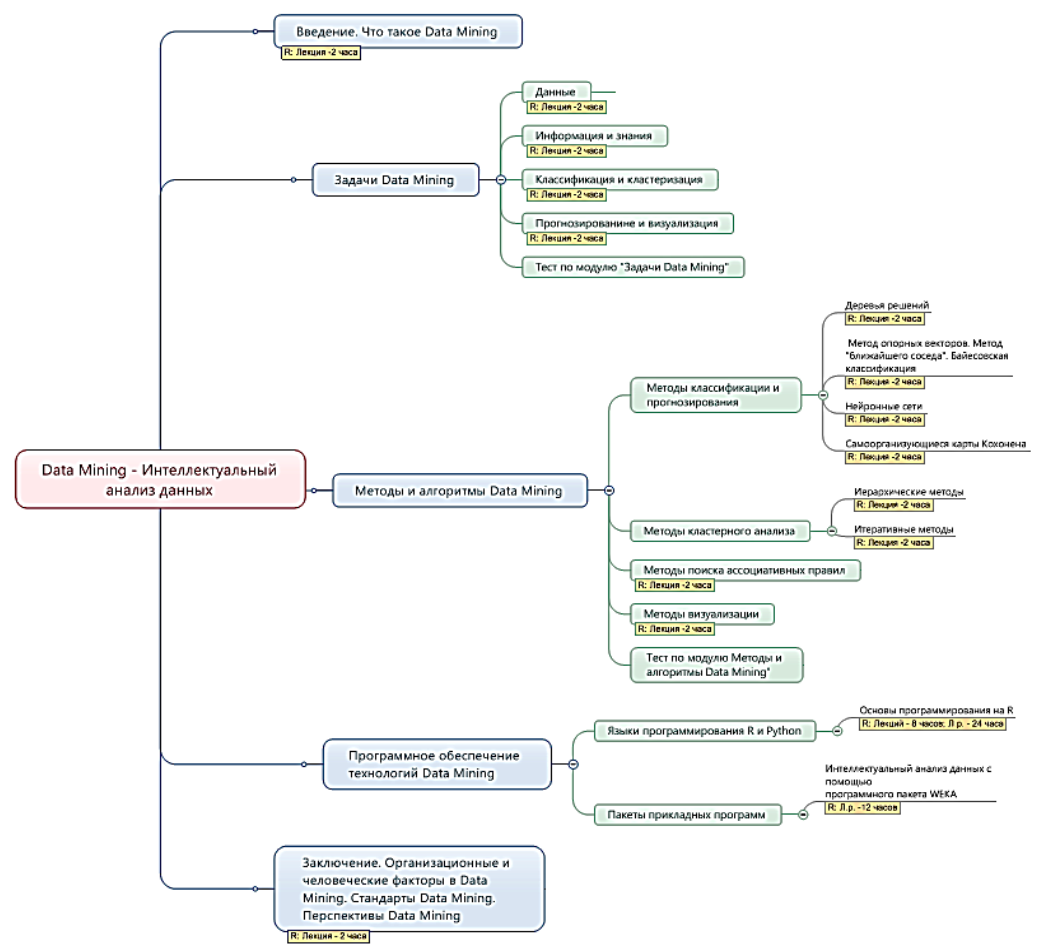

Рис. 1. Интеллект-карта учебной программы дисциплины

В модуле «Задачи Data Mining» описывается суть задач, решаемых с применением технологий Data Mining и приводится классификация этих задач. Подробно рассматриваются такие понятия как «Данные», «Информация», «Знания» и их взаимные связи и отношения.

Модуль «Методы и алгоритмы Data Mining» является главным модулем в теоретической части курса. Он состоит из восьми лекций, описывающих все основные методы Data Mining, а также алгоритмы их реализации. Методы объединены в четыре группы. В группе «Методы классификации и прогнозирования» рассматриваются де- 
ревья решений, байесовская классификация, методы опорных векторов и «ближайшего соседа», а также нейронные сети и карты Кохонена. Группа «Методы кластерного анализа» посвящена описанию двух основных подходов к решению задачи кластеризации - иерархическому и итеративному. В этом же модуле кратко рассматриваются методы поиска ассоциативных правил и методы визуализации.

Следующий модуль описывает программное обеспечение, используемое для реализации алгоритмов Data Mining. Рассматриваются языки программирования, предназначенные для решения задач интеллектуального анализа данных, а также специализированные пакеты прикладных программ, используемые для этих целей. Освоение знаний, умений и навыков из этого раздела предполагается путём прохождения лабораторного практикума, общим объёмом 36 академических часов.

И, наконец, в последнем модуле «Заключение. Организационные и человеческие факторы в Data Mining. Стандарты Data Mining. Перспективы Data Mining» поводятся итоги, рассматриваются стандарты и обозначаются перспективы технологий Data Mining.

Для организации практикума по данному курсу необходимо загрузить с соответствующих ресурсов и установить на компьютерах лабораторного класса следующий набор инструментов:

- $\mathrm{R}$ - свободно распространяемое программное обеспечение для статистических расчетов и визуализации [2].

- RStudio Desktop - свободно распространяемая среда разработки приложений для языка программирования R [3]

- WEKA - свободно распространяемое программное обеспечение для решения задач Data Mining [4]

Для выполнения лабораторных работ необходимы заранее подготовленные наборы данных (учебные датасеты). На сайте [5] доступны для бесплатной загрузки и использования в исследовательских или учебных целях более пятидесяти тысяч различных наборов данных. Мы использовали датасет «All Space Missions from 1957». Он состоит из 4322 наблюдений и содержит сведения о стране, выполнившей запуск космической ракеты, месте и дате запуска, организации, реализующей проект, стоимости миссии, названии ракеты и её статусе (действующая или списанная), успешности миссии.

Используя данный датасет можно познакомиться со следующими видами анализа данных: разведочный анализ данных, визуализация, кластеризация, прогнозирование. 
Рассмотрим теперь подходы к организации учебного процесса по дисциплине.

В последние годы при проведении занятий с магистрантами мы активно используем технологии смешанного обучения [6].

По определению, под смешанным обучением понимается совместное использование классических методик обучения и современных дистанционных технологий.

Главным достоинством классической методики является прямой, непосредственный контакт обучаемого и обучающегося, оказывающий большое эмоциональное воздействие на обучаемого и способствующий лучшему усвоению учебного материала. Применение технологий дистанционного обучения позволяет задать для каждого обучающегося собственную образовательную траекторию, индивидуализировать процесс обучения, сделать его асинхронным. Каждый обучающийся может осваивать учебный материал в любое удобное для него время, в привычной обстановке, с оптимальной скоростью. Сочетание этих двух подходов и образует систему технологий, имеющих общее название «Смешанное обучение» (Blended Learning).

Как показал зарубежный опыт, из всех многочисленных моделей смешанного обучения, наибольшее распространение получила модель, называющаяся «Перевёрнутый класс» (Flipped Classroom). Термин «Перевернутый класс» можно отнести к широкому спектру технологий смешанного обучения, при использовании которых студенты, до очной встречи с преподавателем, получают удаленный доступ к образовательному контенту по теме, а во время очного занятия закрепляют изученный контент и выполняют практические задания по теме.

При этом наибольшее распространение получил подход, при котором студенты просматривают дома серию коротких видеолекций по теме предстоящего занятия, а в аудитории совершенствуют свои знания, выполняя практические задания.

Технология «Перевёрнутый класс» органично вписывается в любую систему информационной поддержки обучения. При этом, как уже отмечалось выше, появляется возможность индивидуализации обучения, реализуется подход, при котором каждый обучающийся усваивает новые знания по изучаемой дисциплине, двигаясь по своей образовательной траектории.

Для организации дистанционного обучения в Полоцком государственном университете используется платформа G Suite for Education, разработанная корпорацией Google LLC. Платформа находится в открытом доступе и может быть использована любым государственным учебным заведением после регистрации. Главным сервисом, 
обеспечивающим эффективную организацию учебного процесса на платформе G Suite for Education, является приложение Google Classroom. Это приложение позволяет создавать учебные курсы, назначать и проверять задания, обмениваться со студентами файлами, проводить онлайн-тестирование знаний, обсуждать в режиме живого общения отдельные темы учебного курса. Летом текущего года, внося свой вклад в борьбу с пандемией коронавируса, корпорация Google сделала бесплатным ещё один свой веб-сервис, Google Meet, интегрировав его с Google Classroom. C помощью Google Meet можно организовывать вебинары, онлайн-встречи, совещания, конференции. Таким образом, в настоящее время Google Classroom имеет функционал, позволяющий удовлетворить все потребности пользователей, использующих платформу G Suite for Education для организации дистанционного обучения.

C учетом всего сказанного выше, занятия по дисциплине «Data Mining - Интеллектуальный анализ данных» в текущем семестре будут организованы следующим образом. Перед началом семестра во вновь созданный Google-класс дисциплины будет выложен электронный учебно-методический комплекс. В течение семестра, во время очных занятий, магистрантам будут предлагаться наборы учебных задач, соответствующие различным уровням усвоения дисциплины. Результаты этих тестов для каждого студента будут сохраняться и анализироваться. Это позволит выделить, по крайней мере три группы, состоящие из магистрантов с примерно одинаковыми способностями. Дальнейшая работа будет организовываться с учетом специфики каждой группы, что должно повысить эффективность и, в конечном счете, качество обучения.

\section{Библиография}

1. KDNuggets ${ }^{\circledast}$, сайт Г. Пиатецкого-Шапиро - URL: https://www.kdnuggets.com/ (дата обращения: 29.08.2020).

2. The R Project for Statistical Computing - URL: https://www.r-project.org/ (дата обращения: 29.08.2020).

3. RStudio Desktop - URL: https://rstudio.com/products/rstudio/download/\#download (дата обращения: 29.08.2020).

4. WEKA. Machine learning software to solve data mining problems - URL: https://sourceforge.net/projects/weka/ (дата обращения: 29.08.2020).

5. Kaggle: Your Machine Learning and Data Science Community - URL: https://www.kaggle.com/ (дата обращения: 29.08.2020).

6. Оськин А.Ф., Оськин Д.А. Применение технологий смешанного обучения в учебном процессе высшей школы: Сборник материалов IV Международной научнопрактической конференции «Педагогический опыт: теория, методика, практика». Том 1. - Чебоксары, 2015. С. 207-209. 
https://doi.org/10.29003/m1847.978-5-317-06529-4/447-453

Оськин Д.А.

Белорусский государственный экономический университет, Минск

Оськин А.Ф. Полоикий государственный университет

\section{Образовательная аналитика.}

\section{Новый подход к повышению качества учебного процесса}

Аннотация. В статье описывается тенденции в области онлайн образования, вызванные пандемией COVID-19. Обосновывается внедрение образовательной аналитики в образовательный процесс. Рассматриваются основные методы и инструменты образовательной аналитики. На конкретном примере разбирается построение и оценка модели классификации студентов с использованием высокоуровневого языка программирования Python.

Ключевые слова: Дистанционное обучение, образовательная аналитика, машинное обучение, Python.

Oskin D.A. Belarusian State Economic University, Minsk

Oskin A.F. Polotsk State University

\section{Educational analytics.} A new approach to improving the quality of the educational process

Abstract. This article describes the trends in online education caused by the COVID-19 pandemic. The introduction of learning analytics into the educational process is substantiated. The main methods and tools of educational analytics are considered. Using a specific example, we will understand the construction and assessment of a student classification model using the high-level programming language Python.

Keywords: Distance learning, learning analytics, machine learning, Python.

\section{Введение}

C началом пандемии вызванной COVID-19 учебные заведения всех уровней обучения, по всему миру частично или полностью перевели процесс обучения в онлайн. По данным ЮНЕСКО 53 государства уже развернули национальные образовательные платформы для дистанционного обучения[1]. При этом активно используются такие методики преподавания как смешанное и дистанционное обучение. Кроме этого наблюдается взрывной рост интереса к онлайнкурсам размещенных на МООСплатформах. Согласно отчету, опубликованному на pecypce ClassCentralMOOCReport [2], количество 
новых пользователей зарегистрированных в апреле 2020 года на трех наиболее популярных платформах (Coursera, edX, FutureLearn) превысило суммарное количество новых пользователей за весь 2019 год. По мнению экспертов Всемирного банка, резкий переход на дистанционное образование вызовет ряд сложностей, а именно [3, стр. 4-6]:

- На данный момент очень мало систем образования (даже среди самых высококлассных), которые обладают хорошим техническим обеспечением, чтобы осуществить быстрый переход на дистанционное обучение.

- Переход на дистанционное обучение требует огромных затрат. Безусловно, важно обеспечить инфраструктурный потенциал

- Переход на дистанционное обучение вызывает обеспокоенность в связи с социальным расслоением.

- Большинство учащихся будет испытывать трудности при переходе к дистанционному образованию.

- При переходе на дистанционное обучение нужно иметь в виду, что поначалу учащиеся будут показывать более слабые результаты.

- Перед учебными заведениями встанет вопрос выбора, каким предметам обучать онлайн, а какие оставить для самостоятельного освоения.

- Только некоторые учителя будут способны осуществить быстрый и эффективный переход к онлайн-модели обучения, поскольку процессы преподавания удаленно и в классах значительно отличаются друг от друга.

Помимо этого, мы можем говорить о том, что переход на дистанционные формы обучения повлечет за собой увеличение количества отчисленных студентов. Так, по данным исследования [4], показатели завершения курсов для некоторых групп студентов, обучающихся дистанционно, могут быть на 22\% ниже, чем для студентов, обучающихся на очных курсах. В тоже время средний процент завершения МООС курсов составляет не больше $10 \%$ от общего количества записавшихся на прохождение курса [5].

Одним из возможных путей улучшения ситуации с дистанционным обучением является объективный анализ процесса обучения путем применения образовательной аналитики. Это позволит выявить трудности, связанные с адаптацией студентов и пониманием их поведения и увеличит количество успешных студентов. 


\section{Образовательная аналитика: определения, цели, задачи}

Образовательная аналитика относительно новая сфера научной и практической деятельности. Так, профессиональное сообщество ученых и практиков Society of Learning Analytics Research (SoLAR) образовано в 2010 году, а первая конференция под эгидой сообщества прошла в 2011 году.

Согласно определению, предложенному Джорджем Сименсом на первой конференции под эгидой SoLAR, образовательная аналитика это измерение, сбор, анализ и предоставление данных об учащихся и других сопутствующих факторах, с целью понимания и оптимизации обучения и условий, в которых оно происходит [6].

Цель образовательной аналитики - дать оценку поведению пользователей в контексте преподавания и обучения с ее последующими анализом и интерпретацией. Это позволяет получить новую информацию об учебном процессе и его участниках вместе с новыми моделями улучшения обучения, преподавания, эффективной организации учебного процесса, принятия решений [6]. Ключевым является факт передачи полученных знаний педагогам и студентам для оптимизации их педагогического и образовательного поведения, с целью развития соответствующих навыков в данной области, лучшего понимания образовательного процесса и сопутствующих ему областей, например, таких как университетский маркетинг и бизнес.

Основная задача образовательной аналитики - сбор и анализ данных, а также проведение своевременных вмешательств, с целью совершенствования процесса обучения у обучающихся [7].

Образовательная аналитика фокусируется на образовательном процессе, с результирующими преимуществами для всех основных участников процесса [8]. Romero and Ventura (2013) разделили основных участников в соответствии с их основными целями, на четыре группы (см. табл. 1).

Таким образом, образовательная аналитика это:

- подход, в основе которого лежит анализ данных;

- подход, затрагивающий всех участников образовательного процесса и все структурные подразделения учреждения высшего образования, ответственные за образовательный процесс;

- процесс, для организации которого требуется интеграция информационных потоков из различных источников, относящихся к поддержке и проведению образовательного процесса в организации;

- процесс, для успешной реализации которого требуется понимание подходов к анализу данных, наличие ресурсов для его реализации, правильная постановка целей процесса. 


\section{Таблица 1}

Цели основных участников образовательного процесса

\begin{tabular}{|c|l|}
\hline $\begin{array}{c}\text { Участник } \\
\text { процесса }\end{array}$ & \multicolumn{1}{|c|}{ Основная цель, преимущества, перспективы } \\
\hline Обучающиеся & $\begin{array}{l}\text { Поддержка обучающихся с помощью адаптивных } \\
\text { форм обратной связи, рекомендаций, отвечающих } \\
\text { индивидуальным потребностям, целью улучшения } \\
\text { показателей обучения }\end{array}$ \\
\hline $\begin{array}{c}\text { Преподаватели } \\
\text { (Еducator) }\end{array}$ & $\begin{array}{l}\text { Понимание процесса обучения студентов, отражение } \\
\text { образовательных методик и показателей, когнитив- } \\
\text { ные и бихевиористские аспекты }\end{array}$ \\
\hline Аналитики & $\begin{array}{l}\text { Подбор и применение техник образовательной анали- } \\
\text { тики согласно текущей проблеме, оценка эффектив- } \\
\text { ности обучения в различных ситуациях. }\end{array}$ \\
\hline Администраторы & Оценка ресурсов и их образовательной стоимости \\
\hline
\end{tabular}

Справедливость этих выводов подтверждается опубликованным в 2015 году исследованием Improving the Quality and Productivity of the Higher Education Sector [9] от сообщества SoLAR. B работе проанализирован опыт внедрения образовательной аналитики в вузах США, Австралии и Великобритании. В ходе анализа выявлено, что основными целями внедрения образовательной аналитики, как правило, являются: повышение качества образования, эффективности университета и снижение расходов, а также удержание студентов, особенно на начальном этапе обучения. Инструментом реализация целей и задач являются рабочие группы, службы или институты, создаваемые внутри университетов. Помимо этого, практически у всех вузов реализация осуществляется через пилотные проекты по анализу данных.

\section{Методы и инструменты образовательной аналитики}

Поскольку основой для образовательной аналитики являются данные, то используемые методы и инструменты характерны для анализа данных в целом. К наиболее часто встречающимся методам, по мнению авторов [10], относят следующие.

1. Прогнозные модели:

• классификация;

- регрессионный анализ;

- оценка скрытых знаний. 
2. Обнаружение структуры:

- кластеризация;

- факторный анализ.

3. Поиск закономерностей (взаимосвязей)

- поиск по ассоциативным правилам;

- поиск по последовательной схеме;

- корреляционный анализ;

- поиск причинных взаимосвязей.

4. Открытие с помощью модели.

Если говорить об инструментах, наиболее часто применяемых для реализации методов образовательной аналитики, то на основании опроса, проведенного на платформе сообщества аналитиков данных Kaggle в 2018 году, можно выделить два наиболее популярных языка программирования для интеллектуального анализа данных - Python и R [11].

Согласно опросу обнаружено, что $83 \%$ из почти 24000 профессионалов в области анализа данных используют Python. Специалисты по обработке данных и программисты любят Python, за его универсальность. Python оказывается быстрее R в циклах с менее 1000 итераций. Специалисты отмечают, что Python лучше R для предобработки данных. Кроме этого в Руthon встроены пакеты для обработки естественного языка и анализа данных, а также язык является объектно-ориентированным. В тоже время $\mathrm{R}$ лучше подходит для специального анализа и изучения наборов данных, чем Python. Это язык с открытым исходным кодом и программное обеспечение для статистических вычислений и графики. Это непростой язык для изучения, и большинство людей считают, что с Python легче освоиться.

В циклах, которые имеют более 1000 итераций, R фактически превосходит Python. Это может заставить некоторых задуматься, лучше ли R для анализа данных с большими наборами данных, однако R был создан статистиками, что и отражено в его операциях. Приложения для обработки данных в Python кажутся более естественными.

Таким образом, можно сделать вывод, что на текущий момент наиболее популярным языком для реализации методов образовательной аналитики является язык Python. 


\section{Пример из практики}

Рассмотрим на практическом примере применение образовательной аналитики в образовательном процессе учреждения высшего образования. Начиная с 2017 учебного года в Высшей школе управления и бизнеса при Белорусском государственном экономическом университете ведется прием студентов на дистанционную форму обучения по специальности «Правоведение» (специализация «Хозяйственное право»). В качестве системы управления обучением (СУО) выбрана платформа Moodle.

Цель исследования - снижение количества отчисленных студентов после первого семестра обучения. Задача исследования - разработка и внедрение модели раннего выявления студентов, подверженных высокому риску отчисления на основе их взаимодействия с системой управления обучением. На момент построения модели на специальность суммарно зачислены 238 студентов, 67 из которых в 2019 году.

Данные для построения модели - таблица с выгрузкой активностей всехстудентов специальности «Правоведение» с сентября 2017 по февраль 2020 года в формате csv. В качестве инструмента выбран язык программирования Phyton 3.7 с подключенными программной библиотекой для обработки и анализа данных Pandas и библиотекой машинного обучения Scikit-learn. Средой реализации модели выбрано бесплатное веб-приложение с открытым исходным кодом JupiterNotebook. Временной интервал для прогнозирования 60 дней с момента первого взаимодействия студента с СУО. Т.к. задача решается методом классификации, то в качестве метода для модели выбран алгоритм машинного обучения «Дерево решений».

На первом этапе построения модели проводится подготовка данных к анализу. В рассматриваемом случае остаются лишь столбцы, непосредственно описывающие взаимодействие студентов с модулями СУО. Далее студенты размечаются по признаку продолжения учебы после первого семестра на тех, кто продолжил учиться группа 1 и тех, кто отчислен - группа 0. После разметки создается сводная таблица по количеству действий студентов с курсами в рамках первого семестра, количеству уникальных дней пребывания в системе и дней учебы. После этого таблица разбивается на обучающую - студенты, зачисленные до 2019 года и тестовую выборку студенты, зачисленные в 2019 году. Из тестовой выборки убирается столбец с разметкой по признаку - учится/отчислен. 
Таблица 2

Таблица представлений обучающей выборки

\begin{tabular}{|c|c|c|c|c|c|c|c|}
\hline userid & course_tried & study_days & reviewed & started & submitted & viewed & $\begin{array}{c}\text { stay__ } \\
\text { studied }\end{array}$ \\
\hline 88 & 1 & 12 & 15 & 4 & 4 & 83 & 1 \\
\hline 89 & 1 & 11 & 7 & 4 & 4 & 95 & 1 \\
\hline 90 & 1 & 10 & 4 & 4 & 4 & 83 & 1 \\
\hline$\ldots$ & $\ldots$ & $\ldots$ & $\ldots$ & $\ldots$ & $\ldots$ & $\ldots$ & $\ldots$ \\
\hline 363 & 3 & 36 & 36 & 9 & 8 & 268 & 1 \\
\hline 364 & 2 & 18 & 5 & 5 & 2 & 66 & 0 \\
\hline 365 & 1 & 1 & 0 & 0 & 0 & 3 & 0 \\
\hline
\end{tabular}

Столбцы таблицы 2 обозначают: userid - идентификатор студента, course_tried - количество начатых курсов, study_days - количество дней обучения, reviewed - количество просмотров результатов, started - количество начатых заданий, submitted - количество завершенных заданий, viewed - количество просмотров модулей курсов, stay_studied - учится/отчислен после первого семестра.

Второй этап - обучение модели. Для обучения модели используется класс DecisionTreeClassifier библиотеки Scikit-learn. Подбор оптимальных значений параметров дерева осуществляется с помощью класса GridSearchCV - поиск наилучшего набора параметров, доставляющих минимум ошибке перекрестного контроля (crossvalidation). В итоге оптимальное дерево решений выглядит следующим образом.

started $<=3.5$

gini $=0.428$

samples $=113$

value $=[35,78]$

gini $=0.219$

samples $=24$

value $=[21,3]$

gini $=0.265$

samples $=89$

value $=[14,75]$

Рис. 1 Оптимальное дерево решений

Третий этап - прогнозирование и оценка качества модели. Прогнозная выборка - набор данных о студентах, зачисленных в 2019 году. Для оценки качества бинарной классификации проводится 
ROC-анализ. В данном случае значение $\mathrm{ROC}=0,64$, что говорит о удовлетворительном качестве классификатора.

Следующим этапом должна стать отладка модели и ее внедрение в образовательную практику.

\section{Выводы}

1. Образовательная аналитика - перспективное и быстро развивающееся научное направление, результаты внедрения которого могут существенно изменить подходы к управлению учебным процессом.

2. Разработка моделей для интеллектуального анализа образовательных данных является актуальной и важной задачей.

3. Для быстрого построения систем интеллектуального анализа данных может быть весьма эффективно использован язык программирования Python.

\section{Библиография}

1. National learning platforms and tools [Электронный pecypc] // Web-site UNESCO. - URL: https://en.unesco.org/covid19/educationresponse/nationalresponses (Дата обращения: 23.08.2020).

2. By the Numbers: MOOCs During the Pandemic [Электронный ресурс] - URL: https://www.classcentral.com/report/mooc-stats-pandemic (Дата обращения: 23.08.2020).

3. Эпидемия коронавируса: воздействие на сферу образования [Электронный pecypc] / Департамент международного и регионального сотрудничества СП РФ. Москва, 2020. - Режим доступа: https://ach.gov.ru/upload/pdf/Covid-19-edu.pdf (Дата обращения: 23.08.2020).

4. Online Education Statistics [Электронный ресурc] - URL: https://education data.org/online-education-statistics/ (Дата обращения: 24.08.2020).

5. Jordan, K. MOOC completion rates: The data. [Электронный pecypc] /K. Jordan, 2014 - URL: https://www.researchgate.net/publication/249994962_MOOC_completion rates_The_data (Дата обращения: 24.08.2020).

6. Long, P., Siemens, G. Penetrating the Fog: Analytics in Learning and Education. [Электронный pecypc]: https://er.educause.edu/articles/2011/9/penetrating-the-foganalytics-in-learning-and-education (Дата обращения: 24.08.2020).

7. Romero, C. Data mining in education / C. Romero, S. Ventura // Wiley interdisciplinary reviews. Data mining and knowledge discovery. 2013. -3(1). - P. 12-27.

8. Siemens, G., Dawson, S., Lynch, G. Improving the Quality and Productivity of the Higher Education Sector [Электронный ресурс] - URL: https://solaresearch.org/wpcontent/uploads/2017/06/SoLAR_Report_2014.pdf (Дата обращения: 24.08.2020).

9. Larusson, J.A., White, B. Learning Analytics: From Research to Practice / J.A. Larusson, B. White. New York: Springer Science+Business Media, 2014 - 191 p.

10. Kaggle ML \& DS Survey [Электронный ресурc] URL: https://www.kaggle.com/ kaggle/kaggle-survey-2018 (Дата обращения: 23.08.2020). 
https://doi.org/10.29003/m1849.978-5-317-06529-4/462-468

Сергеенкова В.В. Белорусский государственный университет, Минск

Балькина Е.Н. Республиканский институт высшей школь, Минск

\section{Опыт электронного сопровождения учебных дисциплин} на кафедре истории России Белорусского государственного университета

Аннотация. Анализируется опыт использования электронных средств обучения учебных дисциплин на кафедре истории России БГУ.

Ключевые слова: кафедра истории России, электронные средства обучения, электронные образовательные проекты.

Sergeenkova $\boldsymbol{V} . \boldsymbol{V}$. Belarusian state University, Minsk

Balykina E.N. Republican Institute of higher education, Minsk

\section{Experience in electronic support of academic subjects at the Department of Russian history of the Belarusian state University}

Abstract. The article analyzes the experience of using electronic learning tools for academic disciplines at the Department of Russian history of BSU.

Keywords: Department of Russian history, electronic learning tools, electronic educational projects.

Согласно «Концепции цифровой трансформации процессов в системе образования Республики Беларусь на 2019-2025 годы», важным и необходимым направлением в сфере образования является активное внедрение в образовательный процесс использование наряду с учебниками на бумажных носителях различных видов электронного сопровождения изучаемых дисциплин. Цифровая трансформация образовательного процесса должна обеспечить:

- использование дистанционных технологий обучения и популяризацию принципа «обучение через всю жизнь»;

- совершенствование образовательного процесса путем гармоничного внедрения достижений в сфере ИКТ;

- использование электронных образовательных ресурсов и возможностей современных дидактических методик на базе ИКТ в образовательном процессе и др. [1]. 
В практике работы кафедры истории России Белорусского государственного университета (БГУ) активно используются различные формы электронного сопровождения преподаваемых дисциплин. Следует отметить, что электронное обучение не просто все шире применяется в учебном процессе, но становятся и все более разнообразными сами виды электронного обучения:

- электронные учебно-методические комплексы (ЭУМК), размещенные в электронной библиотеке БГУ;

- диагностирующее тестирование на основе тестовых заданий с выбором для контроля;

- обучающее тестирование на основе тестовых заданий четырех форм в локальных и сетевых инструментальных тестовых средах прежде всего для тренинга;

- активное использование образовательного портала исторического факультета для обеспечения дистанционного обучения, например, на платформе Moodle и другие.

Так, на кафедре истории России работает кружок «Актуальные проблемы восточнославянской истории (историческая картография)», в рамках которого всем заинтересованным студентам и аспирантам исторического факультета предлагается пройти курс обучения по созданию исторических карт в электронном виде.

Целостность ЭУМК обеспечивается методическими указаниями по изучению дисциплины, в которых раскрываются внутренние связи между разделами комплекса. ЭУМК предназначен для реализации требований образовательных программ и образовательных стандартов высшего образования. Он состоит из теоретического, практического, вспомогательного разделов и раздела контроля знаний.

Теоретический раздел включает в себя материалы для теоретического изучения учебной дисциплины в объеме, установленном типовым учебным планом по специальности. В практический раздел входят материалы по проведению семинарских, практических и иных учебных занятий в соответствии с учебным планом. Раздел контроля знаний содержит материалы текущего контроля и аттестации, иные материалы, позволяющие определить соответствие результатов учебной деятельности обучающихся требованиям образовательных стандартов высшего образования и учебно-программной документации образовательных программ высшего образования. Вспомогательный раздел имеет элементы учебно-программной и учебно-методической документации образовательной программы 
высшего образования, перечень учебных изданий и информационноаналитических материалов, рекомендуемых для изучения учебной дисциплины.

Уже не одно десятилетие на кафедре истории России разрабатываются и внедряются в учебный процесс тематические электронные образовательные проекты (ЭОП) [2; 3; 4]. Особенностью разработки этих проектов является то, что они создаются на протяжении всего учебного года творческим коллективом преподавателей и студентов. Безусловно, все это требует больших и физических, и моральных, и временных затрат от преподавателя. Однако, как показывает опыт, такой контакт преподаватель - студент дает положительные результаты.

Конечно, с каждым новым проектом происходит их совершенствование в структурном и техническом отношении, используются новые компьютерные технологии. Разработанные ЭОП внедряются в учебный процесс не только на историческом факультете БГУ, но и в других учреждениях высшего образования Республики Беларусь, России и Украины, в лицеях и общеобразовательных школах (на факультативных занятиях по всемирной истории и / или русской литературе). ЭОП по истории России неоднократно представлялись на конференциях, выставках, конкурсах.

Так, ЭОП «Культура России во второй половине XIX - начале XX в.» участвовал в конкурсе студенческих научных работ в 2015 г. в МГУ им. М.В. Ломоносова и был отмечен дипломом I степени.

Особенно активно ЭОП создаются по дисциплине «История России и Украины» (XIX - начало XX в.). Фактически по всем темам этой дисциплины имеются е-проекты, в которых используются различные виды обучения: наглядно-демонстрационный, лекционнодемонстрационный, выборочно контрольный (тестовая среда) и др. Разветвленная и удобная система гиперссылок и управляющих кнопок позволяет оперативно переходить к интересующей информации. Эффективность ЭОП достигается благодаря тщательному отбору и структурированию материала и последовательности его подачи, визуальным возможностям и гибкой структуре программы.

ЭОП предназначены для изложения учебного материала, закрепления и контроля знаний и умений, формирования социальноличностных и профессиональных компетенций, навыков самостоятельной работы с источниками, фактами, картами и схемами. Как правило, ЭОП включают в себя: «Содержание» (лекционный материал), «Источники и исследования», «Карты, схемы», «Глоссарий», 
«Тест» для самоконтроля и контроля знаний, «Галерею исторических деятелей», «Хронолинию», видеоматериал и музыкальные сопровождение, «Библиографический список», «Создатели» (краткая справка об авторах ЭОП), навигатор и др. Наличие в ЭОП большого количества текстов источников и исследований позволяет использовать их не только для изучения общих и специальных курсов, но и для написания курсовых и даже дипломных работ, что особенно ценно для студентов-заочников.

ЭОП активно используются в учебном процессе. Они применяется для демонстрационной поддержки лекционного материала и на семинарских занятиях по дисциплине «История России и Украины». В полном объеме они работает в рамках преподавания дисциплин специализации и дисциплин по выбору студентов. ЭОП позволяют студентам выполнять задания по управляемой самостоятельной работе.

ЭОП - это как бы мини электронные учебные пособия и могут стать базой для создания электронного учебника по учебной дисциплине. При разработке таких ЭОП можно выделить несколько этапов: выработка концепции проекта (определение его целей и задач, требований и результатов); разработка его структурно-логической схемы, содержания и структуры; реализация проекта; апробация и корректировка; внедрение в учебный процесс.

Примерами ЭОП по «Истории Росси и Украины» являются работы, созданные на кафедре истории России: «Император Александр I», «Император Александр II», «Император Александр III», «Крымская война», «Русско-японская война», «Отечественная война 1812 г. и зарубежный поход русской армии», «Общественное движение в России во второй четверти XIX в.», «Общественно-политическая борьба на рубеже XIX-XX вв. в России. Революция 19051907 гг.», «Внутренняя политика Николая I», «Украинские земли в первой половине XIX в.», «Русская культура в первой половине XIX в.», «Русская культура во второй половине XIX - начале XX в.» и многие другие [5]. Фактически ЭОП созданы по всем темам учебной дисциплины. В основу ЭОП легли учебные пособия, изданные кафедрой истории России [6], материалы тематических электронных галерей, энциклопедий, различных публикаций, а также Интернетресурсы. Они содержат интересный иллюстративный материал, карты, портреты, глоссарий, персоналии исторических деятелей, аудиои видео- сопровождение. 
ЭОП по истории Украины [4] (создан на русском и белорусском языках) стал электронным дополнением (CD-ROM) к разработанному кафедрой истории России учебно-методическому пособию по истории Украины с древнейших времен до начала XX в. [7]. Демоверсия электронного дополнения расположена в системе дистанционного обучения Moodle и активно востребована. Надо отметить, что это не первое электронное приложение к учебному пособию, созданное совместно профессорско-преподавательским корпусом и студентами и изданное кафедрой [8].

Использование ЭОП позволяет не только оживить учебную работу студентов, но и способствует более глубокому изучению учебных тем по дисциплине «История России и Украины».

Таким образом, современная высшая школа требует внедрения в учебный процесс все новых и новых электронных средств обучения, без чего не может осуществляться подготовка специалистов на основе формирования профессиональных компетенций. Важно умело сочетать новые ИКТ и традиционные формы обучения.

\section{Библиография}

1. Концепция цифровой трансформации процессов в системе образования Республики Беларусь на 2019-2025 годы / Национальный правовой Интернет-портал Республики Беларусь - URL: http://www.pravo.by/novosti/obshchestvenno-politicheskiei-v-oblasti-prava/2019/april/33742/ (дата обращения: 30.11.2019).

2. Оржеховский, И.В. Концепция компьютерной технологии обучения в приложении к историческим наукам / И.В. Оржеховский, Е.Н. Балыкина // Применение компьютерной техники в преподавании общественных наук. - Л., 1990. - С. 48-50.

3. Балыкина, Е.Н. Из опыта тестового контроля знаний студентов на историческом факультете / Е.Н. Балыкина, В.В. Сергеенкова // Актуальные вопросы научнометодической работы: многоуровневая система подготовки специалистов. - Гомель, 2003. - C. 94-96.

4. Балыкина, Е.Н. Разработка электронных образовательных проектов по истории как средство оптимизации учебного процесса / Е.Н. Балыкина, В.В. Сергеенкова // Информационные ресурсы, технологии и модели реконструкции исторических процессов и явлений. - М., 2010. - С. 155-156.

5. Балыкина, Е.Н. Использование мультимедиа-коллекции линий времени в процессе самостоятельной работы студентов при изучении истории Великой Отечественной войны / Е.Н. Балыкина, О.В. Бригадина, С.М. Блашко // Инновационные подходы в исторических исследованиях: информационные технологии, модели и методы. - М., 2012. - С. 185-186.

6. Сергеенкова, В.В. Информационно-коммуникационные технологии в изучении истории России и Украины в вузах Беларуси / В.В. Сергеенкова // Россия, Беларусь, Украина: история, современность, будущее. - Минск, 2014. - С. 346-352.

7. Яновский, О.А. Электронные учебные издания: итоги 30-летнего межкафедрального сотрудничества на историческом факультете Белорусского государственного университета / О.А. Яновский, Е.Н. Балыкина, В.В. Сергеенкова // Информационный бюллетень Ассоциации «История и компьютер». - М., 2014. - № 42. - С. 214-221. 
8. Сергеенкова, В.В. Электронные образовательные проекты как основа электронного учебного пособия по истории / В.В. Сергеенкова, Е.Н. Балыкина // Актуальные проблемы теории и методики преподавания истории и обществознания. - Псков, 2017. - C. 182-190.

2. Балыкина, Е.Н. Культура России в 1917-2000 гг.: компьютерный контроль знаний / Е.Н. Балыкина, О.В. Бригадина, В.С. Левшик [и др.] // Женщина. Общество. Образование. - Минск, 2009. - Т. 1. - С. 217-219.

3. Балыкина, Е.Н. Создание электронного образовательного проекта «25 лет Содружеству Независимых Государств» / Е.Н. Балыкина, О.В. Бригадина // Исторические исследования в цифровую эпоху: информационные ресурсы, технологии, методы. - М., 2016. - С. 225-226.

4. Балыкина, Е.Н. Электронное учебное издание «Немецкий оккупационный режим на территории Беларуси» / Е.Н. Балыкина, Г.А. Болсун // Наука и глобальные вызовы XXI века. - Пермь, 2018. - С. 201-206.

5. Сергеенкова, В.В. Электронный образовательный проект «Украина в XIX начале XX века» и его использование в учебном процессе / В.В. Сергеенкова, Е.Н. Балыкина // Современные информационные технологии в образовании - Троицк, 2020. - C. 124-126.

6. Балыкина, Е.Н. Электронное образовательное издание «Общественное движение в России во второй четверти XIX века» // Е.Н. Балыкина, В.В. Сергеенкова, Н.Н. Карбалевич [и др.] // Новые образовательные технологии в вузе. - Екатеринбург, 2010. - T. 2. - C. 15-18.

7. Сергеенкова, В.В. Электронное обучение на историческом факультете Белорусского государственного университета (на примере электронного учебного издания «Движение декабристов») / В.В. Сергеенкова, Е.Н. Балыкина // Новые образовательные технологии в вузе. - Екатеринбург, 2014. - С. 292-298.

8. Сергеенкова, В.В. Электронное учебное издание «Внутренняя политика Николая I» / В.В. Сергеенкова, Е.Н. Балыкина // Проблемы истории России, Беларуси и Украины ХІХ - начала XX века. - Минск, 2014. - С. 321-322.

9. Сергеенкова, В.В. Применение электронного учебного издания «Культура России во второй половине XIX - начале XX в.» в учебном процессе Белорусского государственного университета / В.В. Сергеенкова, Е.Н. Балыкина // Исторические исследования в цифровую эпоху: информационные ресурсы, технологии, методы. M., 2016. - C. 231-236.

10. Сергеенкова, В.В. Электронный образовательный проект «Российская империя в годы Первой мировой войны» как мини-вариант будущего электронного учебника / В.В. Сергеенкова, Е.Н. Балыкина // Методология исследований политического дискурса: актуальные проблемы содержательного анализа общественнополитических текстов. Дискурсы рефлексии и рефлексия как дискурс. - Минск, 2017. - С. $165-170$.

11. Яновский, О.А. История России и Украины (XIX - начало XX в.) : пособие для студ. ист. фак. спец. 1-210301 «История» : в 2 ч. Ч. 1 / О.А. Яновский, В.В. Сергеенкова, Ю.А. Блашков [и др.] / Под ред. О.А. Яновского, В.В. Сергеенковой. Минск, 2008. - 367 с.

12. Сергеенкова, В.В. История России и Украины (XIX - начало XX в.): учеб.метод. пособие для студ. вузов, обуч. по спец. 1-21 0301 «История»: в 2 ч. Ч. 2 / В.В. Сергеенкова, Ю.А. Блашков, О.В. Бригадина [и др.]. / Под ред. В.В. Сергеенковой, О.А. Яновского, В.И. Меньковского. - Минск, 2010. - 535 с. 
13. Кортеж российской власти. IX-XXI века: биогр. справ. В 3 ч. - Ч. 1. / Сост.: О.А. Яновский, Ю.А.Блашков, Г.А. Болсун [и др.]. / Под ред. О.А. Яновского. Минск, 2013. - 400 с.; Ч. 2. / Сост.: О.А. Яновский, Ю.А. Блашков, Г.А. Болсун [и др.] / Под ред. О.А. Яновского. - Минск, 2014. - 290 с.; Ч. 3. / Сост.: О.А. Яновский, Ю.А. Блашков, Г.А. Болсун [и др.]. / Под ред. О.А. Яновского. - Минск, 2014. - 332 с.

14. Лугауцова, С.Л. Гісторыя Украіны са старажытных часоу да пачатку XX ст. (з электронным дадаткам): дапаможнік / С.Л. Лугауцова, В.А. Кахновіч, С.М. Цемушау; - Мінск, 2019. - 240 с.

15. Яновский, О.А. Университетоведение : учеб.-метод. пособие : (с приложением CD) / О.А. Яновский, В.А. Федосик, Л.В. Хведченя [и др.] ; - Минск, 2011. - 343 с. + электрон. диск.

16. Яновский, О.А. Проектная деятельность студентов в процессе создания электронного приложения к учебно-методическому пособию «Университетоведение» / О.А. Яновский, Е.Н. Балыкина // Инновационные подходы в исторических исследованиях: информационные технологии, модели и методы. - М., 2012. - С. 223-224. 


\section{ИНФОРМАТИКА: СТРАНИЦЫ ИСТОРИИ}

https://doi.org/10.29003/m1850.978-5-317-06529-4/469-474

Злобин Е.B.

Москва

\section{Зачем был построен компьютер Колоссус (неизвестные страницы истории информатики)}

Аннотация. В статье описано использование первого в мире компьютера Колоссус для взлома шифров верховного немецкого командования, включая Гитлера. Источником послужили уникальные мемуары взломщика кодов, работавшего в годы войны в центре дешифровки в Блечли-Парке. Ввиду абсолютной секретности проекта в течение 60 лет, воспоминания были написаны после его рассекречивания в начале 2000-х. Изданы после смерти автора.

Ключевые слова: История информатики, первый компьютер, шифрование, дешифровка, взлом шифров, Блечли-Парк.

Evgenii Zlobin

Moscow

\section{Why was the Colossus computer built? (unknown pages of the history of computer science)}

Abstract. In the article is described the use of the 1st world computer Colossus for the breaking of the ciphers of supreme German command, including Hitler. The unique Memoirs of the codebraker, who worked during the years of war in the center of decoding in the Bletchley Park, served as source. In view of the absolute secrecy of project in time of 60 years, Memoirs were written after project declassification in the early 2000s. Memoirs were published after author death.

Keywords: History of informatics, First computer, coding, decoding, codebracking, Bletchley Park.

Создание и использование англичанами в годы второй мировой войны первого в мире компьютера Колоссус (Colossus) - один из наиболее секретных британских проектов, сравнимых по степени закрытости пожалуй только с делом Гесса. Более полувека данные материалы оставались недоступны, и были окончательно рассекречены только в начале 2000-х годов. К этому времени оказалось, что в английских архивах материалов сохранилось немного - к примеру вся техническая документация на компьютер была уничтожена [1]. Значительно более полная коллекция документов отложилась в архивах ЦРУ [2], с её помощью энтузиасты воссоздали работающую модели этого уникального устройства, о которой мы уже писали [3]. 
В немногочисленных публикациях, которые вышли после первых упоминаний о Колоссусе еще до его полного рассекречивания и сразу после, приводятся сведения об устройстве компьютера, его элементной базе, и о главном предназначении - взломе шифров т.н. «Лоренца», шифровальной машины SZ42, использовавшйся в переписке верховного командования рейха во главе с Гитлером [4]. Однако до недавнего времени в публикациях обходился вопрос о том, а каким образом взламывались эти шифры, по каким алгоритмам работал и что именно считал первый в мире компьютер. Прежде чем коснуться этого вопроса, опишем кратко что из себя представлял, кем и как был взломан самый секретный немецкий шифратор.

SZ42, которых было изготовлено всего несколько сотен, использовал стандартную телетайпную 5-ти позиционную перфоленту как носитель текста, и шифр Вернама (Vernam) - к двоичному коду символа текста прибавлялись по модулю 2 коды двух случайных символов. При дешифровке эти же два символа снова прибавлялись по модулю два, и на выходе получался исходный текст. Полученная перфолента распечатывалась на стандартном буквопечатающем аппарате. Широкое применение данного шифратора началось в 1940 г.

Шифратор включал 3 группы дисков или роторов - всего их было 12 (для сравнения в другой взломанной англичанами шифровальной машине Энигма - 3 или 4) - пять «сhі» (чи), два «моторных» и пять -«рsi» (пси). Увеличение числа роторов больше чем в три раза по замыслу конструкторов обеспечивало потенциальную невзламываемость шифра. Однако «человеческий фактор» - ошибка оператора, передавшего в 1942 г. подряд два больших по объёму сообщения без смены установки роторов, позволил дешифровщикам получить статистически значимый объём текста для взлома структуры устройства. В течение 3 месяцев Билл Тат (Tutte), криптоаналитик из Блечли-Парка - самого секретного места Великобритании в годы войны, анализируя этот массив текста, сумел определить логическую структуру SZ42, которую англичане называли «Рыбой» (Fish) [5, p. 72-75]. Основываясь на его результатах был построен электромеханический эмулятор шифратора, получившая название «Тунец» (Tunny). Всего их было построено 15, все они были уничтожены после войны, один восстановлен после рассекречивания в 2011 г. [6] Меняя его установки штекерами на коммутационной панели, имитирующими изменения положение роторов, дешифровщики получили возможность просматривать результаты различных вариантов расшифровки. 
По оценке генерала армии Дуайта Эйзенхауэра, верховного главнокомандующего экспедиционными силами союзников в Европе, а впоследствии президента США, взлом шифров криптоаналитиками из Блечли-Парка приблизил окончание войны как минимум на два года [5, p. 17]. Поразительным является тот факт, что до конца войны в руки союзников не попала ни одна шифровальная машина Лоренц, в отличие от Энигмы. Шифратор, который в настоящее время экспонируется в музее криптографии в Блечли-Парке, использовался фельдмаршалом Кессельрингом, командующим немецкими войсками в Италии. В конце войны его конвой при возвращении в Германию был перехвачен союзными силами в начале мая 1945 года, и перенаправлен в Блечли-Парк. И уже там, разбирая попавшие к ним трофеи, дешифровщики обнаружили шифратор Лоренца и смогли «вживую» увидеть то устройство, работающую модель которого они успешно создали на основе своих умозрительных заключений. И если сам шифратор - относительно небольшой и по размеру сопоставим с типичным буквопечатающим телеграфным аппаратом, то его английский аналог - стойка аппаратуры выше человеского роста.

Решаемые в ходе дешифровки первым компьютером практические задачи впервые были описаны в изданной в 2017 году книге воспоминаний другого взломщика кодов, капитана Джерри Робертса (Jerry Roberts) [5]. Свои записки он начал писать в 87 лет, после того, как появились первые публикации о Колоссусе и был официально рассекречен проект по взлому Лоренца (2002 г.). До этого на протяжении всего послевоенного периода, и об этом неоднократно упоминается в книге, он никогда и ни с кем, включая родителей и бывших сослуживцев, не обсуждал свою работу дешифровщика в силу секретности. Поскольку в этом почтенном возрасте он уже имел проблемы со зрением, то в основном надиктовывал текст, который затем практически не правился и не редактировался. В книге много повторов, используются разговорные выражения и пр. Поэтому в какой-то степени его мемуары можно отнести к т.н. «oral history». Автор скончался в марте 2014 года вскоре после завершения работы над книгой в возрасте 94 лет. Издание было подготовлено к печати его вдовой Мей. Робертс стал единственным из сотрудников дешифровальных подразделений Блечли-парка, кто написал книгу воспоминаний. И только он спустя полвека в 2012 году был награждён за взлом шифра Гитлера став кавалером (MBE - самая младшая степень) ордена Британской империи (для сравнения - одновременно с ним высшей степени ордена - рыцарской - был удостоен известный 
велогонщик). Главная задача, которую Робертс перед собой ставил, принимаясь за мемуары - восстановление исторической справедливости, необходимость отдать должное английским дешифровщикам, внесшим существенный вклад в достижение победы над фашизмом.

Если верить его воспоминаниям, собственно взлом каждого сообщения включал 7 этапов, при этом компьютер выполнял первые два этапа. Как мы уже упоминали шифратор Лоренц включал 3 группы шифродисков или роторов (названия группам дал Тат) пять «сhі» (чи), два «моторных» и пять - «рsi» (пси). Последовательность взлома шифровок с помощью Колоссуса была следующей. Первоначально исходный текст, записанный на стандартную бумажную ленту от телетайпа, считывался оптическим устройством и обрабатывался на компьютере в котором псевдослучайный ключ генерировался электронными схемами на тиратронах. Обработка шла параллельно на пяти счётчиках с суммарной скоростью считывания до 20000 символов в минуту. Методом простого перебора возможных комбинаций компьютер вычислял т.н. гамма-функцию, которая позволяла определить установку роторов первой группы - чироторов. При этом оператор, управляющий работой машины, с коммутационного пульта мог менять направления подсчёта функции.

После этого чи-роторы выставлялись в нужное положение на Тунце. Закодированное сообщение еще раз обрабатывалось на нём, и получался частично расшифрованный, т.н. де-чи текст. Дальнейшая работа производилась уже вручную, для чего, по воспоминаниям Робертса, ему надо было держать в памяти возможные 992 комбинации из 32 символов по 3 [5, р. 87]. Дешифровщики вычисляли положение двух оставшихся групп роторов, и после их установки на Тунце можно было получить полностью расшифрованное сообщение.

Использование компьютера для первичного взлома сделало возможным ускорить первичный взлом сообщений и позволило существенно убыстрить процедуру дешифровки, сократив её с недель и месяцев до дней и часов. С течением времени всё возрастающие объёмы обмена информацией в радиосетях немецкого командования потребовали постройки новых машин. К концу войны успешно функционировало уже 10 компьютеров, на них работали и их обслуживали 26 криптоаналитиков, 28 инженеров, 275 техников, которые работали круглосуточно в три смены заряжая и меняя бумажные ленты. Всего с помощью в том числе и этой команды, было перехвачено и расшифровано документов Верховного немецкого главного 
командования объёмом 64 млн (!) символов, или около 35000 машинописных страниц. Число перехваченных и расшифрованных сообщений составило по годам: 1942 - 872, 1943 - 3454, 1944 - 4724, 1945 - 4475, всего более 13 500. Основываясь на своих воспоминаниях, Робертс составил примерную таблицу вклада компьютерной расшифровки в общий объём выполненных работ [5, p. 119].

Таблицุа 1

\section{Примерный вклад компьютера в расшифровку}

\begin{tabular}{|c|c|c|}
\hline Период & Условия дешифровки & Вклад Колоссуса \\
\hline Май 1942 - середина 1943 & $\begin{array}{c}7 \text { этапов расшифровки, } \\
\text { только вручную }\end{array}$ & $100 \%$ вручную \\
\hline Июль 1943 - февраль 1944 & $\begin{array}{c}5 \text { этапов расшифровки, } \\
90 \% \text { вручную }\end{array}$ & $\begin{array}{c}10 \% \text { с помощью } \\
\text { Колоссуса }\end{array}$ \\
\hline Февраль 1944 - май 1945 & $\begin{array}{c}5 \text { этапов расшифровки, } \\
75-80 \% \text { вручную }\end{array}$ & $\begin{array}{c}20-25 \% \text { с помощью } \\
\text { Колоссуса }\end{array}$ \\
\hline Всего & $\begin{array}{c}5 \text { этапов расшифровки, } \\
75-80 \% \text { вручную }\end{array}$ & $\begin{array}{c}20-25 \% \text { с помощью } \\
\text { Колоссуса }\end{array}$ \\
\hline
\end{tabular}

Всего по расчётам Робертса вручную выполнено 78\% работы, с помощью компьютера - 22\%. Столь незначительная оценка вклада компьютерных технологий может обьясняться, во-первых, тем, что сам Робертс служил в конкурирущем подразделении названном по имени начальника, майора Ральфа Тестера (Ralph Tester), «Тестери» (Testery). Его служащие занимались только ручной дешифровкой. А Колоссус был построен и все действующие компьютеры эксплуатировались в подразделении Макса Ньюмана (Max Newman) «Ньюменри» (Newmanry). Между этими подразделениями существовало определенная конкуренция в оценках их вклада в дело дешифровки. Строгий режим секретности внутри Блечли-Парка также не способствовал распространению лишней информации о происходящем буквально в соседней комнате. Во-вторых, спустя 60 лет речь может идти о самой приближеннойэкспертной оценке суммарного общего вклада в расшифровку сообщений, поскольку каких-либо отчётных документов не сохранилось, а память могла легко подвести ветерана. В то же время, сопоставляя процедуры ручной и машинной дешифровки, Робертс упоминает также о том, что он слышал якобы, что в конце войны компьютер смогли запрограммировать таким образом, что он полностью расшифровывал поступающие сообщения, но это, по его мнению, «highly unlikely» [5, p. 120]. 
Таким образом, с помощью первого в мире компьютера Колоссус производились вычисления, существенно убыстряющие взлом и дешифровку переписки немецкого верховного главнокомандования. Его использование позволило британским криптографам обеспечивать командование экспедиционными войсками союзников в Европе важнейшей информацией для принятия стратегических решений. Тем самым был внесён существенный вклад в обеспечение победы во Второй мировой войне.

\section{Библиография}

1. Account of the methods used for breaking German teleprinter cypher messages. Ref. HW 25/4. - The National Archives, UK.

2. Small A. W. Special Fish Report. National Archive and Records Administration. RG 457, Historical Collection. - Box 1417. - Nr 4628 (1944); Campaigne H. Report on British Attack on "Fish". National Archives and Records Administrations. - RG 457, NSA Historical Collection. - Box 457. - Nr. 1407 (1945).

3. Злобин Е.В. К истории информатики - как был утрачен и восстановлен первый в мире компьютер (казус Тони Сэйла) // Современные информационные технологии и ИТ-образование. Сборник научных трудов II Международной научной конференции и XII Международной научно-практической конференции. - М.: 2017. C. $76-81$.

4. Paul Gannon. Colossus. Bletchley Park's Greatest Secret. - London: Atlantic Books, 2006. - 562; B.Jack Copeland and others. Colossus. The secrets of Bletchley Park's Codebreaking Computers. - Oxford: University Press, 2006. - $462 \mathrm{p}$.

5. Captain Jerry Roberts. Lorenz. Breaking Hitler's top secret code at Bletchley Park. - Brimscombe Port: The History Press, The Mill, 2017. - 240 p.

6. Codebreaking Tunny machine rebuilt for Bletchley Park. - URL: https://www.bbc.com/news/uk-england-beds-bucks-herts-13559856. (дата обращения: 25.08.2020). 


\section{Содержание}

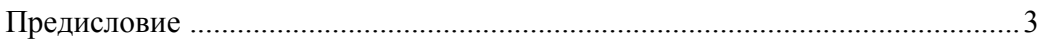

КВАНТИТАТИВНАЯ ИСТОРИЯ И КОМПЬЮТЕРНОЕ МОДЕЛИРОВАНИЕ ИСТОРИЧЕСКИХ ПРОЦЕССОВ

Аблаев Э.Ю. Отраслевая специфика краткосрочного кредитования в 1928-1935 гг.: количественный анализ по архивным материалам Государственного банка СССР

Акашева A.A. Земельная аренда как фактор модернизации пореформенного города. На примере Нижнего Новгорода 1860-1910-х гг.

Баканов С.А. Электронная база данных «Государственный бюджет СССР в 1950-1980-е гг.»: особенности создания и анализа

Воронкова Д.С. Сравнительный анализ тематики публикаций журнала «Вестник финансов, промышленности и торговли» за 1913 и 1917 гг. ....25

Главачкая Е.М., Торвальдсен Гуннар. Виновата ли «испанка?»: анализ причин смерти в Екатеринбурге (1917-1919 гг.)

Диденко Д.В., Гринева Н.В. Методологические подходы к моделированию роли институтов и технологий в экономическом росте позднего СССР (середина 1950-х - конец 1980-х гг.)

Жуков Д.С., Канищев В.В., Лямин С.К. Соотношение фрактального моделирования и кластерного анализа социальных процессов в России XVII-XX вв.

Кандаурова T.Н. Социокультурная деятельность российкого предпринимательского сообщества XIX - начала XX вв. в контексте квантитативной истории

Кузьмин Ю.В. Конструкторские школы как акторы истории техники. На примере статистического анализа мирового самолётостроения 64

Мазур Л.Н., Бродская Л.И. Моделирование жизненного цикла крестьянской семьи (на материалах бюджетных обследований)

Максимов O.E. Лёгкая промышленность в годы Косыгинской реформы (1965-1970) гг.: анализ темпов роста общего объёма выпуска продукции лёгкой промышленности на основании справочников по советской промышленности и Сводных отчётов ЦСУ при Совмине СССР ......79

Пушков В.П., Завьялов С.М. Уроженцы Смоленской губернии - первокурсники Московского университета 1917-18 гг.

Харитонов И.М. Динамика финансовых операции СССР за рубежом в 1920-е гг.: по архивным материалам Гарантийного и кредитного банка для Востока (Гаркребо)

Шnирко C.B. Математическое моделирование иерархичной структуры пространственного размещения средневекового сельского населения ... 103

КОМПЬЮТЕРИЗОВАННЫЙ АНАЛИЗ ТЕКСТОВЫХ ИСТОЧНИКОВ .. 108 Колесник М.O., Баранова Е.В. Создание информационной системы «Мемориальные доски Калининграда»: контент-анализ коммеморативного текста 
Баранов В.А., Гнутиков Р.М. Инструменты извлечения и приемы подготовки лингвистических данных для статистического анализа в историческом корпусе «Манускрипт»

Корниенко С.И., Исмакаева И.Д. Анализ идейно-политических и агитационно-пропагандистских дискурсов «красных» и «белых» в годы Гражданской войны: задачи изучения и организации данных для исследования (на материалах Пермской губернской газетной периодики 1918-1919 гг.)

Ренев Д.А. Благотворительная деятельность в Пермской губернии в начальный период Первой мировой войны (1914-1915 г.): опыт пространственного анализа (На материалах газеты «Пермская земская неделя»)

Саенко A.B. Проблема освоения историко-культурного наследия Возвращенных земель (Польша) на страницах журнала «Осадник»: опыт контент-анализа

Солощенко Н.В. Отраслевая газета пищевой промышленности СССР в 1928-1937 гг. как исторический источник (возможности анализа в программе MAXQDA)

Филёв М.В. Сельская повседневность на страницах газеты «Колхозная правда» (1950-1961 гг.): опыт контент-анализа

БАЗЫ ДАННЫХ И ИНФОРМАЦИОННЫЕ РЕСУРСЫ

Боровик Ю.В. Социальный облик городского православного прихода на рубеже XIX-XX вв. по данным метрических книг Богоявленского собора Екатеринбурга

Бочаров A.B. Проект исторического предметного рубрикатора-тезауруса на базе конструктора комбинаторных поисковых запросов Inspert в контексте перспектив корпусной историографии

Житин Р.М., Топильский А.Г. «Усадебные библиотеки Тамбовской губернии конца XVIII - начала XX века»: методика создания информационного ресурса

Ильин А.Ю., Лямин С.К. Электронная Тамбовская энциклопедия: функциональные возможности и перспективы развития проекта

Лихтер Ю.А. Статистический и информационный подходы к изучению древних артефактов и реляционная база данных

Ловцов В.А. «Губернаторский корпус при П.А. Столыпине: 19061911 гг.»: первые результаты работы с базой данных

Стрекалова Н.В., Рахманов П.С. «Бывшие» в социальной структуре провинциального города в 1917-1919 гг.: опыт создания и обработки баз данных (на материалах Тамбова)

Ульянова С.Б., Аладышкин И.В. Проект «Цифровая история СанктПетербургского политехнического университета» и перспективы моделирования институциональной истории высшей школы 


\section{МЕТОДЫ И ТЕХНОЛОГИИ СЕТЕВОГО АНАЛИЗА В ИСТОРИЧЕ-} СКИХ ИССЛЕДОВАНИЯХ

Владимирова A.B. Особенности диагностики пропущенных данных при проведении историко-экономических исследований сетей внешней торговли

Владимирова A.B. Изучение эволюции международных торговых сетей: обзор проблем предварительной обработки данных

Гарскова И.М. Методика сетевого анализа в исторических исследованиях: специфика проблематики и источниковой базы исследования

Головашина O.В., Кунавин К.С. Сетевая модель межличностных связей высшего чиновничества Российской империи. Проблемы и решения ....229

Гребенченко И.В. Сетевой анализ личных и профессиональных контактов создателей советской космонавтики по материалам просопографической и полнотекстовой баз данных ...........................................2235

Саломатина С.А., Гарскова И.М., Валетов Т.Я. Иерархия финансовых центров Российской империи в конце XIX в.: сетевой и геоинформационный анализ межрегиональных банковских переводов

Сметанин A.B. Реконструкция ценности товаров в период российского экономического транзита на основе бартерных объявлений

ИСТОРИЧЕСКАЯ ГЕОИНФОРМАТИКА: ТРАДИЦИИ И ТРАНСФОР-

МАЦИИ

Брюханова Е.А., Чекрыжсва О.И. Проблемы on-line реконструкции городского пространства Сибири на рубеже XIX-XX вв. (на примере города Тобольска)

Владимиров В.Н., Сарафанов Д.Е., Крупочкин Е.П. Численность населения в пространстве приходов Колывано-Воскресенского горного округа во второй половине XVIII в.: возможности ГИС для анализа массивов данных

Воробьева E.M. Анализ градостроительной реформы Екатерины II средствами ГИС

Карпова М.В., Степанова Ю.В. Историко-географическое исследование Торопецкого уезда XVI в. с применением геоинформационных технологий

Крупочкин Е.П., Воробъев Д.А., Суханов С.И. Пространственно-временны́е аспекты исследования археологических памятников Юстытского археологического микрорайона: теория, методика, результаты

Кунавин К.С. Гришин Е.С. Применение данных дистанционного зондирования Земли для изучения хозяйственной деятельности в Новое время

Петров Р.П., Журбин И.В., Васина Т.А., Пислегин Н.В., Чураков В.С. Исторические картографические материалы XVIII-XIX вв. для оценки антропогенного воздействия на территории горнозаводских округов (Пудемский железоделательный завод) 
Самойлов Д.В. Геоинформационный анализ отхожих промыслов и локальных миграций крестьян Вологодского уезда в пореформенный период

Санжаров B.A. Комплексная цифровая модель параллельных франкобургундских итинерариев (Людовика XI, Филиппа Доброго и Карла Смелого) как инструмент изучения управленческих институтов, военно-политической и дипломатической активности

Степанова Ю.В., Фролов А.А., Гаврилов П.В. Землевладение в Тверской половине Бежецкой пятины в конце XV - первой половине XVI в.: представление в ГИС

Уманский Л.А., Гришин Е.С. Историческая морфология преступности в российской империи XIX в. как компонент комплексных и тематических карт

Фролов А.А. Оценка средствами геоинформатики параметров координатной системы арабских географов XIII - XIV вв. Абу-л-Фиды и Ибн Са'ида о побережье Средиземного моря

Щекотилов В.Г., Лазарев О.Е. Методика применения ГИС и архивных материалов при подготовке обоснования для признания погибшими воинов, считавшихся пропавшими без вести

Щекотилов В.Г., Лазарев О.Е. Методика формирования атласов по архивным и современным картам

3D-РЕКОНСТРУКЦИИ ОБЬЕКТОВ ИСТОРИКО-КУЛЬТУРНОГО НАСЛЕДИЯ. ВИРТУАЛЬНАЯ И ДОПОЛНЕННАЯ РЕАЛЬНОСТЬ (VR/AR)

Бородкин Л.И., Жеребятьев Д.И., Энтин А.Л., Ким О.Г., Чернов С.З., Моор B.B. Цифровые технологии создания виртуальной реконструкции исторического ландшафта и городской застройки Белого города (XVII-XVIII вв.)

Баранова E.B., Верещзагин В.A. Виртуальная реконструкция дома Иммануила Канта в Кенигсберге XVIII в.

Мироненко М.C. Модуль верификации 3D-реконструкций объектов историко-культурного наследия в виртуальной и дополненной реальности. Проблема совмещения 2D и 3D-материалов

Чертополохов В.А., Григорян Г.Л. Применение технологии фовеального рендеринга для оптимизации производительности сложных сцен виртуальной исторической реконструкции

ИНФОРМАЦИОННЫЕ ТЕХНОЛОГИИ В АРХИВАХ И МУЗЕЯХ: ПРОБЛЕМЫ МЕТОДОЛОГИИ И МЕТОДИКИ В КОНТЕКСТЕ ИСТО-

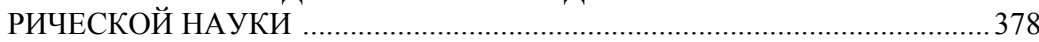

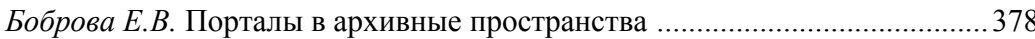

Гук Д.Ю. Веб-аналитика как инструмент анализа сетевого ресурса с разновидовыми источниками материалов археологических исследований 
Кижнер И.А., Лаптева М.А. Музейные цифровые коллекции и проект «Открытый музей» 390

Киселев И.Н. Зарубежное ПО на российской архивной почве: два проекта

Поврозник Н.Г. Веб-архив как источник для изучения современной истории 401

Юмашева Ю.Ю. Аудиовизуальные архивы в эпоху цифровой трансформации: новые формы представления и исследования

ЦИФРОВЫЕ РЕСУРСЫ И ТЕХНОЛОГИИ В ПРОФЕССИОНАЛЬНОМ ИСТОРИЧЕСКОМ ОБРАЗОВАНИИ

Балькина E.H. Невербальная поддержка информационного материала в электронном гуманитарном образовании

Гернович Т.Д. Цифровые технологии и их роль в современном историкоархивном исследовании и образовании

Иванова H.П., Брюханова E.A. Digitaleducation - новые вызовы или чему учить историков?

Липницкая О.Л., Попова Е.Э. Информационные технологии в подготовке историков-архивистов на историческом факультете БГУ: достижения и проблемы

Можаева Г.В. Интеграция массовых открытых онлайн-курсов в учебный процесс вуза как фактор персонализации исторического образования

Оськин А.Ф., Оськин Д.А. Об учебной программе курса «Data Mining Интеллектуальный анализ данных» для магистрантов специальности «История»

Оськин Д.А. Оськин А.Ф. Образовательная аналитика. Новый подход к повышению качества учебного процесса

Сергеенкова B.B., Балькина E.H. Опыт электронного сопровождения учебных дисциплин на кафедре истории России Белорусского государственного университета

ИНФОРМАТИКА: СТРАНИЦЫ ИСТОРИИ

Злобин E.B. Зачем был построен компьютер Колоссус (неизвестные страницы истории информатики) 


\section{ИМЕННОЙ УКАЗАТЕЛЬ}

Аблаев Э.Ю. ...................................6

Акашева А.А. ...................................13

Аладышкин И.В. ..................196, 202

Баканов С.А. ..................................21

Балыкина Е.Н. .............................413

Баранов В.А. ................................. 113

Баранова Е.В. .....................108, 361

Боброва Е.В. ..................................378

Боровик Ю.В. ................................154

Бородкин Л.И. ................................352

Бочаров А.В. ................................. 160

Бродская Л.И. ..................................71

Брюханова Е.А. ..................257, 427

Валетов Т.Я...............................242

Васина Т.А. ..................................298

Верещагин В.А. .............................361

Владимиров В.Н. ........................264

Владимирова А.В................203, 209

Воробьев Д.А. ..............................285

Воробьева Е.М. ............................2272

Воронкова Д.С...............................25

Гаврилов П.В. ...............................316

Гарскова И.М. ...................217, 242

Гернович Т.Д. …………………......420

Главацкая Е.М. ...............................33

Гнутиков Р.М. .............................113

Головашина О.В. ......................... 229

Гребенченко И.В. .........................235

Григорян Г.Л. ...................................371

Гринева Н.В. ...................................40

Гришин Е.С. ........................292, 323

Гук Д.Ю. .......................................384

Диденко Д.В. .....................................40

Жеребятьев Д.И..........................352

Житин Р.М. ....................................166

Жуков Д.С. .......................................48

Журбин И.В.....................................298

Завьялов С.М. …………................89

Злобин Е.В. .....................................469

Иванова Н.П. ...................................427

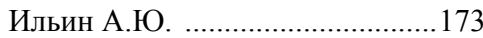

Исмакаева И.Д..............................120

Кандаурова Т.Н. ..............................56
Канищев В.В. ................................. 48

Карпова М.В. .............................2278

Кижнер И.А. ................................... 390

Ким О.Г. .......................................... 352

Киселев И.Н. ..................................395

Колесник М.О. .............................. 108

Корниенко С.И. ........................... 120

Крупочкин Е.П. ...................264, 285

Кузьмин Ю.В. .................................. 64

Кунавин К.С. ……………....229, 292

Лазарев О.Е. ........................ 339, 346

Лаптева М.А. ................................ 390

Липницкая О.Л. .............................433

Лихтер Ю.А................................. 178

Ловцов В.А. .................................. 184

Лямин С.К. ............................ 48, 173

Мазур Л.Н. ...................................... 71

Максимов О.Е. ………………...... 79

Мироненко М.С. ...........................366

Можаева Г.В................................ 441

Moop B.B. ..................................... 352

Оськин А.Ф. ........................ 447, 454

Оськин Д.А....……………. 447, 454

Петров Р.П. ....................................2298

Пислегин Н.В................................ 298

Поврозник Н.Г. ............................ 401

Попова Е.Э. ..................................... 433

Пушков В.П. ................................... 89

Рахманов П.С. ................................ 190

Ренев Д.А. ..................................... 126

Саенко А.В. ................................... 134

Саломатина С.А. ..........................2242

Самойлов Д.В................................ 303

Санжаров В.А. ............................. 311

Сарафанов Д.Е. ...............................264

Сергеенкова В.В. ..........................462

Сметанин А.В. .............................251

Солощенко Н.В. ............................ 140

Степанова Ю.В.................. 278, 316

Стрекалова Н.В. .......................... 190

Суханов С.И. ………………........228

Топильский А.Г. ............................ 166

Торвальдсен Г. .................................33 
Ульянова С.Б.

196

Чертополохов В.А. 371

Уманский Л.А.

323

Филёв М.В.

.146

Чураков В.С.

.298

Фролов А.А.

316,329

Харитонов И.М.

Шпирко С.В.

103

Чекрыжова О.И.

Щекотилов В.Г.

339,346

Энтин А.Л.

352

Чернов С.3.

Юмашева Ю.Ю. 407 .352 
Historical research in the context of data science: Information resources, analytical methods and digital technologies. Materials of the International Conference, Moscow, 4-6 December, 2020 : MAKS Press, 2020. $-484 \mathrm{p}$.

ISBN 978-5-317-06529-4

https://doi.org/10.29003/m1781.978-5-317-06529-4

The book contains materials of the International Conference. Within the framework of the International conference, the XVII conference of the Interregional Association "History and Computing" was held.

Keywords: history, historical information science, data science, research methods, information resources, digital technologies. 
Научное издание

ИСТОРИЧЕСКИЕ ИССЛЕДОВАНИЯ

В КОНТЕКСТЕ НАУКИ О ДАННЫХ:

информационные ресурсы,

аналитические методы и цифровые технологии

Материалы международной конференции

4-6 декабря 2020 г., Москва

Подготовка оригинал-макета:

Издательство «МАКС Пресс»

Главный редактор: Е. М. Бугачева

Верстка: Н. С. Давыцова

Подписано в печать 15.12.2020 г.

Формат 60х88 1/16. Усл. печ. л. 30,25.

Тираж 300 (1-150) экз. Изд. № 204.

Издательство ООО «МАКС Пресс»

Лицензия ИД N00510 от 01.12.99 г.

119992, ГСП-2, Москва, Ленинские горы,

МГУ им. М. В. Ломоносова, 2-й учебный корпус, 527 к.

Тел. 8(495) 939-3890/91. Тел./Факс 8(495) 939-3891

Отпечатано в полном соответствии с качеством предоставленных материалов в ООО «Фотоэксперт»

115201, г. Москва, ул. Котляковская, д.3, стр. 13. 